
$A-G$

\section{HARVARD UNIVERSITY.}

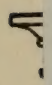

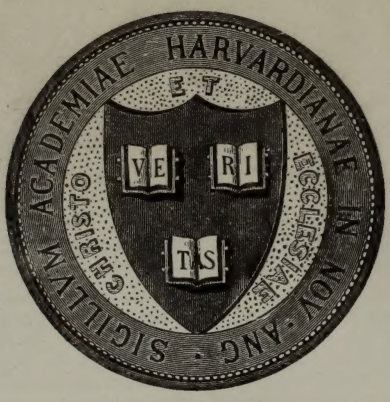

\section{LIBRARY}

OF THE

MUSEUM OF COMPARATIVE ZOÖLOGY 52,995

BEquest of

WILLIAM BREWSTER

E December 17. 1919. 
Hilleare Brewstes.

$$
\text { hoventote } 19^{\text {th }} / 910
$$

it gift, from 2. a. Mami Mouron) 
DEC 18 |519 


\section{THE BIRDS OF DUMFRIESSHIRE}






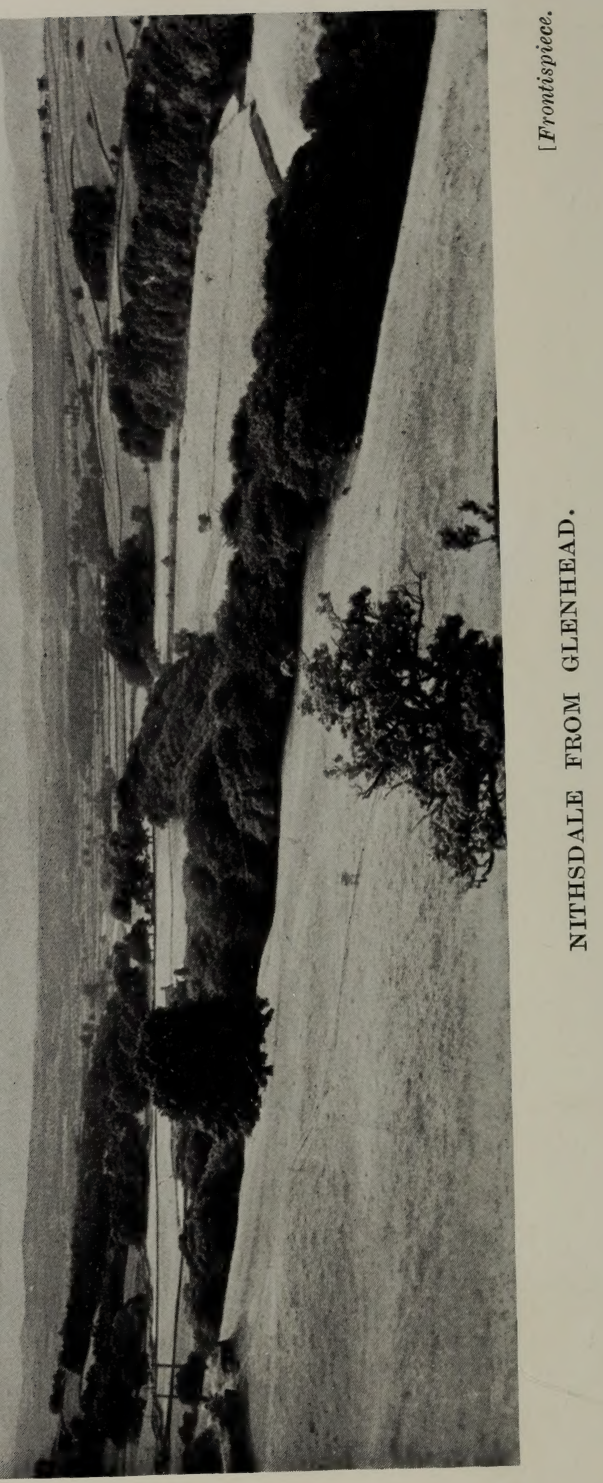




\title{
THE BIRDS
}

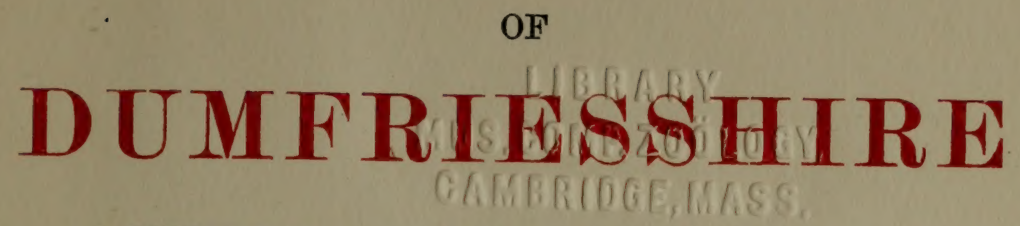

A CONTRIBUTION TO THE FAUNA OF THE SOLWAY AREA

\author{
BY \\ HUGH S. GLADSTONE \\ M.A., F.Z.S., F.R.S.E., M.B.o.U. \\ President of the Dumfriesshire and Galloway Natural History \\ and Antiquarian Society.
}

WITH ILLUSTRATIONS FROM PHOTOGRAPHS

BY

MESSRS. D. LEGARD, F. BARBER-STARKEY, THE AUTHOR AND OTHERS, AND A MAP.

WITHERBY \& CO.

326 HIGH HOLBORN LONDON 


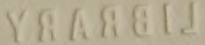 vacodorsmog. 2um

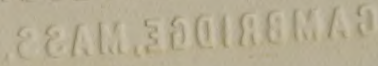

The number of Copies of this Work is strictly limited to Three Hundred and Fifty, of which this Copy is No. 213 


\section{DEDICATED TO MY SON \\ JOHN}

BORN THE 17TH OF JANUARY, 1908

“ flature, ivbicly is the Time-freature of Goù, and retreals

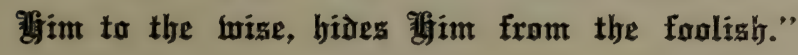

\section{Thomas CarlyLe.}

Sartor Resartus. Bk. III., ch. 8, par. 21

(written at Craigenputtock (Dunseore): October, 1830). 



\section{PREFACE.}

THE writer of a County avifauna is of necessity greatly dependent upon the co-operation of his correspondents, and I take this opportunity of thanking all those who have aided me. With so many willing assistants it becomes almost invidious to mention any by name; it is, however, quite certain that pre-eminent among them stands $\mathrm{Mr}$. Robert Service. The frequent mention of his name throughout the volume, testifies to my obligation to him ; and he has moreover helped in the revision of the book in all its various stages.

Messrs. J. A. Harvie-Brown and W. Eagle Clarke have answered numerous questions ; and Messrs. J. Bartholomew and W. J. Laidlaw have freely given me advantage of their local ornithological knowledge. Mr. G. F. ScottElliot has contributed largely to the remarks on the Physical features of the county; and to Mr. C. B. Ticehurst I am indebted for his perusal both of the manuscript and the proofs. Mr. D. Legard has been my companion on many an expedition resulting in several of the illustrations here given. Mr. E. E. Riseley, who is responsible for the index, has been indefatigable in checking references; and Mr. G. W. Shirley has placed at my disposal his knowledge of local literature, and has further helped me in passing these pages through the press. Throughout the tedious task of correcting proofs I have received the assistance of my wife, whose enthusiasm and encouragement can only be fully appreciated by myself. Finally, to my publisher, Mr. H. F. Witherby, I tender my best thanks for his great kindness not only in personally superintending the issue of my book to the public, but also for his advice as an ornithologist. 
I have followed the classification and nomenclature of Howard Saunders in the second edition of his Manual of British Birds, 1899, together with the revisions made by him in his List of British Birds revised to July, $190 \%$. I have departed from that system so far as to introduce trinomials where the British form of a species has been separated as a distinct geographical race from its continental allies. For this purpose I have followed the nomenclature employed by Dr. E. Hartert in his Vögel der paläarktischen Fauna, and his article in British Birds (Magazine) (Vol. I., pp. 208-228) on the races of birds peculiar to the British Isles.

As regards local names, it has seemed to me a mistake not to include those which may now be obsolete. References to birds by such names may from time to time be found in old periodicals or magazines ; and the fact that they are given throughout my book, among the "Local Names" of the various species to which they are applied, may prove useful to the student of our local avifauna. It should also be remembered that persons coming into a county may bring nicknames with them, and that many so-called "Local Names" have a far less restricted meaning than is implied by the term. In view of the fact that many birds are known in Dumfriesshire by names which are misleading, the list of "Local Misnomers" (see p. XCIII) is worth attention.

I have been tempted by numerous enquiries on the subject, to give, very briefly in each case, an epitome of what is known as regards the distribution extraneous to Dumfriesshire of our visitors and visitants. The whole question of migration is as yet so imperfectly understood and is of so great magnitude that it is impossible, in such a book as this, to deal adequately with the subject; yet it is hoped that such information as is here given may not be without interest.

It is hardly necessary for me to point out that unless otherwise stated, the summary, given as a heading when dealing with each individual species, refers to the county as 
a whole. That is to say, a species described as " a resident" indicates that it is a resident in some part of, not necessarily throughout, the county ; but the text, it is hoped, will in each case elaborate the summary so as to make its meaning clear. As regards the value of the term "resident," the reader is referred to the chapter on Migration (see p. LXXIX).

Parishes are designated throughout the book by being placed in parentheses directly after the place-name to which they refer: thus :-Capenoch (Keir); denotes that Capenoch is in the parish of Keir.

It has been my endeavour in dealing with each bird to arrange the records in sequence, so as to obtain as far as possible a chronological history in every case.

Any species whose occurrence locally has seemed at all doubtful, has had attention drawn to it as such, by the use of square brackets, thus [ ]; a system advocated and used by Mr. J. A. Harvie-Brown in his Scottish faunas.

The "Solway Area" is so often mentioned throughout the following pages, that it may be well to state that this "area" covers all Dumfriesshire, Kirkcudbrightshire and Wigtownshire from the watersheds of the Esk and Liddel in the east, to the western seaboard of the last-named county: a considerable part of Cumberland, and portions of Ayrshire, Roxburghshire, and Northumberland, are also included.

The sub-title of this book announces it as " a contribution" to the fauna of the Solway Area; and it may be found of assistance when that larger work comes to be written-a task which it is hoped will be undertaken by Mr. Robert Service.

The majority of the places mentioned in the text will be found marked in the map folded in at the end of the volume ; but its necessarily small scale has rendered it impossible to show them all.

Throughout this book, I have confined myself to those birds that have occurred in Dumfriesshire, and mention of external occurrences, or general distribution have only been 
made for the sake of comparison. I trust that the numerous references will be taken as proof of my indebtedness to the authorities I have so often quoted; and that the reader may find them useful in pursuance of the study of the subject. I need hardly add how much I shall at all times welcome any communications that may be addressed to me relative to the birds of Dumfriesshire ; and I only hope that the pleasure $I$ have had in compiling this volume, may in some degree be enjoyed by my readers.

Hugh S. Gladstone.

Capenoch,

Thornhill,

Dumfriesshire.

June, 1910. 


\section{CONTENTS.}

$\begin{array}{lllllllll}\text { Preface } & \ldots & \ldots & \ldots & \ldots & \ldots & \ldots & \text { Page vII }\end{array}$

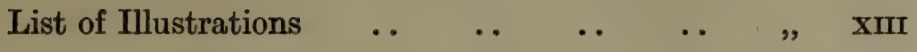

$\begin{array}{llllllll}\text { List } \text { of Subscribers } & \ldots & \ldots & \ldots & \ldots & , & \mathbf{x v}\end{array}$

Ornithologists of Dumfriesshire $\quad \ldots \quad \quad \ldots \quad \quad, \quad \quad$ xxv

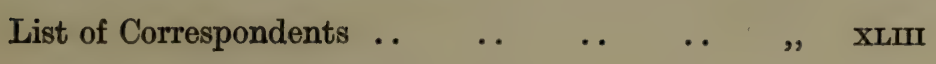

$\begin{array}{llllllll}\text { Bibliography } & \ldots & \ldots & \ldots & \ldots & \ldots & , & \text { xLIX }\end{array}$

Physical Features and Climate of Dumfriesshire $\quad$, $\quad$ Lxv

$\begin{array}{llllllll}\text { Migration .. } & \ldots & \ldots & \ldots & \ldots & \ldots & , & \operatorname{LxxIX}\end{array}$

$\begin{array}{llllllllll}\text { Flight-Nets } & \ldots & \ldots & \ldots & \ldots & \ldots & , & \mathbf{L x x x v}\end{array}$

$\begin{array}{llllllll}\text { Protection } & \ldots & \ldots & \ldots & \ldots & \ldots & , & \text { LXXXVII }\end{array}$

Local Misnomers and Names $\ldots \quad \ldots \quad \ldots \quad \ldots \quad$, $\quad$ xcm

$\begin{array}{lllllll}\text { Number of Species } & \ldots & \ldots & \ldots & \ldots & , & \text { xCVII }\end{array}$

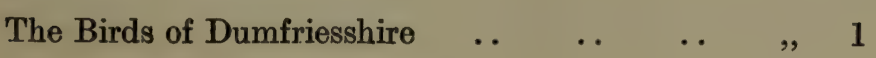

$\begin{array}{lllllllll}\text { Index } & \ldots & \ldots & \ldots & \ldots & \ldots & \ldots & , & 473\end{array}$ 



\section{LIST OF ILLUSTRATIONS.}

Nithsdale from Glenhead. (From a photograph by Mr. D. Legard)

-. Frontispioce

To face page

View above Langholm from Warblaw Hill. (From a photo-

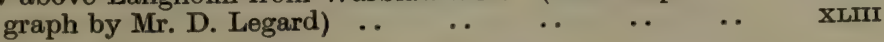

The River Esk at Gilnockie Bridge. (From a photograph

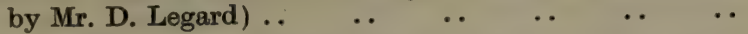

LXVII

Nest and Eggs of the Ring-Ouzel (Turdus torquatus). (From a photograph by the Author) $\quad$. $\quad$. . $\quad$.. $\quad$..

The Haunt of the Dipper (Cinclus c. britannicus) on Capel Burn. (From a photograph by Mr. D. Legard).. . .

Nest and Eggs of the Grey Wagtail (Motacilla melanope). (From a photograph by the Author) . $\quad$.. $\quad$.

Pied Flycatcher (Muscicapa atricapilla) at the Nest. (From a photograph by Mr. D. Legard) .. $\quad \ldots \quad$.. $\quad .$.

The Two-barred Crossbills (Loxia bifasciata) shot at Dardarroch (Glencairn), March lst, 1890 . (From a photograph

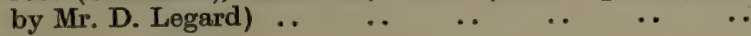

Nightjar (Caprimulgus europous) on the Nest. (From a photograph by Mr. D. Legard) $\quad$. $\quad$.. $\quad \ldots \quad$..

British Great Spotted Woodpecker (Dendrocopus major anglicus) at the Nest. (From a photograph by Mr. D. $\begin{array}{llllllll}\text { Legard) } & \ldots & \ldots & \ldots & \ldots & \ldots & \ldots & \ldots\end{array}$

Egg of the Cuckoo (Cuculus canorus) in a Nest of the MeadowPipit (Anthus pratensis). (From a photograph by the Author)

Short-eared Owl (Asio accipitrinus) on the Nest. (From a photograph by Mr. F. Barber-Starkey) .. $\quad$.. . .

Loch Skene. (From a photograph by Mr. D. Legard) .

The Night-Heron (Nycticorax griseus), shot on Cluden Water in 1825. (By permission of the Royal Scottish Museum, $\begin{array}{llllllll}\text { Edinburgh) } & \ldots & \ldots & \ldots & \ldots & \ldots & \ldots & \end{array}$

The Solway Firth at Sarkfoot. (From a photograph by Mr.

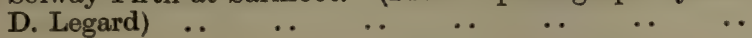


The American Blue-winged Teal (Querquedula discors) obtained in Upper Nithsdale in 1858. (By permission of the Royal Scottish Museum, Edinburgh) .. ..

Nest and Eggs of the Tufted Duck (Fuligula cristata). (From a photograph by Mr. D. Legard) .. $\quad$. $\quad \ldots \quad$..

Greyhen (Tetrao tetrix) on the Nest. (From a photograph by

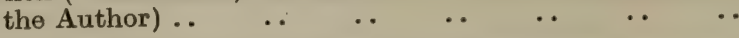

Nest and Eggs of the Golden Plover (Charadrius pluvialis). (From a photograph by Mr. D. Legard) .. .. ..

The Black-winged Stilt (Himantopus candidus). From Sibbald, Scotia Illustrata (1684), Tab. XI., Fig. 1. Drawn from the actual specimen "shot ... at a lake near the town of Dumfries." (From a photograph

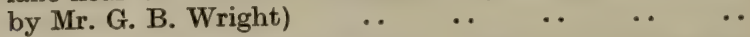

Snipe (Gallinago coelestis) on the Nest. (From a photograph

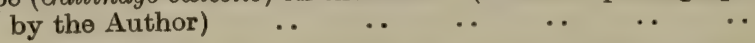

Nest and Eggs of the Common Sandpiper (Totanus hypoleucus). (From a photograph by Mr. D. Legard) ..

The Whiskered Tern (Hydrochelidon hybrida) shot near Friar's Carse (Holywood) on May 28th, 1894. (By permission of the Royal Scottish Museum, Edinburgh) .. ..

Nesting-colony of the Black-headed Gull (Larus ridibundus). (From a photograph by Mr. D. Legard) .. .. . 


\section{LIST OF SUBSCRIBERS.}

Alexander, C. J., B.Sc.

Baird, J. G. A.

Balfour-Browne, V. R.

Barber, William, M.A.

Barber-Starkey, F. W. G., B.A.

Barber-Starkey, W. H. J.

Barbour, Miss.

Bates, Lady Constance.

Bateson, Mrs. Frank.

Baxter, Miss Evelyn V.

Bayne-Jardine, The Rev. D.

Bedford, Her Grace the Duchess of

Bedford, His Grace the Duke of

Bell, Mrs. Henrietta

Bell, Will., A.R.I.B.A. (2 copies.)

Black, The Rev. David, M.A.

Blackwood, G. G.

Bonar, Rev. H. N., F.Z.S., M.B.O.U.

Bonhote, J. L., M.A., F.L.S., F.Z.S.

Borland, John.

Brook, Charles.

Brook, E. J., M.B.O.U.

Brooke, John A., J.P., M.B.O.U.

Brown, Stephen.

Brown, Thomas $\mathrm{M}$.

Brown, Tom.

Brown, William.

Bryce, Mrs. A. 
Buccleuch, His Grace the Duke of, K.G., K.T.

Buchanan, J. Hamilton.

Buchanan, Keith.

Buxton, Lionel, M.V.O.

Caird, Patrick T.

Campbell, W. Middleton.

Campion, Sheriff.

Carlisle Museum.

Carlyle, William Lee.

Carroll, C. J., M.B.O.U.

Carruthers, Major F. J.

Carruthers, John J., M.B.

Cassillis, The Rt. Hon. the Earl of.

Chapman, Abel, M.B.O.U., F.Z.S.

Chisholm, The Right Rev. Bishop.

Clark, James, M.A., D.Sc., A.R.C.S.

Clark, The Rev. Thomas.

Cole, A. C.

Cook, Chas., W.S.

Corrie, John.

Couper, The Rev. David.

Coward, T. A., F.Z.S.

Crewe, Sir V. H., Bart.

Crichton-Browne, Sir James.

Crichton Royal Institution, Dumfries.

Cross, Miss.

Darell, Captain W.

Davidson, James, F.Z.S., M.B.O.U.

Dear, L. S.

Dewes, Hugh W.

Dickson, Miss.

Dickson, Charles W.

Dinwiddie, L. M., J.P. 
Drummond, Bernard G.

Dudgeon, Colonel.

Dumfries Book Club, Ewart Public Library, Dumfries.

Dumfriesshire and Galloway Natural History and Antiquarian Society.

Duncan, John Bryce.

Dunlop, Eric B.

Easterbrook, C. C., M.A., M.D., F.R.C.P.Ed.

Edgar, Irving.

Evans, William, F.R.S.E.

Ferguson, Major S. C.

Fletcher, Mrs. G. L.

Galbraith, Charles E.

Gilchrist-Clark, Mrs.

Gilmour, Sir John, Bart.

Gladstone, Arthur S.

Gladstone, Ernest S.

Gladstone, Miss Helen S.

Gladstone, Henry N.

Gladstone, Sir John, Bart.

Gladstone, J. S.

Gladstone, Robert, LL.D., J.P.

Gladstone, Robert, Junr., B.C.L., M.A.

Gladstone, Mrs. Steuart. (5 copies.)

Gladstone, Walter L.

Goodall, J. M., M.B.O.U., F.Z.S.

Gordon, H. S.

Gordon, J. G.

Gordon, Robert.

Gould, Edward. (2 copies.)

Graham-Hutchison, Captain. 
Gray, Leonard.

Greaves, A. R.

Gurney, J. H., F.Z.S., M.B.O.U.

Hall, Major H.

Halliday, Provost Wm. J., J.P.

Harley, Andrew.

Harvie-Brown, John A., F.R.S.E., F.Z.S., M.B.O.U., Hon.

Life Member, A.O.U.

Herries, Major W. D.

Hignett, Theodore.

Hislop, The Rev. Robert.

Hoggan, C. J.

Hollond, Edmund R., J.P.

Home, J. H. Milne.

Hope, Thomas.

Hough, Edwin Leadam.

Houston, James H.

Irving, Colonel.

Irving, H. Cavan.

Jardine, Sir Robert W. Buchanan, Bart.

Johnson-Ferguson, E. A.

Johnston, R. E.

Johnstone, J. J. Hope.

Johnstone, William.

Johnstone-Douglas, A.

Jourdain, Rev. F. C. R., M.A., M.B.O.U.

Kennedy, Colonel John.

Kennedy, J. M.

Keswick, J. J.

Kinnear, Norman B., M.B.O.U.

Kirke, D. J. Balfour. 


\section{LIST OF SUBSCRIBERS XIX}

Laidlaw, T. G., M.B.O.U.

Laing, Lady.

Lang, John.

Laurie, Cecil E.

Leach, Richard H. W.

Lings, G. H., M.B.O.U.

Lumsden, James, F.Z.S., M.B.O.U.

Lyon, J. Stewart.

Macara, Graham F.

McBurnie, John.

McCall, Major William.

McConnel, J. I.

McDowall, The Rev. Wm., M.A.

McJerrow, David.

Mackenzie, Colonel E. P., J.P., D.L.

MacKenzie, W. Dalziel.

McKerrow, M. H.

McKerrow, Matt. S., J.P.

McKie, Major John, D.S.O.

McKie, Fleet-Engineer John, R.N.

Macmillan, $\mathbf{R}$.

Macmillan, Thomas M.

MacRae, D. M.

Marshall, James McL., F.Z.S.

Marsham-Townshend, Hugh S.

Martin, Henry. (2 copies.)

Martin, Robert.

Massey, Herbert, M.B.O.U., F.Z.S.

Mather, Lady.

Mathieson, Robert, F.R.S.E., F.C.S.

Maxwell, Francis Xavier.

Maxwell, Wellwood.

Maxwell, W. J.

Maxwell, W. J. H. 
Maxwell-Scott, Captain Walter.

Miller, Frank.

Mitchell Library, Glasgow.

Molteno, P. A., M.A., LL.M., M.P.

Monteith, Mrs.

Moore, Charles Henry.

Morris, Arthur M.

Mullens, W. H., F.L.S., M.B.O.U.

Murray, Patrick.

Murray, William.

Nichols, Walter B., J.P., M.B.O.U.

Nicholson, Francis, F.Z.S., M.B.O.U.

Oldham, Chas., F.Z.S., M.B.O.U.

Oliver, Edm. Ward.

Oliver, Sir Thomas, M.D.

Osselton, Christopher.

Oswald, The Rev. James Honeyman, M.A.

Parker, Frederick Cyril F.

Parker, Thomas Cowper.

Paterson, David.

Paterson, J. Jardine.

Paterson, R. Jardine.

Paterson, William.

Paton, E. Richmond, M.B.O.U., F.Z.S.

Pemell, James.

Penman, Andrew Clark, J.P.

Phillips, The Rev. C. T.

Phillips, Mrs.

Pickering, Robert Young.

Prevost, Sir Augustus, Bart., F.S.A.

Proudfoot Endowment, Moffat, Trustees of. 
Ralston, C. W.

Ranken, Thomas. (2 copies.)

Rankine, A.

Reid, John.

Richards, Lewis M.

Rimmer, Miss.

Roberts, A. W. Rymer.

Robertson, J. Mair, M.B., C.M.

Robinson-Douglas, W. T.

Robson, George $\mathrm{H}$.

Robson, John.

Ross, Rev. D.

Ross, J. Maxwell, M.A., M.B., F.R.C.S, Ed.

Russell, George.

Sanders, Mrs.

Scott, Rev. Canon.

Scott, William, M.B., C.M., J.P.

Shakerley, Miss.

Sharp, T. W.

Sheldon, Edward Rider.

Signet Library, Edinburgh.

Smalley, F. W., M.B.O.U.

Smith, E. T. Leeds.

Smith, H. F.

Stanley, Mrs. (2 copies.)

Stanley, William.

Steel, Arthur J.

Steele, James E.

Stewart, Rev. E. H.

Stewart, Sir Mark McT., Bart., M.P.

Stirling, Mrs.

Stonham, C., F.R.C.S., F.Z.S., M.B.O.U.

Symons, J., F.L.S. 
Talbot, Mrs. G. C.

Talbot, G. A.

Taylor, Richard S.

Terry, Major Horace.

Theobald, Fred. V., M.A., F.E.S., Hon. F.R.H.S.

Thomson, Professor Alexis, M.D.

Thomson, A. Landsborough.

Thorpe, D. Losh, M.B.O.U.

Ticehurst, N. F., M.A., M.B., F.R.C.S. Eng., F.Z.S.

M.B.O.U.

Turner, Alexander, M.P.S.

Vane, Dowager Lady.

Veitch, G. Douglas.

Veitch, Walter Hardie.

Wadd, H. W. F.

Walker, Captain G. L.

Walker, Lady. (2 copies.)

Wallace, James.

Wallace, James R. W.

Wallace, S. Williamson.

Watson, $\mathrm{T}$.

Watt, Andrew, M.A., F.R.S.E.

Watt, James, B.A. Oxon.

Wheat, John B., M.A.

White, John.

Whymper, Charles, F.Z.S., M.B.O.U.

Wightman, John.

Wiglesworth, Joseph, M.D., M.B.O.U.

Will, George.

Williams-Wynn, R. W.

Williamson, N. A.

Witherby, Harry F., F.Z.S., M.B.O.U., F.R.G.S.

Woollcombe, H. L. 


\section{LIST OF SUBSCRIBERS XXUI}

Young, J. J. Baldwin, M.A., M.B.O.U.

Young, Harold Edward.

Young, Miss.

Younger, William, M.P.

Zoological Society.

\section{BOOKSEL̇LERS.}

Blacklock, W.

Brockhaus, F. A.

Brown, William.

Bryce, William.

Bumpus, J. \& E., Ltd.

Douglas \& Foulis.

Dulau \& Co.

Forrester, Robert.

Harrison \& Sons.

Howell, Edward.

Lamley \& Co.,

Maxwell, J., \& Son.

Menzies, John, \& Co.

Oliver \& Boyd.

Porter, R. H.

Simpkin, Marshall \& Co.

Snaith, G. C.

Sotheran, H., \& Co.

Thurnham \& Sons.

Wheldon, John, \& Co.

Young, Henry, \& Sons. 



\section{INTRODUCTION.}

\section{THE ORNITHOLOGISTS OF DUMFRIESSHIRE.}

I HAVE been at some pains to give a biography, necessarily very short, of, so far as possible, all those who, by the observations they have left behind them, seem to have been acquainted with the bird-life of Dumfriesshire.

William Macgillivray, Alfred Newton, and other eminent ornithologists have sojourned in the county, and have duly recorded their local observations, but their inclusion under this title seems unwarrantable. Other ornithologists, certainly of Dumfriesshire, such as Sir John Richardson, have contributed little or nothing towards the avifauna of the county, but their mention here becomes obligatory in view of their birthright. The task of elimination has been difficult and the result therefore may be unsatisfactory ; for while many of those whose biographies are included could scarcely claim the rank, yet others were indisputably ornithologists of the highest standing. As regards living ornithologists and contributors, the reader is referred to the "Bibliography" (p. XLIX), and "List of Correspondents" (p. xLIII).

Aird, Thomas, b. at Bowden, Roxburghshire, August 28th, 1802. Educated at the schools of Bowden, Melrose, and at Edinburgh University, where he was the companion of James Hogg, Thomas Carlyle, and De Quincey. He published his first poetical work, Martzoufle, in 1826, and his Collected Poems in 1848. He was a frequent contributor to Blackwood's Magazine, and was editor of the Dumfries and Galloway Herald from 1835 to 1863 . On the 6th of December, 1864, he read a paper to the Dumfriesshire and Galloway Natural History and Antiquarian Society, 
entitled Notes on Birds, taken in 1864, at Mountainhall, a mile east from Dumfries ; in which he asks, "Is it possible to classify . . migrations of birds on a geological basis ?" He himself says, "I am not a naturalist, in the usual sense of the term ; but I take a living interest in the characters, habits, and fortunes of my country neighbours, the birds." Many quotations throughout this volume from his poetical works, testify to his knowledge of bird-life, no less than to his skill as poet. He died April 25th, 1876.

Archbald, Dr. George, son of Rev. Robert Archbald, " minister of Dunscore from 1651 to 1662 , and one of the four hundred uncompromising Presbyterians, who, on the re-establishment of Episcopacy by Charles II., gave up their livings in the Church of Scotland rather than do violence to their convictions"; $*$ he died in Edinburgh in 1688. George Archbald, b. 1645 or 1646 , adopted the medical profession, and eventually became one of the leading physicians of Dumfries ; being entered as a Burgess of the Burgh, May 4th, 1668. I have frequently quoted from his "Account of the Curiosities at Drumfriess," and have given the date of this manuscript as written "circa 1684." This I have done in the belief that it was sent through some common friend to Sir Robert Sibbald, in answer to the latter's circular addressed to men of education throughout Scotland, asking for information for his Scotia Illustrata. There is, however, internal evidence which seems to show that at least part of the manuscript was written subsequent to 1707 . A small quarto volume, entitled "Sibbald's MS. Collections" (which I have seen in the Advocates' Library at Edinburgh), contains, with several other similar manuscripts, a copy of this "Account." It includes information concerning the county of Dumfries, its "fishes, fowls, quadrupeds, insects, fossils, wells, and serpents." Under "fowls " are interesting references to the Bittern, Jay, Snipe, etc. Dr. George

* Trans. D. and G. Nat. Hist. Soc., March 8th, 1901. 
Archbald died at Dumfries July 6th, 1715, and was buried in St. Michael's Churchyard. The inscription on his tombstone describes him as " Mr. George Archibald, Doctor of Physick. Clarus in arte fuit emdica, pius, æquus, amator doctrinæ et morum, lepidus, cunctisque benignus."*

Bell, Richard, b. September 12th, 1833. Son of George Graham Bell, advocate. Educated at Dollar Academy. For many years tenant of the extensive sheepfarms of Tanlawhill (Eskdalemuir), and Billholm (Westerkirk). Succeeded his nephew Graham Bell as proprietor of Crurie and Castle O'er (Eskdalemuir) in 1876. He was a friend and correspondent of Frank Buckland. A keen naturalist, he contributed a paper, entitled Some Bird Notes from Eskdale, to the Transactions of the Dumfriesshire and Galloway Natural History and Antiquarian Society, April 17th, 1901. During his lifetime he kept many birds and animals in captivity and was the first to breed Emus in Scotland. In 1905 he published My Strange Pets and other Memories of Country Life, a book frequently laid under contribution throughout this work. He died May 25th, 1909.

Burgess, Rev. Dr. JoHN, b. 1725. Educated at the University of Glasgow. Licensed by Presbytery of Kirkcudbright May 1st, 1754. Presented to Kirkmichael by Charles, Duke of Queensberry and Dover, January 19th, and ordained, June 26th, 1759. D.D. University of Edinburgh, April 11th, 1769. Minister of Kirkmichael till his death, September 2nd, 1795. He compiled the account of that parish (1791) for the Statistical Account of Scotland (vol. i., pp. 54 64), and states therein (p. 60), "there is great plenty of the rarer species of birds. . . the pine and the common bulfinch, the wryneck," etc. This record of the occurrence locally of the Pine Grosbeak, has often been referred to in subsequent ornithological works; but it is not known that Dr. Burgess had

* He was distinguished in the medical profession, pious, just, a lover of good principles and conduct, cheery, and kind to all. 
any special knowledge of ornithology sufficient to validate his statement. He was an acknowledged botanist, and the Rev. John Lightfoot in his Flora Scotica writes of him thus: "To the Rev. Dr. Burgess, of Kirkmichael, in Dumfriesshire, I am eminently indebted for the botany of the Lowlands. Unsolicited and without reserve, he was ready to impart all the botanical discoveries he had made during the course of many years. To him I am likewise obliged for the provincial names of plants, or those made use of by the common people of the country."* Robert Riddell, of Glenriddell, says of him : "This clergyman was considered as one of the first Botanists in Scotland by Linnæus, and I have seen letters from Linnæus to Dr. Burgess in the highest degree flattering to him." $\dagger$

Bushnan, Dr. John Stevenson, b. ? 1808. M.D. Heidelberg; qualified as a practitioner in Edinburgh, 1830. At one time surgeon in Dumfries. A writer on medical subjects, he edited in London The Medical Times and Gazette, 1849-1852. He wrote in 1834, An Introduction to the Study of Nature, and in 1840, Ichthyology. Fishes, Particularly their Structure and Economical Uses. (vol. ii., Jardine's Naturalists' Library). He also contributed ornithological notes (some of them local) to the Edinburgh Journal of Natural History. Dr. Bushnan was an F.R.S.E. and F.L.S., and a correspondent of Sir William Jardine. His latter days were blighted by misfortune, and his sight failing, he became a "poor brother" of the Charter House, where he died on February 17th, 1884.

Carrothers, William Thomas, of Dormont (Dalton), and Arthington Hall, Yorkshire, b. January 31st, 1799. $\mathrm{He}$ was of an artistic and poetical temperament. He formed a large collection of British birds, which cannot now be traced. Specimens of a locally

* Flora Scotica, 1777, Vol. I., p. xiii.

† Robert Riddell's MS. Notes to Stat. Act. Scot. 
obtained Smew, and of a hybrid between a Mallard and a Pintail are known to have been in this collection. He was a friend and correspondent of Sir William Jardine, to whom he sent a collection of birds from Madeira. J.P. and D.L., Dumfriesshire. $\mathrm{He}$ died October 26th, 1848.

Clark Kennedy, Captain Alexander William Maxwell, eldest son of Colonel John Clark Kennedy, C.B., of Knockgray, Kirkcudbrightshire, b. September 26th, 1852. Educated at Eton. At the age of sixteen published The Birds of Berkshire and Buckinghamshire. On leaving Eton he obtained a commission in the Coldstream Guards. Lieutenant 1872. Captain 1874. His love of travel and his enthusiasm for sport induced him to retire from the army on being gazetted Captain. From that date he gave himself up to a country life, residing for the most part at Knockgray. He published in 1878 To the Arctic Regions and Back in Six Weeks ; in 1884 Robert the Bruce, a poem historical and romantic. He was a frequent contributor to the Zoologist, Field, Baily's Magazine, and Land and Water. A friend and correspondent of Mr. J. E. Harting. His home at Knockgray was but a few miles beyond the confines of Dumfriesshire, and many of his ornithological observations were made in Nithsdale, 1874-1876. Captain Clark Kennedy was an F.Z.S., F.L.S., F.R.G.S., M.B.O.U., etc. "A good sportsman and an accomplished naturalist." He died on December 21 st, 1894.

Gibson, William George, b. at Dumfries, December, 1828. Son of Dr. John Erskine Gibson, who was surgeon to at least one of William Scoresby's Arctic Expeditions, and died January, 1833, at Milnhead (Kirkmahoe). William George Gibson was a collector of antiquities, and at one time secretary to Dr. J. Gilchrist, of the Crichton Royal Institution, Dumfries. Appointed first treasurer of the Dumfriesshire and Galloway Natural History and Antiquarian Society at the Society's 
initiation on November 20th, 1862. A correspondent of A. G. Moore ("Distribution of Birds in Great Britain during the Nesting Season." Ibis, 1865, pp. 119-142 and 425-458). A contributor to Notes for Naturalists, and The Naturalist. To him we owe the first record of the Blue-winged Teal in Europe (Naturalist, 1858, vol. viii., p. 168). He died 1890.

Gray, Robert, b. at Dunbar, August 15th, 1825. Son of Archibald Gray, Merchant. Educated at the parish school. In 1840 he became an apprentice in the British Linen Company's Bank at Dunbar. Five years later he went to Glasgow, where he entered the City of Glasgow Bank. There he attained the position of travelling inspector. Always a keen naturalist, he had in this capacity many opportunities for making the acquaintance of ornithological correspondents in various centres in the West of Scotland. In Dumfries, his two principal were George Kirkpatrick and Thomas Corrie. He was elected a corresponding member of the Dumfriesshire and Galloway Natural History and Antiquarian Society on December 4th, 1862. In 1869 he, with Thomas Anderson, published The Birds of Ayrshire and Wigtownshire; and in 1871, The Birds of the West of Scotland. He was one of the founders of the Natural History Society of Glasgow in 1851 (Secretary 1858 to 1871). In 1874 he entered the Bank of Scotland at Edinburgh, and became cashier in 1882, which appointment he held till his death. In 1877 he accepted the secretaryship of the Royal Physical Society of Edinburgh, and by his energy restored that society to useful activity. In 1882 he was elected Vice-President of the Royal Society of Edinburgh. He died February 18th, 1887. Robert Gray cannot strictly be considered " an Ornithologist of Dumfriesshire," but from the numerous references to our local Avifauna in his works above quoted, there is abundant proof that he was acquainted with the bird-life of Dumfriesshire; the inclusion, therefore, of this short biography would seem justifiable. 
Grierson, Dr. Thomas Boyle, only son of William Grierson draper in Dumfries. b. February 19th, 1818. Educated at Edinburgh. After obtaining his degree as a Doctor of Medicine he resided for a short time at Elvanfoot, removing to Thornhill in 1842. Shortly afterwards he went to Moniaive, but on the requisition of the residents of Thornhill he returned there and, worked up an extensive practice. He was one of the founders of the Dumfriesshire and Galloway Natural History and Antiquarian Society in 1862 and contributed many papers to the subsequent Transactions of that Society. During his residence at Thornhill, he formed a miscellaneous collection of fossils, shells, anatomical and botanical specimens, antiques, stuffed birds, eggs, manuscripts, books, etc., etc. Having been granted a site together with building material by the then Duke of Buccleuch, the foundation stone of his "Museum" was laid on June 22nd, 1869, but it was not till July, 1872, that it was open to the public. Grierson's MS. Notes, and his "Running Catalogue of the Contents of My Museum," 1860-1875, have been laid under frequent contribution throughout this volume. At his death on October 3rd, 1889, he bequeathed his "Museum" to the village, with $£ 1,000$ for upkeep. The collection in 1894 was valued at $£ 5,000$. His memory is still cherished in the district, and as recently as 1908 , when speaking to a carpenter who had assisted in the construction of the various glass-cases in the Museum, I was told that " the only way to make the Doctor angry was to say some object of Nature was ugly; such a remark invariably resulted in the order-' get out of this!'”

Hastings, William, b. 1811, in Glencairn Parish. Was employed as under-gardener at Drumlanrig and Closeburn, and head-gardener at Gribton (Holywood) in 1852. As taxidermist at Dumfries, in a good way of business from 1860-1885, he received many consignments of birds' skins from Indian officers. A frequent contributor, 1879-1889, of "Notes on Birds," to the Transactions of the Dumfriesshire and Galloway 
Natural History and Antiquarian Society, of which Society he was elected a member on January 6th, 1863. A friend of Mr. R. Service, and thoroughly reliable in his general facts, if somewhat doubtful as regards dates. He died 1893 . The frequent mention of his name throughout this volume testifies to his having been in his day one of the most successful bird-stuffers in the south of Scotland. Many of the birds he mounted, especially Hawks and Owls, were perfect examples of artistic excellence.

Howter, William Graham, b. 1877. Son of Mr. David Hunter, Shearington (Caerlaverock). A contributor of natural history sketches of much merit to the Dumfries and Galloway Courier and Herald. He died on January 18th, 1908, and his loss as a field-naturalist is much to be deplored.

Jardine, Sir William, Bart., of Applegarth, b. February 23rd, 1800, in Edinburgh. He was, to use his own words, sent to York "to learn English," and subsequently to Edinburgh and Paris to study medicine. On the death of his father Sir Alexander in 1821, he succeeded as seventh Baronet, and took up his duties as a large landed proprietor in the county, residing at Jardine Hall (Applegarth). Deputy Lieutenant of the county of Dumfries, 1841. In 1860 was appointed one of the Royal Commissioners on Salmon Fisheries in England and Wales. Amongst many other works, he published with P. J. Selby in 1825-1843, Illustrations of Ornithology, and in 1833-1843 "conducted" the Naturalist's Library in forty volumes. His list, written in 1832, of the birds of the parish of Applegarth and Sibbaldbie (New Statistical Account of Scotland, 1845, vol. iv., pp. 178-182), is frequently referred to throughout this volume. He published Contributions to Ornithology, 1848-1852; Calendar of Ornithology, 1849 ; Illustrations of the Duck Tribe (Dumfries, N.D.); Ichnology of Annandale, 1853; Memoirs of Hugh Edwin Strickland, 1858; Birds of Great Britain and 
Ireland, 1876 ; etc. Editions of Gilbert White's Natural History of Selborne in 1829, 1850, 1853, and 1880, contain notes by him, as also Alexander Wilson's American Ornithology, 1832. He was a frequent contributor to the scientific magazines of his day. In 1837 he acted with P. J. Selby and Dr. Johnston as co-editor of the Magazine of Zoology and Botany which in 1838 became Annals of Natural History, and in 1841 Annals and Magazine of Natural History. $\mathrm{He}$ was also for some years a joint-editor of the Edinburgh Philosophical Journal. Sir William Jardine was elected a Member of the Wernerian Society on December 2nd, 1820; Member of Council, 1823 ; and Vice-President, 1826. Member of the Berwickshire Naturalists' Club, 1832; President, 1836. He took a keen interest in the Dumfriesshire and Galloway Natural History and Antiquarian Society, of which he was President on its inauguration on November 20th, 1862. He was also LL.D., F.R.S., F.R.S.E. He died at Sandown, Isle of Wight, on November 21st, 1874, his remains being interred at Applegarth Parish Kirk on November 27th. I have been fortunate in having had access to many MSS., notes, letters, etc., by him, and numerous sketches therein testify to his abilities as a draughtsman. The sale of his collection of birds by Messrs. Puttick and Simpson on June 17th, 1886, only realised $£ 216$, but ten years previously his main collection of British birds had been sold to the Edinburgh Museum for $£ 200$. Some of these specimens can still be seen in the Royal Scottish Museum, Edinburgh, in wonderfully good preservation. The illustrations in this volume of the Blue-winged Teal and Night-Heron, thanks to the courtesy of the officials of the above-mentioned Museum, are taken from the actual birds formerly in Sir William's collection.

Laidlaw, WiLliam, b. November 19th, 1780. "The friend, factor and amanuensis of Sir Walter Scott." $\mathrm{He}$ "was a Borderman, but after the death of Sir 
Walter Scott he left Kaeside, where he at that time resided, on the Abbotsford Estate, and became manager on the estate of Coul, Ross-shire, afterwards going in the same capacity to Balnagowan."* An author of lyrics. Compiled under the direction of his patron part of the Edinburgh Annual Register after 1817. An able and observant field-naturalist, who above his initials, W.L., frequently contributed to the Magazine of Natural History; notably articles concerning Eagles at Loch Skene, vol. i., 1837, pp. 118-122 and pp. 443-445. He died at Marybank near Balnagowan on May 18th, 1845.

Little, Rev. William, b. 1798, or 1799. Minister of Kirkpatrick-Juxta, 1841-1867. An accepted authority on entomology, a keen student of botany and ornithology, and a correspondent of Sir William Jardine. Assisted Andrew Murray in the compilation of his Catalogue of the Coleoptera of Scotland, 1853. Died February 17th, 1867. The small remnant of his collection of birds, mostly obtained in his parish, is now in the possession of Mr. R. Service.

McDiarmid, John, b. (it is stated) in Edinburgh 1790. Son of Rev. Hugh McDiarmid, minister of the Gaelic Church, Glasgow. He was educated at Edinburgh, being mainly self-taught, and became a clerk in the Commercial Bank of Edinburgh. A frequent contributor of poetry to Blackwood's Magazine and other journals, his poems on the stirring events of 1815 brought him into literary prominence, and meanwhile he had risen to a high position in the bank. In 1816, together with his friends Charles Maclaren and William Ritchie, he was considering the production of a new weekly magazine, which resulted on January 25th, 1817, in the appearance of The Scotsman. A few weeks previously John McDiarmid had been appointed editor of the Dumfries and Galloway Courier. His editorial duties left him little time for other writing, but in that year he

* Vertebrate Fauna of the Moray Basin, 1895, Vol. II., pp. 297. 
published an edition of Cowper, with a life of the poet. In 1820, the first volume of The Scrap Book appeared. In 1823, he issued an edition of Goldsmith's Vicar of Wakefield, with a memoir of the author. In 1825, he started The Dumfries Monthly Magazine. In 1830, he wrote Sketches from Nature, which contain much ornithological information, referring chiefly to Galloway. In 1832, he published The Picture of Dumfries. He continued his duties as editor of the Dumfries and Galloway Courier till his death on November 18th, 1852. John McDiarmid had a deservedly high reputation as a naturalist, and " though holding the difficult position of a newspaper editor for thirty-six years, it may be truly said of him that he never made an enemy or lost a friend."**

Macpherson, Rev. Hugh Alexander, b. February 19th, 1858, at Calcutta. Educated at Haileybury, 1872, and Oriel College, Oxford, 1878. B.D. 1881. Inherited the Glendale Estates in Skye circa 1881. Ordained 1882, and commenced his clerical duties at St. James', Carlisle. Appointed to a curacy in London, 1885. Published with William Duckworth in 1886, the Birds of Cumberland. In 1888 returned to Cumberland as chaplain of Carlisle Gaol. In 1889 issued The Visitation of Pallas' Sand-grouse to Scotland in 1888. In 1892 published $A$ Vertebrate Fauna of Lakeland, and in 1897 A History of Fowling. In the same year he obtained the living of Allonby, Cumberland; but in 1899 was appointed to the charge of the Episcopal Church at Pitlochry, Perthshire, where he died on November 26th, 1901. The numerous references to the birds of Dumfriesshire, in the works above quoted, as also in the Scottish Naturalist, and Annals of Scottish Natural History, warrant the inclusion here of this short biography.

Maxwell, Thomas, b. 1808 at The Leys (Kirkmahoe). Butler at Dalswinton (Kirkmahoe), and later at Dabton (Morton). Entered the service of William

* Obituary Notice, Dumfries Courier, December 7th, 1852. 
Copland of Blackwood (Keir), as gamekeeper in 1837, and during the following fourteen years killed on that estate no less than one hundred and twentyeight foxes, besides other vermin. He was the principal bird-stuffer in Nithsdale, 1830-1864. On the death of his employer in 1851 he leased Allanton Mill (Dunscore) from the Duke of Buccleuch, till his death on January 1st, 1883. He had a family of eighteen, and is buried in the New Churchyard, Keir. $\mathrm{He}$ was a correspondent of Dr. Thomas Grierson, who writes of him in his MS. diary, October 17th, 1862 :- "He knew birds generally, but not scientifically." His two brothers, John (b. 1826, d. April 12th, 1905), and Robert (b. August 31st, 1830, d. April 12th, 1907), who lived together on Dalswinton Estate, were also both keen observers of nature.

Menteath, Sir James Stuart, Bart., b. 1792. Son of Charles Granville Stuart Menteath, of Closeburn. Member of the Wernerian Society, March 2nd, 1808; Member of Council, 1818, who was created Baronet, August 11th, 1838. A keen agriculturist and naturalist, he died December, 1847. James Stuart Menteath succeeded as second Baronet of Closeburn. Member of the Wernerian Society, December 7th, 1816. Published in 1838 a pamphlet of twenty-seven pages, entitled Farmers versus Rooks. This pamphlet, which was printed at Ayr, by Messrs. McCormick and Carnie, is now extremely rare. It sets forth "The substance of a trial supposed to have taken place in Ayrshire before a Committee of gentlemen appointed by the Agricultural Society of that county to consider the supposed damage done by Rooks to their tenantry." Many witnesses, such as Benrick [Bewick], Bushnan, Selby, and Macgillivray are called to testify to the utility of the species, which is, however, found "guilty," and the judges " pronounce sentence of death and extermination against every rookery in Ayrshire." I possess his copy of The Natural History of Selborne (New Edition, 1836), in which are some interesting notes in his hand, 
and in which his autograph is spelt as above.* $\mathrm{He}$ died on February 27th, 1870.

Murray, John DaLrymple, of Murraythwaite, b. June 5th, 1800. A friend of Sir William Jardine who accompanied him on board his yacht "Columbine " on a cruise round the north of Scotland. A keen collector of birds, but gave up this pursuit in 1827. In 1844 the "Bird-room" at Murraythwaite, where his collection was stored, was demolished in the enlargement of the mansion, and the specimens were dispersed to Carlisle, Dormont (Dalton), and Dumfries. He died on October 17th, 1863.

Richardson, Sir JoHn, b. at Nith Place, Dumfries, on November 5th, 1787. Eldest son of Gabriel Richardson, who was a brewer, Provost of the Burgh, J.P., and a great friend of Robert Burns: he died on January 26th, 1824. John Richardson entered Dumfries Academy 1795, and subsequently Edinburgh University to study medicine. In 1800 he acted as assistant to his uncle James Mundell, surgeon in Dumfries, and was house-surgeon at the Infirmary from 1804-1806. Appointed assistant surgeon in the Royal Navy 1807 , and saw much hard service in the war with France then waging. Served in the American war of 1815, and at its conclusion was retired on half-pay. He resumed his studies at Edinburgh, took his full medical degree, 1816 ; and commenced practice in Leith, 1817. Appointed surgeon and naturalist to Lieutenant John Franklin's Arctic Expedition, 18191822. On his return home, was presented with the freedom of the Burgh of Dumfries, June 28th, 1823. Elected Fellow of the Royal Society, 1825. Again surgeon and naturalist to Captain John Franklin's Expedition, 1825-1827. Physician to Royal Hospital, Haslar, 1838. Inspector of Hospitals 1840. Was knighted 1846. Leader of the search

* The spelling of this family name seems elastic : I have found the varying forms of Menteath, Menteith, Menteth, Monteath, Monteith and Montieth. 
party to discover and relieve Sir John Franklin, 1848-1849. Returning, he retired from public service. Created C.B. 1850 ; LL.D. (Dublin), 1857. He resided at Lancrigg, Westmorland; (the property of his wife), where he died on June 5th, 1865. The species Stercorarius crepidatus has been named after this eminent explorer and naturalist. His publications, chiefly on ichthyology and polar exploration, include Fauna Boreali-Americana, 18291837 ; Icones Piscium, or Plates of Rare Fishes, 1843 ; Journal of a Boat Voyage Through Rupert's Land and the Arctic Sea, 1851; and The Polar Regions, 1861. He also contributed largely to the Zoologies of H.M.S. "Blossom," 1839 ; "Sulphur," 1844 ; "Samarang," 1848 ; and "Herald," 1854.

Rimmer, Richard, of Dalawoodie (Holywood), b. May 25th, 1826. Educated at Liverpool and at Exeter College, Oxford. J.P. for the counties of Dumfries and Suffolk. A keen all-round naturalist and a high authority on conchology and malacology. One of the first scientists to employ photography in connection with natural history study. Elected a Fellow of the Linnæan Society, May 1st, 1879. Published in 1880 The Land and Freshwater Shells of the British Isles, the work being illustrated by photographs taken by the Albertype process under his personal supervision. In 1887 he went from Westbourne Crescent, Hyde Park, to St. Albans, and after two years in that town removed to Dumfries. He was elected a member of the Dumfriesshire and Galloway Natural History and Antiquarian Society, September 8th; and President, October 5th, 1888. From time to time he contributed interesting ornithological notes to the Transactions of that Society. He was one of the original members of the Dumfries and Maxwelltown Observatory Museum Committee, and succeeded the late Patrick Dudgeon of Cargen as President in April, 1895, which office he held till his death on August 19th, 1905. Richard Rimmer's large collection of mounted birds, most of which had 
been obtained in Dumfriesshire, was presented to the Observatory Museum about 1860, but perished by imprudent handling and neglect some ten years later. Fortunately his great conchological collection, presented by him and arranged by his own hands, may still be seen at the above Museum, intact and in beautiful condition.

Shaw, James, b. April 22nd, 1826. Schoolmaster for many years at the Upper School, Tynron. "He was steeped to the lips in Darwinism ...... Next to natural history in all its provisions, he was much interested in philology."* He read many papers, some of them containing ornithological references, to the Dumfriesshire and Galloway Natural History and Antiquarian Society. He was also a frequent contributor to Nature, and The Graphic. He died at Tynron on July 15th, 1890. His biography, entitled $A$ Country Schoolmaster, was published in 1899 by Professor Robert Wallace, in which is included his "Avifauna of Upper Nithsdale." $\dagger$

Shaw, JoHN, native of Dalkeith, b. 1797, is chiefly famous for the experiments he carried out in 1833-1836, to prove that Parr were the young of Salmon. His paper on this subject, read to the Royal Society of Edinburgh, December 15th, 1839, gained for him the Keith silver-medal from that Society, besides a silver-salver. He was a correspondent of Sir William Jardine and Dr. Thomas Grierson. $\mathrm{He}$ introduced Grayling and Roedeer, attempted but failed to establish either the Virginian Quail or Capercaillie, as also to re-establish the Ptarmigan in the county. The Blue-winged Teal recorded as obtained in 1858 is said to have been shot by him near Drumlanrig. He was elected a member of the Dumfriesshire and Galloway Natural History and Antiquarian Society, November 3rd, 1863. After forty-six years' service as gamekeeper in the employ-

* A Country Schoolmaster, pp. xxxi., xxxij.

† Op. cit., pp. 287-290. 
ment of the Duke of Buccleuch in Upper Nithsdale, John Shaw died on March 13th, 1867, and was buried in Penpont Parish Kirkyard.

SnNger, Rev. Dr. William, b. 1764, native of Aberdeenshire, son of James Sinziur. Educated at University and Marischal College, Aberdeen. Appointed schoolmaster at Kilmalie (Aberdeen), May 6th, 1789. Presented to Wamphray by James, Earl of Hopetoun, in August, and ordained October 23rd, 1794. Translated to Kirkpatrick-Juxta, July 12th, 1797. D.D. University of Edinburgh, September 19th, 1808. Moderator of the General Assembly, May 20th, 1830. After forty-three years' ministry he died at Kirkpatrick-Juxta, October 27th, 1840. Dr. Singer, who was a Justice of the Peace, was an eminent agriculturist, and was often employed as an arbitrator. He published several theological works : contributed four articles to the Edinburgh Encyclopoedia: and papers by him appear in The Transactions of the Highland Society. He compiled the accounts of the parishes of Wamphray, Moffat, and Kirkpatrick-Juxta: as also the general observations on the county of Dumfries, for the Statistical Account of Scotland (1791-1798). He published in 1812, General View of the Agriculture, State of Property, and Improvements in the County of Dumfries. In several of the above-mentioned publications there are interesting references to local birds.

Stewart, Willtam, b. 1739. Third son of Charles Stewart, of Appin, Argyllshire. Present as a boy of seven in the rear of the Highland Army at Culloden in 1746, where his father fought in the fighting line. In 1773 he left Argyllshire, and bought the small estate of St. Michael's (Dryfesdale). A few years later he undertook the management of the Marquis of Annandale's estates, and resided at Hillside near Lockerbie. In 1794 he wrote the description of the parish of Hutton and Corrie for the Statistical Account of Scotland (vol. xiii., pp. 567-581), in which he states 
his opinion (p. 580) that the Carrion and Hooded Crows are one and the same species. He also records a Heronry at "Shaw on Dryfe, where hundreds are bred yearly " (loc. cit.). D.L. Dumfriesshire. He died about 1833.

Thorburn, Lieutenant-Colonel William Stewart, son of James Stewart Thorburn, Barrister, Inner Temple, London. b. 1838. Educated at Dumfries and Edinburgh. Entered Army: Lieutenant, First Royal Regiment, but exchanged to Pay Department. He was an enthusiastic collector of coins, butterflies, birds, eggs, etc. In 1883 he published $A$ Guide to the Coins of Great Britain and Ireland (second edition, 1888). In Notes for Naturalists, he recorded many interesting local observations on birds above the initials W.S.T., notably the occurrence of the Quail in Lochar Moss (pp. 70 and 107), a white-headed Wren (p. 47), etc. At the time of his death, in 1886, he was Lieutenant-Colonel, and chief Paymaster in Ireland.

WaLKer, Rev. DR. John, D.D., b. 1731 " in the Cannongate suburb of Edinburgh, and received his education at the grammar school of that district, of which his father was at the time rector."* He entered the University to further his education for the Ministry. Appointed to the parish of Glencorse (Midlothian), seven miles from Edinburgh, September 13th, 1758. While here he began his lifelong friendships with Lord Kames and Lord Woodhouselee. On July 13th, 1762, he was presented to the parish of Moffat by the Earl of Hopetoun, where he remained till 1764. In that year he was appointed by the Commissioners of Annexed Estates on the recommendation of Lord Kames, " to make a survey of the Western Isles with regard to their moral and physical state and capabilities for improvement." $\dagger$ This itinerary lasted seven months, and his report was not

* Nat. Lib., 1842, Vol. XII., p. 17.

† Op. cit., pp. 22, 23. 
printed by the Commissioners, but was published in 1808 after his death by his friend Charles Stewart, as An Economical History of the Hebrides. He returned to Moffat, where he pursued his scientific studies. Hon. M.D.Glasgow, and D.D.Edinburgh, 1765. On June 15th, 1779, he obtained the post of Professor of Natural History at Edinburgh University, at the same time refusing to retire from his Ministry. On February 13th, 1783, he was translated from Moffat to Colinton, where, in the latter years of his life he became blind, and died January 22nd, 1804. His publications include Schediasma Fossilium, 1781; Delineatis Fossilium, 1782; Institutes of Natural History, 1792; and Essays on Natural History and Rural Economy, published posthumously in 1812 by Charles Stewart. Dr. Walker wrote numerous essays and contributions to vols. i. and ii. of the Transactions of the Highland Society, and to the Transactions of the Royal Society of Edinburgh, of which latter Society he was one of the first members of management in 1783 .

His favourite study was Botany, but he seems to have been "a kind of naturalist by intuition." In a letter to Lord Kames he writes:- "Let your Lordship pursue the analogy between plants and mankind as far as you will, it is not likely I shall be as much offended as will my friend Linnæus. I have been from my cradle fond of vegetable life, and though I like my species and the rank I hold in creation, I declare I would sooner claim kindred to an oak or to an apple-tree than to an ape."*

$$
\text { * Nat. Lib., 1843, Vol. XII., p. } 17 .
$$





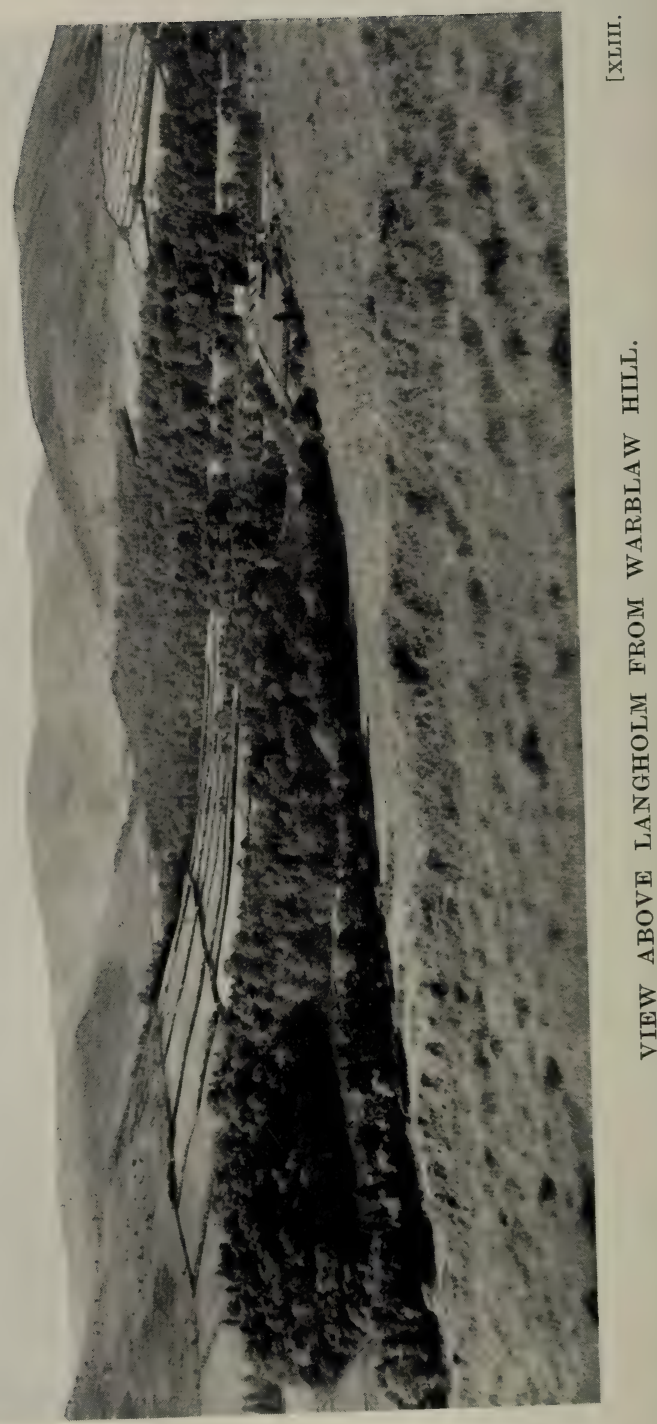




\section{LIST OF CORRESPONDENTS.}

My list of correspondents is, I hope, complete, as I should indeed be sorry to omit the name of any person who has helped me to compile this volume.

Alexander, James, Brydekirk.

Anderson, John, Collin.

Armstrong, B., Dunscore.

Armstrong, R., Thornhill.

Arnott, S., F.R.H.S., Maxwelltown.

Ballantyne, Thomas, Sanquhar.

Barbour, James, F.S.A.Scot., Dumfries.

Bartholomew, J., Beattock.

Bate, Miss Dorothea M., Hon. M.B.O.U., London.

Bayne-Jardine, Rev. D., Keir Manse.

Bell, Richard, (the late), Castle O'er.

Bell, Rev. R., Wamphray Manse.

Bell, S., Thornhill.

Bell, Dr. W., New Brighton, Cheshire.

Bell, William, Jr., Annan.

Borland, John, Closeburn.

Borthwick, A. H., Langholm.

Brook, E. J., M.B.O.U., Hoddom.

Brown, R. E., Dunscore.

Brown, Tom, Wheathampstead, Herts.

Brown, Thomas M., Closeburn.

Brunskill, W., Ecclefechan.

Buchanan, Keith, Giffnock.

Campbell, Hugh, Moffat.

Campbell, J., Ecclefechan.

Carruthers, Major F. J., Dormont, Ruthwell.

Chapman, Abel, F.Z.S., M.B.O.U., Wark-on-Tyne,

Northumberland. 
Chapman, Andrew, Dinwoodie.

Clarke, W. Eagle, F.L.S., F.R.S.E., Royal Scottish Museum,

Edinburgh.

Coleman, P., Kirkmahoe.

Coltherd, Wm., Ecclefechan.

Copland, S., Canonbie.

Corbett, T., Eaglesfield.

Corrie, John, Moniaive.

Coupland, W., Kirkmahoe.

Cowan, J., Moniaive.

Critchley, Major E. A., Stapelton Tower, Annan.

Crosbie, Tom, Penpont.

Dalzell, J., Ecclefechan.

Davidson, Dr. Anstruther, Los Angeles, California.

Davidson, A. L., Ruthwell.

Davidson, James, F.Z.S., M.B.O.U., Edinburgh.

Dinwiddie, Rev. J. L., Ruthwell.

Dixie, Sir Beaumont, Bart., Glen Stuart, Cummertrees.

Dresser, H. E., F.L.S., F.Z.S., M.B.O.U., London.

Dudgeon, Col., Cargen, Dumfries.

Duncan, John Bryce, Newlands, Dumfries.

Earsman, W., Kirkmichael.

Edmond, John, Wanlockhead.

Evans, A. H., F.Z.S., M.B.O.U., Cambridge.

Gilchrist-Clark, Mrs., Dunscore.

Gillespie, The Very Rev. John, LL.D., Mouswald Manse.

Gladstone, Robert, Junr., Liverpool.

Gordon, J. G., Corsemalzie, Wigtownshire.

Graham, Sir Richard, Bart., Netherby, Cumberland.

Graham, W. F., Ecclefechan.

Grierson, Sir Alexander, Bart., Blackheath.

Gurney, J. H., F.Z.S., M.B.O.U., Norwich.

Haines, C. R., M.A., F.S.A., Pulborough.

Haining, W., Unthank, Ewes. 
Hall, Major H., Denbie, Lockerbie.

Halliday, Provost Wm. J., J.P., Lochmaben.

Harkness; J., Ruthwell.

Hartert, Ernst J. O., Ph.D., F.Z.S., Tring.

Harting, J. E., F.L.S., F.Z.S., Weybridge.

Harvie-Brown, John A., F.R.S.E., F.Z.S., M.B.O.U.,

Hon. Life Member A.O.U., Dunipace, Larbert.

Home, J. H. Milne, Canonbie.

Hope, L. E., Tullie House Museum, Carlisle.

Hunter, D., Caerlaverock.

Irvine, John, Collin.

Jardine, Sir William, Bart., Dumfries.

Jeffreys, Peter, Dunscore.

Johnson-Ferguson, E. A., Ecclefechan.

Johnstone, Rev. J. B., Falkirk.

Johnstone, J. T., Moffat.

Johnstone, T. A., Moffat.

Johnstone-Douglas, S., London.

Kerss, Geo., Moffat.

Kinnear, Norman B., M.B.O.U., Bombay.

Kirkpatrick, J., Tinwald.

Laidlaw, W., Langholm.

Laidlaw, W. J., Eliock, Sanquhar.

Laurie, Cecil E., Moniaive.

Laurie, J., Kirkconnel.

Little, W. J., Moffat.

Lowdon, D., Ecclefechan.

Lyon, J. Stewart, Kirkmichael, Amisfield.

McCall, Major William, Barndennoch, Moniaive.

McCarfrae, J., Sanquhar.

McCluskie, T., Lockerbie.

McCombie, Rev. J., Holywood.

McDonald, A., Eskdalemuir.

Macdonald, Rev. W., Tinwald. 
McDowall, The Rev. Wm., M.A., Kirkmahoe.

Mackay, Hugh, Edinburgh.

Maclachlan, N., Carnsalloch, Dumfries.

McMillan, Robert, Sanquhar.

McRoberts, J., Ruthwell.

Malcolm, J., Langholm.

Martin, Henry, Victoria, British Columbia.

Martin, John, Glasgow.

Martin, Dr. J. W., Holywood.

Martin, Robert, Dardarroch, Dunscore.

Mathieson, Robert, F.R.S.E., F.C.S., Innerleithen.

Maxwell, Rt. Hon. Sir Herbert, Bart., P.C., F.R.S.,

Monreith, Wigtownshire.

Maxwell, J., Sanquhar.

Maxwell-Scott, Capt. Walter, The Cameronians.

Menzies, N., Newtonairds, Dumfries.

Miller, Frank, Annan.

Murray, J., Tynron.

Murray, James, Ecclefechan.

Murray, William, Murraythwaite, Ecclefechan.

Nichol, W., Skinburness, Cumberland.

Noble, Heatley, F.Z.S., M.B.O.U., Henley-on-

Thames.

Park, A., Kirkconnel.

Parry, Rev. Hugh, Leicester.

Pasley-Dirom, P. A., Mount Annan, Annan.

Paterson, John, Glasgow.

Payne, J. W., Annan.

Philip, Rev. R. G., Glencairn.

Pollock, Mrs., London.

Porter, R., Dumfries.

Pringle, J., Lochmaben.

Proudfoot, James, Collin.

Pycraft, W. P., F.L.S., F.Z.S., British Museum of Natural History. 
Quinn, Myles, Caerlaverock.

Ranken, Miss Dora, Dalswinton, Dumfries.

Ranken, Thomas, Dalswinton, Dumfries.

Reid, John, Penpont.

Renwick, W., Lockerbie.

Rice, Miss E. L., Eastry, Kent.

Rimmer, Miss, Dumfries.

Riseley, E. E., Zoological Library, London.

Robertson, Adam, Closeburn.

Robson, John, Dumfries.

Rogerson, Col. W., Hutton.

Rutherford, T. J., Fairnington, Roxburgh.

Sanderson, C. M., Lockerbie.

Scott, D., Kirkmichael.

Scott, The Lord Henry, Langholm.

Scott, R., Corrie Common.

Scott, William, M.B., C.M., J.P., Ruthwell.

Scott-Elliot, G. F., F.L.S., F.R.G.S., Dumfries.

Service, R., Maxwelltown.

Shiels, J. A., Newtonairds, Dumfries.

Shirley, G. W., Ewart Public Library, Dumfries.

Smith, Andrew, Langholm.

Smith, Patrick, Caerlaverock.

Steel, Arthur J., Kirkwood, Dalton.

Steele, James E., Glencairn.

Swanston, Walter, Lockerbie.

Tait, D., Kirkmahoe.

Tayleur, Mrs., Kirkconnel Lea, Dumfries.

Theobald, Fred V., M.A., F.E.S., Hon. F.R.H.S., Wye,

Kent.

Thorburn, Col. C. J., Dumfries.

Thorburn, W., Ecclefechan.

Ticehurst, C. B., M.A., M.B.O.U., High Halden, Kent.

Underwood, George, Lochmaben. 


\section{BIRDS OF DUMFRIESSHIRE}

Veitch, Walter Hardie, Ecclefechan.

Villiers, F. V., Ayr.

Walker, Capt. G. L., Crawfordton, Moniaive.

Wallace, Miss C. N., Lochmaben.

Waterhouse, F. H., Zoological Library, London.

Watt, Andrew, M.A., F.R.S.E., Meteorological Office, Edinburgh.

Wilson, Campbell, Tundergarth.

Wilson, J. R., (the late), Sanquhar.

Wilson, T., Mouswald.

Winge, Herluf, C.M.Z.S., Copenhagen.

Witherby, Harry F., F.Z.S., M.B.O.U., F.R.G.S., London.

Wright, A. W., Beattock.

Wright, Wm., Annan. 


\section{BIBLIOGRAPHY.}

THE following alphabetical Bibliography is by no means exhaustive, and though some of the works included contain but few ornithological or local references, others have supplied much interesting information.

The poetical works and their authors, all of them local, are throughout this list indicated by an asterisk; and in including Robert Burns, I have followed the precedent of Mr. Frank Miller (The Poets of Dumfriesshire), in only giving quotations from those of his poems which have a local connection. As regards the works of the Rev. James Grahame (who cannot be regarded as a Dumfriesshire poet, and whose Birds of Scotland would otherwise have been a fruitful field for search), I have only quoted from his British Georgics, which was written at Mount Annan in the summer of 1808 .

Adams (H. G.).-Notes for Naturalists (1857).

Agricultural Statistics for 1909, published by the Board of Agriculture and Fisheries, 1910, vol. XLIV., part I. *Aird (Thomas).- " Notes on Birds, taken in 1864, at Mountainhall, a mile east from Dumfries," Trans. D. and G. Nat. Hist. Soc., February 2nd, 1864.

The Poetical Works of (1856).

Amer. Ornithology.-See Wilson, Alexander. *Anderson (Alexander).-Ballads and Sonnets (1879). Anderson (Thomas). Joint-author.-See Gray, Robert. Annals and Magazine of Natural History (1841 et seq.). Annals of Natural History (1838-1840).

Annals of Scottish Natural History (1892 et seq.). 
Archbald (Dr. George).- " Account of the Curiosities at Drumfriess" [? circa 1684], in MS. Collections of Sir Robert Sibbald, p. 228.

Armistead (J. J.).- " Notes on some of the Birds occurring in the Solway District," Naturalist, 1884-1885, vol. X., pp. 293-298; and 1886, vol. XI., pp. 69-78.

Armistead (W. H.).-Many Notes of interest in the Scotsman, and local newspapers.

Bell (Richard).-My Strange Pets, and other Memories of Country Life (1905).

"Some Bird Notes from Eskdale," Trans. D. and G. Nat. Hist. Soc., April 17th, 1901.

*Bennet (Rev. Willtam).-Echoes of the Past (1899).

[Bennet, William].-Traits of Scottish Life and Pictures of Scenes and Character (1830).

Berwickshire Naturalists' Club, History of, 1834, et seq.

Bird-Life of the Borders.-See Chapman, Abel.

Birds of Ayr.-See Gray, Robert.

Birds of Berwickshire.-See Muirhead, George.

Birds of Britain.-See Bonhote, John Lewis.

Birds of Cumberland.-See Macpherson, Rev. Hugh

Alexander.

Birds of West Scotland.-See Gray, Robert.

Blaed (Johannes).-Theatrum Orbis Terrarum, sive Atlas

Novus. 1662.

Bonноте (JohN LewIS).-Birds of Britain (1907).

British Birds-An Illustrated Magazine devoted to the Birds

on the British List, June 1st, 1907, et seq.

*British Georgics.-See Grahame, James.

Brit. Warblers.-See Howard, Henry Eliot.

Brown (Thomas).- "A List of the Birds of Tynron Parish,"

Trans. D. and G. Nat. Hist. Soc., December 4th, 1885.

Buckley (Thomas Edward). Joint-author--See HarvieBrown, John Alexander. 
Bulletin of the British Ornithologists' Club, 1893, et seq.

*Burns (RoBert), The Poetry of, edited by W. E. Henley and T. F. Henderson (1901).

CAmpbell (BRUCE).- " A List of Birds observed in the District of Moffat, Dumfriesshire; from October, 1896, to February, 1897," Zoologist, 1898, pp. 507508.

Carlisle Natural History Society, Transactions, 1909.

Carlisle, Tullie House Museum Registers.

Catalogue of the Library of the Zoological Society of London, 1902.

Cat. Birds in Coll. Sir W. J._See Jardine, Sir William, Bart. Cat. Contents of Museum.-See Grierson, Dr. Thomas Boyle. *Chambers (R.).-Popular Rhymes of Scotland (1870).

Chambers (William).-History of Peeblesshire (1864). Birds, pp. 525-528.

Chapman (AвEL).-Bird-Life of the Borders, 2nd Edition (1907).

Chrystie (SAmuel)._- "Birds that Breed in the Parish of Dumfries." Trans. D. and G. Nat. Hist. Soc., December 4th, 1881.

Col. Figs. Eggs, Brit. Birds'.-See Seebohm, Henry.

Col. Illustr. Eggs, Brit. Birds'. - See Hewitson, William Chapman.

Corrie (JoHN)._- “Leach's Petrel," Trans. D. and G. Nat. Hist. Soc., December 3rd, 1891.

"A Note on Birds," op. cit., February 16th, 1894.

"Notes on Birds," op. cit., February 6th, 1890.

"On the Nesting of the Nightjar in Glencairn," op. cit., March 9th, 1900.

"An Ornithological List for the Parish of Glencairn," op. cit., November 10th, 1888.

Country Schoolmaster, A.-See Wallace, Robert, ed. Coward (T. A.).-The Vertebrate Fauna of Cheshire (1910). Crawford (J. H.).-Wild Life of Scotland (1896). 
Cumberland and Westmorland Association for the Advancement of Literature and Science, Transactions, No. XIII., 1887-1888.

*Conningham (Allan).-Poems and Songs (1847).

Davidson (Dr. Anstruther).- "The Birds of Upper Nithsdale," Trans. D. and G. Nat. Hist. Soc.,

November 10th, 1888.

"Fauna of Sanquhar District," pp. 28-34 : Appendix to History of Sanquhar, by James Brown (1891).

Dict. Birds.-See Newton, Prof. Alfred.

Dictionary of National Biography (1885-1900): and Reissue (1908-1909).

Dresser (Henry Eeles).-Eggs of the Birds of Europe (1905 et seq.).

A History of the Birds of Europe (1871-1881);

Supplement (1895-1896).

Duckworth (WILLIAM). Joint-author.-See Macpherson,

Rev. Hugh Alexander.

Dumfries and Galloway Courier.-December 6th, 1809-

April 2nd, 1884.

Dumfries and Galloway Courier and Herald.-April 2nd,

1884, et seq.

Dumfries and Galloway Herald.-April 24th, 1835-April

2nd, 1884.

Dumfries and Galloway Standard.-March 22nd, 1843, et

seq.

Dumfriesshire and Galloway Natural History and Antiquarian Society, Transactions, November 20th, 1862May 5th, 1875, and November 3rd, 1876, et seq. MS. Minutes, November 20th, 1862-May 5th, 1875 , and November 3rd, 1876, et seq.

Dumfries Weekly Magazine.-1773-1776.

*Dunbar (David).--Poems of Home Life (1873).

Edinburgh Journal of Natural History, 1835-1840.

Edinburgh Magazine and Literary Miscellany, August, 1817June, 1826. 
Edinburgh, Royal Physical Society, Proceedings, 1854, et seq. Transactions, 1854, et seq.

Eggs Birds Europe.-See Dresser, Henry Eeles.

Essays on Nat. Hist.-See Walker, Dr. John.

Farmers versus Rooks.-See Menteath, James Stuart.

Fauna of Argyll.-See Harvie-Brown, John Alexander.

Fauna of Clyde Area.-See Paterson, John.

Fauna of Lakeland.-See Macpherson, Rev. Hugh Alexander.

Fauna of Tay.-See Harvie-Brown, John Alexander.

Feathered Tribes of Brit. Islands.-See Mudie, Robert.

Field, The, 1853, et seq.

Fleming (John).-History of British Animals (1828).

Flora of Dumfriesshire.-See Scott-Elliot, George Francis.

Game Birds.-See Millais, John Guille.

Gen. View of Agriculture, in Dumfries.-See Singer, Dr. William.

*Gillon-Fergusson (Miss Isa).-Parables in Song (1889).

Glasgow, Natural History Society, Proceedings 1869-1884.

Transactions 1883, et seq.

Glasgow Naturalist, The-November, 1908, et seq.

*Grahame (James).-British Georgics (1809).

GRAY (RoBerT).-The Birds of the West of Scotland (1871).

and Anderson (Thomas).-The Birds of Ayrshire and Wigtownshire (1869).

Grierson (Dr. Thomas Boyle).-MSS., Diary and Notes $1834-1889$.

MS. "Running Catalogue of the Contents of my Museum," 1860-1875.

Grouse Disease Inquiry.-Interim Report, August, 1908. GuRNey (JoHN HenRY).-The House Sparrow (1885). "On the Claims of the Pine Grosbeak to be regarded as a British Bird," Zoologist, 1877, pp. 242250 . 
Handbook Brit. Birds.-See Harting, James Edmund.

Harting (James Edmund).-Handbook of British Birds (1901).

Harvie-Brown (John Alexander).-The Capercaillie in Scotland (1879).

"The Great Spotted Woodpecker's Resuscitation in Scotland since 1841 or 1851," Ann. Scott. Nat. Hist., 1908, pp. 210-216.

"The Starling in Scotland," op. cit., 1895, pp. 2-22.

"The Stock Dove in Scotland," Proc. Roy. Phys. Soc. Edin., 1883, vol. VII., pp. 241-254.

"The Tufted Duck in Scotland," op. cit., 1896, vol. XIII., pp. 144-160.

Vertebrate Fauna of the Tay Basin and Strathmore (1906).

and BuckLex (Thomas Edward).-Vertebrate Fauna of Argyll, and the Inner Hebrides (1892).

Vertebrate Fauna of the Moray Basin (1895).

Vertebrate Fauna of the Orkney Islands (1891).

Vertebrate Fauna of the Outer Hebrides (1888).

Vertebrate Fauna of Sutherland, Caithness, and West Cromarty (1887).

and Macpherson (Rev. Hogh Alexander).Vertebrate Fauna of the North-west Highlands and Skye (1904).

AND OTHERs.-Reports on the Migration of Birds in the Spring and Autumn of 1879-1887 (1880-1889). Hastings (Wriliam).- "Natural History Notes," Trans. D. and G. Nat. Hist. Soc., November 4th, 1887.

"Natural History Notes," op. cit., February 1st, 1889.

"Notes on Local Ornithology," op. cit., November 7th, 1884.

"Notes on Local Ornithology," op. cit., December 4th, 1885 .

"Notes on Some Scarce Birds," op. cit., December 5th, 1879. 
___ “ "Ornithological Notes," op. cit., December 7th, 1883. " Ornithological Notes for 1886," op. cit., November 5th, 1886.

"Rare Birds," op. cit., November 3rd, 1882.

Hewitson (WILLiam Chapman).-Coloured Illustrations of the Eggs of British Birds (1856).

Heysham (Dr. John).-A List of Birds, [written after 1797,] in The History and Antiquities of Cumberland, by W. Hutchinson (1794), vol. I., pp. 4-23.

Heysham (Thomas Covltherd).- “"The Dotterel," Mag. Nat. Hist., 1838, vol. II., pp. 295-304.

Hist. and Antiq. Cumb.—See Heysham, Dr. John.

Hist. Birds, Eur.-See Dresser, Henry Eeles.

Hist. Brit. Animals.-See Fleming, John.

Hist. Fowling.-See Macpherson, Rev. Hugh Alexander.

Hist. Berwick. Nat. Club. See Berwickshire Naturalists' Club. Hist. Peebles.-See Chambers, William.

Hist. Sanquhar.-See Davidson, Dr. Anstruther.

Howard (Henry Eliot).-The British Warblers (19071909), parts 1, 2, 3, 4 .

Hunter (William Graham).- Several Articles on Ornithology in local newspapers.

*Hyslop (James).-Hyslop's Poems (edited by Mearns) (1887).

Ibis, The, 1859, et seq.

Illust. Brit. Ornith.-See Selby, Prideaux John.

Innes (Professor Cosmo).- Scotland in the Middle Ages, 1860.

JARDINE (SiR WiLliam, BART.), ed.-American Ornithology.-See Wilson, Alexander.

Catalogue of the Birds contained in the collection of Sir W. Jardine [? July, 1847].

Contributions to Ornithology (1848-1852).

A List of Birds [written in 1832], of the Parish of Applegarth and Sibbaldbie. New Statistical Account of Scotland, vol. IV., Dumfriesshire (1845), pp. 178-182. 
- MS. Calendar, January-May, 1829 (at Dunipace, Larbert).

MS. Correspondence (at Dumfries, at Dunipace, Larbert; in the author's possession, etc.).

MS. Correspondence with P. J. Selby, 1825-1854 (at Univ. Mus. of Zoology, Cambridge).

MS. Notes in his personal copy of the Naturalists' Library.

ed.; Natural History of Selborne.-See White, Gilbert.

Naturalist's Library, The, vol. IV. (1834); vol. IX. (1838); vol. XI. (1839); vol. XII. (1842); vol. XIV. (1843).

"Note of Rare Birds that have occurred in Dumfriesshire and Galloway," Trans. D. and G. Nat. Hist. Soc., May 5th, 1868.

Sale Catalogue of Sir William Jardine's collection of Birds, by Messrs. Puttick and Simpson, June 17th, 1886.

Kearton (Richard).-British Birds' Nests (1901).

Kirkcudbright Advertiser, July 30th, 1858, et seq.

L., W., see Laidlaw, William.

Latdlaw (William).-MS. Diary and Notes, circa 18311837 (at Dunipace, Larbert).

"Notice of the Breeding of Woodcocks in Selkirkshire; with observations upon the habits and manners of the Black and Red Grouse, and Carrion Crow in Scotland," Mag. Nat. Hist., 1837, vol. I., pp. 118-122; and 443-445.

Large Desc. of Galloway.-See Symson, Andrew.

Liber Sancte Marie de Melros.-Bannatyne Club, vol. I. (1837) ; charter 198.

List of British Birds, A, compiled by a Committee of the British Ornithologists' Union (1883).

Lloyd's Nat. Hist.-See Sharpe, Richard Bowdler. McCall (RoBert).- "Birds observed on the Solway," Trans. D. and G. Nat. Hist. Soc., February 10th, 1905. 
McDiaRmid (JoHN). - Sketches from Nature (1830).

Many ornithological contributions to Dumfries and Galloway Courier, 1817-1852.

Macaillivray (WiLliam).-A History of British Birds (1837-1852).

Manual of British Ornithology (1840-1842).

Mackay (Hugh).- " Bird Notes from Dumfriesshire and Galloway," Naturalists' Journal, 1894, vol. III., pp. 61-63.

MS. Diary and Notes, etc.

"Ornithological Notes," Trans. D. and G. Nat. Hist. Soc., May 12th, 1893.

"Ornithological Notes," op. cit., April 20th, 1894. MoKIE (JoHN)._- " Recent Zoological Additions to the Kirkcudbright Museum," Trans. D. and G. Nat. Hist. Soc., February 16th, 1894.

*McKie (Thomas).-Lyrics and Sonnets (1893).

Macpherson (REv. Hugh Alexander).-History of Fowling (1897).

MS. letters to R. Service, J. H. Gurney, etc.

The Partridge, pp. 3-66, (1893), Fur, Feather and Fin Series.

Vertebrate Fauna of Lakeland (1892).

Visitation of Pallas' Sandgrouse to Scotland in 1888.

land (1886).

—, Joint-author.—See Harvie-Brown, John Alexander.

MaCtaGGaRT (JoHN).-The Scottish Gallovidian Encyclopædia (1824).

"Mabie Moss." - See Service, Robert.

Magazine of Natural History (1829-1836), edited by Loudon ;

(1837-1840), edited by Charlesworth.

Magazine of Zoology and Botany (1837-1838).

Mammals of Gt. Brit.-See Millais, John Guille.

Man. Brit. Birds.-See Saunders, Howard.

Man. Forestry._See Slich, William. 
Marriott, (C. H.).-“"The Study of Bird Life," Trans. D. and G. Nat. Hist. Soc., April 3rd, 1908.

Martin (Dr. J. W.).- "List of the Birds of Glencairn," Trans. D. and G. Nat. Hist. Soc., December 13th, 1901.

MAXwell (SIR Herbert, BART.).-History of Dumfries and Galloway (1896).

Memories of the Months $(1897,1900,1903,1907)$.

Numerous Ornithological Notes in Pall Mall Gazette, and Ann. Scott. Nat. Hist.

MAxwell (W. J.).- " Destruction of Beasts and Birds of Prey," Trans. D. and G. Nat. Hist. Soc., March 7th, 1884.

"Natural History Notes," op. cit., January 14th, 1898.

Mem. Wernerian Nat. Hist. Soc., see Wernerian Natural History Society.

Menteath (James StuaRT).-Farmers versus Rooks (1838). *Mickle (William Julius).-The Poetical Works of, vol. XI., pp. 625-272 ; Anderson's British Poets (1795). MILLATs (JоHN GUILLE).-Game Birds and Shooting Sketches (1894).

Mammals of Great Britain and Ireland (1905). * Mirler (Frank).-The Poets of Dumfriesshire (1910). *Mititgan (Dr. James).-Wimpleburn and Other Poems (1891).

Minutes of D. and G. Nat. Hist. Soc.-See Dumfriesshire and Galloway Natural History and Antiquarian Society.

Mon. of Turdidae.-See Seebohm, Henry.

Montagu (George).--Ornithological Dictionary, edited by Edward Newman, 1866.

More (Alexander Goodman).- - "Distribution of the Birds in Great Britain during the Nesting Season," Ibis, 1865, pp. 119-142; and 425-458.

Morris (Rev. Francis OrPen).-A History of British Birds (1870). 
Mudie (Robert).-The Feathered Tribes of the British Islands (1841).

MUtrhead (GEORGE).-The Birds of Berwickshire, vol. I. (1889) ; vol. II. (1895).

My Strange Pets._See Bell, Richard.

Nat. Hist. Selborne.-See White, Gilbert.

Nat. Lib._See Jardine, Sir William, Bart.

Naturalist, The, 1837-1839; 1851-1858; 1865, et seq.

Naturalists' Journal, The, 1892-1894.

Nature, 1870, et seq.

New Statistical Account of Scotland, vol. IV., Dumfriesshire (1845).

Newton (Professor Alfred). - Dictionary of Birds (18931896).

*Nithsdale Minstrel, The (1815).

Notes for Naturalists.—See Adams, H. G.

Partridge, The.-See Macpherson, Rev. Hugh Alexander.

Paterson (John).-Birds, in The Fauna, Flora and Geology of the Clyde Area (1901), pp. 159-170.

PAYNe (J. W.).- “ Natural History Notes from Annandale,"

Trans. D. and G. Nat. Hist. Soc., February 1st, 1907.

Pennant (Thomas).-British Zoology (1776).

Caledonian Zoology, in Flora Scotica, by Rev. John Lightfoot, vol. I., pp. 16-46 (1771).

Tour in Scotland, 1769, 3rd edition (1774); and 4th edition (1775).

*Poets of Dumfriesshire, The.-See Miller, Frank.

*Pop. Rhymes Scot.-See Chambers, R.

Proc. Nat. Hist. Soc. Glasg.-See Glasgow, Natural History Society.

Proc. Roy. Phys. Soc. Edin._See Edinburgh, Royal Physical Society.

Prov. names of Brit. Birds.-See Swainson, Rev. Charles.

*Reid (RoBert).-Poems, Songs, and Sonnets (1894). 
Report of the Departmental Committee appointed by the Board of Agriculture to enquire into a Plague of Voles in Scotland (C.-6943), 1893.

Report on the Food of the Black-headed Gull. Prepared by

D. Losh Thorpe and L. E. Hope for the Cumberland County Council, June, 1907.

SAUNders (Howard).-Manual of British Birds (1899). Science Progress.-See Theobald, Frederick V.

Scotia Illustrata.-See Sibbald, Sir Robert.

Scotland in the Middle Ages.-See Innes, Professor Cosmo.

Scots Magazine, The.-January, 1739-December, 1803.

Scots Magazine and Edinburgh Literary Miscellany, January, 1804 -June, 1826.

Scottish Gallovidian Encyclopædia.-See Mactaggart, John.

Scottish Naturalist, The, 1871-1891.

Scott-Elitot (George Francis).-Flora of Dumfriesshire (1896).

*Scott-Riddell (Rev. Henry).-The Poetical Works of (1871).

Seebohm (Henry).-Coloured Figures of the Eggs of British Birds (1896).

Monograph of the Turdidae, edited by R. Bowdler Sharpe (1902).

Selby (Prideadx John). - Mllustrations of British Ornithology (1825-1833).

Service (RoBerT).- " The Bar-Tailed Godwit as a Solway Bird," Ann. Scott. Nat. Hist., 1908, pp. 85-87.

"Bird Migration in Solway," op. cit., 1903, pp. 193-204.

Birds, in Maxwell's Guide Book to the Stewartry of Kirkcudbright (1902), pp. 199-210.

"The Black-headed Gull," Zoologist, 1902, p. 216.

"Changes in the Avifauna of the Solway Area," Trans. Edin. Field. Nat. Soc., 1904-5, vol. V., pp. 181-186.

"The Disappearance of the Chough," Trans. Nat. Hist. Soc. Glasg., 1883, vol. I., pp. 117-122. 
The Diurnal and Nocturnal Raptorial Birds of the Solway Area," Trans. D. and G. Nat. Hist. Soc., December 18th, 1903.

MS. Diary, and Notes.

"Natural History Notes," Trans. D. and G. Nat. Hist. Soc., November 3rd, 1905.

"Notes for Naturalists," and many other ornithological contributions, both in his own name and under the nom de plume of "Mabie Moss," to the Dumfriesshire and Galloway Courier and Herald, Kirkcudbrightshire Advertiser, etc.

"Notes on Bird Migration in the District," Trans. D. and G. Nat. Hist. Soc., April 18th, 1907.

"Notes on Local Ornithology," op. cit., February 3rd, 1882.

"On the former existence of Ptarmigan in Southwest Scotland," Zoologist, 1887, pp. 81-89.

"Provincial Names of British Animals. Stewartry of Kirkcudbright," op. cit., 1878, pp. 427-428.

"The Rarer Birds of the Solway Area," Trans. D. and G. Nat. Hist. Soc., April 20th, 1905.

"Recent Occurrences of Rare Birds," op. cit., February 19th, 1909.

"The Sparrow Hawk," op. cit., February 16th, 1903.

"The Sylviidae of Solway," Trans. Nat. Hist. Soc. Glasg., 1905, vol. VII., pp. 1-11.

"The Vertebrates of Solway - a Century's Changes," Trans. D. and G. Nat. Hist. Soc., November 16 th, 1890.

"The Waders of Solway," op. cit., 1905-06, vol. VIII., pp. 46-60.

SharPe (RICHARD Bowdler).-Lloyd's Natural History, Birds of Great Britain (1896-1897). ed., See Seebohm, Henry.

Shaw (JaMes).-Many contributions to The Graphic, Nature, local newspapers, etc.

"Avifauna of Upper Nithsdale," in A Country Schoolmaster, pp. 287-290. See Wallace, Robert. 
Stbbald (Sir Robert).-Scotia Illustrata, sive Prodomus Historiæ Naturalis (1684).

MS. Collections, in Advocates' Library, Edinburgh.

Singer (Dr. WILLIAM).-General View of the Agriculture, State of Property, and Improvements in the County of Dumfries (1812).

Sketches from Nature.-See McDiarmid, John.

Slich (William).-Manual of Forestry, vol. IV. (1895).

Statistical Account of Scotland (1791-1799).

Swainson (Rev. Charles).-Provincial Names and Folklore of British Birds (1885).

Symson (ANDREw).-A Large Description of Galloway with an appendix containing original papers from the Sibbald and Macfarlane MSS. Edinburgh (1684). Printed for W. and C. Tait, Edinburgh, 1823.

Theatrum Orbis Terrarum.-See Blaeu, Johannes.

Theobald (Frederick V.).- " Economical Ornithology," Science Progress, 1907, vol. II., pp. 263-283.

Tour in Scotland, 1769.-See Pennant, Thomas.

Traits of Scottish Life and Pictures of Scenes and Character.-See [Bennet, William.]

Trans. Carlisle Nat. Hist. Soc.-See Carlisle, Natural History Society.

Trans. Cumb. and Westmorland Assoc.-See Cumberland and Westmorland Association for the Advancement of Literature and Science.

Trans. D. and G. Nat. Hist. Soc.-See Dumfriesshire and Galloway Natural History and Antiquarian Society.

Trans. Edin. Field Nat. Soc.-See Service, Robert.

Trans. Nat. Hist. Soc. Glasg.-See Glasgow, Natural History Society.

Trans. Roy. Phys. Soc. Edin. See Edinburgh, Royal Physical Society.

Tullie House Museum Registers._See Carlisle.

Vert. Fauna Cheshire.-See Coward, T. A. 
Vertebrate Fauna of Lakeland.-See Macpherson, Rev. Hugh Alexander.

Vert. Fauna Moray.-See Harvie-Brown, John Alexander. Visit of Sandgrouse to Scotland.-See Macpherson, Rev. Hugh Alexander.

WALKer (Dr. John).-Essays on Natural History and Rural Economy (1812).

Institutes of Natural History (1792).

Wallace (Miss Amy Jeannetta).-MS. Diary.

Wallace (Professor Robert), ed., A Country Schoolmaster, James Shaw (1899).

Wernerian Natural History Society, Memoirs (1808-1837).

WhITE (GILBERT).-The Natural History and Antiquities of Selborne (1789).

Do. Notes by Sir William Jardine, Bart., edited by Edward Jesse (1851).

Do. Edited by Sir William Jardine, Bart. (1853).

Wild Life of Scotland.-See Crawford, J. H.

Willughiy (Francis).-The Ornithology of, ed., by John Ray (1678).

Wilson (ALEXANDer).-American Ornithology. Notes by

Sir William Jardine, Bart. (1832).

YARRELL (WIILIAM).-A History of British Birds, 1st edition (1843); 2nd edition (1845); 3rd edition (1856); 4th edition, edited by Alfred Newton and Howard Saunders (1871-1885).

Yorkshire Naturalist, The, 1878, et seq.

Zoologist, The, 1843, et seq. 



\section{THE PHYSICAL FEATURES AND CLIMATE OF DUMFRIESSHIRE.}

THE avifauna of a county greatly depends on its physical features and attendant climate. The absence or presence of plantations, the increase or decrease of cultivated land, the extent of the lakes and rivers, and the character of the coast, no less than the rainfall and temperature, all influence the species of birds which are residents in or migratory visitants to the area under consideration.

Dumfriesshire is bounded on the north by Lanarkshire, Peeblesshire and Selkirkshire; on the north-east by Roxburghshire; on the south-east by Cumberland; on the south by the Solway Firth; on the south-west and west by Kirkcudbrightshire; and on the north-west by Ayrshire.

Its length from east to west varies from 21 to $46 \frac{1}{2}$ miles; its breadth from north to south is between 13 and 32 miles; and its area 1,106 square miles. It comprises forty-three parishes, namely :-

Annan.

Applegarth and Sibbaldbie. Ewes.

Caerlaverock.

Canonbie.

Closeburn.

Cummertrees.

Dalton.

Dornock.

Dryfesdale.

Dumfries.

Dunscore.

Durisdeer.
Glencairn.

Gretna.

Half-Morton.

Hoddom.

Holywood.

Hutton and Corrie.

Johnstone.

Keir. 
Kirkconnel.

Kirkmahoe.

Kirkmichael.

Kirkpatrick-Fleming.

Kirkpatrick-Juxta.

Langholm.

Lochmaben.

Middlebie.

Moffat.

Morton.

Mouswald.
Penpont.

Ruthwell.

St. Mungo.

Sanquhar.

Tinwald.

Torthorwald.

Tundergarth.

Tynron.

Wamphray.

Westerkirk.

The areas of land and water in the county of Dumfries are as follows :-

Acres.

$\begin{array}{lrrrrr}\text { Land } & . & \ldots & \ldots & \ldots & 686,302 \\ \text { Water } & . & \ldots & \ldots & \ldots & 3,992 \\ \text { Foreshore } & & \ldots & \ldots & \ldots & 16,429 \\ \text { Tidal Water } & \ldots & \ldots & \ldots & 1,348\end{array}$

A group of lakes (the largest of them the Castle Loch, 194.394 acres) lies near Lochmaben, forming a well-defined, if miniature, lacustrine district. The other lochs or lochans throughout the county are small, with the exception of Loch Skene (204 acres), which lies at the extreme northeast of Moffat parish at an elevation of some 1,700 feet; and Loch Urr (137.765 acres), of which 33.741 acres are within the county-boundary of Kirkcudbrightshire, the remainder being in Glencairn parish.

The mountains on the northern, north-eastern and north-western boundaries attain in some cases to over 2,000 feet in height, the highest points being White Coomb (2,695 feet), and Hartfell (2,651 feet), in Moffat parish, and Lowther Hill (2,377 feet), in Durisdeer parish. "The high ground about the 'Devil's Beeftub' (Moffat) forms the watershed of this part of the Southern Scottish uplands, and it might almost be described as a 'mountain complex' 



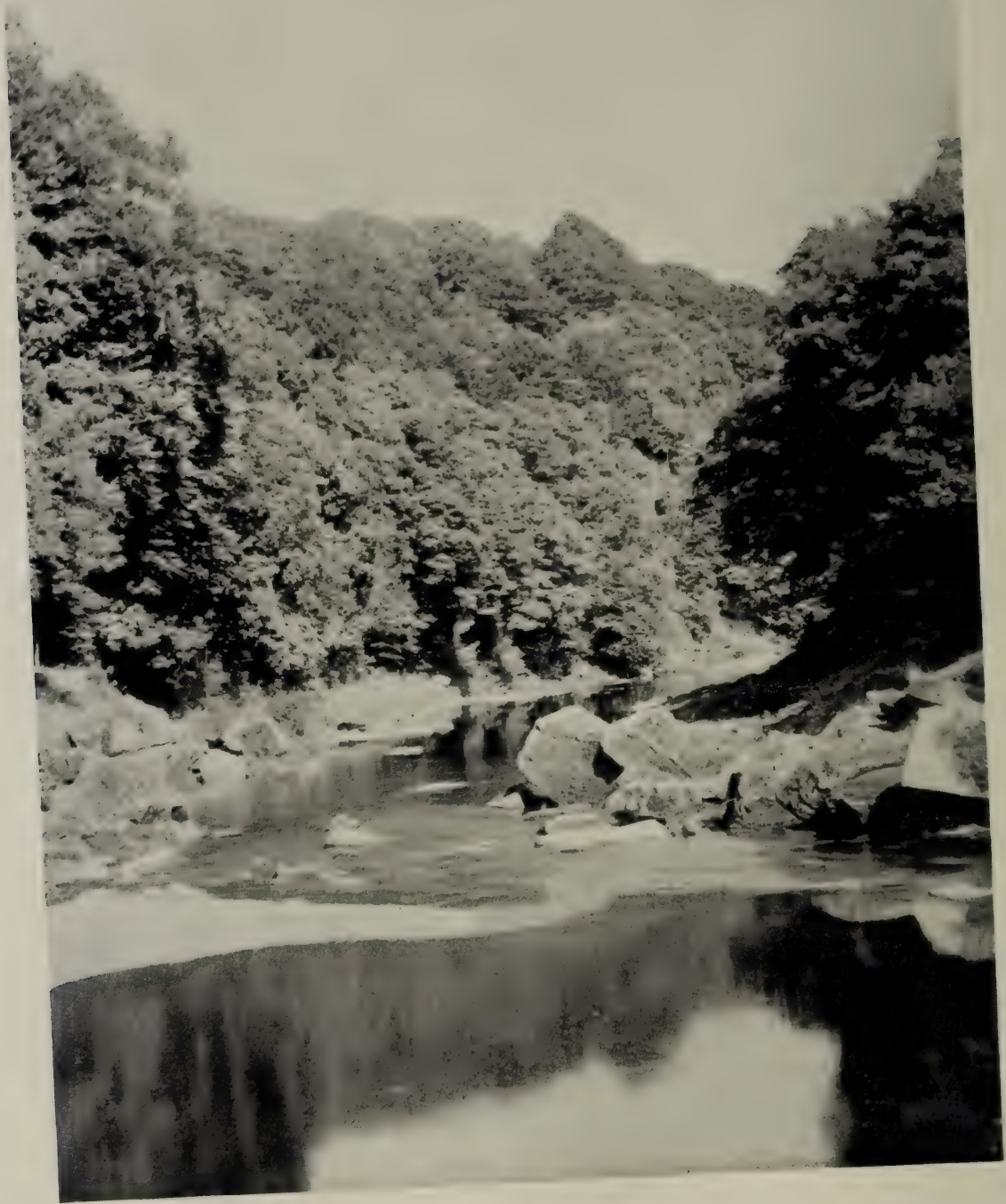




\section{PHYSICAL FEATURES AND CLIMATE LXVII}

on a small scale, for the sources of the great rivers Clyde, Tweed, and Annan are all close together, hence the old saying, 'Annan ran, Tweed won, Clyde fell and broke his neck." "* All the northern part of the county is upland. Mountains or high hills, intersected with a few glens or valleys, occupy a mean breadth of seven or eight miles, and spurs of these run southwards to lengths extending from two to eight miles, the most striking being Cairnkenna ( 1,819 feet) in Penpont parish; Queensberry (2,285 feet), in Closeburn parish; and Langholm Hill (1,162 feet) near Langholm.

The region southwards of the uplands breaks into three great "dales," which take their names from the three principal rivers of the county : the Nith, the Annan, and the Esk. Into these rivers flow numerous small rivulets, but three streams, each ten miles or more in length, have an independent course southwards to the Solway Firththe Lochar, the Cummertrees Pow, and the Kirtle Water. The river Sark, which forms the south-eastern boundary between Dumfriesshire and Cumberland, also flows independently into the Firth. Several of the tributary streams, like the three principal rivers, give their names to their own basins. The Dryfe and the Moffat, which join the Annan; and the Ewes, which flows into the Esk, giving, for example, their names to Dryfesdale, Moffatdale, and Ewesdale.

Mention must be made of Cairn Water (called the Cluden in its lower reaches below Routin Brig), which forms the boundary between the county and Kirkcudbrightshire on the south-west, and which joins the Nith about one mile above Dumfries; and Liddel Water, which forms a portion of the south-eastern boundary between Dumfriesshire and Cumberland, rises in Roxburghshire and flows into the Esk a mile and a half below Canonbie. Of the other tributary streams, the more important are, perhaps, the Waters of Kello, Crawick, Euchan, Cample, and Scaur, the latter

* G. F. Scott-Elliot, in litt., April 2nd, 1909. 
being augmented by Shinnel Water, all of which flow into the River Nith.

Into the Annan flow Kinnel Water, fed by the Water of E, and the Waters of Evan, and of Milk. The Esk, which is formed by the Black and White Esk, is swelled by the Waters of Wauchope and Tarras.

"All the valleys are of very ancient date, so that the sandstone and carboniferous rock not only contribute to the river shingles and boulders of the till, but are sometimes also exposed and cut into by the shifting of the modern rivers. The valley of the Nith is, in its lower part, full of clay, sand, gravel and shingle, brought down by the great floods which mark the close of the glacial period. These deposits form a very complex series of small terraces cut out into dips, folds and winding depressions. Where they occupy the valley, the land is for the most part rich, fertile and dry. Altogether different are the heavy clay soils found in parts of Eskdale, and the lower part of Annandale, and which are deposits of boulder clay belonging to the District Ice-sheets."*

The tides of the Solway Firth are of extraordinary rapidity, and its channel has shifted more than once in recent years. After the great storm of January 25th27th, 1884, the Nith completely altered its direction in a couple of tides, scooping out a new channel, or, rather, resuming an old one that had not been used for forty years. Such changes have consequently altered the feedinggrounds of our shore-birds, as the waders and geese; and to these changes may possibly be attributed the increase of certain species and the decrease of others on the Solway.

Dumfriesshire may be said to divide itself naturally into four districts, namely, lacustrine, littoral, arable, and pastoral or upland, the latter district in places being of a moorland or mountainous character.

The littoral, or sea-shore, consists of sand, shingle, and estuarine mud-flats, affording ideal haunts for geese and

* G. F. Scott-Elliot, in litt., April 2nd, 1909. 
waders; and to the absence of cliffs may be attributable the lack of such birds as Guillemots, Razorbills, and some gulls as breeding-species.

The arable area may be said to extend from sea-level up to about 800 or, rarely, 900 feet. The soil is light, lying on rock, gravel, or sand, and in Nithsdale and Annandale is mostly dry; in Eskdale generally wet. Considerable tracts of a rich loamy character lie along the rivers, and on the more level lowland portions. This area is comparatively well wooded, and the 'holms' contiguous to the lower reaches of the main rivers form the most fertile districts in the county. Here the country is mainly flat, and it is remarkable that the 200 feet contour in Nithsdale is not attained till Drumlanrig, some 18 miles from the sea.

"The rich holm lands of recent alluvial formation extend into the recesses of the hills. At the head of these valleytracks there are often deep ravines full of rapids and waterfalls such as Crichope Linn, Wamphray Linn, Penton Linn, and many others. Although these rocky winding glens have been perhaps (at least for the most part) planted by man, yet they are practically natural woodlands incapable of agricultural exploitation."*

The pastoral area or sheep-farms are chiefly on silurian rock or drift. The soil is mainly poor, unsuitable for tillage and partly irreclaimable. It comprises numerous corries and glens, some of them fringed with a stunted growth of birch and rowan, and extends from the limits of the arable area to an ill-defined upland and more rugged country. Here there are peat-haggs and mosses, steep crags, and scaurs of bare whinstone rock and mudstone, and generally wild mountainous country, seldom visited by anyone but the shepherd or the sportsman. The moorlands are now desolate in the extreme. They consist of sphagnum peat-bogs, cotton-grass swamps, or grass and heather. According to Dr. Lewis's recent researches, they were once for the most part occupied by a

* G. F. Scott-Elliot, in litt., April 2nd, 1909. 
magnificent forest of Scots pine, with trunks eighteen inches to two feet in diameter. The peat is now everywhere being eroded and destroyed, though the original capping of peat eight to ten feet in thickness, can still be detected on the higher plateaux.

Mr. G. F. Scott-Elliot writes: "Originally the county probably consisted of deciduous forest, broken along the river-sides by stretches of marshy soil or peat-moss. I believe this forest probably continued from nearly sea-level to about 800 feet, from which level to that of the present haggs there may have been, either after a belt of conifers or throughout, rough grass and heather. The succession found in most parts of the world of deciduous forest, conifers, and heather or moss may be traced therefore without much difficulty.

"Arable land now replaces the deciduous forest, which still persists along the rivers and burns up to 2,200 feet.

"The hill-farms and permanent pastures represent probably what was once rough grass and heather, but man has not yet been able to bring the peat-haggs into cultivation. These are laid down in a capping of peat some ten or twelve feet thick, though varying enormously in depth over all the higher hills in Dumfriesshire."*

"These peat-mosses form one of the most remarkable features of the county. Those of Lochar Moss, as well as those of Kirkconnell, and Dalskairth Mosses in Kirkcudbrightshire, belong for the most part to the 25-foot beach. Remnants of quite similar peat-mosses occur on the 50-foot beach, and at other altitudes corresponding to the old river-terraces of the Nith. Besides these, there are the upland peat-mosses, which occur at all elevations from the Solway to that of Loch Skene, and which depend on the local conditions of drainage." $\dagger$

Dr. Singer, in 1812, refers in his agricultural survey of Dumfriesshire, to the pre-existent forests of the county,

* Flora of Dumfriesshire, 1896, p. x.

† G. F. Scott-Elliot, in litt., April 2nd, 1909. 


\section{PHYSICAL FEATURES AND CLIMATE LXXI}

and surmises, at the date at which he wrote that " probably not much more than one acre in a hundred is occupied by trees."*

Perhaps nothing in Nature tends to change the avifauna of a county more rapidly than its cultivation. It is therefore most interesting to compare the local agricultural conditions circa 1835, as set forth in the New Statistical Account of Scotland, $\uparrow$ with those found at the present day, as given in the Agricultural Statistics for 1909, published by the Board of Agriculture and Fisheries. $\div$

\begin{tabular}{|c|c|c|c|c|c|}
\hline Circa 1835. & \multicolumn{2}{|c|}{ Acres. } & In 1909. & \multicolumn{2}{|c|}{ Acres. } \\
\hline $\begin{array}{l}\text { Acres cultivated, } \\
\text { or occasionally } \\
\text { in tillage }\end{array}$ & & 234,648 & Arable land & & 133,732 \\
\hline $\begin{array}{l}\text { Acres supposed } \\
\text { capable of cul- }\end{array}$ & & & Permanent grass & 121,889 & \\
\hline $\begin{array}{c}\text { profit } . . \\
\text { Acres uncultiva- } \\
\text { ted .. }\end{array}$ & $\begin{array}{r}17,160 \\
381,499\end{array}$ & 398,659 & $\begin{array}{lr}\begin{array}{c}\text { Mountain } \\
\text { heath }\end{array} & \text { land } \\
\text { used for graz- } \\
\text { ing .. }\end{array}$ & 378,223 & 500,112 \\
\hline Acres under wood & & $18,087 \frac{1}{2}$ & Woods (1905) ... & & 30,275 \\
\hline
\end{tabular}

The above figures, it will be observed, do not take into account the acreage occupied by water, roads, houses, foreshore, tidal-water, etc., of the county: and the discrepancy between the total acreages as shewn by the two comparative tables is remarkable.

In 1832 Sir William Jardine wrote : "The Missel-Thrush deserves notice on account of its increase during the last few years. Fifteen years ago they were rarely to be seen ; but in consequence of the increased extent of plantations, they are now frequently met with in pairs, or in parties of five or six." $\$$

* Gen. View of Agriculture, in Dumfries, p. 286.

$\dagger$ New Stat. Acct. Scot., 1845, Vol. IV., p. 587.

$\ddagger$ Agric. Stat., 1909, Vol. XLIV., pt. 1, p. 57.

$\S$ New Stat. Acct. Scot., 1845, Vol. IV., p. 178. 
The reafforestation that has taken place to such a wide extent since the earlier years of the last century, has provided suitable habitats for many species of birds ; and the hedgeenclosures, with rows, belts, or clumps of ornamental or "wind-breaking" trees, have greatly encouraged the increase of small passerine birds.

Mr. R. Service, reviewing the changes in our local fauna during the past century, states: "The great agricultural progress made during the period has had much effect on our native species. With the extensive drainage that has taken place, and reclamation of bog and moss, the wild-fowl have been dispossessed of their chosen haunts. The numbers of several species of wading birds have become more and more restricted.

"Arable land has gone out of fashion in a marked degree, and pastoral cultivation is taking its place, to the advantage of such species as the Starling. On the rougher and hill portions of the county black cattle have long since been replaced by sheep. One consequence is that heather is slowly dying out. No heather patches ever extend now, and plenty of it has disappeared altogether.

"Many members of our fauna have suffered severely from game preserving. Since early in the 'twenties the passion for this form of sport has gone on increasing. A more discriminate method of keeping down the enemies of game is now in the ascendant, under which Buzzards, Kestrels, Owls and others ought to receive the total exemption from ruthless slaughter to which they are entitled. From the naturalist's point of view there was a compensating advantage in even the merciless old system of game preserving. It resulted in a maximum stock of small birds, which, in their haunts on the mosses, woods and coverts, enjoyed almost complete immunity from raptorial birds and an undisturbed quiet during the nesting season."*

* Trans. D. and G. Nat. Hist. Soc., November 16th, 1900. 
It is to be regretted that such birds as the Eagles and Harriers no longer nest in the county, and that the Martins and Barn-Owls are not so numerous as formerly; but it is satisfactory to be able to note the arrival within the last thirty-five years of the Stock-Dove, Pied Flycatcher, and Tufted Duck: and more recently the increasing number of Great Spotted Woodpeckers, Jays, and Woodcock as breeding-species, is a matter for congratulation. The arrival of such species can hardly be due to their overcrowding in their usual breeding-places, and Mr. R. Service, in the paper already quoted, suggests that this "may be attributed to some slow and obscure alteration in the climate. No evidence, however, can be adduced from meteorological records that any such change is in progress."

Gilbert White, of Selborne, has said that "the weather of a district is undoubtedly part of it's natural history,"* and the following remarks may not be here out of place. The climate of the county is peculiarly mild and genial, the mean temperature for the year, worked out over a number of years, being about forty-five degrees. The rainfall varies in different localities per annum from thirty-five inches at Dumfries (altitude 60 feet), to upwards of fifty-two inches at Wanlockhead (altitude 1,409 feet).

Of course Dumfriesshire gets its share of storms and severe weather. Under such circumstances the Lochar Moss in the early part of the last century, before being agriculturally improved, formed an attractive resort for wild-fowl. We read, for example, that during the extraordinarily hard winter of 1822-1823 "thousands of waterfowl found an asylum there." $\dagger$ But, perhaps, no winter is more memorable than that of 1878-1879, of which Mr. R. Service wrote at the time: "It is questionable if even the most favourable nesting times will replace the birds which this winter has destroyed." $\ddagger$

* Nat. Hist. Selborne, 1789, p. 287.

$\dagger$ Dumfries Courier, February 4th, 1823.

$\ddagger$ Op. cit., March 25th, 1879. 
The strongest prevailing wind is westerly, and cyclones passing over the county almost invariably travel from SW. or SSW. to NW. and N. Snowstorms, after the new year, as regularly come from the SE., or SSE. by E.; and it is interesting to note that Sir William Jardine, in a letter to his friend P. J. Selby in 1836, records a snowstorm from the south-west as most unusual.* Gales from the north occur at rare intervals, and are extremely destructive to timber, notably the one on January 25th-27th, 1884, when many woods in Upper Nithsdale were laid low.

An idea, which cannot be entirely proved, exists locally that our weather runs in cycles extending over periods of thirty-three years. Throughout the last quarter of a century or so, the occurrences of certain species of birds rare to Dumfriesshire have been disappointing. Previous to that time, possibly about 1880 , one of these thirty-three year periods may have terminated, since when we have been experiencing the contrary cycle of northerly and easterly winds continued long into spring, which has been unfavourable to the appearance of what were former visitants. Although weather phenomena do not entirely control migration, yet they affect the general increase or diminution in the numbers and species of birds occurring during such periods, and only time and observation will show the validity of the existing belief that our weather runs in thirtythree year cycles. In connection with this speculation, it is interesting to note that Mr. Andrew Watt writes on this subject : "In Russia we have a great country whose internal trade is dependent on its navigable rivers, which are frozen during the winter months. The dates of the opening and closing of these rivers are known with tolerable certainty for the last two hundred years, and appear to show that exceptionally cold years occur at intervals of from thirty to thirty-five years, and exceptionally warm years within a similar period." $\dagger$

* Sir W. Jardine, in litt., to P. J. Selby, February 1st, 1836.

† Scottish Geographical Magazine, April, 1908, p. 186. 


\section{PHYSICAL FEATURES AND CLIMATE LXXV}

The following table has been compiled at Cargen, Kirkcudbrightshire, and it is interesting to know that these observations have all been recorded by Mr. A. Peacock during his service there as gardener to the Dudgeon family. Although meteorological stations of long standing exist actually in Dumfriesshire, it has seemed preferable to publish the following statistics on account of their continuity and trustworthiness :-

Observations taken at Cargen (Troqueer), Kirkcudbrightshire.

80 feet above sea-level. Three miles south of Dumfries. Lat. $55^{\circ} 2^{\prime} 5^{\prime \prime}$. N. Long. $3^{\circ} 37^{\prime} 15^{\prime \prime} \mathrm{W}$.

\begin{tabular}{|c|c|c|c|c|c|c|c|c|c|c|c|c|c|c|c|c|}
\hline \multirow{2}{*}{ YEAR } & \multicolumn{3}{|c|}{ BAROMETER. } & \multicolumn{3}{|c|}{ THERMOMETER. } & \multicolumn{2}{|c|}{ RAIN. } & \multicolumn{8}{|c|}{ W I N D. } \\
\hline & Mean. & Highest. & Lowest. & Mean. & Highest & Lowest & Days. & Inches. & N. & N.E. & E. & S.E. & s. & s.w. & w. & N.w. \\
\hline 1860 & 29.725 & 30.692 & 28.444 & 45.9 & 79.3 & -4 & 150 & 44.27 & $68 \frac{1}{2}$ & $23 \frac{1}{2}$ & $50 \frac{1}{2}$ & 44 & 26 & $34 \frac{1}{2}$ & 55 & 64 \\
\hline 1861 & 29.782 & 30.478 & 28.514 & 48.1 & 79.9 & 9.6 & 131 & 44.25 & 56 & $20 \frac{1}{2}$ & 38 & 26 & $32 \frac{1}{2}$ & 53 & $98 \frac{1}{2}$ & $40 \frac{1}{2}$ \\
\hline 1862 & 29.766 & 30.574 & 28.428 & 47.4 & 74.3 & 17 & 150 & 47.49 & 27 & $19 \frac{1}{2}$ & 45 & 40 & 27 & 41 & $109 \frac{1}{2}$ & $55 \frac{1}{2}$ \\
\hline 1863 & 29.779 & 30.544 & 28.618 & 48.2 & 78.5 & 24 & 145 & 40.60 & $35 \frac{1}{2}$ & 20 & $31 \frac{1}{2}$ & $19 \frac{1}{2}$ & $19 \frac{1}{2}$ & 58 & 128 & 53 \\
\hline 1864 & 29.829 & 30.612 & 28.556 & 47.1 & 82.1 & 16 & 123 & 40.12 & $58 \frac{1}{2}$ & $22 \frac{1}{2}$ & 57 & 43 & 32 & $33 \frac{1}{2}$ & 65 & $55 \frac{1}{2}$ \\
\hline 1865 & 29.812 & 30.674 & 28.262 & 48.4 & 79.9 & 8 & 120 & 41.19 & 57 & 31 & $31 \frac{1}{2}$ & 43 & $35 \frac{1}{2}$ & $43 \frac{1}{2}$ & 71 & $54 \frac{1}{2}$ \\
\hline 1866 & 29.710 & 30.530 & 28.592 & 48.6 & 83.3 & 18 & 148 & 50.17 & $41 \frac{1}{2}$ & $17 \frac{1}{2}$ & $40 \frac{1}{2}$ & $36 \frac{1}{2}$ & $36 \frac{1}{2}$ & 43 & $97 \frac{1}{2}$ & 52 \\
\hline 1867 & 29.821 & 30.698 & 28.480 & 47.4 & 80.6 & 15 & 130 & 31.08 & $46 \frac{1}{2}$ & $26 \frac{1}{2}$ & 41 & 27 & 38 & $49 \frac{1}{2}$ & 74 & 62 \\
\hline 1868 & 29.758 & 30.590 & 28.240 & 49.2 & 87.6 & 25 & 162 & 54.35 & $41 \frac{1}{2}$ & 17 & $35 \frac{1}{2}$ & $40 \frac{1}{2}$ & $30 \frac{1}{2}$ & $58 \frac{1}{2}$ & $85 \frac{1}{2}$ & 52 \\
\hline 1869 & 29.811 & 30.560 & 28.542 & 48.2 & 87.5 & 10 & 128 & 50.40 & 31 & 49 & 29 & $37 \frac{1}{2}$ & 27 & $43 \frac{1}{2}$ & $62 \frac{1}{2}$ & $35 \frac{1}{2}$ \\
\hline 1870 & 29.874 & 30.612 & 28.428 & 47.8 & 87.7 & 9.5 & 116 & 39.97 & 69 & $47 \frac{1}{2}$ & $52 \frac{1}{2}$ & 24 & 20 & 35 & 54 & 63 \\
\hline 1871 & 29.849 & 30.520 & 28.460 & 47.9 & 80.1 & 14.5 & 149 & 44.52 & 46 & $39 \frac{1}{2}$ & $50 \frac{1}{2}$ & 43 & 30 & $47 \frac{1}{2}$ & 62 & $46 \frac{1}{8}$ \\
\hline 1872 & 29.681 & 30.398 & 28.420 & 48.9 & 80.5 & 21.7 & 191 & 63.50 & $34 \frac{1}{2}$ & 30 & $38 \frac{1}{8}$ & 56 & 69 & 42 & 60 & 36 \\
\hline 1873 & 29.807 & 30.590 & 28.140 & 48.1 & 87.1 & 23.5 & 168 & 43.64 & $33 \frac{1}{2}$ & $36 \frac{1}{2}$ & 52 & $21 \frac{1}{2}$ & 69 & $61 \frac{1}{2}$ & 54 & 37 \\
\hline 1874 & 29.811 & 30.768 & 28.570 & 48.2 & 81.3 & 9.5 & 174 & 51.06 & 23 & $41 \frac{1}{2}$ & 36 & $22 \frac{1}{2}$ & 61 & $80 \frac{1}{2}$ & $64 \frac{1}{2}$ & 36 \\
\hline 1875 & 29.882 & 30.590 & 28.644 & 48.5 & 79.1 & 15.5 & 168 & 42.14 & 27 & $30 \frac{1}{2}$ & 92 & $32 \frac{1}{2}$ & 60 & $63 \frac{1}{2}$ & $33 \frac{1}{2}$ & 26 \\
\hline 1876 & 29.776 & 30.556 & 28.328 & 48.9 & 90.4 & 13.4 & 167 & 48.22 & 39 & $54 \frac{1}{2}$ & $61 \frac{1}{2}$ & $39 \frac{1}{2}$ & $71 \frac{1}{2}$ & 40 & $36 \frac{1}{2}$ & $23 \frac{1}{2}$ \\
\hline 1877 & 29.750 & 30.612 & 28.388 & 48.5 & 81.4 & 16.4 & 215 & 61.42 & $26 \frac{1}{2}$ & 36 & $63 \frac{1}{2}$ & $39 \frac{1}{2}$ & $54 \frac{1}{2}$ & $63 \frac{1}{2}$ & $42 \frac{1}{2}$ & 39 \\
\hline 1878 & 29.832 & 30.612 & 28.796 & 48.7 & 86.6 & 6 & 158 & 34.35 & $56 \frac{1}{2}$ & $51 \frac{1}{2}$ & 67 & 45 & 43 & $39 \frac{1}{2}$ & $33 \frac{1}{2}$ & 29 \\
\hline
\end{tabular}




\begin{tabular}{|c|c|c|c|c|c|c|c|c|c|c|c|c|c|c|c|c|}
\hline \multirow{2}{*}{ YEAR } & \multicolumn{3}{|c|}{ BAROMETER. } & \multicolumn{3}{|c|}{ THERMOMETER. } & \multicolumn{2}{|c|}{ RAIN. } & \multicolumn{8}{|c|}{ N D. } \\
\hline & Mean. & Highest. & Lowest. & Mean. & $\mathrm{H}$ & Lowest & Days. & Inches. & N. & N.E. & E. & S.E. & s. & s w. & w. & N.w \\
\hline 1879 & 29.861 & 30.680 & 28.760 & 45.7 & 76 & 9 & 160 & 36.72 & 31 & $38 \frac{1}{2}$ & 90 & 54 & $56 \frac{1}{2}$ & $33 \frac{1}{2}$ & $29 \frac{1}{2}$ & 32 \\
\hline 1880 & 29.906 & 30.594 & 28.560 & 48.6 & 81.4 & 16 & 159 & 30.77 & $27 \frac{1}{2}$ & 31 & $104 \frac{1}{2}$ & 28 & $67 \frac{1}{2}$ & 45 & 41 & $21 \frac{1}{2}$ \\
\hline 1881 & 29.855 & 30.710 & 28.270 & 46.5 & 79 & 7 & 180 & 44.51 & 36 & 25 & $84 \frac{1}{2}$ & $30 \frac{1}{2}$ & $77 \frac{1}{2}$ & $46 \frac{1}{2}$ & $40 \frac{1}{2}$ & $24 \frac{1}{2}$ \\
\hline 1882 & 29.815 & 30.858 & 28.794 & 48.7 & 77.2 & 18.8 & 202 & 44.43 & 43 & $18 \frac{1}{2}$ & $62 \frac{1}{2}$ & 23 & $87 \frac{1}{2}$ & $60 \frac{1}{2}$ & 44 & 26 \\
\hline 1883 & 29.845 & 30.680 & 28.598 & 46.9 & 72.2 & 24 & 185 & 44.66 & $38 \frac{1}{2}$ & 28 & $50 \frac{1}{2}$ & $25 \frac{1}{2}$ & 52 & $66 \frac{1}{2}$ & 62 & 42 \\
\hline 1884 & 29.868 & 30.670 & 27.660 & 48.1 & 83.6 & 20.8 & 191 & 43.85 & $30 \frac{1}{2}$ & 30 & $46 \frac{1}{2}$ & 46 & 57 & 65 & $55 \frac{1}{2}$ & 35 \\
\hline 1885 & 29.834 & 30.592 & 28.540 & 45.8 & 80.8 & 17.4 & 160 & 40.93 & $28 \frac{1}{2}$ & 37 & 72 & 38 & 50 & $46 \frac{1}{2}$ & 65 & 29 \\
\hline 1886 & 29.808 & 30.604 & 27.620 & 45.9 & 79.2 & 7.2 & 183 & 43.31 & $35 \frac{1}{2}$ & $29 \frac{1}{2}$ & 81 & $29 \frac{1}{2}$ & 42 & 55 & $51 \frac{1}{2}$ & 41 \\
\hline 1887 & 29.924 & 30.648 & 28.540 & 46.2 & 83.4 & 19.2 & 143 & 32.06 & $43 \frac{1}{2}$ & 50 & 62 & 13 & $29 \frac{\pi}{2}$ & 62 & $53 \frac{1}{2}$ & 51 \\
\hline 1888 & 29.862 & 30.610 & 28.732 & 45.8 & 85 & 12.4 & 159 & 35.76 & 26 & $36 \frac{1}{2}$ & 101 & 26 & 41 & $36 \frac{1}{2}$ & $61 \frac{1}{2}$ & 371 \\
\hline 1889 & 29.874 & 30.644 & 28.490 & 47.4 & 80.8 & 19 & 168 & 37.07 & 34 & $36 \frac{1}{2}$ & $70 \frac{1}{2}$ & $32 \frac{1}{2}$ & $33 \frac{1}{2}$ & 55 & $58 \frac{1}{2}$ & $45 \frac{1}{2}$ \\
\hline 1890 & 29.859 & 30.660 & 28.540 & 47.4 & 73 & 1 & 185 & 39.53 & $37 \frac{1}{2}$ & $43 \frac{1}{2}$ & 77 & 25 & 36 & $55 \frac{1}{2}$ & $54 \frac{1}{2}$ & 36 \\
\hline 1891 & 29.844 & 30.730 & 28.446 & 46.6 & 81.2 & 11 & 163 & 47.66 & $33 \frac{1}{2}$ & $42 \frac{1}{2}$ & 59 & $25 \frac{1}{2}$ & $60 \frac{1}{2}$ & 48 & $55 \frac{1}{2}$ & $40 \frac{1}{2}$ \\
\hline 1892 & 29.81 & 30.534 & 28.780 & 45.3 & 79. & 6.8 & 176 & 39.45 & $48 \frac{1}{2}$ & 38 & $77 \frac{1}{2}$ & 16 & 40 & $50 \frac{1}{2}$ & 59 & 36 \\
\hline 1893 & 29.847 & 30.594 & 28.530 & 48.8 & 83 & 15.4 & 175 & 37.55 & $43 \frac{1}{2}$ & 38 & 59 & 13 & $18 \frac{1}{2}$ & 64 & 79 & 50 \\
\hline 1894 & 29.8 & 30.586 & 28.574 & 47.9 & 83. & 7 & 178 & 49.43 & 34 & $46 \frac{1}{2}$ & 70 & 26 & $13 \frac{1}{2}$ & 47 & 72 & 56 \\
\hline 1895 & 29.795 & 30.586 & 28.544 & 46.1 & 79.8 & .2 & 136 & 38.70 & $35 \frac{1}{2}$ & 67 & 68 & 14 & 63 & 46 & $43 \frac{1}{2}$ & 28 \\
\hline 1896 & 29.887 & 30.928 & 28.404 & 48 & 82.6 & 21.2 & 146 & 38.82 & 36 & 43 & $71 \frac{1}{2}$ & 27 & 5 & 47 & $54 \frac{1}{2}$ & 30 \\
\hline 1897 & 29.823 & 30.57 & 28.680 & 47.7 & 82 & 16 & 168 & 49.48 & 21 & $38 \frac{1}{2}$ & $88 \frac{1}{2}$ & 46 & 50 & 26 & 58 & 36 \\
\hline 1898 & 29.842 & 30.460 & 28.810 & 49 & 80 & 19 & 158 & 49.12 & $36 \frac{1}{2}$ & $35 \frac{1}{2}$ & 61 & 29 & 66 & 39 & 72 & 26 \\
\hline 1899 & 29.932 & 30.630 & 28.346 & 48.2 & 81.6 & 12 & 136 & 49.23 & $22 \frac{1}{2}$ & 57 & $71 \frac{1}{2}$ & $25 \frac{1}{2}$ & 42 & 48 & 61 & $37 \frac{1}{2}$ \\
\hline 1900 & 29.800 & 30.580 & 28.276 & 47.9 & 79 & 5 & 213 & 54.97 & $28 \frac{1}{2}$ & $38 \frac{1}{2}$ & $69 \frac{1}{2}$ & $37 \frac{1}{2}$ & $72 \frac{1}{2}$ & $33 \frac{1}{2}$ & 47 & 38 \\
\hline 1901 & 29.848 & 30.532 & 28.226 & 47.8 & 89 & 16 & 145 & 42.44 & $26 \frac{1}{2}$ & 60 & 84 & 34 & 50 & $22 \frac{1}{2}$ & 49 & 39 \\
\hline 1902 & 29.835 & 30.890 & 28.480 & 47.2 & 84.5 & 6 & 156 & 37.21 & 20 & $34 \frac{1}{2}$ & $85 \frac{1}{2}$ & $38 \frac{1}{2}$ & 39 & $40 \frac{1}{2}$ & 68 & 39 \\
\hline 1903 & 29.756 & 30.540 & 28.460 & 47.2 & 76 & 14 & 205 & 60.86 & 27 & $20 \frac{1}{2}$ & $56 \frac{1}{2}$ & $30 \frac{1}{2}$ & $59 \frac{1}{2}$ & $49 \frac{1}{2}$ & 75 & $46 \frac{1}{2}$ \\
\hline 1904 & 29.824 & 30.590 & 28.526 & 47.3 & 77.4 & 17 & 160 & 38.91 & $22 \frac{1}{2}$ & 22 & $59 \frac{1}{2}$ & $30 \frac{1}{2}$ & 77 & $38 \frac{1}{2}$ & $93 \frac{1}{2}$ & 22 \\
\hline 1905 & 29.835 & 30.792 & 28.620 & 47.8 & 83 & 18 & 144 & 34.69 & 20 & 31 & $43 \frac{1}{2}$ & 32 & $55 \frac{1}{2}$ & 53 & 79 & 51 \\
\hline 1906 & 29.821 & 30.660 & 28.410 & 48.0 & 85 & 15 & 167 & 45.42 & 22 & $14 \frac{1}{2}$ & $38 \frac{1}{2}$ & 41 & $40 \frac{1}{2}$ & $58 \frac{1}{2}$ & 96 & 54 \\
\hline 1907 & 29.894 & 30.912 & 28.610 & 46.9 & 81.4 & 15 & 164 & 49.29 & $33 \frac{1}{2}$ & 5 & 42 & $35 \frac{1}{2}$ & 42 & $48 \frac{1}{2}$ & 121 & $37 \frac{1}{2}$ \\
\hline 1908 & 29.961 & 30.796 & 28.648 & 48.1 & 87 & 14 & 163 & 46.66 & $21 \frac{1}{2}$ & $25 \frac{1}{2}$ & 26 & $42 \frac{1}{2}$ & $29 \frac{1}{2}$ & $41 \frac{1}{2}$ & 129 & $50 \frac{1}{2}$ \\
\hline 1909 & 29.848 & 30.545 & 28.270 & 46.5 & 77 & 13 & 147 & 52.65 & 52 & $34 \frac{1}{2}$ & $40 \frac{1}{2}$ & 24 & 18 & $35 \frac{1}{2}$ & 108 & $52 \frac{1}{2}$ \\
\hline
\end{tabular}




\section{PHYSICAL FEATURES AND CLIMATE LXXVII}

AVERAGES.

\begin{tabular}{|c|c|c|c|c|c|c|c|c|c|c|c|c|}
\hline \multirow{2}{*}{$\begin{array}{c}\text { Average } \\
\text { for }\end{array}$} & \multirow{2}{*}{$\frac{\text { BAROMETKR. }}{\text { Mlean. }}$} & \multirow{2}{*}{$\frac{\text { THER MOMETER. }}{\text { Mean. }}$} & \multicolumn{2}{|c|}{ RAIN. } & \multicolumn{8}{|c|}{ W IN D. } \\
\hline & & & Days. & Inches. & N. & N.E. & E. & S.E. & s. & s.w. & w. & N.w. \\
\hline 20 yrs. & 29.795 & 47.9 & 152 & 45.46 & 43.9 & 32.6 & 50.1 & 36.7 & 41.8 & 48.2 & 65.8 & 45.9 \\
\hline 25, & 29.808 & 47.9 & 154 & 44.70 & 42.1 & 31.4 & 54 & 35.5 & 47.1 & 49.9 & 62.3 & 42.7 \\
\hline 30 & 29.816 & 47.6 & 156 & 42.89 & 40.7 & 32.5 & 57.9 & 34.3 & 45.8 & 50.1 & 61.6 & 42.3 \\
\hline 35, & 29.819 & 47.6 & 158 & 43.44 & 40 & 33.8 & 59.4 & 32 & 44 & 50.5 & 61.9 & 42.5 \\
\hline 40 & 29.824 & 47.6 & 157 & 43.64 & 39.2 & 35.6 & 61 & 31.8 & 45.5 & 49.3 & 61.4 & 41.2 \\
\hline 45 & 29.823 & 47.6 & 159 & 44.01 & 37.7 & 35.7 & 62.1 & 32.1 & 47.1 & 47.9 & 62 & 40.7 \\
\hline 50 & 29.827 & 47.6 & 159 & 44.20 & 36.8 & 34.2 & 59.7 & 32.4 & 46.1 & 47.9 & 66.5 & 41.4 \\
\hline
\end{tabular}

Lowest annual average temperature, $45.3^{\circ}$ (1892).

Highest annual average temperature, $49.2^{\circ}$ (1868).

Highest actual temperature, $\ldots .990 .4^{\circ}$ (August 14th, 1876).

Lowest actual temperature (December 24th, 1860).
Highest reading of Barometer, 30.928" (January 9th, 1896).

Lowest reading of Barometer, 27.620" (December 8th, 1886). 



\section{MIGRATION.}

THROUGноणт these remarks on Migration I must particularly acknowledge the assistance of Mr. R. Service, whose interest in the subject is so well known, and to his paper on "Bird Migration in Solway"* I constantly refer.

As has already been pointed out, the avifauna of a county depends greatly upon its physical features, while its geographical position is an even more important consideration.

Situated as Dumfriesshire is in the western half of Great Britain, it is not to be wondered at that many of the rare stragglers which from time to time occur on the east coast, should never have penetrated so far west as to enter the confines of the county, which seems in fact to lie just outside the range of the general east coast migrants.

The map will show that the Nith, the Annan, the Esk, and in fact all our rivers, flow into the Solway Firth. " All of these flow in the same general direction, and have for ages been scooping out valleys that all trend in a southerly direction. The Firth that receives this large volume of fresh water has its outlet into the Irish Channel, the arm of the sea that divides Scotland and England from Ireland. There is no doubt that in comparatively recent geologic times the Irish Channel was a great tidal river, of which the Solway streams were its northernmost tributaries, and that this ancient river valley was the route by which the birds came and went in long by-past ages - a route which has left so strong an impression on posterity that the birds still travel along what is now a broad sea-way." $\dagger$

\footnotetext{
* Ann. Scot. Nat. Hist., 1903, pp. 193-204.

† Op. cit.: 1903, p. 193.
} 
Mr. William Evans, writing of the Fauna of the Forth Area, states: "It is a feature of our bird-life for many species to be partially resident and partially migratory. Thus, while some of our Song Thrushes are resident all the year round, a large proportion are essentially only summer visitants ; others, again, visit us merely as birds of passage, and it may be that some play the part of winter visitants. Such cases, it will be seen, render satisfactory grouping difficult, and show the importance of the study of geographical races."* The fact that certain species may be seen perennially in a locality does not prove that the individuals seen in spring are the same as those seen in winter; though, from the want of a better term, such species are classed as "residents." An annual emigration in reality frequently takes place, and what would otherwise become conspicuous blanks in our bird-world are filled up by immigrants of the same species from elsewhere. Thus, though it may be that individuals in the middle zone are sedentary, it is expected that at the northern limit of the distribution of a species, no birds of that species will be found in winter; while conversely at the southern limit of its range no bird of that species will be found in summer.

It would scarcely come within the scope of the present work to offer suggestions for the impulse and reason of migration. Wind and weather, high or low temperatures, at the time of migration, all influence the actual dates of arrival and departure of the migrants; and "one thing seems tolerably certain, and that is, such migration mornings in autumn always occur when the barometer is stationary, or has just commenced to fall." $\dagger$ "In the spring time of the year, any mild, moist, and therefore dark night, with not too strong a wind from any compass except the north," $\ddagger$ is pretty sure to be utilized by the feathered immigrants.

* Proc. Roy. Phys. Soc. Edin., Vol. XVII., p. 64.

† Ann. Scot. Nat. Hist., 1903, p. 195.

$\ddagger$ Op. cit., 1903, p. 204. 
The Solway Firth has been likened by H. A. Macpherson to "a great ornithological junction," and "this likening of the meeting place of the two main lines of Bird flight to a railway junction was a very happy analogy."

"Species that are quite abundant along the east coast of England and Scotland may cross England at its narrowest part opposite the Solway Firth, either in scanty numbers, very rarely, or not at all. West of the Solway Firth such species become scarcer still. It is noteworthy that a directly northward flight in spring is rather exceptional; all have a more or less westward bend in their direction. On the contrary, the autumn flight is far more direct, and goes almost, if not quite, due south."*

Mr. G. F. Scott-Elliot has stated: "Civilisation and human immigrants have followed the line of the Glasgow and South-Western Railway from the earliest prehistoric times. This is due probably to the depth and great inland extent of the valley." $\dagger$ This valley of the Nith is a very well-defined "fly-line," up and down which the birds pass in a north and south direction, in their vernal and autumnal migration, respectively; their emigration flight being in a direction which would take them down channel midway between the Isle of Man and the opposite headlands of England.

The other "fly-line," utilized by such species as the Fieldfare and Redwing, is directly east or west, according to season.

The average dates of arrival and departure of the various species have been given, so far as possible, when writing of the birds of Dumfriesshire individually in the subsequent pages; but it should be remembered that just as "One swallow maketh not summer," so the appearance of an individual is no real proof of the general immigration of that species. For example, towards the end of February or early

* Ann. Scot. Nat. Hist., 1903, p. 202.

$\dagger$ Flora of Dumfriesshire, p. ix. 
in March, those Curlews which have possibly wintered on the shores of the Mediterranean return via the Solway to their nesting-grounds in our upland districts; but at the same time numbers arrive and remain on our shores, awaiting the instinct that tells them that their breeding-haunts in the far north are ready for their reception, and individuals of this species are occasionally seen or heard passing overhead as late as May.

So far as can be gathered, our spring-migrants are noticed some seven to ten days earlier near the shore than in the northern and eastern districts of the county; the Cuckoo, for instance, being as a rule first reported from the littoral parishes, then from Lochmaben, then Canonbie, and then generally throughout the county. The sequence of passage of our immigrants from littoral to inland localities is usually quite marked. It is also believed that such species as the Swallow, Martin and Cuckoo come up the Irish Channel and are noted on either side, and in Galloway and Dumfriesshire, distinctly sooner than throughout Great Britain at localities to the eastward of this line. There would seem to be less obstacles (such as low temperature) to be overcome by birds coming along this route from the Spanish and French headlands; and observations extending over many years have led Mr. R. Service to form this opinion.

"In some springs the Redwings and Fieldfares 'crowd down' in Solway to a very large extent during April, and they occasionally remain well on into May. . . . The late stay of these birds when they cover the pasture fields, their voices mingling with the songs of the Willow-Warbler, the Cuckoo, and the Corncrake is of somewhat incongruous effect, but is a pleasant and not rare experience."*

From time to time irregular immigrations take place; as in 1888 (and in a lesser degree in 1863), when the county was visited by Pallas's Sand-Grouse. In seasons when beechmast is plentiful, large flocks of Bramblings arrive with 
certainty. The outbreaks of the vole-plague in 1874-1876 and 1891-1893, attracted Short-eared Owls in veritable hordes, while Buzzards and Rough-legged Buzzards were similarly drawn to our uplands in unwonted numbers. Winters of arctic severity bring with them such species as the Waxwing, Mealy Redpoll and Smew; and, possibly tempted by unusually warm and genial summers, the Hoopoe, Quail and Turtle-Dove, at long intervals, visit Dumfriesshire. Tempestuous weather and wild gales from the west drive before them species such as the Grey Phalarope, Leach's Fork-tailed Petrel, and Little Auk to our coast. 



\section{“ FLIGHT-NETS.”}

"Flight-Nets" are employed in most parts of Europe. The net is stretched between upright poles so as to catch the flights of waterfowl during their nocturnal movements. On the shores of the Solway the fishermen in the off-season often utilize their nets, which they erect at the estuaries of the rivers, as far as possible in well-observed lines of flight. H. A. Macpherson writes in 1897 : "The use of flight-nets has extended in our own time to the Dumfriesshire Coast, otherwise I believe that their manipulation is unknown in Scotland. The nets used vary in depth from three and a half to six feet. They are suspended upon cords stretched between poles, which are set in the ground about fifteen yards apart. Irving Murray has used such nets on the Scottish side of the Solway Firth for a good many years. He tells me that he finds it necessary to shift the nets from one position to another occasionally. He lives in a cottage on the shore, and his 'better-half' walks down the sands at daybreak to take the birds out of the nets. It often happens that there is nothing in any of the nets except an odd Dunlin or a few sea-gulls; but enough birds are taken in the last three months of the year to remunerate the old couple (the man is a Crimean veteran) for their expenditure upon the netting."* Writing in February, 1888, Mr. R. Service records that: "John Kennedy says flight-nets are now an established custom all along the Blackshaw. They were first put up some three years ago. Some good catches have been made. About a score of Barnacles were caught in each of two nights in one net lately." $\dagger$

* Hist. Fowling, p. 446.

+ R. Service's MS. Diary, February 22nd, 1888. 
It is satisfactory to be able to state that of more recent years this ' custom' has not been found to repay the labour of setting the nets. So many valueless fowl are emeshed by the use of the "flight-net," that it is hoped this engine of destruction may ere long fall into disuse, or, better still, become prohibited by law. 


\section{PROTECTION.}

A copy of the Wild Birds Protection Act as applied to the county, and as now in force, follows hereafter. It is noteworthy that in protecting the Woodcock from February 1st to October 1st, Dumfriesshire, with Kirkcudbrightshire and Wigtownshire, has given the lead to the rest of Scotland, in granting what must be regarded as a most beneficial close-time to this species, and it is to be hoped that this sportsmanlike example may be as unselfishly followed by the rest of Great Britain, on the first opportunity. The SheldDuck is protected throughout the year, as being a harmless and ornamental species on our coast, and it is encouraging to know that this bird has already increased during the currency of this Order. Prosecutions under the Act have been few and far between, and it is satisfactory to find that the community at large regard the protection of birds and their eggs as neither injudicious nor irksome.

Is it too much to hope that the various (and it is to be regretted, varying) County Council Orders for the protection of birds may one day be drawn up by a competent committee of ornithologists, so as to apply to the individual requirements of every county in Great Britain and Ireland, and thus ensure the effectual protection of our British avifauna?

\section{COUNTY OF DUMFRIES.}

The Wild Birds Protection Order, 1908.

Whereas the Wild Birds Protection (County of Dumfries) Order, 1905, will expire on the twenty-ninth day of February, 1908 :

And whereas it is expedient to renew the said Order: 
Now, therefore, I, the undersigned, His Majesty's Secretary for Scotland, in pursuance of the powers conferred upon me by the Wild Birds Protection Acts, 1880 to 1904, and upon application by the Joint Committee of the County and Burghs of Dumfries (to whom the administration of the said Acts has been delegated by the County Council of Dumfries in terms of Section 76 of the Local Government (Scotland) Act, 1889, do hereby make the following Order :-

1. This Order shall apply within the County of Dumfries.

2. The "Wild Birds Protection Act, 1880," shall apply to the following Wild Birds as if they had been included in the Schedule to the said Act, viz. :-

Bullfinch
Buzzard
Crossbill
Dipper
Hawfinch

Jay

Kestrel

Merlin

Osprey

Peregrine Falcon
Quail

Raven

Siskin

Tufted Duck

3. The taking or killing of any of the following Wild Birds is hereby prohibited throughout the whole year :-

Buzzard
Chough
Dotterel
Goldfinch
Great-crested
Grebe

Kestrel
Kingfisher
Osprey
Owl, Barn
Owl, Long-eared
Owl, Short-eared

Owl, Tawny

Peregrine Falcon

Sheld Duck

Woodpecker,

Great Spotted

4. The taking or killing of the Woodcock is hereby prohibited between the first day of February and the first day of October in each year.

5. The taking or destroying the eggs of the following Wild Birds is hereby prohibited, viz. :-

Bullfinch
Buzzard
Chough
Crossbill
Dipper
Dotterel
Eider Duck
Goldfinch
Great-crested
Grebe
Gull, Common
Hawfinch
Jay
Kestrel
Kingfisher

Mallard

Merlin

Nightjar

Osprey

Owl, Barn

Owl, Long-eared

Owl, Short-eared

Owl, Tawny

Oyster Catcher

Peregrine Falcon

Plover, Golden

Plover, Ringed

Pochard

Quail

Raven
Sheld Duck

Shoveller

Siskin

Skylark

Snipe

Teal

Tern, Common

Tern, Little

Tern, Sandwich

Tufted Duck

Wigeon

Woodcock

Woodpecker, Great Spotted 
6. The taking or destroying the eggs of the Lapwing is hereby prohibited after the fifteenth day of April in each year.

7. This Order, which may be cited as "The Wild Birds Protection (County of Dumfries) Order, 1908," shall take effect on the first day of March, 1908, and shall remain in force until the twenty-eighth day of February, 1911.

Given under my hand and seal of office at Whitehall, this 30th day of January, 1908.

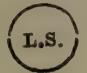

(Signed) JOHN SINCLAIR, His Majesty's Secretary for Scotland.

In terms of the Wild Birds Protection Acts, 1880 to 1904, the Joint Committee of the County of Dumfries and Burghs hereby give public notice of above order by the Secretary for Scotland.

JOHN ROBSON, Clerk of the Committee.

County Buildings, Dumfries, 10th February, 1909.

A circular, of which the following is a copy, explaining the preceding Wild Birds Protection Order, and setting forth the penalties incurred by its contravention, is circulated annually, by means of the County Police and others, with the statutory publication of the Order throughout the county :-

\section{COUNTY OF DUMFRIES.}

\section{WiLd Birds Protection.}

1. Briefly the Wild Birds Protection Acts, 1880 to 1904, as applicable to the County of Dumfries, and the Wild Birds Protection (County of Dumfries) Order, 1908, made by the Secretary for Scotland in terms of these Acts, made it unlaw. ful-

(a) For any person at any time to take or kill any of the following wild birds, viz. :-

Buzzard

Chough

Dotterel

Goldfinch

Great-crested Grebe
Kestrel

Kingfisher

Osprey

Owl, Barn

Owl, Long-eared
Owl, Short-eared

Owl, Tawny

Peregrine Falcon

Sheld Duck

Woodpecker, Great

Spotted 
(b) For any person, between 1st February and 1st October in any year, to take or kill the Woodcock.

(c) For any person, between 1st March and 1st August in any year, to take or kill any of the following wild birds, viz. :-

\begin{tabular}{l|} 
American Quail \\
Auk \\
Avocet \\
Bee-eater \\
Bittern \\
Bonxie \\
Bullfinch \\
Colin \\
Cornish Chough \\
Coulterneb \\
Crossbill \\
Cuckoo \\
Curlew \\
Dipper \\
Diver \\
Dunbird \\
Dunlin \\
Eider Duck \\
Fern-owl \\
Fulmar \\
Gannet \\
Goatsucker \\
Godwit \\
Grebe \\
Greenshank \\
Guillemot \\
Gull (except black- \\
backed gull) \\
Hawfinch \\
Hoopoe \\
Jay \\
Kittiwake
\end{tabular}

Lapwing
Lark
Loon
Mallard
Marrot
Merganser
Merlin
Murre
Night-hawk
Night-jar
Nightingale
Oriole
Owl
Ox bird
Oyster Catcher
Peewit
Petrel
Phalarope
Plover
Ploverspage
Pochard
Puffin
Purre
Quail
Raven
Razorbill
Redshank
Reeve or Ruff
Roller
Sanderling
Sandpiper

Scout

Sealark

Seamew

Sea Parrot

Sea Swallow

Shearwater

Shelldrake

Shoveller

Siskin

Skua

Smew

Snipe

Solan Goose

Spoonbill

Stint

Stone Curlew

Stonehatch

Summer Snipe

Tarrock

Teal

Tern

Thickknee

Tufted Duck

Tystey

Whaup

Whimbrel

Widgeon

Wild Duck

Willock

Woodcock

Woodpecker

(d) For any person (other than the owner or occupier of the land on which the wild bird is killed or taken or any person authorised by the owner or occupier of such land) between 1st March and lst August in any year to take or kill any wild bird other than those mentioned in sub-sections (a) (b) and (c) above.

(e) For any person between fifteen days after the commencement and the end of the annual close time for the several species of wild birds, to expose or offer for sale or to have in his control or possession any wild bird of that species recently killed or taken, unless such person shall prove (1) that the killing or taking of such wild bird was lawful at the time when, and by the person by whom, it was killed or taken, or (2) that the wild bird was killed or taken in some place to which the Acts do not extend.

(f) For any person at any time to take or destroy the eggs of the following wild birds, viz. :- 
Bullfinch

Buzzard

Chough

Crossbill

Dipper

Dotterel

Eider Duck

Goldfinch

Great-crested Grebe

Gull, Common

Hawfinch

Jay

Kestrel

Kingfisher
Mallard

Merlin

Nightjar

Osprey

Owl, Barn

Owl, Long-eared

Owl, Short-eared

Owl, Tawny

Oyster Catcher

Peregrine Falcon

Plover, Golden

Plover, Ringed

Pochard

Quail
Raven

Sheld Duck.

Shoveller

Siskin

Skylark

Snipe

Teal

Tern, Common

Tern, Little

Tern, Sandwich

Tufted Duck

Wigeon

Woodcock

Woodpecker, Great

Spotted

(g) For any person after 15th April in any year to take or destroy the eggs of the Lapwing.

(h) For any person to affix, place or set, on any pole, tree or cairn of stones or earth, any spring, trap, gin, or other similar instrument calculated to cause bodily injury to any wild bird coming in contact therewith.

(i) For any person found offending against the Acts or Order to refuse to give his Christian name, surname, and place of abode to any other person requiring him to do so, or to give an untrue name or address to such other person.

Note. - "Take or kill" includes shooting or attempting to shoot; using any boat for the purpose of shooting or causing to be shot; and using any lime, trap, snare, net, or other instrument for the purpose of taking.

2. The Acts provide various pecuniary penalties, with alternatives of imprisonment, for the offences against the Acts and Order indicated above, and provide also for forfeiture of the wild birds or eggs, in respect of which an offence was committed, and of any trap, net, snare, decoy bird, etc., used for taking any such wild bird.

County Butldings, Dumfries.

In view of the fact that many of the names of the birds in the Schedule of the Wild Birds Protection Act, 1880, (which is quoted in the local circular (see p. xc (c)), are somewhat obscure, it may here be useful to give a translation of them :-

\begin{tabular}{|c|c|c|}
\hline il & & The \\
\hline BC & & kua \\
\hline Coli & & The Vir \\
\hline
\end{tabular}


Coulterneb

Dunbird

Fern-owl

Goatsucker

Loon

Marrot

Murre

Night-hawk

Oxbird

Peewit

Ploverspage

Purre

Scout

Sealark

Seamew

Sea Parrot

Sea Swallow

Solan Goose

Stonehatch

Summer Snipe

Tarrock

Thickknee

Tystey

Whaup

Willock
$=$ The Puffin.

$=$ The Pochard.

= The Nightjar.

= The Nightjar.

.. Usually applied to the Divers, but also to the Grebes and the Little Auk.

. Applied indifferently to the Guillemot, Razorbill and the Puffin.

. Applied indifferently to the Guillemot and the Razorbill.

$=$ The Nightjar.

$=$ The Dunlin.

$=$ The Lapwing.

$=$ The Dunlin.

$=$ The Dunlin (in winter plumage).

.. Applied indifferently to the Guillemot and the Razorbill.

$=$ The Ringed Plover.

.. Applied indifferently to the various Gulls.

$=$ The Puffin.

.. Applied indifferently to the various Terns.

$=$ The Gannet.

$=$ The Ringed Plover.

$=$ The Common Sandpiper.

$=$ The Kittiwake Gull (in immature plumage).

$=$ The Stone-Curlew.

$=$ The Black Guillemot.

$=$ The Curlew.

.. Applied indifferently to the Guillemot and the Razorbill. 


\section{LOCAL MISNOMERS AND NAMES.}

IN view of the fact that many birds are locally called by names which are misleading, or which are generally or elsewhere given to other birds, it will be useful here to give a list of these misnomers. The wrong identification of a species is responsible for many such, and one name in some cases serves for two different birds. Thus, for example, the name "Goldeneye" is given to the Tufted Duck and the Goldeneye ; and "Felty" to both the Mistle-Thrush and the Fieldfare. The following list will show to what birds these misleading names are most frequently applied locally, and throughout the book they will be included in every case among the "Local Names" of the individual species.

Local Name.

SPECIES INTENDED.

Blackcap

.. Often applied to the Coal-Titmouse.

Black-headed Bunting. . For the Reed-Bunting.

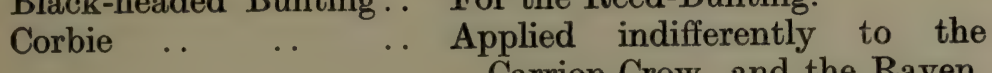
Carrion-Crow and the Raven.

Crane $\quad . \quad$.. $\quad$.. For the Heron.

$\begin{array}{llll}\text { Crested Tit } & . . & \text {.. } & \text { For the Holden-crested Wren. }\end{array}$

$\begin{array}{lllll}\text { Crow } & \text {.. } & \text {.. } & \text {.. } & \text { Often applied to the Rook. }\end{array}$

Feltifleer, Felty... .. $\quad$ Often applied to the MistleThrush.

Glead, Gled .. . . For the Common Buzzard.

Goldeneye $\quad \ldots . \quad \ldots$ Often applied to the Tufted Duck.

Goshawk.. $\quad . \quad$.. For the Peregrine.

Greater Blackcap ... $\quad$.. For the Great Titmouse.

Green, or Grey Plover ... Often applied to the Golden Plover. 
Local Name.

Grey Wagtail .

Hoodie, Hoodie-Craw .. Often applied to the Carrion-

Kingfisher

Moorhen, Muirhen

Pirr

Redlegs .. $\quad . . \quad$.. For the Redshank.

Redpoll .. $\quad . . \quad$.. Often applied to the Linnet.

Rock-Dove .. .. For the Stock-Dove.

Snowbird $\quad$. $\quad$.. $\quad$ For the Fieldfare.

Stanechacker .. .. For the Wheatear.

Stockannet, Stockgander Applied both to the Sheld-Duck, and the Goosander.

Water-Crow .. .. Often applied to the Cormorant (on the coast): but to the Dipper (inland).

Wee Horned-Owl

Wood-Lark

Woodpecker

Yellow Wagtail ..

Crow.

Often applied to the Dipper.

. Old names for the Red Grouse.

.. Applied indifferently to the Arctic and Common Tern.

\section{Species Intended.}




\section{LOCAL MISNOMERS AND NAMES XCV}

Lochan $=a$ small loch; a lakelet.

Merse $\quad=$ land gained from the sea or a river.

Moss . = a bog.

Moss-hag = a cutting in the bog.

Muir $=$ a moor.

Parr = the young of salmon.

Peat-hag $=$ a cutting in the peat.

Peat-moss $=$ a bog producing peat.

Stake-net $=$ a fixed net erected for the capture of salmon.

Steading = the barns, stables, cattle-yards, etc., of a farm.

Stook $=$ a collection of sheaves set up in the field.

Wae $\quad=$ woeful.

Water $=$ a river or stream; thus Shinnel

Water, Water of $\mathbb{E}$, etc. 



\section{NUMBER OF SPECIES.}

UNDER their respective titles I have enumerated 218 species as having occurred in the county, not including some thirty-nine others, which have either been introduced or whose occurrence is doubtful, such being placed between square brackets.

The birds of Dumfriesshire may be classified roughly as :-

Residents (see qualifying remarks, p. LXXX).. 70

$\begin{array}{llllll}\text { Summer-visitants } & \ldots & \ldots & \ldots & \ldots & 31\end{array}$

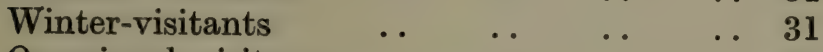

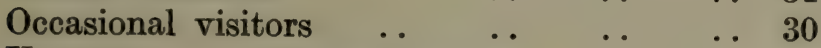

Very rare or accidental visitors $\quad \ldots \quad \ldots \quad \ldots 6$

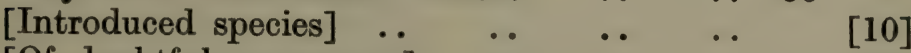

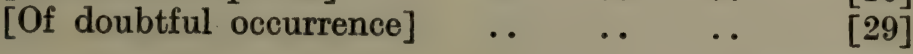

$218 \quad[39]$

The status of each species has been fully dealt with in the subsequent pages, so that only a very brief review seems here necessary. The local histories of the Starling and Stock-Dove are noteworthy, as are also those of the Jay, Tufted Duck, and Great Crested Grebe; while the Hawfinch and Great Spotted Woodpecker may, it is hoped, soon become more generally dispersed. The Pheasant I have regarded as a resident species, and though of course, originally introduced, its establishment locally for upwards of a hundred years warrants its inclusion as such. It is satisfactory to be able to record with certainty the breeding of the Lesser Whitethroat, but it is to be regretted that there is no visible increase in the numbers of Pied Flycatchers that come here to nest. The records of the White Wagtail are disappointing, since this species is described as "a fairly common bird 
of passage,"* in the neighbouring area of Clyde; and this must surely be due to the lack of observation or discrimination on the part of our local observers. The changes in the species of Geese that visit the Solway in winter are dealt with in their proper place. The majority of our winter-visitants are affected numerically by the severity or mildness of the season.

As " occasional visitors" I have classified those species which cannot be regarded as either summer or wintervisitants, but by the frequency of their occurrence are entitled to rank as more than "accidental visitors." Under this latter category I include the Two-barred Crossbill, Night-Heron, Black-winged Stilt, Whiskered Tern, etc. The Bittern and Ptarmigan are among the species which have long since become locally extinct. My inclusion of such birds as the Lesser Spotted, and Green Woodpeckers, Snow-Goose, Blue-winged Teal, Great Snipe, and Spotted Redshank, without square brackets, has been done deliberately after full consideration of the evidence at hand ; in fact, I may say that no bird has been so admitted without full investigation.

As regards those species which are included in square brackets :- The absence of the Tree-Sparrow is remarkable. The allegations of the occurrence of the Black Redstart and Woodlark have not stood the test of minute inquiry. The evidence regarding the Crested Titmouse, Blue-headed Wagtail, Little Egret, Garganey, Red-breasted Goose, Rock-Dove and Fulmar is in each case too slender to admit of their inclusion otherwise. The records of the Nightingale, Reed-Warbler, Fire-crested Wren and Wandering Albatross need not be seriously considered. Mention is made of the Parrot-Crossbill, Great White Heron and Spoonbill only to show that their claims for inclusion have not been forgotten, and ancient history is responsible for the Crane and the Goshawk. As regards the PineGrosbeak, Montagu's Harrier, Kite and Lesser White-fronted 
Goose, I confess to an inclination to eliminate the square brackets, especially in the case of the latter. The IvoryGull was presumably wrongly identified. The Ruddy SheldDuck has been shown to have been an "escape," as were undoubtedly the Egyptian Goose, North American SummerDuck, Black-necked Swan, Black Swan, Muscovy Duck, Chukar Partridge and Red-winged Starling; while the Virginian Colin was an introduced species which never became established, and the Red-legged Partridge comes under the same category.

Reference will not again be made to the Emus and Rheas kept in semi-captivity from 1875 to 1885 by Richard Bell at Billholm and Castle O'er,* as such introductions do not come within the scope of this volume. There remain several ornithological puzzles presented by descriptions of birds which were unknown to their chroniclers; such as a bird (possibly a Nutcracker) recorded in $1794 \uparrow$; and an extraordinary duck described by William Hastings in $1885 . \ddagger$ These and others I have been unable to identify with sufficient certainty to mention hereafter.

I must not conclude these introductory remarks without pointing out that the hand-rearing of various species of wildfowl, now in progress at Netherby, Cumberland, is likely to make itself felt in Dumfriesshire. Sir Richard Graham has most courteously informed me of various experiments he has in hand there on a large scale, both as regards hybrid ducks and the establishment of such species as the American Wigeon, and Garganey, in a full-winged state. Reference to the map will show how presumable it is that some of these domesticated wildfowl may any day visit this county, and subsequent students of the avifauna of Dumfriesshire may find it useful to bear this in mind.

* My Strange Pets, pp. 1-38.

† Stat. Acct. Scot., Vol. X., p. 2:4.

‡ Trans. D. and G. Nat. Hist. Soc, December 4th, 1885. 



\section{THE BIRDS OF DUMFRIESSHIRE.}

\section{THE MISTLE-THRUSH. Turdus viscivorus, Linnæus.}

Local names-STORMBIRD ; STORMCOCK ; WoOd-ThrUSH ; Felty ; Feltiflier.

A common resident throughout the county. Formerly rare.

That the Mistle-Thrush was formerly a rarity in the south of Scotland we have good evidence. In 1791, in an account of the parish of Kirkmichael, we find it mentioned among the "rare birds" thus - " there is great plenty of the rarer species of birds, the land and the water rails, the quail, the missel thrush,"* etc. Sir William Jardine writes in 1832 as follows: "Fifteen years ago they were rarely to be seen, but in consequence of the increased extent of plantations, they are now frequently met with in pairs, or in parties of five or six." $\dagger$ In a letter to P. J. Selby, dated April 15th, 1836, he mentions a Mistle-Thrush's nest near Jardine Hall. Dr. Grierson (who, it is only fair to note, was at the time a boy of sixteen) describes, in 1834, a nest and eggs of the Mistle-Thrush given to him by J. Douglas, a gamekeeper at Drumlanrig; but they were so far unknown to him that he records them as those of the Starling, $\ddagger$ a bird equally rare in the county in those days. Thomas Aird, in 1864, speaks of the species as " multiplying yearly "§ in the vicinity of Dumfries.

The Mistle-Thrush is now distributed throughout the county, and its welcome song may be expected by the middle of January, should there be sunny intervals between the squally showers so prevalent at that time.

* Stat. Acct. Scot., Vol. I., p. 60.

† New Stat. Acct. Scot., Vol. IV., p. 178.

‡ Grierson's MS. Diary, May 5th, 1834.

§ Trans. D. and G. Nat. Hist. Soc., December 6th, 1864. 
In the autumn these birds may be seen in small straggling parties, and towards the middle of October a great number of our Mistle-Thrushes migrate southwards.

In defence of its nest or young this bird is most bold, and Mr. Tom Brown records an attack on an inoffensive fowl.* Small boys, bent on robbing its nest, have been driven back terrified and with their caps knocked off, while a pony coming too near has been buffeted and frightened away.

A curious albinistic variety, shot by me near Capenoch (Keir) on August 6th, 1908, is now in the possession of Mr. R. Service.

\section{THE BRITISH SONG-THRUSH.}

Turdus musicus clarkei, Hartert.

Local names-MaveY; Mavis.

"Hark, the mavis' e'ening sang

Sounding Clouden's woods amang."

ROBERT BURNS.- "Ca' the yowes to the knowes."

A very common resident throughout the county; found nesting in all suitable localities and penetrating in spring even into the upland glens and ravines wherever there are any trees or bushes.

Towards the end of February or in the early days of March, those of our nesting Song-Thrushes which had emigrated, return; but large numbers are seen or heard high overhead so late even as the middle of May, going further north to breed. Early in October an influx of Thrushes takes place, of apparently smaller and darker birds, such birds at this season being particularly noticeable in the turnipfields. Some ornithologists have considered these immigrants to have a Hebridean origin $\uparrow$; but Dr. Ernst Hartert, who has most kindly examined some local skins sent him by Mr. R. Service and myself, states that he can only recognise two races of Song-Thrushes in Europe-" (1) the

* Trans. D. and G. Nat. Hist. Soc., December 4th, 1885.

$\dagger$ Mon. of Turdidoe, Vol. I., p. 131. 
Continental one, and (2) the British one." The latter he has named T. musicus clarkei, and this race is the prevailing form found with us. An extensive migration undoubtedly goes on in the county, but whence our autumnal visitants come is a question still to be decided.

About the third week of October the numbers of our Thrushes are much reduced by a great emigration to the south. In severe winters, such as 1879-1880, 1885-1886, those that remain suffer terribly, and numbers die of starvation.

Nests built on the ground are often found, although it was not until the spring of 1890 that this habit was first noticed locally. On May 12th, 1903, a nest was found at Capenoch (Keir) which contained two Thrush's eggs and three of a Blackbird.

James Shaw, the Tynron schoolmaster, records that a Thrush lived twelve years in captivity and was then drowned, as it could no longer clean itself properly.*

Mr. Fred. V. Theobald writes, that in spite of the damage it does to fruit, "we must record the fact that for nine months the Thrush does good, feeding on snails, slugs, insects, worms and berries. ... Everyone interested in the economic aspect of bird-life seems agreed that they should be kept in check, but that a wholesale slaughter is not essential." $\dagger$

THE REDWING. Turdus iliacus, Linnæus.

"Fieldfares and redwings on the dun blanched leas, And flocks of finches from the stubbles bare, Shall rise before you with their glistening wings As for yon upland through the fields you strike."

Thomas Arrd.- "A Winter Day."

A winter-visitant throughout the county.

This bird usually arrives about the 7th to 12th of October, and, though occasionally seen well on into May, usually

* A Country Schoolmaster, pp. 297, 298.

† Science Progress, 1907, Vol. II., p. 279. 
departs early in April for its more northerly breedingquarters in north-west Europe. Redwings are sometimes found in large flocks, but more generally in small parties, and in some winters, as in 1907 , are more than usually numerous.

When the berry-crop has become exhausted, these birds subsist mainly on beetles, snails and such like, and it is quite astonishing how they can find so much insect-life in the depth of winter, when the ground is frozen and covered with snow. They would seem to suffer more than any other members of the genus in severe winters, as in 1878-1879, when, as I am informed by Mr. R. Service, he found "four lying dead together in one rabbit hole." In the winter of 1894-1895 they also succumbed in large numbers.

The song of the Redwing is particularly sweet and pleasing, and occasionally in April an isolated bird may be heard bursting forth into melody.

THE FIELDFARE. Turdus pilaris, Linnæus.

Local names-Felty; Feltiflier; Snowbird.

"If, 'mid the tassels of the leafless ash,

A fieldfare flock alight, for early frosts

Prepare."

James Grahame.-_"British Georgics" (October).

A common winter-visitant throughout the county.

"Feldefares" were well known to Dr. Archbald, as he refers to them in his "Curiosities at Drumfriess," written circa 1684.* The species is also recorded in the Statistical Account of Scotland as a migrant to the parishes of Johnstone, $\uparrow$ Mouswald, $\ddagger$ and Canonbie. $\S$

* Sibbald's MS. Collections, p. 228.

† Stat. Acct. Scot., Vol. IV., p. 226.

‡ Op. cit., Vol. VII., p. 294.

§ Op. cit., Vol. XIV., p. 413. 
The Fieldfare arrives here about the middle of October, though Mr. R. Service records in his diary its arrival so early as September 24th, in 1879. The following severe winter caused great destruction to its numbers, though it would seem a hardier bird than the Redwing, and is always extremely wary and shy.

In his MS. Calendar Sir William Jardine writes: "May 3rd, 1829. Never before saw Fieldfares in flocks with the Swallows here. Pairs have been known to remain longer." Not infrequently a few linger with us so late as the middle of May, but the majority depart at the end of April to their breeding-places in northern Europe where they nest, usually in colonies.

The following statement by Mr. J. Simpson is unsubstantiated: "Some years ago, when I was a youth and living in Dumfriesshire . . . one day I noticed what seemed to me to be a Thrush's nest, but in rather an unusual place. ... The bird flew out as I ascended the tree, and I saw at once it was a Fieldfare."*

The Fieldfare is often confused with the Mistle-Thrush, and the reported occurrences of its having nested in the county may be accounted for in this way, and cannot be credited.

\section{THE BLACKBIRD. Turdus merula, Linnæus.}

\section{Local names-BLACKIE; MerLe.}

"And now, perched proudlie on the topmost spray,

The sootie blackbird chaunts his vespers shrill;

While twilight spreads his robe of sober gray,

And to their bowers the rooks loud cawing wing their way."

W. J. MICKLE.-"Sir Martyn."

A very common resident throughout the county.

In September a general " crowding-down" of Blackbirds takes place, and numbers are to be found at the sides of the fields searching about in the hedge-bottoms * Field, 1873, Vol. XLI., p. 491. 
for food, and about the third week in October a wellmarked emigration of a great number of our birds is observed.

In 1904 I wished to photograph a Lapwing on her nest, so a hut of spruce-branches was built and placed for several days conveniently near a nest, but when I went to photograph the bird, her eggs had all been destroyed by Rooks. On moving the hut I found a Blackbird had made its nest in the spruce-branches, so care was taken when erecting the hut near a fresh Lapwing's nest not to disturb that of the Blackbird. This Lapwing's nest was also destroyed by Rooks, so the hut was moved a third time to another nest, where I obtained my photograph. As I sat in the hut with my camera, the Blackbird, which had fearlessly followed her nest, incubated her eggs within two feet of me. Eventually, as the field had to be harrowed, the sprucebranches of the hut were carefully placed at one side of the field about one hundred yards off, and here the faithful Blackbird had the satisfaction of rearing her brood without further disturbance.

Nests on the ground, or in stone-dykes, are frequently recorded, as are also abnormally small and misshapen eggs. Thos. Corrie states that in the spring of 1870 a pair of Blackbirds brought up two broods in the same nest after re-dressing it.* A nest with two eggs was found in the first week of January, 1909, at Millpool (KirkpatrickDurham, Kirkcudbrightshire).$\dagger$

In the garden the Blackbird is even more destructive than the Song-Thrush, and it has been aptly described as "the blackest of thieves" ; but its utility at other times of the year when there is no fruit should be taken into consideration. I have been confidently told by Mr. J. Murray that in 1904 he saw "a Blackie carrying an egg which it subsequently broke and sucked," a habit occasionally observed in the Mistle- and Song-Thrush.

* Minutes of D. and G. Nat. Hist. Soc., December 6th, 1870.

† Dumfries Courier and Herald, January 9th, 1909. 
Pied varieties are reported from many parts of the county, particularly from the lower portion of Eskdale, and Mr. J. Harkness writes me of a curious reddish-brown variety he once had to stuff. Pure white specimens are more rare, but I know of one true albino with pink eyes captured at Kirkconnel. Mrs. Pollock writes me that about 1866 a white Blackbird was occasionally seen on the lawn at Dalswinton. "Its appearance was invariably followed by family disasters, so that when it was seen we knew it heralded bad news."

\section{THE RING-OUZEL. Turdus torquatus, Linnæus.}

Local names-Modntain-BlaCkBIRD; Mountain-BLACKie.

A common summer-visitant to the upland districts of the county.

Dumfriesshire may certainly be considered as one of the headquarters in Great Britain of the Ring-Ouzel. Abundant as it is in the mountainous parts of Lakeland, and the neighbouring counties, it can scarcely be more numerous than it is with us in spring, when every crag and ravine at a suitable elevation may be confidently expected to be tenanted by a pair of breeding-birds. In the low-lying districts and littoral parishes of the county it is a comparatively rare bird, being only seen there on migration.

Rarely at the end of March, more generally towards the middle of April, the Ring-Ouzel arrives at its nestinggrounds ; the earliest date of its arrival that I know of being at Sanquhar on March 25th, 1907.* Early in September when the rowan-berries have been finished, these birds may be found at lesser altitudes, frequenting the hedgerows at the sides of the roads, or even coming into gardens in search of food. The general emigration to the countries of the Mediterranean takes place in October, though nearly every season laggards are reported as here in

* Trans. D. and G. Nat. Hist. Soc., April 18th, 1907. 
November, while "Mabie Moss" records that a RingOuzel was shot near Dumfries on December 9th, 1892,* a remarkably late date, though not unprecedented.

The nest is seldom found at an altitude of less than seven hundred feet, and usually away from the haunts of man amidst rocks and rough heather; such a situation is shown in my photograph here reproduced. "Mabie Moss" writes of a nest built in an evergreen bush in the garden of Townhead Farm $\dagger$ (Closeburn), a truly strange choice of locality. Dr. Anstruther Davidson, in 1888, speaks of the parishes of Kirkconnel and Sanquhar as "the home par excellence" of this species, and he mentions a pair of birds which, owing to the destruction of their nests and eggs, built three nests and laid twelve eggs between April 24th and May 19th.

Pied varieties are rare, but have been met with, and Mr. R. Service informs me that one with an almost entirely white head was killed near Closeburn on October 13th, 1893.

THE WHEATEAR. Saxicola œnanthe (Linnæus).

\section{Local names-Stanechacker; Dyker; Dykie.}

"Stane Chack !

De'il tak' !

They who harry my nest

Will never rest,

Will meet the pest !

De'il break their lang back

Wha my eggs wad tak' tak'."

CHAMBers' "Popular Rhymes of Scotland."

\section{A common summer-visitant :hroughout the county.}

The Wheatear is included in a list of birds of the parish of St. Mungo, in 1794, as a bird of passage.§ Sir William Jardine, writing in 1839 , says that they arrive during the

* Dumfries Courier and Herald, December 9th, 1892.

$\dagger$ Op. cit., January 22nd, 1891.

† Trans. D. and G. Nat. Hist. Soc., November 10th, 1888.

§ Stat. Acct. Scot., Vol. XI., p. 389. 


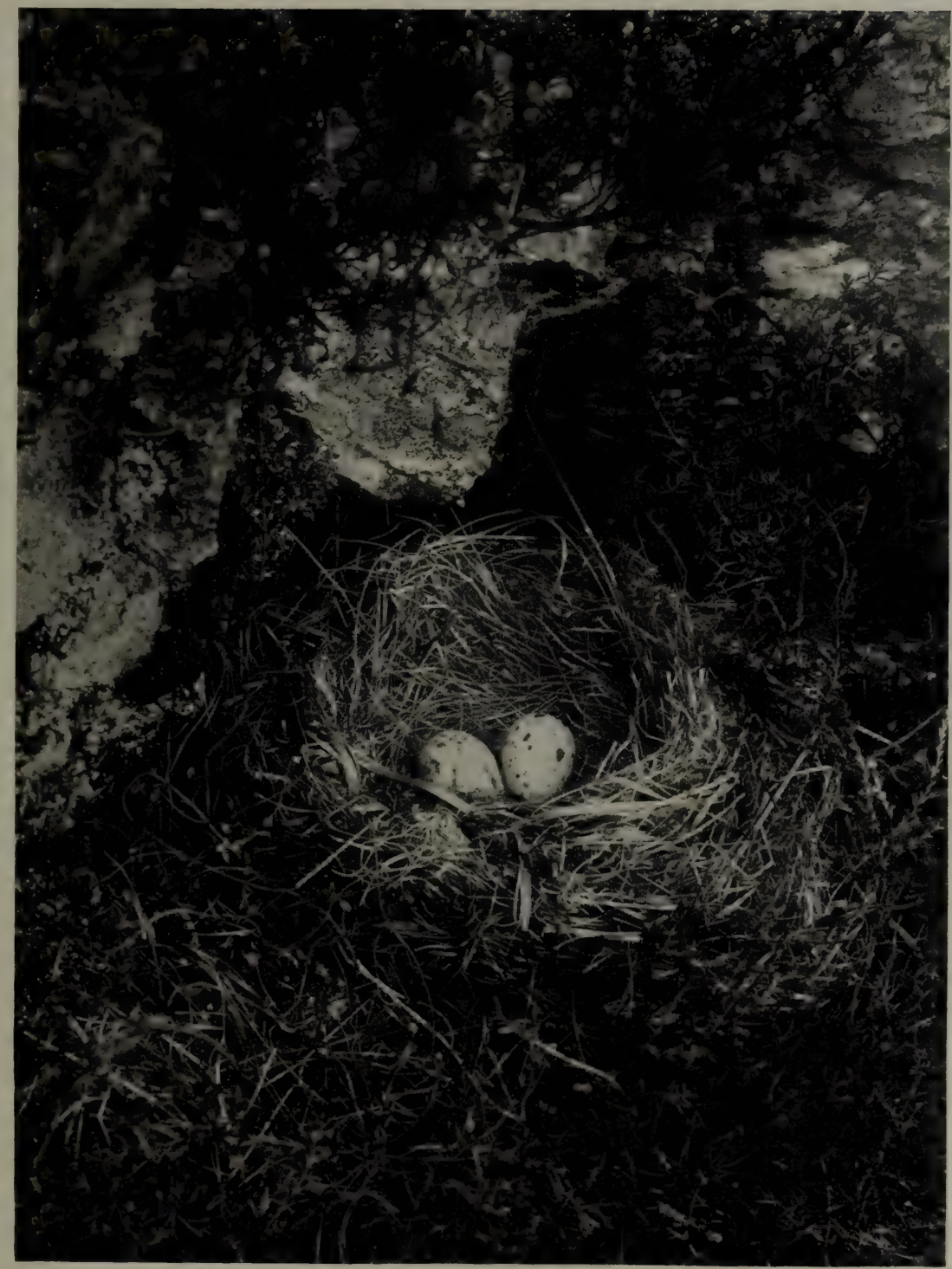

NEST AND EGGS OF THE RING-OUZEL (Turdus torquatus). 

first week of March,* which nowadays would be considered early; in 1907 this species was noticed near Dumfries on the 19 th, $\uparrow$ but it is not until towards the end of that month, or in the early days of April, that the bird usually puts in an appearance. Migratory individuals often arrive for a month later, especially on the Dumfriesshire "Banks," but these birds do not nest in the county, and are simply resting on their way further north. Amongst these later arrivals may be detected some members of the Greenland race (Saxicola onanthe leucorrhoa), which are larger and generally less neat-looking birds than our own nesting-species.

In the nesting-season the Wheatear is most plentifully found in the pastoral, arable and lacustrine districts, where our loose stone-walls or "dykes" afford capital nestingplaces, and rabbit-burrows are often utilized for this purpose. In August and September, prior to migration, a general " crowding-down" to the littoral districts is observed.

The Wheatear winters in the countries south and east of the Mediterranean, and in some seasons it leaves us as early as the end of August; but more generally the emigration takes place about the middle of September, and a few laggards may usually be found on our littoral in October.

Mr. R. Service writes me that "the universal local name for this bird in Dumfriesshire is Dyker, i.e., owing to its habits of sitting and flitting along the tops of the stone-dykes." But I have not heard it so called in the north-western parts of the county.

[The Isabelinne Wheatear (Saxicola isabellina, Rüppell) has not been recorded from this county, but in a letter to Mr. R. Service, H. A. Macpherson writes : "I think it only neighbourly to tell you that the new avis shot on November 11th, 1887, is a young Isabelline Wheatear. Very likely it reached us from Siberia via Heligoland,

\footnotetext{
* Nat. Lib., 1839, Vol. XI., p. 108.

$\dagger$ Ann. Scot. Nat. Hist., 1908, p. 133.
} 
the Firth of Forth and the valley of the Nith. Aigle Gill, a farm near Allonby, must be about opposite the mouth of the Nith, as indeed the map shows. It was shot on a ploughed field. I am busy, and will only add that having asked the brothers Mann to look out for S. deserti they shot this as a candidate... Saunders, Seebohm and Sharpe handled it in the flesh, and all agreed about its being "Isabelline." This Cumberland specimen is the only record of the occurrence of this species in Great Britain. The distinguishing characteristics of the Isabelline Wheatear may be thus summed up: "It is larger, more tawny, and has more black in its comparatively short tail than any Common Wheatear; the colour of the underwing is much lighter, and the bill and tarsi are longer."**]

\title{
THE WHINCHAT. Pratincola rubetra (Linnæus).
}

\author{
"I have heard \\ Where melancholy plovers hovering screamed, \\ The partridge-call, at gloamin's lovely hour, \\ Far o'er the ridges break the tranquil hush; \\ And morning larks ascend with songs of joy, \\ Where erst the whinchat chirped from stone to stone." \\ James GraHame.- "British Georgics" (February).
}

A common summer-visitant to all suitable localities where there are copses, and tangled, rank herbage.

The above lines, written at Mount Annan in the summer of 1808 , refer to the improvement of moorland by ploughing and cultivation which deprived this species of many a favourite nesting-site.

The Whinchat arrives here at the end of April or in May, and departs for its winter-quarters in Africa in September, occasionally lingering till October.

The interior of the nest is usually neatly lined with fine grass or horsehair, but "Mabie Moss" has recorded a Whinchat laying in an unlined nest in Upper Nithsdale. $\dagger$

* Man. Brit. Birds, 1899, p. 22.

† Dumfries Courier and Herald, June 30th, 1891. 


\section{- THE BRITISH STONECHAT.}

Pratincola torquata hibernans, Hartert.

A resident of extremely local distribution, though often fairly plentiful where it occurs; probably increasing.

In 1832 Sir William Jardine writes of the Stonechat as the most uncommon of the Saxicola found in Applegarth parish, and adds, "a few pairs may be met with about waste brushwood or whin-coverts during the whole year."* Two specimens obtained at Jardine Hall were in his collection. $\dagger$ In 1835 it is recorded in an account of Lochmaben parish as "found in great abundance on the moors," $\ddagger$ a statement which I am inclined to doubt; and it may well refer to the Wheatear or Whinchat, as neither of these are mentioned in the account. Mr. S. Chrystie in 1881 includes the Stonechat in a "List of birds that breed in the parish of Dumfries" as "rare."§ Mr. Tom Brown speaks of it in 1885 as "very rare" in Tynron parish.\| In 1901 it is described by Dr. J. W. Martin as "seldom seen" in Glencairn, 1 and Dr. Anstruther Davidson in 1888 discredits the report that it had nested in Upper Nithsdale as he had " never seen the bird at any time."**

Mr. R. Armstrong writes me from Thornhill that he considers the Stonechat as very rare in Nithsdale, the only occasion on which he had seen it breeding being in 1902, when he found a nest with six eggs at Kirkbog (Closeburn). Personally I have only once met with the species in this district. It was in June, 1905, when I saw a pair

* New Stat. Acct. Scot., Vol. IV., p. 179.

$\dagger$ Cat. Birds in Coll. Sir W. J., p. 83 (3361) a, a.

\$ New Stat. Acct. Scot., Vol. IV., p. 382.

§ Trans. D. and G. Nat. Hist. Soc., December 4th, 1881.

II Op. cit., December 4th, 1885.

If Op. cit., December 13th, 1901.

** Op. cit., November 10th, 1888. 
on Capenoch Moor (Keir) ; they undoubtedly had a nest, which, however, was not actually discovered.

Reports from correspondents in other parts of the county tend to show that the Stonechat is not so rare as is generally supposed. In August and September it becomes widely and more generally distributed, though never really abundant.

The British Stonechat has been separated by Dr. Hartert from the Continental form by reason of the more rufous colouring of its upper surface and the brighter chestnut of its under parts.*

THE REDSTART. Ruticilla phonicurus (Linnæus).

Local names-Redtail; Firetail; Pink.

\section{A summer-visitant of local distribution.}

Dr. Walker, in his MS. notes or Adversaria for 1773, states that the Redstart "builds in Glenea, in Dumfriesshire; comes in May, and goes about the end of August. Is called the Pink." $\uparrow$ It is, however, noteworthy that in an account of the parish of Colinton, Mid-Lothian, from his pen in 1795, Dr. Walker uses the name "Pink" for the Blue Titmouse.

The Redstart is recorded as one of the "rarer species of birds" found in the parish of Kirkmichael in 1791.ई In 1832 Sir William Jardine writes of it as "an occasional summer-visitant, preferring those parts of the country which abound most in coppice wood." $\|$ A specimen from the collection of Rev. W. Little, of Kirkpatrick-Juxta, probably obtained prior to 1840 , now in the collection of

* British Birds (Mag.), Vol. III., p. 315.

$\dagger$ Hist. Brit. Animals, 1828, p. 68.

† Essays on Nat. Hist., p. 597.

$\S$ Stat. Acct. Scot., Vol. I., p. 61.

\|| New Stat. Acct. Scot., Vol. IV., p. 179. 
Mr. R. Service, is labelled : "Rather local. A summervisitant. Inhabits woods and orchards; building in holes of trees, and in walls."

The present distribution of the Redstart in the county is difficult to define, for it is unaccountably absent from many suitable localities. It would seem to be uncommon in the upland and littoral districts, and elsewhere by no means generally dispersed.

It arrives in the latter half of April or beginning of May, and departs for its winter-quarters on the southern shores of the Mediterranean, at the end of August or in September.

H. A. Macpherson records that in June, 1888, Mr. Bell, of Liddelbank, Dumfriesshire, found on the banks of the Liddel " the nest of a Redstart built into an old nest of a Song-Thrush. The Thrush's nest measured about four inches across, and that of the Redstart two inches and one-fifth inside measurement; the former was placed in a thick thorn-bush, and was therefore open to the sky, though well screened by branches above."*

The pale blue eggs closely resemble those of the HedgeSparrow, but have been recorded as being faintly spotted with brown at the larger end. $\dagger$

\section{[THE BLACK REDSTART. Ruticilla titys (Scopoli).}

There is no authentic record of the occurrence of this species in the county. Two allegations of its having bred here have appeared in print, and have been subsequently quoted by other authors, but cannot be upheld.

The first is by Robert Gray, who states: "I have been informed by Mr. George Kirkpatrick that in 1858 he found a nest and eggs at Duncow near Dumfries, which he could not make out to belong to any other than this

* Zoologist, 1888, Vol. XII., p. 352.

$\dagger$ Trans. D. and G. Nat. Hist. Soc., December 4th, 1885. 
species. The nest was placed on the ground, on a patch of waste moor, and in structure resembled a YellowHammer's, but was larger ; the eggs, five in number, were shining and pure white. The eggs of the Black Redstart are so characteristic that when found in a situation like that described, they can hardly be mistaken for those of another species."* As regards this statement, Mr. R. Service writes me: "On June 16th, 1886, I found on the identical 'patch of waste moor' above referred to a nest of the Yellow-Hammer containing three eggs. These were most remarkable 'varieties,' two of them being practically pure white, while the third was also white; but close examination showed some very faint speckles. The thought at once struck me that here was the explanation of the supposed Black Redstart's nest found nearly thirty years previously on almost, if not exactly, the same spot of ground! So I sent nest and eggs to Mr. Gray, who replied as follows: 'I am greatly obliged to you for your kind letter and for the nest and eggs which accompanied it. The question you have raised is one of much interest, inasmuch as an inexperienced collector might be readily enough deceived by the finding of such a nest. There is not, of course, the shining appearance of the eggs characteristic of the Black Redstart in those you have sent; nevertheless, to a young naturalist especially, their whiteness is a little startling. Had you sent the nest without any letter I should not have thought of the Black Redstart; there is an indefinable something which points more readily to mere variety. Still, the nest and eggs coming from the quarter in which the supposed nest and eggs of the Black Redstart were recorded suggest that a mistake may have been made. The shining gloss was, I recollect, strongly dwelt upon, and this does not appear in the Yellow Hammer's.'

The second allegation of this species having nested in the county is made by W. Oxenden Hammond: "A

* Birds of West Scotland, 1871, p. 85. 
lady, a near neighbour of mine, who is fond of observing birds, tells me that about the 12th of June, 1889, she found a nest of the Black Redstart about half a mile from Maxwelton in Dumfriesshire. The nest was in a stone 'dyke' (wall), by the side of a road on a high hill called Crossford. The young were hatched. She tells me that she often went to watch the birds, both with a field-glass and without one, that they let her get very near, that she is certain of their identity, and that they were Black, and not Common Redstarts."* Mr. R. Service writes me as regards this second supposed occurrence : "At least three experienced field-naturalists were over the locality in the season of 1889 referred to, two of them being resident in the neighbourhood. None of these gentlemen will accept the record, so that Mr. Hammond's dictum that this was an undoubted instance of the breeding of this species is scarcely warranted. That the Black Redstart may be confidently expected to put in an appearance before long as a winter-visitant is a justifiable anticipation, but to find it breeding in Solway is quite another story. Twice now I have been sent for to see a supposed Black Redstart's nest, once near Kirkland (Kirkmichael) and on the other occasion near Closeburn, and in both cases they were the common species." W. Oxenden Hammond is dead, but I have a most courteous letter from Miss Rice, his informant, which, however, gives no further evidence as to this alleged occurrence of its nesting near Maxwelton (Glencairn).

Mr. R. Service tells me that he feels certain he saw a female Black Redstart in his nursery-gardens at Maxwelltown (that is, within half a mile of the Dumfriesshire boundary), on March 4th, 1910. This is most interesting as being the first record of the occurrence of this bird in the vicinity, but does not, however, warrant my including the species among the birds of Dumfriesshire without square brackets, since it was, as has been stated, actually seen some eight hundred yards from the county boundary.

* Zoologist, 1890, Vol. XIV., p. 220. 
The Black Redstart breeds in central and southern Europe, wintering in northern Africa and so far south as Nubia. It may be considered as a fairly regular wintervisitant to the southern and eastern coasts of England and Ireland, but elsewhere in the British Isles it is more uncommon.]

\section{THE BRITISH REDBREAST.}

Erithacus rubecula melophilus, Hartert.

\section{Local names-RoBIN; RoBIN-REDBREAST.}

"But here comes Robin. In our boyish days We thought him Kitty's* husband. He, like her, Sings all the year; but she is not his wife.

Look how the knowing fellow turns the head This way and that, peeping from out the leaves With curious art, and still comes hopping near.

Strong in his individual character,

His full black eye, short neck, and waistcoat red,

His pipe mellifluous, and pugnacious pride,

Darting to strike intruders from his beat,

His love of man is still his leading type."

THOMAS AIRD.- "A Summer Day."

A common resident throughout the county, though subject to seasonal migration.

In September and October the majority of the Robins that have bred, or have been bred here, emigrate south, a return immigration taking place towards the end of March. There is no evidence, however, of the occurrence in this county of the Continental form of the Redbreast, and all our birds appear to belong to the British race, which has been separated by Dr. Hartert by reason of its darker upper surface and the richer red of its throat and breast. $\dagger$

In the spring of 1899 , according to $\mathrm{Mr}$. R. Service, nests of this species were unusually numerous, and he attributed

* The Wren.

† British Birds (Mag.), Vol. I., p. 219. 
the fact to a " crowding-down " in this county by a retarded migration. In 1851 a nest with eggs was found at the end of November at Gribton (Holywood).*

Curious nesting-sites are annually discovered, and I have personally found nests in an old kettle, a discarded shoe, and in the pocket of a coat hung up in an outhouse. In the Daily Mail of June 26th, 1909, appears the following :

"A Dumfriesshire Robin has made its nest in a corner of a lady's boudoir. Owing to the awkward position which it chose, the bird had some difficulty in constructing the nest, but the young lady who occupied the room placed a small cardboard box at its disposal, of which the Redbreast availed itself. Five eggs have been duly hatched out. The bird enters and leaves the room by a window which is purposely left open, and it shows no signs of timidity."

The eggs vary considerably in intensity of colour, and pure white specimens have been found.

Robins are at all times pugnacious, particularly so in the spring. Richard Bell mentions a cock Robin in his aviary at Castle $\mathrm{O}^{\prime} \mathrm{er}$ which killed four others on four consecutive days. $\dagger$

There is an old local rhyme :-

"The Robin and Wren

Are God's cock and hen,"

which even now seems to be respected by the egg-stealing schoolboy, and many are the curious, improbable stories connected with this universal favourite. We read of a Robin near Annan which had been fed daily during the winter of 1819-1820 turning up one day as usual for its dole, but dragging after it the dead carcase of another of its species, apparently to share the meal! $\$$ Mr. Kirkpatrick states that a Robin which frequented his garden in

* Naturalist, Vol. II., 1852, p. 206.

† My Strange Pets, pp. 114, 115.

$\ddagger$ Dumfries Courier, January 4th, 1820. 
Irish Street, Dumfries, during the autumn of 1870, imitated " in the most accurate manner the notes and calls of several other birds such as the Swallow, Sparrow and Pied Wagtail. These imitated calls were uttered generally in the morning,"* and this " interesting practice " was resumed at the same season the following year. $\dagger$

White varieties are occasionally met with, and it is recorded in May, 1852, that " a few weeks ago Mr. Rimmer, who is an enthusiastic ornithologist, observed a small light-coloured bird in the grounds at Kirkmichael House which he did not recognise. He shot it, and discovered it to be a Robin with the usual orange-red breast, but the rest of the plumage of a light cream-colour. The specimen procured by Mr. Rimmer has been stuffed, and placed by the side of an ordinary bird; compared with which it appears about a third smaller in size, and is altogether of a weaker build, bearing out the idea that albinos are either diseased or weakly. The back is white, with a few streaks of light brown; the belly with more white than usual ; the wings nearly all white, with a few pale olive feathers, and the legs very light coloured." $\ddagger$ Another white specimen was exhibited by Dr. Grierson at a meeting of the Dumfriesshire and Galloway Natural History and Antiquarian Society on April 5th, 1864. Mr. W. Laidlaw writes me of a white Robin seen at Canonbie, and Mr. F. M. Gourlay tells me of a similar variety seen near Moniaive during the winter of 1908-1909.

[It is necessary to mention the Nightingale (Daulias luscinia (Linnæus)), simply to deny emphatically its frequently alleged occurrences in this county. In the early part of June, 1903, an unusually large immigration of Blackcaps and Garden-Warblers took place, and so unaccustomed were people to the subsequent outburst of melody, "that

* Minutes of D. and G. Nat. Hist. Soc., December 6th, 1870.

+ Op. cit., December 3rd, 1871.

‡ Dumfries Courier, May 4th, 1852. 
to this cause," says Mr. R. Service, "must be attributed the strong allegations made from more than one district that the Nightingale himself had crossed the Border."** From time to time the local newspapers have published paragraphs as to its song having been heard, but such statements will not bear investigation. The Nightingale is a regular summer-visitant to England south of mid-Yorkshire and east of mid-Devonshire, where it breeds ; as also in central and southern Europe, parts of Asia Minor and North Africa; its winter-quarters are in Africa, as far south as Abyssinia and the Gold Coast.]

\section{THE WHITETHROAT. Sylvia cinerea, Bechstein.}

\section{Local names-Cut-throat; Maggie CUt-Throat; Nettle-} Creeper ; Jenny Cut-throat.

" Her nest is here. But ah ! the cunning thing, See where our White-throat, like the partridge, feigns A broken wing, thick fluttering o'er the ground, And tumbling oft, to draw you from her brood Within the bush. Now that's a lie, my birdie! Your wing's not broken, but we'll grant you this, The lie's a white one, white as your own throat."

THоMAS AIRD. - "A Summer Day."

\section{A very common summer-visitant.}

The Whitethroat arrives here at the end of April or beginning of May, and leaves again for its winter-quarters on the southern shores of the Mediterranean and as far south as Abyssinia and Damaraland in August or September.

Mr. R. Service has already drawn attention to the fact that its usually frail nest may sometimes be found "more substantially woven together." $\uparrow$

* Trans. Edin. Field Nat. Soc., 1904-1905, Vol. V., Part 3, p. 181.

† Trans. Glasg. Nat. Hist. Soc., 1905, Vol. VII., p. 138. 
Mr. J. Harkness writes me that this species has increased in the south-west of the county since the hedges have been allowed to grow larger, and that it was remarkably numerous in the spring of 1908 .

\section{THE LESSER WHITETHROAT.}

Sylvia curruca (Linnæus).

A very scarce summer-visitant; very local in its distribution.

Sir William Jardine, writing in 1839 of this species, says, it " is known to extend northward as far as Durham. Upon the Border in Scotland, or in Ireland, there has, however, been no instance of its capture recorded."* It is recorded that H. A. Macpherson and others have found this bird breeding in Eskdale, $\dagger$ and Howard Saunders writes: "Mr. R. Service informs me that it is seldom met with in Kirkcudbrightshire, although better known in the eastern part of Dumfriesshire and down by the Borders, and he has only twice found its nest." $\ddagger$

Year after year reports of its nest having been found are circulated, but on investigation these reports have been proved to refer to some other species. Mr. R. Service has dismissed the supposed occurrence of the Lesser Whitethroat in Glencairn, $\S$ and I equally doubt its alleged appearance in Tynron.\| Mr. T. A. Johnstone records from near Moffat that "a nest with four eggs of this rare bird was found early in June, 1906', amidst some bramble bushes on the banks of the River Annan," II and Mr. J. Harkness

* Nat. Lib., 1839, Vol. XI., p. 136.

† R. Service, Trans. Glasg. Nat. Hist. Soc., 1905, Vol.jVII., p. 141.

$\ddagger$ Man. Brit. Birds, 1899, p. 43.

§ Trans. D. and G. Nat. Hist. Soc., April 20th, 1905.

|| A Country Schoolmaster, 1899, p. 289.

I Dumfries Courier and Herald, April 6th, 1907. 
writes me from Ruthwell that an "odd pair used to nest; not noticed lately"; but these and many similar reports from all parts of the county cannot be substantiated. Mr. W. Bell, however, informs me that he found a nest with five eggs in a whin-bush on the Solway shore in Dornock parish on June 16th, 1907, and one of these eggs sent to me for verification was undoubtedly of this species.

The Lesser Whitethroat winters in northern and central Africa, and breeds, as regards Great Britain, in tolerable abundance in the southern, eastern and midland counties of England, where it arrives in April or May, and departs early in September.

\section{THE BLACKCAP. Sylvia atricapilla (Linnæus).}

\section{A summer-visitant generally distributed throughout the county.}

Sir William Jardine, writing in 1839, says, "in our own vicinity [it] has only appeared within these few years, which may be perhaps owing to the gradual increase of more extensive shrubbery and plantations giving it suitable

Nowadays, from the reports I have received, the Blackcap would appear to be a more abundant species than the Garden-Warbler, which is the reverse of its status in the Clyde area, $\uparrow$ and it is recorded from all the arable districts of Dumfriesshire, although unaccountably absent from some seemingly most suitable haunts. Thus Mr. William Laidlaw writes me from Canonbie that it is "very rare,
have only seen one."

The Blackcap seldom comes to us before the latter half of April from its winter-quarters in Africa and southern Europe, for which it again departs in October or November. In some seasons it arrives here in markedly greater numbers

* Nat. Lib., 1839, Vol. XI., p. 130.

$\uparrow$ Fauna of Clyde Area, 1901, p. 159. 
than in others, as in early June, 1903,* and it has been recorded in some cases to have wintered in Great Britain. The latest date of its occurrence locally, so far as I know, is November 29th, $1881, \uparrow$ when Mr. R. Service captured an adult male near Dumfries.

It may be well to note here that the name Blackcap is commonly applied to the Coal-Titmouse, and with the prefix Greater, to the Great Titmouse.

\section{THE GARDEN-WARBLER.}

Sylvia hortensis, Bechstein.

\section{A summer-visitant, in some years far more numerous than in others.}

This bird is the Greater Pettychaps of Sir William Jardine, who writes of it in 1832, as regards the parish of Applegarth and Sibbaldbie, "abundant, and though seldom observed: is often betrayed by its melody." $\ddagger$ Thus in June, 1903 after an unusually large immigration of Blackcaps and Garden-Warblers, the local newspapers were full of reports of the advent of the Nightingale! (See p. 18.)

Mr. R. Service tells me that Howard Saunders must have misunderstood him when he makes him say "that the species is more abundant in the Solway district than the Blackcap,"§ and it is unaccountable why this usually generally-distributed bird should appear to be absent from certain localities in Dumfriesshire ; possibly it may be often overlooked. So far as I can learn, the Garden-Warbler is of more common occurrence in the littoral parishes and parishes adjoining; elsewhere it is distributed more or less

* Trans. Edin. Field Nat. Soc., 1904-1905, Vol. V., Part 3, p. 181.

$\dagger$ Man. Brit. Birds, 1899, p. 47.

$\ddagger$ New Stat. Acct. Scot., Vol. IV., p. 179.

§ Man. Brit. Birds, 1899, p. 49. 
locally throughout the arable districts of the county. Since the beginning of the last century its numbers are believed to have increased, and it may be regarded as an increasing species.* Mr. William Laidlaw writes me that the Garden-Warbler is very plentiful in the south of Eskdale, where "it is a treat to hear them."

Late in April this welcome songster arrives, and it leaves us again in August or September for continental Europe, whence it wanders as far south as Cape Colony.

\section{THE BRITISH GOLDEN-CRESTED WREN.}

Regulus cristatus anglorum, Hartert.

Local names-Gold-Crest ; Crested Wren ; Crested Tit ; Basket-Hinger ; Golden Cuttie.

\section{A common resident.}

The Golden-crested Wren is included in 1791 in a list of the birds of Kirkmichael $\dagger$ and Mouswald, $\ddagger$ and Sir William Jardine writes of it in 1832 as breeding in small numbers in the parish of Applegarth and Sibbaldbie, "but during winter," he adds, "when the migratory flocks have arrived, [it] is very abundant." $\$$ Dr. J. W. Martin noted a decrease in the numbers of this species in Glencairn after the devastating storm of 1883-1884, $\|$ but since then the extensive cultivation of spruce and other evergreen pines has provided numerous suitable habitats for these birds, which have been, and are, increasing. Mr. Bruce Campbell, in a list of the birds of Moffat as observed by him between October,

* R. Service, Trans. Glasg. Nat. Hist. Soc., 1905, Vol. VII., p. 140.

$\dagger$ Stat. Acct. Scot., Vol. I., p. 60.

$\ddagger$ Op. cit., Vol. VII., p. 294.

§ New Stat. Acct. Scot., Vol. IV., p. 179.

II Trans. D. and G. Nat. Hist. Soc., October 13th, 1901. 
1896, and February, 1897, describes the Golden-crested Wren as: "Very plentiful, perhaps the commonest bird in the district."*

In the autumn, seldom before the latter half of September, the numbers of our resident birds are greatly increased by an immigration from further north. Such of these immigrants as have been examined have proved to belong to the British race of the Golden-crested Wren, which has been separated by Dr. Hartert on account of its darker and duller coloration. $\dagger$ In winter, flocks of this tiny bird may be seen in company with Titmice and Tree-Creepers, busily searching the tree-trunks and branches for insectfood. In March and April the emigration of these winterbirds takes place, and often not before our residents have built their beautiful nests. The latter are generally placed beneath the extremity of the branch of some evergreen tree, and are so difficult to find that the bird is often wrongly considered a rare breeding-species.

It should be remembered that locally the Golden-crested Wren is often given the name of the "Crested Tit," a species unknown in the county. (See p. 42.)

[The rumours which have reached me of the occurrence of the FIRE-CRESTED Wren (Regulus ignicapillus (C. L. Brehm) ), in Dumfriesshire are due to confusion with the last species. The Fire-crest, as its name implies, has a more brilliantly-coloured crown than the Gold-crest, and the adult male is easily distinguished by the "golden frontal band, which unites on each side with a white streak passing above and behind the eye, and separating a parallel black line [which passes through the eye] from the broader and blacker upper bands which enclose the rich orange yellow crest."‡

Its winter-quarters are in Algeria and some parts of

* Zoologist, 1898, p. 507.

† British Birds (Mag.), Vol. I., p. 218.

$\ddagger$ Man. Brit. Birds, 1899, p. 60. 
southern Europe, and its breeding-area does not appear to extend beyond $50^{\circ} \mathrm{N}$. lat. "Between the months of October and April in various years, many genuine examples have been obtained on [the] south and eastern coasts"* of England, but there are no authenticated records from Scotland.]

\section{THE YELLOW-BROWED WARBLER.}

Phylloscopus superciliosus (J. F. Gmelin).

\section{Has occurred once.}

The summer-home of this species would appear to be "in the pine forests of North-eastern Siberia," $\dagger$ whence in winter it migrates to "Southern China, Formosa, Burma, and parts of India." $\ddagger$

"To Europe it is only an accidental visitor on migration." There are over forty records of its occurrence in Great Britain, nearly a third of which have been on Fair Isle (which lies midway between the Orkney and Shetland
archipelagos).

The occurrence of the Yellow-browed Warbler in Dumfriesshire is thus recorded by Mr. George Stout: "At Lockerbie on April 11th [1909]. I had the pleasure of watching one of these singularly interesting birds for fully half an hour as it flitted along a hedge, occasionally making short flights in the air to catch some insect on the wing. I got within about four feet of the little creature while it was busily engaged searching for food, and was able to identify it beyond doubt. I was first attracted by the bird's peculiar note, with which I am quite familiar from my Fair Isle experiences, which extend over several autumns."

* Man. Brit. Birds, 1899, p. 59.

$\dagger$ Op. cit., 1899, p. 61.

$\ddagger$ Brit. Warblers, Part 2, p. 3.

$\S$ Ann. Scot. Nat. Hist., 1909, pp. 182, 183. 
To this most interesting record the editors of the Annals of Scottish Natural History add: "We have no hesitation in accepting this record, for Mr. Stout is, to our knowledge, quite familiar with this bird. The record is of great interest as being the first known instance of the occurrence of Phylloscopus superciliosus in spring in the British Islands and for the mainland of Scotland."

\section{THE CHIFFCHAFF. Phylloscopus rufus (Bechstein).}

A summer-visitant, local in its distribution, annually varying greatly in its numbers, and cannot be considered common.

Sir William Jardine describes this species as "very rare" in 1832, when writing the avifauna of the parish of Applegarth and Sibbaldbie, ${ }^{*}$ and some seven years later he writes: "We have heard it once or twice of late years in our own neighbourhood."†

The would-be compiler of ornithological facts would be saved from unconscious errors, and the true distribution of our avifauna past and present would be more readily ascertained if all observers, when recording their notes, were as humble as that excellent field-naturalist Mr. Tom Brown, who says of the birds of the parish of Tynron, "There is almost no doubt but that the Chiffchaff visits the parish, but I have not seen its nest, and I cannot distinguish the bird from the Willow-Warbler." $\$$ Mr. $R$. Service is of the opinion that the species is scarcer in this county than in Kirkcudbrightshire, and he suspects that "the Chiffchaff and the Wood-Warbler occupy different grounds."§ It has been observed at Carnsalloch

* New Stat. Acct. Scot., Vol. IV., p. 179.

$\dagger$ Nat. Lib., 1839, Vol. XI., p. 152.

† Trans. D. and G. Nat. Hist. Soc., December 4th, 1885.

§ Trans. Nat. Hist. Soc. Glasg., 1905, Vol. VII., p. 145. 
(Kirkmahoe), so Mr. Norman Maclachlan informs me. In the littoral parishes and those adjoining them it would appear fairly well distributed, and Mr. P. A. Pasley-Dirom writes to me in 1908: "When I was a boy I have often seen great numbers arrive in the Manse garden at Kirkpatrick-Fleming, and I have occasionally seen them of late here" (i.e., Mount Annan). From Eskdale I have no reports of this species, and elsewhere in the county it would seem to be of extremely sparse distribution. In Upper Nithsdale this bird is rare, but I have eggs taken from Strathmilligan Wood (Tynron) on May 31st, 1905. Mr. N. E. Douglas-Menzies, of Newtonairds (Holywood), writes me :- "Last year (i.e., 1907), for the first time there was a small colony of Chiffchaffs here... The nest, entered at the side of the top, was made almost entirely from delicate fronds of fern and soft feather-lining, and the three nests which I found had their entrances facing south, and were all in small spruce trees, about three feet from the ground." In 1908 the Chiffchaffs again returned to the same locality.

This species arrives in our county in the latter half of April, and leaves us again in September.

The distinctions between this and the two following species have thus been summarized by Mr. J. E. Harting : "I have come to the conclusion that, as regards the wings, the following formulæ may be relied on (the first primary is quite rudimentary and is therefore not taken into consideration): Chiffchaff, second primary $=$ seventh ; third, fourth, fifth and sixth with outer web sloped off towards the extremity. Willow-Wren, second = sixth ; third, fourth and fifth sloped off. Wood-Wren, second = fourth ; third and fourth sloped off."* The nest of the Wood-Wren is not lined with feathers: that of the WillowWren (though like the Chiffchaff's with a copious featherlining) is usually built on the ground, but not above it, as is the custom of the latter. As regards the call-note, the regular repeated dissyllabic "chiff-chaff" (to my ear more

* Handbook Brit. Birds, 1901, pp. 56, 57. 
like "chaff-chiff"), and the more alert appearance of the bird, will serve to distinguish it from the two following species. The Chiffchaff in winter is found in the countries bordering on the Mediterranean and in Africa as far south as Somaliland and Abyssinia.

\section{THE WILLOW-WREN.}

Phylloscopus trochilus (Linnæus).

Local names-Sulver-Wren; Wee Cut-throat.

\section{A common summer-visitant throughout the county.}

A specimen of the Willow-Wren from the collection of Rev. W. Little, now in the possession of Mr. R. Service, is labelled "very abundant in every wood and thicket, builds on the ground, with us a summer visitor." These remarks refer to the distribution of this bird some seventy years ago, when it was apparently as common as it is now.

It arrives here about the middle of April, and from ten years' observation the date of the first arrivals near Dumfries varies from the 14th to the 25th of April, but the value of such dates is very slight, as these first arrivals are generally but the precursors of larger flocks ; indeed, the immigration of this species has been noticed here as continuing till nearly June. In 1902 Willow-Wrens were seen on April 14th, and two inches of snow fell the same day.

Their departure usually takes place in September, but in 1895 they were seen so late as October 15th.

In some seasons they appear in greater numbers than usual, as in 1880 , when they were particularly numerous.*

The nest, as already stated (see p. 27), is usually built on the ground, but Mr. R. Service records them as occasionally built " five feet up in a thick hedge or bush," $\dagger$ but such a situation is exceptional.

* Proc. Nat. Hist. Soc. Glasg., 1880, Vol. IV., pp. 305, 306.

† Trans. Nat. Hist. Soc. Glasg., 1905, Vol. VII., p. 144. 
The Willow-Wren's winter-quarters are in the countries bordering the Mediterranean and in central and southern Africa.

\section{THE WOOD-WREN. \\ Phylloscopus sibilatrix (Bechstein).}

\section{Local name-YeLLOW Wren.}

\section{A summer-visitant, very locally distributed.}

Sir William Jardine writing of the birds of the parish of Applegarth and Sibbaldbie in 1832, says of this species that it is "chiefly confined to the woods on Dryfe."* A specimen (probably collected prior to 1840 ) from the collection of the Rev. W. Little, now in the possession of Mr. R. Service, is labelled: "Not very abundant. Inhabits tall trees in woods. A spring-visitant ; builds on the ground."

Mr. R. Service in his paper on "The Sylviidae of Solway" states that the Wood-Wren " appears to be confined to oak and spruce plantations or their immediate vicinity. And yet all oak and spruce plantations do not harbour it, for I know many where it is not found. With us in Solway it occupies a rather narrow belt of country in contiguity to the bare hillside or sheep-farm district. Outside of this particular locality it is in rather isolated colonies, mostly in wooded glens of the small streams." $\dagger$ In mid-Nithsdale this species has been reported as more common than the Willow-Wren, and although I regard this statement as an exaggeration, it is of frequent occurrence both in this district and Upper Nithsdale, whence I have seen a clutch of seven eggs from Kirkconnel. Throughout Annandale it would appear to be very local, and in the lower part of Eskdale Mr. William Laidlaw writes me that it is "very scarce, but still a few."

\footnotetext{
* New Stat. Acct. Scot., Vol. IV., p. 179.

† Trans. Nat. Hist. Soc. Glasg., 1905, Vol. VII., p. 143.
} 
Towards the end of April or in May it arrives in this county, and departs again in August or September.

The Wood-Wren in its winter-migrations visits the west and east coasts of Africa as far south as the Gold Coast and Abyssinia, and more generally the northern portion of that continent.

[The REED-WARbLer (Acrocephalus streperus (Vieillot)) is only mentioned to repudiate emphatically the rumours that have been spread abroad from time to time as to its occurrence in this county. Such rumours have doubtless emanated from the careless confusion of this species with the Sedge-Warbler. A specimen of the Reed-Warbler, obtained prior to 1840 from the Rev. W. Little's collection, now in Mr. R. Service's possession, is without a label. Most of this gentleman's specimens came from his parish of Kirkpatrick-Juxta, but this is one which I believe did not. The assertions that it has occurred in Glencairn* and in Moffat $\uparrow$ have proved to have been entirely erroneous.

Up till now the only Scottish record of this bird is from Fair Isle on September 24th, 1906, and Mr. Wm. Eagle Clarke writes: "The occurrence of this bird at Fair Isle presents one of those enigmas . . . . with which the study of bird migration is so much beset." $\ddagger$ The Reed-Warbler winters in the basin of the Mediterranean and as far south as central Africa, and is an annual visitant to England towards the end of April, departing again in September.]

\section{THE SEDGE-WARBLER.} Acrocephalus phragmitis (Bechstein).

\section{A common summer-visitant.}

Sometimes in the last week of April, but more usually early in May, the Sedge-Warblers arrive in the county, and speedily

* Trans. D. and G. Nat. Hist. Soc., December 13th, 1901.

+ Dumfries Courier and Herald, April 6th, 1907.

$\ddagger$ Ann. Scot. Nat. Hist., 1907, p. 74. 
scatter amongst those localities where there are swampy woods, or reed-fringed lochs and lochans. Along the sides of the more slow-flowing rivers they are also to be found, but owing to their partiality for dense, marshy places of retirement they are confined to the vicinity of the arable districts. Few suitable localities are left untenanted, and occasionally nests are found in surprisingly "dry" situations, far from any water. It was observed in the spring of 1908 that Sedge-Warblers were singularly scarce.

Mr. R. Service writes : "A fact in the life history of this species that I do not remember having seen any allusion to is that, whenever there is an extensive haunt, a party of about a score, or often more, of non-breeding birds will generally be found consorting together in a loosely attached flock throughout the whole season."*

Though this species usually leaves us at the end of August, it occasionally stays so late as the first week in September.

Its "winter home is principally central and southern Africa, but it probably also remains in some of the countries bordering on the Mediterranean, since it has been found at this season in Dalmatia." $\dagger$

\section{THE GRASSHOPPER-WARBLER.}

Locustella naevia (Boddaert).

\section{A summer-visitant of very local distribution.}

Of the Grasshopper-Warbler Sir William Jardine writes in 1839: "We possess a single specimen shot near New Abbey in Galloway, for which we were indebted to the kindness of Dr. Bushnan, and the individual who procured it was aware of its occasional occurrence." $\ddagger$ This

* Trans. Glasg. Nat. Hist. Soc., 1905, Vol. VII., p. 146.

$\dagger$ Brit. Warblers, Part 1, p. 5.

† Nat. Lib., 1839, Vol. XI., p. 144. 
record can in no sense be regarded as belonging to Dumfriesshire, but " as the crow flies" (and perhaps as this Grasshopper-Warbler flew) New Abbey is only two miles from the nearest limit of our boundary, and I mention this occurrence simply to show that the species in Sir William's time was known as a visitor to the Solway area, and doubtless to our county.

Mr. R. Service writes: "This is a shy, retiring little bird, which though not really rare in south-west Scotland, is very seldom heard and still more seldom seen, and the finding of its nest, by any except those who possess the key to its habits, a rare accident.... This season (1892) some of the birdnesting boys seem to have stumbled on the bird somehow, and no less than three juveniles brought me eggs of this bird for identification. These had all been taken within a short distance of Dumfries."* Mr. John Corrie writes: "In Glencairn it occurs in considerable numbers. I had my attention first directed to the bird some five or six years ago [i.e., 1882-1883] when rod-fishing on the Cairn, and I have frequently heard it during similar excursions since. The nest is said to be very difficult to find, and to this circumstance may perhaps be attributed my want of success in the search." $\dagger$ Mr. R. Service confirms this, and writes me that he has seen the bird at Craigdarroch, Maxwelton, and elsewhere in the Cairn valley. A note in Miss Wallace's diary for April 22nd, 1906, would seem to refer to this bird's presence at that date near Lochmaben, but it seldom arrives here so early; and it departs by the end of August or early in September.

The Grasshopper-Warbler shuns cultivation, and a favourite nesting-site is the tussocky grass in a thickly-grown plantation five or six years old. By walking through such a place, and beating the ground in front of one with a long branch, one may disturb the bird from its nest, and thus reveal its carefully concealed eggs.

* Zoologist, 1892, p. 333.

† Trans. D. and G. Nat. Hist. Soc., November 10th, 1888. 
The ventriloquistic "song" of the bird, from which it has earned the cognomen "grasshopper," when once heard is never forgotten, and is very seldom heard except at dawn or dusk. Mr. Norman Maclachlan kindly sends me the following extract from his diary: "Grasshopper-Warbler heard and then observed in a rough sedgy field immediately below Milnhead House on Carnsalloch Estate, Dumfriesshire, between 9 and 9.30 p.m., Sunday, June 17th, 1906. . . The light was not good enough to note the colouring distinctly, but as it sat facing the light some eight or ten yards from me I noticed that the chin and upper part of the throat were decidedly pale, resembling those parts of the Whitethroat. Though sitting in full view of me on a dead twig of meadow-sweet, it continued its song till I had approached within ten yards. It then flew off some twenty yards, and alighted on another twig, but immediately crept down into the thick sedge, and again began its song." Mr. R. Armstrong writes me that he has never met with this bird in Upper Nithsdale, but that he has heard it in the Lochar Moss.

Its winter-quarters are in "Morocco, Algeria, and the south of Spain."*

\section{THE BRITISH HEDGE-SPARROW.}

Accentor modularis occidentalis, Hartert.

\section{Local names-Hempie; Dunnock.}

"The starved Hedge-sparrow haunts the moistened sink
On gurly winter days, the bitter wind
Ruffing her back, showing the bluer down
Beneath her feathers freckled brown above,
But ne'er she ventures nearer where man dwells."

Thomas AIRD.-" A Summer Day."

\section{A resident of very general distribution throughout the county.}

The Hedge-Sparrow may be regarded as stationary, as no local migration has been actually observed; though in all * Brit. Warblers, Part 1, p. 9. 
probability a migration to the south does take place in September and October, its numbers are certainly not seriously affected by a general emigration. Dr. Hartert has lately separated the resident British Hedge-Sparrow from the continental form chiefly on account of a difference in the wing formula.*

The neat little nest with its pale blue eggs is not only frequently destroyed by school children, but often robbed. by weasels, and many of my informants write me as to the bird's decrease in numbers. A nest with five eggs, built in the heart of a kail-stock at Gribton (Holywood), is a peculiar site recorded in $1850 . \dagger$ Incubation I have found requires thirteen days.

The small song of the Hedge-Sparrow is seldom heard before the latter half of February, but Miss Wallace records it as singing at Lochmaben on January 25th, 1906.

\section{THE BRITISH DIPPER.}

Cinclus cinclus britannicus, Tschusi.

Local names-Water-OUSEL; WATER-Pyet ; WAter-Craw ; Water - Crow ; Burnbecker ; Water - Peggie ; KingFISHER.

"There, Annan Water, pure and bright, The child of pastoral hills afar,

Sweeps through the vale with curve of light,

To hazelly bank and ruddy scaur;

Where waging an unequal war,

His chafing streams abruptly turn,

Still eddying round the sedgy bar

Of Moss-land's ousel-haunted burn." Rev. William Bennet.- "The King's Holm."

\section{A resident of very general distribution.}

In winter this bird is to be found along our rivers and streams, often gladdening the ear with its small song. In

* British Birds (Mag.), Vol. III., p. 313.

$\dagger$ Dumfries Courier, April 30th, 1850. 
early spring it goes further afield, and many pairs are to be found nesting in the upland burns and water-courses.

The nest, which is large and domed, is made chiefly of moss, lined with dry leaves, the entrance being low down on one side. In structure it resembles the nest of the Wren, and is usually built in a hole; under a bridge, in a bank, among the roots of trees, or on a ledge of rock often behind a cascade of water through which the bird has to fly. In 1870 a pair of Dippers made their nest in a hole in a wall at Dumfries Town Mill, the eggs "were unfortunately harried, and the birds again attempted to nest in the same place, but out of kindness to themselves they were prevented."* On March 28th, 1903, I found a nest ready for eggs in a most unusual situation. It was quite ten feet above the water, and was built on to the side of an oak tree covered with polypody fern (Polypodium vulgare).

Favourite nesting-sites are resorted to annually with great regularity, and the following statements give the history of an interesting instance of constancy in this respect. In the Annandale Herald of June 27th, 1865, we read, "In the Capel Burn, on the farm of the same name in the parish of Tundergarth, at an elevation of nearly 900 feet above the elevation of the Solway, a huge gray rock rises many yards right perpendicular, and over it the stream dashes, roaring and foaming into the pool below. Away in the rock, underneath the projected column of water, are two shelves or 'dasses,' whereon during the summer there is a slight vegetation, chiefly grass and nettles. These 'dasses' afford fine shelter for the little white breasted Water-Craw, and there for the last eighty years she has built her nest and laid her eggs, and reared her young unmolested." ... "According to the observations of shepherds extending over a period of seventy years, whenever she has made her nest on the lower shelf, it has always turned out a very dry summer, whereas whenever she has occupied the higher shelf, the season has invariably proved cold,

* Minutes of D. and G. Nat. Hist. Soc., May 3rd, 1870. 
moist and changeable, with heavy waters and the dark pool heaving and fluctuating higher than the lower shelf. This year the interesting little architect began her nest two months ago choosing the lower of the shelves." I was anxious to know whether the same situation was still being utilized, so I wrote to Mr. A. Hay Borthwick, who replied on May 14th, 1908: "There is a fall at what is called the 'Old Washing Pool' where the Laird of Meikledale, who subsequently bought the Creive Estate, used to drive his sheep from Meikledale to be washed in the Capel ; at this place there is a rock in the centre of the burn with a shelf underneath where there is always a Water-Crow's nest. I have seen the bird sitting with a top-flood flowing over the rock. Thos. Armstrong, who 'herded' in Capelfoot for forty-seven years and is still alive, told me he had never seen this rock without a nest in all the seasons he knew it." These statements would seem to justify me in saying that from 1785 to 1908 , or for one hundred and twentythree years, this particular nesting-site was resorted to annually by a pair of Dippers. Mr. D. Legard and I took the photograph, here reproduced, of the spot in July, 1908.

The eggs are usually laid in the first fortnight of April; and in one nest which I watched, incubation lasted fourteen days, and the young had left the nest eight days later.

Towards winter, under stress of weather, the Dippers leave the upland water-courses and become more numerous on our lowland and larger rivers, but there is no evidence of the occurrence in our county of any form other than the British one. In very hard winters, as in 1878-1879, they suffer severely.

They have often been blamed for destroying the ova of trout, but Mr. J. J. Armistead writes: "I have seen this bird occasionally carrying off young trout, but do not think it destroys the ova; nor is it destructive to the former, except in special cases, such as the frequenting of ponds where very young fish are kept."*

* Naturalist, 1884-85, p. 295. 


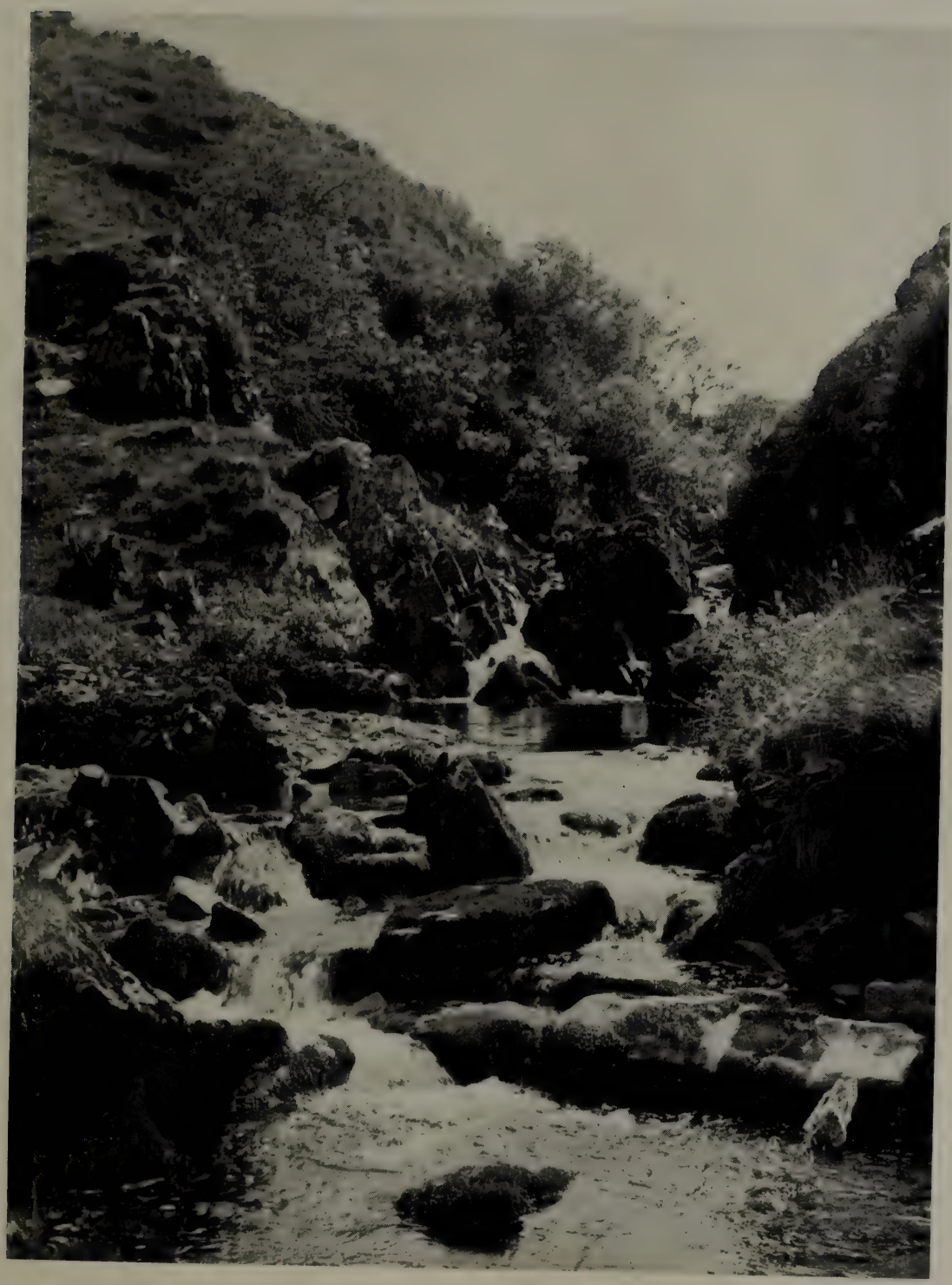

THE HAUNT OF THE DIPPER (Cinclus c. britannicus) ON CAPEL BURN. 

Its method of progression below water has been remarked on by William Macgillivray, who says: "In August, 1834, while ascending White Coom [2,695 feet], the highest mountain in Dumfriesshire, ..... a Dipper was hedged in, and the chase afforded another rare opportunity of viewing its subaqueous flight, which in all probability was caused by excessive alarm."*

\section{THE BRITISH LONG-TAILED TITMOUSE.} Acredula caudata rosea (Blyth).

Local names-Long-TAILEd Wren ; BeLLringer ; FeATHERРоке.

\section{A fairly numerous resident.}

The Long-tailed Titmouse is mostly in evidence in winter, when it consorts with other species of titmice in small parties, and may be seen busily flitting from tree to tree in search of insect-food. In early spring it ceases to be gregarious, and in April or May the nest is built, a favourite site being the common sloe.

In 1834 the extensive woods about Raehills (Johnstone) are mentioned as favourite nesting-haunts, $\dagger$ and in 1853 these birds are recorded as breeding in abundance near Dalswinton $\ddagger$ (Kirkmahoe). It is interesting to know that, according to Mr. J. Davidson, their nests are frequently met with there now. Sir William Jardine describes the nest as "woven among the branches of some evergreen, appearing rather large externally, but is beautifully patched over with the mosses and lichens furnished by the tree or shrub

* Macgillivray, Hist. Brit. Birds, 1839, Vol. II., p. 56.

$\dagger$ New Stat. Acct. Scot., Vol. IV., p. 179.

$\$$ Naturalist, 1853, p. 162. 
which supports it; interiorly it is lined with abundance of feathers, or soft down; the form is oval, appearing rather suspended, and from its form and warmth it, in some districts, gains the popular appellation of 'Feather Pokes.' "**

The British form of the Long-tailed Titmouse has been granted subspecific rank as Acredula caudata rosea (Blyth). The true $A$. caudata caudata, found throughout northern Europe, is distinguished by the greater purity and extent of the white colouring of the head, and it has not yet been ascertained whether both forms occur in the county.

\section{THE BRITISH GREAT TITMOUSE.}

Parus major newtoni, Prazák.

Local names-Greater Blackcap; OxeE; OXeye.

\section{A common resident.}

Writing collectively of the titmice Mr. Fred V. Theobald says, that in spite of a few errors in their ways, "All seem agreed that the Tits do much good, for they hunt summer and winter for insects. The mussel scale, codling moth, woolly aphis, etc., are their especial favourites, and the good they do in this way is incalculable." $\dagger$ "Mabie Moss," referring to the quantity of bumble bees found dead under the lime trees each year when that tree is in bloom, describes the great havoc this bird causes amongst them thus: "Having got hold of them somehow, it places them on the upper surface of a branch, holds the bee a moment with one foot, and having taken a peck which brings out the interior of the thorax, lets the remainder of the body fall to the ground." + Apiarists well know the persistent way in which

* Nat. Lib., 1839, Vol. XI., p. 180.

† Science Progress, 1907, Vol. II., p. 277.

$\ddagger$ Dumfries Courier and Herald, July 30th, 1896. 
this species waits at the bee-skeps and murders the bees as they make their entry and exit.

Holes in walls and in trees are utilized for the nest, and Mr. Hay Borthwick writes me, in June, 1908, from Billholm (Langholm): "A Greater Blackcap has nested in our letter box, and is now sitting on eleven eggs."

It must be pointed out here that the local names of "Greater Blackcap" and "Blackcap," applied to this species, are apt to lead to confusion with Sylvia atricapilla. (See p. 21.)

The British Great Titmouse has been separated from its continental representatives chiefly on account of its stouter bill and duller coloration, and it appears to be the only form found in our county.

\section{THE BRITISH COAL-TITMOUSE.}

Parus ater britannicus, Sharpe and Dresser.

\section{Local name-BLACKCAP.}

\section{A resident throughout the county.}

Sir William Jardine writing of the Coal-Titmouse in 1839 says : "This little species we think to be the most abundant, and one which, in winter at least, is seen in greater profusion in the south of Scotland than any of the rest of the tribe. Ten or twelve years since it was by no means common, and its frequency now may be accounted for by the increasing age of the plantations, and by the immense quantity of wood which has been lately planted, and which is now rapidly advancing to maturity."*

Commenting on the above Mr. R. Service says, in 1900 : "Nowadays, and for many years past, Coal-Tits, though common enough, cannot be considered 'the most abundant

* Nat. Lib., 1839, Vol. XI., p. 172. 
of the tribe,' they being exceeded in this respect by both the Blue Tit and the Great Tit."*

"As Parus britannicus, Messrs. Sharpe and Dresser have separated our own race from that of the Continent, because the upper back is olive-brown in the British bird, and slate-grey in the Continental forms." $\dagger$

Whether there are immigrants from across the sea among the parties of Coal-Tits we see here in winter flitting from tree to tree is a question still to be decided by local ornithologists.

It must be noted that the local name of "Blackcap" for this species is apt to lead to confusion with Sylvia atricapilla. (See p. 21.)

\section{THE BRITISH MARSH-TITMOUSE.}

Parus palustris dresseri, Stejneger.

\section{A very scarce and very local resident.}

Sir William Jardine writes in 1839 of the Marsh-Titmouse as follows:-" In the district where we have been for many years attending to ornithology, it has decreased, and is at present a rare bird, an occurrence which we cannot satisfactorily account for, as its former localities have not been so much changed in character as to drive them entirely away." $¥$ Since that date it is believed that this species has slowly become more abundant. A specimen of the Marsh-Tit from Jardine Hall was in Sir William Jardine's collection.§

Mr. Tom Brown saw a pair at Auchanhessnane (Tynron) in the winter of 1884-1885, consorting with Long-tailed and Coal-Tits. In a list of birds seen near Moffat in the winter of 1896-1897, Mr. Bruce Campbell mentions "three

* Trans. D. and G. Nat. Hist. Soc., November 16th, 1900.

$\dagger$ Man. Brit. Birds, 1899, p. 105.

‡ Nat. Lib., 1839, Vol. XI., p. 174.

§ Cat. Birds in Coll. Sir W. J., p. 78 (3126), a. 
or four Marsh-Tits; only observed among the firs at Evanside."* Mr. J. Davidson writes me that when tenant of Dalswinton (1896-1898) he once found a Marsh-Tit evidently feeding young, though he did not actually find the nest. He adds, "I think this the only time I noticed the bird in the district."

Miss Ranken tells me she sees a pair occasionally in winter at Dalswinton. Mr. J. Little is confident that it " has bred half a mile below Moffat in the hole of an old elm tree." This species is considered as "very rare " in Upper Nithsdale by Mr. R. Armstrong, who writes me: "I have never seen a nest; the first pair I saw was at Boatbrae (Morton) on February 14th, 1903, and I have occasionally seen others since." Personally, I have seen this bird more than once up Scaur Water, and one was shot in the Capenoch Garden on August 1st, 1908. "Around Dumfries the Marsh-Tit is nowhere common," $\dagger$ and the reports I have received of it from Lochmaben, Kirkpatrick-Fleming and elsewhere in the county, lack confirmation.

This species, probably often confused with the CoalTit (but may be readily distinguished by the absence of the white spot on the nape, and by its peculiar call-note) is undoubtedly an uncommon bird, though it may possibly often be overlooked; and I quite expect that if a correct census of its numbers could be obtained, it would be found more generally dispersed throughout the county than the above account of its status infers.

The British Marsh-Tit differs from its nearest continental ally by its darker upper surface and its smaller size. $\ddagger$ It may here be remarked also that the British Willow-Titmouse (Parus atricapillus kleinschmidti), although never yet detected in our county, has been found in the faunal areas of "Forth" and "Moray," $\S$ as well as in various parts of

* Zoologist, 1898, p. 507.

$\dagger$ Trans. D. and G. Nat. Hist. Soc., April 3rd, 1908.

$\ddagger$ British Birds (Mag.), Vol. I., p. 214.

§ Fauna of Tay, 1906, p. 91. 
England, and should be looked out for. It differs from the Marsh-Tit chiefly by its crown being of dull brownishblack or sooty-black rather than glossy-black and by its more graduated tail.*

\section{THE BRITISH BLUE TITMOUSE.}

Parus cœruleus obscurus, Prazák.

Local name-Blue Bonnet.

A common resident.

This species and the Great Tit are the most abundant of their family in the county. Sir William Jardine writing from Jardine Hall (Applegarth), records an individual which "for nearly ten years ... during summer and winter, has slept under the carved oak of one of the capitals heading the pillars which support our own front door, and during the period mentioned we have only known the place untenanted once or twice." $\dagger$

The British form of the Blue Tit, which is the only one known to have occurred in our county, differs from its continental representatives mainly by its darker, duller coloration.

[Mr. J. A. Harvie-Brown writing of the Crested Titmouse (Parus cristatus scoticus (Prazák)) says : "There is, I think, an account of its occurrence, or of a casual appearance, somewhere near Dumfries, but I cannot lay hand upon the reference at present. I may, however, safely leave that in the hands of Mr. Robert Service, when he comes to complete his volume upon the fauna of Solway. It may be possible that, just as at one time isolated small colonies of Crossbills were known to frequent certain portions of pine-growth

* British Birds (Mag.), Vol. I. p. 45.

† Nat. Lib., 1839, Vol. XI., p. 167. 
in that district, a far south remnant of Crested Tits survived ; but I prefer not to accept that theory unproved, or in the absence of stronger proofs. . . . I wish to add here that there is no specimen of this bird mentioned in the printed catalogue of the late Sir William Jardine's collection, nor are there any in the sale catalogue (Puttick and Simpson, June 17, 1886); nor do I remember seeing any in Sir William's collection, where I certainly looked for and expected to find one or more."*

Neither Mr. R. Service nor myself know anything more of this alleged occurrence of the Crested Tit near Dumfries. The species is confined to the pine-forests of the central Highlands of Scotland, and it must be remembered that a local name of the Golden-crested Wren is the "Crested Tit."]

\section{THE WREN. Troglodytes parvulus, K. L. Koch.}

Local names-KItTY; KitTy-Wren; KITtY-RAAN ; CutTY; CUTTY-Wren ; JenNy-Wren.

"Ah! There's Miss Kitty Wren, with her cocked tail, Cocked like a cooper's thumb. Miss Kitty goes

In 'neath the bank, and then comes out again

By some queer hole. Thus all day long she plies

Her quest from hedge to bank, scarce ever seen

Flying above your head in open air.

Unsmitten by the heat where now she is,

She strikes into her song-Miss Kitty's song !

(We never think of male in Kitty's case.)

Short is the song, not varied, yet not dull,

So liquid clear of pipe she opens it,

And, with increasing vigour to the end,

Goes through it quite: Thus all the year she sings,

Except in frost, the spunky little bird !"

Thomas AIRD.—“ A Summer Day."

A common resident throughout the county.

Mrs. Pollock tells me that at Dalswinton in the spring of 1866, the eggs of a Willow-Warbler, which had been

* Fauna of Tay, 1906, pp. 92-94.

$\dagger$ Plucky. 
deserted, were placed in the nest of a Wren, and the bird successfully hatched and reared the young in addition to its own brood. Pure white eggs are often found. In May, 1905, I found near Stenhouse (Tynron) a nest built into an empty circular tobacco-tin which had been thrown away, and had been caught up about three feet from the ground in the fork of a thorn-bush.

A curious variety in which the head, cheeks and neck, with the exception of the throat, were all pure white,* is recorded from Dormont (Dalton) in February, 1857.

\section{THE BRITISH TREE-CREEPER.}

Certhia familiaris britannica, Ridgway.

\section{Local names-TREE-SPELER; WOODPECKER.}

"What life the little Creeper of the Tree

To leafdom lends! See how the antic bird, Her bosom to the bark, goes round away

Behind the trunk, but quaintly reappears

Through a rough cleft above, with busy bill

Picking her lunch; and now among the leaves

Our birdie goes, bright glimmering in the green

And yellow light that fills the tender tree."

Thomas AIRD.- "A Summer Day."

A common resident in our woods and plantations.

The Tree-Creeper is not so noticeable in spring as it is in winter, when it may often be seen among small parties of titmice, busily searching for insect-food on the branches and trunks of trees.

"The Creeper" is included in a list of the "Rarer Species of Birds" found in the parish of Kirkmichael in 1791. $\dagger$

The nest is usually in a hole or rent of a tree, or behind a semi-detached piece of bark, but our stone-walls or

* Notes for Naturalists, p. 47.

† Stat. Acct. Scot., Vol. I., p. 61. 
"dykes" often afford a secure nesting-site. Mr. Robert Martin tells me he once found a nest at Dardarroch (Glencairn) on the ground below a stone. In May, 1905, a TreeCreeper nested behind a loose board at the side of a window of an outhouse which was in daily use. It was noticed that the eggs took thirteen days to hatch, and it was eight days more before the nestlings left the nest.

Mr. R. Service informs me of a bird of this species found tapping against a lighted window of Nithmount House (Dumfries) at midnight on October 10th, 1907, and he thinks that this bird may possibly have been a migrant; but the Tree-Creeper, although known to be subject to local wintermovements, is one of those few birds as to which no evidence exists of a regular migration, and I believe there is no record of the occurrence anywhere in the British Isles of any form other than our British bird, which is more rufescent in the colour of its upper surface than its continental representatives.

\section{THE PIED WAGTAIL. \\ Motacilla alba lugubris, Temminck.}

Local names-Water-WagtaIL; WUllite Wagtail ; Grey WAGTAIL.

"Along the shingly shallows of the burn, The smallest bird that walks, and does not hop

How fast yon Wagtail runs; its little feet Quick as a mouse's! Thus its shaking tail Is kept in even balance, poised, and straight. . . . W. Aloft in air, each chirrup keoping time With each successive undulation long, The Wagtail flies, a pleasant summer bird." Thомas ATRD. - A Summer Day."

A common summer-visitant, nesting throughout the arable and lower pastoral districts. A few are seen throughout the winter.

The Pied Wagtail arrives here towards the end of March or beginning of April, and leaves us again about September 
or October for its winter-quarters in western Europe; but some stay with us throughout the winter. At this time they draw in from their more scattered breeding-places to the lower arable districts, and often take up their residence in the vicinity of some farm or dwelling-house. At the seasons of their migrations they are gregarious at roosting time, and I have often been astonished in April and October to see so many Pied Wagtails together at dusk, in the bulrushes round a pond known as the Bobie Loch at Capenoch (Keir).

This species has been noticed to take small trout at the Solway Fisheries,* but its principal food consists of worms, slugs, insects and water-snails, and it is therefore most beneficial to agriculture. The following story $\mathrm{Mr}$. R. Service assures me is perfectly authenticated: "Mr. McDuff, gardener at Kirkwood (Dalton), reports that a Pied Wagtail built a nest in an overhanging creeper in the conservatory in early May. The house being shut up closely at night the bird was then excluded. One morning McDuff found an egg on the doorstep. This he put into the nest. The same thing happened on three subsequent mornings, and each egg was put into the nest. The bird then began to brood, and ultimately hatched and reared the lot."

\section{THE WHITE WAGTAIL.}

Motacilla alba alba, Linnæus.

\section{A fairly regular visitant in early spring.}

The White Wagtail is doubtless often overlooked on account of its similarity in appearance to the preceding species; the adult male, however, may be easily distinguished from that of the Pied Wagtail by its slate-grey upper-parts and 
wing-coverts, while the female is paler on these parts than is the female Pied Wagtail. The young can be distinguished by the grey rump and upper tail-coverts.

Writing of the avifauna of the Solway area in 1900, Mr. R. Service says: "Of late years this species has put in a tolerably regular appearance during the vernal migration. It seems to have been first noticed here about 1880."* Later he states: "Within recent years it has been found that a migration flight line of the White Wagtail is along the west coast of England and Scotland, passing about the latter end of March, and proceeding by some short cut up the west of our islands, so as perhaps to avoid the east wind, and on to the northern parts of Scandinavia." $\dagger$ On April 14th, 1908, I watched one of these birds at close quarters at Kirkland Station (Glencairn), as it ran about the furrows of a ploughed field, seeking for insects.

Mr. John Corrie writes me from Moniaive on April 13th, 1909: "It is only recently that I have identified the White Wagtail here. I was much interested last week when a railway surface-man came to me about a 'queer' Wagtail which he had seen. He did not know there was a White Wagtail, but he certainly gave a very accurate description
of that species."

A glance at the map will perhaps warrant my inclusion of the following observations, although all the localities are in Kirkcudbrightshire :-

1890. April 21st, one seen at Maxwelltown Loch by Mr. R. Service.

1901. April 14th, a fine male seen alone on Nith near Mavisgrove. $\ddagger$

1902. May 10th, observed at Maxwelltown.

1903. April 5th, a male seen at Four Mile House.\|

* Trans. D. and G. Nat. Hist. Soc., November 16th, 1900.

$\dagger$ Op. cit., April 20th, 1905.

$\ddagger$ Ann. Scot. Nat. Hist., 1902, p. 77.

§ Op. cit., 1903, p. 144.

\| Op. cit., 1904, p. 147. 
1910. May 14th, three seen by myself and Mr. H. F. Witherby at Southerness.

I can only repeat that I believe this species to be a fairly regular spring-visitant to Dumfriesshire, often passing unrecognised, and I wonder, like "Mabie Moss," "are the appearances now of the White Wagtail to be set down to a real change of migration line, or to merely want of skill in observation of former years?"*

In spring it is found over the whole of Europe, and it winters in Africa as far south as the Niger and British East Africa.

THE GREY WAGTAIL. Motacilla melanope, Pallas.

Local name-Yellow WagtaIL.

A common summer-visitant. A few remain throughout the winter.

Sir William Jardine writing in 1832 of the birds in the parish of Applegarth and Sibbaldbie, says that Grey Wagtails were to be found there "for a few weeks in spring and autumn, while passing to and from their breeding places among the hills." $\dagger$

Though not so generally distributed as the Pied Wagtail, this species is found throughout the county along our rivers and streams in spring, and Mr. J. W. Payne informs me that on the lower reaches of the Annan it is as common as that bird.

Towards the end of March or beginning of April the Grey Wagtail arrives here, from its winter-quarters further south in Europe and in North Africa, to which the majority depart in September or October. A few individuals stay throughout

* Kirkcudbright Advertiser, November 27th, 1908.

+ New Stat. Acct. Scot., Vol. IV., p. 179. 



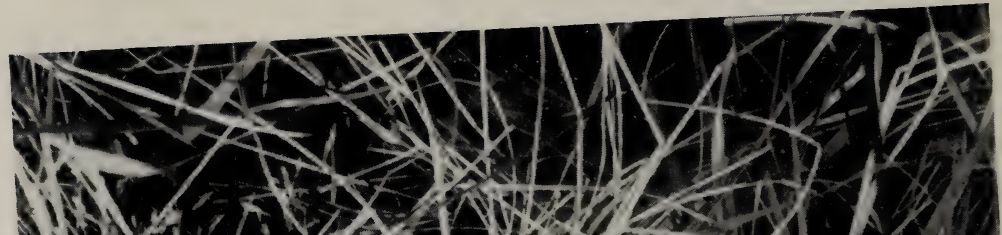

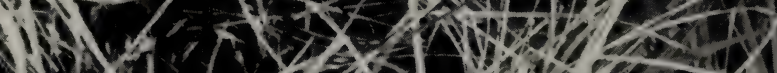

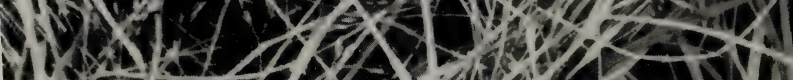

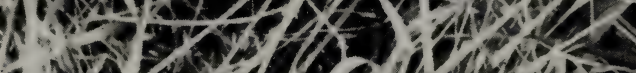

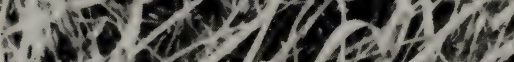
if

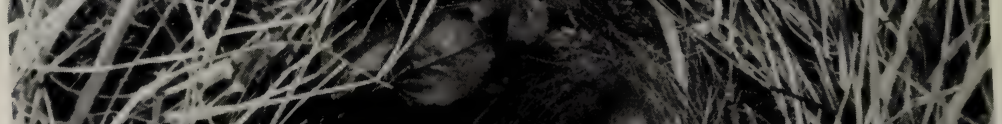

if

Q

$2,1=2,2$

$\rightarrow 108 \%$

ing 2020

retis

Non

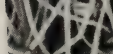

1.47m -

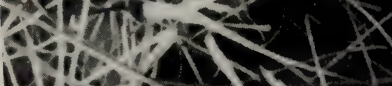

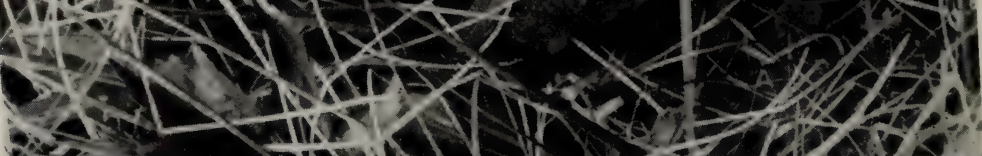

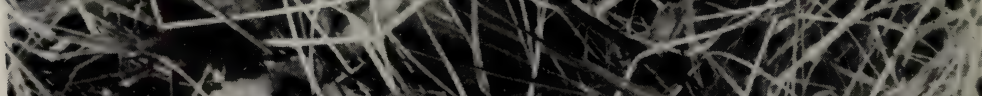

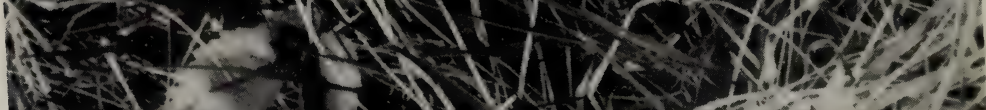

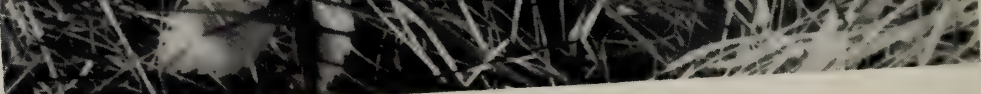

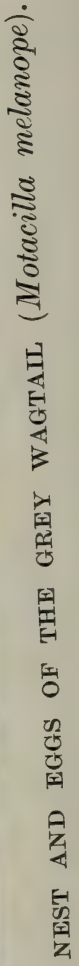




\section{BIRDS OF DUMFRIESSHIRE}

the winter, and a specimen in Sir William Jardine's collection was labelled as obtained in "winter" at Jardine
Hall.*

They are early nesters, and Mr. J. W. Payne tells me of a nest and eggs found on the Annan on April 16th, 1908. In a "Running Catalogue" of the contents of his museum Dr. Grierson writes: "Albino variety of the Wagtail, Motacilla; understood to be the Grey Wagtail or M. boarula, found on the bank of the Nith about the Parish of Keir many years ago; presented by Mr. Thomas Maxwell of Allanton Mill, March, 1866." $\dagger$

My photograph (reproduced in the accompanying plate) of the nest and eggs of this species was taken on Shinnel Water below Tynron village.

The Grey Wagtail is often confused with the Yellow Wagtail because of its yellow appearance. A common report to receive is : "We have only the Grey and the Yellow Wagtails with us," the Grey here, of course meaning the Pied, and the Yellow the Grey Wagtail.

\section{[THE BLUE-HEADED WAGTAIL. Motacilla flava flava, Linnæus.}

Mr. R. Service informs me that he saw one of these birds at Lettrick (Dunscore) on April 13th, 1908. He writes: "I had no binoculars with me, and the bird was shy, but it was one of the 'Blue-heads,' which one I cannot say. The bird was within a trifling distance of me for twenty minutes, but each time I tried to approach closely it flew
off farther."

This species breeds in the central portions of Europe, including south-east England, and though some winter in

* Cat. Birds in Coll. Sir W. J., p. 91 (3689), c.

$\dagger$ Cat. Contents of Museum. 
South Europe and North Africa, the majority pass on to tropical Africa and as far south as Cape Colony.

The Blue-headed Wagtail closely resembles the next species, particularly when its plumage becomes worn, but the white eye-stripe will always distinguish it, and in adult males the grey-blue head and grey ear-coverts are characteristic.]

THE YELLOW WAGTAIL. Motacilla raii (Bonaparte).

\section{A summer-visitant, but very local.}

Sir William Jardine in 1832, wrote of this species as " very common on the banks of the Annan, and is particularly noticed here as being a bird extremely local in its distribution."* A specimen of this bird, obtained at Jardine Hall, was also in his collection. $\dagger$ In 1834, when a boy of sixteen, Dr. Grierson records in his diary that a Yellow Wagtail's nest was shown to him "up Shinnel Water," but my personal knowledge of this locality would lead me to suspect that it was the Grey Wagtail that had been observed. He also records in his "Notes" under October 17th, 1862, that Thomas Maxwell told him he had seen the rare Yellow Wagtail on the Nith.§ Thomas Aird says in 1864: "I see the Yellow Wagtail sometimes in spring, about the corners of the fields of young corn, but it is rare about Dumfries. The Grey Wagtail, from having a good deal of yellow about it, is often mistaken for the Yellow Wagtail." II

Eggs of this species, taken in the valley of the Cairn,

* New Stat. Acct. Scot., Vol. IV., p. 179.

† Cat. Birds in Coll. Sir W. J., p. 91 (3698), a.

+ Grierson's MS. Diary, April 24th, 1834.

$\S$ Grierson's MS. Notes, 1860-1875.

II Trans. D. and G. Nat. Hist. Soc., February 2nd, 1864. 
are in the possession of Mr. R. Service ; and Mr. John Corrie of Glencairn writes: "Ray's Wagtail, the smallest of the Wagtails, is also the least common. I have seen it in one locality for several years in succession, but I am doubtful if it occurs anything like generally."* Mr. J. Harkness tells me it occurs near Ruthwell, and I am confidently informed that a pair were seen on the Nith below Drumlanrig Castle in the spring of 1908. Mr. William Laidlaw informs me that it nests below Langholm, and that he has kept both it, the Pied, and Grey Wagtails in captivity.

The Yellow Wagtail may nest in many more localities, but the epithet yellow is so commonly applied both to $M$. melanope and $\boldsymbol{M}$. raii, that in many reports $I$ have been unable to satisfy myself as to which species was intended.

The Yellow Wagtail has no grey about it, the head and back, which in the Grey Wagtail are of a slate-grey, being greenish-olive; and in general appearance it is of a more yellow colour, besides being smaller in size.

Its winter-home may be said to be in western Africa, and it arrives here in April and departs about September.

\section{THE TREE-PIPIT. Anthus trivialis (Linnæus).}

Local names-TreE-LARK; Wood-LARK.

\section{A summer-visitant throughout the arable district.}

The most common name in this county for the Tree-Pipit is the "Wood-Lark," and this fact accounts for the numerous reports of the occurrence locally of a species which has hitherto only occurred in Scotland at Fair Island. Poets, making full use of their poetic licence, have erred egregiously in this respect.

It is perhaps one of the most enjoyable sights in spring * Trans D. and G. Nat. Hist. Soc., November 10th, 1888. 
to see the Tree-Pipit rise up off some tree to a considerable height and then descend, with extended wings and outspread tail, pouring out its small, yet pleasing, song until its perch is regained. This habit will serve at once to identify it from the next species.

The Tree-Pipit usually comes to us late in April or in May ; but Sir William Jardine in a MS. note in his personal copy of the Naturalist's Library records its arrival at Jardine Hall in 1836 on April 7th. The bird leaves us in September and October for its winter-quarters in northern and tropical Africa, and it occurs as far south as South Africa.

THE MEADOW-PIPIT. Anthus pratensis (Linnæus).

Local names-Moss-Cheeper; Titlark; FieldLark; MEADow-LaRK.

An abundant summer-visitant to the upland districts ; less numerous, and local in winter.

The vast majority of the Meadow-Pipits, which are ubiquitous on our hill-sides during the breeding-season, emigrate to the south towards the end of September, and comparatively very few remain throughout the winter in the lower and less exposed districts of the county near the coast. In March and April the immigration movement sets in, and the bird becomes abundant once more in the upland districts of the county. Sir William Jardine in his personal copy of the Naturalist's Library writes: "1858. April 2nd. Flocks in field in front of Manse." "1860. April 9th. The first arrivals here." When migrating they travel in flocks, and a party of thirty-one was seen at Closeburn on April 28th, 1901.

Writing of the benefits to agriculture rendered by the pipits, Mr. Fred V. Theobald states that they " are uniformly accepted as beneficial by virtue of being great destroyers 
of insects, slugs, water-snails, worms, etc., and help materially in keeping down many noxious creatures such as the water-snail (Limnoeus trunculatus), that is the secondary host of the liver fluke of sheep."*

In Dumfriesshire this bird is perhaps the most usual victim of the Cuckoo, and the latter can hardly cross a moor without being pursued by a pair or more of "MossCheepers."

Dr. J. W. Martin records one of a canary-colour seen in Glencairn parish in August, 1901. $\uparrow$

[RICHARD's PIPIT (Anthus richardi, Vieillot) is an uncommon visitor to England from central Asia in late autumn and winter, some sixty to seventy occurrences having been recorded. H. A. Macpherson writes of it as an occasional straggler to the English Solwayt; and there is an authentic record of its occurrence at Terregles§ which, as will be seen in the map, is in Kirkcudbrightshire, barely a mile over our boundary. Possibly this species may have occurred in Dumfriesshire, but I am not at present aware of any actual record.]

\section{THE ROCK-PIPIT. Anthus obscurus (Latham).}

\section{Local name-Rock-LARK.}

\section{A common resident in our littoral parishes.}

This species frequents the foreshore in autumn, and may be seen feeding on the minute flies (Limosina) bred in the decaying sea-weeds. In spring their nests, so Mr. $R$. Service assures me, are made on the saltings, and at all

* Science Progress, 1907, Vol. II., p. 278.

$\dagger$ Trans. D. and G. Nat. Hist. Soc., December 13th, 1901.

\$ Fauna of Lakeland, 1892, p. 114.

§ Trans. D. and G. Nat. Hist. Soc., April 20th, 1905. 
times they are to be found from Caerlaverock to Annan. The migrations of this species observed on the east coast would not seem to influence in any material degree the numbers of our own, apparently resident, birds.

THE GOLDEN ORIOLE. Oriolus galbula, Linnæus.

A very rare casual visitor, only twice recorded.

The first Dumfriesshire specimen of the Golden Oriole has been variously reported as "shot in the parish of Tynron,"* "caught near the Nith in Closeburn parish," $†$ "near Sanquhar," $\ddagger$ and "found at Kirkconnel dead amidst the snow." § Through the courtesy of Mr. J. A. Harvie-Brown I am informed that Robert Gray has written in his interleaved copy of The Birds of the West of Scotland, "Oriolus Galbula, 1872. A specimen of the Golden Oriole $\delta$ was shot near Kirkconnel in Dumfriesshire in June last, and is now in the collection of Dr. Grierson, Thornhill. R.G., in lit. 25.10.72." In a letter to Mr. R. Service in March, 1877, Dr. Grierson wrote: "I have not many birds. The rarest is the Golden Oriel found in Kirkconnel parish." From the foregoing it would appear that Kirkconnel is the successful claimant to our first specimen of the Golden Oriole obtained in June, 1872; and the bird may still (1909) be seen (but in a sadly dilapidated condition) in what is now known as Grierson's Museum at Thornhill.

Our second specimen was caught in Penton Linn Wood (Canonbie) by Mr. Charles Vere on April 30th, 1909. It was observed flying about the banks of the river

* Trans. D. and G. Nat. Hist. Soc., December 4th, 1885.

† Op. cit., October 27th, 1886.

†p. cit., April 20th, 1905.

$\S$ Hist. Sanquhar, p. 28. 
in a feeble condition, and when pursued sought refuge among the rocks. On being caught it was found to be very thin, and it only lived a day after being caged by its captor. It was stuffed by Mr. Raine, taxidermist of Carlisle, who reported that it was an adult male. I have personally seen the specimen which is now in Mr. Vere's possession, and it is certainly a male in splendid mature plumage.

The Golden Oriole, a rare visitor to all parts of Great Britain except to the south coast of England, breeds throughout Europe south of the Baltic and as far east as Persia. In winter it is found in Africa, migrating to Natal, the Transvaal and Damaraland.

\section{THE GREAT GREY SHRIKE.}

Lanius excubitor, Linnæus.

\section{An uncommon and irregular autumnal or winter-visitor.}

Sir William Jardine wrote in 1839 that the Great Grey Shrike was a rare bird in the south of Scotland, "a few instances only of its capture having occurred to our notice."*

Writing in 1905 of this bird in the Solway area, Mr. R. Service says that " every winter for a long series of years one or more visitants were recorded, but during the last halfdozen years I have not been made aware of any occurrence here." $\dagger$ Mr. Tom Crosbie tells me that in the severe winter of 1878-1879 he shot a bird of this species at Kirkbog
(Closeburn) and that he gave it to Dr. Grierson for his museum at Thornhill; but I have been unable to trace it. Early in 1890 there was an unusual number of occurrences of this species in Scotland, and "Mr. T. Bell of Liddel Bank, near Canonbie, observed a double-barred Grey Shrike on

* Nat. Lib., 1839, Vol. XI., p. 58.

† Trans. D. and G. Nat. Hist. Soc., April 20th, 1905. 
February 24th."* Mr. Hugh Mackay records in 1895 that "A specimen of the Great Grey Shrike or Butcher Bird was lately observed in the vicinity of Greenbrae (Dumfries) with the remains of a small bird in its claw." $\dagger$ An immature female was taken alive below Glencaple (Caerlaverock) on October 14th, 1899. It was kept in a cage, but died in a few days. I am informed by Mr. George Kerss that one of these birds was caught in Craigieland's garden (KirkpatrickJuxta) in 1899 or 1900 . A fine example of the double-barred form was shot by Mr. Norman Menzies at Newtonairds on December 27th, 1906 ; it was a male and not a female as I described it at the time in the Annals of Scottish Natural History. Mr. Robert Martin writes me that he has seen this species in Glencairn, once at Dardarroch, and again at Maxwelton Mains.

The Great Grey Shrike is a fairly regular visitor from the Continent to Scotland and England in autumn and winter. The typical form, Lanius excubitor of Linnæus, has a double wing-bar ; Lanius major of Pallas, which shows only a single wing-bar, is now considered by modern authorities to be a mere variety; both forms have occurred in the county.

THE RED-BACKED SHRIKE. Lanius collurio, Linnæus.

\section{A very rare visitor.}

It was recorded in 1835 that, "Among the more rare birds ... may be noticed the Butcher Bird (Lanius collurio) [which has been] seen in this parish" $\|$ (Langholm), and a similar record is found in the description of Lochmaben

* Scottish Naturalist, 1891, Vol. XI., p. 62.

† Dumfries Courier and Herald, February 16th, 1895.

† Ann. Scot. Nat. Hist., 1900, p. 48.

$\S$ Op. cit., 1907, pp. 112, 113.

|| New Stat. Acct. Scot., Vol. IV., p. 418. 


\section{BIRDS OF DUMFRIESSHIRE}

parish.* Mr. R. Service tells me that when he stated in 1905 that this species "was only once found at Lochmaben," $†$ he had in his mind the latter of the above records. I was told by a keeper on the Drumlanrig estate that many years ago a shrike had been shot near the farm of Holm (Closeburn). My informant was emphatic that it was not a Great Grey Shrike, but I am of the opinion that he referred to the bird already recorded under the preceding species as shot at Kirkbog (Closeburn) in the winter of 1878-1879 (see p. 55). Mr. John Corrie writes me, "On May 22nd, 1910, a strange bird was seen here (Moniaive, Glencairn), which I have not the slightest doubt was the Red-backed Shrike. It was seen first by my son, and later in the day I had the satisfaction of seeing it myself. I examined it carefully through a field-glass and I have independent reports which confirm my observations. The bird or birds (my son thinks there may have been two) remained for three days, but I have been unable to find any trace of them since."

The winter-quarters of the Red-backed Shrike extend to Natal and Cape Colony, and it is a common summer-visitor to England, becoming rarer towards the north. H. A. Macpherson wrote as regards Lakeland, in 1892, of "their extreme scarcity at the present time, though formerly not very uncommon." $\ddagger$ This species has also been known to breed occasionally in south-east Scotland.

\section{THE WAXWING. Ampelis garrulus, Linnæus.}

\section{A very rare accidental visitor.}

The specimen of the Waxwing now in the Kirkcudbright Museum was killed on December 25th, 1882, at Kingholm (Dumfries). It was knocked over by a boy with a stone as it was sitting on a hedge. William Hastings, the taxidermist

* New Stat. Acct. Scot., Vol. IV., p. 382.

† Trans. D. and G. Nat. Hist. Soc., April 20th, 1905.

¥ Fauna of Lakeland, 1892, p. 120. 
in Dumfries, mounted it, and sold it to the museum authorities for ten shillings. The previously-published dates of 1878 and November, 1882, are incorrect. Mr. John Corrie records, "The Bohemian Waxwing was once seen many years ago in the vicinity of Hasting's Hall" (Glencairn).* Dr. Grierson, in a letter to Mr. R. Service in 1877, wrote concerning the late Mr. Shaw, head-gamekeeper to the Duke of Buccleuch, "He scarcely had any birds, and none now kept at Drumlanrig; the only bird that I remember of Mr. Shaw having was the Waxwing, which I remember him telling me he shot in the parish of Keir." Mr. James Malcolm writes me that he has in his possession a Waxwing which was shot at Langholm in November, 1901. It was one " of a flock of about a dozen, which was seen in the vicinity for about a week. They were feeding on privet berries, which were a very abundant crop that winter."

A specimen which $I$ found in a cupboard at Capenoch had no information attached to it, and may, or may not, have been locally obtained.

The Waxwing is "an irregular visitor to the British Islands. It breeds in the pine regions at or near the Arctic Circle in both hemispheres, wandering southwards in winter." $†$

\section{THE SPOTTED FLYCATCHER.}

Muscicapa grisola, Linnæus.

A common summer-visitant to the arable parts of the county, extending into the upland district where there are suitably wooded localities.

There is, I think, no doubt that the Spotted Flycatcher has become more common within the last fifty or sixty years. Robert Mudie wrote of it in 1841 as being " rare in Scotland, if indeed it at all reaches that country."

* Trans. D. and G. Nat. Hist. Soc., November 10th, 1888.

† List of British Birds, B.O.U., 1883, pp. 39, 40.

‡ Feathered Tribes of Brit. Islands, 1841, Vol. I., p. 240. 
The bird seldom arrives here before the middle of May, and leaves us again early in September. On its arrival in the county it commences nesting-operations at once, selecting a situation for its nest in ivy-covered walls or trellised porches, often confidingly near the haunts of man. In June, 1891, a nest built into an old Blackbird's nest was found at Waterside (Keir), and a similar site is recorded from Sanquhar by Dr. Anstruther Davidson, who also states that in that district the species is comparatively rare.*

Spotted Flycatchers are often accused by gardeners of taking fruit, but Mr. Fred. V. Theobald says that they are "most beneficial, feeding solely upon insects, including many of those which devour our crops and fruit. It seems that all accusations against them fail when carefully examined. Their encouragement and protection should therefore be rigidly enforced." $\dagger$

Richard Bell of Castle O'er records an albino specimen from Eskdalemuir $\ddagger$

The winter-quarters of this species are in Africa to as far south as Cape Colony.

\section{THE PIED FLYCATCHER. Muscicapa atricapilla, Linnæus.}

Local name-Black and White Flycatcher.

A scarce, but regular summer-visitant to some parts of the county.

Sir William Jardine writing of this species in 1839 says : "We are not aware that it has been met with . . . in any part of Scotland."§

The Pied Flycatchers, which have within a short period

* Trans. D. and G. Nat. Hist. Soc., November 10th, 1888.

† Science Progress, 1907, Vol. II., p. 276.

† My Strange Pets, p. 223.

\$ Nat. Lib., 1839, Vol. XI., p. 220. 
of some five and twenty years visited certain favoured localities in our county, are probably off-shoots of the stock in Cumberland, where they have been known to nest for upwards of one hundred years.*

In 1865 a male Pied Flycatcher was seen near Drumlanrig Castle (Durisdeer) by William Hastings; but it was not until May 30th, 1884, that Mr. Tom Brown found a nest and six eggs in a hole in an alder growing by the banks of Scaur Water in Tynron parish. $\dagger$ The same hole was resorted to in the following year, and in subsequent years there has always been a nest within half a mile of the first-discovered site. In 1889 there were reports of several nests found on Cample Water, Scaur Water, and the River Nith, and on the River Annan near Kirkwood (Dalton), where in August of that year Mr. R. Service saw a brood of three flying about. In 1894 they were first observed on Shinnel Water, a tributary of the Scaur; and in 1897 they were first noticed in the Cairn valley, both near Dunscore and in Glencairn parish; and on the Nith near Kirkmahoe. Mr. W. F. Graham informs me that he took a nest of this species about 1899 below Bonshaw, on the Kirtle Water, which is interesting as being the most easterly record I have yet received. On May 9th, 1908, a male Pied Flycatcher was seen near Chanloch (Penpont) on the Scaur, a very suitable spot for this species, but further up that water than has been previously reported. At many of the above localities they have been noticed subsequently, but I cannot say that the species has annually visited all of them.

The birds would appear yearly to vary in numbers on different streams, and it is therefore most difficult to say whether the breeding-area of the species is extending, though its numbers during the last ten years are believed to have increased. A glance at the map will, however, show that it is still confined to Annandale and Nithsdale. The photograph

* Fauna of Lakeland, 1892, pp. 123-129.

† Trans. D. and G. Nat. Hist. Soc., December 4th, 1885. 


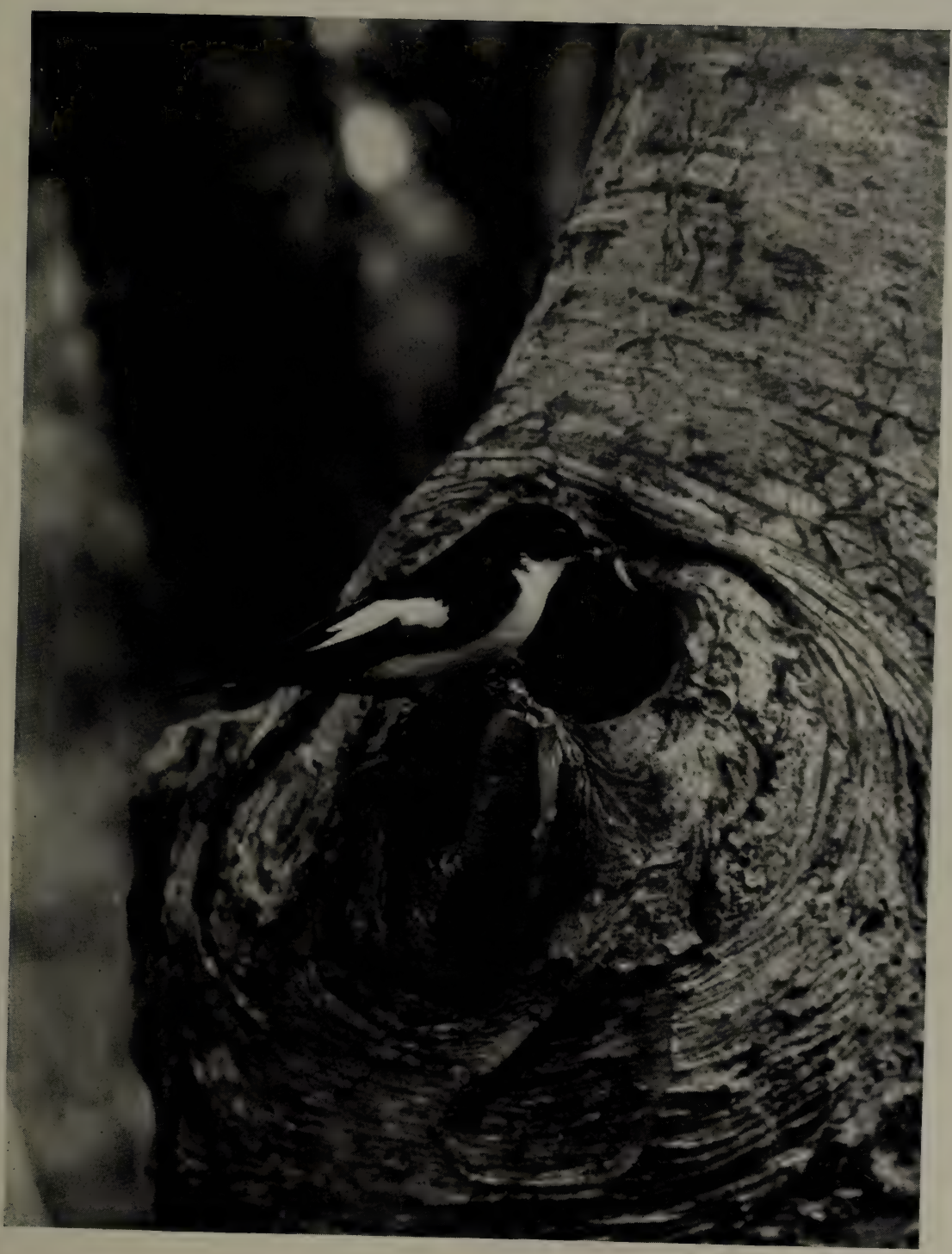

PIED FLYCATCHER (MUscicapa atricapilla) AT THE NEST. 

of the male bird at the nest, here reproduced, was obtained at a favourite haunt of this species.

Usually before the middle of May, and sometimes as early as the last week in April, this species arrives from its African winter-quarters, the males preceding the females by about a week. The five to eight eggs are laid towards the end of May or early in June, and from personal observations, take thirteen days to hatch ; some ten days later the young leave the nest, and by the end of July or early in August the birds have all emigrated.

THE SWALLOW. Hirundo rustica, Linnæus.

Local names-House-Swallow; Barn-Swallow; ChimneySwaLlow.

"The little comer's coming, the comer o'er the sea,

The comer of the summer, all the sunny days to be,

How pleasant through the pleasant sleep thy early twitter heard O swallow by the lattice! Glad days be thy reward."

Thомas AIRD.- "The Swallow."

\section{A common summer-visitant.}

In 1839 it was stated that in Dumfriesshire there was scarcely one Swallow's nest where they formerly counted ten,* but in 1854 Swallows were particularly numerous. $\dagger$ Their numbers now, as then, fluctuate much according to season, but I believe that this species has not only decreased, but will be found to be decreasing. In some seasons our erratic climate plays great havoc with these birds. "In the spring of 1886 after the Swallows had arrived, a spell of exceedingly cold weather occurred which destroyed the insects on which they fed and the poor birds were picked up dead across the country," $\ddagger$ and a similar misfortune seems to have befallen them in 1840 , for it is recorded that

* Dumfries Courier, April 24th, 1839.

$\dagger$ Op. cit., May 23rd, 1854.

¥A Country Schoolmaster, 1899, p. 303. 
"A short time ago a great many Swallows were found dead, for a sudden change of temperature, amounting to twentyfive degrees, is too much for their delicate frames."*

The earliest date I have found recorded for the arrival of the Swallow in this county is March 26th, 1903, on which day some were seen at Lochmaben, the species having been observed three days previously on the Galloway coast. $\dagger$ Swallows have probably seldom been later in their arrival than in 1908, when they were not seen in the county till April 29th. If an average date for their arrival is permissible, it would seem to lie between April 16th and 20th; but someone, I forget who, has written: "The fallacy of averages of arrivals of spring migrants has been proved," and in this opinion I entirely concur.

The poet James Grahame, writing in his British Georgics from Annan in the summer of 1808, would have farmers observe the migration of the Swallows, for he wrote :-

"Soon as the earliest swallow skims the mead,

The barley sowing is by some begun;

While others wait her clay-built nest,

Completed, in the window corner hang;

Or till the school boy mock the cuckoo's note." $\ddagger$

And in his notes on the above he adds : "Magna fides avium est; experiamur aves" (Ov. Fast., Lib. iii., 814), and continues: "In choosing the proper time for performing the different operations of husbandry the farmers' plans ought not to be regulated by the present appearances of the weather. . . . On the other hand the birds of passage undoubtedly possess an instinctive forecast of what is to be the state of the weather. . . A Swallow, for instance, is probably able to traverse Europe in four and twenty hours, consequently its determinations to begin or to continue its migration may easily be the result of observations on the state of the atmosphere, made not in this or that particular district, but in a compass of several hundreds of miles." §

* Dumfries Courier, June 9th, 1840.

† Ann. Scot. Nat. Hist., 1904, p. 65.

† British Georgics, p. 73.

§ Op. cit., pp. 274, 275. 
The latest date for a Swallow that I have found recorded is October 25th, 1896; * but Sir William Jardine speaking of the departure of the Swallows on September 20th, 1836, owing to the very inclement weather, remarked that this emigration was "a month earlier than usual." $\dagger$ Mr. R. Service states that in 1895 some Swallows stayed until October 16th, and that a few days later there was "curling" at Wanlockhead. $\ddagger$ In 1889 many Swallows went south on August 26th, the earliest date that I have seen recorded for their departure, the usual time being between September 24th-27th.

Before their departure Swallows flock together, and often choose a reed-bed in which to roost. Sir William Jardine says this habit " has given rise to the idea that they retired during winter under water, for the departure of the great mass takes place simultaneously; and the retreat which was one night enlivened by their evolutions and sprightly twitter, is the next solitary, or rendered to appearance more deserted, by the appearance of the few who have been unable to accompany the great body of the flight." $\|$ Mr. R. Service tells me that in their autumnal emigration Swallows nearly always go in a direction a little east of south, but that in 1899 on September 22nd and 27th, and on October 2nd, he observed them working west, a notable diversion.

The confidence of this species at the nesting-season is perhaps the reason that endears it to all classes. "Two pairs of Swallows built their nest and hatched their young in the [ship] 'Alexander Maxwell' at Glencaple, whilst the workmen were employed building her." W. C. Hewitson describes a curious egg of this species which is of local interest, thus: "The variety which I have drawn at Figure 4 (Plate $1 \times v$.) was sent me by Mr. J. W. Johnston

* Ann. Scot. Nat. Hist., 1897, p. 144.

$\dagger$ Hist. Berwick Nat. Club, Vol. I., p. 104.

$\ddagger$ Ann. Scot. Nat. Hist., 1896, p. 98.

§ Proc. Nat. Hist. Soc. Glasg., 1881, Vol. V., p. 51.

|| Nat. Lib., 1839, Vol. XI., p. 399.

ๆ Dumfries Courier, July 28th, 1812. 
of Dumfries, under the belief that it is an egg of the HouseMartin. As Mr. Johnston has no positive evidence to confirm this belief, I have taken the liberty to differ from him, and to figure it as a curious variety of the egg of the Swallow."* "Figure 4" referred to depicts a whitish egg strongly marked with dark chocolate-coloured spots, with underlying markings of grey. $\dagger$

White varieties of the bird are rarely seen; Mr. J. Macduff saw one at Kirkwood (Dalton) in 1887, and "Mabie Moss" records a white Swallow seen on the Nith in August, 1905. $\ddagger$

The winter-quarters of this species are "throughout the Indian region as far east as Burmah and the Malay Peninsula, and all over Africa." \$

The following table is sufficiently interesting for publication, but it should be noted that the observations emanate from inland localities, and that the observers relied only on their own eyes, and not on the reports of other persons.

\begin{tabular}{|c|c|c|c|}
\hline Year. & First seen. & District. & Observer. \\
\hline $\begin{array}{l}1874 \\
1875 \\
1876 \\
1878 \\
1879 \\
1880 \\
1881 \\
1882 \\
1883 \\
1884 \\
1885 \\
1886 \\
1887 \\
1888 \\
1889\end{array}$ & $\begin{array}{lr}\text { April } & 23 \mathrm{rd} \\
\text { May } & 6 \mathrm{th} \\
\text { April } & 9 \mathrm{th} \\
\text { April } & 28 \mathrm{th} \\
\text { May } & 7 \mathrm{th} \\
\text { April } & 20 \mathrm{th} \\
\text { May } & 6 \mathrm{th} \\
\text { April } & 23 \mathrm{rd} \\
\text { May } & 1 \text { st } \\
\text { April } & 29 \mathrm{th} \\
\text { April } & 22 \mathrm{nd} \\
\text { April } & 22 \mathrm{nd} \\
\text { April } & 22 \mathrm{nd} \\
\text { April } & 15 \mathrm{th} \\
\text { May } & 6 \mathrm{th}\end{array}$ & $\begin{array}{l}\text { Tynron } \\
\text { Do. } \\
\text { Do. } \\
\text { Do. } \\
\text { Do. } \\
\text { Do. } \\
\text { Do. } \\
\text { Do. } \\
\text { Do. } \\
\text { Do. } \\
\text { Do. } \\
\text { Do. } \\
\text { Do. } \\
\text { Do. } \\
\text { Do. }\end{array}$ & $\begin{array}{c}\text { Mr. Tom Brown. } \\
\text { Do. } \\
\text { Do. } \\
\text { Do. } \\
\text { Do. } \\
\text { Do. } \\
\text { Do. } \\
\text { Do. } \\
\text { Do. } \\
\text { Do. } \\
\text { Do. } \\
\text { Do. } \\
\text { Do. } \\
\text { Do. } \\
\text { Do. }\end{array}$ \\
\hline
\end{tabular}

* Col. Ill., Eggs Brit. Birds, 1856, Vol. I., pp. 259, 260.

† Op. cit., Vol. I., Plate 65.

$\ddagger$ Kirkcudbright Advertiser, August 25th, 1905.

§ Man. Brit. Birds, 1899, p. 168. 


\section{BIRDS OF DUMFRIESSHIRE}

\begin{tabular}{|c|c|c|c|c|}
\hline Year. & First & seen. & District. & Observer. \\
\hline 1890 & April & 30 th & Tynron & Mr. Tom Brown. \\
\hline 1891 & April & 27 th & Do. & Do. \\
\hline 1893 & April & 8 th & Langholm & Mr. William Laidlaw. \\
\hline 1895 & April & 15 th & Do. & Do. \\
\hline 1896 & April & 18th & Do. & Do. \\
\hline 1898 & April & 23rd & Do. & Do. \\
\hline 1899 & April & 25 th & Do. & Do. \\
\hline 1901 & April & 21st & Do. & Do. \\
\hline 1902 & April & 15 th & Do. & Do. \\
\hline 1903 & April & 26 th & Do. & Do. \\
\hline 1904 & April & 12 th & Do. & Do. \\
\hline 1906 & April & 10th & Do. & Do. \\
\hline 1907 & April & 15th & Do. & Do. \\
\hline 1908 & April & 29 th & Do. & Do. \\
\hline 1909 & April & 12th & Do. & Do. \\
\hline 1910 & April & 20 th & Do. & Do. \\
\hline
\end{tabular}

\section{THE HOUSE-MARTIN. Chelidon urbica (Linnæus).}

\section{Local names-Window-Swallow; Window-MarTiN.}

"If in an evening sky, serene and calm, The Martins higher than their wonted flight, On arrowy pinions, scarcely quivering soar,

Its utmost buoyancy has . . then the air as gained ; and hence Each bird and insect, fiquid region ply, On such an eve, who marks the Martin's flight, A ruddy morning tinge the dappled foresees JAMES GRAHAME. - British Georgics" (July).

\section{A common summer-visitant.}

Sir William Jardine in 1832 wrote of this species: "The numbers of window-martins have diminished much since the 
old Mansion House of Jardine Hall was pulled down, previous to which two or three pairs of Martins tenanted every window. Now a few pairs only are to be found. The Martins are strictly gregarious, living in large colonies like Rooks and Herons."* Again, in 1839: "Of the little white rumped Swallow which used to breed in hundreds we have not a single nest ; such are the changes in circumstances fitting to these creatures." $†$

Throughout the county a lamentable decrease in the numbers of the House-Martins that visit us has been observed during the last five and twenty or thirty years. Mr. R. Service, reviewing the changes in the vertebrates of Solway during the past century, wrote in 1901: "Scores of farmhouses where it used to breed have now not a single pair attached to them. It has been alleged that great numbers of this homely little bird are killed on passage through France and Italy. While that is undoubtedly the case, I am rather inclined to believe that its increasing scarcity here is caused by some obscure climatic change." $\ddagger$ It is difficult, on account of its presence in some localities in small colonies, and its absence from others, to compare its numbers with those of the more generally dispersed Swallow, but of the two species it appears to be the least numerous. As regards its arrival in this county, the HouseMartin is usually preceded by the Swallow, and it is so frequently confused with the latter that it would be difficult to arrive at an average date for its appearance, were such a calculation deemed necessary. An old record from Kirkmichael in 1791 says: "The house and window swallows arrive about the 20th of April and depart from the fourth to the thirteenth of September,"§ and these dates may still be said to hold good in a general way. In 1904 I saw a single House-Martin at Capenoch (Keir) on

* New Stat. Acet. Scot., Vol. IV., p. 180.

† Sir W. Jardine, in litt., to P. J. Selby, July 2nd, 1839.

‡ Trans. D. and G. Nat. Hist. Soc., November 16th, 1900.

§ Stat. Acct. Scot., Vol. I., p. 61. 
March 28th, which was of course exceptionally early ; and in 1882 some birds lingered here suntil so late as the third week of October.

The names window- or House-Martin are obviously applied because of the nesting-habits of the bird, as compared with the next species.

Professor Newton points out: "The forms Martyn, Mertyn, and Morton are found printed in some Scottish Acts of Parliament, and from the context may be inferred to mean a bird, but of what kind it is hard to guess."*

In winter this species "visits Africa as far south as Natal." $\dagger$

\section{THE SAND-MARTIN. Cotile riparia (Linnæus).}

Local names-BANK-Swallow ; RIVER-SWALLOW ; WATERSwallow ; Brown Martin.

Well drilled by Marting " The red sandy scar The low-banked stragg that each year frequent

Where only a few stunted unromantic stream

Dr. James MrLigan._"Wimpleburn."

\section{A common summer-visitant to all suitable localities.}

Sir William Jardine in his notes to White's Selborne in 1851 says, "our observations in South Scotland and the North of England have always noted the H. riparia, or Bank-Swallow, to be the first in arriving." $\$$ In 1791 it is stated in an account of the parish of Kirkmichael, "The River-Swallow appears in the middle or end of March, and departs about the first of September."§ Nowadays,

* Dict. Birds, 1893-1896, p. 536, footnote 1.

$\dagger$ Lloyd's Nat. Hist., Vol. I., p. 328.

¥ White's Selborne, 1851, p. 406.

$\S$ Stat. Acct. Scot., Vol. I., p. 61. 
these dates would both of them appear to be too early, the more usual date of their arrival being between April 8th and 12th, their departure taking place about the middle of September. This species usually arrives in this county in advance of the Swallow and House-Martin, and on March 25th, 1897, they were seen in Annandale and at Glencaple (Caerlaverock); but in 1889 and 1890 they apparently arrived after the Swallows. But the movements of this, as well as of the two preceding species, are largely influenced by climatic conditions, and it must be remarked that the appearance of an individual does not necessarily indicate the arrival of the main bodies, which often appear a week or more later; similarly, individuals or small flocks may linger after the majority has emigrated south. Previous to emigration they congregate in large flocks, and it was recorded that on September 16th, 1843, " an immense mass of Sand-Martins were seen skimming about the Crichton Royal Institution ; there were thousands of them congregated together."* Sir William Jardine once observed at the season of their departure "many hundreds of the Sand Martin resting on the sands of the Solway Frith, upon a space not exceeding two acres; a small stream entered the sea, and they seemed partly resting and washing, and partly feeding on a small fly that had apparently come newly to existence, and covered the sands in immense profusion." $\dagger$ Mr. R. Service tells me that he has also seen similar large flocks on the sands of the Solway at Southerness (Kirkcudbright), and that he believes they were collected in search of the fly of which Sir William wrote. This is a small dark dipteron (Scatophaga litorea (Fallen)), the larvoe of which feed on the "wrack" or rotting seaweed flung up by the tide.

The nests which are placed at the end of small tunnels excavated by the exertions of the Sand-Martins themselves, are in sand-banks, often by the sides of rivers. The Sand-

* Dumfries Courier, September 18th, 1843.

$\dagger$ Nat. Lib., 1839, Vol. XI., p. 404. 
Martin breeds throughout Europe and across northern Asia and in North America ; in winter it is found in China, India and parts of Africa, and in Central and South America.

\section{THE GREENFINCH. Ligurinus chloris (Linnæus).}

Local names-Green Linnet ; Green Lintie.

"I love the broom where the gay green-linnet

Bigs* its wee bower in the broken tree,

And loving the fragrance, sings sweet to win it,

When the dew lies deep on the lily lee."

HENRY Scott-RIDDELL.- " The Bonnie Broom."

\section{A partial resident, common throughout the arable districts.}

Late in October many of our home-bred Greenfinches migrate south, returning again in early spring to nest.

The breeding-season of this species is very prolonged, nests being commonly found from April to September. The Greenfinch may almost be said to breed in colonies, in such close proximity are their nests found in clumps of evergreens, bushes, or young spruce-plantations. The period of incubation I have found to be fifteen days, and two broods are often reared in one season. During the summer months large parties of non-breeding birds congregate together.

Mr. John Boreland of Auchencairn (Closeburn) wrote me on May 21st, 1908: "I heard considerable comment yesterday on the damage done to brairding turnips by the common linnet. This seems to have been only noticed of late years." Specimens of the culprits being forwarded, it was found that they were Greenfinches ; and Mr. Service tells me that in 1900 or 1901 this species (oddly enough on a neighbouring farm to Auchencairn) had been reported to be the cause of the same trouble. The birds try to pick off the empty seed-case adhering to the seed-leaf as the latter is still " brairding," and so pull up the embryo plant.

* Builds. 
The seed of the dandelion would seem also to possess peculiar attractions for these birds.

Mr. William Laidlaw informs me that a pure white Greenfinch was seen on the farm of Crookholm (Canonbie) in 1907 and 1908.

Three instances of the capture of a hybrid between a Greenfinch and a Goldfinch in a wild state, have come under my notice. The first, taken near Sanquhar in January, 1887, was seen by Mr. R. Service in possession of its captor, who told him it had been caught in company with some Linnets. Mr. W. J. Halliday writes me from Lochmaben that a bird-catcher in 1902 caught a hybrid Goldfinch and Greenfinch in a field at Lochvale near the Mill Loch, and that he stated the Goldfinch was the male parent. Mr. W. Coupland from Kirkmahoe informs me that in 1904 a Goldfinch had for a mate a Greenfinch; the eggs were hatched out successfully and a bird-catcher caught one of the hybrids afterwards.

\section{THE HAWFINCH. Coccothraustes vulgaris, Pallas.}

An uncommon irregular visitor, but recently found nesting in Eskdale.

Sir William Jardine in 1839, writing of the distribution of the Hawfinch in Great Britain states: "In the north it is a straggler, but has been killed and seen in the counties of Durham and Cumberland, reaching across the border to Dumfriesshire; farther north in Britain we do not know of its occurrence."* Dr. Grierson records in his "Notes" for October 17th, 1862, that Thomas Maxwell told him that "a specimen was found dead many years ago at Blackwood (Keir). They have been got at Drumlanrig." $\dagger$ Robert Gray wrote in 1871 that "it has been

* Nat. Lib., 1839, Vol. XI., p. 269.

† Grierson's MS. Notes, 1860-1875. 
traced from Dumfriesshire to East Lothian thence to Aberdeenshire, Banffshire and Caithness in all of which counties several specimens have been obtained."*

The late J. Gilchrist Clark of Speddoch (Holywood) saw this species there on more than one occasion about 1890: and Mr. John Anderson informs me that he saw what he took to be a Hawfinch at the end of November or early in December, 1894, near Torthorwald. Howard Saunders states " the species has been taken in winter in the Solway area." $\uparrow$ Individuals have since been recorded; Mr. Bartholomew found one dead near a shepherd's house, about one thousand feet above sea-level, among the hills near Kinnelhead (Kirkpatrick-Juxta), on April 6th, 1903 ; the specimen was identified by Mr. W. Eagle Clarke.t A Hawfinch was shot near Langholm in July, 1903, and Mr. James Malcolm informs me that it was a solitary one, and in its depredations amongst the green peas " it snapped the pods with its strong bill just as if they had been done with a pair of pincers."

A Hawfinch was believed to have been seen at Gribton (Holywood) in 1907, and Mr. Steele is confident that he saw one of these birds at Stonehouse (Gretna), in April, 1908. On June 17th, 1906, a nestling Hawfinch which was being fed by the parent birds, was taken from the nest near Langholm, and was reared by Mr. William Laidlaw. He further informs me that in the first week of June, 1908, a pair of these birds were seen feeding a young one close to the engine-house at Burnfoot Saw Mill (Canonbie); and that in the preceding winter a flock of nine was observed within a mile of that place. In the near vicinity, but within the boundaries of Cumberland, I hear that this species nested in 1907 and 1908. During the winter of 19091910 Hawfinches were plentiful near Canonbie, as many as twenty-five being seen together in one flock; but they all

* Birds of West Scotland, 1871, p. 144.

$\dagger$ Man. Brit. Birds, 1899, p. 171.

$\ddagger$ Ann. Scot. Nat. Hist., 1903, pp. 184, 185. 
disappeared before the spring. On April 10th, 1908, I saw a beautiful specimen caught the day before in a trap at the Grove, just over our boundary in Kirkcudbrightshire, and I heard authentically of others being seen later in the neighbourhood. I am therefore inclined to regard with less incredulity than they would otherwise have been received, the rumours which have reached me of its recent occurrence in our littoral parishes.

I am still at a loss to know what bird is referred to by many of my correspondents who describe the Hawfinch as "common," " not uncommon," " rare," " makes a nest like a tree-sparrow," etc. In several cases I have ascertained that the Hedge-Sparrow and the Chaffinch are the birds so named; but in view of the fact that the Hawfinch has of late years appeared more frequently in our county, some of these reports may not be so erroneous as might seem at the first glance.

The Hawfinch is distributed generally throughout England, becoming more rare in the northern counties, but an extension in its breeding-range would seem to be in progress.

THE BRITISH GOLDFINCH.

Carduelis elegans britannicus, Hartert.

Local names-Goldie; GoLdFLINCH ; GouldSPINK : GoolDIE ; GOWDSPINK.

"The gowdspink woos in gentle note, And ever singeth he,

'Come here, come here, my spousal dame'-

A theme which pleaseth me.'

Ailan CUNnINGHaM.- " Return of Spring."

A rather scarce and local resident.

Formerly the Goldfinch was abundant in the county. Robert Gray writing of the bird about 1870 says : "For 
many winters past I have been surprised at the very large numbers that are sent weekly from Dumfriesshire to Glasgow. Many hundreds must be taken in a season. . . . From being a comparatively common bird, therefore, the Goldfinch is, from this cause alone, now rather a scarce species, and as cultivation extends, the plants on the seeds of which they feed are naturally becoming diminished."*

A great many that are caught and caged are paired with a canary, the resulting hybrid being considered to possess remarkably fine powers of song. In captivity the Goldfinch mates with several species of finches, and instances of its having bred in a wild state with the Greenfinch have already been noted. (See p. 70.) A local bird-catcher confidently told me that the real "Dumfries goldie" should " have yellow, the commoner sort flesh-coloured, and the "foreigners" dark brown legs; but I have been unable to confirm this fancy from any of the standard works on ornithology.

Within the last fifteen or twenty years the Goldfinch seems to have been on the increase, and reports show that it has nested recently, though not regularly, in nearly every parish. In autumn and winter there may be a small accession to their numbers from further north, but there is no evidence that these birds are other than examples of the British race, which is darker and more olivebrown on its upper surface. In winter, Goldfinches gather into small flocks, and Mr. J. E. Steele informs me that once at this season he saw a flock of sixty near Dunscore. Mr. W. Coupland writes me from Kirkmahoe, that in the winter of 1907-1908 the bird-catchers there caught so many that they nearly exterminated the local flocks, some of which contained over twenty birds.

Improved agriculture, and with it the disappearance of such favourite food as the thistle, burdock, ragweed, and horse-knot, may account for the reduction in numbers of this species since the "good old days"; but the fore-

* Birds of West Scotland, 1871, p. 144. 
going will show that a more strict enforcement of the Wild Birds Protection Act is most necessary and would probably be most beneficial.

\section{THE SISKIN. Chrysomitris spinus (Linnæus).}

An irregular winter-visitor; as a nesting-species extremely local and scarce.

Sir William Jardine writing in 1832 of the Siskin says that it "appears at uncertain intervals in very large flocks." * and again elsewhere: "In 1827 Annandale... was visited by large flocks, which did not again return, and where, since, they have only been partially seen in small parties or pairs." $\uparrow$ In 1839 he recorded that a few pairs had been known to breed near New Abbey in Galloway, $\ddagger$ which, although outside our county, I give as contemporaneous with their nesting at Dalswinton (Kirkmahoe). Here the birds used to breed annually, and W. G. Johnstone recorded that "In an old plantation, parish of Kirkmahoe, Dumfriesshire, I this year (April, 1853) had the pleasure of discovering a Siskin's nest, containing one egg. The nest was close to the trunk of a larch tree about eight feet from the ground, not particularly well concealed, and not remarkable for neatness; it was composed of hypnum, hair, and fibrous roots (no feathers) rather firmly compacted. Near to the same spot last year a nest was taken containing young, the party who took them succeeded in rearing two of them."§ In 1855 a nest containing young was again found in Dalswinton Wood, and by the assistance of the male bird they were

* New Stat. Acct. Scot., Vol. IV., p. 179.

† Nat. Lib., 1839, Vol. XI., p. 278.

$\ddagger$ Op. cit., 1839, Vol. XI., p. 278.

$\S$ Naturalist, 1854, Vol. IV., p. 51. 
reared in captivity.* A. G. More in 1865 , on the authority of Mr. W. G. Gibson, says that this species breeds occasionally in Dalswinton Woods, $\uparrow$ and Mr. R. Service records in his diary under June 20th, 1888, that Robert Maxwell told him that "there are many Siskins at Dalswinton and a few breed." The wood referred to is now no longer standing, and the species has ceased to nest in that locality.

Mr. N. E. Douglas Menzies of Newtonairds (Holywood) writes me that his keeper, Shields, who has often seen the Siskin in autumn, found a nest about 1902 in a young plantation. Mr. William Laidlaw informs me that this species has nested in South Eskdale; in 1902, below Langholm, and also in Mr. Carthew Yorstoun's policies ; in 1903, near Tarras, and again in 1906, when he caught "a young one, new flown which could not feed itself." The same year a pair were seen nesting at the second milestone on the Carlisle Road below Langholm ; and another pair nested on Mr. Carthew Yorstoun's property. In 1907 a young one was caught by Mr. Tweddle, junior; and in July, 1908, a pair were seen near Langholm. Mr. James Cowan writes me from Glencairn: "In August, 1905, I caught a young Siskin in nest-plumage near the lake above Crawfordton House. I only saw three birds in company at the time, the one I caught and two others, one of which was a cock bird in adult plumage. I did not see any more Siskins that year till well on in October, when I saw considerable flocks of them. I have not come across their nest in this district, so I cannot say that they actually

Elsewhere throughout the county the Siskin appears irregularly in the winter, sometimes in large flocks, and is often reported as frequenting alders by the sides of streams. During the winter of 1888 they were numerous on the

* Dumfries Courier, July 31st, 1855.

† Ibis, 1865, p. 129. 
River Cairn,* and Mr. Bruce Campbell reports them as fairly common near Moffat in 1896-1897. $\dagger$ In 1903 this species was again noticed in numbers on the Cairn near Dardarroch, and that part of Nithsdale would seem to possess a special attraction for these birds. The winter of 1905-1906 brought unusual quantities to the south of Eskdale, and Mr. John Edmond tells me that he has seen Siskins in some autumns, so far afield as Wanlockhead (Sanquhar).

The Siskin breeds in parts of Scotland and Ireland, and throughout Europe to the limit of conifer-growth; in winter it migrates south and has occurred in Morocco and Algeria.

\section{THE HOUSE-SPARROW. Passer domesticus (Linnæus).}

Local names-SPedg; SPYNG; SPrdg; SParRY.

\section{A very common resident.}

It has been stated of the House-Sparrow that there are many isolated spots in Scotland where it is very rare, $\ddagger$ and in our upland districts at many farms and cottages this species is not met with. Mr. R. Service stated in 1878 that at Wanlockhead (one thousand four hundred and nine feet above sea-level) a mining village on the borders of Dumfriesshire, the Sparrow was quite unknown.§ Mr. John Edmond, who has long been a resident at that remote spot, writes me: "In twenty-six years I have only once seen Sparrows in Wanlockhead. In the autumn of

* Trans. D. and G. Nat. Hist. Soc., December 13th, 1901.

$\dagger$ Zoologist, 1898, p. 507.

‡ Yarrell's Hist. Brit. Birds, 1882, Vol. II., p. 94.

§ Zoologist, 1878, p. 427. 
1906 about a dozen settled on some bushes in my garden, and seemed to be after the snow-berries still hanging on the bare bushes. When these continued their flight, one stayed behind, a weakly hen. I noticed the bird from time to time for a day or two, but I fancy the harmless but necessary cat would soon restore the old condition, and make us once more a sparrowless community."

In the more cultivated districts this species has become a pest, since, as has been calculated by Mr. J. H. Gurney, about seventy-five per cent. of an adult Sparrow's food during its life is corn of some kind.* But when feeding its young, which are wholly insectivorous, this bird confers great benefits on agriculture by the amount of noxious insects which are then consumed. Its predilection, however, for occupying the nests of such valuable and charming birds as the House-Martin makes it unwelcome even at this season.

In early spring the Sparrows, which during the autumn and winter have gone about in flocks, resort more to the neighbourhood of houses, where they nest in rain-water pipes, holes in walls, in trees, and in fact almost anywhere. Mr. W. F. Graham tells me that the Sparrows build in the old Rooks' nests at Wyseby (Kirkpatrick-Fleming); and to the fact of their commonly nesting in trees is attributable the numerous alleged occurrences of the Tree-Sparrow in the county.

Piebald, white, or true albino specimens are frequently recorded, and the latter are, according to Mr. William Laidlaw, very common in Canonbie. "Mabie Moss" in 1890 recorded that a female with greenish-yellow feathers on its back was seen in English Street, Dumfries. $\dagger$ Mr. J. Harkness informs me of a "yellow" Sparrow seen in 1908 at Cocklick (Ruthwell), and that he once, some years ago, had a similar specimen sent him to stuff.

An old rhyme, which our school-children, before the days

* The House-Sparrow (1885), p. 17.

$\dagger$ Dumfries Courier and Herald, April 10th, 1890. 
of Higher Education, used to sing, may perhaps be given to save it from oblivion :

"I'll tell ye a story about Johnnie Murray,

He went to the woods and killed a sparry ;

I'll tell ye anither about his brither,

He went to the woods and killed anither."

[THE TREE-SPARROW. Passer montanus (Linnæus).

Sir William Jardine wrote of the Tree-Sparrow in 1839: "We ... have no note of its occurrence in Scotland"*; and though since those days this species has been found nesting in this country, I have not yet received sufficient evidence to enable me to include it in this avifauna of Dumfriesshire without square brackets.

A specimen from the collection of Rev. W. Little, most of whose birds were obtained in his parish of KirkpatrickJuxta, is without a label, so I am informed by Mr. R. Service, its present owner. Mr. William Wright of Annan wrote to me in 1908: "I am pretty certain of the TreeSparrow, but here again I can give no further proof than that I have come across what appeared to me to be this bird, nesting in a thatched house, now demolished. I have not the date exactly, but to the best of my memory it will be twenty years ago. They certainly departed from the place when the thatch was removed." A rumour that this species was common in Ruthwell was disproved by Mr. J. Harkness, who wrote to me that a few he had shot for the purpose of identification, proved to be HouseSparrows.

The Tree-Sparrow is recorded from the neighbouring areas of "Clyde" and "Tweed" as also from Cumberland; so that it might occur in our county at any time, especially as it seems to be extending its range. It is even possible that from its similarity to the preceding species it may already have been overlooked.]

* Nat. Lib., 1839, Vol. XI., p. 297. 


\section{THE CHAFFINCH. Fringilla cœlebs, Linnæus.}

Local names-Shelfie; Shilfa; SNabBy.

"We laid a strong framework and fixed it so fast,

That though the tree rocked it resisted the blast.

We made it of mosses all daintily twined

With wool and with feathers 'twas cushioned and lined;

I picked her gray lichens to match the tree stem

And neatly she finished the outside with them.

Then, lifting her eyes to the blue sky above,

We entered it singing, and filled it with love.

Car-oo, tweet, tweet, tweet,

Made by you, tweet, tweet, tweet,

Was ever a nest that was builded so neat ?"

Miss Isa Gillon-Fergusson.- "The Chaffinch's Love Song."

A very common resident; nesting even in the upland woods and bushes ; found in flocks in winter, often at the most isolated homesteads.

The immigration of this species which in autumn is observed on the east coast of Great Britain, is not so much felt here, and at this season the sexes often separate into different flocks. It is owing to this partial and temporary separation that " the name coelebs, or bachelor, was used by Linnæus in reference to the deserted males."*

The Chaffinch does great damage to newly-sown seeds in the autumn, and we read in 1832, that it was generally considered a most pernicious bird in gardens, and was treated accordingly $\dagger$; but Howard Saunders wrote in 1899, "both young and old feed largely on insects and the seeds of weeds... and ... may be considered as one of the gardener's best friends." $\$$

From more than one personal observation, I regard the number of days required for the incubation of the eggs of this species as twelve.

* Man. Brit. Birds, 1899, p. 183.

+ Mag. Nat. Hist., 1832, Vol. V., p. 65.

‡ Man. Brit. Birds, 1899, p. 184. 
Thomas Aird describes how a female Chaffinch, which he had tamed in the winter of 1863-1864, subsequently mated, reared her brood, or rather two, and disappeared till one day in the following autumn, when she detached herself from the flock with which she was in company, and came to him with signs of the most pleasing recognition.*

The popular belief that the alarm- or challenge-note of this bird foretold rain-

Weet-weet! (The cry),

Dreep-dreep! (The consequence)-

is fast dying out.

Pied varieties are occasionally met with. One such, obtained about 1868 at Nithside (Morton), is in Dr. Grierson's museum at Thornhill. Mr. J. Harkness tells me that a white specimen was to be seen at Ruthwell Manse, and on May 21st, 1904, I saw a cock Chaffinch with a pure white head in Penpont village.

THE BRAMBLING. Fringilla montifringilla, Linnæus.

Local names-Modntain-Finch ; Cock o' the North.

An irregular winter-visitor to certain localities.

Sir William Jardine wrote of the " mountain finch" in 1832 as " a winter-visitant in large flocks, delighting to feed on beech-mast." $\dagger$

This species, in the years in which it does visit us, arrives in November and leaves us again in January or February for its nesting-grounds in the northern forest-regions from Norway to Kamchatka. On their arrival here they often consort with Chaffinches, from which they can be readily distinguished by their white rumps.

A large flock seems to have visited the county in 1852-

* Trans. D. and G. Nat. Hist. Soc., December 6th, 1864.

$\dagger$ New Stat. Acct. Scot., Vol. IV., p. 179. 
1853.* In 1889-1890 they were conspicuously absent, $\nmid$ but in the following winter they were unusually plentiful. $f$ In November, 1894, they were, says "Mabie Moss," very numerous, and continued to increase till March 18th, 1895, when they began to diminish, $\S$ but Mr. Hugh Mackay observed that some were still to be seen on May 10th.\| The following year the beech-nuts failed to fill, and not a Brambling was to be seen. In 1898 a small immigration took place; and in 1906-1907 they were much more generally distributed throughout the county than usual. In 1908-1909 large flocks were seen near Langholm, and also at Penpont.

It is remarkable that in his experience, so Mr. R. Service tells me, this county is never visited by such large flocks as those which occur in Kirkcudbrightshire, where upward of a thousand birds have been seen together at one time.

\section{THE LINNET. Linota cannabina (Linnæus).}

Local names-Red LINNet ; Rose-Linnet ; Rose-Lintie ; Brown Linnet ; Redpoll; Whin-Lintie; Lintie.

“The Radiance from a sunset sky, The Song of Lark or Linnet, May move the heart as God were nigh, And Love divine were in it." Tномаs McKre._- "Eternal Nature."

\section{A fairly common resident of local distribution.}

The Linnet, a lover of broom and gorse, of whin, and of juniper, suffered in the advancement of agriculture, and is not to-day so widespread in its range as it was in Sir

* Naturalist, 1853, p. 156.

† Trans. D. and G. Nat. Hist. Soc., February 6th, 1890.

† Scottish Naturalist, 1891, Vol. V., p. 95.

$\S$ Dumfries Courier and Herald, February 4th, 1895.

|l Dumfries Standard, May 29th, 1895. 
William Jardine's time. In many places, where formerly common, it has disappeared, but quite recently a slight extension in its breeding-area seems to have been noticed.

Linnets would appear to be almost confined in spring to the lower arable districts. In autumn they gather into flocks and frequent the stubbles and low-lying fields. At this season their numbers are increased by an immigration from the north and east, and these flocks are found more generally distributed, and "higher out" than are our Linnets in the spring; but in exceptionally hard winters the whole Linnet population moves farther south till the return of the nesting-season.

The first three local names are of course derived from the appearance of the cock bird in breeding-plumage, when he has the forehead, crown and breast crimson; and it may be well to note that on this account the species is sometimes called the "Redpoll," which must not lead to confusion with either the Lesser, or the Mealy Redpoll - the next species to be dealt with.

THE MEALY REDPOLL. Linota linaria (Linnæus).

\section{A scarce irregular winter-visitor.}

Sir William Jardine in 1832, writing of the birds of the parish of Applegarth and Sibbaldbie, says of this species: "The northern Linnet has been seen only once or twice, it is not commonly known in Scotland."* Robert Gray records that in 1868, "Mealy Redpolls were taken in Dumfriesshire, and sent to the Glasgow bird-market." $\dagger$ As regards the Solway area Mr. R. Service states: "We had them in 1879, again in 1895, and none afterwards occurred till the winter of 1900." " "Mabie Moss" records that in March,

* New Stat. Acct. Scot., Vol. IV., p. 180.

$\dagger$ Birds of West Scotland, 1871, pp. 148, 149.

‡ Trans. D. and G. Nat. Hist. Soc., April 20th, 1905. 
1905, a bird-catcher on the Stewartry side of the Nith caught two, and saw more; he said that two others had been obtained by another man ;* and these two I believe were captured within the limits of our county.

"In Europe and Asia the Mealy Redpoll nests rather farther north than the limits of birch-growth, but southward, it may be doubted if it reaches below $58^{\circ} \mathrm{N}$. lat." $\dagger$ It only visits this county in winters of arctic severity.

\section{THE LESSER REDPOLL. Linota rufescens (Vieillot).}

\section{A resident of very local distribution during the breeding-season, becoming}

Writing in 1832 Sir William Jardine records the Lesser Redpoll as a breeding-species in Applegarth and Sibbaldbieł; and in 1839 he says: "During winter it is not uncommon in flocks in the south, or lowlands of Scotland; ... [In $1827 \mathrm{it]}$ was observed to be more than ordinarily
numerous." $\$$

In autumn and winter Lesser Redpolls congregate in flocks, and may be seen consorting with Siskins; at this season their numbers are augmented, probably by those which have bred further north.

Mr. Tom Brown in 1885 remarks on the increasing number of their nests in Tynron parish within the last two years $\|$; and Dr. J. W. Martin in 1901 regarded it as a more common bird in Glencairn than the Linnet. 1 From the

* Dumfries Courier and Herald, February 4th, 1895.

$\dagger$ Man. Brit. Birds, 1899, p. 190.

¥ New Stat. Acct. Scot., Vol. IV., p. 179.

\& Nat. Lib., 1839, Vol. XI., p. 288.

II Trans. D. and G. Nat. Hist. Soc., December 4th, 1885.

Tा $O p$. cit., December 13th, 1901. 
reports I have received it would appear that the Lesser Redpoll is either very locally distributed or else often unobserved as a nesting-species; though generally reported throughout the arable districts of the county as common in flocks in winter; but varying considerably in numbers according to the season.

The following observations by Mr. R. Service, although referring mainly to the neighbouring county of Kirkcudbright, may be quoted as instructive.

"At one part of our nursery grounds here, a small colony of Lesser Redpolls took up a location in February [1903]. Remaining on instead of departing when spring advanced, they began to nest in May, and eventually reared about a dozen broods. Instead of being placed in Birches, Alders, and Honeysuckle as is their wont-and plenty of these trees were close at hand-the nests were all built in thickly branched little spruces, at heights from the ground varying from four to nine feet. But the most interesting point of all, was in the fact that every nest was thickly lined with feathers. The down of the Willow catkins was plentiful within three hundred yards of the colony, all the nests of which were within a radius of one hundred and twenty yards. In the year 1879 we had a perhaps colder but not so wet a season, and in that spring $I$ found the nests of the Redpoll lined with feathers. . . Another small colony several miles distant, that I have known since boyhood, had an odd feather or two in their nests, but nothing at all in the way of feather lining in the full sense. Not a single bird of the Nursery colony remained after July 10th, all had gone elsewhere."*

Mr. William Laidlaw informs me of a cream-coloured specimen seen in a flock in the winter of 1907-1908 near Canonbie, and Mr. J. Reid tells me he once saw an albinistic variety of this species, but with a brilliantly red poll, in his garden at Greystone (Dumfries).

* Ann. Scot. Nat. Hist., 1904, pp. 67, 68. 


\title{
THE TWITE. Linota flavirostris (Linnæus).
}

Local names-Mountain-Linnet ; Heather-Lintie.

\begin{abstract}
A very local resident in spring; but in winter sometimes seen in consider-
able numbers on arable land.
\end{abstract}
Of the Twite Sir William Jardine observes : "I have seen a flock here during the winter, frequenting wild stubble land. Last winter [1838] I shot a pair within a few hundred yards of Jardine Hall, evidently driven in by the storm. They were feeding on the heads of the Black Knapweed (Centaurea nigra)."* In 1839 he wrote: "In the south of Scotland, and in England, the general time of appearance is in winter, frequenting nearly the same localities as the common Linnet, though perhaps selecting the more upland districts. ... They are known to the southern bird-catchers by their cry, and the difference in this was in fact the first thing that drew our own attention to them in the south of Scotland, their manners being in other respects similar to those of the last." $\dagger$

During autumn and winter, when Twites flock together, they become fairly well dispersed throughout the arable districts of the county, and are even met with on the lower moors until the weather becomes too severe. At this season a "crowding-down" of the more northerly-bred Twites takes place, and our resident numbers are for a time increased. Mr. Tom Brown states that in Tynron "great numbers of Twites frequent the lower ground, particularly fields in which Prunella vulgaris grows." $\ddagger$

The Twite appears to be well known in the littoral parishes in winter, as also in Canonbie and Langholm. To Upper Nithsdale, Moffat, and Eskdalemuir, this bird is also an autumnal visitor, arriving at the latter end of September.

* Naturalist, 1838-1839, Vol. IV., p. 387.

$\dagger$ Nat. Lib., 1839, Vol. XI., pp. 285, 286.

† Trans. D. and G. Nat. Hist. Soc., December 4th, 1885 . 
Mr. John Corrie says he once (about 1883-1884) " caught two of these birds in the hand, by simply following a flock of them and imitating their feeding note."*

As regards the nesting of this species, A. G. More in 1865 stated that he had no authority for saying the Twite nested in the Solway area. $\uparrow$ However, Dr. Anstruther Davidson in 1888 records that it is reported to have bred in Upper Nithsdale, $t$ and Mr. W. F. Graham confidently informed me in 1908 that it nested in Nutberry Moss (Kirkpatrick-Fleming).

The Twite will probably be found to breed, less rarely than is indicated, in the long, rank heather, in fox-coverts (as in Dryfesdale), in furze thickets, and in similar situations scattered throughout the county.

\section{THE BRITISH BULLFINCH.}

Pyrrhula pyrrhula pileata, Macgillivray.

\section{Local name-BuLly.}

"Then forth into his garden, counsel there

To hold with the old gardener, or with ear

Patient attend his manifold complaints

Of Birds unthinned, the bullfinch worst of all, Whose cursèd beak-what can the fellow mean?

For worms he seeks not, nor one blossom eats-

Plays such wild havoc with the apple buds.

'He's a bad boy,' says Frank, and whistles off

Along the broad green walk-__ "

Thomas AIRD._-"Frank Sylvan."

A resident: in autumn fairly generally distributed, but in spring found somewhat locally in the arable districts.

In the Statistical Account of Scotland the Bullfinch is mentioned as one of the birds found in the parishes of Ruthwell, $\S$

* Trans. D. and G. Nat. Hist. Soc., November 10th, 1888.

$\dagger$ Ibis, 1865, p. 130.

† Trans. D. and G. Nat. Hist. Soc., November 10th, 1888.

$\S$ Stat. Acct. Scot., Vol. X., p. 224. 
Mouswald,* Kirkmichael, $\dagger$ Johnstone, $\ddagger$ and in Eliock Woods, Sanquhar $\S$; while in 1795 it is recorded as "migratory in Canoby" $\|$; and the Rev. Alexander Brown in his report dated Moffat, 1792, says: "The Bullfinch has appeared within the last seven years and seems to multiply fast." " Some forty years later we read of it as abundant in Mouswald** and Holywood, $\dagger \dagger$ and as "found in the woods of Comlongon" (Ruthwell). +

In 1878 Mr. R. Service drew attention to "the appearance of large numbers of Bullfinches in the district during the last two years, which were proving most destructive to the fruit trees. Dr. Sharpe remarked that the same thing had happened at Eccles (Morton); these birds had been very scarce for many years, but were now met with commonly. Mr. W. G. Gibson stated that a number of Bullfinches' nests had been seen in the grounds of the Crichton Institution in the summer of 1877 for the first time." $§ \S$

At the present day it cannot be said to be increasing, owing perhaps to the persecution it meets from any gardener who is allowed a gun. In some of the upland and less wooded districts the Bullfinch is decidedly uncommon, as in Upper Eskdale where Richard Bell of Castle O'er described it, in 1905, as very rare in the district, a nest only once seen, and an occasional flock in autumn.\|\|

In the spring this species is often found in the garden or "policies," attracted perhaps by such favourite nesting-

* Stat. Acct. Scot., Vol. VII., p. 294.

† Op. cit., Vol. I., p. 60.

$\ddagger$ op. cit., Vol. IV., p. 226.

§ Op. cit., Vol. VI., p. 460.

\| Op. cit., Vol. XIV., p. 413.

If op. cit., Vol. II., p. 291.

** New Stat. Acct. Scot., Vol. IV., p. 443.

†† Op. cit., Vol. IV., p. 556.

$\ddagger \ddagger$ Op. cit., Vol. IV., p. 220.

\$ Trans. D. and G. Nat. Hist. Soc., February 1st, 1878.

|| || My Strange Pets, p. 115. 
places as are afforded by yew or box. Twelve days are required for the incubation of the eggs, and the broods are to be seen with their parents till autumn, when they gather into small parties of from ten to twenty, and wander far afield wherever they can find a wood or plantation in which to get a living. At this season their numbers may be swelled by an incursion or "crowding-down" of those Bullfinches that have passed the summer further north, and these emigrate again on the approach of spring.

Writing from a fruit-growing district (Kent), Mr. Fred. V. Theobald says : "A single Bullfinch will do more harm in a plantation of fruit than all the rest of the birds put together. For six months they live entirely on fruit buds, and as they come from the woods in autumn and continue till March, the loss they occasion can well be estimated."*

Mr. R. Martin of Dardarroch possesses a very fine stuffed specimen of a white cock Bullfinch which was obtained in Ruthwell on January 1st, 1907, but such abnormalities in this species are not common. What is known as the "black Bullfinch" to the bird-fancier, is the result of a surfeit of hemp and other alterations in its diet. As the "piping Bullfinch" the species is well known to the cage-bird fraternity for it proves an apt pupil, and after constant reiteration by its instructor of some catchy song, is able to warble it with a very full clear note. Richard Rimmer writing from Kirkmichael House on February 4th, 1852, records a young female Bullfinch which had learnt to repeat one or two short sentences with great distinctness. $\dagger$

Dr. Hartert has shown that the British Bullfinch is distinctly darker and duller (especially in the female) than continental birds, $\ddagger$ and that Macgillivray's name $\S$ must be adopted for this race.

* Science Progres8, 1907, Vol. II., p. 273.

$\dagger$ Naturalist, 1852, Vol. II., p. 206.

† British Birds (Mag.), Vol. II., p. 130.

§ Hist. Erit. Birds, Vol. I., p. 407. 


\section{[THE PINE-GROSBEAK. Pyrrhula enucleator(Linnæus).}

In his account of the parish of Kirkmichael for the Statistical Account of Scotland in 1791 Dr. Burgess states: "There is great plenty of the rarer species of birds, ... the pine and the common bulfinch."* Mr. J. H. Gurney writing "On the claims of the Pine-Grosbeak to be regarded as a British Bird," $\dagger$ dismisses this record, for he says: "Dr. Burgess' name is unknown to ornithologists, and what weight may be attached to his authority in the matter it is impossible to say. Professor Newton informs me that Kirkmichael is close to Jardine Hall, but that Sir William Jardine (who, as everyone knows, was a very good naturalist), writing on the fauna of Dumfriesshire in the New Statistical Account of Scotland, makes no mention of the Pine-Grosbeak. Robert Gray, who I believe first drew attention to Dr. Burgess' catalogue, has not been able to throw any light on the matter in his Birds of the West of Scotland." Dr. Burgess was an acknowledged botanist, and as at the time he wrote, we learn from contemporary writers that the Crossbill put in an appearance in Kirkmichael, he very likely confused the two species.

A most puzzling record occurs in the Memoirs of the Wernerian Society : "Specimens of the Hawfinch, Corythus enucleator, recently shot at Drumlanrig, were exhibited at the meeting, February 9th, 1833." +

Corythus was never, it seems, used for the Hawfinch, except by Fleming, who in his History of British Animals, under "Corythus enucleator, common Hawfinch," certainly does not give a description applicable to that bird;

* Stat. Acct. Scot., Vol. I., p. 60.

$\uparrow$ Zoologist, 1877, pp. 242-250.

¥ Mem. Wernerian Nat. Hist. Soc., Vol. VII., p. 464. 
and he also goes on to mention Pennant as having seen these birds in Invercauld Forest, and quotes: "Mr. Selby in his 'Illustrations,' p. 257, seems inclined to regard them as only occasional visitants." * Both these references refer to the Pine-Grosbeak, as indeed do all Fleming's references to previous ornithological works given at the heading of his chapter on "Corythus enucleator." Moreover, he describes the Hawfinch with sufficient accuracy under the name of "Coccothraustes vulgaris, Common Grosbeak." $\dagger$ It therefore seems possible that the Drumlanrig specimens may actually have been Pine-Grosbeaks, which were perhaps identified and named by aid of the History of British Animals. But the silence of Sir William Jardine as regards both the alleged Drumlanrig and Kirkmichael occurrences is strong negative evidence. It is improbable that he, a member of the Wernerian Society, and living in the county of Dumfriesshire, should never have heard of these allegations ; and I quote what he wrote of the "Pine Bullfinch, Corythus enucleator" in 1839. "In Britain it stands as one of our rarest and most sought after birds. One of our first authorities for its occurrence is Mr. Pennant, who met with them [August 5th, 1769], flying above the great forests of Invercauld in Aberdeenshire, and since that we are not aware of any authentic instance of their occurrence in Scotland, and we have never ourselves met with them in the north, though they have been often anxiously looked for." $\ddagger$

The absence of any remarks by Sir William on these alleged local occurrences leads me to suspect errors in identification, and this species therefore is here included in square brackets.

The Pine-Grosbeak is an inhabitant of the conifer-zone of the northern parts of Europe and West Siberia, straying southwards in winter.]

* Hist. Brit. Animals, 1828, pp. 76, 77.

† Op. cit., pp. 82, 83.

† Nat. Lib., 1839, Vol. XI., p. 336. 


\section{THE COMMON CROSSBILL. \\ Loxia curvirostra curvirostra, Linnæus.}

A periodic resident in some localities, and a fairly frequent early autumn-
visitor.

The earliest record of the Crossbill in Dumfriesshire that I have come across occurs in the Dumfries and Galloway Courier for July 31st, 1810 : "Within the last ten days past a flock of birds have made their appearance about the town of a species rarely seen in this country. They are the ... Crossbill or German Parrot. The last flock seen in Scotland was about seventeen years ago."

In his correspondence with P. J. Selby, Sir William Jardine has three interesting local references to this species. In a letter dated July 11th, 1837, from Jardine Hall, he states : "We shot a Crossbill last week the first I have seen near us ; a considerable flock appeared but have not since been seen." In a further letter dated January 19th, 1838, and addressed to the same correspondent, he says : "Crossbills still here, nothing rare arriving." Again on July 2nd, 1839, he writes to him from Newbie House (Annan): "At home I have seen the Crossbills weekly almost until we came off, there are generally three or four together and although frequenting pretty nearly the same places (the fir wood where you shot the first Buck and down to the turn of the river); they do not seem exactly as if breeding. It has been told to me several years since that they bred in some fir woods up Nithsdale, but I never could get at more definite information. They have been with us now without leaving for ten months and may ultimately take up a permanent and breeding residence." In his Naturalist's Library (1839) Sir William Jardine thus describes the species: "Since 1829 and 1830 , scarcely a year has passed without the English border and the southern counties of Scotland, being visited by 
flocks of Crossbills. In our own vicinity they were, however, rare, the first birds having been seen in 1836 ; next year, at the commencement of winter, a small flock appeared, and continued for some months; and in the November following, $(1838$,$) a party of from fifty to seventy returned, and have$ been seen every week up to the present date, (July 30, 1839 ;) notwithstanding, we have been unable to discover the nest, or any traces of their having built. During winter, the flock kept together, but after spring they have been seen in pairs or small parties, and it is possible that some of the older pine woods, from twelve to fifteen miles distant, may have furnished breeding stations, though as yet we have been unable to ascertain this."* In a note to Jesse's edition of White's Selborne, published in 1851, Sir William Jardine writes : "In our own vicinity ... for several years previously to 1839 they were regularly seen, but not one has appeared since. In one season they remained from November to the July following, but no traces of nidification could be discovered." $\dagger$

In a letter written to the late J. H. Gurney, dated April 1st, 1840, T. C. Heysham writes: "I have every reason to believe that the Crossbill has entirely left the northern counties this year; at least I have not been able so far as to see or hear of a single specimen in Cumberland, Northumberland or the south of Scotland." $\ddagger$

In his MS. notes Dr. Grierson records under date October 17th, 1862, that Thomas Maxwell told him that Crossbills were " not noticed until about twenty-six years ago " (i.e., about 1837) " some seasons they are very plentiful, other seasons scarce and not met with; have bred at Dalswinton; they breed as early as the month of March, probably have more than one brud (sic) in the season." $\$$ It may here be noted that Thomas Maxwell was the principal bird-

* Nat. Lib., 1839, Vol. XI., pp. 340, 341.

$\dagger$ White's Selborne, 1851, p. 400.

‡ Fauna of Lakeland, 1892, p. 144.

§ Grierson's MS. Notes, October 17th, 1862. 
stuffer in Nithsdale, 1830-1864; he had at one time been in service on the Dalswinton estate (Kirkmahoe) and his brothers John and Robert were foresters there all their lives.

In the Naturalist, 1854, it is recorded that Crossbills bred in an old fir-plantation in Kirkmahoe ; " for some years the nests have been found regularly with young."*

Robert Gray writes in 1871: "The common Crossbill is also very plentiful in Dalswinton woods near Dumfries, where many nests have been obtained every year." $\dagger$ and in 1876 the species is recorded as breeding in Dalscone Wood (Dumfries). $\ddagger$

William Hastings, the taxidermist, states that nests "with young birds have been taken in Dalswinton 'Big Wood,' and I have had them from Raehills, and seen them in Closeburn the whole season through. ... The Crossbill is a very uncertain visitant to this country, many years elapsing and not one being seen or heard. However, when they do come, a few pairs often remain with us to breed and rear their young." $\$$

In 1878 it was recorded that they had entirely disappeared from the Dalswinton woods, $\|$ but Mr. R. Service, in his diary of June 20th, 1888, writes: "Robert Maxwell, Forester Hall, Dalswinton, tells me the Crossbills are at Dalswinton now, and bred there winter of 1887-1888." Mr. D. Tait writes me that when he first went as gamekeeper to Dalswinton in 1874 they were very plentiful, but that they left some fourteen years later; "Mabie Moss" states in 1890 : "Dalswinton used to be a favourite haunt, and so was Raehills; but I believe they have left both localities for some years." "**

* Naturalist, 1854, Vol. IV:, p. 51.

$\dagger$ Birds of West Scotland, 1871, p. 153.

¥Dumfries Courier, September 12th, 1876.

$\S$ Trans. D. and G. Nat. Hist. Soc., November 4th, 1887.

il Op. cit., October 4th, 1878.

II R. Service's MS. Diary, June 20th, 1888.

** Dumfries Courier and Herald, January 7th, 1890. 
In no other locality in the county has the Crossbill been observed with such regularity as it has in the "Big Wood" of Dalswinton; but since their favourite giant pines have been laid low they have not put in an appearance there.

At Dardarroch (Glencairn) this species has often been seen, though no nests have been found. By the kindness of Mr. R. Martin I have been able to examine specimens of the Common Crossbill shot at Dardarroch in the winter of 1888 and now in his possession. Another specimen labelled "Polgowan, August, 1877," interested me particularly, because this bird had been recorded as " a young Crossbill sent in to William Hastings from Polgowan, a sheep-farm in Penpont, which had no doubt been bred in that part of the county"*; and I had always wondered why this bird had turned up at such a treeless, bleak spot as I know Polgowan to be. The explanation was forthcoming when Mr. Martin told me that he had killed it with a catapult when a boy at Polgowan, in Kirkcudbrightshire. It is a bird in the "striped" juvenile plumage, but as the Crossbill regularly migrates when in this stage, the specimen itself affords no proof that it was bred in the locality. "In the spring of 1890," so Mr. Henry Martin writes me, " there were a great many of the common Crossbills in the woods of Dardarroch, and had been there as far as I could make out continuously for two years, but although I looked very carefully I never discovered a nest, nor did I see any young birds." Again in 1892, this species is recorded as having been seen throughout the year at Dardarroch. $\dagger$

In Eskdale, Crossbills were seen during the winter of 1873-1874 at Carlesgill (Westerkirk), $\ddagger$ and Mr. A. Smith writes me from Langholm that he has not seen this species there for some years, but that he noticed them first in

* Trans. D. and G. Nat. Hist. Soc., October 4th, 1878.

$\dagger$ Op. cit., May 12th, 1893.

$\ddagger$ Dumfries Courier, March 11th, 1874. 
January and February about 1893. Richard Bell of Castle O'er records in 1901: "Three or four years ago " (i.e., 1896 or 1897) " a small flock of these birds frequented the avenue for some time; when the flock left, one pair stayed all summer, but no nest was found."* I hear that since 1900 , Crossbills have been frequently seen at Newtonairds (Holywood), usually in the autumn; and in 1908 in the early spring.

Elsewhere throughout the county, small flocks are from time to time noticed, but in no case with anything like. regularity, except in the localities above dealt with; yet the numerous stuffed specimens to be seen as ornaments in farmhouses and cottages, testify to the bird's variable distribution in one season and another. In the autumn of 1909 a very large "irruption" of Crossbills from the Continent was noted in many parts of the British Isles and was very fully recorded $\dagger$; but the only occurrence in Dumfriesshire in this year that I am aware of, is reported by Mr. John Corrie, who writes me that two Crossbills were observed feeding on the berries of a cotoneaster at Craigdarroch (Glencairn) on December 12th, 1909.

Mr. H. F. Witherby has recently pointed out that the true status of the Common or Continental Crossbill in England, Wales and Ireland, was revealed by an examination of the records of its nesting taken in conjunction with the records of its previous "irruptions" from the Continent. Mr. Witherby proceeds to demonstrate that the majority of the authentic nesting-records had immediately followed wellmarked "irruptions," and that in parts of Ireland the Crossbill, although not indigenous, had settled down for many years as a resident after such invasions. An examination of the records of the Crossbill nesting in our county in the light of the above suggestion shows,

* Trans. D. and G. Nat. Hist. Soc., April 17th, 1901.

$\dagger$ British Birds (Mag.), Vol. III.

$\ddagger$ Bull, B.O.C., Vol. XXV., pp. 77-79. 
I think, that Mr. Witherby's interpretation of the facts regarding the status of the Common Crossbill in other parts of the British Isles applies equally here. Thus Sir William Jardine's account of the Crossbills appearing. in July, 1837, and staying on (although apparently not nesting) until 1839, should be read in conjunction with the well-recorded fact that "irruptions" of the bird from the Continent occurred in the autumns of 1837 and 1838, and that there were several nesting-records in England in the springs of 1838 and 1839. Thomas Maxwell says that they first came to Dalswinton also about 1837 and there they appear to have settled down for some years but seem to have left or died out in 1878. In 1887-1888, however, the bird reappeared at Dalswinton and bred there; again we find that there were great movements of Crossbills from the Continent to the British Isles in the winters of 1887-1888. and 1888-1889 and that the bird nested in new districts in Ireland in 1888 and in Norfolk, Suffolk and Berkshire in 1889. Three specimens shot at Dalswinton during the period in which Crossbills were resident there and now in the possession of Mrs. Maxwell, have been examined by Mr. Witherby and myself and found to be of the Continental race and not of the Scottish form (vide infra).

We may conclude, therefore, that the Common Crossbill is not indigenous to our county but that it is a somewhat irregular immigrant from the Continent in the early autumn, often staying through the winter and occasionally for a considerable time without nesting; and further that it settled down and bred for some years in one localityDalswinton-at all events ; that it died out in that locality and subsequently reappeared and bred again only to disappear once more.

It should be noted that the Crossbill nests very early in the year, usually in February or March; and that for this reason its nest may have been overlooked. The young, however, which would be flying in April are not so likely to have escaped notice. 


\section{THE SCOTTISH CROSSBILL. \\ Loxia curvirostra scotica, Hartert.}

Three examples have occurred, but others may have passed undetected.

The exact range of the Scottish Crossbill is as yet uncertain, but it appears to be confined to the forests of Scots fir in the central and northern parts of Scotland, where the bird is a resident. The occurrence of this form of the Crossbill in southern Scotland appears to be very rare, and it is therefore interesting to note that on examining with Mr. H. F. Witherby the specimens of Crossbills in the collection of Mr. R. Martin, we found that a male and female which had been shot at Dardarroch in November, 1887, undoubtedly belonged to the Scottish race; while another specimen, unfortunately without date, was also of this form. Crossbills were plentiful at Dardarroch in the winter of 1887-1888, but unfortunately these are the only two birds in Mr. Martin's possession obtained during that winter, and two others shot in December, 1888, are undoubtedly of the continental form. On the other hand, a specimen obtained near our border at Shambellie (Kirkcudbrightshire) about the year 1887, and kindly submitted by Mr. W. Stewart on my behalf to Mr. Witherby for examination, proves to be an example of the Scottish Crossbill, although others obtained about the same time at Shambellie belong to the continental form. Mr. Witherby and I have examined a number of other specimens of the Crossbill obtained in different localities in Dumfriesshire and have found them all to belong to the continental race, so that for the present, in any case, we must regard the Scottish Crossbill as a very rare visitor to Dumfriesshire.

This interesting local form of the Crossbill, which has been separated by Dr. E. Hartert on account of its higher 
and thicker bill as compared to that of the typical continental race, does not yet appear to have received the recognition it deserves at the hands of ornithologists, and its distribution is consequently, as has been said above, not accurately known.

\section{[PARROT-CROSSBILL.}

Loxia pytyopsittacus, Borkhausen.

F. O. Morris records one occurrence of the Parrot-Crossbill in Dumfriesshire,* which Mr. J. E. Harting, who most kindly wrote to me on the subject, does not see fit to include among the list of the occurrences of this bird in Great Britain; $\dagger$ in view of which $I$ include this species in square brackets.]

\section{THE TWO-BARRED CROSSBILL.}

Loxia bifasciata (C. L. Brehm).

Has occurred once.

Mr. Hugh Mackay in 1893 drew attention to a pair of Two-barred Crossbills thus: "I am indebted to Mr. Henry Martin, of Dardarroch, for the following note, and although it is three years since the specimens were obtained, they were not recorded, and are therefore worthy of mention here. He informed me that on the 1st of March, 1890, three specimens of the American White-winged Crossbill were observed in Dardarroch Woods, a male and female of which he shot, and are now in his collection. I doubted his statement at first, and remarked that it might be the Two-barred Crossbill, which in appearance is much similar to the American species, but he assured me

* Morris, Hist. Brit. Birds, 1870, Vol. III., p. 8.

† Handbook British Birds, 1901, pp. 381, 382. 
that they were undoubtedly the American species, and could be seen at any time."*

Mr. R. Martin in answer to my request sent me these birds, which were labelled: "American White-winged Crossbill (Loxia leucoptera), male and female Loc. Dardarroch, March 1st, 1890." I identified them as an immature male and mature female of the Two-barred Crossbill ; but to make assurance doubly sure, I sent them to the authorities at the Natural History Museum, South Kensington, who concurred in my identification.

In correspondence, Mr. Henry Martin informed me that he had shot the birds himself in the spring of 1890 , and added that there were " three White-winged Crossbills together when I shot the two, the other being a female; and as I had obtained a male and female did not wish to kill the other in case there might be more. At that time there were a great many common Crossbills in the woods of Dardarroch. ... I may remark that the White-winged Crossbills when I saw them were engaged feeding on the cones of the larch trees, and twittering as if quite at home; and as I believed they were different from the common variety, I could not resist securing the two specimens."

The above would appear to be the second authenticated record of the occurrence of the Two-barred Crossbill in Scotland. The first, a male, was shot on December 19th, 1889, in Berwickshire. $\dagger$ Birds obtained previous to this date and recorded as examples of Loxia leucoptera may, however, have really belonged to the present species.

The Two-barred Crossbill "inhabits the coniferous forests of northern Russia and Siberia as far as Kamchatka and the Pacific, wandering in autumn and winter further south. The forests of America, from Alaska to Labrador, are inhabited by a bird known as the White-winged Crossbill, Loxia leucoptera," $\ddagger$ now regarded by ornithologists as only entitled to subspecific distinction.

* Trans. D. and G. Nat. Hist. Soc., May 12th, 1893.

† Ann. Scot. Nat. Hist., 1897, p. 86.

$\ddagger$ Man. Brit. Birds, 1899, p. 204. 
For the accompanying illustration I am indebted to the kindness of Mr. R. Martin, who lent Mr. D. Legard the actual specimens described, in order that they might be photographed.

\section{THE CORN-BUNTING. Emberiza miliaria, Linnæus.}

A fairly common resident in the littoral parishes, but very local elsewhere; gathering into small flocks, increased by immigrants, in autumn.

Sir William Jardine writing of the birds of Applegarth and Sibbaldbie in 1832, says that the Corn-Bunting " is migratory, and is met with in autumn in small flocks and breeds in the lower pasture-land. It also is a bird of local distribution."**

It is somewhat strange that after so many years and so many changes, the present distribution of this species should be the same, so far as we know, as in the days of Sir William Jardine. In autumn and winter this bird gathers into flocks which are swelled by immigrants from further north, and at this season it becomes more generally distributed throughout the arable districts, having been seen so far afield as Wanlockhead. A flock of seventy or more was seen near Dumfries on December 12th, 1908. $\dagger$

The Corn-Bunting appears to nest but locally in the lower portions of Nithsdale, Annandale and Eskdale, though more commonly in the littoral parishes; and I have confident reports of its nesting on White Hill Farm (Kirkconnel) and in Sanquhar parish.

The late W. G. Hunter of Shearington (Caerlaverock) in his last contribution to the Dumfries and Galloway Courier and Herald (July 10th, 1907) writes as follows: "One of the most familiar cries of the countryside in June is that of the Corn-Bunting. You cannot mistake him as he sits on the top of a hawthorn or other tree fringing a field of corn

* New Stat. Acct. Scot., Vol. IV., p. 179.

† Ann. Scot. Nat. Hist., 1909, p. 201. 


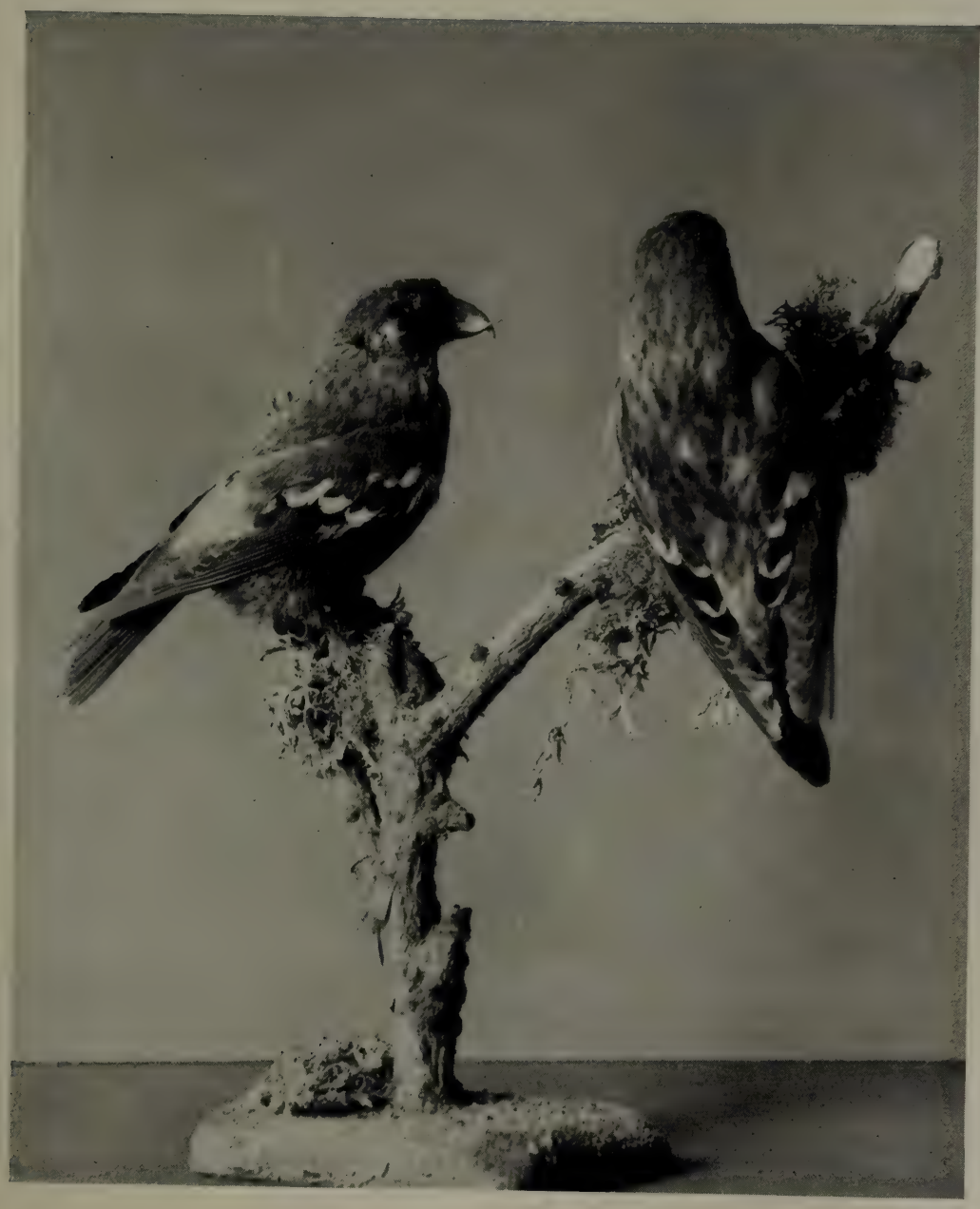

THE TWO-BARRED CROSSBILLS (Loxia bifasciata) SHOT AT DARDARROCH (GLENCAIRN), MARCH IsT, 1890. 

or rye-grass, uttering all the while a collection of harsh notes at a somewhat rapid rate, which has been likened to the jingling of a bunch of keys. This may go on with monotonous repetition for several minutes, after which he will fly off awkwardly towards the centre of the field, with his legs hanging down as if broken, where he will land for a short time before returning to his original or other perch. Corn-Buntings are late nesters, and are now only bringing up their broods in the thick clovered patch of a rolling field of rye-grass."

THE YELLOW BUNTING. Emberiza citrinella, Linnæus. Local names-Yellow Hammer ; Yoit ; Yellow Yite ;
Yeorlin; YeldRock.

A common resident in the arable and lower pastoral districts, gathering
into small flocks as autumn advances. The superstition still survives that the Yellow Bunting
has some connection with his Satanic majesty. I quote three doggerels, formerly more often heard.

"The Robin and the Wren, are God's right hand :

The Yeldrock and the Sparrow, are the devil's bow and arrow."*

Macgillivray mentions that in some parts of Scotland "their dolorous ditty is interpreted as "Deil, Deil, Deil, take ye"; that is the cruel nesters, and for this reason probably the Yellow Bunting is named the "Devil's Bird." " $\dagger$ In some "Reminiscences " published in 1867 we read, "The boys at school had a barbarous practice of transfixing Yellow Hammers, all the while repeating this rhyme" :

" Half a paddock, $\ddagger$ half a toad, (or ta'ed)

Half a Yellow Yeorlin,

Drinks a drap o' the de'il's bluid

Every Monday morning." §

* A Country Schoolmaster, 1899, p. 31.

$\dagger$ Macgillivray, Hist. Brit. Birds, 1837, Vol. I., p. 49.

$\ddagger$ Paddock = frog.

§ Dumfries Courier, July 30th, 1867. 
But the rhyme which is now more commonly beard is :

"The Brock, the tod, the yellow yeorlin, Drink a drap o' the de'il's bluid

Ilka May mornin'."

The Yellow Bunting in spring is a common resident throughout the arable and lower pastoral districts ; whether or not its numbers are reduced in winter by emigration it is difficult to say, as at this season it mixes with Chaffinches and Sparrows, frequenting the stubbles and farm-yards. Its eggs have gained for it the name of the "Writing Lark" on account of their wavy scrawl-like markings; but they have been found pure white, as at Duncow (Kirkmahoe) in 1886 (see p. 14). In its nesting-season the species is most erratic, eggs being frequently found in September and even later, which are no doubt second or even third broods.

THE REED-BUNTING. Emberiza schœniclus, Linnæus.

Local names-Ring-Bunting; Reed-Sparrow; BlackHEADED BUNTING.

\section{A common but local resident, subject to partial migration.}

This species is often called the "Black-headed Bunting," and in spring and summer its black head affords some excuse for the misnomer, but the Black-headed Bunting proper, the Emberiza melanocephala of ornithologists, is only a very rare visitor to Great Britain from the southeastern portions of Europe.

The Reed-Bunting is to be found in spring, but somewhat locally, in fairly damp spots; such as by the side of slowrunning streams (e.g., the Cairn), or on swampy moorlands (e.g., the head of Loch Urr). It is common on all the

* Brock $=$ badger. Tod $=$ fox. Ilka $=$ each. 
sluggish streams running through or into Lochar Moss. Reports from many such localities throughout the county tell me that it is known as a nesting-species. Some of my informants regard it as solely a summer-visitant; but many Reed-Buntings remain all the winter through; escaping observation, since the black head is not very noticeable then. At this season they often consort with other species, and visit the stack-yards in search of food. As spring approaches these flocks break up, and the Reed-Buntings revisit their nesting-haunts in their more conspicuous breeding-plumage.

\section{THE SNOW-BUNTING.}

Plectrophenax nivalis (Linnæus).

Local names-SNow-Finch ; SNow-Flake; SNow-FleCK.

A common winter-visitant to the upland districts.

In 1832 Sir William Jardine wrote that the Snow-Bunting "appears on the higher grounds in immense flocks during winter, and in severe weather visits the edges of the Annan feeding among the sand or gravel."*

The distribution of this species over the county depends upon the severity of the winter; in a mild season it will only be seen in the upper portions of the upland district, but after a heavy fall of snow it will be found "crowded down" to our very coast. Its numbers are similarly affected, and it is only in severe winters that it appears in large flocks.

Early in December, 1882, Mr. Tom Brown wrote to Mr. R. Service from Auchanhessnane (altitude four to five hundred feet) as follows: "On Sunday the ground was covered with snow and the Snow-Buntings seemed to gather down from the hills, as we saw a flock of several hundreds,

* New Stat. Acct. Scot., Vol. IV., p. 179. 
but on Monday the snow was all gone, and they seemed to have all scattered over the hills, in pairs often, and in small flocks occasionally." In February, 1897, it was said that the species was " more numerous towards the shore and contiguous land, having apparently been driven down from the hills by the prevalence of snow."* A specimen obtained near Ruthwell on January 19th, 1907, is now in the Tullie House Museum, Carlisle.

The Snow-Bunting usually appears late in October, or early in November, though in 1902 an adult male was recorded from Glencaple on September 20th. $\dagger$ By April they have usually departed, but Dr. Anstruther Davidson states that he has seen them at Wanlockhead as late as Maył; and it is recorded that "In the south-west of Scotland Captain Kennedy has observed them in July and August. (Zoologist, 1874, p. 3914.) These birds may have been bred in Great Britain."§ The late Captain Alexander Clark Kennedy's observations were made near his home, Knockgray in Kirkcudbrightshire, contiguous to the north-western boundary of Dumfriesshire.

"Mabie Moss" draws attention to the good these birds do in early spring by taking the larvoe of the antler-moth (Charoeas graminis), which is so injurious to hill-pastures.|l

The Snow-Bunting nests on the Cairngorm Mountains, on Ben Nevis, and on some of the higher ranges in Scotland. It breeds in the Arctic regions generally, and in winter migrates south, reaching the countries bordering the Mediterranean; and in the western hemisphere, as far as Georgia.

This species has never yet been detected as nesting within the county, but such late dates of its occurrence locally, as those given above, seem promising.

* Dumfries Courier and Herald, February 8th, 1897.

+ Ann. Scot. Nat. Hist., 1903, p. 147.

‡ Hist. Sanquhar, p. 28.

§ Yarrell, Hist. Brit. Birds, 4th ed., Vol. II., p. 6.

|| Dumfries Courier and Herald, June 28th, 1894. 
[Regarding the occurrence of the AMERICAN REDWINGED STARLING (Ageloeus phoeniceus, Vieillot) at Kirkconnel in the winter of $1887^{*}$, Dr. Anstruther Davidson writes me that the bird was seen by him, and was brought to his notice by Mr. J. Harkness, in whose yard it was found. "It was not in a condition to preserve, and I have nothing but the record that it was found in the winter of 1887." This bird was probably one of a small consignment from America, turned down at Inverary in October, 1886, by the Duke of Argyll. Thriving well through the winter, they were kept in confinement till May, 1887, when seven couple were liberated. They were seen for a few weeks in the vicinity, but then disappeared, and subsequently " one or two were reported as having been seen and shot in different parts of Scotland." $\dagger$

The occurrence of this species being due to importation, it cannot be regarded as a genuine visitor to the county. It is an inhabitant of the United States, migrating southwards to Central America.]

\section{THE STARLING. Sturnus vulgaris, Linnæus.}

\section{Local name-STURLIN.}

"The Starling flew to his mother's window stane,

It whistled and it sang;

And aye the ower-word $0^{\prime}$ the tune

Was-'Johnie tarries lang!" ",

"Johnie of Breadislee." Ancient Nithsdale Ballad.

A very common resident throughout the county, but subject to partial as
well as general migrations.

At the end of the eighteenth century there is reason to believe that the Starling was quite common.

* Trans. D. and G. Nat. Hist. Soc., April 20th, 1905.

$\dagger$ Fauna of Argyll, 1892, pp. 80, 81.

$\ddagger$ Refrain. 
Sir William Jardine writing in 1832 says : it "is found in flocks during autumn and spring, but few in number, having diminished much of late years. In 1819 and 1820 flocks of many hundreds frequented the holms on the Annan, but of late not more than from ten to twenty have been seen together."* About the time that Sir William. wrote, Sir Charles Granville Stuart Menteath sent a pair of young Starlings to Closeburn Hall to be brought up and liberated. They were entrusted to William Hastings, then an under-gardener on the estate (subsequently the taxidermist of Dumfries), "who did as he was instructed; and in the following year one was shot and no one knew what it was." $\dagger$ From Newbie House (Annan) in 1839, Sir William Jardine wrote to P. J. Selby that "A pair of Starlings bred in a hole in one of the large trees in front ; the first time I have ever known any remain over summer." The editor of the Dumfries and Galloway Courier (John McDiarmid) wrote of the Starling in 1840, "we would esteem it a high favour could Mr. W. $\ddagger$ contrive to send us a pair or even an odd one. It is true the same curious bird is partial to Kirkbean, in our own neighbourhood, but with all our art we could not secure a nestling either from Arbigland or Cavens."§ None of the places here mentioned, it will be observed, are in Dumfriesshire; and the bird locally had become more than a rarity.

Thomas Aird records that "eight years ago [i.e., 1856] there was not a Starling at Mountain Hall [Dumfries]; now they breed, and large flocks are seen in autumn." $\|$ So long had they been strangers that Mr. John Corrie states: "I am credibly informed that the first Starling seen in Glencairn was sold for half a sovereign, and the bird was a dead one." "

* New Stat. Acct. Scot., Vol. IV., p. 180.

+ R. Service's M.S. Diary, March 23rd, 1887.

† Rev. Thomas Wright, Minister of Borthwick, Midlothian ; 1818-1841.

§ Dumfries Courier, January 1st, 1840.

II Trans. D. and G. Nat. Hist. Soc., December 6th, 1864.

T Op. cit., November 10th, 1888. 
The resuscitation of the species had begun in 1865 , since when they have increased steadily. They escaped the hardships of the severe winter of 1878-1879, for we read, "Starlings completely disappeared from the neighbourhood of Dumfries in the end of November, 1878, and did not reappear till the beginning of March, 1879." There seems little doubt that "pastoral grazing which has succeeded so largely to arable cultivation has favoured the remarkable extension of the species."*

As this increase has been maintained, a change in their nesting-habits has taken place; suitable holes being too few for their numbers, nests had to be constructed in trees or bushes. "Mabie Moss" describes a "nest in a Portugal laurel bush, very large and clumsy, domed over with straw and rough litter, like a House-Sparrow's nest in a tree " $\dagger$; and the same observer states: "At Corrie Common near Lockerbie over half a dozen nests of this description may be seen close together in one clump of trees." $\ddagger$ Nowadays, these open nests are commonly observed, and very curious nooks and crannies are utilized. In 1893 it is recorded that "In a drain hole in front of the platform at Shieldhill Station (Tinwald) quite on a level with the rails, a pair of Starlings are rearing their young. The low situation of the nest is quite as remarkable as the boldness evinced by the parent birds in successfully hatching their young within a few feet of the trains that are continually passing along the line."§

Their nesting-period would seem to be becoming more and more prolonged. "Mabie Moss" reports "five young in nest at Guilliehill (Moffat) on November 21st, 1899." Mr. William Wright in a letter to Mr. R. Service mentions a brood of Starlings successfully fledged by February 14th,

* Trans. Edin. Field Nat. Sor., 1904-1905, Vol. V., Part 3, p. 183

$\dagger$ Dumfries Courier and Herald, January 22nd, 1891.

$\ddagger$ Op. cit., May 30th, 1891.

\& Op. cit., June 2nd, 1893.

\| Kirkcudbright Advertiser, December 11th, 1899. 
1890 ; they had been hatched in the garden of the Free Church Manse, Annan, and the female bird, it was observed, was on March 1st engaged in hatching her second lot of eggs. On January 3rd, 1908, Mr. Andrew Callow, Stenhouse Cottage (Tynron), discovered " in the hollow of a plane tree near his house the nest of a Starling. It contained five young ones, lively, noisy, and in the early feathering stage of development."*

The coloration of the eggs of this species is, I think, considerably lighter than it used to be, the standard of pale blue being lowered to bluish-white.

As regards the utility of the species, Mr. Fred. V. Theobald writes: "The general opinion may be summed up that the Starling is most beneficial to the farmer and stock-breeder, and should be encouraged; but that in fruit districts its numbers should be kept down." $\dagger$ Writing in 1908, "Mabie Moss" states that this bird has only taken to eating elderberries during the last twenty years. $\$$ They are eager devourers of wire-worms and cockchafers; and Richard Bell of Castle O'er states that in June, 1885, when the plague of caterpillars of the antlermoth was at its height in Eskdalemuir, thousands upon thousands of Starlings visited the pasture-land. They dug up the stones on the roads for grit to such an extent that the actual surface became loose. $\S$ In the summer months they may be seen catching flies and insects in the air, a habit, it is believed, only acquired in comparatively recent years.

When moving about in very large flocks they do considerable damage to the trees, shrubs, and undergrowth where they roost, and should therefore be banished from any valuable plantation. At Winterseugh, or Starling Wood (Cummertrees), some ten to twelve thousand Starlings

* Dumfries Courier and Herald, January 8th, 1908.

† Science Progress, 1907, Vol. II., p. 280.

‡ Kirkcudbright Advertiser, November 27th, 1908.

$\S$ Trans. D. and G. Nat. Hist. Soc., April 17th, 1901. 
roost at certain seasons; and I am informed by $\mathrm{Mr}$. P. Jeffreys that in October, 1905, thousands came to roost at Friar's Carse (Dunscore) and continued to do so till March, 1906, the trees being black with them. The same thing happened in the autumn of 1906, but not in 1907. I have seen similar flocks roosting in a small reed-bed at Capenoch (Keir), and their incessant chattering, and the noise of their wings when they rose were remarkable.

The power of mimicry in this bird is, I fancy, influenced by the sounds which are most commonly heard by the individual. As I write I can hear a Starling from time to time copying admirably the calls of the Curlew, Blackbird, Tawny Owl and Heron. In the Outer Hebrides I remember the characteristic "whee-oh" of the Wigeon had been learnt to a nicety. Dr. Gilchrist records a Starling which imitated "the voices of a variety of birds, and particularly the Goose, Duck and Plover, with great perfection."*

Abnormalities of plumage in the Starling have been noticed frequently. "Mabie Moss" records " an example of leucotism. A young bird all over of a beautiful pale yellow. The forehead, throat and back show a pretty canary-yellow tint, in some lights. Bill, light orange ; feet and legs flesh colour. It was got at Dargavel (Dumfries) in May, 1894." $\dagger$ Mr. J. A. Shiels writes me from Newtonairds (Holywood), that a pure white Starling was reared there in the summer of 1903. It kept about the district for some time, but suddenly disappeared; and this may be the white specimen which Mr. J. Harkness describes as now in his possession.

I have already alluded to the partial and general migrations to which this species is subject. The partial migrations are due to the birds gathering in from outlying nestingstations in autumn, and flocking together in search of food to those localities where they will find it most abundant;

* Minutes of D. and G. Nat. Hist. Soc., December 3rd, 1872.

$\uparrow$ Dumfries Courier and Herald, June 28th, 1894. 
but a conspicuous immigration takes place in autumn, and is followed by an emigration in early spring, at the same time as those birds, which will breed with us, are distributing themselves for nesting-purposes throughout the county.

\section{THE CHOUGH. Pyrrhocorax graculus (Linnæus).}

\section{Formerly a very rare accidental visitor.}

The Chough was at no time common within the limits of our county, though in the days when it nested freely in the sea-cliffs of Kirkcudbrightshire and Wigtownshire it may have occurred occasionally.

As an inhabitant of inland localities it is but rarely known, and Mr. R. Service states: "I have not been able to authenticate two or three instances known to me, except in the case of a pair which took up their abode on an old ruined building at Bogrie in 1848. These were seen by Mr. Hastings, taxidermist, Dumfries, and others, and although the birds were evidently preparing for nesting, they mysteriously disappeared after frequenting the place for several months." * Bogrie in Dunscore parish is about twenty miles in a direct line from the nearest sea-cliffs. "The only 'Solway' Chough," writes H. A. Macpherson, " that we know T. C. Heysham to have seen, came under his notice in the Carlisle market, November 20th, 1849. This he ascertained to have been taken in the neighbourhood of Dumfries." $\dagger$ It is quite possible that William Hastings, who gave Mr. R. Service the information about the Choughs at Bogrie, may have forgotten the exact dates; and if so, the record of T. C. Heysham may explain their mysterious disappearance.

* Trans. Nat. Hist. Soc. Glasg., 1885, Vol. I., p. 120.

$\dagger$ Fauna of Lakeland, 1892, pp. 152, 153. 
This species, formerly a comparatively common resident along the British coast, is now only found in some spots on the west of Scotland, Ireland, Wales and south-west of England.

\section{THE BRITISH JAY.}

Garrulus glandarius rufitergum, Hartert.

Local names-JAY-PIET; JAY-PIE.

A very local resident whose numbers are in some autumns considerably increased by visitors, most of which, however, depart again in spring.

Dr. Archbald mentions the Jay in his list of local birds written about 1684, as "called Lipper-jayes, taught to speak as exactly as any parrot."* During the eighteenth century this species, I believe, was a regular resident, generally distributed throughout the county, although there is no mention of it in the description of the Dumfriesshire parishes in the Statistical Account of Scotland compiled in 1791-1799. In the New Statistical Account, Sir William Jardine writes of it in 1832 as "very rare " in Applegarth and Sibbaldbie parish. $\dagger$ About this date it is described from Lochmaben as, though not abundant, to be found in the woods of Elshieshields, $\ddagger$ and from Mouswald to be seen in the woods of Rockhall. Writing of the Jay in 1839 Sir William Jardine says: "Residing in a district where the Jay is not immediately common, we have not had a constant opportunity of seeing them." $\|$ Dr. Grierson records in his notes that Thomas Maxwell told him that in

* Sibbald's MS. Collections, p. 228.

$\dagger$ New Stat. Acct. Scot., Vol. IV., p. 180.

$\ddagger$ Op. cit., Vol, IV., p. 382.

§ Op. cit., Vol. IV., pp. 443, 444.

\| Nat. Lib., 1839, Vol. XI., p. 254. 
1837 Jays used to be met with " in the woods of Dalswinton, Blackwood, Duncow and Closeburn, and at that time they were getting scarce, and now [1862] are unknown."

In $1875 \mathrm{Mr}$. Lumsden made very careful researches as to its status in Scotland. As regards Dumfriesshire he writes: "Rev. James E. Somerville of Langholm states that the Jay does not occur in that parish. In the parish of Canonbie, five miles below Langholm, it is found, but not abundantly; a few pairs breed, but it is not increasing. It is met with altogether in about seven or eight places in this parish which is of considerable extent. On the Springkell estate the Jay has not been seen for upwards of nine years, but it is reported to have been known at one time in that district. In the neighbourhood of Annan and in Hoddom parish the species is also quite unknown. Dr. Grierson of Thornhill informs me that "The common Jay has not been known in Nithsdale for a very long time, some forty or more years ago, but about that time I have heard it said there were a few." "*

Shot at sight on account of its egg-stealing habits, or for the value of its pretty blue feathers used by anglers for tying artificial flies, the Jay had been banished from most of its nesting-haunts by about 1860, and very few were left in the county. It is recorded in 1876 as having "been seen occasionally in Dalscone Wood" $\dagger$ (Dumfries), and Mr. W. Thorburn informs me that Jays have been seen in the Hoddom woods more or less continuously since 1878. Specimens were shot at Eliock (Sanquhar) and Hunter House (Tinwald) in 1892. In October, November and December, 1897, a sporadic immigration occurred. During these months small flocks or individuals were reported from the parishes of Tynron, Keir, Closeburn, Penpont, Kirkmahoe, Kirkmichael, Tinwald, Dryfesdale, Lochmaben, Moffat and Annan. It was calculated that rather more than three hundred altogether

* Scottish Naturalist, 1875, Vol. III., p. 239.

† Dumfries Courier, September 12th, 1876. 
visited the county.* Whether this was a local movement or one from continental Europe cannot be ascertained, as no specimens appear to have been obtained. This is unfortunate as we now know that series of British Jays can be distinguished from continental birds, on account of the more uniform vinous and less grey colour of the upper surface of the British form; but Mr. R. Service, who thought the birds were of continental origin, states: "My warrant for this opinion is in two facts. The first is that there are no resident colonies of Jays sufficiently near us from whence the immigrants under notice could have come ; and second, that former sporadic visitations to various other parts of Britain, have always been ultimately ascertained to be parties from off the enormous swarms of Jays that at certain irregular intervals fly from the far north-east to central and western Europe." $\dagger$ Most of these birds departed before the end of April, 1898; but a few pairs stayed on. I am informed that on the Mount Annan estate Jays have continued to nest annually since 1893. On the Kinmount and Hoddom estates the species has become more numerous since 1896, and Mr. W. H. Veitch tells me (1908) that seven or eight pairs nest there annually, and that he has taken the nest in a spruce. They also breed fairly commonly on the Castlemilk property. In 1900, 1901 and 1902 similar incursions, but on a smaller scale, took place, chiefly in the lower parishes of Nithsdale and Annandale. Mr. T. Ranken informs me that " a solitary bird was seen about the garden wood at Dalswinton (Kirkmahoe) on several occasions in 1900 and 1901. I am not sure about 1902, but it certainly stayed for two years if it was the same bird."

Since 1900 the Jay has increased in numbers as a breedingspecies, and has been known to nest in the parishes of Langholm, Canonbie, Kirkpatrick-Fleming, Dornock, Annan, Cummertrees, Hoddom, Dalton, Ruthwell, Caerlaverock,

* Kirkcudbright Advertiser, May 10th, 1898.

† Dumfries Standard, December 29th, 1897. 
Kirkmahoe and Tinwald. It would therefore appear that the bird has become once more established in the south of the county, and if unmolested it will undoubtedly extend its range.

\section{THE MAGPIE. Pica rustica (Scopoli).}

\section{Local names-Piet ; Pie; Pegrie.}

"With all the thick short rowing of her wings, The Magpie makes slow way. But her glib tongue Goes chattering fast enough, in yonder fir, The summer solstice cannot keep her mute. Ominous pie! The peasant sees it tear With mad extravagant bill his cottage thatch, And fears for death within; the schoolboy, forth On morning errand, counts with eager awe The sidelong pies high hopping o'er his road And learns the fortunes of the coming time."

ThомAS AIRD.- "A Summer Day."

A very local resident in the littoral parishes; sporadically, in small flocks,

At the beginning of the nineteenth century Magpies were numerous throughout the county, and were often seen in parties of fifteen to twenty. Sir William Jardine wrote (circa 1839): "Like its congeners, it would even seem to delight in the vicinity of population, perhaps in some degree attracted by the food which is there presented to it, and the neighbourhood of villages, or the trees which generally surround the farm-steading, are almost sure to be tenanted by a pair at least of these active birds. . . . There was an ancient law or regulation in Scotland, whereby tenants were obliged to plant and rear a certain number of ash trees around the farm-steading, and accordingly most of those sites are surrounded by some venerable trees of this species on which the Pies love to build, and the prevalence of this tree in such situations may be the cause, without any particular partiality in the birds existing for it."* * Nat. Lib., 1839, Vol. XI., p. 247. 
About 1850, Magpies appear to have been still very numerous; but with the increasing preservation of game their numbers correspondingly decreased. Mr. R. Service tells me that he saw quantities near Lockerbie in 1863, but Thomas Aird recorded in the following year that they were already getting scarce round Dumfries,* and the Rev. Dr. R. W. Weir writing of the birds of that parish in 1876 says: "The common Magpie, one of our most beautiful birds, once so common here, has now all but disappeared, thanks to the zeal of the vultures called game-keepers." $\dagger$ My father well recollected, as a most unusual sight in 1872, seeing a flock of thirteen at Durisdeer.

The species escapes annihilation in Upper Nithsdale more easily than elsewhere. Mr. James Laurie, gamekeeper, informs me that in 1899 he killed no less than three hundred Magpies on his beat near Kirkconnel. These were all bred in the district in the natural birch-coverts, and he pulled down all the old nests after killing the birds. This must have been an isolated colony where they had been allowed to increase for many years. Since 1900, nests have been recorded from Kirkconnel, Morton, Closeburn. Keir, St. Mungo, Kirkmahoe and Canonbie, as well as from the littoral parishes of the county, where the bird would seem to be slightly on the increase. With adequate protection there is no reason why it should not once more become generally distributed throughout the county.

As an inveterate egg-stealer the Magpie bears a deservedly bad character, and Mr. Tom Brown narrates that he once saw a pair attack and kill a hare. $\ddagger$ Whatever its faults may be, it is always to be regretted when any bird becomes exterminated. Keeping undesirables in check requires different procedure, and is undoubtedly essential in some cases for the welfare of other species of our avifauna.

Sir William Jardine records a pair of Magpies, " entirely

* Trans. D. and G. Nat. Hist. Soc., December 6th, 1864.

+ Dumfries Courier, September 12th, 1876.

‡ Trans. D. and G. Nat. Hist. Soc., December 4th, 1885. 
of a cream colour, hatched at a farm-steading in Eskdale, and being much thought of by the tenant, were strictly preserved and continued near the spot for many years."*

Owing to the rarity of these birds nowadays, one seldom hears the old rhymes telling what varying numbers portend :

"One's joy, two's grief,

Three's a marriage, four's death,"

is the version given by the late James Shaw. $\dagger$ For the superstitious it may be comforting to remember an alternative version, given as equally reliable:

"One's sorrow, two's mirth,

Three's a wedding, four's a birth,

Five's a funeral, six is snaw,

Seven draws the dead awa'." $\ddagger$

By conveniently forgetting the version unpropitious to the occasion, the observer of Magpies may escape the feeling of an unpleasant augury!

THE JACKDAW. Corvus monedula, Linnæus.

Local names-Keea ; Keeaw ; Daw.

\section{A common resident.}

In spite of persecution there has been an undoubted increase in the number of Jackdaws during the last fifteen years.

In its choice of a nesting-site this bird often becomes a nuisance to the householder, and its nests can even be seen in the chimneys of our county-town. At this season of the year its fear of man seems lessened, and any unused chimney, or cavity may be tenanted by the unwelcome visitors. Sir William Jardine writes of these birds at Jardine Hall: "We have seen attempts made to build

* Mag. Nat. Hist., 1834, Vol. VII., p. 595.

$\uparrow$ A Country Schoolmaster, 1899, p. 31.

‡ Trans. D. and G. Nat. Hist. Soc., February 14th, 1896. 
amidst the capitals of large supporting columns, and week after week endeavours to place the sticks across the projecting ledges or ornaments. One or two might remain for a short while, but were sure to be displaced in fresh attempts, while underneath the result of a morning's labour was often as much as a single person could at once remove; this we have known continued in the same spot for some years."* The usual nesting-place, however, is in a young fir tree from fifteen to twenty feet high, where huge nests are built, and often two or three are seen in one tree. Old nests formerly tenanted by the Long-eared Owl or WoodPigeon are frequently used as a foundation, but in many parts of the county the Jackdaws breed in colonies in rabbitburrows, or on the ledges and crevices of steep cliffs.

The habit of hawking insects in the air, referred to under the Starling (p. 108), has also been noticed in this species. $\dagger$

Sir William Jardine writing of the birds of the parish of Applegarth and Sibbaldbie in 1832 says that this bird is sometimes seen varied with white, $\ddagger$ but I am not aware of any such varieties obtained recently.

\section{THE RAVEN. Corvus corax, Linnæus.}

Local name-CoRBIE.

"The Raven croaks a softer way, His sooty love to woo."

Alian Cunningham._- The Return of Spring."

A resident nesting annually, where protected, on some of the more inaccessible crags ; in autumn and winter it roams more widely in search of food.

The Raven was certainly more common at the beginning of the nineteenth century than it is now. David Tweedie,

* Nat. Lib., 1839, Vol. XI., p. 236.

$\dagger$ Dumfries Courier and Herald, April 10th, 1890.

$\ddagger$ New Stat. Acct. Scot., Vol. IV., p. 180. 
interviewed in 1834 at the age of eighty-three, is reported to have described it as "the most lordly of all birds, builds in rocks the most inaccessible, and would be a positive ornament to a hill country, but for his disposition to pike out the een $o^{\prime}$ innocent lambs." *

In the days when Ravens were more plentiful they occasionally nested in trees, but I am not aware of any such site being utilized nowadays. Writing in 1839 of a female specimen in his collection, Sir William Jardine says she "was so wary that she could not be approached on the nest, which was built on an old tree, growing from the precipitous bank of a deep mountain ravine, and which commanded a view of the country around. Finding access impossible, stratagem was resorted to, and a gun was fixed at about thirty yards distance, pointed at and bearing on the nest, a long string was attached to the trigger, the gun was cocked, and some hours after dark the string was pulled, the result was the capture of the bird alluded to." $\dagger$ This specimen may be the bird still on view in the Royal Scottish Museum, Edinburgh, labelled as from Sir William Jardine's collection, "No. 99. Raven, from Moffat Hills."

It is satisfactory to be able to record at least two nestingplaces in the county to which Ravens have resorted annually for upwards of forty and thirty years respectively. At one of these in 1906 much damage was done to fallen sheep. Believing that such bad habits belong more to the individual than to the whole species, one of the offending pair was shot. The remaining one (the male) obtained a new mate with which he has nested successfully these last four seasons, without a repetition of complaint from the farmers or shepherds. Such names as Raven Craig (Moffat), and Ravenscleuch (Applegarth), testify to former nesting-

* Dumfries Courier, August 27th, 1834.

† Nat. Lib., 1839, Vol. XI., p. 226. 
places of this species; and from what I can learn there would appear to be some twelve to sixteen sites within the limits of the county, now usually visited annually in February or early March for nesting-purposes. I regret that I cannot give more accurate information as to local breeding-places; if we are to admire the enthusiastic zeal of the egg-collector, so we must beware of his indiscriminate greed.

The parties of Ravens occasionally seen at the end of autumn, or early in February, may possibly be migrants on their way to more northern climes.

A fine pair of Ravens are to be seen in Tullie House Museum, Carlisle, labelled "Dumfriesshire, February 17th, 1894. Presented by Mr. D. L. Thorpe." Specimens are also to be found in many country houses, evidences of the "warm welcome" given to an uncommon bird directly it appears within gunshot.

Mr. S. Copland tells me of a pair in Sanquhar which frequently took rabbits from his snares, but would not touch the rabbits in his traps, sagacity which may have been learned by experience. The disposition to pick out the eyes and tongues of new-born lambs or weakly sheep has often sealed their doom; but like many other evil-doers they too play a useful part in Nature, by keeping in check smaller obnoxious animals, and by disposing of offal. About 1835 they are recorded from Lochmaben, "as occasionally seen by the sides of the lakes picking up the small fish that happen to come within their reach."*

Young Ravens taken from the nest have frequently been brought up as pets, but have generally been destroyed because of their subsequent peccadilloes. In one case at Penpont, about 1899, a bird took to bullying the smaller children, who became so frightened at it that it had to be shot. 


\section{THE CARRION-CROW. Corvus corone, Linnæus.}

\section{Local names-Corbie; Corbie-Craw; Hoodie Craw ;} HoodIE.

“ A hoggie* dead! a hoggie dead! a hoggie dead!

O where? O where? O where?

Down i'e park! down i'e park! down i'e park !

Is't far? is't far ? is't far ?

Come try ! come try ! come try !"

Chambers" "Popular Rhymes."

A fairly common resident throughout the county, although much persecuted by game-preservers.

The above rhyme, said to describe the call of the CarrionCrow, is here given on account of its antiquity rather than for its truthfulness to nature.

Feeding on any carrion or offal, as its name implies, the Carrion-Crow has been known to attack weakly sheep and lambs; it is an inveterate stealer of the eggs of other birds; and on a grouse-moor it can do a fearful amount of harm. John McDiarmid records how "John Tait, residing at Craigshiel, parish of Kirkmichael, counted in 1828 no fewer than ninety-six Grouse eggs which the Crows had purloined from a neighbouring heather field, and broken and sucked on a verdant knoll." $\uparrow$ As early as $\mathbf{1 7 9 4}$ William Stewart notes that "The most destructive of all ravenous animals to game and to sheep also, is the small raven, which in this part of the country [i.e., Hutton and Corrie] is entirely black, but is the same with the grey or hooded crow of other parts of Scotland." $\ddagger$

The nest is usually placed high up on a tree from which a good look-out may be kept; but Mr. James Pollock tells me

* Lamb.

$\dagger$ Sketches from Nature, 1830, pp. 51, 52.

$\ddagger$ Stat. Acct. Scot., Vol. XIII., p. 580 . 
that he once found one in a holly bush in a glen near Moffat. Their nesting-sites are usually chosen well away from the haunts of man, but "Mabie Moss" writes : "On the wellknown tree in Buccleuch Street, Dumfries, a pair of CarrionCrows had settled and nearly completed a nest in the early part of last month [i.e., April, 1890], a place incompatible with their usual haunts and habits"*; but the birds left without utilizing it. Mr. R. Armstrong writes me that he once saw a nest in Gilchristland Glen (Closeburn), mainly built of sheep's bones, and beautifully cushioned inside with sheep's wool and rabbit's fur.

In the winter months this species often becomes numerous on the sea-shore and on the estuaries of our rivers, where it not only feeds on various offal, but picks to pieces any wounded wildfowl.

Specimens with malformed beaks are from time to time recorded; one such bird from Kelton (Dumfries) was shot by Mr. Watt in November, 1832, and was in good condition although "The upper mandible was so much curved over the lower as to make it appear almost impossible for the bird to feed." $\dagger$ A bird showing a similar abnormality was shot at Capenoch (Keir) on March 18th, 1903, in which the lower mandible was half an inch longer than the upper, and both were fully half an inch out of the straight.

In the Royal Scottish Museum, Edinburgh, there is a remarkable specimen which is of a curious café-au-lait colour all over. It was presented, so I am informed by Mr. Eagle Clarke, by Mr. J. Shaw-Stewart in October, 1870 , and is entered in the Museum catalogue as "shot in Dumfriesshire a few months ago."

The two species $C$. corone and $C$. cornix are known to interbreed, and their size, shape and habits are much alike; but I think it is worthy of note that the dictum, already quoted, of William Stewart of Hillside (in his account of the parish of Hutton and Corrie, written over one hundred

* Dumfries Courier and Herald, May 1st, 1890.

† Trans. D. and G. Nat. Hist. Soc., May 12th, 1893. 
years ago), should still be the opinion of some ornithologists who do not consider the Carrion-Crow as specifically distinct from the Hooded Crow ; others, however, take exactly the opposite view.

\section{THE HOODED CROW. Corvus cornix, Linnæus.}

Local names-Grey Crow; Grey-backed Crow; SeaCrow; Hoodie Craw; Hoodie.

A not unfrequent visitant to our littoral in autumn and winter; uncommon elsewhere and departing in spring. Has occasionally bred with the CarrionCrow.

In his manuscript written about 1837 William Laidlaw says: "In former times the Gray, Royston or Hooded Crow has as I think been the more common species even in the Border counties of Scotland where it is now almost unknown, for the Carrion crow is called everywhere the Hoodie craw; it seems to have gradually banished the other, which although almost as subtle and cautious has somewhat more of a wild character. These two nearly connected species do not at all times decline to associate, for I have twice seen them paired in Selkirkshire, but never a pair of Grey Hooded Crows together. . . . I am inclined to suppose that the emigration of the Grey sort took place alongst with the destruction of the woods from the demand of charcoal in the early part of the seventeenth century." Whether this supposition is correct I do not know, but by the end of the eighteenth century, it would appear to have ceased to be a general resident. Sir William Jardine writing in 1839 says: "An individual occasionally strays inland, and in spring finds a mate in the Carrion Crow. We have repeatedly seen them breeding together, and could only account for it in this way, one or two individuals only occurring in the district alluded to during the winter. 
The produce is birds of intermediate plumage; but we have never been able to trace them again breeding, or for any long period."* A hybrid, such as described, from Jardine Hall was in Sir William Jardine's collection. $\dagger$ Thomas Maxwell told Dr. Grierson in 1862 that "The Royston Crow or the light-coloured variety of the Hooded Crow is occasionally met with, and will breed with the Carrion-Crow." $\ddagger$ Mr. J. MacCarfrae sent me, for my collection, such a hybrid which he shot from her nest on June 11th, 1908, in Carco Glen (Kirkconnel). He subsequently wrote me: "The bird I sent was the female. I am sorry I could not get the male bird as it fell into the nest which was built on a very tall tree, branchless for a long way up and situated in a very precipitous place. However, standing on the brow above, I could see the back of the bird very well, and I am almost certain it was a Carrion-Crow. After it fell into the nest the two young ones flapped out and came to the ground, where I got hold of them as they were too young to fly properly." My informant brought them up in captivity; and I saw them at the Holm (Sanquhar) in March, 1909. So far as I could see, one resembled a Hooded, the other a Carrion-Crow. The parent female has the nape and hind-neck ash-grey and a broad band of the same colour across the upper breast, the rest of the plumage being black glossed with greenishblue.

Another instance of this hybrid breeding, has I believe, occurred at Raehills (Johnstone).

On May 23rd, 1853, a "Hooded Crow was shot by Alix McClunie, coachman to Mr. Maxwell of Gribton, and has been sent to William Hastings, Flesher, to be stuffed. . . . The Crow had been seen on the estate of Gribton for seventeen years. His back and belly are of a beautiful ashgrey, which chiefly distinguishes the Hooded from the

* Nat. Lib., 1839, Vol. XI., p. 234.

† Cat. Birds in Coll. Sir W. J., p. 128 (5189), a.

‡ Grierson's MS. Diary, October 17th, 1862. 
Carrion-Crow, the rest of his feathers jet black. He wasnever, we believe, seen with a mate. His size was not unusual, but in his predatory habits he was bold and fierce. At one time he killed a bantam hen, and only a few days before he was shot he had a tough battle with a bantam cock."*

In some winters the Hooded Crow appears on our shores in greater numbers than in others, as in 1886-1887, 18881889 , and in the severe winter of 1894-1895, when Mr. Hugh Mackay records that he had several specimens sent to him for preservation from the county. $\dagger$ Inland, however, it is more rarely seen, though it has been reported from Holywood, Keir, Glencairn, Johnstone, Closeburn, Durisdeer, Moffat, Sanquhar and Kirkconnel.

A report that a pair nested at Mitchellslacks (Closeburn) in May, 1903, lacks confirmation; and it must be remembered that the name "Hoodie Craw" is so generally applied throughout the county to the Carrion-Crow, as to lead to confusion. The places nearest to Dumfriesshire, in which C. cornix breeds regularly inter se, appear to be in the Isle of Man and the Loch Lomond district, although a few pairs may nest in some of the Clyde Isles, e.g., Little Cumbrae and Inchmarnock. Farther north in Scotland it still continues in places to be a more common species than $C$. corone, but it is believed that the latter is gradually dispossessing it of its former strongholds.

THE ROOK. Corvus frugilegus, Linnæus.

Local names-Corncrow ; Crow.

A very common resident throughout the county.

Mr. Fred. V. Theobald says: "That the Rooks do an enormous amount of good there is no doubt, at the same

* Dumfries Courier, May 24th, 1853.

$\dagger$ Dumfries Courier and Herald, February 16th, 1895. 
time everyone acknowledges that they do some harm."* They are eager devourers of wire-worms and cockchafers, and have on more than one occasion helped to check phenomenal plagues of the larvee of the antler-moth or hill grub (Charceas graminis) when they have been devastating our upland pastures. Thus, so early as 1765 we read in an account of Eskdalemuir, of " a species of worms which destroyed the grass by cutting its roots. They were of a green colour, and about an inch long. They appeared about the end of May, and continued till the beginning of August, when they were destroyed by great flocks of crows and heavy rains." $\dagger$ Again in 1802, 1812 and 1824, when this pest was rampant, we learn of great incursions of Rooks to those parts most affected, as also in 1843 and 1885 .

During the vole-plague of 1891-1893, when some fortyseven to fifty thousand acres were damaged in the north of the county from Eskdalemuir by Moffat to Thornhill, the "greatest service was rendered by the Rooks, which tore out the nests and destroyed thousands of young voles," $\ddagger$ and the Committee appointed to enquire into the cause of the vole-plague was led to report on the "excellent services" of the Rook, "which it is to be hoped no short-sighted policy will greatly reduce in numbers." § Indeed, some authorities attributed the visitation of the voles in such numbers to the previous excessive persecution of Hawks, Owls and Rooks. All this to the credit side of the Rooks' account. Now the debit side : damage done to newly-sown corn and potato-fields in spring, to the corn when cut and in "stooks" or sheaves, and to turnips in winter by picking holes in the bulbs. Add to these faults all the crimes attributed to the CarrionCrow and you have a serious total of defalcations.

* Science Progress, 1907, Vol. II., p. 269.

$\dagger$ Stat. Acct. Scot., Vol. XII., pp. 610, 611.

¥ Mammals of Great Britain, Vol. II., p. 276.

§ Report Field Voles Scot. (C. 6943), 1893, p. 13. 
In 1870 came a great change in their habits. "Previous to that time they attacked the farmers' growing and harvested crops at the same time that they were destroying untold quantities of grubs and noxious insects." But, at about this period, "eggs of all kinds, young birds, small rodents, young rabbits, chickens and ducklings were devoured as greedily as ever the Carrion-Crow did the same thing. At the same time came a curious structural alteration. The feathers round the base of the bill, which always used to fall off during the young Rooks' first summer and winter, were in many cases retained for years. There is no doubt this retention of these feathers was the-direct result of the assumption of Carrion-Crow habits by the Rooks. . . . The cause of such a sudden change to what may be considered ancestral habits ... is rather obscure... [and] Mr. John HarvieBrown . . . traces it to two causes. The first one is the immense increase of the Starling, depriving the Rooks of their grub and insect food. The other is the practice all over the country of spreading on the fields near the larger towns of so-called scavenger's manure or refuse. Eggshells and garbage of all kinds are amongst the stuff, and the Rooks compelled to forage amongst it, coon learned a bad lesson."* Nowadays they are justly regarded by gamekeepers as equally destructive to an exposed nest of eggs as any Carrion-Crow ; and I once saw one take two half-fledged Mistle-Thrushes out of their nest. Among ground-game they are almost as destructive as they are to the eggs of feathered game, and they have been seen to attack and kill a small leveret. These fresh depredatory habits aroused once more the human ire against the species; and though about 1877 they may have attained to perhaps four-fifths of their maximum number reached in 1830-1835, their numbers to-day are not much more than in 1860 , when they were at their lowest ebb.

A long correspondence for and against the Rook was * Trans. D. and G. Nat. Hist. Soc., November 16th, 1900. 
carried on in two of our local newspapers in 1899, between one of our best Scottish field-naturalists, and an eminent light of the Scotch Kirk (though perhaps not less famous as one of our greatest authorities on agriculture). The letters and their replies at times grew almost acrimonious, but left the matter in statu quo, and I should be sorry to say more than repeat Mr. Fred. V. Theobald's judgment on the species, which I have already quoted. Mr. R. Service deprecates the idea that the Rooks should be exterminated. They should be scared off the fields-and gamekeepers should protect themselves. Certainly the occupation of "crow-herding" has become a dead art.*

"The years 1830-1835 mark the maximum of the Rook population in these south-western counties (i.e., Wigtownshire, Kirkcudbright and Dumfriesshire). The rookeries then round old ancestral homes were a source of pride and satisfaction to their owners." $\dagger$ But the outcry against the species had already begun; for we read in 1826, " The enlightened proprietor of Dalswinton destroys Rooks on his property." $\ddagger$ In the following year a petition signed by one hundred and more farmers was presented to the gentry craving them to put down Rooks.§ In 1838 James Stuart Menteath of Closeburn published a pamphlet,\| in which he deplored the proposed extermination of every rookery in South Ayrshire; on February 14th, 1844, the "Anti-Rook Society" met at Dumfries, resolved to destroy as many Rooks as possible, and inter alia fifty rookeries were to be destroyed, and a Committee was appointed to carry out the above intention in conjunction with the proprietors, who seem to have acquiesced in the resolutions

* Trans. D. and G. Nat. Hist. Soc., March 20th, 1908.

† Kirkcudbright Advertiser, April 6th, 1899.

† Dumfries Courier, May 23rd, 1826.

$\S$ Op. cit., May 8th, 1827.

|| Farmers versus Rooks, 1838. 
passed.* It is believed that about 1860 the Rooks in the county were at their lowest numerical strength, and that from that time onwards they were in the ascendant. Mrs. Pollock writes me that about 1866 " The Rooks had innumerable nests in the old wood (Dalswinton). On a summer's night (put early to bed!) I have lain by the nursery window, watching them flying home from the White Hill ; the sky would be black with them, their flight overhead would occupy at least an hour and a half-a wide stretch, apparently one hundred and eighty yards. It looked like a river."

Certain woods are resorted to as roosts, perhaps the most notable being Woodcockair (Annan), where thousands upon thousands of Rooks flock nightly throughout the summer, autumn and winter months. A similar but smaller resort is in what remains of the old wood at Dalswinton (Kirkmahoe) where, Mr. T. Ranken tells me, they come in thousands to roost at all times but the spring. Other woods in different parts of the county are also resorted to, but none are more patronized than that at Woodcockair.

In so common a species varieties in coloration are to be expected. The rookery at Castledykes in Dumfries became at one time famous for its white Rooks. A fullgrown one which had left the rookery was shot in June, 1834, near Craigs (Dumfries), and passed into the possession of Mr. Shanks of Friars Vennel. $\dagger$ Another is recorded in 1835 "Discovered on the very tree occupied by the previous one. Its eyes are a delicate light-blue. Its body, a duskywhite, no black feathers, the legs the same colour as the body" + ; and in 1847, "The rookery at Castledykes has ... again produced one this year, which was caught on the Kingholm Road. It is a handsome young bird of

* Dumfries Courier, May 6th, 1844.

$\dagger$ Op. cit., June 18th, 1834.

$\ddagger$ Op. cit., May 20th, 1835 . 
a pure cream colour."* Writing in 1853 of the large rookery at Jardine Hall, Sir William Jardine says : "Although we have never had an entire white or creamcoloured variety, scarcely a year passes without some young being observed with more or less white in the plumage, and in these the bill and feet, as well as the claws, are also white." $\dagger$ Richard Bell of Castle O'er records an albino Rook, more cream-coloured than white, the legs and beak being equally cream-coloured and the eyes red. Dr. Grierson thus records a variety of this bird. "Young bird with white markings on the feathers from Barjarg in Keir about 1865, presented by Mr. Thos. Maxwell, Allanton Mill, July, 1867 "§; and this specimen, as well as one of a brown Rook, are still to be seen in Grierson's Museum, Thornhill. Mr. R. Service is of the opinion that brown birds are not very rare, and that this variation only lasts till the adult plumage is attained. "A Rook of a dark chocolate-brown colour, with indistinct darker vermiculations when held to the light," is recorded by "Mabie Moss," $\|$ and a similar variety was shot by Mr. John Kennedy at Priestside (Cummertrees).

A Rook with three legs was reported from Gribton (Holywood) in May, 1854, 9 and abnormalities in the growth of the beak of this bird, caused presumably by being caught in a trap, are frequently recorded.

Rooks, when they are seen diving and tumbling in the air towards evening, are popularly supposed to foretell rain.

The following list of rookeries in the county has been prepared mostly from answers to circulars sent by me throughout the county in May, 1908:

* Dumfries Courier, May 18th, 1847.

$\dagger$ White's Selborne, 1853, p. 37.

¥My Strange Pets, p. 221.

$\S$ Cat. Contents of Museum.

|| Dumfries Courier and Herald, May 30th, 1891.

If Dumfries Courier, May 16th, 1854. 
ROOKERIES.

\begin{tabular}{|c|c|c|c|c|c|}
\hline \multirow[b]{2}{*}{ Place. } & \multicolumn{3}{|c|}{ Nests. } & \multirow{2}{*}{$\begin{array}{c}\text { Remarks. How long } \\
\text { in existence, etc. }\end{array}$} & \multirow{2}{*}{$\begin{array}{l}\text { Source of } \\
\text { information. }\end{array}$} \\
\hline & Situation. & $\begin{array}{c}\text { Maxi- } \\
\text { mum No. } \\
\text { about. }\end{array} \mid$ & $\begin{array}{l}\text { No. in } \\
1908 .\end{array}$ & & \\
\hline \multicolumn{6}{|c|}{ Parish of ANNAN. } \\
\hline Mount Annan & $\begin{array}{l}\text { Scots Fir, Lime, } \\
\text { Beech, Ash, } \\
\text { Oak, Plane. }\end{array}$ & 1,500 & 1,000 & $\begin{array}{l}\text { Known to have exis- } \\
\text { ted at least one } \\
\text { hundred years. }\end{array}$ & $\begin{array}{l}\text { P. A. Pasley- } \\
\text { Dirom, } \\
\text { 29.v.1908. }\end{array}$ \\
\hline Greenbank .. & $\cdots$ & $\cdots$ & $\cdots$ & In Annan Burgh & Do. \\
\hline The Moat .. & $\ldots$ & $70-80$ & 30 & $\begin{array}{llll}\text { Do. } & \ldots & \ldots & \ldots \\
\end{array}$ & Do. \\
\hline \multirow[t]{2}{*}{ Fruids Park .. S } & \multirow[t]{2}{*}{ Small Ash } & \multirow[t]{2}{*}{$\cdots$} & \multirow{2}{*}{ I } & $\begin{array}{l}\text { Do. An offishoot from } \\
\text { The Moat, since } \\
\text { about 1902. }\end{array}$ & $\begin{array}{l}\text { J. W. Payne, } \\
\text { 3.vi.1908. }\end{array}$ \\
\hline & & & & $\begin{array}{l}\text { Between thirty and } \\
\text { forty years ago there } \\
\text { were only two prin- } \\
\text { cipal rookeries in } \\
\text { the district, Mount } \\
\text { Annan and Wood- } \\
\text { cockair. Of late } \\
\text { years they have } \\
\text { built their nests } \\
\text { almost everywhere, } \\
\text { even in trees in the } \\
\text { middle of Annan, a } \\
\text { thing unknown up } \\
\text { to now. They cer- } \\
\text { tainly have in- } \\
\text { creased, though the } \\
\text { numbers appear to } \\
\text { be more widely } \\
\text { spread. Woodcock- } \\
\text { air is still a remark- } \\
\text { able roost in autumn } \\
\text { and winter, though, } \\
\text { since about 1875, } \\
\text { the Rooks no longer } \\
\text { nest there. }\end{array}$ & $\begin{array}{l}\text { W. Wright, } \\
\text { 20.v.1908. }\end{array}$ \\
\hline
\end{tabular}

Parish of APPLegarth.

\begin{tabular}{|c|c|c|c|c|c|}
\hline \multirow[t]{2}{*}{ Jardine Hall .. } & \multirow[t]{2}{*}{$\begin{array}{l}\text { Beech, Oak, Scots } \\
\text { Fir. }\end{array}$} & . & . & $\begin{array}{l}\text { A large rookery in } \\
1853 .\end{array}$ & $\begin{array}{l}\text { White's Selborne, } \\
\text { Ed. 1853, p. } 37 . \\
\end{array}$ \\
\hline & & $\begin{array}{l}\mathbf{1}, 500- \\
\mathbf{2}, 000\end{array}$ & $\begin{array}{l}\text { about } \\
1,020\end{array}$ & $\begin{array}{l}\text { Very ancient, would } \\
\text { increase if not kept } \\
\text { in check. Still a } \\
\text { great many nests. } \\
\end{array}$ & $\begin{array}{l}\text { S. Copland, } \\
\text { 19.ix.1908. }\end{array}$ \\
\hline Balgray & 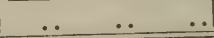 & $\ldots$ & $\cdots$ & Not very large & Do. \\
\hline
\end{tabular}




\section{BIRDS OF DUMFRIESSHIRE}

ROOKERIES-continued.

\begin{tabular}{|c|c|c|c|c|c|}
\hline \multirow[b]{2}{*}{ Place. } & \multicolumn{3}{|c|}{ Nests. } & \multirow[b]{2}{*}{$\begin{array}{c}\text { Remarks. How long } \\
\text { in existence, otc. }\end{array} \mid$} & \multirow[b]{2}{*}{$\begin{array}{l}\text { Source of } \\
\text { information. }\end{array}$} \\
\hline & Situation. & $\left|\begin{array}{c}\text { Maxi- } \\
\text { mum No. } \\
\text { about. }\end{array}\right|$ & $\begin{array}{l}\text { No. in } \\
1908 .\end{array}$ & & \\
\hline \multicolumn{6}{|c|}{ PARISH of Cakriaterock. } \\
\hline Wardlaw Hill & Oak, Scots Fir & . & 100 & $\begin{array}{c}\text { Came about } 1887 \\
\text { now greatly reduced. }\end{array}$ & $\begin{array}{l}\text { P. Smith, } \\
\text { 19.vi.1908. }\end{array}$ \\
\hline Hutton Hall .. & Oak, Scots Fir & 400 & 50 & \begin{tabular}{|l|} 
Came about 1860, \\
reached maximum \\
1890, now much \\
reduced.
\end{tabular} & Do. \\
\hline
\end{tabular}

Parish of Canonbie.

\begin{tabular}{|c|c|c|c|c|c|}
\hline Crow Wood ... & Every variety ... & .. & .. & \begin{tabular}{cc} 
Practically & \multicolumn{2}{c}{ cleaned } \\
out, used & to be \\
thousands.
\end{tabular} & $\begin{array}{l}\text { W. Laidlaw, } \\
\text { 6.vi.1908. }\end{array}$ \\
\hline Irvine House & $\cdots \quad \cdots$ & 6 & 3 & $\begin{array}{l}\text { Probably in existence } \\
\text { for more than thirty } \\
\text { years. }\end{array}$ & $\begin{array}{l}\text { J. H. Milne- } \\
\text { Home, } \\
\text { 30.v.1908. } \\
\end{array}$ \\
\hline $\begin{array}{l}\text { Auchanrivoch } \\
\text { Bank. }\end{array}$ & -. & 15 & 10 & $\begin{array}{llll}\text { Do. } & \ldots & \ldots & \ldots \\
\end{array}$ & Do. \\
\hline Sark Tower .. & Oak & 30 & . & $\begin{array}{l}\text { Came about } 1858 \text { or } \\
1868 \text {. None now. }\end{array}$ & $\begin{array}{l}\text { S. Copland, } \\
30 . v .1908 \\
\end{array}$ \\
\hline Forge & High old Beech ... & 15 & $\cdots$ & None now $\quad .$. & Do. \\
\hline Brockwoodlees & Old Scots Fir & 8 & .. & Do. ... & Do. \\
\hline $\begin{array}{l}\text { Nether Wood- } \\
\text { houselees. }\end{array}$ & .. & $\cdots$ & $\cdots$ & $\cdots \quad \ldots$ & Do. \\
\hline Parkhouse .. & . $\quad \ldots$ & $\ldots$ & $\ldots$ & . & Do. \\
\hline
\end{tabular}

PARISH OF Closebura.

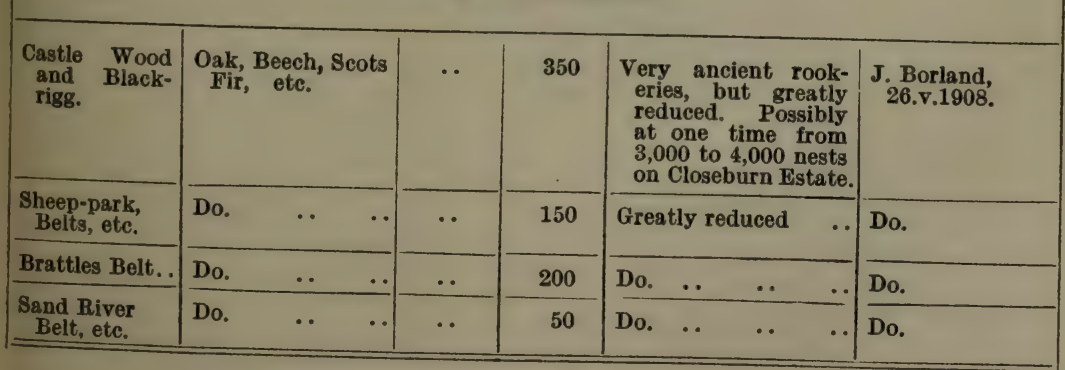


ROOKERIES-continued.

\begin{tabular}{|c|c|c|c|c|c|}
\hline \multirow{2}{*}{ Place. } & \multicolumn{3}{|c|}{ Nests. } & \multirow{2}{*}{$\begin{array}{l}\text { Remarks. How long } \\
\text { in existence, ete. }\end{array}$} & \multirow{2}{*}{$\begin{array}{l}\text { Source of } \\
\text { information. }\end{array}$} \\
\hline & Situation. $\mathrm{m}$ & $\begin{array}{c}\text { Maxi- } \\
\text { mum No. } \\
\text { about. }\end{array}$ & $\begin{array}{l}\text { No. in } \\
1908 .\end{array}$ & & \\
\hline \multicolumn{6}{|c|}{ PARISH OP CUMMERTREES. } \\
\hline Murraythwaite & Beech and Oak .. & .. & 220 & Since about $1896 \quad$.. & $\begin{array}{l}\text { W. Murray, } \\
\text { 3.v.1908. }\end{array}$ \\
\hline Glen Stuart .. & Beech and Fir .. & . & 150 & $\begin{array}{l}\text { Came about 1898, } \\
\text { when there were } \\
\text { two nests, subse- } \\
\text { quently increased, } \\
\text { but for the last six } \\
\text { or seven years have } \\
\text { not done so. } \\
\end{array}$ & $\begin{array}{l}\text { Sir Beaumont } \\
\text { Dixie, Bart., } \\
\text { 16.xi.1908. }\end{array}$ \\
\hline Hoddom & $\cdots \quad \cdots$ & . & 200 & 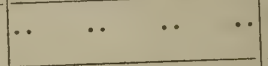 & $\begin{array}{l}\text { E. J. Brook, } \\
\text { 17.ii.1909. }\end{array}$ \\
\hline Forkhill & . & $\ldots$ & 200 & $\ldots$ & Do. \\
\hline \multicolumn{6}{|c|}{ PARISI OF DALTON. } \\
\hline Denbie House & $\begin{array}{l}\text { Tall Beech and } \\
\text { Scots Fir. }\end{array}$ & .. & $90-100$ & $\begin{array}{l}\text { At one time very } \\
\text { large; now much } \\
\text { decreased. }\end{array}$ & \begin{tabular}{|c|} 
J. E. Hall, \\
11.xi.1908.
\end{tabular} \\
\hline Kirkwood .. & Oak and Fir & . & $800-900$ & $\begin{array}{l}\text { Birds only breed here, } \\
\text { leaving about the } \\
\text { end of September. }\end{array}$ & $\begin{array}{c}\text { A. J. Steel, } \\
\text { 23.xi.1908. }\end{array}$ \\
\hline Dormont & $\begin{array}{l}\text { Sycamore, Elm, } \\
\text { Beech and Silver } \\
\text { Fir, etc. }\end{array}$ & .. & $200-300$ & $\begin{array}{l}\begin{array}{l}\text { From time } \\
\text { memorial, } \\
\text { reduced in } \\
\text { greatly } \\
\text { recents. }\end{array} \\
\end{array}$ & \begin{tabular}{|l} 
Major F. J. \\
Carruthers, \\
25.xi.1908. \\
\end{tabular} \\
\hline
\end{tabular}

PARISH OF DORYOCK.

\begin{tabular}{|c|c|c|c|c|c|}
\hline Robgill Tower & $\begin{array}{l}\text { Tall Ash, Oak and } \\
\text { Fir. }\end{array}$ & .. & 150 & $\begin{array}{l}\text { Greatly diminished. } \\
\text { (See Woodhouse, } \\
\text { parish of Kirkpat- } \\
\text { rick-Fleming.) } \\
\end{array}$ & $\begin{array}{l}\text { W. Bell, } \\
\text { 20.viii.1908. }\end{array}$ \\
\hline Stapleton & $\begin{array}{l}\text { Tall Ash, some } \\
\text { Scots Fir, mostly } \\
\text { Oak. }\end{array}$ & .. & 180 & An ancient rookery .. & $\begin{array}{c}\text { Major E. A. } \\
\text { Critchley, } \\
\text { 19.vi.1908. }\end{array}$ \\
\hline
\end{tabular}




\section{BIRDS OF DUMFRIESSHIRE}

ROOKERIES-continued.

\begin{tabular}{|c|c|c|c|c|c|}
\hline \multirow{2}{*}{ Place. } & \multicolumn{3}{|c|}{ Nests. } & \multirow[b]{2}{*}{$\begin{array}{l}\text { Remarks. How long } \\
\text { in existence, ete. }\end{array}$} & \multirow[b]{2}{*}{$\begin{array}{l}\text { Source of } \\
\text { information. }\end{array}$} \\
\hline & Situation. & $\left|\begin{array}{c}\text { Maxi- } \\
\text { mum No. } \\
\text { about. }\end{array}\right|$ & $\begin{array}{l}\text { No. in } \\
1908 .\end{array}$ & & \\
\hline
\end{tabular}

PARISH OF DRYFesdale.

\begin{tabular}{|c|c|c|c|c|c|c|}
\hline St. Michaels .. & $\cdots$ & . $\quad$. & 200 & 80 & $\begin{array}{l}\text { At least sixty years } \\
\text { old, decreasing. }\end{array}$ & $\begin{array}{c}\text { C. Sanderson, } \\
16.1 i .1909 . \\
\end{array}$ \\
\hline $\begin{array}{c}\text { Lockerbie } \\
\text { Burgh. }\end{array}$ & $\cdots$ & $\cdots$ & . & . & $\begin{array}{l}\text { A few nests near } \\
\text { police station. }\end{array}$ & \begin{tabular}{|c|} 
S. Copland, \\
19.ix.1908. \\
\end{tabular} \\
\hline Bishopcleuch.. & $\cdots$ & .. & 150 & 50 & Decreasing $\quad$. & $\begin{array}{l}\text { C. Sanderson, } \\
\text { 16.ii.1909. } \\
\end{array}$ \\
\hline Underwood ... & Oak and & Beech ... & .. & 100 & Do. .. & $\begin{array}{l}\text { Campbell Wilson, } \\
\text { 4.v.1908. }\end{array}$ \\
\hline
\end{tabular}

Parish of DUMrries.

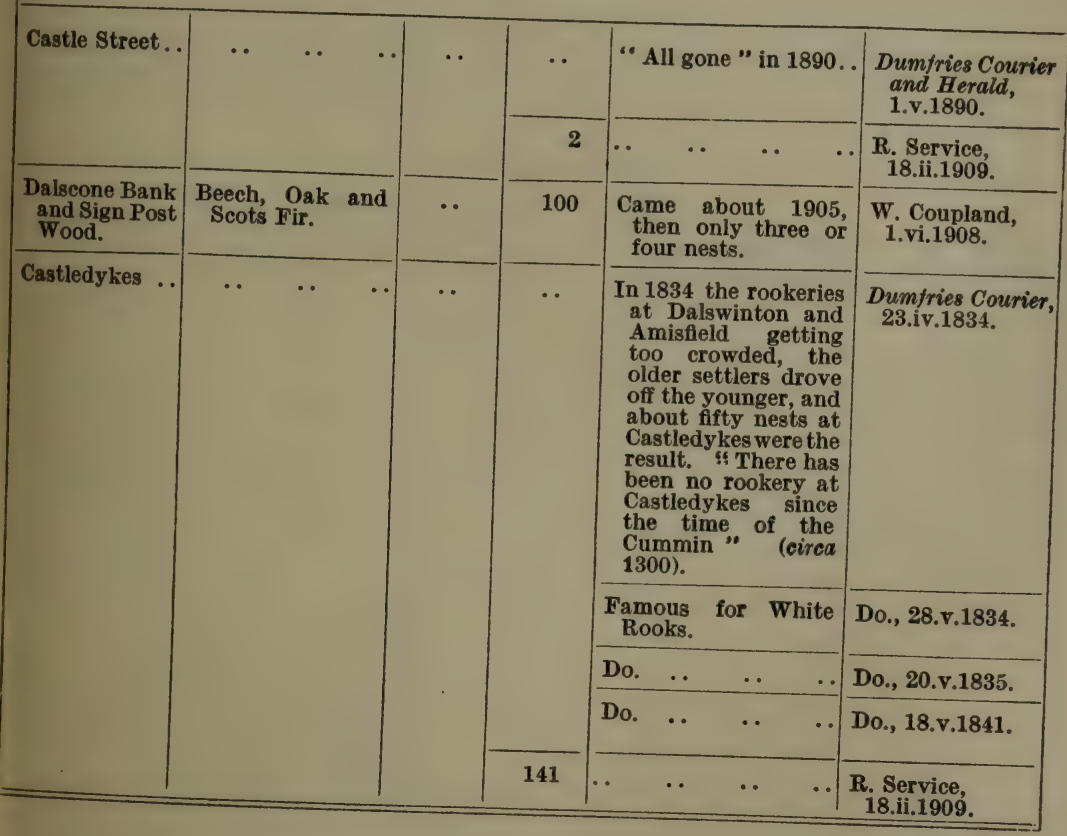




\section{ROOKERIES-continued.}

\begin{tabular}{|c|c|c|c|c|c|c|}
\hline \multirow{2}{*}{ Place. } & \multicolumn{4}{|c|}{ Nests. } & \multirow{2}{*}{$\begin{array}{c}\text { Remarks. How long } \\
\text { in existence, etc. }\end{array}$} & \multirow{2}{*}{$\begin{array}{l}\text { Source of } \\
\text { information. }\end{array}$} \\
\hline & \multicolumn{2}{|l|}{ Situation. } & $\left|\begin{array}{c}\text { Maxi- } \\
\text { mum No. } \\
\text { about. }\end{array}\right|$ & $\begin{array}{l}\text { No. in } \\
1908 .\end{array}$ & & \\
\hline \multicolumn{7}{|c|}{ PARISH OF DUNSCORE. } \\
\hline Dalgonar $\quad \cdots$ & Old Scots Fir & .. & . & $150-200$ & $\begin{array}{l}\text { Over thirty-five years } \\
\text { at least. }\end{array}$ & $\begin{array}{r}\text { R. Martin, } \\
\text { 18.xi.1908. }\end{array}$ \\
\hline Laggan & $\cdots$ & $\cdots$ & $\cdots$ & $\cdots$ & $\begin{array}{llll} & \ldots & \ldots & \ldots \\
\end{array}$ & Do. \\
\hline Upper Linburn & Tall Scots Fir & $\cdots$ & $\cdots$ & 40 & $\begin{array}{l}\text { Has decreased ; at } \\
\text { one time the farmer } \\
\text { got a suit of clothes } \\
\text { annually out of the } \\
\text { sale of young Rooks } \\
\text { sold at } 1 \frac{1}{2} \mathrm{~d} \text {. each. }\end{array}$ & Do. \\
\hline Friars Carse ... & $\begin{array}{l}\text { Beech, Oak an } \\
\text { Plane. }\end{array}$ & & $\cdots$ & $\begin{array}{r}700- \\
1,000\end{array}$ & $\begin{array}{l}\text { Thirty-one nests in } \\
\text { one large Plane. } \\
\text { Increasing annually. } \\
\text { In existence since } \\
\text { time immemorial. }\end{array}$ & $\begin{array}{l}\text { P. Jeffreys, } \\
\text { 3.v.1908. }\end{array}$ \\
\hline Sundaywell ... & $\cdots$ & $\cdots$ & $\cdots$ & 30 & $\begin{array}{l}\text { A fairly old rookery, } \\
\text { neither increasing } \\
\text { nor decreasing. }\end{array}$ & $\begin{array}{c}\text { R. F. Brown, } \\
\text { 24.vi.1909. }\end{array}$ \\
\hline Greenhead ... & $\cdots$ & $\cdots$ & $\cdots$ & 20 & $\begin{array}{l}\text { In existence sixteen } \\
\text { years at least. }\end{array}$ & $\begin{array}{l}\text { B. Armstrong, } \\
\text { 9.vii.1909. }\end{array}$ \\
\hline
\end{tabular}

\section{Parish of EskdaLEMUIR.}

\begin{tabular}{|l|l|c|c|c|c|}
\hline Crurie.. $\quad .$. & $\begin{array}{l}\text { Tall Spruce, Ash, } \\
\text { etc. }\end{array}$ & 150 & $\ldots$ & \begin{tabular}{|} 
From time immemorial, \\
but now cleaned out.
\end{tabular} & $\begin{array}{c}\text { Rev. R. Bell, } \\
\text { 25.v.1908. }\end{array}$ \\
\hline
\end{tabular}

PARISH OF EWES.

\begin{tabular}{|c|c|c|c|c|c|c|}
\hline Sorbie & Scots Fir.. & $\cdots$ & .. & 12 & Greatly reduced $\quad$.. & $\begin{array}{c}\text { W. Laidlaw, } \\
\text { 6.vi.1908. }\end{array}$ \\
\hline Unthank .. & .. & $\cdots$ & . & .. & $\begin{array}{l}\text { About 1880, three } \\
\text { hundred nests; now } \\
\text { almost extinct. }\end{array}$ & $\begin{array}{l}\text { J. Pringle, } \\
20 . \text { ix.1908. }\end{array}$ \\
\hline Mosspebble ... & .. & .. & .. & .. & Do. $\quad \ldots \quad \ldots \quad \ldots$ & Do. \\
\hline The Manse ... & .. & . & $\cdot \cdot$ & . & $\begin{array}{l}\text { About } 1860 \text {, nearly } \\
\text { eight hundred nests; } \\
\text { about } 1870 \text { num- } \\
\text { bers of Rooks } \\
\text { were poisoned dur- } \\
\text { ing nesting season, } \\
\text { since when the nests } \\
\text { have become greatly } \\
\text { reduced and now } \\
\text { very few, if any. }\end{array}$ & Do. \\
\hline
\end{tabular}


ROOKERIES-continued.

\begin{tabular}{|c|c|c|c|c|c|}
\hline \multirow[b]{2}{*}{ Place. } & \multicolumn{3}{|c|}{ Nests. } & \multirow[b]{2}{*}{$\begin{array}{c}\text { Remarks. How long } \\
\text { in existence, etc. }\end{array}$} & \multirow[b]{2}{*}{$\begin{array}{c}\text { Source of } \\
\text { information. }\end{array}$} \\
\hline & Situation. & $\left|\begin{array}{c}\text { Maxi- } \\
\text { mum No. } \\
\text { about. }\end{array}\right|$ & $\begin{array}{l}\text { No, in } \\
1908 .\end{array}$ & & \\
\hline \multicolumn{6}{|c|}{ Parish of Glempatrin. } \\
\hline Shaw Wood .. & $\begin{array}{lll}\cdots & \cdots & \cdots\end{array}$ & 80 & $\cdots$ & $\begin{array}{l}\text { Twenty years ago a } \\
\text { large rookery, but } \\
\text { harried out of exist- } \\
\text { ence. They still } \\
\text { come to roost here } \\
\text { in autumn and } \\
\text { winter. }\end{array}$ & C. Laurie. \\
\hline Caitloch & $\begin{array}{l}\text { Beech, Oak, Scots } \\
\text { Fir. }\end{array}$ & 200 & 100 & $\begin{array}{lll}\cdots & \cdots & \cdots \\
\end{array}$ & $\begin{array}{c}\text { W. McCall, } \\
\text { 1.v.1908. }\end{array}$ \\
\hline Barbuie & Ash & 100 & 10 & $\ldots \quad \ldots$ & Do. \\
\hline Dalwhat & $\begin{array}{c}\text { Lime and Scots } \\
\text { Fir. }\end{array}$ & 150 & 1 & $\begin{array}{llll}\cdots & \cdots & \cdots & \cdots \\
\end{array}$ & Do. \\
\hline Snade.. & $\begin{array}{c}\text { Oak and Ash, } \\
\text { about thirty-five } \\
\text { feet high. }\end{array}$ & $\cdots$ & $\begin{array}{c}100 \\
\text { or more. }\end{array}$ & $\begin{array}{l}\text { Now the largest } \\
\text { rookery in parish. }\end{array}$ & $\begin{array}{l}\text { J. Corrie, } \\
\text { 17.ix.1908. }\end{array}$ \\
\hline Shancastle $\quad .$. & Scots Fir .. & $\cdots$ & $10-12$ & $\begin{array}{c}\text { In } 1909 \text { some forty- } \\
\text { eight to fifty nests. }\end{array}$ & $\begin{array}{r}\text { J. E. Steele, } \\
\text { 29.vi.1909. }\end{array}$ \\
\hline Gilmerston ... & $\begin{array}{c}\text { Scots Fir, about } \\
\text { thirty-five } \\
\text { high. }\end{array}$ & $\cdots$ & 60 & Started in 1906 & $\begin{array}{l}\text { R. Martin, } \\
\text { 18.ix.1908. }\end{array}$ \\
\hline
\end{tabular}

PARish of Gretna.

\begin{tabular}{|c|c|c|c|c|c|}
\hline East Scales ... & $\begin{array}{llll}\text { Ash } & \ldots & \ldots & \ldots\end{array}$ & 50 & 50 & $\begin{array}{c}\text { A new rookery within } \\
\text { the last few years, } \\
\text { increasing rapidly. }\end{array}$ & $\begin{array}{l}\text { W. F. Graham, } \\
\text { 26.v.1908. }\end{array}$ \\
\hline Gretna Hall .. & Trees round house & .. & .. & $\begin{array}{lll}. \cdot & \cdots & \end{array}$ & $\begin{array}{l}\text { E. A. Johnson- } \\
\text { Ferguson, } \\
\text { 23.v.1908. } \\
\end{array}$ \\
\hline
\end{tabular}

PARISH OF HODDOM.

\begin{tabular}{|c|c|c|c|c|c|}
\hline \multirow[t]{2}{*}{ Knockhill } & Beech and Oak .. & 397 & 250 & $\begin{array}{l}\text { A very ancient } \\
\text { rookery. The follow- } \\
\text { ing numbers counted } \\
\text { by Mr. D. Bell-Irving } \\
\text { when occupant, 1899, } \\
390 ; 1900,397 \\
1901,376 ; \\
320 ; 1903,314, \\
\text { 1904, 266; slightly } \\
\text { decreasing since 1904. }\end{array}$ & $\begin{array}{l}\text { W. Thorburn, } \\
\text { 12.vi.1908. }\end{array}$ \\
\hline & & & & $\begin{array}{l}\text { A marked decrease } \\
\text { here recently. }\end{array}$ & $\begin{array}{l}\text { C. Sanderson, } \\
\text { 10.ii.1909. }\end{array}$ \\
\hline
\end{tabular}




\section{ROOKERIES-continued.}

\begin{tabular}{|c|c|c|c|c|c|}
\hline \multirow{2}{*}{ Place. } & \multicolumn{3}{|c|}{ Nests. } & \multirow{2}{*}{$\begin{array}{c}\text { Remarks. How long } \\
\text { in existence, etc. }\end{array}$} & \multirow{2}{*}{$\begin{array}{l}\text { Source of } \\
\text { information. }\end{array}$} \\
\hline & Situation. & $\begin{array}{c}\operatorname{Maxi-} \\
\text { mum No. } \\
\text { about. }\end{array}$ & $\begin{array}{l}\text { No. in } \\
1908 \text {. }\end{array}$ & & \\
\hline \multicolumn{6}{|c|}{ PARISH OF HODDOM-continued. } \\
\hline $\begin{array}{l}\text { Aitchison's } \\
\text { Hill. }\end{array}$ & Beech and Oak .. & . & 30 & $\cdots \quad .$. & $\begin{array}{l}\text { C. Sanderson, } \\
1.0 .1 i .1909 . \\
\end{array}$ \\
\hline Shortrigg & Do. $\quad$. & .. & 50 & $\begin{array}{llll} & \ldots & \ldots & \\
\end{array}$ & Do. \\
\hline Crossfield .. & $\begin{array}{l}\text { Beech, Oak and } \\
\text { Elm. }\end{array}$ & 50 & 2 & Destroyed in $1907 \quad$. & $\begin{array}{l}\text { W. Coltherd, } \\
\text { 25.v.1908. }\end{array}$ \\
\hline $\begin{array}{l}\text { Kirkconnel } \\
\text { Hall. }\end{array}$ & Scots Fir... & .. & 150 & $\cdots \quad \cdots \quad \cdots$ & $\begin{array}{l}\text { W. Thorburn, } \\
\text { 12.vi.1908. }\end{array}$ \\
\hline Relief & . $\quad .$. & *. & 100 & $\begin{array}{c}\text { Five hundred and } \\
\text { twenty-five birds } \\
\text { killed in 1907 } \\
\text { seventy-five in } 1908 . \\
\end{array}$ & $\begin{array}{l}\text { C. Sanderson, } \\
\text { 11.ii.1909. }\end{array}$ \\
\hline Burnswark .. & $\begin{array}{l}\text { Scots Fir and } \\
\text { Spruce. }\end{array}$ & .. & 150 & $\cdots \quad \cdots \quad \cdots$ & Do. \\
\hline Newfield & $\ldots$ & .. & 100 & $\begin{array}{l}\text { Three hundred and } \\
\text { forty-three killed } \\
\text { in } 1907 ; \text { eighty- } \\
\text { three in } 1908 \text {. } \\
\end{array}$ & Do. \\
\hline Hoddom Castle & $\begin{array}{l}\text { Beech, Scots Fir } \\
\text { and Birch. }\end{array}$ & .. & 150 & $\begin{array}{l}\text { Reduced a third in } \\
\text { recent years. }\end{array}$ & $\begin{array}{l}\text { W. Brunskill, } \\
\text { 15.vi.1908. }\end{array}$ \\
\hline $\begin{array}{c}\text { Hoddom } \\
\text { Parish } \\
\text { Church. } \\
\end{array}$ & Beech $\quad$. & 30 & 8 & An ancient rookery. & $\begin{array}{l}\text { W. Coltherd, } \\
\text { 25.v.1908. }\end{array}$ \\
\hline \multicolumn{6}{|c|}{ PARISH OF HOLYWOOD. } \\
\hline \multirow[t]{2}{*}{ Gribton } & \multirow[t]{2}{*}{$\begin{array}{l}\text { Beech, } \quad \text { Plane, } \\
\text { Spruce, Yew and } \\
\text { Oak. }\end{array}$} & .. & . & In existence in $1800 .$. & $\begin{array}{l}\text { Dumfries Courier, } \\
\text { 16.v.1854. }\end{array}$ \\
\hline & & 300 & 200 & $\begin{array}{l}\text { Not so numerous as } \\
\text { formerly. }\end{array}$ & $\begin{array}{l}\text { Dr. J. W. Martin, } \\
\text { 8.vi.1908. } \\
\end{array}$ \\
\hline Steilston & Ash & 60 & .. & $\begin{array}{l}\text { All destroyed in } \\
1903 .\end{array}$ & $\begin{array}{l}\text { N. Menzies, } \\
\text { 17.ii.1909. }\end{array}$ \\
\hline Greenhead .. & $\begin{array}{l}\text { Lime, Oak and } \\
\text { Spruce. }\end{array}$ & .. & $30-40$ & $\begin{array}{l}\text { Came here in } 1905 \\
\text { when trees at Glen- } \\
\text { gaber were cut } \\
\text { down. }\end{array}$ & $\begin{array}{l}\text { Dr. J. W. Martin, } \\
\text { 8.vi.1908. }\end{array}$ \\
\hline Broomrigg ... & $\cdots$ & .. & very few & $\ldots$ & Do. \\
\hline Cluden Bank. . & . $\quad \ldots$ & 200 & $20-30$ & $\begin{array}{l}\text { Formerly one hun- } \\
\text { dred and fifty to } \\
\text { two hundred ; now } \\
\text { possibly increasing. } \\
\end{array}$ & $\begin{array}{l}\text { Rev. J. } \\
\text { McCombie, } \\
\text { 22.v.1908. }\end{array}$ \\
\hline Portrack & $\ldots \quad \ldots$ & .. & $200-300$ & . $\quad \ldots$ & Do. \\
\hline Cowhill & Plane, Fir, Oak & . & Do. & Ancient rookery & Do. \\
\hline
\end{tabular}




\section{BIRDS OF DUMFRIESSHIRE}

ROOKERIES-continued.

\begin{tabular}{|c|c|c|c|c|c|}
\hline \multirow[b]{2}{*}{ Place. } & \multicolumn{3}{|c|}{ Nests. } & \multirow[b]{2}{*}{$\begin{array}{c}\text { Remarks. How long } \\
\text { in existence, etc. }\end{array}$} & \multirow[b]{2}{*}{$\begin{array}{c}\text { Source of } \\
\text { information. }\end{array}$} \\
\hline & Situation. & $\left|\begin{array}{c}\text { Maxi- } \\
\text { mum No. } \\
\text { about. }\end{array}\right|$ & $\begin{array}{l}\text { No. in } \\
1908 .\end{array}$ & & \\
\hline
\end{tabular}

Parish of hutton and Corrie.

\begin{tabular}{|c|c|c|c|c|c|c|}
\hline Cowburn & Chiefly & Spruce .. & 70 & 40 & $\begin{array}{l}\text { Have been there these } \\
\text { last thirty years, but } \\
\text { recently many nests } \\
\text { destroyed. }\end{array}$ & $\begin{array}{l}\text { J. McCluskie, } \\
\text { 4.vi.1908. }\end{array}$ \\
\hline Paddockhole.. & Do. &.. & 80 & $30-35$ & $\begin{array}{llll}\text { Do. } & \ldots & \ldots & \ldots \\
\end{array}$ & Do. \\
\hline Shaw ... & Do. & . & .. & 200 & $\begin{array}{l}\text { Formerly in great } \\
\text { numbers, but have } \\
\text { recently been kept } \\
\text { in check. }\end{array}$ & $\begin{array}{l}\text { Col. Rogerson, } \\
\text { 16.ii.1909. }\end{array}$ \\
\hline Marygill & Spruce & $\therefore$ & $\ldots$ & 40 & $\ldots$ & Do. \\
\hline Upper Hutton & Do. & $\ldots$ & $\therefore$ & 10 & $\ldots$ & Do. \\
\hline Winshields .. & Ash and & 1 Sycamore & .. & . & $\begin{array}{l}\text { A small rookery de- } \\
\text { serted about } 1870, \\
\text { when trees were cut } \\
\text { down. }\end{array}$ & Do. \\
\hline
\end{tabular}

PARISH OF KEIR.

\begin{tabular}{|l|c|c|c|c|c|}
\hline Barndennoch.. & Beech and Oak .. & 600 & 130 & $\begin{array}{c}\text { Believed to have come } \\
\text { from Barjarg about } \\
\text { 1865. }\end{array}$ & $\begin{array}{l}\text { C. Hyslop, } \\
\text { 15.vii.1908. }\end{array}$ \\
\hline \hline
\end{tabular}

PARISH OF KIRKMAHOE.

\begin{tabular}{|c|c|c|c|c|c|}
\hline \multirow[t]{3}{*}{ Dalswinton } & \multirow[t]{3}{*}{$\cdots$} & \multirow[t]{3}{*}{.. } & \multirow[t]{3}{*}{$\cdots$} & $\begin{array}{l}\text { "The enlightened pro- } \\
\text { prietor of Dalswin:" } \\
\text { ton destroysRooks." } \\
\end{array}$ & $\begin{array}{l}\text { Dumfries Courier, } \\
\text { 23.v.1826. }\end{array}$ \\
\hline & & & & "Overcrowded" & Do., 23.iv.1834. \\
\hline & & & & $\begin{array}{l}\text { Storm of } 1884 \text { de- } \\
\text { stroyed many trees } \\
\text { and practically for- } \\
\text { saken by 1899. } \\
\text { Though thousands } \\
\text { roost in autumn and } \\
\text { winter, none nest } \\
\text { here now. } \\
\end{array}$ & $\begin{array}{l}\text { T. Ranken, } \\
\text { 28.v.1908. }\end{array}$ \\
\hline \multirow[t]{2}{*}{ Carnsalloch } & \multirow[t]{2}{*}{$\begin{array}{l}\text { Beech, Lime and } \\
\text { Scots Fir. }\end{array}$} & \multirow[t]{2}{*}{.. } & . & $\begin{array}{l}\text { Sadly damaged by } \\
\text { storm of April 28th, } \\
1829 . \\
\end{array}$ & $\begin{array}{l}\text { Dumiries Courier, } \\
\text { 12.v.1829. }\end{array}$ \\
\hline & & & 200 & $\begin{array}{l}\text { In 1894, one thousand } \\
\text { two hundred young } \\
\text { were shot in one day, } \\
\text { now you might get } \\
\text { one hundred. }\end{array}$ & $\begin{array}{l}\text { W. Coupland, } \\
\text { 1.vi.1908. }\end{array}$ \\
\hline
\end{tabular}


ROOKERIES-continued.

\begin{tabular}{|c|c|c|c|c|c|c|}
\hline \multirow[b]{2}{*}{ Place. } & & \multicolumn{3}{|c|}{ Nests. } & \multirow{2}{*}{$\begin{array}{l}\text { Remarks. How long } \\
\text { in existence, etc. }\end{array}$} & \multirow{2}{*}{$\begin{array}{l}\text { Source of } \\
\text { information. }\end{array}$} \\
\hline & & Situation. & $\left|\begin{array}{c}\text { Maxi- } \\
\text { mum No. } \\
\text { about. }\end{array}\right|$ & $\begin{array}{l}\text { No. in } \\
1908 \text {. }\end{array}$ & & \\
\hline \multicolumn{7}{|c|}{ PARISH OF KIRKMAHOR-continued. } \\
\hline Cullievet & .. & $\begin{array}{l}\text { Beech and Scots } \\
\text { Fir. }\end{array}$ & $\cdots$ & 170 & $\begin{array}{l}\text { This rookery started } \\
\text { about fifty years ago } \\
\text { with five nests a an } \\
\text { offshoot from Carn- } \\
\text { salloch. }\end{array}$ & $\begin{array}{l}\text { W. Coupland, } \\
\text { 1.vi.1908. }\end{array}$ \\
\hline Duncow & $\cdots$ & $\begin{array}{l}\text { Oak, Scots Fir, } \\
\text { Ash and Elm. }\end{array}$ & 500 & 300 & ․ $\quad \cdots \quad \cdots \quad \cdots$ & $\begin{array}{l}\text { P. Coleman, } \\
\text { 1.vii.1908. }\end{array}$ \\
\hline
\end{tabular}

PARISH OF KIRKMICHAEL.

\begin{tabular}{l|lll|l|l|l|l}
\hline Over Courance & $\ldots$ &. &. & $\ldots$ & $\ldots$ & $\begin{array}{c}\text { Small ; a long time } \\
\text { in existence. }\end{array}$ & $\mathbf{D}_{\text {i3.xi.1908. }}$ Scott, \\
\hline
\end{tabular}

\section{Parish OF KIRKPATRICK-FLEMING.}

\begin{tabular}{|c|c|c|c|c|c|}
\hline Broats House & $\begin{array}{l}\text { Oak, Elm, Beech } \\
\text { and Fir. }\end{array}$ & 200 & 50 & $\begin{array}{l}\text { At least thirty years. } \\
\text { Fifteen years ago } \\
\text { many trees were } \\
\text { felled, which thus } \\
\text { reduced the accom- } \\
\text { modation. }\end{array}$ & $\begin{array}{l}\text { W. Bell, } \\
\text { 20.viii.1908. }\end{array}$ \\
\hline Mossknow $\quad$. & $\begin{array}{l}\text { High Beech and } \\
\text { Ash. }\end{array}$ & 500 & 450 & $\begin{array}{l}\text { A very old rookery, } \\
\text { but shows signs of } \\
\text { being deserted ; } \\
\text { probably owing to } \\
\text { age of trees and } \\
\text { Rooks being ousted } \\
\text { by Jackdaws and } \\
\text { Starlings. } \\
\end{array}$ & $\begin{array}{l}\text { W. F. Graham, } \\
\text { 26.v.1908. }\end{array}$ \\
\hline Wyseby & Ash $\quad \ldots$ & .. & 200 & $\begin{array}{l}\text { An old rookery, } \\
\text { showing no signs } \\
\text { of being deserted. }\end{array}$ & Do. \\
\hline Hayfield & Scots Fir .. & 100 & 50 & $\begin{array}{l}\text { For at least seventy } \\
\text { years. Being de- } \\
\text { serted as trees are } \\
\text { very old. } \\
\end{array}$ & Do. \\
\hline Scales Bank & Old Ash.. & 100 & 20 & $\begin{array}{l}\text { Being deserted for } \\
\text { East Scales (Gretna), } \\
\text { q.v. }\end{array}$ & Do. \\
\hline Grahamshill . & $\begin{array}{l}\text { Scots Fir on } \\
\text { roadside. }\end{array}$ & 90 & 90 & $\begin{array}{l}\text { An old rookery, and } \\
\text { generally nest very } \\
\text { early. }\end{array}$ & Do. \\
\hline Springkell .. & Mostly Beech .. & $\cdots$ & 6 & $\begin{array}{l}\text { A few nests annually } \\
\text { in different clumps, } \\
\text { but always de- } \\
\text { stroyed. }\end{array}$ & $\begin{array}{l}\text { E. A. Johnson- } \\
\text { Ferguson, } \\
\text { 23.v.1908. }\end{array}$ \\
\hline
\end{tabular}




\section{BIRDS OF DUMFRIESSHIRE}

ROOKERIES-continued.

\begin{tabular}{|c|c|c|c|c|c|}
\hline \multirow[b]{2}{*}{ Place. } & \multicolumn{3}{|c|}{ Nests. } & \multirow[b]{2}{*}{$\begin{array}{l}\text { Remarks. How long } \\
\text { in existence, etc. }\end{array}$} & \multirow[b]{2}{*}{$\begin{array}{c}\text { Source of } \\
\text { information. }\end{array}$} \\
\hline & Situation. & $\left|\begin{array}{c}\text { Maxj- } \\
\text { mum No. } \\
\text { about. }\end{array}\right|$ & $\begin{array}{l}\text { No. in } \\
1908 .\end{array}$ & & \\
\hline
\end{tabular}

PARISH of KIRKPATRIoK-FLEMINa-eontinued.

\begin{tabular}{|c|c|c|c|c|c|}
\hline Woodhouse & $\begin{array}{l}\text { Firs mainly, some } \\
\text { Oak. }\end{array}$ & . & $\begin{array}{l}800- \\
1,000\end{array}$ & \begin{tabular}{|} 
In 1887 a severe storm \\
uprooted many of \\
the trees of the Rob- \\
gill Tower rookery \\
(Dornock) during \\
nes tin g oper a - \\
tions. This seems \\
to have frightened \\
geveral members of \\
the colony, and \\
three nests were \\
built on the other \\
side of the Kirtle, \\
these forming the \\
nucleus of the \\
present great rook- \\
ery. Next spring \\
there were nine, and \\
the third year \\
twenty-one nests.
\end{tabular} & $\begin{array}{l}\text { W. Bell, } \\
\text { 20.viii.1908. }\end{array}$ \\
\hline
\end{tabular}

PARISH OF LANGHOLM.

\begin{tabular}{|c|c|c|c|c|c|c|}
\hline 'Greenbank .. & $\begin{array}{r}\text { Plane, Be } \\
\text { Scots Fi }\end{array}$ & $\begin{array}{l}\text { eech and } \\
\text { ir. }\end{array}$ & $\cdots$ & 100 & Protected .. & $\begin{array}{c}\text { W. Laidlaw, } \\
\text { 6.vi.1908. }\end{array}$ \\
\hline Edensholm ... & $\begin{array}{l}\text { Every } \\
\text { mostly }\end{array}$ & $\begin{array}{l}\text { variety, } \\
\text { Oak. }\end{array}$ & 50 & .. & $\begin{array}{l}\text { Used to be about } \\
\text { ffty, now cleaned } \\
\text { out. }\end{array}$ & Do. \\
\hline $\begin{array}{l}\text { Townhead } \\
\text { Church. }\end{array}$ & $\cdots$ & .. & .. & 90 & $\begin{array}{l}\text { In existence a num- } \\
\text { ber of years ; not } \\
\text { so numerous as last } \\
\text { year. } \\
\end{array}$ & $\begin{array}{l}\text { w. Haining, } \\
\text { 1.v.1908. }\end{array}$ \\
\hline${ }^{*}$ Erkinholm .. & $\cdots$ & $\cdots$ & $\cdots$ & $20-30$ & $\cdots \quad \cdots$ & $\begin{array}{l}\text { J. H. Milne- } \\
\text { Home, } \\
\text { 30.v.1908. }\end{array}$ \\
\hline $\begin{array}{l}\text { 'Langholm } \\
\text { Burgh. }\end{array}$ & *. & $\cdots$ & 80 & 60 & $\begin{array}{l}\text { In existence thirty } \\
\text { years or more, for- } \\
\text { merly more numer- } \\
\text { ous. }\end{array}$ & $\begin{array}{l}\text { J. Smith, } \\
\text { 4.v.1908. }\end{array}$ \\
\hline
\end{tabular}

Practically one and the same rookery ; and over estimated.-J. H. Milne-Home, 19.iv.1908. 
ROOKERIES-continued.

\begin{tabular}{|c|c|c|c|c|c|}
\hline \multirow[b]{2}{*}{ Place. } & \multicolumn{3}{|c|}{ Nests. } & \multirow[b]{2}{*}{$\begin{array}{l}\text { Remarks. How long } \\
\text { in existence, etc. }\end{array}$} & \multirow[b]{2}{*}{$\begin{array}{l}\text { Source of } \\
\text { information. }\end{array}$} \\
\hline & Situation. & $\mid \begin{array}{c}\text { Maxi- } \\
\text { mum No. } \\
\text { about. }\end{array}$ & $\begin{array}{l}\text { No. in } \\
1908 .\end{array}$ & & \\
\hline \multicolumn{6}{|c|}{ Parish of Lochmaber. } \\
\hline *Broadchapel.. & $\begin{array}{l}\text { Ash, Lime and a } \\
\text { few Scots Fir. }\end{array}$ & .. & 100 & $\begin{array}{l}\text { Came here in } 1902 . \\
\text { In 1906, seventy- } \\
\text { eight nests. Trees } \\
\text { cut down in March, } \\
1909 . \\
\end{array}$ & $\begin{array}{l}\text { W. J. Halliday, } \\
\text { 27.iii.1909. }\end{array}$ \\
\hline *Broomwood .. & .. & 250 & 200 & $\begin{array}{llll} & \ldots & \ldots & \ldots \\
\end{array}$ & Do. \\
\hline \multirow[t]{2}{*}{ *Bruce's Castle } & 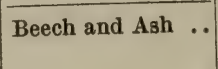 & $\cdots$ & .. & $\begin{array}{l}\text { Boy killed by falling } \\
\text { off tree in rookery. }\end{array}$ & $\begin{array}{l}\text { Dumfries Courier, } \\
\text { 24.v.1859. } \\
\end{array}$ \\
\hline & & & 150 & $\begin{array}{l}\text { In existence very } \\
\text { many years. Rooks } \\
\text { very numerous in } \\
\text { parish. } \\
\end{array}$ & $\begin{array}{l}\text { W. J. Halliday, } \\
\text { 8.vi.1908. }\end{array}$ \\
\hline $\begin{array}{c}\text { *Thornie- } \\
\text { thwaite }\end{array}$ & Ash & .. & .. & $\cdots$ & $\begin{array}{l}\text { G. Underwood, } \\
\text { jun., 28.v. 1908. }\end{array}$ \\
\hline
\end{tabular}

* All these four rookeries are kept in check and are decreasing.-J. Pringle, 4. v. 1908.

PARISH OF MIDDLEBIE.

\begin{tabular}{|c|c|c|c|c|c|c|}
\hline $\begin{array}{l}\text { Blackwood } \\
\text { House. }\end{array}$ & In trees & at gate.. & . & small & $\begin{array}{lll}* & \cdots & \cdots\end{array}$ & $\begin{array}{l}\text { E. A. Johnson- } \\
\text { Ferguson, } \\
\text { 23.v.1908. }\end{array}$ \\
\hline Craigs.. & . & .. & $\cdots$ & $70-100$ & $\begin{array}{l}\text { A rookery number- } \\
\text { ing consi derably } \\
\text { over one hundred, } \\
\text { existed till 1904 } \\
\text { at Between - the - } \\
\text { Waters. On being } \\
\text { evicted by the } \\
\text { keepers on Spring- } \\
\text { kell Estate, the } \\
\text { Rooks migrated to } \\
\text { Craigs, about half } \\
\text { a mile from their } \\
\text { old home. } \\
\end{array}$ & $\begin{array}{l}\text { J. Campbell, } \\
\text { 30.v.1908. }\end{array}$ \\
\hline $\begin{array}{l}\text { Waterbeck } \\
\text { Village. }\end{array}$ & Beech & -. & .. & small & $\begin{array}{l}\text { A small offshoot from } \\
\text { the same rookery } \\
\text { has taken up house } \\
\text { on some beech trees. }\end{array}$ & Do. \\
\hline $\begin{array}{c}\text { Burnfoot } \\
\text { Covert. }\end{array}$ & .. & . & 100 & 100 & Over thirty-five years & \begin{tabular}{|l} 
J. Dalziel, \\
2.vi.1908.
\end{tabular} \\
\hline Braes Estate. & .. & .. & 100 & 80 & Do. ... & Do. \\
\hline
\end{tabular}




\section{BIRDS OF DUMFRIESSHIRE}

ROOKERIES-continued.

\begin{tabular}{|c|c|c|c|c|c|}
\hline \multirow[b]{2}{*}{ Place. } & \multicolumn{3}{|c|}{ Nests. } & \multirow[b]{2}{*}{$\begin{array}{l}\text { Remarks. How long } \\
\text { in existence, etc. }\end{array}$} & \multirow[b]{2}{*}{$\begin{array}{l}\text { Source of } \\
\text { information. }\end{array}$} \\
\hline & Situation. & $\left|\begin{array}{c}\text { Maxi- } \\
\text { mum No. } \\
\text { about. }\end{array}\right|$ & $\begin{array}{l}\text { No. in } \\
1908 .\end{array}$ & & \\
\hline
\end{tabular}

Parish of Moffat.

\begin{tabular}{|c|c|c|c|c|c|}
\hline $\begin{array}{l}\text { Craigieburn } \\
\text { Wood. }\end{array}$ & $\begin{array}{l}\text { Oak, Ash, Elm, } \\
\text { Beech and Scots } \\
\text { Fir. }\end{array}$ & $\cdots$ & 200 & $\begin{array}{l}\text { Came here about } \\
\text { 1858-1868, after } \\
\text { Dumcrieff rookery } \\
\text { was destroyed. De- } \\
\text { creasing. }\end{array}$ & $\begin{array}{l}\text { J. T. Johnstone, } \\
\text { 4.vi.1908. } \\
\end{array}$ \\
\hline $\begin{array}{l}\text { Heathery } \\
\text { Haugh. }\end{array}$ & $\begin{array}{l}\text { Oak, Ash and } \\
\text { Beech. }\end{array}$ & 80 & 50 & $\begin{array}{l}\text { In existence ever since } \\
\text { I can remember, but } \\
\text { has decreased till } \\
\text { recently. }\end{array}$ & Do. \\
\hline Archbank & $\begin{array}{l}\text { Oak, Ash and } \\
\text { Elm. }\end{array}$ & $\cdots$ & 34 & Since about $1868 \ldots$ & $\begin{array}{l}\text { G. Kerss, } \\
\text { 4.vi.1908. } \\
\end{array}$ \\
\hline Ballplay & $\begin{array}{lll}\cdots & \cdots & \cdots\end{array}$ & $\cdots$ & 40 & $\begin{array}{l}\text { Their appearance here } \\
\text { is synchronous with } \\
\text { the decrease at } \\
\text { Heathery Haugh, } \\
\text { vide supra. }\end{array}$ & $\begin{array}{l}\text { J. T. Johnstone, } \\
\text { 4.vi.1908. }\end{array}$ \\
\hline Parish Church & $\ldots \quad \ldots$ & $\cdots$ & $70-80$ & Since $1898 \quad \ldots$ & Do. \\
\hline Emu Villa $\ldots$ & . $\quad \ldots$ & $\ldots$ & 26 & $\begin{array}{lll}\text { Since } 1902 & \ldots & \ldots \\
\end{array}$ & Do. \\
\hline Laurencefleld & $\ldots$ & $\cdots$ & $\cdots$ & $\cdots$ & Do. \\
\hline Dumcrieff $\quad \ldots$ & Beech & $\cdots$ & $\cdots$ & $\begin{array}{l}\text { Used to be large: } \\
\text { now almost non- } \\
\text { existent. }\end{array}$ & $\begin{array}{l}\text { G. Kerss, } \\
\text { 4.v.1908. }\end{array}$ \\
\hline $\begin{array}{l}\text { Shortwood } \\
\text { End. }\end{array}$ & $\begin{array}{lll}\cdots & \cdots & \cdots\end{array}$ & .. & $\cdots$ & $\begin{array}{l}\text { Old rookery } \\
\text { moderate size, but } \\
\text { decreasing. }\end{array}$ & $\begin{array}{l}\text { G. Kerss, } \\
\text { 4.v.1908. }\end{array}$ \\
\hline \multicolumn{6}{|c|}{ PARISH OF MOUSWALD. } \\
\hline Brocklehirst .. & $\begin{array}{l}\text { Scots Fir, Oak, } \\
\text { etc., thirty-five } \\
\text { feet high. }\end{array}$ & $\cdots$ & 110 & Ten nests in $1903 \ldots$ & $\begin{array}{l}\text { J. McRoberts, } \\
\text { 4.vi.1908. }\end{array}$ \\
\hline The Manse .. & $\begin{array}{l}\text { Beech, Ash, Chest- } \\
\text { nut. }\end{array}$ & 30 & 24 & Since about 1898 & $\begin{array}{l}\text { Very Rev. J. } \\
\text { Gillespie, } \\
\text { 6.xi.1908. } \\
\end{array}$ \\
\hline $\begin{array}{l}\text { Beyond the } \\
\text { Burn. }\end{array}$ & Scots Fir .. & $\cdots$ & $70-80$ & $\begin{array}{l}\text { Old established, not } \\
\text { increasing. }\end{array}$ & $\begin{array}{l}\text { T. Wilson, } \\
\text { 23.ix.1908. }\end{array}$ \\
\hline
\end{tabular}


ROOKERIES-continued.

\begin{tabular}{|c|c|c|c|c|c|}
\hline \multirow{2}{*}{ Place. } & \multicolumn{3}{|c|}{ Nests. } & \multirow{2}{*}{$\begin{array}{c}\text { Remarks. How long } \\
\text { in existence, etc. }\end{array}$} & \multirow{2}{*}{$\begin{array}{l}\text { Source of } \\
\text { information. }\end{array}$} \\
\hline & Situation. & $\begin{array}{c}\text { Maxi- } \\
\text { mum No. } \\
\text { about. }\end{array} \mid$ & $\begin{array}{l}\text { No. in } \\
1908 .\end{array}$ & & \\
\hline \multicolumn{6}{|c|}{ PARISH OF RUTHTELI.* } \\
\hline The Manse .. & $\begin{array}{l}\text { Sycamore, Lime, } \\
\text { Elm and Beech. }\end{array}$ & .. & 100 & \begin{tabular}{|} 
In existence about \\
thirty-three or \\
thirty-four years, \\
has increased during \\
last fifteen.
\end{tabular} & $\begin{array}{c}\text { J. Harkness, } \\
\text { 18.ix.1908. }\end{array}$ \\
\hline $\begin{array}{l}\text { Summerfield } \\
\text { Farm. }\end{array}$ & $\begin{array}{l}\text { Scots Fir, Beech, } \\
\text { Oak. }\end{array}$ & 160 & $120-130$ & $\begin{array}{l}\text { In existence about } \\
\text { thirty-five years. }\end{array}$ & Do. \\
\hline $\begin{array}{l}\text { Comlongon } \\
\text { Castle. }\end{array}$ & Beech and Oak .. & 250 & 80 & $\begin{array}{l}\text { Old yews having been } \\
\text { blown down, num- } \\
\text { bers have decreased. }\end{array}$ & $\begin{array}{l}\text { A. Davidson, } \\
\text { 4.vi.1908. }\end{array}$ \\
\hline $\begin{array}{l}\text { Nether Lochar } \\
\text { Woods. }\end{array}$ & $\begin{array}{l}\text { Beech and Scots } \\
\text { Fir. }\end{array}$ & 300 & 80 & $\begin{array}{l}\text { Greatly diminished } \\
\text { since } 1906 .\end{array}$ & $\begin{array}{c}\text { J. Harkness, } \\
\text { 1.vi.1908. }\end{array}$ \\
\hline $\begin{array}{l}\text { Belridding } \\
\text { Farm. }\end{array}$ & Beech .. & .. & . & $\begin{array}{l}\text { Deserted since about } \\
1903 .\end{array}$ & Do. \\
\hline $\begin{array}{l}\text { Peter's } \\
\text { Plantation. }\end{array}$ & Scots Fir & 230 & 230 & $\begin{array}{lll}\cdots & \cdots & \cdots\end{array}$ & Do. \\
\hline
\end{tabular}

* Eight hundred and twenty-five nests in parish in 1879.-R. Service, 1. ix. 1908.

PARISH OF ST. MUNGO.

\begin{tabular}{|c|c|c|c|c|c|c|c|c|}
\hline Castlemilk .. & Beech & .. & $\cdot \cdot$ & .. & 200 & Much reduced & .. & $\begin{array}{c}\text { C. Sanderson, } \\
\text { 11.ii.1909. }\end{array}$ \\
\hline Nutholm $\quad .$. & . & . & .. & . & $\cdots$ & Now extinet & .. & $\begin{array}{c}\text { C. Sanderson, } \\
\text { 16.ii.1909. }\end{array}$ \\
\hline Nutholmshaw & $\cdots$ & .. & .. & .. & .. & Do. ... & .. & Do. \\
\hline Norwood & .. & .. & $\ldots$ & .. & .. & Do. ... &. & Do. \\
\hline Beech Bank .. & . & .. &.. & 500 & . & Do. ... & $\ldots$ & Do. \\
\hline Kirkbank $\quad$. & . & .. & $\cdots$ & . & $\cdots$ & $\begin{array}{l}\text { Thirty-two k } \\
1907 \text {, now ex }\end{array}$ & $\begin{array}{l}\text { d in } \\
\text { ct. }\end{array}$ & Do. \\
\hline
\end{tabular}

PARISH OF SANQUHAR.

\begin{tabular}{|c|c|c|c|c|c|c|}
\hline \multirow[t]{2}{*}{ Eliock } & \multirow[t]{2}{*}{$\cdots$} & \multirow[t]{2}{*}{$\begin{array}{l}\text { Oak, Beech, Spruce } \\
\text { and Scots Fir. }\end{array}$} & \multirow[t]{2}{*}{. } & \multirow[t]{2}{*}{$\cdots$} & $\begin{array}{l}\text { In existence over two } \\
\text { hundred years }\left(i . e_{.},\right. \\
1640) \text {. }\end{array}$ & $\begin{array}{l}\text { Dumfries Courier, } \\
\text { 1.v.1846. }\end{array}$ \\
\hline & & & & & $\begin{array}{l}\text { This rookery sup- } \\
\text { plies enough Rooks } \\
\text { for the whole } \\
\text { county, 1891. }\end{array}$ & $\begin{array}{l}\text { Dr. A. Davidson, } \\
\text { 1891. }\end{array}$ \\
\hline
\end{tabular}




\section{BIRDS OF DUMFRIESSHIRE}

ROOKERIES-continued.

\begin{tabular}{|c|c|c|c|c|c|}
\hline \multirow[b]{2}{*}{ Place. } & \multicolumn{3}{|c|}{ Nests. } & \multirow[b]{2}{*}{$\begin{array}{c}\text { Remarks. How long } \\
\text { in existence, etc. }\end{array}$} & \multirow[b]{2}{*}{$\begin{array}{l}\text { Source of } \\
\text { information. }\end{array}$} \\
\hline & Situation. & $\left|\begin{array}{c}\text { Maxi- } \\
\text { mum No. } \\
\text { about. }\end{array}\right|$ & $\begin{array}{l}\text { No. in } \\
1908 \text {. }\end{array}$ & & \\
\hline
\end{tabular}

\section{Parish of SANQUHAR-continued.}

\begin{tabular}{|c|c|c|c|c|c|}
\hline Eliock-contd. & & & 400 & \begin{tabular}{|} 
The following totals \\
have been killed in \\
spring; 1904, 488 \\
old,244 young; 1905, \\
351 old, 538 young; \\
1906,268 old, 281 \\
young; 1907,214 old, \\
209 young; 1908, \\
112 old, 82 young. \\
Decreasing.
\end{tabular} & $\begin{array}{l}\text { W. J. Laidlaw, } \\
20 . v .1908 .\end{array}$ \\
\hline The Manse .. & Oak, Scots Fir .. & .. & $120-130$ & $\begin{array}{l}\text { Came here about } 1880 \\
\text { from trees at Church. }\end{array}$ & $\begin{array}{c}\text { J. R. Wilson, } \\
\text { 5.vi.1908. }\end{array}$ \\
\hline
\end{tabular}

Parish of TINwaLd.

\begin{tabular}{|c|c|c|c|c|c|c|c|}
\hline \multirow[t]{3}{*}{ Amisfleld } & \multirow[t]{3}{*}{$\cdots$} & \multirow{3}{*}{\multicolumn{2}{|c|}{$\cdots$}} & \multirow[t]{3}{*}{$\cdots$} & \multirow[t]{3}{*}{$\cdots$} & Getting overcrowded & $\begin{array}{c}\text { Dumfries Courier, } \\
\text { 23.iv.1834. }\end{array}$ \\
\hline & & & & & & $\begin{array}{l}\text { Man killed by falling } \\
\text { from tree in } \\
\text { rookery. }\end{array}$ & Do. 18.v.1847. \\
\hline & & & & & & A busy colony in 1908 & $\begin{array}{l}\text { Dr. J. W. Martin, } \\
\text { 22.ix.1908. }\end{array}$ \\
\hline Dalruscan & $\ldots$ & Oak & $\cdots$ & & 140 & $\begin{array}{l}\text { In existence certainly } \\
\text { thirty years; about } \\
\text { the same numbers } \\
\text { these last twelve } \\
\text { years. }\end{array}$ & $\begin{array}{l}\text { J. Kirkpatrick, } \\
\text { 2.vi.1908. }\end{array}$ \\
\hline Carse Gien & $\ldots$ & $\begin{array}{l}\text { Oak, Ash, } \\
\text { Spruce, } \\
\text { Fir. }\end{array}$ & $\begin{array}{r}\text { Larch, } \\
\text { Scots }\end{array}$ & & 400 & $\begin{array}{l}\text { Annually increasing. } \\
\text { In existence for at } \\
\text { least fifteen years. }\end{array}$ & Do. \\
\hline Glenæe & $\cdots$ & - & .. & $\cdots$ & $\cdots$ & $\cdots$ & $\begin{array}{l}\text { Rev. W. Macdon- } \\
\text { ald, 4.v.1908. }\end{array}$ \\
\hline
\end{tabular}

Parish of TORThorwatid.

\begin{tabular}{|l|c|c|c|c|c|} 
The Manse & $\begin{array}{c}\text { Beech, Oak and } \\
\text { Ash. }\end{array}$ & 60 & $\cdots$ & $\begin{array}{c}\text { Several nests in 1900 } \\
\text { and numbers in- } \\
\text { creased till 1906, } \\
\text { since when they } \\
\text { have been greatly } \\
\text { reduced. }\end{array}$ & $\begin{array}{c}\text { 18.xi.1900. } \\
\text { reduch }\end{array}$ \\
\hline
\end{tabular}


ROOKERIES-continued.

\begin{tabular}{|c|c|c|c|c|c|}
\hline \multirow[b]{2}{*}{ Place. } & \multicolumn{3}{|c|}{ Nests. } & \multirow{2}{*}{$\begin{array}{l}\text { Remarks. How long } \\
\text { in existence, etc. }\end{array}$} & \multirow{2}{*}{$\begin{array}{l}\text { Source of } \\
\text { information. }\end{array}$} \\
\hline & Situation. & $\left|\begin{array}{c}\text { Maxi- } \\
\text { mum No. } \\
\text { about. }\end{array}\right|$ & $\begin{array}{l}\text { No. in } \\
1908 .\end{array}$ & & \\
\hline
\end{tabular}

PARISH OF TUNDERGARTH.

\begin{tabular}{|c|c|c|c|c|c|}
\hline Whitstonhill .. & $\cdots \quad \cdots$ & 150 & 50 & $\begin{array}{l}\text { Over thirty - five } \\
\text { years. }\end{array}$ & $\begin{array}{c}\text { J. Dalziel, } \\
\text { 12.vi.1908. }\end{array}$ \\
\hline Wylie Hole .. & . $\quad$. & 70 & 50 & Do. $\quad . \quad \ldots$ & Do. \\
\hline Pearsby Hall & Ash and Spruce... & .. & 100 & Decreasing $\quad$. & $\begin{array}{l}\text { Campbell Wilson, } \\
\text { 4.v.1908. }\end{array}$ \\
\hline Burnhead .. & $\begin{array}{l}\text { Tall trees near } \\
\text { house. }\end{array}$ & $\cdots$ & .. & Completely banished & Do., 22.ix.1908. \\
\hline Burnheadwood & \begin{tabular}{|l} 
Tall hardwood \\
trees.
\end{tabular} & .. & 10 & Decreasing $\quad$. & Do. \\
\hline Grange & $\begin{array}{l}\text { Chiefly Oak and } \\
\text { Ash. }\end{array}$ & .. & 50 & Rapidly decreasing .. & Do. \\
\hline North Burn .. & $\begin{array}{l}\text { On tall hardwood } \\
\text { trees. }\end{array}$ & .. & . & $\begin{array}{r}\text { Has decreased rapidly } \\
\text { of recent years, only } \\
\text { a few odd nests now. }\end{array}$ & Do. \\
\hline West Wood .. & . & $\cdots$ & 60 & $\cdots$ & \begin{tabular}{|c} 
C. Sanderson, \\
$16.1 i .1909$.
\end{tabular} \\
\hline
\end{tabular}

PARISH OF TYNRON.*

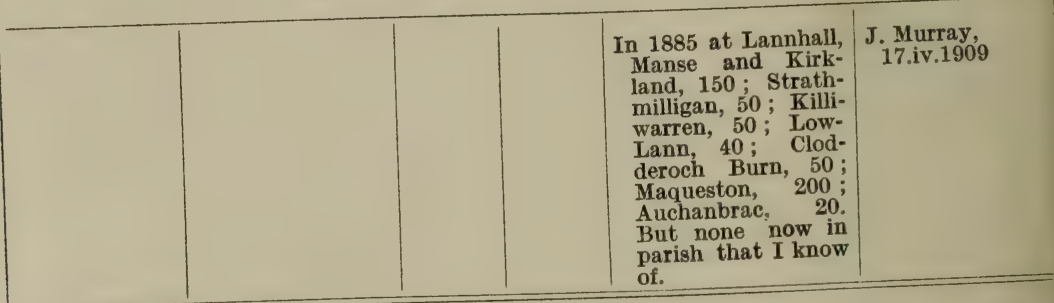

* Six hundred and seven nests in parish in 1879.-R. Service, 1. ix. 1908.

PARISH OF WAMPHRAY

\begin{tabular}{|c|c|c|c|c|c|}
\hline Milnehouse .. & Oak, Ash, Fir, etc. & . & $\begin{array}{l}\text { very nu- } \\
\text { merous. }\end{array}$ & $\begin{array}{l}\text { More than sixty years } \\
\text { old. }\end{array}$ & $\begin{array}{c}\text { Rev. R. Bell, } \\
\text { 9.vi.1908. } \\
\end{array}$ \\
\hline $\begin{array}{c}\text { Near Wam- } \\
\text { phray Rail- } \\
\text { way Station. }\end{array}$ & . $\quad$. & $\cdots$ & . & Do. $\quad . \quad$.. & Do. \\
\hline Girthland & $\cdots$ & & . & Do. .. . . & Do. \\
\hline
\end{tabular}




\section{BIRDS OF DUMFRIESSHIRE}

ROOKERIES-continued.

\begin{tabular}{|c|c|c|c|c|c|}
\hline \multirow[b]{2}{*}{ Place. } & \multicolumn{3}{|c|}{ Nests. } & \multirow[b]{2}{*}{$\begin{array}{c}\text { Remarks. How long } \\
\text { in existence, etc. }\end{array}$} & \multirow[b]{2}{*}{$\begin{array}{c}\text { Source of } \\
\text { information. }\end{array}$} \\
\hline & Situation. & $\left|\begin{array}{c}\text { Maxi- } \\
\text { mum No. } \\
\text { about. }\end{array}\right|$ & $\begin{array}{l}\text { No. in } \\
1908 .\end{array}$ & & \\
\hline \multicolumn{6}{|c|}{ PARISH OF WESTERKIRK. } \\
\hline Westerhall .. & . & $\cdots$ & . & $\begin{array}{c}\begin{array}{c}\text { Formerly } \\
\text { rookery. }\end{array} \\
\end{array}$ & $\begin{array}{l}\text { J. Pringle, } \\
20 . \text { ix.1908. }\end{array}$ \\
\hline Douglan Bank & . $\quad$. & $\cdots$ & $\cdots$ & $\begin{array}{l}\text { Do., decreased for } \\
\text { forty years, but still } \\
\text { a few. }\end{array}$ & Do. \\
\hline Burnfoot & $\begin{array}{l}\text { Beech, Plane and } \\
\text { Scots Fir. }\end{array}$ & $\cdots$ & 50 & Greatly reduced & $\begin{array}{l}\text { W. Laidlaw, } \\
\text { 6.vi.1908. }\end{array}$ \\
\hline Kemra Bank. . & Mostly Scots Fir. & $\ldots$ & 30 & Do. .. & Do. \\
\hline
\end{tabular}

I append a list of Rooks killed in Dumfriesshire under the auspices of The Scottish Gamekeepers' Association, during the seasons 1907, 1908, 1909 and 1910.

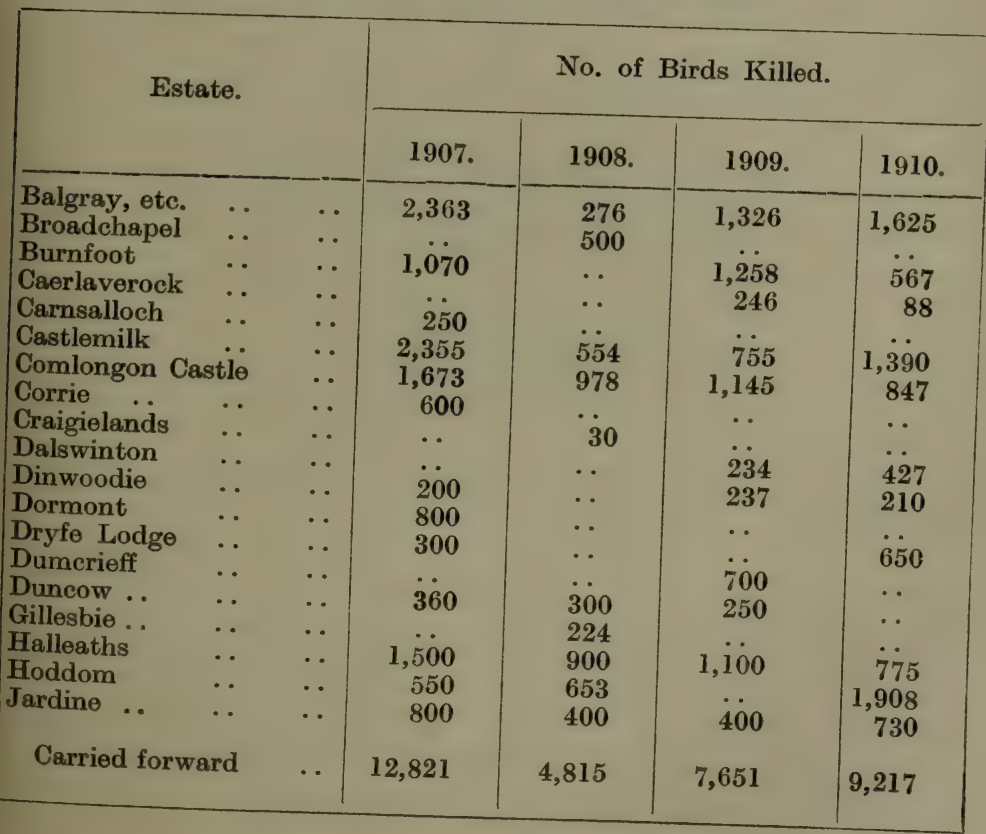




\begin{tabular}{|c|c|c|c|c|}
\hline \multirow{2}{*}{ Estate. } & \multicolumn{4}{|c|}{ No. of Birds Killed. } \\
\hline & 1907. & 1908. & 1909. & 1910. \\
\hline Brought forward & 12,821 & 4,815 & 7,651 & 9,217 \\
\hline $\begin{array}{l}\text { Kinmount } \\
\text { Kirkwood }\end{array}$ & 299 & 135 & & 145 \\
\hline $\begin{array}{l}\text { Kirkwood } \\
\text { Knockhill }\end{array}$ & 1,356 & 600 & 1,020 & .. \\
\hline $\begin{array}{l}\text { Knockhill } \ldots \\
\text { Langholm Lodge }\end{array}$ & 450 & $\cdots$ & .. & *. \\
\hline $\begin{array}{l}\text { Langholm Lodge } \\
\text { Mount Annan . }\end{array}$ & 170 & 1,350 & . & $1, \ddot{100}$ \\
\hline $\begin{array}{l}\text { Mount Annan .. } \\
\text { Murraythwaite .. }\end{array}$ & $\ddot{\cdots}$ & 280 & $\ddot{326}$ & ... \\
\hline Raehills .. . & & . & 46 & .. \\
\hline $\begin{array}{l}\text { Stapleton Tower } \\
\text { Wamphray }\end{array}$ & $\begin{array}{l}546 \\
618\end{array}$ & 843 & 807 & 640 \\
\hline Total .. & 16,260 & 8,023 & 9,850 & 11,102 \\
\hline
\end{tabular}

THE SKYLARK. Alauda arvensis, Linnæus.

Local names-LAVEROCK ; LARK.

"But list! O list! the sun has kissed The mountain tops with golden fire, And called the lark to chase the dark,

With songs of love that never tire.

Each liquid note doth rise and float

In harmony so full and clear,

That hill and dale would mourn and wail

If this sweet songster were not here."

Tномаs McKis._- The Lark."

A common resident throughout the arable, and extending into the pastoral districts.

In all the reports with which I have been favoured, the Skylark is described as plentiful, with the exception of those from Wanlockhead, and parts of Moffat and Eskdalemuir. From Durisdeer I hear that about 1901-1902 the Skylark was very scarce, but that it is now increasing; while in Holywood and Kirkmahoe, I am told, it is getting less 
plentiful ; and Mr. William Wright says of Annan parish that there is not one now for the twenty he remembers some thirty odd years ago. In the Zoologist of 1878 (p. 427) Mr. R. Service wrote: "The increase of Starlings during the last twelve or thirteen years has been most marked, and noticed by the most casual observer.... The search for food leads the Starlings into places frequented by Larks, and when there, from what I have seen of their evil propensities, I believe they will not hesitate to destroy every nest they fall in with. ... I observe Mr. R. Gray is of the same opinion, for in the Proceedings of the Natural History Society of Glasgow (Vol. I., Part 1, p. 13), he mentions that Starlings have become destructive to the Skylark and other birds building on the ground, the nests of which were rifled of their contents, even when the eggs are newly hatched, as has been repeatedly observed by trustworthy observers." This indictment led to an argument, but Mr. R. Service stuck to his point; and I am inclined so far to agree with him that certain individual Starlings may be nest-robbers, and I believe that this thieving is the more general in dry springs.

A great immigration of Skylarks takes place at the end of February, in March and in April, and a return emigration goes on during the latter half of September and in October. While our home-bred Larks are migrating to their winterquarters, others from further north are making their winterhomes with us. In March, 1838, it is recorded that " A migration of Larks from Scotland to the English side of the Solway was noticed by fishermen at sea on a misty night, when hundreds were attracted by the masthead lights, and settled on the decks."*

The place-name Laverock Hall (Dunscore) may owe its title to this species, but it is improbable that the name Caerlaverock has any such origin.

Dr. J. W. Martin writes me that the people in Holywood believe that adders fascinate Larks-a prevalent belief not

* Dumfries Courier, March 28th, 1838. 
confined either to Holywood or to the Lark, it being popularly supposed that snakes attract small birds.

Mr. Fred. V. Theobald writing of the utility of this species says: "The Skylark, although it takes a certain amount of corn, has the balance in its favour, for it is most helpful as an insect-checker, including wire-worm."

In June, 1826, " a white Lark was caught on the farm of Crawick Holm near Sanquhar." $\dagger$

Mr. H. E. Dresser, in drawing attention to the geographical forms of this species which have been claimed as distinct, writes: "von Tschusi Schmidhoffen describes the Scotch Skylark under the name Alauda arvensis scotica (Orn. Jahrb., xiv., p. 162, 1903) as subspecifically distinct." $\ddagger$ This "subspecies" was worked out from skins sent to Ritter von Tschusi Schmidhoffen by Mr. R. Service, who writes me that in his opinion " the distinction cannot be upheld in a long series." The actual specimens were obtained at Barncleugh (Irongray, Kirkcudbrightshire) in 1884, so close to our boundary, that were the "Scotch Skylark" to be recognised as a good subspecies, there is no reasonable doubt but that it would be found to occur in Dumfriesshire. Dr. Ernst Hartert, however, does not admit this form as distinct in his Die Vögel der paläarktischen Fauna.

[THE WOOD-LARK. Alauda arborea, Linnæus.

There is no satisfactory evidence as to the occurrence of this species in the county, and I have no doubt that the older records of the "Wood-Lark" refer to the Tree-Pipit.

We read that the "Woodlark" was "very common," in Johnstone (1792)§; "is found in the woods" of Mouswald

* Science Progress, 1907, Vol. II., p. 275.

$\dagger$ Dumfries Courier, August 1st, 1826.

¥Eggs Birds Eur., p. 397.

S Stot. Acct. Scot., Vol. IV., p. 226. 
(1793) : * and "The wood-lark and bulfinch, birds extremely rare in Scotland, are met with in the extensive wood of Comlongan; they are both natives. They make their nest among the long grass in the wood, and are, of late, observed to have much encreased." (Ruthwell, 1794.) $\dagger$ It is stated in 1834 that " the Woodlark is to be found in the woods of Comlongon" (Ruthwell), $\div$ and in 1836, "the Woodlark, Alauda arborea," is described as " common," in Mouswald. Sir William Jardine writes in 1839 of this species : "In Scotland, it is admitted by many writers, but withoutmentioning particulars. Dr. Fleming gives the Gaelic name, while Mr. Heysham states that it is taken occasionally by bird-catchers in the neighbourhood of Dumfries. (Upon the authority of Mr. Yarrell, Brit. Birds, Vol. I., p. 419). We have not ourselves seen a Scottish specimen, and cannot at present refer to any authentic instance of its capture." II

Richard Bell of Castle O'er has recorded that in the year 1851 or 1852 he found " a nest with eggs in the Galaside wood, about a mile north from Langholm. Being unfamiliar," he continues, "with the eggs, though an ardent collector, I took them to the then keeper of the Natural History Department of the College Museum, Edinburgh, who declared them to be those of the Woodlark. This is the only nest of this bird recorded in the district." I I wrote to Richard Bell, who courteously replied that he could not remember the name of the keeper of the Natural History Department at that time, but that the nest and eggs were found in the spring of 1851 . He further told me that he gave his collection to a nephew and from him it passed, much destroyed, through several

\footnotetext{
* Stat. Acct. Scot., Vol. VII., p. 294.

† Op. cit., Vol. X., p. 224.

$\ddagger$ New Stat. Acct. Scot., Vol. IV., p. 220.

$\$$ Op. cit., Vol. IV., p. 443.

|| Nat. Lib., 1839, Vol. XI., p. 328.

I My Strange Pets, p. 151.
} 
hands, and he had no doubt the Wood-Lark's eggs were amongst the victims.

In his " Distribution of Birds in Great Britain during the Nesting Season," 1865, the late A. G. More says of this species, "not in Scotland."* Having heard that the Rev. Hugh Parry had identified the Wood-Lark at Dalswinton (Kirkmahoe), I wrote to him, and received the following reply: "I may say that my knowledge of the birds of Dalswinton is merely the result of one spring visit in 1902 , and several autumn and winter visits. With regard to the Woodlark I am positive, because its song is quite familiar to me, and I can as easily distinguish its song from that of the Tree-Pipit, as I can the bleating of a sheep from the braying of a donkey. ... I I have spent the last thirty years of my life in verifying the songs and notes of birds and in learning the points of difference."

In view of the fact that hitherto the Wood-Lark has never been taken on the mainland of Scotland, this bird must remain in square brackets until substantial evidence is brought forward to remove them. WoodLarks in small numbers were observed at Fair Isle in the autumn of 1905 and since then have occurred there several times, but Mr. W. Eagle Clarke informs me that these are the only reliable Scottish records so far as he knows.

The Wood-Lark may be said to be a very local bird, more plentiful in the south of England, and decreasing in numbers towards the north, and it has also been known to breed in the south of Ireland. "In winter considerable companies are sometimes found in the southern districts of England, especially in snowy weather, but there does not appear to be any important immigration from the Continent." $\dagger$

Though the species has nested, $\ddagger$ and I believe still nests in Cumberland, it is well to remember that in Dumfries-

* Ibis, 1865, p. 124.

† Man. Brit. Birds, 1899, p. 251.

† Fauna of Lakeland, 1892, p. 162. 

shire the Tree-Pipit is commonly miscalled the Wood-
Lark.]

\section{THE SWIFT. Cypselus apus (Linnæus).}

\section{Local name-BLAck SwIFT.}

"When the corncraik's voice is mute as her young begin to flee, And seek with swifts and martins some home beyond the sea ; And reapers crowd to harvest field in man's and maiden's pride, Dumfric an bonny Nithside."

Dumfries and Galloway Courier and Herald, January 25th, 1899. "Unpublished Verses by John McDiarmid."

A common summer-visitant, nesting locally in suitable situations.

In 1791 it was said that the Swift " arrives about the commencement of continued daylight (i.e., here, about the tenth of May), and departs about the end of it, in the second week of August."* In its comings and goings this species varies very little, and May 9th and August 6th may be taken now as average dates of its arrival and departure, though birds from the far north may be seen passing through later in August. The earliest date of their arrival that I have found recorded is May 3rd, in 1829, and in 1891; and the latest, May 12th, in 1892: as regards their departure, the latest date would appear to be August 15th, in 1896. Mr. R. Service writes me that on July 5th, 1908, he saw two flocks, one of fifteen and the other of over two hundred, at Southerness (Kirkcudbright), "flying out to sea due south, and beyond doubt on migration. The earliest date I ever saw emigrants of the species."

Sir William Jardine writes of the birds of Applegarth and Sibbaldbie in 1832: "The numbers of the Swift have diminished much since the old mansion-house of Jardine Hall was pulled down; previous to which numerous colonies of Swifts built in the rents of the walls. Now a few pairs

* Stat. Acct. Scot., Vol. I., p. 61. 
only are to be found; a striking instance of the change of locality, which is constantly taking place."*

In 1843 a Dumfries observer states that this bird " is occasionally seen with swallows when he condescends to leave the precincts of the Mid Steeple." + Nowadays Swifts nest in the "Nithsdale" and other mills in Dumfries, and small colonies are to be found nesting throughout the county in many church-spires, bridges, ruins, old castles and mansion-houses, such as Sanquhar Castle, Hallows Tower (Canonbie), Drumlanrig (Durisdeer), Capenoch (Keir), etc. I am informed by the Rev. D. L. Jardine, that the birds which bred abundantly in the spire of Durisdeer Kirk twenty years ago, have not done so since certain alterations were made in 1900. Miss Ranken tells me that these birds nest annually at Dalswinton House (Kirkmahoe), where, Mrs. Pollock informs me, they nested abundantly " under the eaves and on the square stones supporting the balustrade, about 1866."

It is a wonderful sight at nightfall to see the Swifts while preying on insects ascending higher and higher into the air till they become invisible.

The Swift is abundant throughout Europe in summer, "while on migration it visits Madagascar and the extreme south of Africa, and is said to breed in Natal." $\ddagger$

THE NIGHTJAR. Caprimulgus europøus, Linnæus.

Local names-Goatsucker ; Nighthawk.

A common summer-visitant to the woodland or lower arable district, but of local distribution.

The Nightjar comes to us from its African winter-quarters, about the middle of May. A male shot on May 4th, 1908, at

* New Stat. Acct. Scot., Vcl. IV., p. 180.

$\uparrow$ Dumfries Courier, May 8th, 1843.

$\ddagger$ Man. Brit. Birds, 1899, p. 262. 
Lannhall (Tynron), in mistake for a Sparrow-Hawk, is the earliest arrival I have heard of. On September 23rd, 1896, an immature example was recorded from Moniaive (Glencairn) by Mr. John Corrie*-a rather late date for this species to linger in this county.

The Nightjar is mentioned in 1791 as one of the birds of Kirkmichael parish, $\dagger$ and Sir William Jardine in 1832 includes it in his list of birds of the parish of Applegarth and Sibbaldbie as "frequently seen, and is abundant in the opposite parishes of Lochmaben and Johnstone." $\$$ Contemporaneous writers say "The common Nightjar is seen in the woods of Rockhall" (Mouswald), § and "the goat-sucker is frequently seen at nightfall, and its nest has been found at Halleaths " (Lochmaben). .

The Nightjar, though common in Langholm and Canonbie, is rare in Upper Eskdale. Richard Bell of Castle O'er stated : "I have known of four specimens only in the neighbourhood." To the littoral parishes it is a regular visitant, as also to the lower and central portions of Nithsdale and Annandale. Burnt Fir Wood, Carnsalloch (Kirkmahoe), is still a favourite resort of these birds, and has been so for many years, as it was mentioned as such in 1881 by Mr. S. Chrystie.** In Sanquhar and Kirkconnel it is said to be rare, but its nest has been taken in the Holm Wood. In April, 1901, a long correspondence ensued in the Dumfries and Galloway Standard between Mr. John Corrie and Mr. R. Service as to the rarity or otherwise of this bird throughout the county, when it was shown that the species was not uncommon but of local distribution.

The crepuscular habits of the Nightjar do not favour

* Trans. D. and G. Nat. Hist. Soc., March 9th, 1900.

$\dagger$ Stat. Acct. Scot., Vol. I., p. 61.

‡ New Stat. Acct. Scot., Vol. IV., p. 180.

\$ Op. cit., Vol. IV., pp. 443, 444.

\| Op. cit., Vol. IV., p. 382.

II Trans. D. and G. Nat. Hist. Soc., April 17th, 1901.

** Op. cit., December 4th, 1881. 
its ready observation, but it is frequently flushed from clumps of bracken during Grouse shooting in August. As twilight falls it may be seen hawking for cockchafers on the wing, and the "churring" note of the male has a peculiar charm. At the breeding-season this species has been noticed to "clap its wings" after the manner of the Ring-Dove. It is to be regretted that living as it does entirely on insects it should ever be shot, though its somewhat hawklike flight often proves fatal to it. Its feathers are used for fly-dressing, but are so friable as to become worn and useless after only a few casts, so this excuse for its destruction should be disregarded.

The Nightjar makes no nest, and the bird in Mr. D. Legard's photograph, here reproduced, was sitting upon two eggs laid on a bare rock surrounded by a dense thicket of bracken.

\section{THE WRYNECK. Iynx torquilla, Linnæus.}

\section{A very rare accidental visitor.}

Dr. Burgess includes the Wryneck in a list, dated 1791, of the "Rarer Species of Birds" to be found in the parish of Kirkmichael.* He has already been taken to task for the inclusion in this list of the Pine-Grosbeak, and it is difficult to guess what bird he may have mistaken for the Wryneck. But without upholding his statement, I may perhaps draw attention to what $\mathrm{H}$. A. Macpherson writes in 1892 of this species, as regards the neighbouring county of Cumberland: "The Wryneck affords an interesting example of the nearly complete disappearance of a regular summer-visitant to Lakeland within the memory of a single generation. Dr. Heysham knew the species well, was familiar with its harsh cry, had taken a female on

* Stat. Acct. Scot., Vol. I., p. 60. 


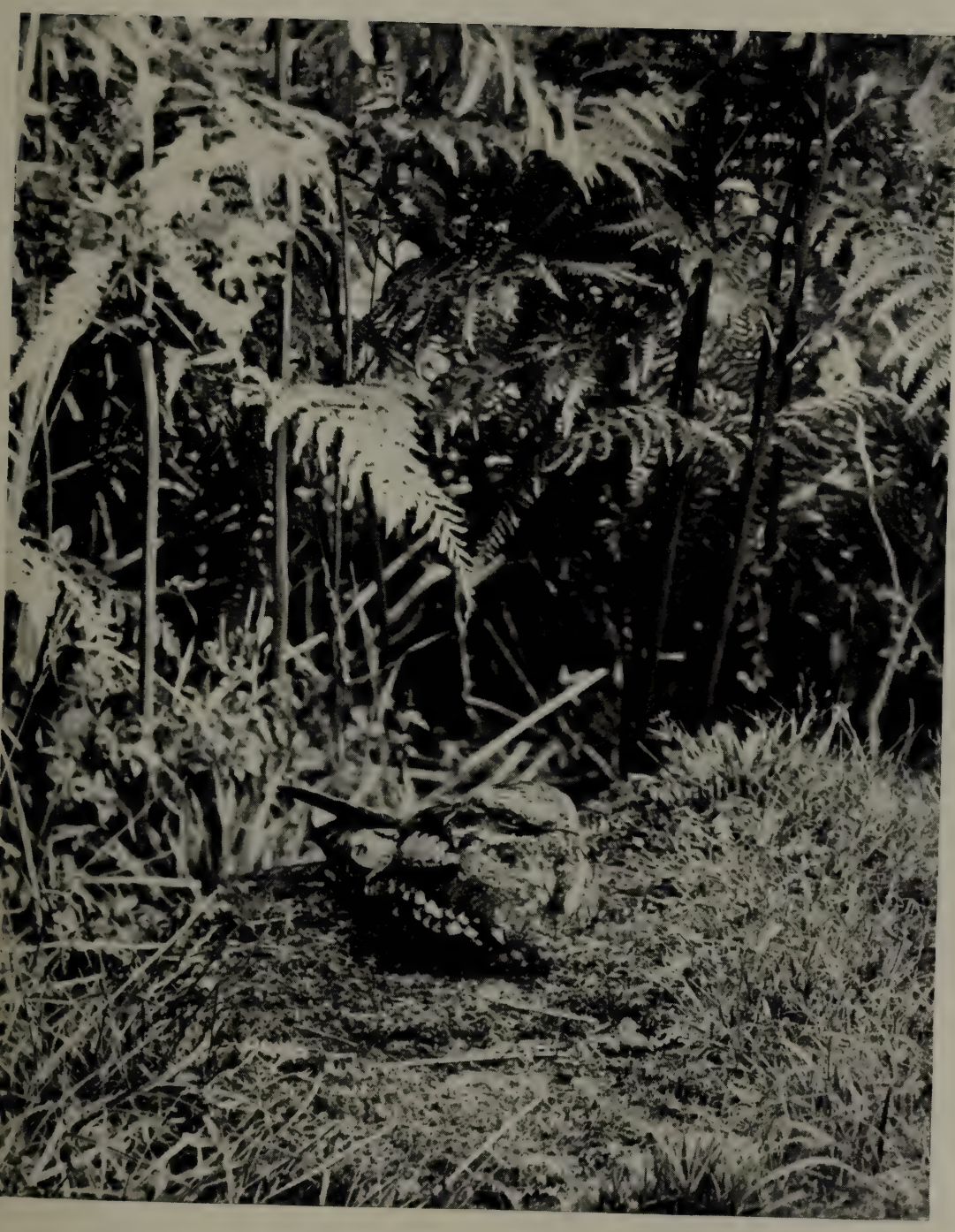

NIGHTJAR (Caprimulgus europoeus) ON THE NEST. 

the nest, and was accustomed with it every season, though he did not happen to find it in 1796. T. C. Heysham noticed its arrival at Carlisle in the thirties regularly," and Macpherson concludes: "Probably the species was always very local. It is now rare."* Sir William Jardine, however, writing in 1839 says : "It does not extend in any numbers, or with regularity, to the northern or the midland counties of England; but southward, in the wooded districts, it is considered to be generally and not uncommonly distributed. ... In Scotland it becomes still less frequent ; we have only heard of very few examples, and one only has come under our own notice, killed on the banks of the Solway, early in spring, and now in our collection; it drew attention by its peculiar, and there unknown, cries." $\dagger$ This specimen passed in a very worn condition into the Royal Scottish Museum in 1876, labelled “No. 150. From Powfoot, Dumfriesshire," so I am informed by Mr. W. Eagle Clarke.

In October, 1857, " a fine specimen of the Wryneck was found ... on the Glasgow and South-Western Railway near Thornhill, Dumfriesshire. It appears to have been killed by flying against the telegraph wires, and has been stuffed for the Thornhill Museum." $\ddagger$ I could find no trace of this specimen when visiting Dr. Grierson's Museum at Thornhill in May, 1908; but in looking through the doctor's MS. "Notes," I found under date October 17th, 1862, in a list of rare birds which Thomas Maxwell of Allanton Mill had given him: "Wryneck; a specimen which had been killed by the telegraphic wires near Auldgirth three years ago, the only one met with here. (Sir William Jardine mentioned to me having seen a specimen in a hedge near Jardine Hall.)" Auldgirth and Thornhill are two stations on the Glasgow and South-Western Railway, some seven miles apart, and though there is

* Fauna of Lakeland, p. 167.

$\dagger$ Nat. Lib., 1839, Vol. XI., p. 359.

$\ddagger$ Naturalist, 1857, Vol. VII., p. 283. 
a difference of two years between the dates, this entry may very possibly refer to the specimen recorded in 1857. As regards the alleged Jardine Hall occurrence, Dr. Grierson probably mistook the locality, for in a MS. note in his private copy of the Naturalist's Library, Sir William Jardine has written: "On November 3rd, 1859, I saw a specimen on the road between Annan and Northfield when returning from an Income Tax Appeal Meeting. It was in the hedge, but on my coming up alighted upon the grass at a gateway, moving its body backwards and forwards. It again flew onwards, alighting in the hedge."

On February 17th, 1874, "Mr. Hastings exhibited a stuffed specimen of the Wryneck recently shot at Holywood "* to the members of the Dumfriesshire and Galloway Natural History and Antiquarian Society.

To England this species is a regular summer-visitant, arriving at or about the same time as the Cuckoo, thus earning its sobriquet of "Cuckoo's Mate" or "Cuckoo's Leader." In September it emigrates to its winter-quarters in Africa, as far south as Kordofan in the east, and Senegambia in the west.

\section{THE GREEN WOODPECKER.}

Gecinus viridis (Linnæus).

\section{A very rare accidental visitor.}

William Hastings records a specimen obtained locally, in November, 1885, "quite fresh and newly killed," $\dagger$ about which I have not been able to find out anything more. In 1886, when I was a small boy, an old bird-stuffer named Robert Brown, who lived in Penpont, gave me a bird of this species. I can still distinctly remember his telling me it had

* Minutes of D. and G. Nat. Hist. Soc., February 17th, 1874.

+ Trans. D. and G. Nat. Hist. Soc., December 4th, 1885. 
been picked up near the village on Stepends Farm, under the telegraph-wires, against which it had presumably flown and killed itself. A Green Woodpecker is believed to have been seen at Kinmount (Cummertrees) in July, 1908. Mr. W. H. Veitch informs me that the gamekeeper who saw it was familiar with the species during a previous residence in Yorkshire, and that when confronted with skins of Gecinus viridis and Dendrocopus major he unhesitatingly identified the bird he had seen as the former.

The Green Woodpecker is not a migratory species, and, though common in the south and plentiful in the Midlands, it becomes rare in the northern counties of England.

\section{THE BRITISH GREAT SPOTTED WOODPECKER.}

\section{Dendrocopus major anglicus, Hartert.}

\section{A rare and very local resident; and an irregular early winter-visitor.}

Dr. Archbald in his "Account of the Curiosities at Drumfriess," written about 1684, says: "I mention none other [fowls] as being ordinary, save woodpeckers."* Sir William Jardine in 1839 wrote of the Great Spotted Woodpecker as partially migratory, birds having been obtained in October and November; $\dagger$ and a specimen labelled "(No. 144) Dumfriesshire" passed into the possession of the Royal Scottish Museum, Edinburgh, from the Jardine collection. In 1868 it is recorded, "The black and white Woodpecker (Picus) has been shot at Kinmount [Cummertrees] within the last two years." $\ddagger$ A specimen which was obtained at Halleaths (Lochmaben) was exhibited to the local Natural History Society on February 14th, 1871. In 1879 there is strong evidence, but not actual proof, that a nest was found in a hole in a trunk of an oak tree at Halleaths (Lochmaben) ;

* Sibbald's MS. Collections, p. 228.

$\dagger$ Nat. Lib., 1839, Vol. XI., p. 351.

¥Trans. D. and G. Nat. Hist. Soc., May 5th, 1868. 
and in the winter of 1879-1880 a Great Spotted Woodpecker was shot at Rammerscales (Lochmaben).

In February, 1881, Mr. William Lennon saw one of these birds in Burnt Fir Wood, Carnsalloch (Kirkmahoe), and in 1882 or 1883 a nest is believed to have been found by a forester in Halleaths Wood (Lochmaben). In 1883 a Great Spotted Woodpecker, which was shot by Colonel Salkeld in Kinmount Wood (Cummertrees), was sent to Mr. J. Harkness of Ruthwell to stuff. One was shot at Carnsalloch (Kirkmahoe) in the last week of November, 1887, while in the winter of 1887-1888 a specimen was found at Marchbank Wood (Moffat), and on March 2nd, 1888, one was picked up in the street at Moniaive (Glencairn). It had evidently struck the telegraph wires overhead, and fallen into the village street, where a cat had devoured it. Only feathers and some fragments of flesh were found, but some of the feathers sent to Mr. R. Service were sufficient to place the bird beyond doubt. "In 1888 a pair nested in Canonbie, and they and their eggs were taken by a gamekeeper."* On February 7th, 1890, one was seen in Carnsalloch Wood (Kirkmahoe), and "Mabie Moss" writes: "This bird is not so scarce on the eastern side of the Nith as it is on the western, and it has been known to nest in both Annandale and Eskdale."†

Mr. John Smith of Langholm informs me that he has only once seen this species in that district (about 1890), and that the specimen is now in the collection of Mr. Malcolm of Burnfoot. In 1891 "Mabie Moss," writing from Dumfries, says that "contrary to the usual rule there have been very few of the Spotted Woodpeckers seen in this district this winter." + Mr. W. J. Laidlaw informs me that late in October or early in November, 1898, one was shot at Eliock (Sanquhar) by Mr. Harold Cowan.

Since 1902 these birds have been annually seen in spring

* Zoologist, 1894, p. 344.

$\dagger$ Dumfries Courier and Herald, February 14th, 1890.

$\ddagger$ Op. cit., February 26th, 1891. 
in the woods at Raehills (Johnstone). An adult female was got at Rigg Kennels (Gretna) on March 23rd, 1904, as entered in the Tullie House Museum (Carlisle) Registers. During February, March and April, 1904, a pair of Great Spotted Woodpeckers were occasionally seen, and constantly heard, near Closeburn, but though the "tappings" ceased in May, no nest was discovered. During the spring of 1905 this species was again reported from Closeburn. In 1906 a pair nested at Springkell (Kirkpatrick-Fleming), and the birds were again observed throughout the spring at Closeburn; while in May a Great Spotted Woodpecker is believed to have been seen in Auchengibbet Wood (Tynron). In 1907 one was reported from Moffat in March, and Mr. W. J. Lowden informs me that a pair successfully hatched and reared their young at Springkell early in June, and disappeared after they were able to fly; while their vernal appearance at Closeburn was reaffirmed. Mr. T. M. Brown writes me in 1908 that although the Great Spotted Woodpeckers have visited Closeburn annually each spring since 1904 he has never yet actually found their nest, and it was not till 1908 that he was certain of two pairs being present. "Their 'tapping' begins about the end of March and lasts till the third week in May, but this year after three weeks' silence it recommenced, and continued some days, being " "teard again on October 28th and 29th." This same "tapping" was frequently heard in Auchengibbet Wood (Tynron) in April, 1908, but the bird was never seen. The hole in which it nested was, however, discovered in the following autumn. On April 21st a specimen was most unfortunately killed at Barndennoch (Keir) by a keeper, who shot it simply because he did not know what it was. Mr. W. J. Lowden writes me as follows: "I saw the Woodpeckers again this year, early in April [1908], and they have made two holes in two different trees for nesting, but have forsaken them both. I saw a Starling fly out of one of their holes a few days ago, and it may have usurped the nest." This species is said to have been heard in May, 1908, at 
Jarbruck Linn (Glencairn), * and from a description of " a strange bird" seen there subsequently by Mrs. C. Laurie I have little doubt that this was a genuine occurrence. Mr. William Laidlaw writes me from Langholm that he has only heard of one pair there, but that they nest every year in the bog (Canonbie). In 1909 Great Spotted Woodpeckers were seen at Castlemilk (St. Mungo) in January; in Closeburn and Glencairn parishes from April to June ; and I have reports of their having nested at Raehills (Johnstone), Auchengibbet Wood (Tynron), Springkell (KirkpatrickFleming), and near Scotch Dyke just outside the parish boundary of Canonbie. One or possibly two pairs are believed to have passed the winter near Closeburn; and on December 23rd, 1909, I watched a bird of this species for about fifteen minutes, in some oak trees at Capenoch (Keir); there were four inches of snow at the time. The following spring Great Spotted Woodpeckers were again seen in Glencairn parish, and are believed to have nested at Closeburn; as they certainly did at Raehills and Springkell. On May 28th, I saw a nest in the decaying branch of an ash tree, about thirty, feet from the ground, in Auchengibbet Wood: both birds were in close attendance.

Owing to their retiring nature and their partiality for the higher branches of trees, these birds may often escape detection; and it is probable that in some suitable localities they may be resident. It is to be hoped that they may receive adequate protection from the local landlords and their gamekeepers, for they would prove a welcome and beautiful addition to our avifauna.

Mr. W. R. Fisher states that "The result of investigation into the utility of woodpeckers tends to show that these birds by their activity in the destruction of insects play a most useful part in nature, and should therefore be protected by foresters." $\dagger$

The extension of the range of this species in Scotland

* Dumfries Courier and Herald, May 23rd, 1908.

† Man. Forestry, 1895, Vol. IV., p. 131. 


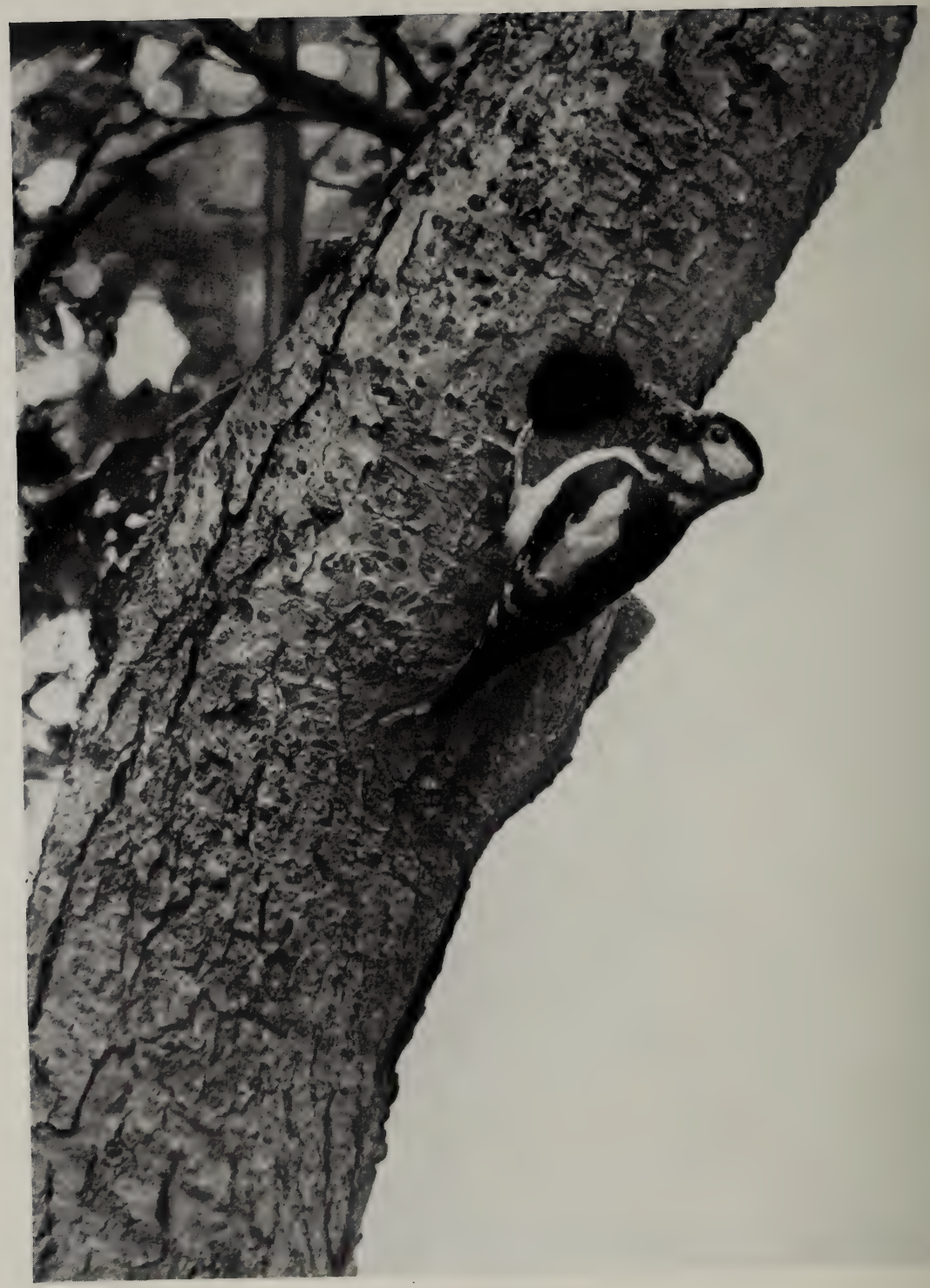

BRITISH GREAT SPOTTED WOODPECKER (Dendrocopus major anglicus) AT THE NEST. 


\section{BIRDS OF DUMFRIESSHIRE}

is believed by Mr. William Evans to be due, not to Scandinavian visitors, but to English birds extending their range northwards, * and Mr. J. A. Harvie-Brown's paper on "The Great Spotted Woodpecker's resuscitation in Scotland since 1841 or $1851, " \dagger$ with a descriptive map, shows the satisfactory progress in Scotland the species has made in recent years.

Some of the examples which have occurred locally in autumn and winter may have been of Scandinavian origin, and thus would belong to the typical form $D$. major major of Linnæus, which is larger, with a more powerful bill and paler under-surface than the British form. $\ddagger$ This, however, could only be determined by a careful comparison of specimens.

The photograph of the Great Spotted Woodpecker here reproduced was obtained by Mr. D. Legard.

\section{THE BRITISH LESSER SPOTTED WOODPECKER.} Dendrocopus minor comminutus, Hartert.

\section{Has occurred once ; possibly twice.}

Howard Saunders states on the authority of Mr. R. Service that three examples of this species have been obtained in the Solway district, at long intervals, since 1860.ई One of these "examples" was a Dumfriesshire specimen, and is referred to thus by William Hastings in 1889: "I once had a specimen of the Lesser Spotted Woodpecker shot at Amisfield [Tinwald] thirty years ago, and have seen none since." $\|$ The correct date, however, so Mr. R. Service informs me, was given him as 1865 by a gardener at Amisfield.

A Lesser Spotted Woodpecker is believed to have been

* Ann. Scot. Nat. Hist., 1908, pp. 216-218.

† Op. cit., 1908, pp. 210-216.

$\ddagger$ British Birds (Mag.), Vol. I., 221.

\$ Man. Brit. Birds, 1899, p. 277.

\| Trans. D. and G. Nat. Hist. Soc., February 1st, 1889. 
seen by Mr. Richard H. W. Leach, in Eskdalemuir, on April 22nd, 1905. In a letter to Richard Bell of Castle O'er, Mr. Leach writes: "The Woodpecker I saw last Easter on the trunk of a fir close to Moodlaw House must have been the Lesser Spotted Woodpecker (Dendrocopus minor, not major). The length of the latter is about $9 \cdot 4$, wing 5.5 inches; whereas the length of the former is only about 6 inches, wing 3.7 inches."

The British Lesser Spotted Woodpecker has been separated from its continental allies by Dr. Hartert by reason of its small size, ${ }^{*}$ and is a fairly numerous resident in the south of England, becoming more rare in the north. Its occurrence in our county is most unexpected, but Mr. R. Service vouches that his information is sufficiently authentic to enable me to place this species in my list without square brackets.

THE KINGFISHER. Alcedo ispida, Linnæus.

Local name-King's Fisher.

A not uncommon resident on the lower reaches of our rivers.

In 1791 it was stated that in Kirkmichael parish "The King's Fisher comes up the rivers about Christmas and usually stays about three or four weeks," $\dagger$ and in 1794 , that in the parish of St. Mungo "The King's Fisher frequently appears on the banks of the rivers." $!$ About 1835 it is recorded as "frequently seen upon the banks of the Annan and of the $\mathbb{E}$," $\S$ and "often seen on the banks of the Scar." In In Langholm it is thus mentioned: "Among the more rare birds may be noticed the Kingfisher, which

* Brit. Birds (Mag.) Vol. I., p. 221.

$\dagger$ Stat. Acct. Scot., Vol. I., p. 61.

$\ddagger$ Op. cit., Vol. XI., p. 389.

§ New Stat. Acct. Scot., Vol. IV., p. 382.

\| Op. cit., Vol. IV., p. 464. 
has been seen in this parish,"* and Sir William Jardine writing of the birds of the parish of Applegarth and Sibbaldbie says it is " occasionally seen on the Annan during winter." $\dagger$ In 1839 Sir William wrote: "Instances of its breeding have been very seldom recorded beyond the English border, or the south of Scotland." $\ddagger$

"Mabie Moss" in 1898 states: "Kingfishers are very far from being the rarities that they are popularly supposed to be, but they are very shy, and small, and unless the flash of emerald sheen is seen as they fly quickly past, or that peculiar shrill squeak they emit is known, the ordinary wanderer by the river's brim will never see them. If one wishes to approach them the utmost stealthiness of approach is necessary, as well as full knowledge of their habits, otherwise they are off at quarter mile distance. ... . The nesting habits are peculiar, and baffling to the birds' nester, so that upon the whole the Kingfisher is far safer against
persecution than many other birds." $\$$

At the nesting-season this species often leaves the river's side for what would seem most unlikely haunts, and its nest is frequently found in a hole in a bank of some half-dried water-course or secluded burn, far from the slower flowing rivers which it frequents in autumn and winter. James Shaw has recorded as regards Upper Nithsdale: "The Kingfisher is exceedingly rare. As it commands a price it was entirely exterminated by a band of bird-catchers, more than a dozen years ago [i.e., 1880], all along that finest tributary of the Upper Nith, the romantic and woodfringed Skarr." $\|$ Mr. Rutherford of Jardington stated in 1898: "Living on the banks of a river [the Cluden] he had every opportunity of observing the Kingfisher. In some seasons he would see half a dozen day after day

* New Stat. Acct. Scot., Vol. IV., p. 418.

† Op. cit., Vol. IV., p. 180.

$\ddagger$ Nat. Lib., 1839, XI., p. 390.

$\S$ Kirkcudbright Advertiser, January 17th, 1898.

|| A Country Schoolmaster, 1899, p. 289. 
one after another; then they disappeared for a time, and they had them now just as plentiful as when he came to Jardington."* Richard Bell of Castle O'er recorded in 1901 that within his remembrance a Kingfisher was unknown on the river Esk, but now scarcely a season passed without one or two being seen, though no nest had ever been discovered. $\dagger$ Reports state that this species has nested on the Nith in Sanquhar, Morton, Closeburn, and Kirkmahoe; on Scaur Water in Keir; on the Annan in Moffat, St. Mungo, Hoddom, and Annan; on Kinnel Water (Lochmaben); on Kirtle Water (Kirkpatrick-Fleming), and on the Esk in Canonbie. The Kingfisher probably nests in many other localities in the county, and in autumn and winter becomes more generally distributed, at which season it is reported from many streams in addition to those already mentioned.

Should the weather in winter become very severe, so that its favourite haunts are frozen over, the Kingfisher is found in unusual numbers at such places where they can still get a living. Of recent years this species has been seen in early autumn in augmented numbers on the Nith and its immediate tributaries. In the hard winter of 1878-1879 a remarkable increase in their numbers on that river was noticed : "They appeared commonly where one, or at most a pair, were previously to be met with at wide intervals. They disappeared for the most part about the middle of December, when the frost became so exceedingly severe." + Under such conditions they are driven down to the coastal streams, as observed by Mr. Hugh Mackay in the winter of 1894-1895.

The following interesting observation has been recorded by Mr. T. A. Johnstone of Moffat: "One or two pairs frequented this neighbourhood in winter, but they never stayed to breed till 1905. In that year, seeing a pair staying long past their usual time of departure, I looked

* Trans. D. and G. Nat. Hist. Soc., January 14th, 1898.

$\dagger$ Op. cit., April 17th, 1901.

$\ddagger$ Op. cit., November 7th, 1879.

§ Dumfries Courier and Herald, February 16th, 1895. 
for their nest, and was fortunate in finding it. It contained seven young, and was consequently almost choked with filth. The young were specially interesting on account of their being in different stages of development. Three were almost ready to leave the nest, two rather more than half feathered, and the last two had but a few quills on their wings. As I have never seen any mention of a similar occurrence in any book, I think it is worthy of note."*

The Kingfisher is a species that probably benefits much from the imposition of the Gun Tax and the Wild Birds Protection Acts. Its brilliant plumage makes it a desirable ornament (?) for the parlour, and its feathers are much in request for "dressing flies."

\section{THE ROLLER. Coracias garrulus, Linnæus.}

\section{Has occurred twice.}

In $1839 \mathrm{Sir}$ William Jardine wrote of this species: "In Scotland, the specimen which served Mr. Selby for his figures was killed in Dunkeld ; we know of another specimen taken in Dumfriesshire, and a third, now in our collection, we received from the southern part of Shetland." $\dagger$ It is recorded in 1865 that "The Chairman [Sir William Jardine] proceeded to call the attention of the Society to ... the occurrence of a very rare bird, the Roller (Coracias garrulus) in this district. . . . Very few specimens (about nine or ten in all) had ever been seen in this country. . . . Some time ago, viz., October, 1864, he got notice of an unknown bird having been observed near Bankhead, (Tinwald); and shortly afterwards it was found lying dead and partially decayed. When he sent for its remains he only got some feathers of the wings and tail, which he now exhibited.

* Dumfries Courier and Herald, April 6th, 1907.

† Nat. Lib., 1839, Vol. XI., p. 387. 
These were sufficient, however, to prove its identity. . . ."* In $A$ Catalogue of the Birds contained in the Collection of Sir William Jardine this specimen is entered as "(No. 1459), e. (Wings and feathers) Tinwald. Found dead by Mr. Yorstoun's Gamekeeper."

A Roller was shot near Auchenbrac (Tynron) on June 23rd, 1910. It had been seen there for three or four days previously, frequenting certain tall trees bordering Shinnel Water. It proved, on dissection, to be a female but not in breeding condition, and the stomach contained the remains of flies, and beetles' wings.

This species, of which there are some twenty to twenty-five records from the mainland of Scotland, is a common summermigrant to the countries bordering the Mediterranean, and to central Europe, being found as far north as Sweden. It winters in Africa as far south as Natal and Cape Colony.

\section{THE HOOPOE. Upupa epops, Linnæus.}

\section{A rare casual visitor.}

Our first local record of the Hoopoe is as follows : one ". . . was lately [October, 1861] shot in the neighbourhood of Ecclefechan, and has passed through the hands of Mr. Peter Muir, the well-known taxidermist of Ecclefechan." $†$ Sir William Jardine in a MS. note in his private copy of the Naturalist's Library records, "William Hastings, Dumfries, had a specimen of the hoopoe shot near Rammerscales (Lochmaben), 5th June, 1869." On February 7th, 1871, William Hastings exhibited the skin of a Hoopoe, shot in the district, to the members of the Dumfriesshire and Galloway Natural History and Antiquarian Society, $\ddagger$ which it is believed had been recently obtained near Trailflat (Tinwald).

* Trans. D. and G. Nat. Hist. Soc., February 7th, 1865.

† Dumfries Courier, October 8th, 1861.

$\ddagger$ Minutes of D. and G. Nat. Hist. Soc., February 7th, 1871. 
Mr. J. E. Harting states " Two were shot in Dumfriesshire in the winter of 1870-1871, as I was informed by Sir William Jardine."* I wrote to Mr. Harting about this record, and he courteously replied, "It must have been in 1871 that Sir William Jardine told me of the Hoopoes 'in Dumfriesshire,' as I understood him, or at all events ' in his own neighbourhood,' and I made a note of it, because I thought it strange though not unprecedented that they should have been met with in winter. ... The circumstance was mentioned by him in the course of conversation during a visit he paid me in London, so that I have no note from him on the subject to which I could refer for further information." Possibly in his conversation with $\mathrm{Mr}$. Harting, Sir William Jardine may have referred to the Rammerscales and Trailflat examples (which I have already mentioned) as having been got in the winter of 1870-1871. I am informed by Mr. R. Service that about 1874 another specimen from Tinwald passed through the hands of William Hastings.

One was shot near Brow Well (Ruthwell) about September 25th, 1893, by Mr. R. Murray, but was not preserved ; and on May 28th, 1903, when fishing at Morton Mains loch, I saw a Hoopoe at very close quarters : it got up and flew off into some oak trees, and my identification of it when on the ground, was confirmed by its peculiar undulatory flight. On May 15th, 1907, one was shot by Alexander Balharry, gamekeeper, close to Drumlanrig Castle (Durisdeer). It was sent for preservation to William Campbell, Errol Park, Perthshire, who writes me that it is a particularly fine male, and is still (1908) in his possession. One was picked up in an exhausted condition near Leadhills (Lanarkshire), on June 1st, 1909, and is now in the possession of Mr. G. W. Campbell, Coatbridge. This specimen is here mentioned as the locality where it was obtained is within two miles of the Dumfriesshire boundary.

This species is a common summer-visitant to central and

* Handbook Brit. Birds, pp. 114-115. 
southern Europe, occurring regularly at this season in the southern counties of England; and it winters in Africa as far south as Abyssinia and Senegambia.

\section{THE CUCKOO. Cuculus canorus, Linnæus.}

Local name-Gowk.

"In the month of Averil,

The gowk comes o'er the hill

In a shower of rain."

Old Dumfriesshire Saying.

A common summer-visitant.

Mr. Patrick Dudgeon writing in $\mathbf{1 8 9 0}$ of the alleged appearance of the Cuckoo in Kirkcudbrightshire as early as April 4 th, gives in support of the allegation what he says was the Fifeshire version of the above :

"On the ninth of Averil

The gowk comes o'er the hill

In a shower of rain.

And on the - of June,

He turns his tune again."*

Though varying annually in the date of its arrival, the male Cuckoo, with his welcome note, may be expected in our littoral parishes about April 16th; and the female follows quickly afterwards. It is noticed as a rule that the first reports of the bird's arrival hail from the coast, next from the vicinity of Lochmaben, then from Canonbie ; and it is often ten days after its first appearance that it is reported in the upper districts of the county.

When on migration the Cuckoo is occasionally seen in flocks, and Richard Bell records once having seen a party numbering several dozens, near Castle O'er (Eskdalemuir). $†$

The parasitic habits of this bird are well known, and the Rev. C. Swainson says: "The border shepherds declare

* P. Dudgeon, in litt., to R. Service, May 24th, 1890.

† My Strange Pets, p. 237. 



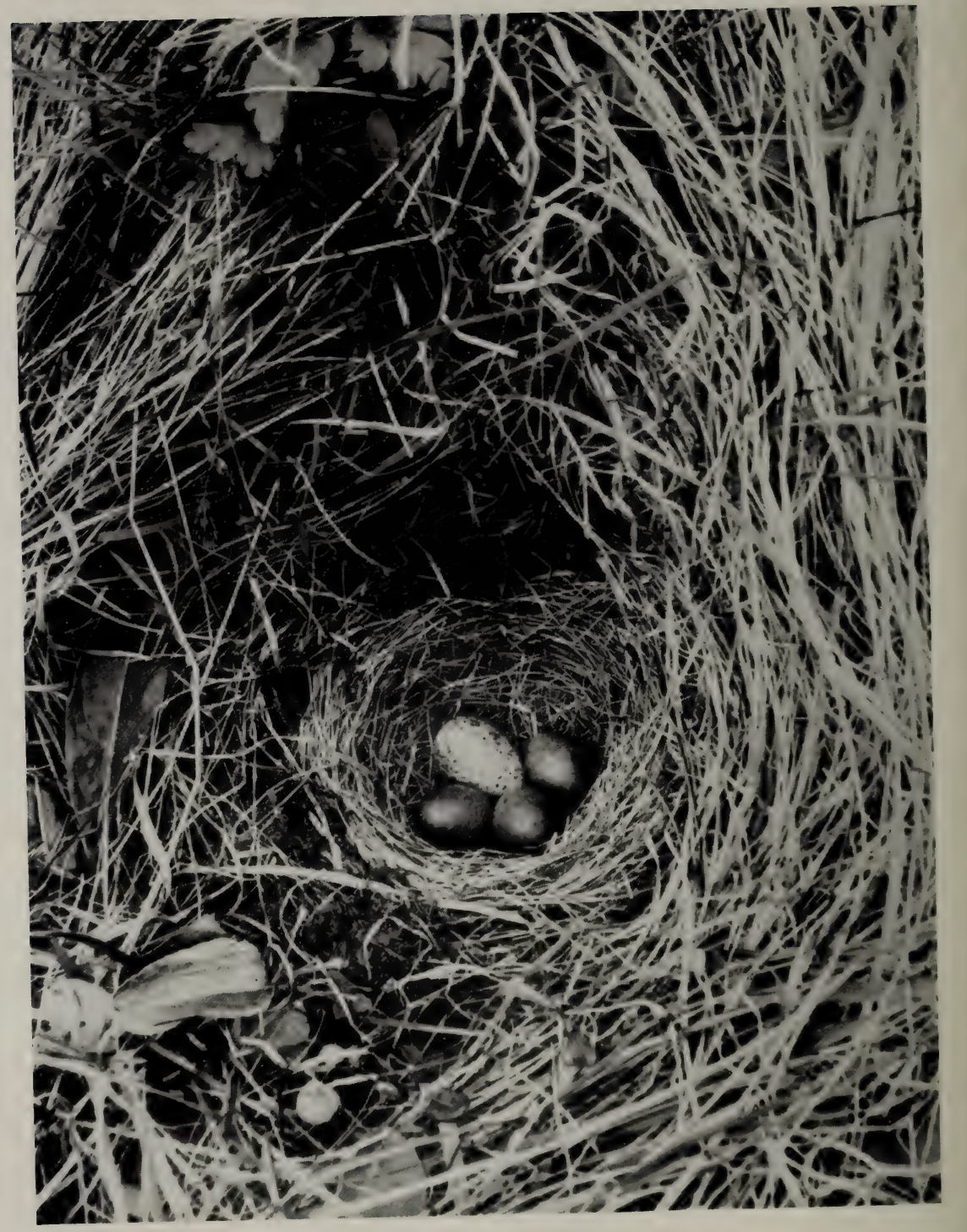

EGG OF THE CUCKOO (Cuculus canorus) IN A NEST OF THE MEADOWPIPIT (Anthus pratensis). 
that the blame for this apparently unnatural alienation of the parent from her offspring does not attach to the female, but is really attributable to the male, who if he had his way would devour the eggs and drive his partner from the nest. To avoid this she conveys the egg out of his reach, and deposits it in the home of some other bird."* The fact that the Cuckoo is at times seen carrying its egg in its bill to foist it on to some foster-parent has probably given rise to the belief that it destroys the eggs of other species. In this county the usual victim of its peculiar habit is the Meadow-Pipit, as shown in my illustration; but the Yellow Bunting, Tree-Pipit, Sky-Lark, and other birds, are also victimized. We read in 1844 of a Grouse's nest found near Queensberry, which contained four Grouse's eggs, four Greyhen's eggs, and one Cuckoo's egg. $\dagger$ We are subsequently told that the Greyhen's eggs were not hatched, but that those of the Grouse were, as also the egg of the Cuckoo ! $¥$ James Shaw states, "Although it delights to lay in a smaller bird's nest, such as the Meadow-Pipit, I have got its egg in the nest of a Kestrel." § Mr. E. Bidwell in 1896 gave a list of one hundred and nineteen different species of Western Palæarctic birds in whose nests Cuckoos had laid their eggs, $\|$ and amongst these were included such unsuitable birds as the Little Grebe and Green Woodpecker ; but it is extremely improbable that the eggs are hatched when deposited in such unsuitable nests.

Howard Saunders states, "From five to eight eggs are produced by the female in the season, and twelve to thirteen days are required for incubation." "I

Two young Cuckoos in one nest have more than once been recorded in the Transactions of the Dumfriesshire and

* Prov. Names Brit. Birds, 1885, p. 121.

$\dagger$ Dumfries Courier, July 1st, 1844.

¥ Op. cit., July 8th, 1844.

\& A Country Schoolmaster, 1899, p. 289.

"I Ibis, 1896, pp. 397-400.

ๆ Man. Brit. Birds, 1899, p. 288. 
Galloway Natural History and Antiquarian Society, but one always ejected the other.

The popular saying, "In June he changes his tune," is locally rendered, "When the barley shoots, the Cuckoo gets a barley-awn* in his throat and can call no more." The Cuckoo calls on the wing, as well as when perched, and is frequently heard at night. On May 13th, 1908, I distinctly heard one using his triple call " cuck-cuck-oo," the earliest date for this change in his tune that I have heard of. It may perhaps here be worthy of note that the bird's name is locally pronounced with the accent on the last syllable.

Many superstitions have been woven round this bird. James Shaw gives this verse as being used in his time:

"Gang and see the swallow flee,

Sit and hear the gowk,

The foal before its minnie's e'e, $\dagger$

And all that year ye've luck." $\ddagger$

Mr. R. Service tells me, "All over this district, when the Cuckoo is first heard, maidens examine the soles of their boots, or failing them the ground near, and if a hair is found its colour will show them the colour of their future husband's hair. The custom is not nearly so general as formerly, or perhaps I am much less in contact with the performers, but I saw and heard it gone through as recently as 1908."

In some summers, as in 1885 and 1903, this species is exceptionally abundant. In the latter year the oak trees at Capenoch (Keir) were infested with caterpillars innumerable, and never in my life have I seen so many Cuckoos gathered together.

They destroy the larvoe of the antler-moth (Charoeas graminis) or "hill-grub" which is so injurious to upland hill-pasture, and Mr. Fred. V. Theobald writes: "The Cuckoo is a decidedly useful bird, and does no harm. It is the only powerful natural check we have on such insect

* The bristle-like beard of the barley.

$\uparrow$ Mother's eye.

† A Country Schoolmaster, 1899, p. 31. 
pests as the hairy caterpillars of the lackey and browntailed moths, and other similar depredators of our woods and plantations."*

Perhaps no species has benefited more than the Cuckoo by the law abolishing the use of the pole-trap; placed as these traps often were on the open moor, they formed a lethal attraction to this innocent insectivorous bird.

The adult Cuckoos leave us in the last week of June, and " one seen later than mid-July is a fact worth noting." $\dagger$ The birds of the year linger occasionally till the end of September; but most have left by then for their winterquarters which extend as far south as Natal.

The following table is interesting because of the long sequence of observations by Messrs. Adamson, Brown, and Laidlaw in different parts of the county, whereby the average earliest arrival of the Cuckoo would appear to work out at the 23rd or 24th of April. But a regular sequence of observations from the littoral districts would be expected to show its first arrival there a week earlier.

\begin{tabular}{|c|c|c|c|c|}
\hline Year. & $\begin{array}{c}\text { First seen or } \\
\text { heard. }\end{array}$ & District. & $\begin{array}{c}\text { Source of } \\
\text { Information. }\end{array}$ & Remarks. \\
\hline 1842 & April 22nd & Dumfries- & Dumfries Courier, & \\
\hline 1854 & April 24th & $\begin{array}{c}\text { shire } \\
\text { Do. }\end{array}$ & $\begin{array}{l}\text { May 8th, } 1842 \\
\text { Do., May 2nd, }\end{array}$ & \\
\hline 1861 & May lst & Do. & $\begin{array}{l}1854 \\
\text { Do., Feb. 25th, }\end{array}$ & \\
\hline & Annil 20 th & & 1862 & \\
\hline 1862 & April 30th & $\begin{array}{l}\text { Collin } \\
\text { (Dumfries) }\end{array}$ & $\begin{array}{l}\text { Mr. William } \\
\text { Adamson }\end{array}$ & \\
\hline 1863 & April 23rd & Do. & $\begin{array}{l}\text { Adamson } \\
\text { Do. }\end{array}$ & \\
\hline 1864 & April 23rd & Do. & Do. & \\
\hline 1865 & April 22nd & Do. & Do. & \\
\hline 1866 & April 21st & Do. & Do. & \\
\hline 1867 & April 20th & Do. & Do. & \\
\hline 1868 & May 2nd & Do. & Do. & \\
\hline 1869 & April 16th & Do. & Do. & \\
\hline 1870 & April 14th & Do. & Do. & \\
\hline 1871 & April 16th & Do. & Do. & \\
\hline 1872 & April 12th & Do. & Do. & \\
\hline
\end{tabular}

* Science Progress, 1907, Vol. II., p. 276.

† Ann. Scot. Nat. Hist., 1903, p. 194. 


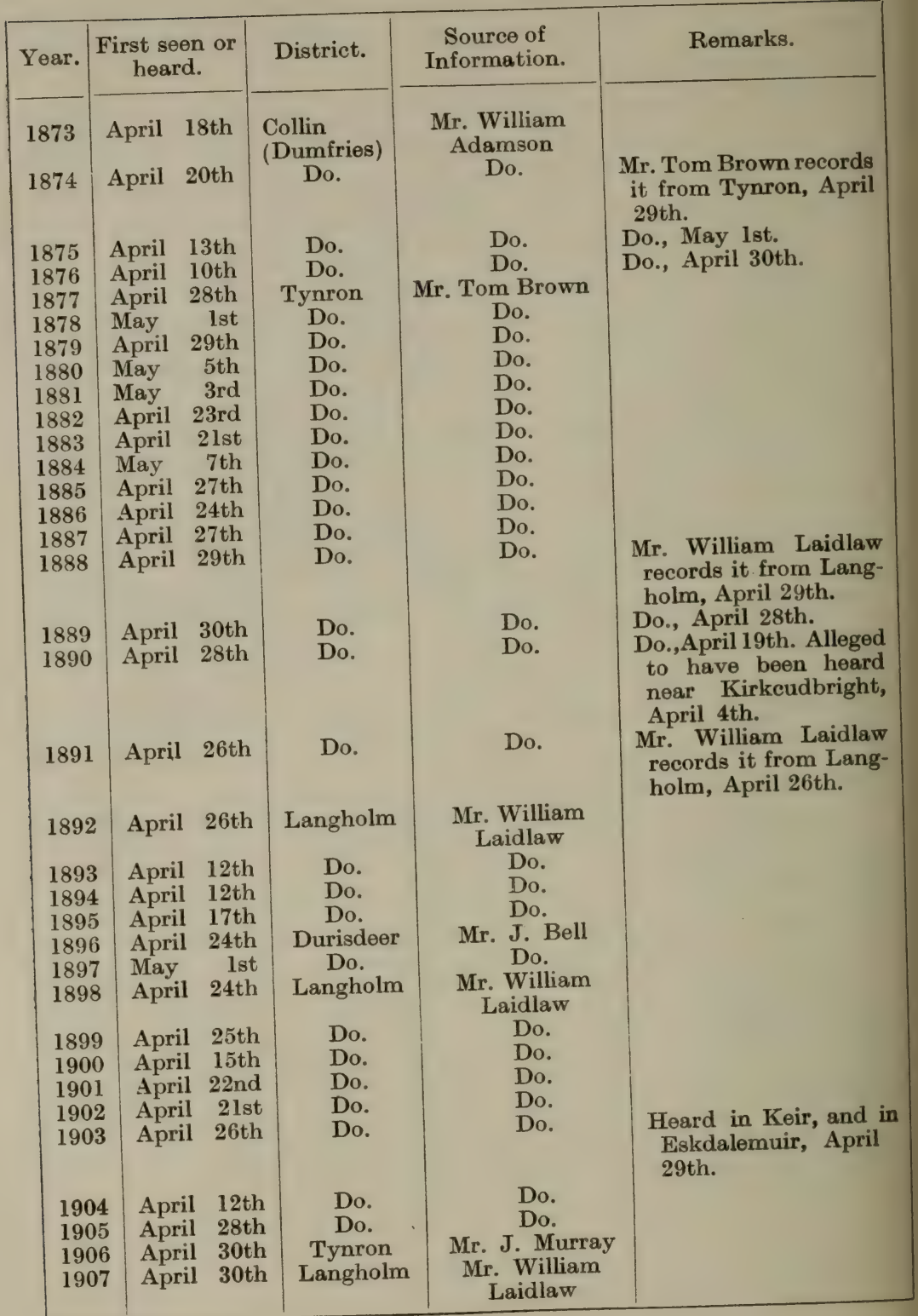




\section{BIRDS OF DUMFRIESSHIRE}

\begin{tabular}{|c|c|c|c|c|}
\hline Year. & $\begin{array}{l}\text { First seen or } \\
\text { heard. }\end{array}$ & District. & $\begin{array}{l}\text { Source of } \\
\text { Information. }\end{array}$ & Remarks. \\
\hline 1908 & $\begin{array}{l}\text { April 29th } \\
\text { April 23rd }\end{array}$ & Langholm & $\begin{array}{l}\text { Mr. William } \\
\text { Laidlaw } \\
\text { Mr. R. Service }\end{array}$ & $\begin{array}{l}\text { Said to have been heard } \\
\text { on April 9th, near } \\
\text { Dumfries. }\end{array}$ \\
\hline 1910 & April 23rd & Langholm & $\begin{array}{l}\text { Mr. William } \\
\text { Laidlaw }\end{array}$ & $\begin{array}{l}\text { Heard on April 15th, } \\
\text { near Dumfries. }\end{array}$ \\
\hline
\end{tabular}

THE BARN-OWL. Strix flammea, Linnæus.

Local names-SCREeCH-OWL; White OWL.

. "Let the screeching owl, A sacred bird be held; protect her nest, Whether in neighbouring crag, within the reach Of venturous boy, it hang, or in the rent Of some old echoing tower, where her sad plaint The live long night she moans, save when she skims, Prowling along the ground, or through your barn,

JAMES Grahame.- "British Georgics" (September).

\section{An uncommon local resident.}

The Barn-Owl has decreased in this county almost to vanishing point. During the first half of the nineteenth century, there is abundant proof that it was quite common, if not the commonest of our four resident species of owls, but all later observers remark on its decrease. In 1888 Robert Maxwell told Mr. R. Service that it was becoming scarce in Kirkmahoe parish; and in the same year Mr. John Corrie spoke of this bird as uncommon in Glencairn, but said that it " nested till a few years ago at Hastings Hall "* (Moniaive). In $1900 \mathrm{Mr}$. R. Service describes the species in the Solway area as "dying out for some unexplained

* Trans. D. and G. Nat. Hist. Soc., November 10th, 1888. 
cause. There are very few left now."* Dr. J. W. Martin in 1901 records that a pair used to nest at Dardarroch, but had not done so for many years. $\dagger$ Mr. R. Armstrong, whose knowledge of the birds of Upper Nithsdale is extensive, describes the species to me as being very rare, and says he has only once seen a nest, in the ruins of Morton Old Castle.

The nesting-period of this species is well known to be very prolonged, and a young bird in down, three weeks old, was brought to William Hastings in December, 1883.

In 1839 we read: "In an opening behind the Coat of Arms cut over the portals of the inner court at Drumlanrig, a pair of Barn-Owls have brought forth their young for the last eight years.'§

It is much to be regretted that the Barn-Owl should have so diminished, as it is one of the farmer's best friends. Mr. Fred. V. Theobald writes that it "lives mostly on voles, long-tailed field-mice, and small birds." $\|$

The characteristic cry of this bird is more of a loud and fearful shriek than a hoot, but Sir William Jardine has stated: "This species does hoot, for I have shot them in the act. They also hiss and scream, but at night, when not alarmed, hooting is the general cry."

\section{THE LONG-EARED OWL. Asio otus (Linnæus).}

Local names-Horned OWL ; WeE Horned OWL ; LugGie.

A common resident in well-wooded localities.

After writing of the sorry decrease of the preceding species it is satisfactory to be able to state that the Long-eared

* Trans. D. and G. Nat. Hist. Soc., November 16th, 1900.

$\dagger$ Op. cit., December 13th, 1901.

$\ddagger O p$. cit., November 7th, 1884.

§ Dumfries Courier, May 22nd, 1839.

|| Science Progress, 1907, Vol. II., p. 268.

If White's Selborne, 1851, p. 158. 


\section{BIRDS OF DUMFRIESSHIRE}

Owl is on the increase. In 1839 Sir William Jardine wrote of this bird: "In the south of Scotland it is certainly the most common next to the White Owl; we have not yet, however, ascertained its range northward."*

The Long-eared Owl is strictly arboreal in its habitat, and it wages war against field-mice, voles, rats, small birds, besides beetles and other insects. During the voleplague of 1891-1893 it had a good time, but Mr. Hugh Mackay records that in 1894, "During the months of July and August I received large numbers of owls from various parts of the county. The long-eared species was by far the most numerous, and from their emaciated condition it was not difficult to perceive that death was due to starvation. ... This great mortality is attributed principally to the cessation of the vole plague, for when the voles were numerous the owls flocked from all parts of the country, attracted by the abundant food supply." $\dagger$

In the autumn a considerable immigration of this species from the Continent frequently takes place on the east coast of Great Britain ; and in Dumfriesshire, at this season of the year, it is often quite common.

Several pairs occasionally nest in proximity, and $\mathrm{Mr}$. William Laidlaw writes me that Crofthead Wood (Canonbie) was a very favourite haunt before it was blown down. Mr. R. Armstrong informs me that at the end of March, 1892, he found on Newton Farm (Closeburn) seven pairs nesting in four trees growing close together. The nests contained from four to seven eggs, and the birds laid again
in June.

Mr. R. Kearton describes the "note" of this bird as "a deep hoot," $¥$ but Howard Saunders states that "The old birds occasionally make a barking or 'quacking, noise, while on the wing as well as when perched; but as

* Nat. Lib., 1838, Vol. IX., pp. 281, 282.

$\dagger$ Trans. D. and G. Nat. Hist. Soc., April 20th, 1894.

† Brit. Birds' Nests, 1901, p. 180. 
a rule this species is rather silent, and certainly does not ' hoot' like the Tawny Owl."*

\section{THE SHORT-EARED OWL. Asioaccipitrinus (Pallas).}

\section{A very local resident.}

In his correspondence with P. J. Selby, Sir William Jardine has three interesting references to this species. On December 18th, 1825, he wrote from Jardine Hall: "I shot a Short-eared Owl (S. brachyotus) on the muir yesterday, it is now late for that species." $\dagger$ Again on September 5th, 1829, he informs his friend that "when out on the 12th August, I had a dead point, and when going up full of expectation discovered a half-fledged Short-eared Owl, and on consulting the herds find they breed yearly; generally two pairs on a bare peat hag, laying six eggs. Did you know this?" $\ddagger$ On December 12th, 1831, he writes: "Nichol brought me a Short-eared Owl yesterday, shot very near their breeding place on the Hills. Will they not be constant visitants ? a female containing a golden plover."§

Sir William Jardine was one of the first to give a good account of the breeding of this species. He writes as follows: "On the extensive muirs at the head of the Dryfe, a small rivulet in Dumfriesshire, I have for many years past met with one or two pairs of these birds ; and the accidental discovery of their young first turned my attention to the range of their breeding; for, previous to this, I also held the opinion that they had commenced

* Man. Brit. Birds, 1899, p. 294.

$†$ Sir W. Jardine, in litt., to P. J. Selby, December 18th, 1825.

$\ddagger I d$., September 5th, 1829.

§ Id., December 12th, 1831. 
their migration southward. The young were discovered by one of my dogs pointing it ; and in the following year, by searching at the proper season, two nests were found with five eggs each. The nests were formed upon the ground on the heath; the bottom scraped until the fresh earth appeared, on which the eggs were placed, without any lining or other accessary covering. When approaching the nest or young, the old birds fly and hover round, uttering a shrill cry, and snapping with their bills. They will then alight at a short distance, survey the aggressor, and again resume their flight and cries. The young are barely able to fly by the 12th August, and appear to leave the nest some time before they are able to rise from the ground. I have taken them, on that great day to sportsmen, squatted on the heath like young black game, at no great distance from each other, and always attended by the parent birds. Last year (1831) I found them in their old haunts, to which they appear to return very regularly."*

In 1838 Sir William wrote: "In the north of England and in Scotland, they will rank as summer, perhaps permanent residents"; he then quotes the above, and adds: "We have since occasionally observed this Owl in December and January; by no means common, however, four or five specimens during five or six years, and it is most probable that the great proportion of those which breed with us return again during winter, and the bird is certainly much more abundant on the ranges of upland muir during summer than in any locality after the breeding season has been completed. Those we have seen at this season have been disturbed from whin covers or patches of long and tangled grass and bramble, sitting close at first, but afterwards
very shy." $\dagger$

William Hastings has recorded that the Short-eared Owl nested near Morton Old Castle about 1830-1846. In 1893 Peter Gray writing the reminiscences of his boy-

* Amer. Ornithology, 1832, Vol. II., pp. 63, 64.

† Nat. Lib., 1838, Vol. IX., pp. 285, 287. 
hood (i.e., circa 1850), says: "I have now reason to believe . . . that the Short-eared Owl, generally described as an autumn and winter visitor only to this country, occasionally nested amongst the tall heather in Lochar Moss."* A specimen is recorded as shot in the Dumfries district on January 30th, 1858. $\dagger$

Thomas Maxwell in 1862 spoke of the species as the rarest of the four owls in Nithsdale.

Richard Bell of Castle O'er states that he knew of this species breeding in Upper Eskdale in $1864, \S$ but it was not until some ten years later that they became plentiful; while H. A. Macpherson records in 1892, "Many years ago I captured a newly fledged Short-eared Owl in Dumfriesshire on Lochar Moss."

A plague of voles (Microtus agrestis) in 1874-1876 was devastating the upland pastures in Upper Eskdale, and a big movement of Short-eared Owls to the infected districts took place. This vole-plague, according to Sir Walter Elliot's report, was felt most severely as regards Dumfriesshire, in the parishes of Tynron, Penpont and Durisdeer, in Nithsdale ; and in Eskdalemuir, on the border of Roxburghshire. I The Short-eared Owls might be said to have accompanied the voles, and when the plague died out in 1877 the birds disappeared.

In 1889 a recurrence of this plague was beginning. In that year voles were noticed in vast numbers on the lowlying pastures in Closeburn parish, and they continued there till 1891, when they disappeared; doubtless to the higher ground. From 1891-1893 there raged such a devastating plague on the upland pastures as will long be remembered. It was estimated that in Eskdalemuir and

* Dumfries Standard, January 18th, 1893.

$\uparrow$ Naturalist, 1858, Vol. VIII., p. 117.

‡ Grierson's MS. Notes, October 17th, 1862.

§ My Strange Pets, p. 256.

II Fauna of Lakeland, 1892, p. 174.

II Mammals of Great Britain, Vol. II., p. 270. 
the north-east of the county some twenty thousand acres were affected; in the upper portion of Annandale from twelve to fifteen thousand; and from Queensberry Hill on the east, to the vicinity of Thornhill on the west, fifteen thousand acres*; a total of something like fifty thousand acres in Dumfriesshire alone, and it was computed that the whole area affected in the border counties was not less than sixty miles in length and from ten to twenty in breadth. $\dagger$ This remarkable visitation caused an altogether marvellous immigration of Short-eared Owls; and, as in the 1874-1876 plague, they were accompanied by Buzzards
and other birds of prey.

Mr. R. Service speaking of this incursion says of these Owls : "In Dumfriesshire alone not less than five hundred pairs of breeding birds were estimated as present. Probably there were three or four times that number on the vole-infested farms. I have elsewhere told how these grand
birds nesting without to nest in February, and continued twelve eggs were the what avidity and untiring vigilance in a clutch ; and with during every one of the hours of day voles were pursued a never-to-be-forgotten experience to see on mile was mile of the moorlands always a dozen or more of them in sight at once. . [but] . . the finest sight of all was when at midsummer of $1892 \mathrm{I}$ had a chance of going along the hills at midnight. The night was bright and clear, and very I ever saw. The voles were scurrying hither and thither, squeaking and rustling as one stepped over and amongst were sitting blinking their eyes and contorting their bodies in groups on almost every little hillock. The parents never troubled to alight amongst their offspring, they simply
flew past, and flung the dead voles at their young in the
${ }^{*}$ R. F. Dudgeon, Zoologist

* R. F. Dudgeon, Zoologist, 1892, p. 165.
† Report Field Voles Scot. (C. 6943), 1893, p. 8. 
byegoing. It was a weird and impressive bit of bird life, one my poor powers of description cannot do justice to."*

The extension in the period of their time of nesting, as well as the abnormal increase in the number of eggs laid, were remarkable facts during the visitation of the Shorteared Owls. Richard Bell records finding a female sitting on her nest of twelve eggs on February 29th, 1892. The snow was lying all round, so that only her head was visible, and at the sides of the nest lay seventeen dead voles, evidently brought to her by the male bird. He also states that in defence of their nests they at times were very bold, and on one occasion severely attacked a boy. $\dagger$ The plague reached its highest point in the summer of 1892, after which the voles decreased; and we read that by November, 1893, all the Short-eared Owls had either left or were starving. +

The Commission, which, under the chairmanship of Sir Herbert Maxwell, had sat to investigate the cause of this outbreak, found from the evidence brought before them that this plague of voles was attributable to mild winters, followed by a succession of dry springs conducive to successful breeding; and the destruction and (hence abnormal) diminution in the numbers of such useful birds as Hawks, Buzzards, and Owls, and also weasels and stoats. Mr. R. Service writes: "The great vole plague came to a very sudden termination, and the destroying angels in the shape of Short-eared Owls died too in hundreds, being picked up everywhere in the last stages of emaciation. 'Died of hunger' was the general verdict, but I believe this was quite wrong. Died of disease incurred through eating the diseased voles is, I fancy, the true reason." Since this notable immigration of Short-eared Owls there

* Trans. D. and G. Nat. Hist. Soc., December 18th, 1903.

† Op. cit., April 17th, 1901.

† Zoologist, 1894, p. 57.

\$ Mammals of Great Britain, Vol. II., p. 273.

II Trans. D. and G. Nat. Hist. Soc., December 18th, 1903. 



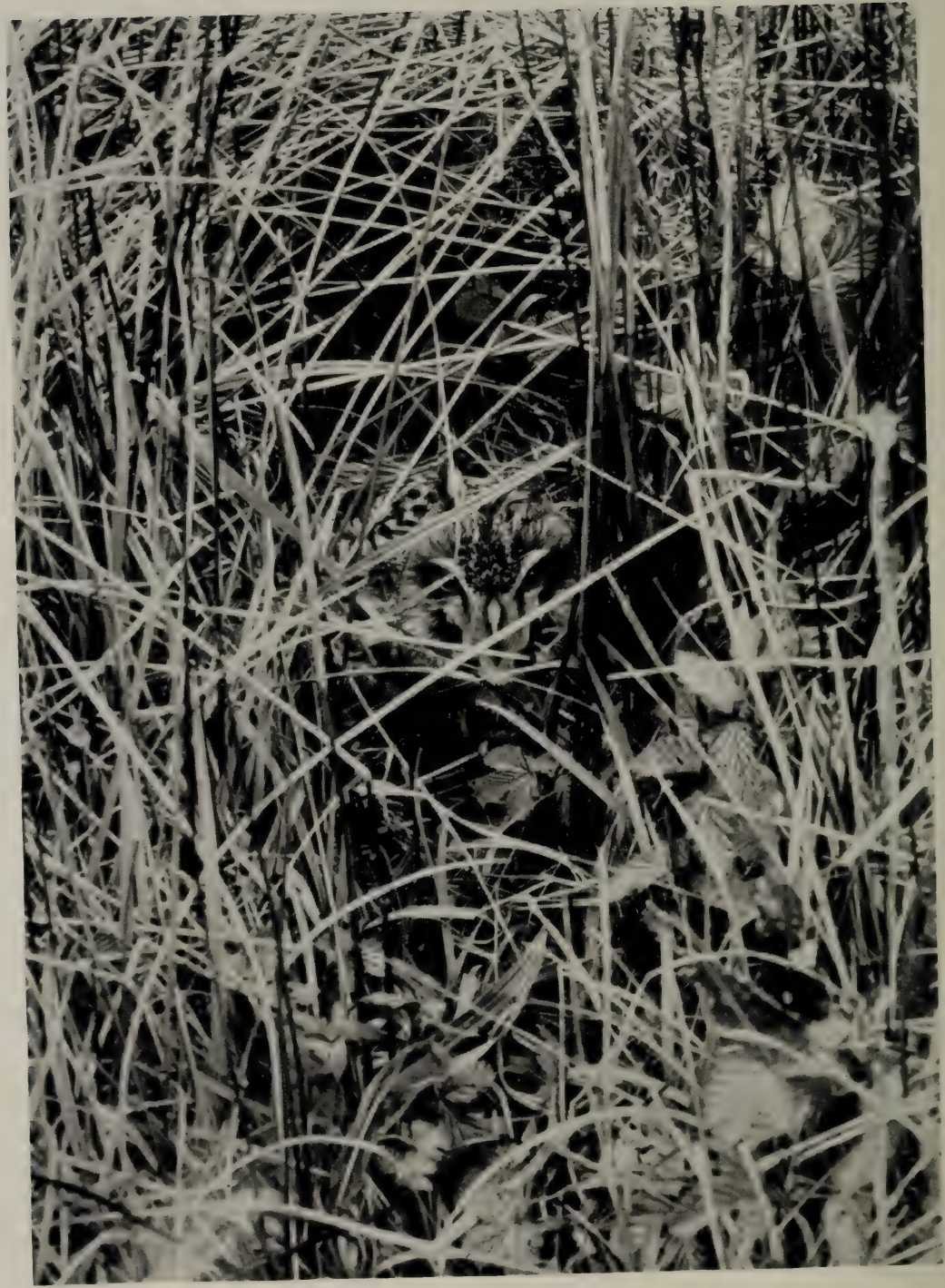

181] SHORT-EARED OWL (Asio accipitrinus) ON THE NEST. 
has been no serious recurrence of the vole-plague, though in 1903 local outbreaks occurred in some of the border

A bird of this species was seen at Ericstane (Moffat) on August 11th, 1894, $\dagger$ and Mr. J. W. Payne informs me that the Short-eared Owl nests in the vicinity of Gretna. It is now confined to but a few isolated spots in the county, where it is to be hoped so useful a bird may be left to multiply in peace. Mr. J. Bartholomew writes me that he occasionally sees this owl near Beattock, but that he does not think it nests there.

For the photograph of this species here reproduced I am indebted to Mr. F. Barber-Starkey.

The Short-eared Owl nests in several counties of England and Scotland, and it may be regarded as a common wintervisitant from the Continent to the eastern coasts of Great Britain, where it is often called the "Woodcock Owl " either on account of its somewhat similar " twisting " flight, or from its appearance about the same time as the Woodcock.

\section{THE TAWNY OWL. Syrnium aluco (Linnæus).}

Local names-Brown OWL; Wood-OWL; GREY OWL; HOOLET; JENNY Hoolet.

A common resident. "Montague calls it 'by far the most plentiful Owl in England.' So far as our observations in the north of England and south of Scotland have extended, this is not the case; the Long-eared Owl appearing much more plentiful and more generally distributed." $\$$ H. A. Macpherson

* Mammals of Great Britain, Vol. II., p. 274.

$\dagger$ Ann. Scot. Nat. Hist., 1895, p. 252.

$\ddagger$ Nat. Lib., 1838, Vol. IX., p. 263. 
has a MS. note in the margin of his copy of Yarrell's British Birds: "Always well known in the south of Scotland" ; and nowadays the Tawny Owl ranks as our commonest species, and is increasing.

The nest of this bird may be found in a rabbit-burrow, in a disused Wood-Pigeon's or Crow's nest, a squirrel's drey, in crevices of rock, or in the hollow trunk of a tree. Three to five eggs usually constitute a full clutch, but Mr. R. Armstrong tells me that in March, 1892, he found a nest on Burn Farm (Closeburn) containing eight eggs. Its chief food consists of voles, moles, and such noxious quadrupeds, and, like the other owls, it takes cockchafers on the wing. Mr. Fred. V. Theobald states that this species is a great devourer of finches,* and it is known to take small surfaceswimming fish. At a nest I found on May 17th, 1905, I recognised the remains of a half-grown pigeon and a three-quarter-grown rabbit; and on another occasion I found a young leveret had been taken.

The Tawny Owl is an early breeder, and its eggs are not infrequently laid in March. Mr. R. Service found a nest with new-laid eggs at Crichope Linn (Closeburn) on September 19th, 1892, but remarks that all owls that year " were nesting late and breeding early because of the superabundance of voles." $\dagger$

The sameobserver is of opinion that, "In autumn and spring many migrant Brown Owls pass through our area, amongst which an occasional fine example in the interesting grey phase of plumage may be distinguished. So far as my experience goes, this grey phase of plumage has no representatives with us as breeding birds. They are, I believe, all migrants passing through the district, and are found usually in the late autumn months." + Such a specimen was got at Craigshiels (Kirkmichael) as late as April 23rd, 1901; but I cannot support the migration-theory advanced by Mr. Service.

* Science Progress, 1907, Vol. II., p. 268.

† Dumfries Courier and Herald, October 11th, 1892.

‡Trans. D. and G. Nat. Hist. Soc., December 18th, 1903. 


\section{BIRDS OF DUMFRIESSHIRE}

The note of the young bird resembles the dissyllable "kee-wick"; a fact that puzzled one of my informants, who reported that she had heard the "kee-wee, or ScopsOwl" regularly near her residence. The "hoo-hoo whooit " of the old birds is a welcome sound, and on a still night it is somewhat weird to hear other Tawny Owls at a distance answering back again out of the darkness.

Mr. R. Martin of Dardarroch writes me: "We have an Owl (Brown) that has been blind all its days, full grown, and now stuffed. No eye-holes at all."

\section{THE SNOWY OWL. Nyctea scandiaca (Linnæus).}

Has occurred once or possibly twice.

Mr. R. Service informs me that the late Mr. Richard Rimmer of Dalawoodie was certain he saw a Snowy Owl in the early spring of 1861. He watched it sitting on a tree in the park from his dressing-room window at Kirkmichael House.

Mr. R. Service also recorded in 1903, "A few years ago a specimen was shot on the Dumfriesshire bank of the Esk. The late H. A. Macpherson fully informed me of the occurrence in his usual kind way, but at the present moment I have mislaid the note and cannot, therefore, give any further particulars."* In answer to my inquiries, Mr. Linnæus Hope (the curator of Tullie House Museum, Carlisle) writes : "A Snowy Owl killed in Dumfriesshire and formerly in the possession of Thomas Armstrong, was given to the Museum by his daughter in 1895 . It was in such a hopeless condition from moth when given to us that I cremated it, with Macpherson's approval."

The Snowy-Owl inhabits the circumpolar regions, occasionally straying south in winter.

* Trans. D. and G. Nat. Hist. Soo., December 18th, 1903. 
THE MARSH-HARRIER. Circus cruginosus (Linnæus).

Local names-Moor-Buzzard; Grey-HEADEd BUZzard.

A very rare visitor.

The Marsh-Harrier is referred to by Sir William Jardine in a list of the birds of the parish of Applegarth and Sibbaldbie in 1832, as follows: "One or two of these birds have occasionally frequented the Perch Hall Loch in the parish. They are rare in this county, and appear about the large swamps and mosses at uncertain intervals."* A contemporary writer states that "The Moor-Buzzard is oceasionally seen in the Lochar Moss." $\dagger$ In 1838 Sir William recorded that "The Marsh-Harrier appears to be common in many parts of England, but is rare generally in Scotland, the western parts being too precipitous for its habits. It would also seem to be partially migratory, for it appears much more numerously in one season than in another; one year we know of seven or eight specimens being killed upon the Border, while for the last ten years it has been comparatively rare." $\$$ He further mentions that he had never seen the nest. "In the "Catalogue" of the collection of British birds bought from Sir William Jardine by the Edinburgh Museum in 1876 appears this entry: "No. 15. Marsh Harrier from Kinmount" (Cummertrees).

Robert Maxwell told Mr. R. Service of a Marsh-Harrier shot at Dalswinton (Kirkmahoe) in September, 1887; and a fine old male of this species killed at Carse Wood (Kirkmichael) on May 5th, 1898, was stuffed by Mr. Day, and passed into the possession of Mr. Service.

* New Stat. Acct. Scot., Vol. IV., p. 178.

† Op. cit., Vol. IV., p. 443.

$\ddagger$ Nat. Lib., 1838, Vol. IX., p. 239.

§ Op. cit., 1838, Vol. IX., p. 238. 
This species nests in central and southern Europe, and those birds that have bred in the northern parts migrate to the countries bordering the Mediterranean, and appear as far south as Abyssinia.

\section{THE HEN-HARRIER. Circus cyaneus (Linnæus).}

\section{Local names-Common Harrier; Ringtail ; Ring- TAILED HawK.}

\section{Formeriy common and resident; now a very rare visitor.}

Writing of the Hen-Harrier in his account of the birds of Cumberland, John Heysham notes that the Duke of Buccleuch's gamekeeper " has destroyed some hundreds, and has frequently shot both male and female from the same nest."* This information referring to the last years of the eighteenth century shows how numerous these birds once were locally, and also that the days of their persecution had commenced. In 1832 Sir William Jardine wrote of the Hen-Harrier, in a list of birds of the parish of Applegarth and Sibbaldbie: "After the season of incubation it leaves the hills, and with its brood visits the low country daily, roosting among whins and long heather." $\dagger$ In his Naturalist's Library he gives a full account of the nests and habits of the Hen-Harrier, but he does not state whether these observations were made in or out of Dumfriesshire. $\ddagger$ In $A$ Catalogue of the Birds contained in the collection of Sir William Jardine two specimens are entered as obtained at Jardine Hall.§

Till the middle of the nineteenth century the HenHarrier was undoubtedly abundant on all our mosses and

* Hist. and Antiq. Cumb., 1794, Vol. I., p. 6.

$\dagger$ New Stat. Acct. Scot., Vol. IV., p. 178.

† Nat. Lib., 1838, Vol. IX., pp. 229-231.

$\S$ Cat. Birds in Coll. Sir W. J., p. 9 (339), a. a. 
moors, where it bred, but the systematic persecution it received from gamekeepers and preservers of game, exterminated this once common resident; though doubtless the improvement in agriculture and drainage have destroyed many attractive haunts. In the neighbouring county of Ayr it is recorded that between June 25th, 1850, and November 25th, 1854, three hundred and fifty-one "Ash-coloured Hawks " were killed by Lord Ailsa's keepers on his estate.* What birds could stand such persecution ? Mr. Tom Crosbie, who is now a man of seventy-eight, tells me he remembers usually seeing these birds every winter till about 1883, in which year he shot one at Holmhill (Morton), and the following spring he saw a pair not far from Tibbers (Penpont) flying west.

A Hen-Harrier, believed to have been a female, was shot on the Kerr Moss below Moffat by Mr. Campbell in the winter of 1905-1906; and Mr. Kerss, the keeper at Craigielands, told my informant Mr. J. Bartholomew, that he had seen these birds occasionally in Eskdalemuir some years ago, and that at a more remote date they used to nest up Ewes Water, on Meikledale or Burnfoot. Mr. J. Little writes me that two were shot on Archbank Moor (Moffat). in September, 1896.

The Hen-Harrier visits the basin of the Mediterranean, north-east Africa, and as far south as Abyssinia, India and China in its winter-migrations. It breeds in central Europe, extending further north in its breeding-range than the preceding species; while it still nests very locally in Ireland, in the Hebrides, Orkneys and Shetlands, and more rarely in the Highlands of Scotland, and in England.

\section{[MONTAGU'S HARRIER. Circus cineraceus (Montagu).}

Mr. R. Service records in his diary on November 15th, 1886, that William Hastings told him he had a bird to

* Birds of Ayr, 1869, p. 11. 
preserve from Closeburn about 1866 which he believed to be of this species. Mr. T. A. Johnstone of Moffat states: "A friend gave me an egg from a nest, which he found in May, 1904, in the Kerr, a marsh a little to the south of the town, which is that of this bird [i.e., Montagu's Harrier]. The egg is pale blue and has a rough texture. In size it is slightly less than that of a Pheasant. The nest consisted of a slight hollow in the ground, lined with dry rushes. This is the second instance of its nesting in this county. The other instance was mentioned in a paper, read before the Dumfries Naturalists' Society by Mr. R. Service, being a female, which was shot in June, 1881, that had been sitting on eggs."* As a matter of fact this female was "caught on Cairnsmore of Fleet" (Kirkcudbrightshire), but "had beyond doubt been sitting on eggs. The date was June 15th, 1881," $\dagger$ not 1882 as given by Howard Saunders.t In reply to my enquiry, Mr. Johnstone most kindly replied: "I very much regret my inability to show you the Harrier's egg. I have been away from home for a year, and a great many of my eggs, including it, have been broken during my absence. I may say that I had an opportunity of seeing the eggs of Montagu's and the Hen-Harrier together (I did not see any of the Marsh-Harrier's) in South Kensington Museum, and I certainly think that the egg I had, agreed most with Montagu's. I named it from a description with measurements contained in a handbook by Dr. R. B. Sharpe."

It is very unfortunate that so interesting an egg should have been lost, though the species for which it is claimed is the most unlikely of the three harriers to breed here; but had it proved to have been but the egg of the Hen-Harrier, so recent a date of that bird's nesting in our county would have been of great interest. When Sir William Jardine wrote in 1838, he was not aware of the

* Dumfries Courier and Herald, April 6th, 1907.

† Trans. D. and G. Nat. Hist. Soc., December 18th, 1903.

$\ddagger$ Man. Brit. Birds, 1899, p. 319. 
occurrence of Montagu's Harrier in Scotland,* and Howard Saunders wrote in 1899 it "was never a resident in the British Islands; . . . on the contrary, it is merely a springand summer-visitor to Europe (hardly excepting the Mediterranean basin), and its northerly range is not extensive." $\dagger$ In winter, Montagu's Harrier is found in Ceylon, Burmah and India, and in Africa as far south as Cape Colony.

The specimen recorded by Mr. R. Service having been obtained in Kirkcudbrightshire, I do not feel justified in including this species on Mr. Johnstone's evidence, otherwise than in square brackets.]

THE COMMON BUZZARD. Buteo vulgaris, Leach.

Local names-Buzzard-Hawk ; Buzzard-GLed ; Puttock ; Glead ; Gled.

Formerly a breeding-species; is now an occasional visitor in autumn and winter, more seldom in spring.

I have been surprised in collecting my notes on this species to have obtained so little evidence of its nesting in the county. That it did so regularly at the beginning of the nineteenth century there can be little doubt, and the place-name Craigenputtock (Dunscore), famous as the residence of Thomas Carlyle, testifies to at least one nestingsite of this species in former days.

Mr. R. Service informs me that Professor Alfred Newton, as a boy (i.e., circa 1845), obtained the eggs of the Common Buzzard from a lad at Dalswinton (Kirkmahoe).

In A Catalogue of the Birds contained in the collection of Sir William Jardine, is entered a Buzzard obtained at Jardine Hall, $\$$ and a specimen without date labelled "from Jardine Hall" is in the possession of Mr. J. H. Gurney.

* Nat. Lib., 1838, Vol. IX., p. 234.

$\dagger$ Man. Brit. Birds, 1899, p. 319.

$\ddagger$ Cat. Birds in Coll. Sir W. J., p. 2 (31), a. 
On December 1st, 1863, Sir William recorded: “In Dumfriesshire, the Common Buzzard and Peregrine Falcon are now very rare."* Mr. John Corrie in 1888 described the Buzzard in Glencairn as rarely seen, but that it was common thirty or forty years before; and he stated emphatically that it no longer nested in the parish. $\dagger$ Mr. Tom Crosbie told me in 1905 that he could well remember the Buzzard nesting in a tree at the foot of Glenquhargen Craig (Penpont) some forty years ago, and the Dumfriesshire naturalists record that, on their excursion to that spot on June 3rd, 1882, the empty nest of the Buzzard was observed. $\$$ Mr. R. Service tells me that about 18601863 he remembers the eggs of this species being newly brought by Walter Harkness of Mitchellslacks from the neighbourhood of Queensberry to Dumfries Academy. Dr. Grierson records in his diary that Thomas Maxwell told him in 1862 that the Common Buzzard, once plentiful at Dalswinton, was now seldom met with. About 1863 a Buzzard nested on Croglin Craig (Tynron) and took a whole brood of Blackgame one by one off the farm of Appin, so I am informed by an old drainer, James Anderson. This incident, by the way, shows the appropriateness of the name "Puttock," i.e., Poult-hawk. In reference to the nesting-site, Mr. J. Harkness tells me that the Buzzards nested regularly on Croglin Craig from 1861 to 1885 , and on one visit to the nest he found the young surrounded by the carcases of a partridge, a rabbit, and many moles. A young bird which he took and reared as a pet, reached maturity, but escaped. In 1885 some drainers employed on Appin Farm took all the nestlings, after which the site was abandoned. Mr. Tom Brown writes me that during his residence at Auchanhessnane (Tynron) from 1874 to 1891 he "frequently saw the birds in the district, and the nest a few times."

* Trans. D. and G. Nat. Hist. Soc., December 1st, 1863.

$\dagger$ op. cit., November 10th, 1888.

$\ddagger$ Op. cit., June 3rd, 1882. 
Robert Gray in a manuscript note in his copy of his Birds of the West of Scotland, records " a Buzzard shot in October, 1873, in Dumfriesshire, remarkable for its dark brown plumage, with a tint of reddish-brown on its wingcoverts." This bird was shot near Drumlanrig and was a male.

During the vole-plague of 1874-1876, the Buzzard which had long been a stranger returned to prey upon the voles.* One was shot about 1877 at Dalpeddar (Sanquhar), and another in the same year near Kirkconnel, so I am informed by J. R. Wilson, while at the end of October, 1880, several Buzzards are recorded by Mr. R. Service. $\dagger$ I am told by one of the gamekeepers at Drumlanrig that one was frequently seen near Dabton Loch (Morton) in the autumn of 1884; and $\mathrm{Mr}$. Wm. Easman tells me that a specimen was trapped on Kirkland Hill (Kirkmichael) in 1885. I hear from Mr. W. Evans that in May, 1887, he saw a Common Buzzard capture a water-vole on the hillside above Loch Skene. When it had devoured the vole Mr. Evans went to the spot and picked up the vole's skin which the bird had left behind.

During the vole-plague of 1891-1893 a marked increase in the number of Buzzards, as well as in other birds inimical to these pestilential rodents, was again generally observed throughout the county. A young bird was killed at Douglaw Glen (Ewes) at the beginning of January, 1892. $\ddagger$ In January, 1894, a Buzzard was trapped in Stenhouse Wood (Tynron) and is now in my possession ; and on September 18th and 21st of the same year I saw a bird of this species circling above Capenoch Hill (Keir). Mr. J. Little tells me he saw a Buzzard on White Coomb (Moffat) in 1897, and in 1901 Dr. J. W. Martin said that these birds were occasionally met with in the higher districts of Glencairn parish in early spring or late in autumn.§

* Mammals of Great Britain, Vol. II., p. 271.

+ Zoologist, 1881, p. 61.

† Hist. Berwick Nat. Club, Vol. XIII., p. 353.

§ Trans. D. and G. Nat. Hist. Soc., December 13th, 1901. 
A pair of Buzzards were often seen near the Far Loch, Capenoch, in the early spring of 1903 ; in which year Mr. R. Service thus summed up the status of this species: "I hardly think it breeds in Dumfriesshire, but it does so in several localities in Kirkcudbrightshire. . . . one was shot in Eskdale a short time ago, and another frequented a locality not more than three miles from Dumfries [i.e., near Cluden Banks, Holywood] most of last winter. Almost every year a few examples are killed during the autumn migration."* In 1904 four Buzzards were seen near Capenoch on September 1st, and in November one was shot and another trapped near Canonbie, while Mr. T. Ranken writes me that in the same year one or two were seen at Dalswinton. A fine specimen was brought in to Mr. R. Service from Craigshiel (Kirkmichael) on October 24th, 1905. A pair of Buzzards (reported to me as "Gleds with square tails") were observed in the spring of 1906 in the parish of Ewes, on the borders of Roxburghshire. They were frequently seen by my informant, Mr. W. Haining, but they did not nest, as far as he knew. On October 18th of the same year Mr. J. Bartholomew believes he saw a Buzzard near Beattock. That winter a pair were noticed near Sanquhar, and two seen on Kirkland Hill (Kirkconnel) in March, 1907, $\dagger$ may have been the same birds. On September 6th, 1907, while shooting with Mr. A. Cator, a Buzzard circled the whole afternoon over Breconside Moor (Durisdeer) and interfered considerably with our sport, as the Grouse seemed either to have been driven off the hill altogether, or else sat so close that we walked over them. Mr. George Kerss informs me that he shot two "Common Buzzards" at Knockhills (KirkpatrickJuxta) in 1904, and Mr. James Malcolm writes me that a Buzzard was once caught in a vermin-trap on Castle Hill, close by Langholm. On January 19th, 1909, Dr. J. W. Martin saw a bird of this species "sailing" over Greenhead (Dunscore).

\footnotetext{
* Trans. D. and G. Nat. Hist. Soc., December 18th, 1903.

$\dagger$ J. Laurie, in litt., June 1st, 1908.
} 
I have numerous reports of these birds being seen from time to time in the upper parts of the county; and it is to be regretted that they should be usually shot at sight. If the Wild Birds Protection Act was better obeyed, the Buzzard might once more become a resident.

This species is found commonly distributed over the greater part of western Europe in the nesting-season, becoming migratory in the autumn; and, though still breeding in some favoured localities in England, Scotland and Wales, its decreased numbers cry out for more protection.

\section{THE ROUGH-LEGGED BUZZARD.}

Buteo lagopus (J. F. Gmelin).

\section{An irregular winter-visitor.}

The first occurrence of this species that we have any note of, was recorded by Robert Gray as "one shot in Dumfriesshire in March, 1840, had a great number of young feathers of a blackish-brown colour, and would have been entirely of that tint had the moult been completed."* This specimen was, according to Macgillivray, probably a young one of the previous year. It was shot by John Shaw, head-keeper to the Duke of Buccleuch. Its length was twenty-two inches and the extent of its wings fifty-eight inches. $\dagger$ On December 1st, 1866, one was shot at Billholm $\ddagger$ (Westerkirk) by Richard Bell of Castle O'er. "It had indulged so heartily in a feast of partridge meat that its crop burst when it fell to the ground." $§$ The correct date of the above occurrence is as now given.

During the vole-plague of 1874-1876 Rough-legged Buzzards put in an unwonted appearance, and so many as

* Birds of West Scotland, p. 48.

† Macgillivray, Hist. Brit. Birds, 1840, Vol. III., p. 737.

$\ddagger$ Zoologist, 1867, pp. 604, 605 .

§ Trans. D. and G. Nat. Hist. Soc., April 17th, 1901. 
seven were seen at one time in 1876 in Upper Eskdale,* where the plague raged fiercely. One was taken at Langholm in October, 1875†; another, a male, was killed near Lockerbie on November 9th $\ddagger$; and others were obtained in the county, in November and December of the same year.\$ In the autumn of 1880 an immigration again took place. "A noble specimen" was obtained at Blackwood (Keir) on October 29th, as recorded by Mr. R. Service\|; one which was trapped that winter at Capenoch (Keir) is now in my possession; and I believe another was killed near there shortly after, but it was not preserved. During the devastating plague of voles in 1891-1893 this species again appeared in unusual numbers in the infested districts.

In 1903 an incursion of Rough-legged Buzzards took place in the autumn. One shot in Glengaber Wood (Holywood) in October, measured fifty inches from tip to tip of its wings, and is now in the possession of Mr. Hall of Berryland. In November one was killed at Auchancheyne (Glencairn) and sent to Edinburgh to be stuffed; three others were observed there about the same time; and one is recorded as seen on January 9th, 1904, near Moniaive. On December 9th, 1903, I watched a bird of this species for several minutes at close range on Kilmark Moor (Tynron). Mr. R. Service in his paper on "The Diurnal and Nocturnal Raptorial Birds of Solway," says of the Rough-legged Buzzards that came under his observation during this immigration of 1903 , that they "were most remarkable for the range of colour in the plumage shown by the various examples. Some were very fine dark-almost black-birds, while others were very light." $"$

This species, an inhabitant of the northern parts of Europe and Asia, is found on migration in autumn and winter as

* Trans. D. and G. Nat. Hist. Soc., April 17th, 1901.

† Proc. Nat. Hist. Soc. Glasg., 1876, Vol. III., p. 30.

† Proc. Roy. Phys. Soc. Edin., Vol. IV., 1876, p. 67.

$\$$ Hist. Berwick Nat. Club, Vol. VII., p. 463.

II Zoologist, 1881, p. 61.

IT Trans. D. and G. Nat. Hist. Soc., December 18th, 1903. 
far south as the islands of the Mediterranean; and though occurring on the east coast of Great Britain almost annually and in considerable numbers, it is seldom that more than two individuals are seen together in this county.

Considerable confusion seems to exist locally in determining this species from the Common Buzzard, so much so, that I have had to keep back several doubtful reports of its occurrence. The Rough-legged Buzzard is, however, at close quarters " distinguishable at a glance from the preceding species by having the front and sides of the legs feathered to the toes."*

\section{THE GOLDEN EAGLE. Aquila chrysaëtus (Linnæus).}

"The eagle soars high o'er the hill, Amid the realms of sky and eloud, And tampers but with what is great, So History soars above the crowd." Henry ScotT RidDell.-"The Notebook."

Formerly a resident species; is now a very rare visitor.

At the end of the eighteenth century it is presumable that both the Golden and White-tailed Eagles bred in Dumfriesshire, but so inextricably have the two species been confused that it is impossible at this late date to disentangle many of the various records; moreover, confusion has become worse confounded by the careless discrimination between the White-tailed Eagle and the Osprey. Further evidence may yet be brought to light; and in treating of this and the following species, I would gladly have avoided the responsibility of arbitration involved by allocating the various local records of eagles, to the Golden and White-tailed species respectively.

It is not a very far cry to the parish of Minnigaff (Kirk* Man. Brit. Birds, 1899, p. 323. 
cudbright), where in 1684, as is recorded, "the eagles . . . are in plenty, both the large gray and the black"*; and in 1837, W. Macgillivray writes that the Golden Eagle "has been extirpated from the south of Scotland, as has nearly been the case with the Sea Eagle." $\dagger$ My presumption, therefore, that both species were present in the county early in the last century seems not unreasonable. "Old David Tweedie, in his day a famous anglers' guide on Tweedside, when interviewed in 1834, when he was in his eighty-third year, is said to have stated that 'there is not one salmon or trout now for twenty that were found in his young days, that everything is changed, saving and excepting the glorious green hills of his native valley, that he perfectly recollects when there were just six pairs of eagles in Moffat water-the shepherds keeping their numbers down to this mark." " $\ddagger$

Dr. Grierson notes in 1872 in his "Running Catalogue of the Contents of my Museum," "A Golden Eagle was found dead on the Burn Hill (Morton), in the year 1825. It had been shot at the previous day by some party from Drumlanrig, the specimen is still preserved at the farmhouse of Burn by Mr. Nivison." Mrs. Gracie, a daughter of Mr. Nivison, confirms the above, and informs me that the specimen remained in the possession of her father till his death in 1874, when it passed to her youngest brother who resided in Wolverhampton, while at his death it was taken by his family to Walsall. Probably the following from the Dumfries and Galloway Courier of October 17th, 1826, refers to this same bird : "Mr. Shanks has . . in his possession at present a very fine specimen of the largest kind of British Eagle which was found drowned in a loch near the head of the parish of Morton. That the bird had, however, been previously shot at was sufficiently plain when it came to be stuffed, and though eagles are enemies

* Large Descr. Galloway, p. 134.

$\dagger$ Edin. Journ. Nat. Hist., 1837, Vol. T., p. 94.

† Trans. D. and G. Nat. Hist. Soc., December 18th, 1903. 
to lambs, we are rather gratified than otherwise to learn that the line or race of the monarchs of the sky is not yet extinct in the south of Scotland." The loch at Morton Castle, as can be seen by the map, is about a mile from the farmhouse of Burn.

In the Dumfries and Galloway Courier of April 30th, 1833, it is stated on the authority of Mr. Aitchison of Menzion, that three eagles located themselves near Loch Skene in 1831 . During the spring of 1833 the favourite height was Loch Hill, and one of these birds (a very fine specimen) was killed and passed into the possession of Mr. Aitchison. The curious circumstances of the capture of this bird have been related by Mr. R. Service : "The very last of the resident Dumfriesshire Eagles (and it was a Golden Eagle, for I have seen the specimen) was brought down by a shepherd in a way which, so far as I know, is quite unique. On the farm of Gameshope, [which, by the way, is just over our boundary in Peeblesshire] near to Loch Skene, one Eagle in particular got so bold as to lift lambs within twenty yards of the herd, a man named Bauldie Hairstanes. He could not stand this, even from an Eagle, which is not to be wondered at, and he used to carry stones in his plaid when going over the hill. One day in April, 1833, this herd was going his rounds, and the Eagle-probably having young in the cliffs above Loch Skene-swooped at the dogs. Bauldie threw a stone, which, very likely more by good luck than good guidance, struck the Eagle and brought it down to the ground, where, with the help of the dogs, it was secured. I question if a similar incident ever happened in this or any other country."* This bird is again referred to in 1842 thus: "In the parlour at Menzion we recognised an old acquaintance in the shape of a stuffed Golden Eagle, we should suppose by far the largest specimen of the tribe the best informed naturalists ever looked upon. A good many years have now elapsed since this bold winged

* Trans. D. and G. Nat. Hist. Soc., December 18th, 1903. 

Reiver rendered himself truly formidable to the tenant,
Mr. Aitchison."*

Writing to the Naturalist in 1837, Macgillivray says : "The Eagle seems to be extirpated ... the claws of one seen at Birkhill by Sir William Jardine belonged to the Golden Eagle." $\dagger$ There is a farm named Birkhill in Moffat parish, to the east and within two miles of Loch Skene, which may be the place referred to. Writing in 1838 Sir William Jardine says: "Upon the wild range of the Scottish Borders one or two pairs used to breed, but their nest has not been known for twenty years, though a straggler in winter is yet seen amidst the defiles." $\$$

Thomas Maxwell of Allanton Mill, in his day the principal bird-stuffer in the county, told Mr. R. Service that he received a Golden Eagle to stuff from Glenquhargen (Penpont) about 1860-1865. Another specimen recorded in 1874 as "recently trapped" near the same locality, $\S$ is now known to have come from Invernessshire. Mr. J. Bartholomew writes me: "Mr. Alexander Sim in May, 1886, saw a yearling or two-year-old Golden Eagle near Loch Skene." "Mabie Moss" wrote in 1894, "I am credibly informed that for a period of several weeks during the past winter a splendid Golden Eagle was regularly seen frequenting the Earn Craig, a great precipice where Eagles once nested in safety, amongst the hills behind Queensberry, up behind Burleywhag. They nested there so regularly as to give a name to the spot sometime in the long ago." $\|$ Mr. John Edmond writes me from Wanlockhead, "Once about ten years ago [i.e., 1898], I saw a Golden Eagle at the boundary between Dumfriesshire and Lanarkshire. I was walking with a friend on the old road that goes from the village up to

* Dumfries Courier, August 22nd, 1842.

$\dagger$ Naturalist, 1837, Vol. II., p. 239.

† Nat. Lib., 1838, Vol. IX., p. 166.

$\S$ Minutes of D. and G. Nat. Hist. Soc., April 14th, 1874.

i) Dumfries Courier and Herald, June 28th, 1894. 
Enterkin, and coming round a bend at Petersykehead, we were suddenly quite near the bird. There seemed no doubt to us that by size, shape and colouring it was a specimen of the Golden Eagle. The day, in autumn, was windy, with bright and cloudy intervals. The bird came from the direction of Enterkin; and rising higher, kept on towards the west."

The Golden Eagle still breeds in some Highland deerforests, where it is welcomed for keeping in check the superabundance of "blue-hares." It " is found throughout the mountains of Europe and North Africa, and extends to the extreme east of Asia"* and is also an inhabitant of the mountain regions in the northern portion of North America.

It is sad to think that so splendid an ornament to our wildest scenery should have been exterminated; but if the return of the species to one of its former haunts in a neighbouring county be encouraged, we may perhaps at no distant date be able to record the Golden Eagle as something more than a very rare visitor.

\section{THE WHITE-TAILED EAGLE.}

Haliaëtus albicilla (Linnæus).

Local names-Sea-Eagle; Erne; Yirn.

"Some ruder and more savage scene,

Like that which frowns round dark Loch Skene,

There eagles scream from isle to shore;

Down all the rocks the torrents roar;

O'er the black waves incessant driven,

Dark mists infect the summer heaven;

Through the rude barriers of the lake,

Away its hurrying waters break."

Str Walter ScotT._-" Marmion."

Formerly a resident; now a very rare visitor.

As has already been stated, the confusion between the White-tailed and Golden Eagles renders it very difficult to

* Lloyd's Nat. Hist., Vol. II., p. 158. 
determine the status of these two birds in Dumfriesshire at the beginning of the nineteenth century. There seems, however, to be a consensus of opinion that it was the White-tailed Eagle that nested at Loch Skene. In an account of Moffat parish, compiled in 1792, we find the following: "Loch Skeen is the only lake in the parish. It is 1,100 yards in length, of unequal breadth, where broadest about 400 yards. The depth is not known. There is a small island in it, where the eagles bring out their young in great safety, as the water is deep, and no boat upon the lake."* In 1834 appears the following statement: "The only rare animal that has been known to frequent this parish [i.e., Tweedsmuir, Peeblesshire] belongs to the feathered tribe, and is called Erne, or White-tailed Eagle (the young bird, the Sea Eagle, or Falco ossifragus; the old bird, the White-tailed Eagle, the Falco albicilla,) which at one time used to hatch in an island in Loch Skeen, and to nestle among the clefts around Tala Linnfoots. So great were its ravages among the sheep, that every effort was made to extirpate it, and for many years past there has been reason to think that these efforts were successful. But in the course of the season just closed [i.e., 1833] it reappeared in the same as well as in other parts of the parish, and committed several depredations. It had well-nigh carried off a shepherd's boy, but fortunately it was discovered hovering over its destined victim, and driven off just before it had pounced upon its prey." $\dagger$ The date of the above statement and the general tone of it, leads me to suspect that it may refer to the Golden Eagle killed by Bauldie Hairstanes (see page 196) but since the White-tailed Eagle is expressly named, I have quoted it here.

"W. L." wrote in March, 1837, "Not many years ago, the eagle was often seen taking a view of the lower mountains of Selkirkshire, and was a native of the neighbouring county of Dumfries, or, rather, of the alpine boundary between the

* Stat. Acet. Scot., Vol. II., p. 287.

† New Stat. Acet. Scot., Vol. III., Peebles, pp. 60, 61. 
two districts, and had its nest annually in two places. One of these was on a precipice in a wild glen in Eskdale, called the Garwald Grains; the other situation was chosen with much of that touch of reflection that we sometimes observe among birds, as well as others of the lower animals. There is a small rocky islet, almost even with the water, in Loch Skene, which is surrounded with the highest mountains south of the Forth; and, although the side of one of these mountains, that overhangs the lake, is rocky and seemingly inaccessible, the eagles chose to have their nest on the islet in the loch, because, forsooth, the loch craig could be approached by ropes from above, while it is almost impossible to convey a boat to the loch, and there never was one there."* This description was commented on by William Macgillivray, then conductor of the Edinburgh Journal of Natural History, $\dagger$ and " W. L." replied on May 24th, 1837 : "The conductor of the Edinburgh Journal thinks it behoves him to observe : 'Now, we would have naturalists to think a little before they state a fact, and be sparing of theory. A boat has been conveyed to the loch, and the eagles of the district are extinct. The side of the mountain that overhangs the lake is a rocky slope of less than 40 degrees, and certainly does not afford a spot to which a person without a rope might not approach to within 10 yards. Eagles often make their nests in very insecure places,' etc. . . . W. L., the afore-mentioned old correspondent of Loudon's Magazine, acknowledges that he has not seen Loch Skene, the Loch Craig or the White Coome, these many years; but he has, however, been many times there along with various companions, and with various views. He has angled around the loch, been on the top of the Loch Craig, and at the foot of it, and seen it from the brow of the neighbouring mountain of White Coome, and from the Mirk-Side-Edge that dark ridge that separates the glen of the Ettrick from Moffatdale ; and always considered the Loch Craig of Pol-

* Mag. Nat. Hist., 1837, Vol. I., p. 119.

† Edin. Journ. Nat. Hist., 1837, Vol. I., p. 91. 
moody as the most precipitous rocky mountain he knew of in the south of Scotland. He uses the word 'overhangs' the loch; but, surely Mr. Macgillivray's conscientiousness is not so straight-laced as to be unable to tolerate a figurative expression almost common-place, when applied to scenery. Mr. Macgillivray says, that a boat has been conveyed to the loch. W. L. cannot doubt it; but no boat had ever been conveyed to Loch Skene, that ever he heard of, before he left the country. But W. L. believes that the Earl of Traquair, either the late Lord Charles, or his uncle, his predecessor, sent his gamekeeper and other servants, one of whom was an expert swimmer, who swam to the islet, and with much difficulty, owing to the opposition of the old birds, brought off the eaglets ; and from that time the eagles made their nests in Loch Skene no more. W. L. has contributed to the Magazine of Natural History almost from its commencement, and never stated a fact that he did not believe to be true. He has continued to write anonymously, no doubt; but his name and address he took care to make known to the conductor, that reference might be given if required."*

William Laidlaw, who was secretary to Sir Walter Scott, was an able ornithologist and naturalist and under the initials W. L. frequently contributed to the Magazine of Natural History, about 1835. The eyrie at Garwald Grains mentioned by him may have been tenanted by this species, or by the Golden Eagle, and it is at this date impossible to determine. But the island in Loch Skene is recorded by subsequent writers as a nesting-place of the White-tailed Eagle, and though undoubtedly this species has been much mixed up with the Osprey, I do not think William Laidlaw would be likely to confuse two birds with which in those days he would be familiar.

"In the Statistical Account of Scotland, in the article on Lyne and Megget, it is stated that this species of Eagle builds its nest on a small island in Loch Skene, and

* Mag. Nat. Hist., 1837, Vol. I., p. 443. 
sometimes carries off a young lamb in view of the shepherd."

The Rev. F. O. Morris writes of the Erne that it "has . . been noticed on an island in Loch Skene, among the high hills on the confines of Dumfries, Peebles and Selkirk," $\dagger$ and he goes on to say, "On one occasion a large salmon was found dead on the shores of Moffat Water, and an immense Erne lifeless also beside it, having met its death by being hooked by its own claws to a fish too large and powerful for it to carry off." $\ddagger$ I have not found the origin of this story, which, if true, may well refer to Loch Skene at the head of Moffatdale.

Robert Gray writing in 1871 states: "Macgillivray mentions having found a Sea Eagle's nest in an island in a Hebridean lake, on a mound of rock not higher than could have been reached with a fishing rod, and a similar eyrie existed many years ago in an island in Loch Skene in Dumfriesshire." \$

I am indebted to Mr. J. Bartholomew for his energetic inquiries on the subject in Moffat. In 1908 he interviewed Mr. William Nettleship, a man of eighty-six years of age, who could remember his father and grandfather speaking of the Eagles which nested at Loch Skene, and who described them as " black, with white tails." Mr. Nettleship also spoke of having known a man named David Don who, when gardener at Beattock Inn, "swam out to the island and took the young ones. This," he said, "would be about a century ago."

Such is the evidence we have of the White-tailed Eagle nesting at Loch Skene, and on visiting this wild spot in 1908 it was difficult to make oneself believe that so tiny an islet (as shown in the accompanying photograph) had formerly been the nesting-place of a bird so fitting to that lonely loch.

* Hist. Peebles, p. 526.

$\uparrow$ Morris, Hist. Brit. Birds, 1870, Vol. I., p. 8.

$\ddagger$ Op. cit., 1870, Vol. I., p. 13.

§irds of West Scotland, 1871, p. 11. 


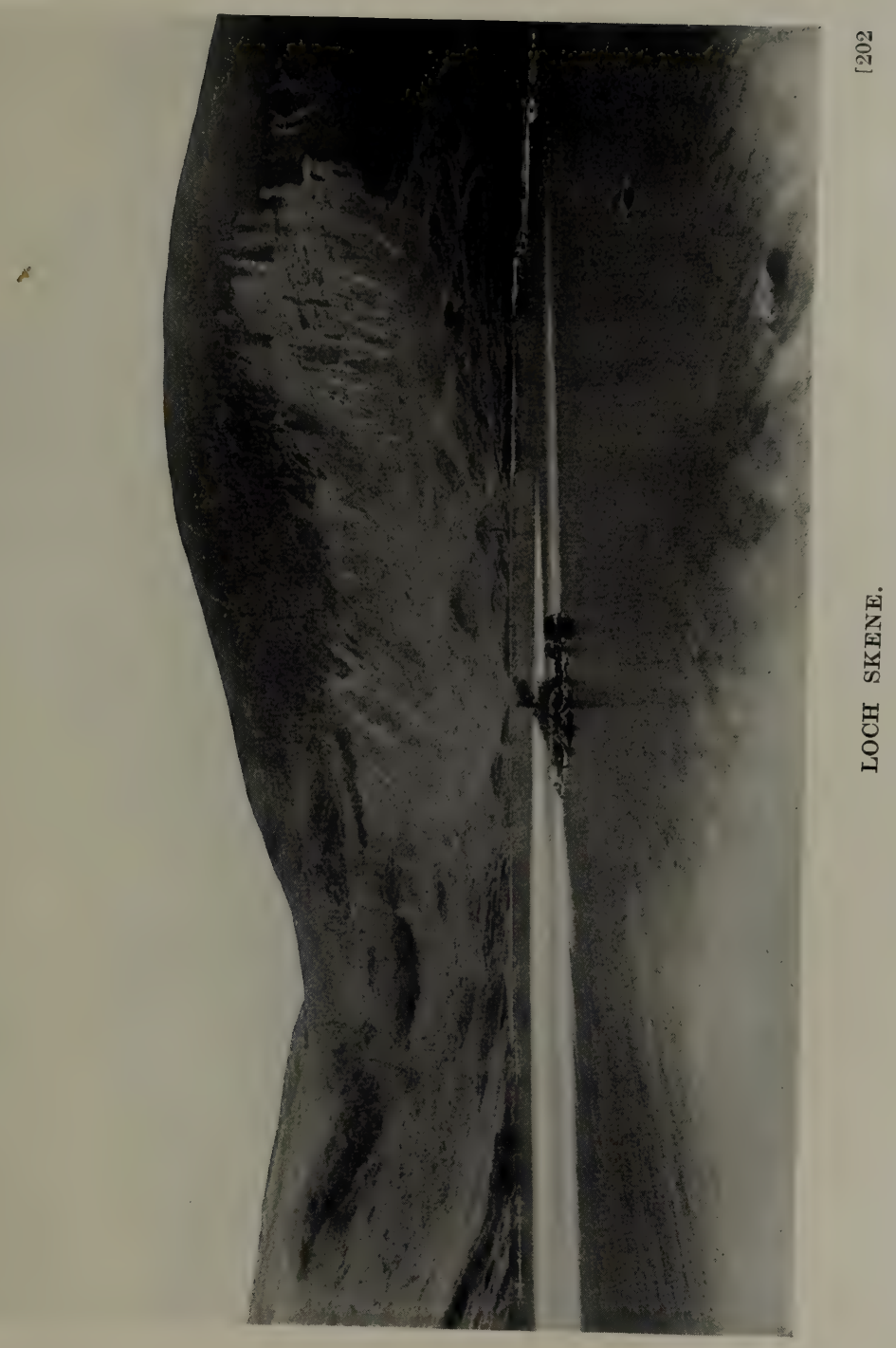



In a description of Loch Urr in 1792 it is stated that that lake is "about three English miles round. It is nine fathoms at deepest, and surrounds a small island.... A vast number of Waterfowls bring forth their young on the island, where there are some bushes. Eagles have been known to breed on it."* The birds here referred to may have been Ospreys; but whether or no, at the beginning of the nineteenth century the White-tailed Eagle was indubitably a nesting-species in certain spots in the county ; though Dr. Bushnan writing in 1834 doubts " whether a pair is to be found in Dumfriesshire, or more than a dozen in Galloway." $\uparrow$ Sir William Jardine writing some four years later says: "In England the breeding places of the Sea Eagle are now very rare, perhaps not more than one or two. The birds themselves are, however, not unfrequently met with and shot, both in the south and the border counties of Scotland, which are also beyond their breeding range ; but the greater part of the birds thus killed are in immature plumage." $\ddagger$

H. A. Macpherson stated in 1892 : "I can only reaffirm my belief that such Eagles as visited the mountains of the Lake district during the first half of the present century had their eyries in Dumfriesshire and Kirkcudbright. Mr. J. Fisher Crosthwaite informs me that ' there was a very fine living Eagle belonging to the proprietors of Crosthwaite's Museum which was caught at Maryport, and was supposed to have come from Scotland." "§

The place-name Earn Craig in Closeburn parish may denote a former nesting-site of this species, which can now only be regarded as a very rare visitor to the county. Mr. James Bartholomew informs me that a White-tailed Eagle was seen at Loch Skene in 1905, and also in 1908 ; and these fitful appearances may induce the hope that there

\footnotetext{
* Stat. Acct. Scot., Vol. II., p. 342.

$\dagger$ Edin. Journ. Nat. Hist., 1837, Vol. I., p. 99.

† Nat. Lib., 1838, Vol. IX., p. 176.

$\S$ Fauna of Lakeland, 1892, p. 201.
} 
will be future visits, possibly uninterrupted and prolonged, till once more we can regard the White-tailed Eagle as a resident.

Not having received the protection afforded to the Golden Eagle in certain deer-forests, this bird has become more and more rare as a British nesting-species; its eyries on the north-west coast of Scotland and Ireland have been reduced almost to a vanishing point, and those individuals which are now only occasionally seen in Great Britain may be said to be stragglers from northern Europe.

[THE GOSHAWK. Astur palumbarius (Linnæus).

Although there are no modern records of the occurrence of the Goshawk in the county, the following documentary evidence, though not amounting to actual proof of its former existence, is interesting. "When the family of Avenel granted the territory of Eskdale to the monks of Melrose," writes Professor Cosmo Innes, " they reserved ... the eyries of falcons and tercels. . . . Even the trees in which hawks usually built, were to be held sacred, and those in which they had built one year, were on no account to be felled, till it should be found whether they were about to build there the next year or no."*

Commenting on the above, Robert Gray says: "None of the commoner tree-building species, as Kites, SparrowHawks, etc., were much valued by the falconer, and it seems to me that the birds thus carefully protected must have been Goshawks. If so, we have here distinct evidence that they bred regularly in the south of Scotland in the thirteenth century." $\dagger$

* Scotland in Mid. Ages, 1860, pp. 129, 130.

$\dagger$ Birds of West Scotland, 1871, p. 38. 
For the following information I am indebted to my cousin Mr. Robert Gladstone, jun., of Liverpool. "The original document above referred to formed part of the muniments of Melrose Abbey, and, with the rest of those muniments, passed into the hands of the Earls of Morton. It is printed (from the original) in the Liber Sancte Marie de Melros (Bannatyne Club).*

"Summary of document.-Declaration by Alexander II., King of Scotland, that on 8 April, 1235, in the 22nd year of his reign, in the presence of himself and his barons, an agreement had been arrived at between the Abbot of Melrose and Roger Avenel regarding certain points in dispute between them, especially as to the sporting rights reserved by Avenel in respect of lands in Eskdale, comprised in a charter (No. 197 in the Liber) which he had previously granted to the Abbey. The Abbot, on the one hand, complained that Avenel was going back on his charter; while Avenel, on the other, asserted that the monks were interfering with the sporting rights which he had expressly reserved for his own use and enjoyment. The King and his Barons decided that Roger Avenel and his heirs should have, among other things, the following: (Translation.) Right to eyries of Falcons and Sparrowhawks, to the effect that the monks shall not intentionally do anything to prevent such birds from continuing to form eyries in any place where they are accustomed to do so, and that the monks shall not take the nests of Falcons or Sparrowhawks within the stated boundaries, and that no trees in which such birds have formed eyries one year shall be cut down until it is ascertained next year whether the birds intend to make their eyries there or not, and that, if the birds have not then formed eyries in such trees, the monks may lawfully make any use of such trees that they may think proper. But in all other parts of the estate [i.e., the parts where there are no such eyries] comprised within the boundaries laid down in the charter of the said Roger, the

* Vol. I. (1837), pp. 181, 182, Charter 198. 
monks may erect lodges and buildings wherever they choose, and may deal generally with the said estate in any manner that they may consider advantageous for themselves, their serving brothers, and their cattle."*

The Sparrow-Hawk in the olden time was the "servingman's" hawk, and the protection demanded as above may have been for it. It is well to remember, too, that the Peregrine Falcon is nowadays sometimes miscalled the Goshawk locally.

The Goshawk nests throughout the wooded districts of northern and central Europe and Asia; in winter the young migrate south, and at this season they have occasionally been taken on the east coast of Great Britain. Upwards of a hundred years ago this species nested in Scotland, but it was probably at no time numerous, even in the most wooded and secluded districts.]

THE SPARROW-HAWK. Accipiter nisus (Linnæus).

A decreasing resident whose numbers are perceptibly augmented during the autumn-migration.

Mr. R. Service speaking in 1903 says: "There can be little question that since the modern form of game preserving set in, now some seventy or eighty years ago, the resident,

*Latin Text.-(Roger Avenel and his heirs should have, among other things,) ... Aerium accipitrum et sperveriorum, ita quod monachi maliciose non impediant quin eo loco quo aeriant possint aeriare quam diu habuerint consuetudinem ibidem aeriandi; neque accipitrum aut sperveriorum capiant nidos infra dictas divisas; nec arbores in quibus aeriant uno anno secentur donec in anno proximo sequenti perpendatur si in illis arboribus velint aeriare vel non, et si tunc non aeriaverint, licite de arboribus commodum suum facient monachi modis omnibus quibus voluerint. In aliis vero locis infra divisas contentas in carta dicti Rogeri facient logias et edificia ubicunque voluerint pro libito et voluntate sua, et utentur tenemento contento infra dictas divisas prout melius et utilius sibi, fratribus suis servientibus, et averiis suis proficere eis visum fuerit. 
or breeding stock of Sparrow-Hawks has been destroyed outright at least half a dozen times over. The places, or beats of the birds thus killed are filled again each season by arrivals from other parts of the Western range of the species. This process, however, cannot go on for ever, and it is showing signs of coming to an end. Like other members of our fauna subjected to like cruel treatment, continued persecution is bound to finally banish the Sparrow-Hawk."* In confirmation of this, I may mention that I know a wood which for upwards of twenty years in succession prior to 1907 , annually contained a Sparrow-Hawk's nest. Each year the eggs were destroyed and the birds shot, yet the following season a pair always put in an appearance, only to meet the same fate. Since 1907 this favourite plantation has not been revisited, and the reports received from all parts of the county testify to the decrease of this species.

In autumn the numbers of our birds are increased by an immigration from elsewhere, and at this season of the year the Sparrow-Hawk is most in evidence.

The male seldom attacks a larger bird than a Blackbird, and the Robin and Greenfinch are its favourite prey. Various seed-eating birds, rats, and voles may be cited as some of the agricultural pests which the SparrowHawk keeps in check, and though the female flies at higher game, and will pursue a Grouse or Partridge, she helps to thin our too numerous Wood-Pigeons. Mr. R. Service has said "One pair of Sparrow-Hawks in the course of a year on an average estate would not cause as much injury to game as would the effects of one "bad shot' on a big
shooting day." $\dagger$ This comparison is perhaps rather invidious, and is but poor consolation to the gamekeeper who has to put up with the unskilled amongst the shooting
parties. A "rogue" Sparrow-Hawk having once ascertained the whereabouts of the "rearing-field," is better put

*Trans. D. and G. Nat. Hist. Soc., December 18th, 1903.
† Op. cit., February 16th, 1903. 
out of the way; indeed the depredations at the Pheasant coops render such a step imperative, and the keeper is justified in thus protecting his own interests.

It is now well known that this bird builds its own nest, or reconstructs the old nest of a Pigeon or Crow for its own use; and though it is believed to pair for life, it is remarkable, if one of a pair be killed, how often the survivor speedily finds another mate.

The boldness of the Sparrow-Hawk in attacking cagebirds has been frequently noticed; and in this connection the following may be quoted: "A few days ago a Sparrow Hawk ... darted against a half open window of a house in High Street (Dumfries), drew the head of a favourite canary through the wires of his cage, held the grip with all the force of a smith's vice, and busied itself with picking out the eyes and brains. The mistress ... of the family hurried to the spot ... and in the first burst of emotion seized the intruder and dashed it to the ground with such force that it instantly expired."* On September 2nd, 1908, a male Sparrow-Hawk fearlessly stooped at a Partridge I had just shot, and which lay within forty yards of me; an act of temerity which should have cost him his life. Mr. J. T. Johnstone writes me from Moffat: "Mrs. Hood, photographer here, on entering her studio one day recently, found a Sparrow-Hawk in possession and the remains of a Sparrow on which it had evidently been feeding. The Hawk having been captured, was photographed and then given its liberty."

A very pale variety, obtained from the Jardine collection in 1854, is now in Mr. J. H. Gurney's possession; but it is not known if this specimen is of local origin.

Our birds of prey have been sadly reduced, and the Sparrow-Hawk still goes unprotected by the Wild Birds Protection Acts. It is left therefore to game-preservers to see that this species is kept in check, but not, it is sincerely to be hoped, exterminated.

* Morning Chronicle, July 14th, 1836. 


\section{[THE KITE. Milvus ictinus, Savigny.}

Of the Kite Mr. R. Service says : "It may have been, and probably was, a resident at one period. But I have never been able to glean a single authentic note on its former existence. It is occasionally reported as seen, the fork in the tail leading sanguine observers to think they have identified it."* Having been no more fortunate than Mr. Service, I have placed this species in "square brackets." The local name "Gled" or "Glead," now so commonly used for the Buzzard is believed to have been once the sobriquet of the Kite ; but this is hardly proof of its former occurrence. We read that in Hutton and Corrie in 1794, "There are other Hawks and Kites of various kinds," $\dagger$ but this statement is too vague for historical purposes. Better evidence is found in a manuscript referring to Upper Eskdale and the vicinity of Loch Skene, of which William Laidlaw wrote in 1837: "The swallow-tailed gled, or Falco . . . chesnut with a white crown inhabited two places but has now departed.” $\$$ Sir William Jardine speaks of the Kite in 1838 as nearly unknown in the south of Scotland, $\S$ and in 1837 he wrote to P. J. Selby: "I have not a specimen of the common Kite, and want a wood-cut of his wing and bill."

Mr. John Corrie speaking in 1888 of the birds of Glencairn says : "The Kite is now almost, if not quite extinct. When a boy a tame Kite, or 'Gled' as we called it, was kept at the Craigdarroch Inn, Moniaive. It was allowed perfect freedom but never attempted to escape. One lamb-fair day a shepherd's dog having stolen a piece of

* Trans. D. and G. Nat. Hist. Soc., December 18th, 1903.

$\dagger$ Stat. Act. Scot., Vol. XIII., p. 580.

$\ddagger$ W. Laidlaw's MS. Diary and Notes.

$\S$ Nat. Lib., 1838, Vol. IX., p. 218. 
beef, retired to a quiet corner of the Inn yard to eat it. The 'Gled' happened to be perched on the roof of an adjoining outhouse at the time, and the dog had no sooner squatted with his prize than the 'Gled' swooped down upon him, seized the piece of beef, and bore it off to his perch, the startled collie meanwhile bolting up the nearest passage. ..."* Later Mr. Corrie says: "I am disposed to claim for Glencairn the honour of having contained the last Dumfriesshire 'Gled' or Kite. The year of its death would be 1869 or $1870 . " \dagger$ Mr. Corrie subsequently informed me that he could not state authentically that the above story referred to this species. The bird " may have been a Buzzard, though Mrs. Donaldson, the mistress of the Inn, had got it from a likely spot near the Lorg Hill "where the three counties, Dumfriesshire, Kirkcudbrightshire and Ayrshire meet. Mr. R. Service records in his diary in 1888, that Robert Maxwell told him he had seen a Kite at Dalswinton (Kirkmahoe) in September, 1872, which was the only one he ever saw there. Modern reports of the occurrence of this species have invariably been found to refer to the Buzzard.

In former days the Kite's tail-feathers were in great request for fly-tying, and though the bird itself is now forgotten, the memory of this favourite "fly" still survives among local salmon-fishers.

The Kite is an inhabitant of central and southern Europe and North Africa, and still nests in Wales. It is not much addicted to migration, so the chances of its appearance in our county are remote.

It may not here be out of place to remark that the name Gledstanes or Gladstone, a name formerly of common occurrence on the Borders, and a place-name not far from Biggar (Lanarkshire), also near Kilbarchan (Renfrewshire), and elsewhere, means the stones or stone which the "Gled," frequents.]

* Trans. D. and G. Nat. Hist. Soc., November 10th, 1888.

† Op. cit., February 6th, 1890. 


\section{THE HONEY-BUZZARD. Pernis apivorus (Linnæus).}

\section{A very rare visitor.}

In the Dumfries and Galloway Courier of June 11th, 1833, appears the following paragraph : "A specimen of that very rare and elegant species, the Honey Buzzard, was shot last week at Drumlanrig. . . . The specimen has been added to the collection of Mr. Bushnan of this place." This bird is referred to by Macgillivray who describes it as a "light coloured specimen... which formerly belonged to Dr. Bushnan then of Dumfries, but is now in the Museum of the University of Edinburgh."* Richard Bell of Castle O'er states that a specimen of the Honey-Buzzard was shot in the year 1850 by his brother, and "was stated by the late Sir William Jardine to have been the second Scottish example then recorded" $\uparrow$; this bird was shown to the Royal Physical Society of Edinburgh by Dr. John Alexander Smith on January 28th, 1857. $\%$ Robert Gray writing in 1871 says: "Specimens have . . . occurred in the [county of] Dumfries (on several occasions)" " ; and Mr. George Kerss wrote me in 1908 that he shot a HoneyBuzzard in Kirkpatrick-Juxta some years before. Mr. $R$. Service has pointed out that the example in Grierson's Museum, Thornhill, was not obtained locally, but came
from Aberdeen.\|

The Honey-Buzzard is widely distributed throughout most of the wooded districts of Europe, and in its spring and autumn-migrations visits Scotland and England, more commonly the east coasts.

* Macgillivray, Hist. Brit. Birds, 1840, Vol. III., p. 260.

$\dagger$ Trans. D. and G. Nat. Hist. Soc., April 17th, 1901.

¥ Proc. Roy. Phys. Soc. Edin., 1857, Vol. I., p. 240.

$\S$ Birds of West Scotland, 1871, p. 49.

|| Ann. Scot. Nat. Hist., 1901, p. 81. 
At intervals pairs formerly bred in various counties of England, and nests have been recorded in Aberdeenshire and Ross-shire, but on account of their rarity persistent persecution has always taken place; with adequate protection this bird might become more generally distributed as a summer-visitor throughout Great Britain.

THE PEREGRINE FALCON. Falco peregrinus, Tunstall.

Local names-Blue Hawk; Hunting Hawk ; Game-Hawk; Goshawk ; FaLcon.

"The rustling of the green branch o'er the flood,

The blue-hawk's scream, 'midst cliffs of hoary gray,

The lark's blythe song far in the morning cloud,

Breaking the silence of the Sabbath day :

Oh! these are dreams of youth that never can decay."

JAMES HysloP. -"To Anna."

A scarce resident, nesting annually where protected; in autumn immigration increases the numbers and it is then more widely distributed throughout the county.

At the beginning of the nineteenth century the Peregrine Falcon had numerous eyries in the mountainous parts of Eskdale, Annandale and Nithsdale, but the persecution to which it has been subjected, in the interests of gamepreservation, has long since reduced its numbers.

The avidity of the egg-collector precludes me from naming the present day nesting-haunts, but it is at least satisfactory to be able to state that there are from twelve to sixteen now annually resorted to. Four or five of these eyries have been in occupation for upwards of a hundred years. These favourite spots are of course in the more inaccessible parts of the county, where such names as the Falcon Rock (Moffat) testify to former haunts of this species. Up till at least 1818 a pair of these birds bred on the farm of Craigs, ${ }^{*}$ which is within four miles of Dumfries,

* Dumfries Courier, March 27th, 1818. 
but the "get-at-able" eyries have long ago been harried, and the breeding-range of this species woefully curtailed. Mr. R. Service in 1903 speaking of the Peregrine Falcon in the Solway area says: "In Dumfriesshire it is much scarcer, and there being no shore cliffs, it is confined to the Moffat Hills, and Upper Nithsdale near the Stewartry boundary. But there is an awful drain year by year by the keepers on these birds. It is curious how persistently birds turn up each recurring season to take the place of the slaughtered ones. At the migration seasons some very fine examples are often got, more particularly in autumn, when 'passage Falcons' are seen now and then. These are mostly fine, large, dark, beautifully-plumaged birds in the feathers of the first autumn."* At this season of the year Peregrine Falcons are met with throughout the county, and are far too frequently shot. It would be tedious to give a list of all the locally-killed specimens, but we may mention two birds in the Royal Scottish Museum, Edinburgh, from Bald Craig and one from the Moffat Hills, formerly in the collection of Sir William Jardine. Another bird, a male, also from Sir William's collection, obtained on the Moffat Hills, is now in the Observatory Museum, Maxwelltown. The specimens from which he described the plumage of the adult male and female, and also young of this species, in his Naturalist's Library, are stated by Sir William Jardine to have been "procured on the Moffat Range of Hills during the breeding season." $\dagger$

Mr. J. Harkness writes me that he possesses a specimen shot by J. Phillip, near Brow Well (Ruthwell) about 1880, in the act of stooping at a decoy wood-pigeon, and their temerity when in pursuit of their prey often seals their doom. A Peregrine Falcon has been known to have followed a Lark down one of the lead-mines at Wanlockhead, where both were taken at the bottom, at a depth of
three hundred and sixty feet.

* Trans. D. and G. Nat. Hist. Soc., December 18th, 1903.

$\dagger$ Nat. Lib., 1838, Vol. IX., p. 123. 
In this county the old nest of a Raven is often selected by the Peregrine for its eyrie, and should one of the pair of birds be shot, it is remarkable how the survivor continues to find a fresh mate. If left unmolested this species would increase, and it is to be hoped that so fine and game a bird may receive the protection to which, under the Wild Birds Protection Acts, it is entitled.

W. G. Johnstone records the following in 1853: "A rather rare circumstance occurred in the town of Dumfries last summer, namely a pair of Peregrine Falcons in confinement not only produced eggs, but continued to sit on them for twelve days, the male taking his share of the duty.... Being disturbed by strangers they would not sit again. The eggs were fertile as proved by being broken, they were two in number."*

As regards the distribution of the Peregrine Falcon. Howard Saunders has written, "under one form or another, it is met with almost all over the world." $†$

It may perhaps be noted that the male is the Tiercel, and the female the Falcon, of Falconers; and it must be remembered that the species has been erroneously, and therefore confusingly, termed the Goshawk.

THE HOBBY. Falco subbuteo, Linnæus.

\section{Has occurred once.}

Sir William Jardine stated in 1838 that he knew of no instance of the Hobby having been captured in Scotland. There is only one record of the occurrence of this species in the county. Robert Gray states : "I have been informed by Mr. George Kirkpatrick that a specimen of the Hobby

* Naturalist, 1853, Vol. III., pp. 106, 107.

$\uparrow$ Man. Brit. Birds, 1899, p. 348.

† Nat. Lib., 1838, Vol. IX., p. 127. 
was shot in June, 1867, on the Rockhall estate, a few miles from Dumfries, and is now in the possession of William Hastings, bird-stuffer, in that town."* Mr. R. Service has pointed out that the correct date is $1866, \dagger$ and he notes in his diary that William Hastings told him that it was the only specimen he had ever had to stuff. Sir Alexander Grierson, Bart., of Rockhall, wrote me in 1908: "I have not the specimen of the bird you refer to, nor do I know what became of it."

The Hobby is a rare summer-visitor to England, and still more so to Scotland and Ireland. It breeds throughout temperate Europe and Asia; and winters in China, India and Africa as far south as Cape Colony.

\section{THE MERLIN. Falco asalon, Tunstall.}

\section{Local names-Wee Hawk; Wee Blue Hawk.} A scarce resident in the moorland districts; more widely distributed in
winter. Sir William Jardine stated in 1838 that the mountainranges on the Scottish border contained in the season many breeding-places of the Merlin, and that they were "as regularly returned to as those of the Peregrine." $\ddagger$ Four specimens recorded as obtained at Jardine Hall are noted in the catalogue of the birds contained in his collection. Dr. Grierson in 1834 (cetat 16) records in his diary that he bought a young Merlin from a boy for $2 \frac{1}{2} \mathrm{~d}$., and kept it in a cage with two rabbits and a Kestrel! A subsequent entry in his diary in 1862 gives the information that Thomas

* Birds of West Scotland, 1871, p. 31.

$\dagger$ Trans. D. and G. Nat. Hist. Soc., December 18th, 1903.

$\ddagger$ Nat. Lib., 1838, Vol. IX., p. 131. 
Maxwell of Allanton Mill told him that the Merlin was not infrequent in the district.

This species, from the reports I have received, appears to have nested in nearly every parish where there is suitable moorland ground. But it is not likely that the Merlin could be expected to flourish when the following are samples of these reports: "Pair nested on Bogrie Moor (Glencairn), 1888; female trapped, male shot."* "I have not seen any here [Kirkmahoe] for years. There used to be a pair annually, but I think I killed them all out." $\dagger$ Happily, however, there are still a few spots where the Merlin is allowed to breed unmolested; and perhaps nowhere in Dumfriesshire is it more common than on the borders of Roxburghshire, and in Upper Nithsdale where I know of one nesting-site which has been annually tenanted for upwards of thirty years. In autumn and winter this species becomes more widely distributed, and numerous stuffed specimens bear witness to the indiscriminate slaughter to which it is still subjected. Protected by the Wild Birds Protection Acts, with mile upon mile of ideal country for its habitat and with also almost a superabundance of small birds on which to prey, the Merlin would, if allowed, soon become once more a common resident in our uplands. Like all other hawks, this species is on most estates ruthlessly persecuted by gamekeepers, and though Mr. J. G. Millais has put it on record that he once saw a Merlin dash at a Blackcock and send it sprawling into some birches below, $\ddagger$ the harm this species does on a grousemoor is infinitesimal. Small birds form its usual prey, and cockchafers and other winged insects are taken in summer.

The nest is, as a rule, a mere hollow scraped in the ground; but an old nest, such as that of a crow, built in a tree, is occasionally utilized. Mr. T. McCluskie informs me that he

* Trans. D. and G. Nat. Hist. Soc., November 10th, 1888.

$\dagger$ D. Tait, in litt., April 28th, 1908.

$\ddagger$ Game Birds, 1894, p. 85. 
has known the Merlin to make use of an old Wood-Pigeon's nest, while Mr. J. Pringle gives me similar information, and Mr. William Coltherd writes me of such a nest in a Scots fir, in Duke's Wood (Hoddom). Of five eggs which I knew of in 1908, the fourth was laid on May 14th, the fifth on the 15th. On June 13th three eggs were hatched, another the next day and the last on the 15th; the period of incubation in this case thus being thirty days. This reckoning is precisely confirmed by similar observations by Mr. David Johnstone.

An immigration of this species from the mountain-districts of northern Europe occurs in the autumn, at which season it is also found in the countries bordering the Mediterranean.

\section{THE KESTREL. Falco tinnunculus, Linnæus.}

\section{Local names-KeELIE; RED HAwK.}

\section{A common resident.}

Of recent years the prejudice against the Kestrel has been fast dying out, and it is satisfactory to be able to record it as an increasing species.

In winter the numbers of our resident Kestrels are considerably augmented by others from farther north.

This species is a most useful bird to agriculture, and well deserves the protection it should receive under the Wild Birds Protection Acts. A " rogue " Kestrel, with a hungry young family of its own to provide for, learns bad habits and visits the Pheasant coops, and a keeper has told me that he was once an eye-witness of an attack by a Kestrel on a brood of young Partridges, but the marauder was kept at bay by the gallantry of the parent birds. However, 
the Kestrel seldom takes birds, its prey usually being mice. During the vole-plague of 1891-1893 the numbers of these birds were augmented to an enormous extent, and " it is impossible to believe (after making due allowance for the largeness of the clutches, and the most unusual frequency with which they nested during the breeding season) that all these birds were of local origin."* The amount of good that this species did during this plague cannot be over-estimated. In the Report of the Departmental Committee on the Plague of Field Voles in Scotland we find the following: "A preponderance of opinion amongst farmers is reported, tracing the cause of the present outbreak to the scarcity of owls, kestrels, hawks, weasels, and other vermin." $\dagger$ At the cessation of this plague the Kestrels suffered severely, apparently dying of disease incurred through eating the diseased voles.:

As a destroyer of noxious insects it also proves its utility. "Mabie Moss" wrote in 1895: "Some years ago Sir George Walker saw a pair of Kestrels playing and diving about for hours like Swallows on a patch of grass close to Crawfordton Mansion. On going to see what it was that the Kestrels were feeding upon, Sir George found myriads of flies of a species of daddy-long-legs emerging from the ground, all over which the empty pupa cases of these flies, so terribly destructive in the larvæ state, were to be seen protruding from the surface."§

The eggs of the Kestrel are often laid in the old disused nest of a Carrion-Crow or Wood-Pigeon, or on a ledge or crevice of some rocky crag.

A pale or white variety of this bird, recorded in $1885 \|$ by William Hastings, has been ascertained to have come from Lochmaben.

* Dumfries Courier and Herald, October 11th, 1892.

$\uparrow$ Report Field Voles Scot. (C. 6943), 1893, p. viii.

† Trans. D. and G. Nat. Hist. Soc., December 18th, 1903.

§ Dumfries Courier and Herald, May 23rd, 1895.

\|I Trans. D. and G. Nat. Hist. Soc., December 4th, 1885. 


\section{THE OSPREY. Pandion haliaëtus (Linnæus).}

Local names-Fishing Hawk; Fish-Eagle.

\section{A very rare visitor.}

There are no authentic records of the nesting of the Osprey in Dumfriesshire, though, as has been already pointed out (see pp. 201, 203), the birds which nested on the islets on Loch Skene and Loch Urr may have been of this species, and not the White-tailed Eagle. I know both these lochs, and the two are strikingly different in appearance. Loch Skene lies at an altitude of seventeen hundred feet with mountains round it a thousand feet higher, as wild a looking spot as one could picture. Loch Urr is barely seven hundred feet above sea-level, and the ground slopes gradually from the water's edge. If we are to credit the report of 1792, that "Eagles have been known to breed on it,"* I should be inclined to believe that the "Fish-Eagle" or Osprey was the species referred to; but, at this date, it is purely a matter of guesswork. Sir William Jardine has made the following MS. note in his private copy of the Naturalist's Library: “Mr. Shaw, Drumlanrig, writes, 1840, that he had observed an Osprey perched on a rotten bough above the fish cruive (see letter)." Unfortunately, this letter cannot now be traced. Dr. Grierson records in his diary in 1862 (October 17th) that Thomas Maxwell of Allanton Mill told him the Fish-Eagle had never been known in Nithsdale. In a letter dated September 13th, 1886, the late Professor Alfred Newton wrote to Mr. J. A. HarvieBrown: "My brother has been up and down Galloway and is convinced that no Ospreys have bred there for fifteen 
or twenty years past, if indeed then," and there is no reason to suppose that Dumfriesshire was more favoured.

An Osprey was s̊een at Kirkmichael in September, 1878, and the incident is thus described: "As some sportsmen were sitting at lunch on the banks of the $\mathbb{E}$ this fine bird suddenly appeared, hovering above a trout-pool in front of them. Each gentleman sprang to his gun, but before the nearest was reached, the Osprey, we are glad to add, had noticed its would-be destroyers, and was half a mile off."*

I am able to give, through the courtesy of Mr. A. H. Evans, the following records of the appearance of an Osprey at Loch Skene in 1881. Mr. Robert Mathieson states: "The Osprey made a short visit this spring (1881) to St. Mary's Loch and Loch Skene, where formerly it used to build on a rocky island which rises a few feet above the waters of this desolate and lonely mountain tarn." $\dagger$ Mr. Evans informs me that Dr. J. Hardy (late) of Oldcambus, Berwickshire, sent him a note on September 26th, 1881, to the effect that A. Brotherston had an Osprey to stuff from College Water (Northumberland) ; and Dr. Hardy added that the Osprey visited Loch Skene that spring, " as if intending to breed on an islet frequented of old by these birds; but that it was frightened by attempts to shoot it; as was noticed in the Scotsman." Mr. J. Bartholomew, to whom I wrote, sent me the following letter from Mr. Alexander Sim : "I saw a single bird at St. Mary's Loch in the spring of 1881 ; it went away in Loch Skene direction, and I heard from the shepherd Willie Brown that he had seen a strange bird at Loch Skene, and that it remained there for two days. By his description it was an Osprey. This was in the end of April or beginning of May, 1881, and was possibly the bird which I saw at St. Mary's Loch, as it was a day or two after I saw it that the shepherd noticed it at Loch Skene. That a single Osprey was there for a day or two in the spring of 1881 I have no doubt."

* Dumfries Courier, March 25th, 1879.

† Hist. Berwick Nat. Club., Vol. IX., 1881, p. 489. 
Mr. J. H. Crawford recorded in 1896 that this species had been known "at rare intervals to fish Loch Skene, and may well pay many an unrecorded visit to that lonely and seldom disturbed place."*

The Osprey is an occasional autumn-visitor to Great Britain, and it may still nest in the Highlands where zealously protected. It is found in nearly every part of the world; "its distribution is, in fact, restricted by two conditions only: the bird must be in the vicinity of waters inhabited by fish which swim sufficiently near the surface to supply it with food, and the proximity of mankind is a decided objection." $†$

\section{THE CORMORANT. Phalacrocorax carbo (Linnæus).}

Local names-SCART; BLACK Douker; Water-RAVEN ; Water-Crow; Colvend Elder; Mochrum Elder.

\section{A very common non-breeding resident on the coast, visiting certain
inland lochs.}

The Cormorant was a frequent visitor to the lochs at Lochmaben in $1835, \ddagger$ and concerning this Mr. R. Service writes me in 1908: "I never heard of or saw any of them breeding there, although they might easily be set down as daily visitants. A diet of fresh-water eels for a change seems to suit them." Sir William Jardine wrote in 1832, that this species had "been seen straggling up the Annan as far as Jardine Hall," $\$$ and a specimen in his collection was obtained near there by his gamekeeper.

\footnotetext{
* Wild Life of Scotland, 1896, p. 193.

$\dagger$ Man. Brit. Birds, 1899, p. 360.

¥ New Stat. Acct. Scot., Vol. IV., p. 382.

Op. cit., Vol. IV., p. 181.
} 
The Cormorant is a regular visitor to Loch Urr, and has " even been seen within a few hundred yards of the village of Moniaive."* A specimen was shot at Jardington on the River Cluden by Mr. Rutherford in 1882, $\dagger$ and one was shot at Steilston Loch (Holywood) in October, 1904, and another in August, 1907, both of which appeared to be young birds of the year, so Mr. Shiels informs me.

Dr. Grierson records in his diary for 1862 that Thomas Maxwell told him that the Cormorant was seen on the Nith repeatedly; and in the "Running Catalogue of the Contents of my Museum," the Doctor notes: "No. 567. Cormorant from the Nith near Thornhill, 1866." In 1871 there is the following record: "On several occasions one has been seen winging his way up the Nith." + A specimen shot on that river above Isle (Holywood) by Mr. T. Ranken on December 31st, 1908, disgorged a grayling six ounces in weight.

The Cormorant nests in the adjoining counties of Kirkcudbrightshire and Wigtownshire, and though it is extremely common on the shores of the Solway Firth from early autumn until the beginning of summer, its appearance inland is unusual; except at, or on its way to and from, regular haunts like Loch Urr and the Lochmaben Lochs.

From the sedate way in which these birds sit at the edge of the ebbing tide they have been likened to " elders of the kirk." The Kirkcudbrightshire name of this species is Colvend (pronounced "Cow'en") Elder, and in Wigtownshire, Mochrum Elder; and these names, derived in each case from parishes in the respective counties, are in common use among our fishermen and shore-shooters. Under certain atmospheric conditions the height of the birds, with their reflections in the water, appears gigantic, and on such occasions they might be mistaken for human beings standing upright in the sea.

* Trans. D. and G. Nat. Hist. Soc., November 10th, 1888.

$\dagger$ Op. cit., February 2nd, 1883.

† Dumfries Courier, December 19th, 1871. 


\section{THE SHAG. Phalacrocorax graculus (Linnæus).}

Local names-Green Cormorant ; Green-Crested CorMORANT.

Formerly more common, is now a very scarce visitor to our sea-coast.

This species was formerly not the rarity it is now, for Sir William Jardine wrote in 1843 as follows: "We have frequently observed from five to twenty ... at rest on the low banks, with which the Solway Firth is so fatally interspersed."* But Mr. R. Service writes me in 1908: "Nowadays one would look in vain for such parties on any of the Solway banks."

A specimen was obtained at Sarkfoot (Gretna) in 1854, and was stuffed by Mr. Andrew Plenderleath of Longtown. $\uparrow$ Dr. Grierson, in the "Running Catalogue of the Contents of my Museum " records: "No. 701, (Carbo graculus) a fine crested specimen of this bird shot in Lochar Moss about 1840, presented by Mr. McKenzie, Farmer, Barnhill, near Dumfries, 24th November, 1868." This specimen is still (1908) to be seen in Grierson's museum at Thornhill.

Dr. J. W. Martin recorded in 1901 that: "One was noticed to haunt a pool in the River Cairn, during the early spring a few years ago " $t$; but the bird not being obtained, its identification is not entirely satisfactory. Mr. R. Service tells me that two Shags were caught just below the Caul at Dumfries in October, 1885, by a fisherman, who said they suddenly flew down and swam to the side of the river. He caught them, put them in a basket, and brought them

* Nat. Lib., 1843, Vol. XIV., p. 242.

$\dagger$ Dumfries Courier, March 28th, 1854.

† Trans. D. and G. Nat. Hist. Soc., December 13th, 1901. 
to Mr. Service, but as the latter did not want them, he liberated them, when they flew to a great height and departed.

The rugged coasts of the north and west of Scotland, Ireland, and south Wales afford numerous suitable localities for breeding-colonies of this species; the nearest colonies to Dumfriesshire being in the Isle of Man, and on the coast of south Ayrshire.*

The Shag may be distinguished from the Cormorant by its smaller size and by its tail-feathers, which are twelve in number, and not fourteen as in the case of the latter; and on the wing the adult is distinguishable by the absence of any white on its throat.

\section{THE GANNET. Sula bassana (Linnæus).}

\section{Local name-Solan Goose.}

\section{An uncommon visitor.}

The Gannet occurs in the Solway Firth at uncertain intervals and in scanty numbers when following shoals of herring and mackerel ; but it is seldom seen off the coast of Dumfriesshire.

All my records of the occurrence of this species in the county are from inland localities, and refer, therefore, to storm-driven birds. The nearest nesting-station is Ailsa Craig, some sixty to seventy miles distant, and here the Gannets nest in thousands. A few pairs have bred on the Big Scaur (Wigtownshire), but not of recent years.

A bird in the plumage of the first year was captured the latter part of October, 1828, " a considerable way up Moffat Water, Dumfriesshire. It was taken on a marshy pool by a herd boy, and seemed much exhausted. There

\footnotetext{
* Fauna of Clyde Area, 1901, p. 165.
} 
appeared no wound. The distance of the place where it was caught from the sea is about twenty-five miles."* Richard Bell of Castle O'er narrates that on September 18th, 1878, a Gannet was found near Billholm (Westerkirk) by a shepherd. It was in an exhausted condition, and had been driven so far (twenty-five miles) inland by a great storm. Oats and trout were offered to it, and in taking one of the latter it bit the narrator's thumb to the bone. $\dagger$ In 1885 several Gannets from inland localities were sent to William Hastings for preservation, $\ddagger$ one of which, sent in October, so Mr. R. Service informs me, came from Annan. Mr. Alexander Sim writes me that he identified an adult found dead at Loch Skene in the winter of 1895 by a shepherd; and in 1898 another adult specimen was obtained in the same neighbourhood.ई A Gannet blown inland by the gale of November 12th, 1902, was captured at Cluden Bank three miles above Dumfries, and was presented by Mr. Kennedy to the Dumfriesshire and Galloway Natural History and Antiquarian Society.

\section{THE COMMON HERON. Ardea cinerea, Linnæus.}

\section{Local names-LoNG-NECKY HeRN; LoNG-NECKY ; JENNY} Hern ; Heronsheugh ; Craigie; Crane.

"A hermit glutton on a sodded root, Fish-gorged, his head and bill sunk to his breast, The lean blue heron stands, and there will stand Motionless all the long dull afternoon."

Thomas AIRD.-_" A Summer Day."

\section{A common resident.}

The Heron is a wary bird, well able to take care of itself, and seldom comes within shot of those who would shoot it

* Mag. Nat. Hist., 1829, Vol. II., p. 90.

$\uparrow$ Trans. D. and G. Nat. Hist. Soc., April 17th, 1901.

$\ddagger$ Op. cit., December 4th, 1885 .

$\S$ Ann. Scot. Nat. Hist., 1901, p. 199. 
at sight because of its depredations. Mr. J. J. Armistead writes: "It frequents the smallest trout streams at the time trout are spawning, and makes havoc amongst them. I have shot them at my trout ponds close to the house, and only a few weeks ago I missed several thousand yearling trout from a nursery pool, and set three or four traps. I next morning had the thief, which proved to be one of these birds."* Herons were popularly supposed to shake scales from their bodies to attract trout, and the grease obtained by cooking one of these birds was eagerly sought after as an ingredient of the pastes used by bait-fishers.

On the coast many are the stalks after wild-fowl that the Heron spoils, and I once saw a pack of Blackcock flushed by one of these birds. As a destroyer of young Wild-Duck, this species becomes obnoxious to the gamekeeper, and it is fortunate for those who would miss the Heron as a fitting ornament to our lochs and streams, that they are well able to look after their own safety. The dietary of this species is mainly supplied by frogs, eels, mice, etc., and Mr. Hugh Mackay states "of the contents of thirty-five Herons' stomachs that I have examined in two years, I have only found eight which contained trout ; the remaining twenty-seven contained the semi-digested portions of rats, mice, frogs, eels, fresh-water snails, beetles, and the fresh-water shrimps (Gammarus pulex)." $\dagger$ During the vole-plague of 1891-1893 these birds proved most useful, and "Mabie Moss" writes: "That the common Heron is a great destroyer of water-rats is pretty well known. The bird has a queer uncanny look about it when holding a rat crosswise in his bill, stretching out its neck meanwhile in strange contortions, and battering the life out of the helpless rodent ere it finally souses it in the water preparatory to bolting it whole." $\neq$ In

* Naturalist, 1886, p. 71.

† Dumfries Courier and Herald, February 16th, 1895.

$\ddagger$ Op. cit., May 1st, 1890. 


\section{BIRDS OF DUMFRIESSHIRE}

1835 it was stated that round Lochmaben the Heron was very seldom destroyed, from a belief that it devoured the adder.*

A Heron, caught in the stake-nets near Glencaple Quay in September, 1828, was taken to the King's Arms Inn, Dumfries, where it was fed on pig-wash. It became most dexterous in catching Sparrows. "Concealment by crouching was carefully studied; distance, too, was calculated with the greatest nicety. . . Unfortunately he was killed by a careless postboy driving over him." $\dagger$ It has been recorded that at Burnfoot (Langholm) a Heron "managed to creep near a trough in which some small birds were feeding and seize a cock shilfa $\ddagger$ with its beak, killed it and swallowed it whole, feathers and all."

In hard winters, as in 1878-1879, and 1894-1895, this species suffers severely; and though a regular autumnal immigration is perceptible on the east coast of Great Britain, our resident stock is scarcely influenced by these visitors. "Mabie Moss," however, recorded that the species was exceptionally numerous in November and December, 1895, and attributed the increase to such an immigration. $\S$

It is recorded that " a nest at Kirkconnel, which contained four eggs, was precipitated to the ground, with the top of the tree, which was blown off by a gust of windan exception to the rule that birds usually select safe trees for nesting." $\|$

The following tables of past and present heronries are possibly incomplete, but I would again thank those of my correspondents who have helped me to compile them :-

\footnotetext{
* New Stat. Acct. Scot., Vol. IV., p. 382.

$\dagger$ Sketches from Nature, pp. 191-194.

$\ddagger$ Chaffinch.

§ Dumfries Courier and Herald, December 18th, 1895.

\| Ann. Scot. Nat. Hist., 1905, p. 210.
} 


\section{HERONRIES FORMERLY IN EXISTENCE IN DUMFRIESSHIRE, NOW ABANDONED.}

\begin{tabular}{|c|c|c|}
\hline Parish. & Situation and Approximate Number of Nests. & Source of Information. \\
\hline APPLEGARTH & $\begin{array}{l}\text { Jardine Hall, } 1872 \text {. } \\
\text { No nests since } 1902 \text {, and previous to that only an } \\
\text { odd nest. }\end{array}$ & $\begin{array}{l}\text { Zoologist, 1872, p. } 3267 . \\
\text { A. Chapman, 10.ii.1909. }\end{array}$ \\
\hline CLOSEBURN & $\begin{array}{l}\text { Beardie's Howe, on Shawsmuir. They built on } \\
\text { two old Silver-Firs, but left when these were cut } \\
\text { down in } 1890 \text { or } 1892 \text {. }\end{array}$ & $\begin{array}{l}\text { T. M. Brown, } \\
\text { 12.viii.1908. }\end{array}$ \\
\hline DALTON .. & $\begin{array}{l}\text { Dormont I remember seeing their nests as a } \\
\text { boy in } 1865 \text {. }\end{array}$ & R. Service, 1.iv.1908. \\
\hline DURISDEER & $\begin{array}{l}\text { Drumlanrig. At the summit of some very tall } \\
\text { Silver-Firs. At one time there were six nests, } \\
\text { now none. I have known this heronry for } \\
\text { twenty years, but latterly it has been deserted. }\end{array}$ & J. Bell, 1.iv.1908. \\
\hline \multirow[t]{2}{*}{ EWES } & $\begin{array}{l}\text { Dean Bank. Formerly two nests on Fir and } \\
\text { Larch, now deserted. }\end{array}$ & W. Laidlaw, 1.iv.1908. \\
\hline & $\begin{array}{l}\text { Arkleton. At one time twenty nests on Firs and } \\
\text { Larches, now deserted. }\end{array}$ & W. Laidlaw, 1.iv.1908. \\
\hline \multirow[t]{2}{*}{ GLENCATRN } & $\begin{array}{l}\text { Dalwhat Water, } 1872 \text {, about twelve nests on Firs. } \\
\text { In } 1901 \text { Dr. Martin states: " They formerly nested } \\
\text { at the head of Glencairn, but the trees having } \\
\text { been cut down they do so no longer." }\end{array}$ & $\begin{array}{l}\text { Zoologist, 1872, p. } 3267 . \\
\text { Trans. D. and G. Nat. } \\
\text { Hist. Soc, December } \\
\text { 13th, 1901. } \\
\end{array}$ \\
\hline & $\begin{array}{l}\text { Barbuie. There was a single nest in a young } \\
\text { plantation here some years ago, but none in 1908. }\end{array}$ & J. Corrie, 16.viii.1908. \\
\hline $\begin{array}{l}\text { HUTTON and } \\
\text { CORRIE. }\end{array}$ & $\begin{array}{l}\text { At Shaw of Dryfe it is recorded in } 1794 \text { that } \\
\text { "there is a heronry where some hundreds are } \\
\text { bred yearly, and have been so, past all account } \\
\text { of the place. The number of breeders do not } \\
\text { seem to have increased in the memory of man, } \\
\text { though they are rather protected than otherwise. } \\
\text { They bring fish for their young, a pound weight, } \\
\text { from the lakes at Lochmaben, eight or ten miles } \\
\text { distant." } \\
\text { The wood where the Herons nested came to be } \\
\text { called Heronbank. They ceased to nest there } \\
\text { about } 1825 \text {; and it is believed locally that they } \\
\text { were ousted by Rooks. }\end{array}$ & $\begin{array}{l}\text { Stat. Acct. Seot., Vol. } \\
\text { XIII., p. } 580 .\end{array}$ \\
\hline KIRKMAHOE & $\begin{array}{l}\text { Burnt Fir Wood, 1876. A solitary pair have bred for } \\
\text { some years. } \\
\text { None since 1896, when there were four nests one } \\
\text { in Scots Fir, three in. Beech trees. }\end{array}$ & $\begin{array}{l}\text { Dumiries Courier, } \\
\text { 12.ix.1876. } \\
\text { w. Coupland, 9.ii.1909. }\end{array}$ \\
\hline $\begin{array}{l}\text { KIRKPATRICK- } \\
\text { JUXTA. }\end{array}$ & $\begin{array}{l}\text { Murthat. Three nests. They nested here for at } \\
\text { least eighty years, but left in } 1907 \text { when the trees } \\
\text { were cut down. }\end{array}$ & $\begin{array}{l}\text { J. Bartholomew, } \\
\text { 29.vi.1908. }\end{array}$ \\
\hline \multirow[t]{2}{*}{ MORTON .. } & $\begin{array}{l}\text { Nithbank. Seven or eight nests in } 1883 \text {; trees } \\
\text { blown down in } 1884 \text {. }\end{array}$ & $\begin{array}{l}\text { Tom Crosbie, } \\
\text { 1.iii.1908. }\end{array}$ \\
\hline & $\begin{array}{l}\text { Dabton. A tall tree here was regularly resorted to, } \\
\text { but the nest being robbed, the birds left. }\end{array}$ & $\begin{array}{l}\text { R. Armstrong, } \\
\text { 5.ix.1908. }\end{array}$ \\
\hline PENPONT.. & $\begin{array}{l}\text { Auchenaight. One or two pairs that used to come } \\
\text { here to nest have of recent years been absent. }\end{array}$ & C. Hyslop, 8.ii.1909. \\
\hline ST. MUNGO & $\begin{array}{l}\text { Castle Milk is included in a list of heronries given in } \\
1872 \text {. } \\
\text { Mr. C. Sanderson, who has been gamekeeper there } \\
\text { since 1868, says he never knew of this heronry. }\end{array}$ & $\begin{array}{l}\text { Zoologist, 1872, } \\
\text { p. } 3267 \\
\text { C.Sanderson, 11.ii.1909. }\end{array}$ \\
\hline SAKQUHAR & $\begin{array}{l}\text { Eliock. The Herons nested here until about } 1888 \text {, } \\
\text { when the trees were blown down. }\end{array}$ & $\begin{array}{l}\text { W. J. Laidlaw, } \\
\text { 20.v.1908. }\end{array}$ \\
\hline
\end{tabular}


In many instances a Heron has made its nest in some wood for only one season, and no attempt has been made to chronicle such occurrences. It is believed that throughout the county many suitable woods and plantations are thus tenanted, and it is to be feared that the birds are often given no chance of returning a second year.

\section{Heronties eXISTING IN DUMfrIEsShiRe IN 1908.}

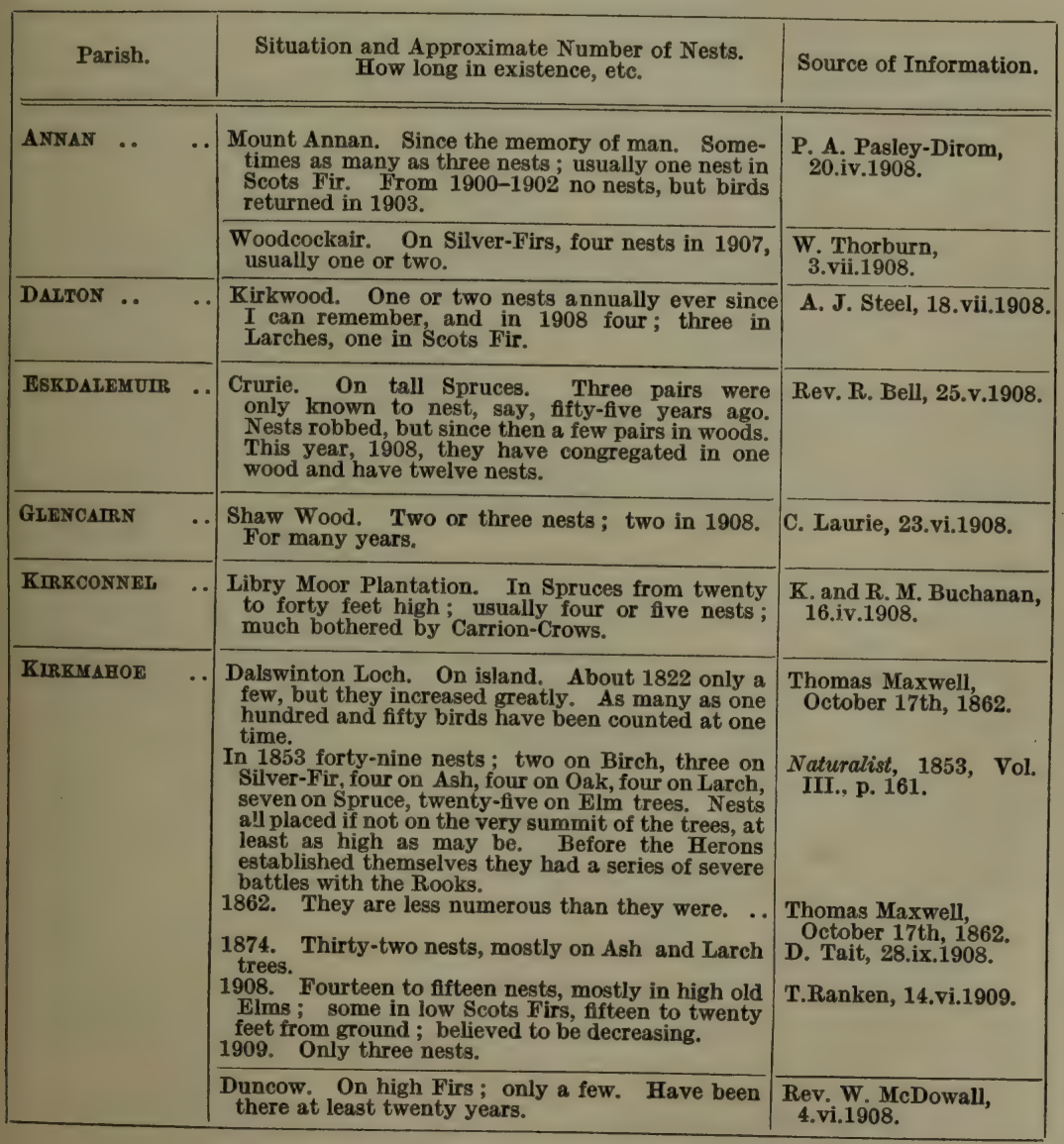




\section{Herontes existing in DUMfriesshire IN 1908-continued.}

\begin{tabular}{|c|c|c|}
\hline Parish. & $\begin{array}{l}\text { Situation and Approximate Number of Nests. } \\
\text { How long in existence, etc. }\end{array}$ & Source of Information. \\
\hline $\begin{array}{l}\text { KIRKPATRICK- } \\
\text { FLEMING. }\end{array}$ & $\begin{array}{l}\text { Hollee Wood. On rather low Oak trees. In exist- } \\
\text { ence since about } 1900 \text {; usually two nests. }\end{array}$ & $\begin{array}{l}\text { W. F. Graham, } \\
\text { 26.v.1908. }\end{array}$ \\
\hline $\begin{array}{l}\text { KIRKPATRICK- } \\
\text { JUXTA. }\end{array}$ & $\begin{array}{l}\text { Hillhouse Plantation. Never more than two nests, } \\
\text { usually one; on tallest trees in wood. They shift } \\
\text { annually. }\end{array}$ & $\begin{array}{l}\text { John T. Johnstone, } \\
\text { 1.vi.1908. }\end{array}$ \\
\hline LANGHOLM & $\begin{array}{l}\text { In } 1872 \text {, two or three nests at Langholm. [This } \\
\text { record may refer to the heronry at Flaskwood] } \\
\text { Flaskwood. In 1908, twelve nests ; top of very } \\
\text { high Spruces. Sometimes they nest further up } \\
\text { the Ewes, but mostly here. Have been known } \\
\text { for the last thirty years. }\end{array}$ & $\begin{array}{l}\text { Zoologist, 1872, p. } 3267 . \\
\text { W. Haining, 1.v.1908. }\end{array}$ \\
\hline LOCHMABEN & $\begin{array}{l}\text { Halleaths. 1835. Breeds in great numbers.. } \\
\text { 1872. Fifteen to twenty nests, chiefly on Scots } \\
\text { Firs. Twenty-seven nests. All on high old Scots } \\
\text { 1908. Twents. } \\
\text { Firs. }\end{array}$ & $\begin{array}{l}\text { New Stat. Acet. Seot., } \\
\text { Vol. IV., p. 382. } \\
\text { Zoologist, 1872, p. } 3267 . \\
\text { w. J. Halliday, } \\
\text { 8.vi.1908. }\end{array}$ \\
\hline Morrat .. & $\begin{array}{l}\text { Dumcrieff Woods. In } 1872 \text { a number of nests. } \\
1908 \text {. In the tallest trees in the woods ; never more } \\
\text { than two, usually one. }\end{array}$ & $\begin{array}{l}\text { Zoologist, 1872, p. } 3267 . \\
\text { John T. Johnstone, } \\
\text { 1.vi.1908. } \\
\end{array}$ \\
\hline RUTHWELL & \begin{tabular}{|lll}
$\begin{array}{c}\text { Nether Lochar Wood. On Scots Firs. Three } \\
\text { pairs since 1905. }\end{array}$ \\
\end{tabular} & $\begin{array}{l}\text { J. Harkness, } \\
20 . \text { ix.1908. }\end{array}$ \\
\hline SANQUHAR & $\begin{array}{l}\text { Glenmaddie. Two nests, Scots Firs, about thirty } \\
\text { feet from the ground. Came about } 1903 \text {. }\end{array}$ & $\begin{array}{l}\text { Thos. Ballantyne, } \\
\text { 23.v.1908. }\end{array}$ \\
\hline TYNRON .. & $\begin{array}{l}\text { Auchanhessnane. In some years six nests; three } \\
\text { in } 1908 \text {. Have nested here about forty years, but } \\
\text { not continuously. On very tall Spruces. }\end{array}$ & J. Currie, 1.vi.1908. \\
\hline
\end{tabular}

[The supposition as to the appearance of the Great Whrte HeroN (Ardea alba, Linnæus) on the Solway, in the winter of 1840-1841, above Port Carlisle in Cumberland,* has been shown by H. A. Macpherson to have been erroneous. $\dagger$ There are no records, so far as I am aware, of the occurrence of this species in the county (see SpoonBuL, p. 239).]

[The LitTue Egret (Ardetta garzetta, Linnæus). It is recorded in the Dumfries and Galloway Courier of March 2nd, 1836, that "On one occasion Colonel

* Nat. Lib., 1842, Vol. XII., p. 135.

$\dagger$ Zoologist, 1888, p. 330. 
Grierson killed an Egret [in Lochar Moss] ; a bird which has become nearly extinct, however common in those days when its feathers formed an ornament for royalty itself. The Egret altho' the smallest and most beautiful variety of the race, is usually classed with the Heron." In answer to my inquiries Sir Alexander Grierson wrote that he knew nothing at all of the whereabouts of this specimen.

Mr. R. Service informs me that "William Hastings, the taxidermist, had a Little Egret in his collection, which at his death passed into my possession. Hastings was not likely to have kept this bird if it had not been killed locally; moreover, judging from the other birds with which it was packed, it appeared to have been a local skin." This specimen cannot now be traced, though Mr. R. Service thinks it is still amongst his lumber, and the claim of this species to inclusion in the list of our county's birds remains unsatisfactory.]

\section{THE NIGHT-HERON. Nycticorax griseus (Linnæus).}

\section{Has occurred once.}

Sir William Jardine wrote in 1842 that : " A specimen in our own collection was obtained just after it had been skinned, and had been killed a day or two previously on the banks of the Cluden, a tributary to the River Nith in Dumfriesshire."* Robert Gray gives the date as 1825. $\dagger$ This bird is still in quite good order, and may be seen in the Royal Scottish Museum, Edinburgh. It was the second example obtained in Scotland, the first having been shot at the Hirsel (Berwickshire) on May 25th, 1822, by the Earl of Home $\neq$.

The Night-Heron inhabits parts of central and southern

\footnotetext{
* Nat. Lib., 1842, Vol. XII., p. 152.

$\dagger$ Birds of West Scotland, 1871, p. 282.

$\ddagger$ Birds of Berwickshire, 1895, Vol. II., p. 52.
} 
Europe, Africa, and southern Asia ; and closely allied forms are found in America.

The accompanying illustration of the actual specimen recorded by Sir William Jardine, is published with the permission of the authorities of the Royal Scottish Museum, Edinburgh.

It is impossible to say to what bird the following paragraph refers, if indeed it may not refer to the alleged occurrence of the Little Egret (see p. 230). But the description here given of the rara avis scarcely indicates that species and rather than omit this interesting extract, it is given under this heading for what it is worth. "On Friday last [i.e., April 18th, 1823] a specimen of that rare and beautiful bird the Crested Heron was shot in Lochar Moss by Wm. Grierson, Esq., of Rockhall. This rara avis though about the same size is somewhat heavier and firmer than the Common Heron; while its plumage in place of a dunnish white, is at once variegated and beautiful. On the top of the head it carries a superb crown from which a solitary feather projects at least six or eight inches in length. In former times this singular feather is said to have been a badge of royalty, and hence the high estimation in which the Crested Heron is held by all feudal and titled sportsmen."*

THE LITTLE BITTERN. Ardetta minuta (Linnæus).

\section{A very rare accidental visitor.}

In 1842 Sir William Jardine wrote: "The Little BitternHeron has been frequently met with in many of the English counties, extending to the Scottish Border." $\dagger$

I have found no records of its occurrence in the county previous to 1874 , when one was obtained. The following is the history of this bird as given by the late H. A. Macpherson

* Dumfries Courier, April 22nd, 1823.

† Nat. Lib., 1842, Vol. XII., p. 141. 


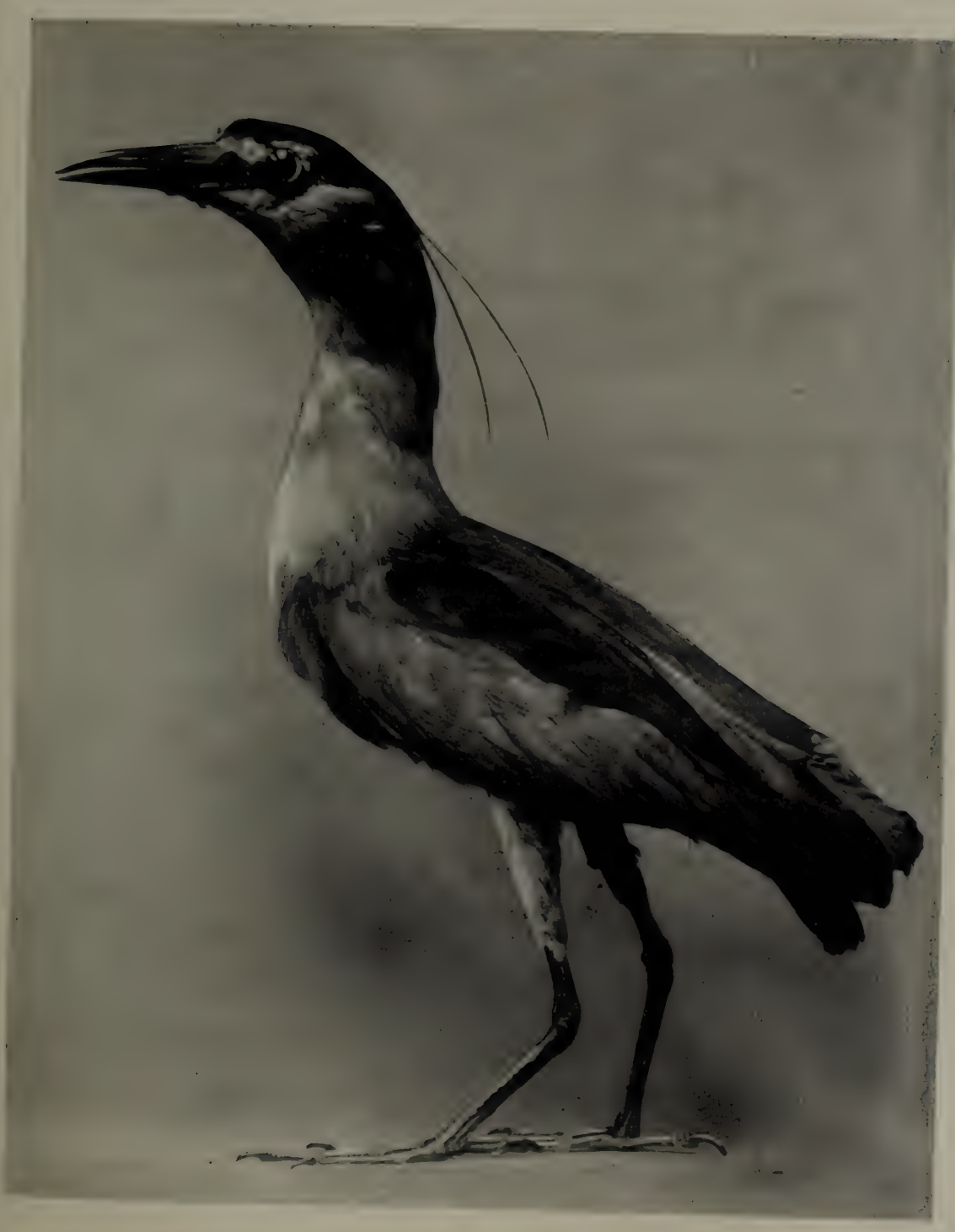

THE NIGHT-HERON (Nycticorax griseus), SHOT ON CLUDEN WATER IN 1825, NOW IN THE ROYAL SCOTTISH MUSEUM, EDINBURGH. 

in a letter to Mr. R. Service: "It is probable that I may have told you that I have heard of a local Little Bittern, killed in your faunal area, but whether or not, you will understand that as soon as I heard of it, I undertook to investigate its character for you. To-night, I met the man who had told me of it, and got him to take me to see it. Undoubtedly, it is a Little Bittern, a lovely bird in full male dress. It was shot at a place called the "Woodhouse," on the Kirtle River, between Kirkpatrick and Kirtlebridge, by its present owner, Mr. Sharp, of Hodgson's Court, Cumberland Street, Carlisle, in the early summer of 1874. It was brought to Carlisle and stuffed by Sam Watson, the verger of Carlisle Cathedral. You may therefore rely entirely on the character of its pedigree." This bird is also described by H. A. Macpherson in his Vertebrate Fauna of Lakeland (p. 226) as shot in June, 1874; and the name of the man who shot it is there given as Steel, in whose possession it is then (1892) said to have been.

A Little Bittern, said to have been more recently taken near Lochmaben,* has baffled the efforts both of Mr. R. Service and myself to verify the allegation of its occurrence.

This species in summer is found in suitable localities throughout Europe south of the Baltic and in north Africa; and in winter it is found in Africa as far south as Nubia. To Great Britain it is only an irregular summer-visitor, and has mostly been met with in the southern and eastern counties of England, where it has sometimes bred.

\section{THE BITTERN. Botaurus stellaris (Linnæus).}

Local names-BitTour ; ButToUR ; BoG-DRUM ; Miredrum.

Formerly not uncommon; is now a rare accidental winter-visitor.

The improvement in agriculture and the draining of suitable localities has deprived the Bittern of many of its favourite

* Trans. D. and G. Nat. Hist. Soc., April 20th, 1905. 
haunts, and has practically banished it as a breeding-species not only from this county but from the whole of the British Isles.

Dr. Archbald, among his "Curiosities at Drumfriess," written about 1684, includes: "Bittour, making a great sound in the summer's evenings and mornings by thrusting her beak into the ground when she cries."* In those days the Lochar Moss in spring must have resounded at night with the "boom" of the Bittern; a weird noise seldom heard during the day, and, needless to say, not produced as above described. "It consists of two notes, one supposed to be produced as the bird inhales, and the other as it exhales its breath. Naumann attempts to express it on paper by the syllables $i i-$ prumb, repeated slowly several times." $†$ The Rev. J. Dickson in 1793 describes the Bittern as a "native of Mouswald," + presumably of Lochar Moss. In December, 1819, a bird of this species was shot in Mouswald by Mr. John Brown, farmer, in Yernhirst, and "was put into the hands of Thomas Heatherton, farrier, at Pyehills, Ruthwell, for careful preservation." On February 21st, 1826, the following appeared in the Dumfries and Galloway Courier: " A Bittern, or Miredrum, of the largest size, and the first we have heard of for a long time, was shot last week on the estate of Broompark, which stretches almost to the side of the Nith, and is within a few minutes walk of this town. This bird, which we have seen, is obviously a cock, with very bright plumage, considering its colour, and has been finely stuffed by Mr. Hellon at Messrs. J. Kerr \& Co.'s." A Bittern recorded as "shot by Mr. Denham Young on his estate of Guilyhill in 1826 " $\|$ may refer to this bird.

In the Royal Scottish Museum, Edinburgh, there is

* Sibbald's MS. Collections, p. 228.

† Lloyd's Nat. Hist., 1896, Vol. III., p. 94.

‡ Stat. Acct. Scot., Vol. VII., p. 294.

§ Dumfries Courier, February 22nd, 1820.

\| Op. cit., January 11th, 1831. 
a fine specimen, still in wonderfully good preservation, from Sir William Jardine's collection, labelled "Winter 1828, from Dumfriesshire"; and this may be the specimen of the "Male Bittern shot in winter in the vicinity of Jardine Hall," described by Sir William Jardine in his Naturalist's Library.* In the Catalogue of the Birds contained in the collection of Sir William Jardine the only Dumfriesshire specimen of a Bittern mentioned, is recorded as shot at Dinwoodie by A. Maxwell. Dinwoodie being in the same parish, and within two miles of Jardine Hall, it is presumable that we now possess the complete history of this specimen.

Sir William Jardine records in his MS. "Calendar" a Bittern sent him from Dumfries on February 4th, 1829, and in 1842 he writes : "The winter of $1830-31$, is mentioned, both by Mr. Selby and Mr. Yarrell, as remarkable for the number of specimens which were obtained. In the south of Scotland a similar comparative abundance occurred ; several were brought to me in Dumfriesshire; and on a visit to Edinburgh, it was found that the bird preservers there had obtained also a more than usual number of specimens. Since that period, they have not been seen in Scotland, except as stray individuals." $\dagger$ Further evidence of this unusual immigration is afforded by the following from the Dumfries and Galloway Courier of January 11th, 1831 : "At one time it tenanted almost every marsh ; . . . but for a number of years, from the draining of bogs, and other improvements, the Bittern seems to have deserted our shores almost entirely, and is only occasionally driven to them by causes which it is not easy to account for. ... Mr. Johnstone informs us that he is aware of no fewer than five Bitterns which have been killed in this neighbourhood [i.e., Dumfries] within the last few days, three of which are in his own possession for the purpose of being stuffed." In the New Statistical Account of Scotland Sir William

* Nat. Lib., 1842, Vol. XII., p. 146.

† Op. cit., 1842, Vol. XII., p. 144. 
Jardine wrote in 1832 that the Bittern once frequented the parish of Applegarth and Sibbaldbie, "but has not been observed of late years. It is still found, however, in Lochmaben and Johnstone."* It was thus recorded from Langholm, in 1835 : "Among the more rare birds may be noticed the Bittern, which has been seen in this parish," $\dagger$ and contemporaneously from Westerkirk thus: "though rarely, is sometimes seen." $\ddagger$ From Mouswald it was described in 1836, as "abundant," $§$ but Mr. R. Service has already pointed out that as the account of this parish "was drawn up by a probationer in temporary charge, and not by the minister, a blunder of this kind may be excused." II however, there was one spot in the county where the Bittern might be expected to linger longer than elsewhere, that spot would be the Lochar Moss, though it is doubtful if there was justification for describing the species as " abundant" in this parish at that time, especially as in the same year the Bittern was recorded as only occasionally found in Lochar Moss. 1

John Shaw wrote to Sir William Jardine that in the winter of 1841-1842 he shot a Bittern at his experimental fishponds near Drumlanrig. Thomas Maxwell told Dr. Grierson that about 1848 he had obtained a Bittern at Blackwood (Keir). The bird was then (1862) in his possession; he had never seen another, but some had been killed in the district.** A specimen in the Royal Scottish Museum, Edinburgh, is labelled "Dumfriesshire, December, 1849." A correspondent signing himself "G. Dumfries" wrote to the Naturalist in 1858: "This beautiful bird promises soon to be among our extinct species" $\dagger \dagger$; while W. G. Gibson

* New Stat. Acct. Scot., Vol. IV., p. 181.

$\dagger$ Op. cit., Vol. IV., p. 418.

$\ddagger$ Op. cit., Vol. IV., p. 431.

§ Op. cit., Vol. IV., p. 444.

|| Kirkcudbright Advertiser, December 19th, 1902.

II Dumfries Courier, March 2nd, 1836.

** Grierson's MS. Notes, October 17th, 1862.

t广 Naturalist, 1858, Vol. VIII., p. 66. 
records one shot near Dumfries on January 7th, 1858.* In November, 1869, William Hastings received a Bittern for preservation from the vicinity of Lochmaben, $\dagger$ and another was shot there at the end of $1873 . \ddagger$ Mr. John Jardine shot a Bittern at the Kirk Loch (Lochmaben) in November, 1875, and "one was heard for some days uttering its travelling call at some places near Lockerbie in January, 1880."

H. A. Macpherson in a letter to Mr. R. Service refers to a Bittern on the Scottish side of the Solway in 1887, but further details are not forthcoming. An adult male, obtained at Gretna on January 13th, 1894, is now in the Tullie House Museum, Carlisle. On January 23rd, 1902, a Bittern was shot by Mr. Adam Fyfe in a small marsh about a mile below Moffat.\|

Unfortunately there are no records of this species having nested in the county, and it is improbable that it has done so within at any rate the last hundred years. As has been seen, the rare occasions on which the bird has been observed more recently in Dumfriesshire have been in the winter-months.

The Bittern " is generally distributed throughout Europe and Asia, but does not extend very far north, and in many of the southern countries it is known chiefly as a migrant, and breeds sparingly." 9

\section{THE AMERICAN BITTERN.}

Botaurus lentiginosus (Montagu).

\section{Has occurred twice.}

Yarrell records that at the end of October, 1844, Sir William Jardine sent him word that a specimen of the American

* Naturalist, 1858, Vol. VIII., p. 117.

$\dagger$ Dumfries Courier, December 7th, 1869.

$\ddagger$ Kirkcudbright Advertiser, December 19th, 1902.

$\S$ Loc. cit.

\| Ann. Scot. Nat. Hist., 1892, p. 137.

ๆ Lloyd's Nat. Hist., 1896, Vol. III., p. 94. 
Bittern "had been killed on the moss near his residence in Dumfriesshire during the previous week, and was preserved in his collection. Mr. Gould was on a visit to Jardine Hall at the time. This is probably the first example shot in Scotland."* This specimen is not mentioned in the Catalogue of the Birds contained in the collection of Sir William Jardine, but is recorded in a MS. note in his personal copy of the Naturalist's Library as " killed Dinwiddie, in coll. W. J." It does not, however, seem to have been included in his collection of British birds which was bought by the Edinburgh Museum for $£ 200$ in 1876, and it certainly is not now in the Royal Scottish Museum, Edinburgh, whither this collection subsequently made its way.

A second specimen is recorded by Mr. J. H. Gurney as follows: "A very good example of the American Bittern was shot at a small inland loch in Dumfriesshire on the 25th March, 1873, which I believe has not yet been noted in the Zoologist. It was exhibited by Dr. J. A. Smith to the Royal Physical Society of Edinburgh on the 25th of February, 1874, and has since, I am happy to say, found a place in my collection." $\dagger$ I have ascertained that this bird was shot by a gamekeeper on the Druid Loch or Swan Pond, within four hundred yards of Drumlanrig Castle. It passed into the hands of William Hope, bird-stuffer, of Edinburgh, who sold it for $£ 2$ to Mr. J. H. Gurney, of Keswick Hall, Norwich, in whose possession the specimen still is.

The American Bittern, as its name implies, is a bird of the western hemisphere, and there can be little doubt that most of the stragglers that have occurred in Great Britain have been aided by vessels in their passage across the Atlantic. The date of Mr. Gurney's example (March 25th) is remarkable, all the other British specimens having been obtained between October and February, at which seasons in America this bird becomes migratory.

* Yarrell, Hist. Brit. Birds, 1856, Vol. II., p. 578.

† Zoologist, 1876, p. 4929. 
[The SpoonbiLl (Platalea leucorodia, Linnæus). Under the Great White EGReT in his Naturalist's Library Sir William Jardine writes: "According to the newspapers a 'White Heron' was several times seen during the ... winter [1840-1841] upon the shores of the Solway, on the English side, above Port Carlisle."* Concerning this statement the late H. A. Macpherson writes : "Among the Heysham Papers I found a letter of one James Irwin, describing carefully the bird which, with some warranty from Sir William Jardine, gave rise to the report that a Great White Heron was seen on the Solway in the winter of 1840-1841. I have shown this letter to Howard Saunders, and we are satisfied that the bird in question was a Spoonbill." $\dagger$ The bird recorded by Sir William Jardine may have crossed from the Cumberland shore to Dumfriesshire, but of this there is no evidence. There is, as far as I know, no record of either the Spoonbill or the Great White Heron in Dumfriesshire, and my excuse for mentioning either of these species here is to show that the above statements have not been overlooked.]

\section{THE GREY LAG-GOOSE. Anser cinereus, Meyer.}

\section{Local names-LaGgie; StegG (of the male).}

"Wild geese, wild geese, ganging to the sea, Good weather it will be :

Wild geese, wild geese, ganging to the hill, The weather it will spill."

Old Dumfriesshire Saying.

A winter-visitant to the Solway; of late years in increased numbers.

The Solway Firth affords ideal winter-quarters for all sorts of geese, and the nature of the shores renders them particularly safe. The banks of the estuaries of the Annan

* Nat. Lib., 1842, Vol. XII., p. 135.

$\dagger$ Żologist, 1888, p. 330. 
and Nith are at times crowded with geese, but they generally prefer the higher reaches of the Firth.

The correct identification of immature specimens of the different species of grey geese is a puzzling question even for experts; and, if it is difficult to write with anything like certainty as to the present comparative distribution of these species on our shores, it is still more difficult to allocate properly the records of the past.

In 1684 the following statement was made concerning Loch Urr: "In this loch there is an old ruinous castle, with planting of sauch or willow-trees for the most part about it, where many wild geese and other water-fowls breed."* In a Description of the Sheriffdom of Wigtown, by Sir Andrew Agnew of Lochnaw and David Dunbar of Baldon, we find the following referring to the same period : "In the loch of Mochrome there are bred a number of herons and wild geese with other fowls." It is not impossible that in these early days this species may have nested at Loch Urr, for it may be noted that so recently as 1843 a few pairs are believed to have bred " annually in Sunbiggin Tarn, near Orton in Westmoreland." $\dagger$ In both the Statistical Accounts of Scotland local references are obscured by the omission of any distinguishing name. There are many records from various parishes of "wild geese" being abundant in hard winters, but no records of their breeding, or, indeed, of their having bred. It is remarkable that neither in the Catalogue of the Birds contained in the collection of Sir William Jardine, is there any mention of Grey Lag-Geese killed locally, nor were there any local specimens of this species in his collection purchased by the Edinburgh Museum in 1876. There is, indeed, no good evidence to prove that this species visited the Solway in the first half of the last century, and its subsequent appearance there, in ever-increasing numbers, is therefore most interesting to trace.

* Large Descr. Galloway, p. 81.

$\uparrow$ Fauna of Lakeland, p. 233. 
William Hastings, who was the principal taxidermist in the district till his death in 1893, told Mr. R. Service that he had occasionally during his lifetime received specimens of the Grey Lag-Goose for preservation.* In 1880 wild-geese arrived at the Solway Firth in the closing days of September, and their arrival had never been known earlier ; these geese Mr. R. Service believed to have been Grey Lags. $\dagger$ The same observer, writing of a bird of this species shot at Kelton (Dumfries) on November 7th, 1895, says that it is " by far the rarest of the Grey Geese that frequent our shores and estuaries in winter. . . . Its occurrence is always noteworthy." $\ddagger$ Mr. Hugh Mackay writes me that when he was in Dumfries (1893-1895) he received one or two Grey Lag-Geese for preservation. In 1897 this species is recorded as more numerous than usual on the Solway shores, $\S$ and Mr. R. Service states that in 1900-1901 the geese were nearer the estuary of the Nith than usual, and that on some occasions a thousand birds could be seen sitting or flying together. All the birds he handled were Grey Lags, and he adds: "In quite recent years all the geese were Bean Geese, and a Grey Lag was but seldom got." Two years later he states: "The Bean Goose was formerly the prevailing 'grey goose,' now the Grey Lag predominates." I In 1909 he writes me: "Lately I have handled a good many grey geese, and they are all Grey Lags. This is startling in view of the fact that up till a very few years ago, one could not get a grey goose that was not a Bean or a Pink-foot, and now these last are all displaced."

There are no records of Grey Lag-Geese having been killed far inland, though these birds are often seen flying over-

* R. Service, MS. Diary, October 9th, 1886.

$\dagger$ Proc. Nat. Hist. Soc. Glasg., 1881, Vol. V., p. 60.

¥ Dumfries Courier and Herald, December 18th, 1895.

$\S$ Ann. Scot. Nat. Hist., 1897, p. 192.

|l Op. cit., 1901, p. 80.

१i Op. cit., 1902, p. 120. 
head to or from their winter-quarters on the Solway, and frequently occur on the lochs at Lochmaben. I remember on April 25th, 1906, a flock of twenty passed over Capenoch very high, making a great "honking," which was answered by the Pheasant cocks; and on October 12th, 1905, I was awakened at 2 a.m. by the calls of geese passing overhead. These dates show approximately the autumn and spring-migrations of these birds, which arrive on the Solway in October, and depart again in April or early May; though in 1908 "grey geese" were still on the Caerlaverock foreshore so late as May 20th; and on June 19th three were seen near Beattock flying north.

The Grey Lag-Goose nests in the Outer Hebrides and northwest of Scotland, and is locally distributed in summer in parts of northern and central Europe ; in winter it migrates as far south as the countries bordering the Mediterranean.

\section{THE WHITE-FRONTED GOOSE.}

\section{Anser albifrons (Scopoli).}

\section{A winter-visitor.}

This is by far the least frequent of the different species of grey geese found in the Solway waters,* and has seldom been noticed in larger parties than a dozen.

Sir William Jardine wrote in 1843 that he had "once or twice fallen in with a small flock during winter in our own vicinity. The last we saw was raised from a rushy upland sheep-pasture, where, after a few turns, it again alighted, and we procured the specimen." $\dagger$ On February 24th, 1845, he wrote from Jardine Hall to his friend P. J. Selby, as follows: "I shot since I came down here a couple of white fronted geese M.F., [i.e., male and

* Dumfries Courier and Herald, February 8th, 1897.

† Nat. Lib., 1843, Vol. XIV., pp. 75, 76. 
female] very beautiful birds (you will see the skins at Fenton's, George Street) ; killed them both with my little rifle." These three birds may be the three specimens referred to in the Catalogue of the Birds contained in the collection of Sir William Jardine, as shot near Jardine Hall,* and one of these passed into the possession of the Edinburgh Museum in 1876.

Mr. Hugh Mackay tells me that when in Dumfries (18931895) he received a few specimens of this bird for preservation; but there is a lack of information regarding the comparative numbers of this species, and it is well to note that the Solway fishermen and gunners call any goose "a White-fronted Goose" that has white at the base of the bill.

This species nests from Nova Zembla eastwards across Arctic Russia as far as the Taimyr district and migrates south in autumn, at which season its distribution in Great Britain is decidedly local.

\section{[THE LESSER WHITE-FRONTED GOOSE.} Anser erythropus (Linnæus).

On January 14th, 1894, Mr. Robert McCall came across a party of seven or eight birds, which are believed to have been of this species, on the Nith Estuary opposite Carsethorn (Kirkcudbright). Being unable to get a satisfactory shot at them with his punt-gun, he killed two with his shoulder-gun. One was too badly shot to be preserved, but the other he gave to Mr. R. Service, who writes to me concerning it as follows :- "It was a very small bird, the smallest grey goose I ever had locally. It was nearly black on the under parts, the colour being dispersed in big patches, and there was a broad basal band of white round the bill. To my extreme regret this specimen was torn to pieces and

* Cat. Birds in Coll. Sir W. J., p. 174 (7102), a, a, a. 
destroyed by a dog that got into the shed where it was being dried."

The Lesser White-fronted Goose has hitherto only been recorded as a visitor to the British Isles on some half-dozen occasions ; and it is to be regretted that the loss of what is firmly believed to have been a specimen of this species, has deprived the county of its first recorded occurrence in Scotland.]

\section{THE BEAN-GOOSE. Anser fabalis (Latham).}

On the pale sky, now lost against the cloud seen

Shifting their trailing figures of array,

The wild geese cackled through the firmament,

Far going down upon the softer south :

These be the tokens of a rigorous time."

Thomas AIRD.-" A Winter's Day."

\section{A winter-visitant to the Solway.}

As has already been pointed out, the confusion of this species with the Grey Lag-Goose, has been considerable. At the beginning of the nineteenth century the Bean-Goose is believed to have been the commonest of the grey geese on the Solway, and it is only of recent years that its numbers. have been surpassed by the Grey Lag.

The local records of "wild geese" in both the Statistical Accounts of Scotland and in the contemporary newspapers, do not differentiate between the various species; and such records for the most part only refer to the abundance or scarcity of geese according to the severity or mildness of the winter.

Sir William Jardine, writing in $\mathbf{1 8 3 2}$ of the birds met with in the parish of Applegarth and Sibbaldbie, says: "The bean goose (Anser ferus) in flocks frequent the flat moors and holms in severe winters "* and at the same date it is

* New Stat. Acct. Scot., Vol. IV., p. 181. 
recorded that the "wild goose (Anser ferus) is frequently shot in the Lochar Moss."* Three specimens of Bean-Geese obtained in Lochar Moss were included in the collection of Sir William Jardine, which passed into the possession of the Edinburgh Museum in 1876; and the Catalogue of the Birds contained in the collection of Sir William Jardine, on p. 174, records a specimen got at Jardine Hall. In the Naturalist's Library Sir William states: "During the winter of 1841-1842, one of considerable severity, comparatively few wild geese appeared in the south of Scotland, and those which came under our notice were all Bean-Geese." $\dagger$

In 1886 this species is stated to be "the common grey goose of the Solway, but it has become much scarcer in winter of late years, though large flocks occur in spring and autumn " $\ddagger$; a statement confirmed by William Hastings.§ Specimens may occasionally be obtained, but seldom can be identified before being sent to market; but a fine female, shot in January, 1906, on the Solway by Mr. Norman B. Kinnear, is now in the Royal Scottish Museum, Edinburgh. One was shot on the River Nith near Carnsalloch on December 30th, 1908, by Mr. Norman Maclachlan, and another was obtained a few days later farther up the river.

The geese that are seen inland flying overhead at the seasons of migration, seldom come within shot, but Mr. J. Little informs me that a Bean-Goose was shot behind the Beef-Tub Moor (Moffat) a good many years ago by Thomas Pagan, gamekeeper at Moffat House.

This species nests throughout Arctic Russia from Kolguev to the Taimyr district, migrating south in autumn, and the date of its arrival on our coast approximately coincides with that of the Grey Lag-Goose, though it probably precedes the latter in its vernal departure.

* New Stat. Acct. Scot., Vol. IV., p. 444.

$\dagger$ Nat. Lib., 1843, Vol. XIV., pp. 70, 71.

$\ddagger$ Birds of Cumberland, 1886, p. 87 .

$\S$ R. Service, MS. Diary, October 9th, 1886. 


\section{THE PINK-FOOTED GOOSE.}

Anser brachyrhynchus, Baillon.

A winter-visitant to the Solway.

The Pink-footed Goose, the fourth species of "grey goose" that visits our Solway coasts, is often confused with the preceding species, but it is believed that during the last ten or fifteen years it has occurred in increasing numbers.

In 1886 the late H. A. Macpherson wrote that Mr. G. Holmes had shot a good many examples on the Scottish side of the Solway, and in the Zoologist of 1894 (p. 114) the same writer states: "In former days the Bean-Goose was the most common grey goose on the Solway Firth. Of late years it has in my experience been replaced to some extent by Anser brachyrhynchus. I lately identified the remains of a Pink-footed Goose, which had been shot out of a flock between Annan and Gretna." During the winter of 1894 1895, large numbers were observed on the Solway; and in the winter of 1896-1897 they were reported as coming in even larger numbers. $\dagger$ On December 16th, 1900, Mr. R. Service identified a goose sent to him from Annan as a male of this species, though he remarks on its similarity to a Bean-Goose.

The Pink-footed Goose nests in north Iceland and Spitzbergen, and migrates south in autumn. As regards Great Britain, it is the commonest of the "grey geese" on the eastern shores.

As there is much confusion between the four common species of "grey geese," I have thought it might be useful to sportsmen and others if I here give a short differential description of the adult of each, $\ddagger$ with the hope that future occurrences may be correctly recorded :-

* Birds of Cumberland, 1886, pp. 87, 88.

† Ann. Scot. Nat. Hist., 1897, p. 192.

$\ddagger$ Man. Brit. Birds, 1899, pp. 398, 400, $402,404$. 
The Grey Lag-Goose.-Bluish-grey rump and wingcoverts; flesh-coloured bill, legs and feet. Total length, 34 inches; weight, 8-10 lbs.

The White-fronted Goose.-White frontal band; breast and belly broadly barred with black; bill orangeyellow; legs and feet orange. Total length 27 inches; weight, $5-6 \frac{1}{2}$ lbs. (In the young the frontal band does not appear till January and the bill-nail is light brown; the young female has no black on the under-parts.)

N.B.-In both these species the bill-nail is white.

The Bean-Goose.-Bill, which is rather long and weak, orange in the centre, black at the base ; legs and feet pinkish-yellow; general plumage darker than the last two species. Total length, 33-34 inches; weight, $7-8 \mathrm{lbs}$.

The Pink-footed Goose.-Smaller than the Bean-Goose; bill, which is pink in the centre, black at the edges and base, proportionately short for the size of the bird; legs and feet pink. (Colour of legs, feet and bill not quite constant.) Total length, 28 inches; weight, 6-7 lbs.

N.B.-In both these species the bill-nail is black.

\section{THE SNOW-GOOSE. Chen hyperboreus (Pallas).}

\section{A very rare accidental visitor.}

In $1879 \mathrm{Mr}$. R. Service records the following: "One of the keepers on Lochar Moss told me he observed in March, 1879 , a flock of fifteen geese remarkable for their pure white colour; but as he had no gun with him at the time the species was not determined. He was very close to them, and felt quite certain they were none of the species in the habit of visiting Lochar."* I have been unable to obtain any

* Trans. D. and G. Nat. Hist. Soc., November 7th, 1879. 
further information concerning these fifteen birds, and whether they were Snow-Geese or not will never be known. A man named John Hepburn told Mr. R. Service of a bird found in the autumn of 1884 in Mr. Beattie's stake-nets at Newbie (Annan). It was " a large white goose with bright red bill and black wings. Mr. Beattie did not know it, nor any of the other men ; after being kept a day or two it was "fired into the tide.'"* Concerning this record the late H. A. Macpherson wrote in 1888 to Mr. R. Service : "I intend to take an early opportunity of visiting Annan to inquire about the Snow-Goose. G. Dawson of Carlisle informs me that he heard a similar account of a white goose to yours at second-hand." The result of these inquiries is given by H. A. Macpherson in his Vertebrate Fauna of Lakeland as follows: "It was on the 22nd of August [1884] that a single Snow Goose made its appearance on the shores of the English Solway, near Allonby. Starting for the coast by an early train, my companion and I reached the beach about 9 a.m., the morning being fine and calm with a haze at sea. My astonishment may be imagined, when a Snow Goose came flying along the edge of the water, coming out of the west. It flew so leisurely that we felt sure it must soon alight to rest, so, instead of trying a long shot at it with small shot, which was all we had, I contented myself with pointing out to William Railton, who accompanied me, the salient points in the Goose, which I had of course no difficulty in recognising. The bird never alighted ; all inquiries on the Scottish and English sides of the firth failed to elicit any detailed information. There can be no doubt that it flew up the whole length of the Solway, and was last seen by a punt gunner making for the Esk. At a later date a Scotch fisherman supplied Mr. R. Service with a description of such a bird, which he said that he had found washed up dead. His employer, to whom he professed to have shown the bird, disowned any such proceeding. I have no doubt that he obtained his description of it from

* R. Service, MS. Diary, May 24th, 1888. 
one of the Scotch fowlers, to whom I had written to describe the bird, and say that it was ' wanted." "* Personally, I cannot see what possible motive John Hepburn could have had in telling Mr. R. Service what H. A. Macpherson plainly suggests was untrue; and therefore I consider that I am justified in including this species in my list.

Mr. L. E. Hope writes me from Carlisle concerning a flock of forty birds seen near Annan, on or about January 2nd, 1909, and said to have been Snow-Geese : "Mr. Marjoribanks in company with Mr. Graham, of Edmond Castle, Cumberland, was on the golf links at Powfoot (Cummertrees) and saw the birds flying from the Solway, circle once or twice over the links and then fly off north. They saw the black primaries distinctly against the white of the body and are sure they were not swans on that account. I have had no confirmation of the occurrence." I wrote to Mr. Marjoribanks, who, in his reply, said that he saw these birds on January 2 nd or 4th, that the flock numbered from thirty to forty, that they came from the direction of Annan and flew off towards the west, and that he and Mr. Graham were within two hundred and fifty yards of the birds when they were circling round the golf links. Quite independently Mr. G. R. Murray informed Mr. R. Service that he believed that he saw a flock of forty Snow-Geese on the Dee near Parton (Kirkcudbright) on February 13th or 14th, 1909, and this is the only confirmatory evidence I have been able to obtain in support of the alleged recent occurrence of the species in our waters.

The summer-home of the Snow-Goose is in the Arctic regions of North America, and it but rarely visits the countries of northern Europe.

[A pair of RED-BREASTED GEESE (Bernicla ruficollis (Pallas)) were reported $\dagger$ as having been seen in March and April, 1909, by Mr. James Wilson; who stated that he was

* Fauna of Lakeland, 1892, p. 243.

$\dagger$ Dumfries Courier and Herald, May 12th, 1909. 
quite certain of the species, and had first observed them in the month of March feeding on the marsh close to Glencaple, and again on April 15th. "I approached," writes Mr. Wilson, "so close to them with my boat that I could have shot them both." The birds were said to have been seen also by several people on the opposite side of the River Nith just below the village of Glencaple, and at a distance of about one hundred yards.

The alleged occurrences of this species in Great Britain are mostly unsubstantiated, and but seven records are given by Howard Saunders.* It breeds in Arctic Russia, north of the limit of forest-growth, from the $\mathrm{Ob}$ to the Boganida, whence it migrates southwards in autumn past the Aral and Caspian Seas.]

\section{THE BARNACLE-GOOSE.}

Bernicla leucopsis (Bechstein).

\section{A common winter-visitant to the Solway.}

Since the memory of man, the Barnacle-Goose has been the dominant and characteristic goose of the long wastes of sand and mud constituting the shores of the Dumfriesshire Solway. Sir William Jardine writes in 1843: "On the shores of the Solway Firth they are at times very abundant ; and although it is not much practised, they are occasionally shot during their flight by waiting, or, as it is called on the Northumbrian coast, "slaking." "† Nowadays they are subject to incessant persecution from the shore-shooters, and although comparatively easy of approach for the first few days after their arrival, they soon become excessively wary. Mr. R. Service has recorded how in early October, 1881, he and his friend the late William Lennon came upon an immense flock of Barnacles asleep on the Blackshaw Bank. They

* Man. Brit. Birds, 1899, p. 407.

† Nat. Lib., 1843, Vol. XIV., p. 78. 


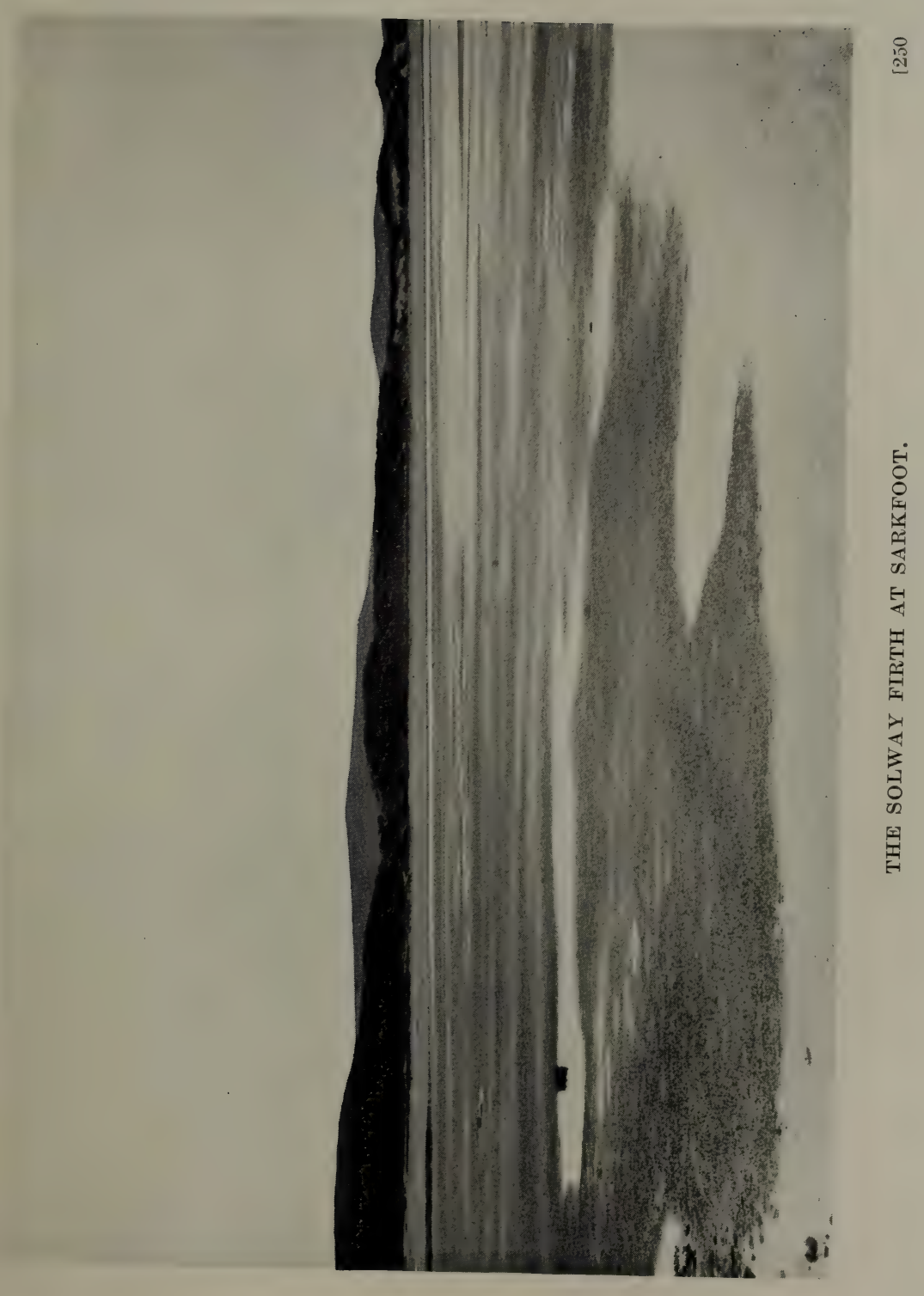



had apparently just arrived from their summer-quarters, for they were so tired as not to fly unless approached within thirty yards. Mr. R. Service estimated their numbers at ten thousand.*

The Barnacles are singularly consistent in the dates of their arrival and departure ; and they always arrive on our shores during the afternoon or evening. September 28th to 30 th is the time of their appearance, and April 18th to 20th of their departure north. In 1908 two flocks, numbering twenty-eight and twelve respectively, were seen on the Solway in the vicinity of Southerness on July 4th, an unprecedented late date; though in 1886 a single BarnacleGoose (probably ailing) was seen on the Blackshaw Bank throughout the summer. "Mabie Moss" writes as regards the direction of their migration: "they come down in a direct line from the Clyde, probably from the Hebrides. In spring they fly off at nightfall direct northwards from the Blackshaw," $\dagger$ but a very large proportion, so Mr. R. Service informs me, take a direction leading north-west. On their migrations they are often seen overhead inland, and are seldom known to alight; but Mr. J. Little writes me that he has seen Barnacle-Geese resting on the moors near Moffat.

In some seasons they are more abundant than in others, their numerical strength on our coast being presumably influenced by the severity of the weather or otherwise in their more northern resorts. Small flocks are occasionally seen in advance of the main bodies, and similarly some linger after the majority have departed. During their stay on our coast, they are constantly changing their feedinggrounds as the grass grows old. In the winter of 18781879 Barnacles were unusually abundant; they fed inland in the daytime along the banks of the Nith, and one gamekeeper near Dumfries shot fifteen in one day. $\ddagger$ In 18811882 they were fewer in numbers as compared with the

* Ann. Scot. Nat. Hist., 1903, p. 199.

† Kirkcudbright Advertiser, October 10th, 1898.

‡ Proc. Nat. Hist. Soc. Glasg., 1879, Vol. IV., p. 178. 
immense flocks seen during the two previous winters.* They were very numerous during the winters of 1886$1887,1887-1888$, and 1888-1889, not so plentiful in 18961897, but were particularly abundant for a few days towards the end of November, $1899 . \dagger$ Since that date the Barnacle-Goose has not been so markedly the dominant species as was formerly the case, and the "grey" geese are nowadays very often more numerous on our coast. Mr. R. Service writes to me as follows concerning the decrease of this species: "It would appear that owing to the culmination (in one direction) of the changes always going on and around the Firth, wide stretches of feeding-grounds, once covered exclusively with the soft green grass beloved by the Barnacles, are now either covered with a coarser growth, or are devoid of grass altogether, thus rendering such spots no longer attractive to the species."

Formerly it was a common practice for the fishermen in winter to set up nets, so as to intercept the shorebirds as they flew along the edge of the tide. This practice of late years seems mercifully to have fallen into desuetude, and numerous small birds, worthless in any market, are thus spared. H. A. Macpherson writes: "Irving Murray, an aged wild-fowler, assured me that Barnacle Geese are occasionally entangled in the flight-nets which are fixed at the mouth of the Nith in Dumfriesshire to catch fowl of every kind," $\ddagger$ and Mr. R. Service records a specimen received from Murray's bird-nets at Priestside on November 28th, 1888.§

Thanks to the innate wariness of this species, and to the difficulties of approach on such a coast as ours, the BarnacleGoose visits our shores with comparative safety. The following curious entry occurs in Mr. R. Service's M.S. Diary for July, 1887 : “John Kennedy, of Priestside, tells

* Trans. D. and G. Nat. Hist. Soc., February 3rd, 1882.

$\uparrow$ Kirkcudbright Advertiser, December 11th, 1899.

$¥$ Hist. of Fowling, 1897, p. 221.

$\S$ R. Service, MS. Diary, November 28th, 1888. 
me that before the Barnacles go off in a late spring, eggs are often found out on the banks where they have been resting; " but in conversation, Mr. R. Service told me that although he offered half-a-sovereign for any such egg, not one was ever forthcoming. The breeding-place of this species is believed to be in north-east Greenland and possibly parts of Spitzbergen, but at present there exists but little information concerning its nidification.

\section{THE BRENT GOOSE. Bernicla brenta (Pallas).}

\section{A winter-visitant to the Solway.}

This entirely maritime species cannot be regarded as a common visitor to our shores, although it is perhaps more frequent now than in former years, but of this we cannot be positive, for there are no old records of its local occurrence ; though William Hastings told Mr. R. Service that in the course of his business (1860-1885) he had occasionally received Brent Geese for preservation.

As regards more recent years; this species was observed off our coast in the winter of 1885-1886, and " On August 25th, 1889, Mr. Nicol obtained a close view of a solitary, whitebreasted Brent, which twice flew round him. It came from the Scottish side, and had perhaps passed the summer on the estuary of the Nith."* In 1895, "Mabie Moss" wrote "The Brent is a species of goose so sufficiently scarce on the Solway as to deserve a note." $\dagger$ Mr. R. Service records them as coming in considerable numbers to the Solway in the winter of 1896-1897‡; and in 1903 he states that though once very scarce, they are now far more often seen.ई A female was shot on January 7th, 1907, at Ruthwell, $\|$ and

* Fauna of Lakeland, 1902, p. 245.

$\dagger$ Dumfries Courier and Herald, February 4th, 1895.

¥ Ann. Scot. Nat. Hist., 1897, p. 192.

\& Op. cit., 1903, p. 200.

|| Tullie House Museum Registers. 
in 1908 one was shot on December 31st at Powfoot (Cummertrees), by Mr. J. Dalrymple. A party of three was observed in the estuary of the Nith, opposite Carsethorn, at various times during the winter of 1908-1909. A Brent Goose was shot as it was feeding alone in a meadow by the side of Moffat Water, near Croftheads (Moffat), on December 21st, 1909, by Mr. Williamson. Croftheads being twenty-five miles inland, is a remarkable locality at which to meet with this species. I have seen the bird, which is a male of the dark-breasted form.

H. A. Macpherson has stated that both the dark ( $B$. brenta) and light-breasted (the so-called B. glaucogaster of Brehm) forms of this species occur on the Cumberland estuaries,* and both forms also occur on our coast. The Brent Goose probably breeds as far north as land is known, the dark-breasted form "being the principal inhabitant of Novaya Zemlya, Spitsbergen, Kolguev, etc., though not exclusively, . . . the light-breasted form taking its place from Greenland to the Parry Islands. In winter it migrates south, and occurs along the coasts of Northern and Western Europe." $\dagger$

[Four Canada Geese (Bernicla canadensis, Gray) are said to have been seen on the shore near Glencaple towards the end of June, 1909 ; but, even if they were correctly identified, there can be no doubt that they were but " escapes" ; the species having been domesticated in Great Britain for more than two centuries.]

[The Egyptian Goose (Chenalopex oegyptiaca (Linnæus)) seen, as Major Critchley informs me, on the shores of the Solway between Torduff Point and the mouth of the Kirtle, for several months in 1907, was undoubtedly an "escape" from some collection of ornamental wild-fowl.]

* Fauna of Lakeland, 1902, p. 245.

† Lloyd's Natural History, 1896, Vol. II., p. 241.

$\ddagger$ Dumfries Courier and Herald, July 23rd, 1909. 


\section{THE WHOOPER SWAN. Cygnus musicus, Bechstein.}

\section{A winter-visitant to the Solway.}

The Whooper, though seldom obtained, is frequently heard and seen in sufficiently hard winters, on the Solway; but Bewick's Swan is believed to be the more regular visitant of the two.

Judging by measurements and weights it would appear that the following records of wild swans, refer to the larger rather than to the smaller species ; and it is possible that in some cases the "wild swans" so recorded were only semidomesticated Mute Swans driven by stress of weather to running water or to the sea-shore. The Whooper weighs from eighteen to twenty-two pounds and is about sixty inches in length, and though, therefore, considerably larger than Bewick's Swan, it is difficult to distinguish between the two when flying high overhead or at a distance except by their call.

Swans are mentioned in 1792 as coming to LocharMoss, * and it is recorded that " the tremendous snow storms of 1822 brought whole flocks of wild swans to our shores." $\dagger$ “ Eleven were seen on Thursday, February 6th, 1823, hovering about Lochar Moss, one of which was fired at and ultimately brought down. . . . This beautiful bird, which we have just seen, is now in the possession of Mr. Johnstone, Grapes Inn. . . It weighs exactly $19 \mathrm{lbs}$., and measures from tail to bill 4 feet 10 inches, and betwixt the extremities of the wings 7 feet 11 inches." $\ddagger$ In subsequent winters, the appearance of swans is recorded in the local papers, and on November 22nd, 1830, a specimen, measuring four feet ten inches in length and weighing fifteen pounds

* Stat. Acct. Scot., Vol. II., p. 2.

$\dagger$ Dumfries Courier, February 21st, 1826.

$\ddagger O p$. cit., February 11th, 1823. 
seven ounces, was shot " out of a covey of three in the parish of Caerlaverock while winging its way along the bed of the Lochar." This occurrence is considered noteworthy, as being an early date and no frost at the time.* Later the other two birds were shot on Green Hill of Caerlaverock and weighed eighteen and nineteen pounds respectively. $\dagger$ In the New Statistical Account of Scotland it is stated that circa 1835 the swan "resorts to the lochs at Lochmaben in severe winters," $\div$ and that the "wild swan (Cygnus ferus) is frequently shot in the Lochar Moss."§ From Dunscore it is recorded that " in the winter of 1823, during a heavy fall of snow, a flock of Norwegian swans was seen in this parish, and one of them was caught in a drain on the estate of Allanton." $\|$

The appearance of swans, then as now, depended upon the severity of the winter; thus in 1838 we find the following statement: "Flocks of wild swans more or less numerous have been seen in almost every part of the county," $I$ but in 1841 : "We are not aware of a single wild swan being seen this winter in the south of Scotland."** Sir William Jardine writes of "The Hooper or Wild Swan" in 1843: "We possess a fine specimen of one killed on the river Annan in our vicinity, and know that they have been shot on the Nith as high as Drumlanrig, and on some alpine lochs on the confines of Dumfriesshire and Selkirkshire, they are frequently to be met with in winter." $\dagger+$ A specimen is recorded in the Catalogue of the Birds contained in the collection of Sir William Jardine as obtained " near Dumfries."

The following extract is worthy of note, if only as a record

* Dumfries Courier, November 23rd, 1830.

† Op. cit., November 30th, 1830.

‡ New Stat. Acct. Scot., Vol. IV., p. 382.

§ Op. cit., Vol. IV., p. 444.

\| Op. cit., Vol. IV., p. 337.

If Dumfries Courier, February 28th, 1838.

** Op. cit., February 8th, 1841.

†† Nat. Lib., 1843, Vol. XIV., p. 94. 
of fine marksmanship : "One evening last week [in March, 1855] Mr. Beattie of Newbie was informed that a flock of wild swans was floating in the Solway opposite his own door. On going out he saw they were beyond ordinary range, and loaded with ball with which he succeeded in killing one of these splendid birds at a distance of two hundred yards."*

A swan was shot some twenty-two miles from the sea on January 20th, 1857, by John Oliver, gamekeeper to Colonel Borthwick, at Raeburnfoot (Eskdalemuir), which " weighed $19 \mathrm{lbs}$. and measured 4 feet from bill to tail, and 8 feet from tip to tip of wings." $\dagger$ The length (four feet) of the specimen is out of proportion with the weight and other measurement given. In March, 1868, “A wild white swan was shot near Browhouses, Gretna, by Mr. John Irving, fisherman. The bird is remarkably large in size, its length being 5 feet, the extension of its expanded wings 7 feet, and its weight $19 \mathrm{lbs}$. The swan has been sent to Mr. Plenderleath, stuffer, Longtown." $\$$ In the winter of 1879-1880 swans were unusually plentiful, particularly in December and January, and they were also recorded as seen in 1881-1882. $\$$ Mr. R. Service informs me that he verified the identification of a Whooper shot at Kingholm (Dumfries) on the Nith in January, 1884. The man who shot it-an English workman-told him that when his wife dressed it for roasting, she used the whole of a big loaf in stuffing it. Mr. John Corrie of Moniaive states : "A pair of wild swans was shot in the district on December 20th, 1893. They weighed $15 \mathrm{lbs}$. apiece and measured 5 feet in length. This is the first time I have known these birds to occur in Glencairn." || Mr. Corrie tells me that these birds were shot on the Cairn below Moniaive (i.e., some eighteen miles inland), and the man who shot them buried

* Dumfries Courier, March 6th, 1855.

$\dagger$ Op. cit., February 10th, 1857.

$¥$ Op. cit., March 31st, 1868.

§ Trans. D. and G. Nat. Hist. Soc., February 3rd, 1882.

\| Op. cit., February 16th, 1894. 
them as he thought he had done wrong; but they were exhumed and identified. In early December, 1899, a flock of forty Whoopers was observed on Blackshaw Bank.*

The story of "The White Swan of Closeburn" is still remembered locally, though the Kirkpatricks, who for so many years lived there, are no longer in residence, and the tale dates back to the end of the seventeenth century. It is thus told by Charles Kirkpatrick Sharpe in 1815 to $\mathrm{Mr}$. (afterwards Sir) Walter Scott :- " There was one picturesque tale attached to Closeburne. A white swan appears on the loch which surrounded the castle before the death of any member of the family. My great grandfather's father, the first baronet, married a daughter of Lord Torphichen, by whom he had two sons. After her death he married Miss Hamilton of Raploch. At the wedding-supper the young heir looked very dowie, and on his father's reproving him for it, supposing he did not like the notion of a stepmother, merely said : 'Before long ye'll look wae too.' He had seen the swan that evening, and died that night." $\dagger$

"The Whooper breeds in high northern latitudes from Iceland eastwards throughout northern Europe and Siberia, wandering south in winter to most of the Mediterranean countries." $\ddagger$

\section{BEWICK'S SWAN. Cygnus bewicki, Yarrell.}

\section{A winter-visitant to the Solway.}

Bewick's Swan weighs from thirteen to fifteen pounds and is from forty-six to fifty inches in length, and is, therefore, a much smaller bird than the Whooper Swan, from which, however, it is not easily distinguished when seen on the wing or at a distance.

* Ann. Scot. Nat. Hist., 1900, p. 120.

† C. K. Sharpe's Correspondence, 1888, Vol. II., pp. 126, 127.

‡Lloyd's Nat. Hist., 1896, Vol. II., p. 248. 
Judging by weights and measurements, all the old local records of wild swans would seem to refer to Whoopers; but the anxiety of the lucky wild-fowler to make out his trophy to be as big as possible may perhaps have led him to exaggerate, and so deprived us of many records of the occurrence of Bewick's Swan. Nowadays this species. is believed to be more frequently observed on our shores. than the Whooper. In 1843 Sir William Jardine writes: "A distinct species of Swan only began to attract attention about the years 1827 or 1828 , although one or two Ornithologists had previously examined specimens. and pointed out distinctions. Soon after, its dedication, to hand down to posterity the Ornithologist of Newcastle [i.e., Thomas Bewick, the Engraver], was by common consent recognised. Specimens have since been procured in several districts of England, Scotland and Ireland, but it is by no means common."* In 1838 he wrote from Jardine Hall to his friend P. J. Selby :- "Swans more than usually common; but so far as I can learn all the common species. I have been looking out for a Bewicki for myself but without success." $\dagger$ Sir W. Jardine in an MS. note in his personal copy of the Naturalist's Library records "Five specimens of this swan were shot in the winter of 1870-1871 in Dumfriesshire and Galloway. They were in company with others which in all probability would be of the same species."

In the winter of 1880 a flock of eleven of these birds was seen, and "Mabie Moss" recorded in 1891 that "Bewick's Swan has been much oftener noticed than the Whooper." $\ddagger$ A party of six was identified at the mouth of the Nith on March 2nd, 1900, $\S$ and they are frequently noticed between this point and Dornock (Annan), especially in severe.
winters.

* Nat. Lib., 1843, Vol. XIV., p. 96.

† Sir W. Jardine, in litt. to P. J. Selby, March 28th, 1838.

‡ Dumfries Courier and Herald, January 22nd, 1891 .

Ann. Scot. Nat. Hist., 1900, p. 120. 
The breeding-places of Bewick's Swan are further north and east than those of the preceding species, and in its winter-migration it does not seem to occur so far south.

\section{THE MUTE SWAN. Cygnus olor (J. F. Gmelin).}

Local name-TAME SwaN.

\section{A resident in a semi-domesticated state.}

The Mute Swan is kept on many lakes throughout the county, and besides being an ornament, it serves a very utilitarian purpose in keeping in check noxious aquatic weeds. In very severe winters, when they are frozen out of their homes, these birds seek the estuaries and open sea of the Solway Firth.

Mr. R. Service writes me : "Looking to the known range of the wild Mute Swan in the breeding season, as well as the complete way in which they are perforce frozen out in winter, I have not the least hesitation in believing that at least a small proportion of the wild swans that visit us in certain favourable seasons are really examples of this species. At the same time I cannot cite any undoubted instances-such would be difficult enough of proof." Howard Saunders states: "The Mute Swan still breeds in a perfectly wild state at no greater distance from us than Denmark and the south of Sweden, whence it is forced by cold to migrate in winter"*; so that Mr. Service's belief may well be correct.

It is not necessary to enumerate the various pieces of water where this beautiful species is kept, but for many years the Swans at Lochmaben have been a feature of its lochs. Here they were introduced about 1835. Mr. John Haining, a man of eighty-six, interviewed by $\mathrm{Mr}$. W. J. Halliday at Lochmaben in 1908, states: "I remember

* Man. Brit. Birds, 1899, p. 417. 
one day when a big boy, my father being from home, a swan flew over our farm from the Castle loch and pitched in the River Annan, which flows along the eastern boundary of the farm of Priestdykes. The ploughman induced me to get an old flint-lock gun out of the house and we charged it. The gun, however, was minus the flint, so I went to the house and brought a piece of live peat from the kitchen fire. The ploughman then levelled the gun at the bird over the bank of the river, and I touched the powder in the flash-pan of the old gun with the live peat, and the swan was shot dead." It is recorded that on November 21 st, 1909, when the Nith was covered with a sheet of ice of considerable thickness, a young Swan, one of those which had been for some time on the river, was found "frozen to death, through its having become embedded in the ice."*

This species is believed to pair for life, and the female does not lay during the first year, sometimes not till the fourth year ; some thirty-six days are taken for the incubation of the eggs, which are laid in increasing numbers, from three or five, to ten or twelve, as the bird advances to maturity. $\dagger$

[A specimen of the BLACK-NECKED SwAN (C. nigricollis, Gmelin) is recorded by H. A. Macpherson as having been shot near Dumfries early in 1891. The bird was full-winged and showed no signs of having been in captivity. $\$$ This species, a native of antarctic America, is not infrequently seen in collections of ornamental wild-fowl, and the specimen in question was doubtless nothing more than an "escape."]

[The Black Swan ( $C$. atratus, Latham), a native of Australia, is often kept in this country in semi-captivity on ornamental pieces of water. A bird of this species was seen on the Castle Loch, Lochmaben, in the spring of 1907. It left in winter, but reappeared there in the following

* Dumfries Courier and Herald, November 24th, 1909.

$\dagger$ Man. Brit. Birds, 1899, p. 418.

$\ddagger$ Naturalist, 1892, p. 260. 
spring. Captain G. L. Walker, of Crawfordton (Glencairn), tells me one of the Black Swans disappeared from his lake about the time of the first appearance of the bird at Lochmaben; so that presumably it came from Crawfordton. A Black Swan is recorded as seen some years prior to 1829 on the Sand Loch,* a piece of water near Dumfries, which has since been drained; and Mr. R. Armstrong writes me that he saw one on the New Loch (Morton) on May 10th, 1906; but any such occurrences can only be attributable to birds which have escaped.]

[A Muscovy Duck (Cairina moschata, Linnæus), shot on the Blackshaw Bank in December, 1886, and preserved by William Hastings, was undoubtedly an "escape." This species is an inhabitant of Central and South America, and is commonly kept in captivity.]

\section{THE COMMON SHELD-DUCK.}

Tadorna cornuta (S. G. Gmelin).

Local names-Sheildrake ; StockanNet ; Stockgander ; SCALEDUCK.

\section{A common resident on our coast.}

In autumn Sheld-Ducks gather together into flocks, and our locally-bred birds emigrate south, their places being taken by others from further west and north. But, in some seasons, as in 1908-1909, the Sheld-Duck is comparatively scarce from November to January. The wintermigration of this species from the Continent to the east coast of Great Britain is not appreciably felt here. In very severe winters they sometimes occur inland, and Mr. Tom

* Dumfries Courier, December 8th, 1829. 
Crosbie tells me he remembers seeing Sheld-Duck on the lochs at Dabton and Kirkbog in 1878-1879. Mr. Hugh Mackay informs me that they did not suffer during the frost of 1894-1895. He adds:- "Those brought me to stuff were all in good condition, and contained minute shells, blunt bubble shell (Cylichna obtusa), small cockle (Cardium edule), porcelain tellina (Tellina tenuis), and the laver spire (Rissoa ulvoe)."

Under the County Council " order " of 1908 (see Introduction) the Sheld-Duck was protected for the three following years throughout the whole year, in the counties of Dumfries, Kirkcudbright and Wigtown, a step taken to preserve this species from the ruthless slaughter by holiday trippers. As an article of food the Sheld-Duck is not generally considered as of any value, and very little hardship can be caused to those engaged in the wild-fowling trade by the protection of this species, which, it is satisfactory to record, is increasing annually.

In early spring Sheld-Duck are seen in pairs about their nesting-places. The nest is made in a rabbit-burrow from a few feet to four or five yards from the entrance, and though usually near the sea-shore, it is sometimes found many miles inland, being occasionally made in a covert of furze or brambles. Mr. R. Service has remarked that nests are now more often found in inland localities than formerly*; and Mr. W. Coupland writes me that he has frequently found this species nesting near Carnsalloch (Kirkmahoe). Young Sheld-Ducks that have been brought out inland are led by their parent to the nearest stream, and so down to the sea. $\dagger$ H. A. Macpherson has already recorded the attractions that the sandy banks of the River Sark possess for this species at this season, $\dagger$ and in July, 1908, I had the pleasure of seeing a pair at close quarters there.

Sir William Jardine writes in 1843 of the "Sheildrake" as a local bird, and says: "When half-fledged they are

* Trans. Edin. Field Nat. Soc., 1904-1905, Vol. V., Part III., p. 183.

† Fauna of Lakeland, 1892, p. 265. 
seldom found far away from water, though we have once or twice come upon them on the flat sands of the Solway, more than half-a-mile from the sea or any stream; but notwithstanding, a single specimen was all that could be obtained, from the brood scattering, and making use of every little pool as a cover by diving, which in an extremity of this kind .they do most actively."*

The young of the Sheld-Duck are often taken and reared by the fishermen; but away from the sea-shore, deprived of their natural food, they do not seem to thrive, nor do they breed readily in confinement. Sir Richard Graham, of Netherby (Cumberland), writes me, however, in 1908 :- "I have got about fifteen pairs of SheldDuck to nest here full-winged. I have bred several drakes, but no ducks, between a Sheld-Drake and WildDuck female."

[A Ruddy SHeld-Duck (Tadorna casarca (Linnæus)), shot in the Solway in the summer of 1888 and sent to William Hastings for preservation $\dagger$ was obtained at the mouth of the Nith and proved on examination to be a "clipped-wing" which had probably escaped from Auchencairn (Kirkcudbrightshire). The flocks of Ruddy Sheld-ducks, undoubted immigrants, seen on the Solway in June and July, 1892, were recorded from the Cumberland side, and though some may have crossed over to our coast, I am not aware of any having done so.

This bird is a native of northern Africa, and southeastern Europe, extending across the elevated districts of Asia as far as Japan and China. It is often kept in collections of ornamental wild-fowl, and many records of its occurrence in Great Britain are regarded as due to " escapes."]

* Nat. Lib., 1843, Vol. XIV., p. 102.

$\dagger$ Trans. D. and G. Nat. Hist. Soc., February 1st, 1889.

$\ddagger$ Man. Brit. Birds, 1899, p. 421. 


\section{THE MALLARD. Anas boscas, Linnæus.}

Local names-FLAPPER (of the young) ; Mire-DUCK ; MossDUCK ; Grey DuCK ; Wild DuCK.

\section{". . The wild ducks oft, \\ With short quick pinions, and long necks stretched out, Sped o'er our valley to the plashy springs \\ That never freeze."}

ThоMAS ATRD.— "A Winter's Day." A common resident, whose numbers are increased in winter by immigrants
from the Continent and the north.

The extensive drainage of what were formerly haunts of the Mallard has deprived this species of many favourite resorts ; but at the present day the fashion of hand-rearing these birds for sport must tend to increase our resident stock. The references in both the Statistical Accounts of Scotland show the Wild Duck to have been generally distributed throughout the county, and in severe winters great numbers were seen in such places as the Lochar Moss and the Lochmaben lakes.

In a collection of local verse entitled the Nithsdale Minstrel, published in 1815, we find :

"For the wild duck spread the artful snare"-

a reference to a practice which I have not personally met with though I am told that on the shores of the Solway ordinary "figure of four" rabbit-traps are set in "plashy" spots frequented by duck; and that also lines and hooks baited with slugs or worms and attached to a stout peg are still used for taking wild-fowl, in spite of the "Wild Birds Protection Act, 1908."

A most remarkable story appears in the Dumfries and Galloway Courier in 1818. A farmer in Annandale took a setting of Wild Duck's eggs, twelve in number, and hatched them successfully under a hen. The brood all left their stepmother with the exception of one duck, 
which continued to fly about the pond, and acted as a decoy to many drakes which were shot. When about four years old she was given to a friend in Fifeshire, but after a night and a day's confinement, she escaped and in the course of a few hours was among her old companions in Annandale. She was caught and sent back, and her wings were clipped, but later, the feathers growing again, she again took wing one day, and was shot en route " in the neighbourhood of Biggar by a gentleman who communicated the circumstance to the owner with the collar which was found about the neck with his name and place of abode."*

In autumn and winter a considerable accession to the number of our residents is caused by the immigration of Mallard from the Continent; these birds are thought to be smaller and somewhat darker. When migrating this species at times travels at a great height. On September 12th, 1902, Mr. R. Service, while using a powerful 8-inch reflecting telescope, suddenly saw at 9.11 p.m. against the disc of the moon, nine or ten Wild Ducks pass SSW. by $\mathrm{S}$. He calculated that these birds were some five miles off, and about three thousand feet up. $\dagger$

In severe winters Mallard become much tamer, and are forced to frequent any open ditches or springs where they can still find a sufficiency of food.

The nest of the Wild Duck is usually on the ground, and often on the moors far from any piece of water. Occasionally it is found in such situations as to make it problematical how the young are got safely to the ground. Dr. Anstruther Davidson recorded that a certain nesting-site in Upper Nithsdale which was annually resorted to, was on an overhanging ledge some twenty feet above the bed of the River Nith, whence the duck had to either carry her ducklings or drop them over into the water.

* Dumfries Courier, March 3rd, 1818.

$\dagger$ Ann. Scot. Nat. Hist., 1903, p. 50.

† Trans. D. and G. Nat. Hist. Soc., November 10th, 1888. 
A Wild Duck's nest in 1844 is recorded as on a horizontal branch of a tree eighteen feet above the River Cluden.* Richard Bell discovered a nest with nine eggs "in May, 1861, amongst the small branches of a thorn tree, at eleven feet from the ground and about forty yards from the River Esk, on the farm of Billholm (Westerkirk). The nest was compactly built of birch twigs, and lined with down, and was apparently the work of the bird itself and not the old one of any other kind." $\dagger$ The old nests of CarrionCrows or Wood-Pigeons are occasionally utilized, and doubtless such a nest formed the foundation of the one described.

Light is thrown upon the problem of how the ducklings reach the ground from such elevated situations, by the following note by Mr. R. Service : "At Raehills to-day (July 16th, 1887) a keeper showed me a wild duck's nest from which a few days ago a second brood of young had fledged. The nest was about twelve feet up in a cleft of an ivy-covered ash tree, and the old duck the keeper asserted was seen to bring the young down on her back to the pond at the tree foot." $\ddagger$ Mrs. Pollock writes me that her mother, Mrs. Leny, was witness to a somewhat similar performance at Dalswinton in the early fifties. Other observers have stated that the ducklings simply throw themselves to the ground from such nesting-sites and are seldom injured by the fall.

The extensive hand-rearing of Mallard, in which there is (unintentionally or not) a strong strain of the domestic duck, is probably the cause of the almost perennial records of finding nests with eggs. A Wild Duck was found sitting on thirteen eggs at Duncow (Kirkmahoe) on December 23rd, 1907, and similar abnormal dates are constantly reported.

Mr. J. J. Armistead has stated that at his fish-hatchery at Newabbey (Kirkcudbrightshire) he was compelled to give up keeping ducks owing to the injury they did to the fish. "Besides taking young trout they eat a great quantity

* Dumfries Courier, May 6th, 1844.

$\dagger$ Proc. Roy. Phys. Soc. Edin., 1862, Vol. II., pp. 420, 421.

‡ R. Service, MS. Diary, July 16th, 1887. 
of trout food, in the shape of mollusca and crustaceans."* Anyone who has reared young Mallard knows how voracious these birds are, and should this practice of artificial rearing become more general, it is quite possible that ere long serious harm may be done to corn-crops. In the autumn of 1907, when the "stooks" remained standing out so long, I knew of a cornfield near a small loch where some two hundred ducks dwelt, which was nightly invaded and much damaged by them.

During $1887 \mathrm{Mr}$. R. Service notes in his MS. Diary, three peculiarly-plumaged birds of this species, as follows : "W. Maxwell tells me that a white Mallard was shot at the beginning of April on Queensberry. It had often been seen during the winter; bill and legs were normal, but the whole plumage purest white, and said to have been extremely beautiful. Was plucked, cooked and eaten." "A splendid variety of Mallard shewn me by R. McMurdo. It was shot on Ellisland (Dunscore). Underparts nearly canary yellow, feet and legs red, bill reddish yellow, eyes normal and tail curled as usual." "Variety of a Wild Duck (female) from Elshieshields (Lochmaben), primaries, belly, and broad ring round neck pure white, the remainder normal." On September 17th, 1897, I myself saw a pure white specimen in company with a flock of Mallard on the Far Loch at Capenoch; but nowadays with so many semi-wild duck artificially reared in the district, such varieties lose any interest they may once have commanded.

THE GADWALL. Anas strepera, Linnæus.

Has occurred twice.

The Rev. W. McDowall writes me that he saw a Gadwall

"shot by Donald Gillespie, gamekeeper at Dalswinton, in

* Zoologist, 1888, p. 269. 
winter about 1896 or 1898 . I identified it from the plate in A. Fritsch, Birds of Europe, Tab. 49, Fig. 8. It was not preserved." Mr. R. Service informs me that a fine female, taken at the mouth of the Nith by Mr. Charles Turner, gamedealer, Dumfries, on February 3rd, 1900, passed into his possession.

Sir Richard Graham, of Netherby, Cumberland, informs me (1908) that he has reared a few Gadwall there each year since 1903 ; these birds being kept in a semi-wild state so near our border, may occur any day in this county. Sir Richard also tells me that he has bred a number of hybrids between a female Gadwall and a Wigeon male, and the knowledge of this fact may at some future date be useful to the ornithologist called upon to identify some strange-plumaged duck from the Solway shores.

The Gadwall may briefly be said to breed in central and eastern Europe, central Asia, and North America, migrating south in winter. The descendants of a pair turned down at Narford Hall, Norfolk, about 1850 by the Rev. John Fountaine, have multiplied and attracted others of their kind to this locality where the Gadwall now nests, as well as in a few places in the midland counties of England. Elsewhere in Great Britain the species can only be considered a comparatively rare visitor, though its breedingrange is known to be extending, and it nested in Peeblesshire in 1906, and in south-east Scotland in 1909.

\section{THE SHOVELER. Spatula clypeata (Linnæus).}

Local name-HaRvest-TeAL.

A very local and scarce autumn and winter-visitor, but has probably bred very occasionally.

Sir William Jardine wrote of this species in 1843 : "In Scotland we have never ourselves met with it living, but have generally seen one or two specimens, during the winter 
and spring, among the Edinburgh poulterers."* Robert Gray records that several were killed on the Nith in Dumfriesshire, in 1850 and 1851, and were preserved by William Hastings, bird-stuffer, of Dumfries. $\dagger$ The following appeared in the Dumfries and Galloway Courier of April 28th, 1857: "Mr. Hastings has at present a fine specimen of the Shoveller Duck, rare in this district, which he is stuffing for Mr. Shaw of Drumlanrig." A "Blue-winged Shovel-bill female" is reported as obtained in the Dumfries district on January 28th, 1858. $\ddagger$

A young female Shoveler was shot at the beginning of August, 1879, in Kirkmahoe, and brought for preservation to William Hastings, who remarks: "This is a most unusual time for the Shoveller to be met with here, and as it was a young bird I believe it must have been bred in the locality."§ Mr. R. Service tells me that he handled this specimen, and quite confirms William Hastings' opinion.

In the autumn of 1884 another was obtained locally $\|$; this bird was a female. Mr. J. Harkness writes me: "I have one shot by J. Phillips on January 1st, 1885, on Blackshaw Bank. There was one shot at Dormont on February 26th, 1886, a fine drake ;" and Mr. Hugh Mackay records: "On 19th November, 1893, Mr. Hume, gunsmith, brought me a fine female specimen of the Shoveller-Duck which had been sent him from the parish of Caerlaverock. This species is chiefly a winter visitor, although a few remain with us all the year round." A female Shoveler, shot near Kirkmahoe, is recorded in the Transactions of the Dumfriesshire and Galloway Natural History and Antiquarian Society for 1894.** Mr. J. Davidson writes me that during his

* Nat. Lib., 1843, Vol. XIV., p. 127.

$\dagger$ Birds of West Scotland, 1871, p. 364.

$\ddagger$ Naturalist, 1858, Vol. VIII., p. 117.

§ Trans. D. and G. Nat. Hist. Soc., December 5th, 1879.

\| Op. cit., November 7th, 1884.

If Op. cit., April 20th, 1894.

** Op. cit., February 16th, 1894. 
tenancy (1896-1898) of Dalswinton (Kirkmahoe) he had seen Shovelers on the loch on one or more occasions, and he thinks that he once shot one. In March, 1902, two males remained on Morton Loch for a fortnight. An adult female was shot near Gretna on February 26th, 1903*; but possibly this specimen may have been obtained in Cumberland and not within the limits of our county. Mr. Myles Quinn writes me that he shot two young birds (male and female) on North Kirkblain meadow (Caerlaverock) about the last week of August, 1907 ; and Mr. T. Ranken informs me that he shot a female Shoveler at Dalswinton Loch in November, 1907, and saw another which was not obtained. Mr. Norman Maclachlan saw a female flying down the River Nith near Carnsalloch on December 30th, 1907. The Rev. W. McDowall states (in litt.) that he once saw a bird of this species in winter on Duncow Loch (Kirkmahoe) and Mr. George Underwood tells me that Shovelers are occasionally seen on the lochs at Lochmaben in winter. A Shoveler was shot near Ruthwell in October, 1908, by Mr. Sholto Douglas. A male was seen on Dalswinton Loch on April 4th, 1909, but no female or nest was discovered, and it disappeared four days later.

Mr. P. Coleman assures me that he found a Shoveler's nest by the River Cairn on Coatstown Farm (Glencairn) in the spring of 1899 or 1900 . Having spent the earlier part of his life in Ireland in a locality where I know this species breeds, I consider his statement may be accepted. Sir Richard Graham, of Netherby (Cumberland), writes me in 1908: "Since 1905 I have reared about twenty Shovelers each year. I have now got Shovelers to breed here fullwinged"; and it is to be hoped that, as a natural consequence of this success, their offspring will extend the breeding-range of the species.

It will have been observed that the majority of the above records hail from Lower Nithsdale, and many of them refer

* Tullie House Museum Registers. 
to specimens obtained in August; there is one record of a female Shoveler identified by two competent authorities as a bird of the year; and the reported discovery of a nest on the Cairn in 1899 or 1900 is made by a man well acquainted with the species; all this points to a justifiable presumption that the Shoveler has occasionally bred in this locality. This presumption is, moreover, strengthened by the fact that the species has been recorded as nesting in Kirkcudbrightshire, Roxburghshire, and in Cumberland in the neighbourhood of the Solway.

The range covered by the Shoveler in its summer-and winter-quarters is hardly exceeded by that of any other duck, and for all practical purposes it may be called cosmopolitan. As regards Great Britain, its breeding-range is believed to be extending, and it nests locally in Scotland, Ireland, and England, but principally in the eastern counties of the latter. In autumn and winter the continental immigrants, which appear on the eastern coasts of Great Britain, may occasionally wander as far as our county.

\section{THE PINTAIL. Dafila acuta (Linnæus).}

\section{An irregular winter-visitant to the Solway in small numbers.}

Writing in 1832 of the birds of the parish of Applegarth and Sibbaldbie, Sir William Jardine states that the Pintail is found there but seldom.* Some eleven years later, he writes: "In the south of Scotland a few specimens have occurred to us every winter, and we once shot a pair in immature dress in the month of September feeding at dusk on some wet stubble, in company with the Mallard and common Teal." $\dagger$ In a letter dated March 10th, 1842, from Drumlanrig, John Shaw wrote to Sir William Jardine

* New Stat. Acct. Scot., Vol. IV., p. 181.

† Nat. Lib., 1843, Vol. XIV., p. 120. 
that the Pintail had been pretty numerous there that season. In the severe winter of 1878-1879 several Pintail were observed, and one obtained locally was brought to William Hastings of Dumfries for preservation.* This species was more than usually plentiful in 1891-1892, and H. A. Macpherson mentions $\uparrow$ that he received on Christmas Eve, 1891, a singularly handsome pair of Pintails from Mr. W. Nichol, who shot them on the Solway, off the Dornock foreshore. In the winter of 1896-1897 Pintail were observed on the Solway, and a male is reported as seen on Auchencrieff Loch (Dumfries) on September 18th, 1903.

Mr. Richard H. W. Leach, then tenant of the Moodlaw shootings (Eskdalemuir) wrote in 1905 to Richard Bell : "John Cartner shot a young female Pintail when out with me on October 19th, 1905." Mr. William Wright informs me that in December, 1905, he saw a male on the lower Annan. It appeared to him to be wounded, and was subsequently shot and eaten. He had some years previously seen another bird of this species in the same locality. I hear from Mr. J. W. T. Corbett that he has twice seen Pintail on a pond near Springkell (Kirkpatrick-Fleming) in winter; he adds: "When in the water they appear to rise at times with a fairly jerky motion, uttering a whistling sound." Pintail were reported as frequently seen on the Caerlaverock shores in the autumn of 1909, and a young male was shot on January 27th, and another on February 1st, 1910.

I hear from Sir Richard Graham that since 1903 he has reared about thirty Pintail annually at Netherby (Cumberland), and that in 1908 some bred there full-winged. This fact will, no doubt, in the near future swell the numbers of our records. Indeed, during the winter of 1908-1909, when this species "was rather frequent in the Solway waters," $§$

* Proc. Nat. Hist. Soc. Glasg., 1880, Vol. IV., p. 320.

$\dagger$ Fauna of Lakeland, 1892, p. 278.

$\ddagger$ Ann. Scot. Nat. Hist., 1904, p. 212.

\& Op. cit., 1909, p. 184. 
a female, bearing a ring which proved that it had been marked at Netherby,* in the spring of 1908 , was shot about February 17th, 1909, in the estuary of the Nith.

Possibly off-shoots from this, so to speak, " acclimatized stock" may soon be found nesting within the limits of our county. The Pintail has of recent years nested on Loch Leven, and is believed to be extending its breeding-range. Throughout northern Europe it nests abundantly, migrating southwards in winter.

In a wild state the Pintail has been known to hybridise with the Mallard, and Sir William Jardine in 1843 writes : "We have seen a hybrid between it and the mallard purchased from a poulterer in Dumfries, who procured it in a wild state; this bird is now in the collection of W. T. Carruthers, Esq., of Dormont. It combined the resemblance of the form and plumage of the pintail, but with a few minor differences; the curled feathers of the tail were completely developed, as much so as in an adult mallard." $\dagger$ I have been unable to ascertain whether this was a Dumfriesshire bird or not, and Major F. J. Carruthers, of Dormont, writes me that he knows nothing whatever about the specimen.

\section{THE TEAL. Nettion crecca (Linnæus).}

Local name-JAY-TeAL.

A common resident, whose numbers are increased by immigrants in autumn and winter.

Both the Statistical Accounts of Scotland contain many local references to the abundance of Teal; Lochar Moss and the Castle and Hightae Lochs (Lochmaben), being especially mentioned. The drainage of many of its

* Ann. Scot. Nat. Hist., 1909, p. 247.

† Nat. Lib., 1843, Vol. XIV., p. 121. 
former favourite haunts has undoubtedly had a diminishing effect on the number of these birds, as Sir William Jardine points out in 1843.*

The Teal, however, is still a common bird in the county and when the lochs are frozen over it is often flushed from an open drain or ditch. Its nest is occasionally found, and the presence of young broods on our various lochs in summer testifies to the fact that this species breeds with us fairly abundantly. In winter a considerable immigration takes place, and at this season our home-bred birds probably migrate farther south.

A nest I knew of at the Far Loch (Keir), in May, 1905, contained seven eggs, which were taken and hatched under a fowl. Twenty-eight days were required for incubation, and four young were reared successfully. Sir Richard Graham, of Netherby (Cumberland), wrote me in 1908 that Teal now breed there full-winged. In his opinion they do best of all the ducks. In 1908 he caught 1,133, and many of these he marked on the leg with a ring stamped with the date. On September 28th, 1908, one which had been caught-up at Netherby in August of the same year, was shot on Lough Derg, in Ireland. $\dagger$

The Teal nests in northern Europe and Asia, migrating south in winter, when it is found all over the Continent, in northern Africa, Egypt, India, etc., and at this season great numbers of migrants are observed on the eastern coasts of Great Britain.

[The North American Summer Duck (Ä̈x sponsa, Gray), an inhabitant of North America, as its name implies, is frequently kept on ornamental waters in Great Britain, and breeds freely. Mr. George Russell writes me that he shot one of these birds in the autumn of 1905 on the Water of E, near Shieldhill (Tinwald). "It was with some Mallard, and although it had been pinioned, it could fly fairly well."]

* Nat. Lib., 1843, Vol. XIV., p. 113.

$\dagger$ Field, 1908, Vol. CXII., p. 745. 


\section{THE AMERICAN BLUE-WINGED TEAL. Querquedula discors (Linnæus).}

\section{Once recorded.}

Only two records of the occurrence in Europe of the American Blue-winged Teal are mentioned by Howard Saunders in his Manual of British Birds, 1899 ; one, an adult male shot near Säby, in Denmark, about the middle of April, 1886, and the other obtained in Dumfriesshire in 1858. Another example has since been recorded as having been obtained in Cheshire. It was shot about the middle of the last century on the Dee estuary, and is considered by Messrs. Coward and Oldham to have been a genuine visitor from America.*

Howard Saunders thus refers to the Dumfriesshire specimen: "In the Naturalist, VIII. (1858), p. 168, Mr. W. G. Gibson, writing from Dumfries, says, without naming any month : ' a specimen of the Blue-winged Teal (Anas discors) was shot here a few weeks ago.' This bird, erroneously stated by the late Robert Gray to have been killed in January, 1863, afterwards passed into the collection of the late Sir William Jardine, and was subsequently acquired by the Edinburgh Museum ; it is a male and undoubtedly genuine." $\dagger$

It may be well here to quote Robert Gray's reference in extenso: "A specimen of this North American Teal was shot by the late Mr. Shaw, of Drumlanrig, on the Nith, in Dumfriesshire, in January, 1863. Sir William Jardine, in whose collection the bird is now preserved, informs me that he happened to be at Drumlanrig, and called to see Mr. Shaw, shortly before his death, when he was told by him that he had shot the Duck and sent it to William Hastings,

* Vert. Fauna Cheshire, Vol. I., p. 332.

$\dagger$ Man. Brit. Birds, 1899, p. 434. 



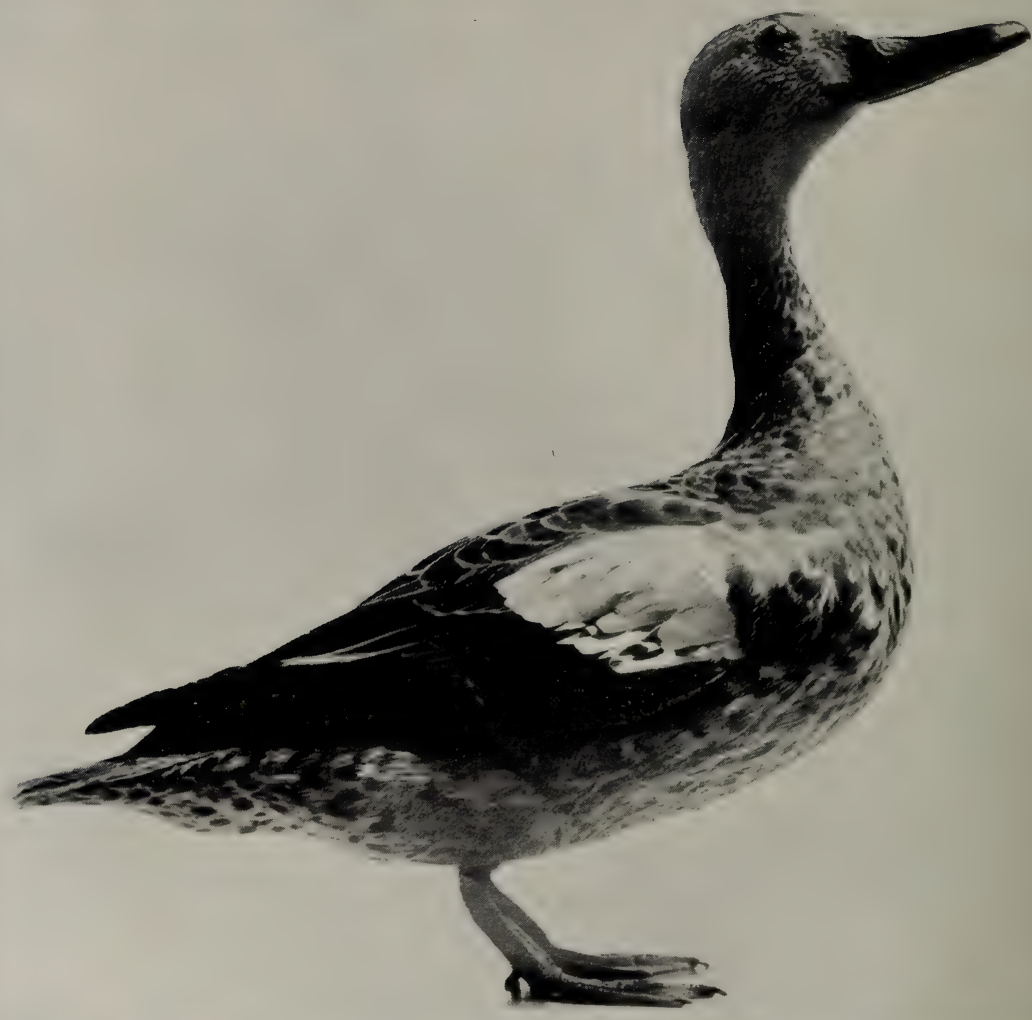

THE AMERICAN BLUE-WINGED TEAL (Querquedula discors), OBTAINED IN UPPER NITHSDALE IN 1858, AND NOW IN THE ROYAL SCOTTISH MUSEUM, EDINBURGH. 
birdstuffer, Dumfries. 'On returning home,' writes Sir William, 'I went to William Hastings, and got the bird from him, and it is now before me." "* The date, 1863, is unquestionably erroneous, for W. G. Gibson's record was published in the June number of the Naturalist, 1858 ; and from the context it might be argued that the specimen was obtained in May of that year.

The bird, as stated above, was stuffed by William Hastings, who subsequently parted with it to Sir William Jardine. Thence it passed into the Edinburgh Museum, and later into the Royal Scottish Museum, Edinburgh, where it may now be seen; and to the kindness of the authorities of this museum I am indebted for the photograph (reproduced in the accompanying plate) of this famous specimen.

Local inquiries at this late date (1909) have failed to add any important details to its history. Mr. J. Reid tells me that he distinctly remembers seeing the bird in a recently stuffed state in Hastings' shop in 1858, and that he personally satisfied himself as to its identification by reference at the time to the description of the species in Wilson's American Ornithology. He cannot now remember any story regarding the specimen; but Mr. R. Service has a distinct recollection of being told by Hastings that it was sent to him by John Shaw, the head-gamekeeper at Drumlanrig, with a note saying it was a Bluewinged Teal, which he had shot as it rose from a burn flowing into the Nith at a spot with which Hastings was well acquainted, as he had in former years been an undergardener at Drumlanrig.

The authenticity of this occurrence has been so generally accepted, that it seems almost unfair at this late date to bring forward anything which might cast any doubt upon it ; but it must be remarked that in none of his writings, published or unpublished, does Sir William Jardine (as far as I know) refer to it, except in the letter to Robert Gray above quoted. This seems a remarkable omission, although it would

* Birds of West Scotland, pp. 373, 374. 
certainly seem equally strange that Sir William Jardine did not publish a criticism of the record, supposing he had afterwards discovered that it was not genuine. I have seen the correspondence on the subject which passed between Mr. R. Service and Howard Saunders early in 1885, and it seems to me only fair to note that in one of his letters Mr. Service points out that in 1858 Shaw introduced Virginian Quail at Drumlanrig, and he asks: "Did Q. discors make the journey along with the Bob-whites?"* Mr. Service had, however, no proof that this was the case, and at the time of this correspondence Shaw and Jardine were both dead, Hastings was too old to be reliable; and, it is stated, W. G. Gibson was no naturalist. $\dagger$ Probably Howard Saunders had good reasons for ignoring Mr. Service's question, and for so strongly affirming the genuineness of the specimen.

The allegations that this species has occurred in Yorkshire and in Cambridgeshire have been rejected after full inquiry; and as regards the Danish specimen, Herr Herluf Winge most courteously writes me from Copenhagen : "To-day (January 22nd, 1909) I have again examined our stuffed specimen of Anas (Querquedula discors) from Säby, April, 1886. As stated by my late brother, the left foot is a little deformed, the inner toe being swollen and contorted, and the hind-toe without a claw; otherwise the specimen is in quite perfect condition. Damage such as this is frequently to be seen in frost-bitten birds in our Zoological Garden, but it may also occur in wild birds. Certainly I have included the species in my list of Danish birds, . . . but I confess that I have been somewhat influenced by the Ibis list and other publications taking the recorded European specimens for valid, and I admit that a doubt always will cling about the Danish record."

This species, an inhabitant of eastern North America, migrates in winter as far south as the West Indies, Mexico and Guatemala.

* R. Service, in litt. to Howard Saunders, February 23rd, 1885.

$\dagger$ Id., February 18th, 1885. 
[THE GARGANEY. Querquedula circia (Linnæus).

A male of this species is said to have been shot by the gamekeeper at Kirkmichael House on December 1st, 1878.* I have not been able to trace this specimen, and am told that it was cooked and eaten! Mr. R. Service notes in his diary that William Hastings told him that in the course of his business (1860-1885) he had seen several Garganeys that had been shot in the Lochar Moss. $\dagger$

This being all the evidence that $I$ have as regards this species in Dumfriesshire, I do not feel justified in including it otherwise than in "square brackets." William Hastings was an experienced bird-stuffer, but his statement is too vague to be acknowledged as fact; and the date of the alleged occurrence at Kirkmichael is so extraordinary as to lead me to suspect an error in identification.

Sir Richard Graham writes me from Netherby (Cumberland) that in 1908 he commenced to breed Garganey there, so that, if successful, the effect of this experiment may be felt in our county.

The Garganey is a very local early spring-visitor to the east coast of England, where it breeds sparingly. Throughout the central and eastern portions of Europe and parts of Asia it is found nesting in summer; and on its wintermigration it extends to south Europe, northern and eastern Africa, and is very plentiful in India.]

\section{THE WIGEON. Mareca penelope (Linnæus).}

\section{A common autumn and winter-visitant.}

Sir William Jardine, writing of the birds of the parish of Applegarth and Sibbaldbie in 1832, says that the Wigeon

* Proc. Nat. Hist. Soc. Glasg., 1879, Vol. IV., p. 182.

† R. Service, MS. Diary, March 13th, 1886. 
is " found here,"* and in 1843 he writes of it as a " winter bird of passage in the south of Scotland." $\dagger$

Mr. John Corrie in 1888 describes this species as a wintervisitor to Glencairn, and adds : "I am told some few birds remain throughout the breeding season, but I have been unable to authenticate this." $\ddagger$ "Mabie Moss" writes in 1908: "The Wigeon has not yet been detected breeding in Dumfriesshire, but such an occurrence may take place any season now."§ The statements that it has already done so \| lack confirmation; and I am requested by Mr. Heatley Noble not to include. it in my list as a nesting-species on his authority.

I am informed by Sir Richard Graham that since 1903 he has reared about thirty Wigeon annually at Netherby (Cumberland). They do next best to Teal, and in 1908 they bred there full-winged, so that we may soon profit by his success. Eggs of this species which were sent to me on more than one occasion from Fasque (Kincardineshire) took between twenty-four and twenty-five days to hatch under a fowl; the young birds were successfully reared, but disappeared as soon as they had attained their full powers of flight.

In 1902, I shot two Wigeon, a mature female and immature male, from a little pond known as the Bobie Loch near Capenoch on September 23rd. This date is rather an early one with us, for although Wigeon occasionally appear towards the end of September, the more usual month is October, when the main body arrives, and the birds are then in large flocks on the Solway. In winter, they occur annually on the Cairn, and the lower reaches of the Nith and Annan; but on the Esk they are scarce: on the lochs at Lochmaben, and on some of our larger

* New Stat. Acct. Scot., Vol. IV., p. 181.

$\dagger$ Nat. Lib., 1843, Vol. XIV., p. 131.

$\ddagger$ Trans. D. and G. Nat. Hist. Soc., November 10th, 1888.

§ Kirkcudbright Advertiser, May 5th, 1908.

II Brit. Birds (Mag.), Vol. II., p. 22; and Eggs Birds Eur., p. 564. 
pieces of water, they are frequently observed. In the first week of January, 1909, Wigeon were unusually abundant in the estuary of the Nith. In very hard weather they become tame ; and during the winter of 1878-1879 : "The Mallard, Teal, Wigeon and Pochard, . . . about the end of December and early in January could easily have been struck down with a stone as they sat about the shore in a weak almost helpless state from privation."* During their stay on our coast they move about from one locality to another, leaving those feeding-grounds when the grass grows old, for "pastures new." In March and April the return migration takes place; but the fact that in 1908 seven pairs were seen on a loch four miles from the Dumfriesshire boundary, so late as April 20th, leads one to hope that the Wigeon may soon qualify to be described as one of our nesting-species.

The Wigeon breeds in northern Europe and Asia, migrating south in winter. For many years it has been known to nest in the north of Scotland, and its breeding-range is extending southwards.

\section{THE POCHARD. Fuligula ferina (Linnæus).}

\section{A fairly regular winter-visitant to the Solway estuaries, and certain
suitable lochs.}

Of the Pochard Sir William Jardine writes in 1843: "We have once or twice shot this species, during winter, in the River Annan." $\dagger$ In the Catalogue of the Birds contained in the collection of Sir William Jardine, are recorded two specimens from Dumfriesshire, one from Castle Loch, Lochmaben, obtained by J. Gould ; the other from Hen Moss, Jardine Hall, shot by Sir William himself.

* Trans. D. and G. Nat. Hist. Soc., November 7th, 1879.

† Nat. Lib., 1843, Vol. XIV., p. 147. 
In the severe winter of 1878-1879 this species suffered greatly, and became very tame on our shores. Mr. Tom Crosbie tells me that during this hard weather he saw Pochards at Dabton Loch (Morton) and at Kirkbog (Closeburn). Mr. R. Armstrong writes me that he has seen them on Morton Mains Loch, and a male in my collection was obtained on the Far Loch near Capenoch in the 'eighties.

The Pochard arrives here in October, and departs in March or April; and though it is sometimes seen so late as May, it is not known to nest with us. In a letter to Mr. J. H. Gurney dated July 27th, 1891, H. A. Macpherson says: "I found the Pochard in Dumfriesshire lately, but only a single male, so whether breeding I do not know."

Sir Richard Graham tells me he commenced to breed Pochard at Netherby (Cumberland) in 1908, so that the status of this species in our county may be shortly expected to change, should Sir Richard's experiment prove successful.

The Pochard breeds very locally throughout Great Britain, and in parts of temperate Europe and Asia; in winter it migrates southwards to the Mediterranean, northern Africa, and parts of India, China and Japan, and it is at this season that the bird is a visitor, but irregular both as regards numbers and localities, to the British Isles.

THE TUFTED DUCK. Fuligula cristata (Leach).

Local names-Tufted Pochard; Golden-eyed Duck.

A fairly common resident, to whose numbers an accession occurs in winter.

Sir William Jardine, writing in 1843 , states: "The tufted duck is only a winter visitant to this country, . . . but not nearly in equal numbers with the scaup. On the Solway we have observed it in a much less proportion, and only in small parties together. Its describers consider it more lacustrine 
than the scaup, and we have frequently shot specimens on the Annan, during winter, fifteen or twenty miles from the sea ; the weather was always, however, severe when this bird appeared, seldom more than a pair were seen together, and they were far from being shy, trusting rather to falling down the river when danger appeared, and not attempting to fly unless surprised or approached very near."* In those days this species was regarded solely as a wintervisitant, but T. C. Heysham has a note of a "Tufted drake shot on the Solway on July 15th, 1838," $\dagger$ a remarkable date at that period, even though it probably does not refer to an occurrence within our boundary.

During the winter of 1878-1879, when all wild-fowl were greatly tamed by the severity of the weather, many Tufted Ducks were obtained; and I am informed by Mr. J. Harkness that about 1888 he shot several birds of this species near Hayberry Mill (Ruthwell). The Rev. W. McDowall writes me that he saw a Tufted Duck on Duncow Loch in the winter of 1890-1891, and Mr. Myles Quinn shot one in Lochar Moss in 1900 or 1901 . In winter the lower reaches of the Cairn, the Nith (as at Carnsalloch) and of the Annan, become the haunts of these birds, and Mr. Milne Home writes me that he believes the species occurs in Eskdale, while Mr. James Malcolm tells me that one was once shot at Eskside near Langholm. I have shot Tufted Duck at the Starn Loch (Penpont), and I have reliable information as to their appearance at Craigielands (Moffat) and Castle Milk (St. Mungo). Doubtless the species occurs elsewhere, but so loose is the application locally of the name "goldeneye" that many records have to be suppressed, as it is uncertain whether these refer to $F$. cristata or $C$. glaucion.

So far I have dealt with the local occurrences of the Tufted Duck in winter. From evidence at hand it is believed that it was in the spring of 1890 that the species nested for the first time in the county : this was at Loch-

* Nat. Lib., 1843, Vol. XIV., p. 143.

$\dagger$ H. A. Macpherson, Zoologist, 1887, pp. 385, 386. 
maben. In $1895 \mathrm{Mr}$. R. Service wrote to Mr. J. A. Harvie-Brown: "I cannot say it has actually bred in Dumfriesshire, but there can be little doubt that it has done so. This species is one of those that arrive and depart from here in a N.N.E. or E. direction." Mr. Service speaking in 1900 of its distribution in the Solway area, says : "Always well-known as a winter visitant, the Tufted Duck was first discovered breeding within our area by myself in 1887. Since then it has spread amazingly, and there is scarcely a loch in the three counties" (i.e., Wigtownshire, Kirkcudbrightshire, and Dumfriesshire) "but has a pair of them upon its surface in summer."*

Mr. J. Davidson writes me : "In 1898, one pair of Tufted Ducks bred on Dalswinton Loch. These probably breed commonly now, but up till then had not been known to do so." I am informed by Mr. T. Ranken that they now nest in this locality every year, and that there were four or five pairs on the Loch in April, 1908. "It is getting to be a very common duck inland," he says, "but most people still call it the Goldeneye. There are three pairs nesting here this year" (1909). Dr. J. W. Martin says in 1901 that they are fairly often seen in Glencairn, and that "one year a pair remained on the Cairn for some time in May." $\dagger$ I am told by Mr. W. Coupland that a pair nested on the railway embankment half a mile south of Holywood Station in 1905 , and in 1906 ; the following year this species bred at Auchencrieff Loch, and in 1908 it was again observed in that neighbourhood. Tufted Duck have been seen annually in spring on Newtonairds Loch (Holywood), practically ever since its reconstruction in 1905 ; but no nest has yet been discovered. Mr. P. Jeffreys writes me that a pair nested at Friar's Carse Loch (Dunscore) in 1908, and the same year a couple were noticed at Morton Loch in May, and I saw a pair on Loch Urr towards the middle of that month. On the lochs at Lochmaben this species continues

* Trans. D. and G. Nat. Hist. Soc., November 16th, 1900.

$\dagger$ Op. cit., December 13th, 1901. 



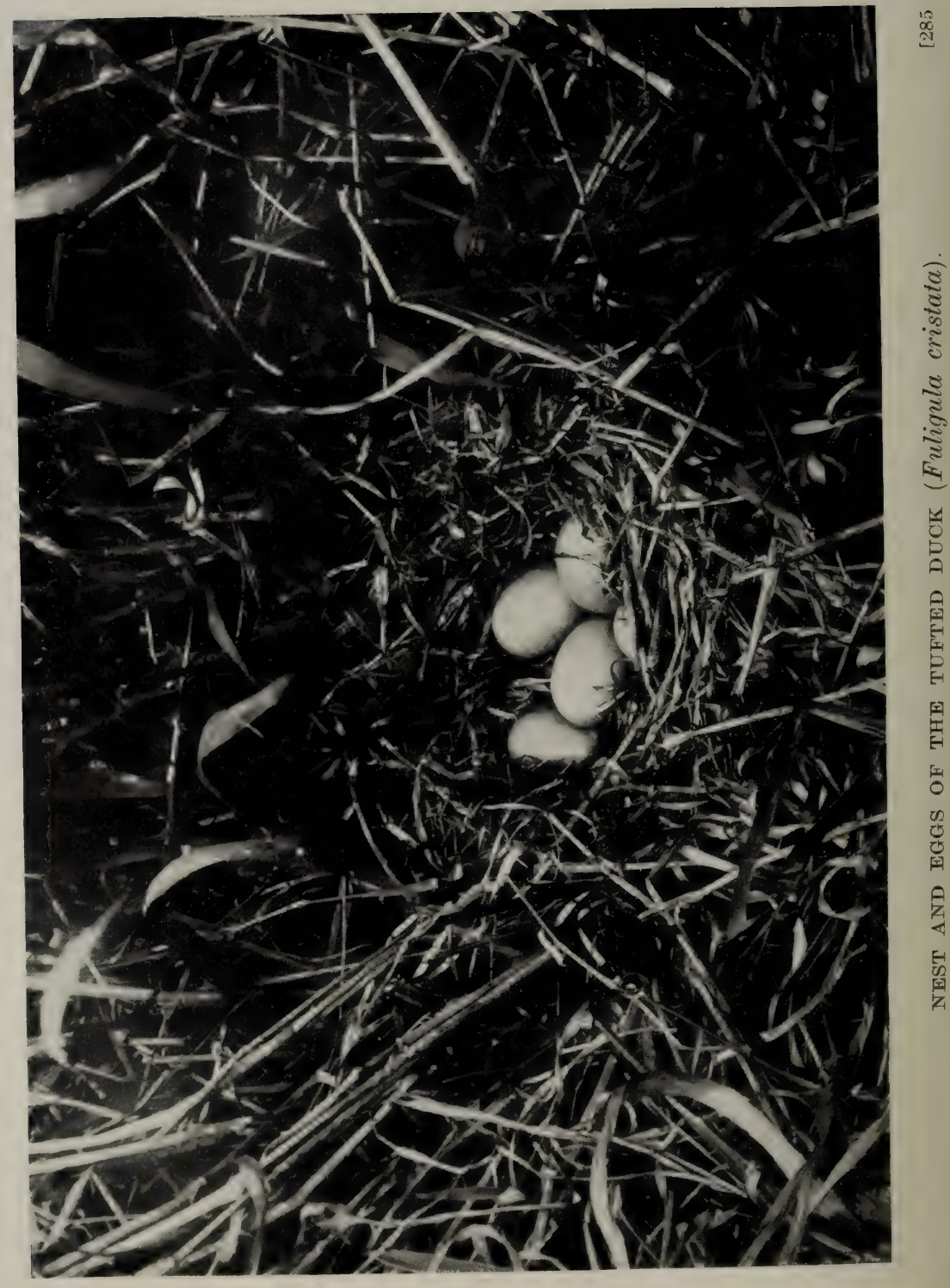


to breed annually, and there are doubtless many other lakes throughout the county where the Tufted Duck nests undetected.

The experiments in breeding various wild-fowl at Netherby, to which reference has already been made, extend to this species, and Sir Richard Graham writes me that he began to rear Tufted Duck there in 1908. Such experiments are bound to influence the status of the birds in the immediate vicinity.

The photograph of the nest and eggs of this species reproduced in the accompanying plate is by Mr. D. Legard.

The Tufted Duck nests but locally throughout Great Britain. It is found in summer in suitable localities in temperate Europe and northern Asia; and in winter, over the rest of Europe, in Africa as far as Abyssinia, India, Japan, China, etc. Between autumn and spring the numbers of residents in the British Isles are increased by continental migrants.

\section{THE SCAUP-DUCK. Fuligula marila (Linnæus).}

Local names-Scadp-Pochard; Musset-Teal; BlueBILL.

\section{A common winter-visitant to the Solway Firth.}

This species is seldom seen on inland waters, but it is plentiful off the coast from November until April, while occasional examples are to be seen throughout the summer.

Sir William Jardine in $\mathbf{1 8 4 3}$ writes of the "Scaup Pochard": "It arrives about the end of October and continues with us till spring, frequenting the lower lying coasts of a soft or muddy character, and feeding on the smaller bivalves, which are generally found there in abundance. We have seen this duck only on the sea, perhaps entering the mouth or estuary 
of some stream ; but we have not observed it, during winter, to frequent fresh waters, either in the vicinity or at a distance from the shore. It is a shy and wary bird, assembling in flocks and feeding together; at the same time, with a stormy wind, we have sometimes openly got within shot, while feeding in the mouths of the muddy creeks, with which the shores of the Solway Firth are in many parts intersected." * In the Catalogue of the Birds contained in the collection of Sir William Jardine is recorded a specimen from the Solway. Thomas Maxwell, of Allanton Mill, told Dr. Grierson in 1862, that a female Scaup was once obtained on the River Nith near Barndennoch (Keir). "It was given to the late Mr. Johnston, bookseller in Dumfries, and was the only specimen ever known in the district." $\dagger$ This locality is some fourteen miles from the sea, and as has been stated, this species is but seldom found inland. The Scaup is recorded as "an occasional winter-visitant" to the Cairn, $\ddagger$ but I suspect an error in identification here. Miss Dorothea M. A. Bate writes me that a young bird was shot by Major H. R. Bate on Kirtle Bridge curling-pond on December 22nd, 1905. This pond is about six miles inland, and the specimen obtained was one of a small party.

During the winter of 1879-1880 Scaup-Duck were unusually numerous on the Solway Firth. A flock of many thousands was to be seen shifting about with the ebb and flow of the tide in search of food. So poor did they become in condition that the local dealers would not take them at any price. Mr. Wilson H. Armistead, who has spent many years in ornithological observations on the Kirkcudbrightshire coast says : "Once I came across a flock in the channel between Barnhourie Bank and the Mersehead Sands, and stepped out the distance from end to end of the flock in a parallel line along the shore. This was done carefully, taking bearings which told me when I was exactly opposite

* Nat. Lib., 1843, Vol. XIV., p. 139.

† Grierson's MS. Notes, October 17th, 1862.

‡ Trans. D. and G. Nat. Hist. Soc., December 13th, 1901. 
each end, and I found that one flock was over a mile and a quarter long! It varied from sixty to one hundred yards in width, and the birds were closely packed. Moreover, only half the flock could be seen at one time."* Though this observation was not made within the actual limits of the county, it is here quoted to show in what immense quantities the Scaup-Duck visits the Solway Firth. Mr. J. Harkness writes me from Ruthwell in 1908 that he considers this species "scarcer than formerly"; but out in the open Firth large flocks of Scaup are still annually seen, though it is only in wild stormy weather that they are driven in to our coast.

Within recent years the Scaup-Duck has been discovered nesting in Sutherlandshire and the Outer Hebrides, and its breeding-range will, it is hoped, extend. It nests in the far north of Europe, and in Siberia as far as Bering Island, migrating southwards to the countries of the eastern Mediterranean, Japan, China, etc., in winter. In North America it is also found in summer, migrating south to the West Indies and Mexico in the colder months.

\section{THE GOLDENEYE. Clangula glaucion (Linnæus).}

\section{Local names-Golden-eyed Garrot ; Golden-eyed TeaL ; GOLDEN-EYED DUCK ; MORILLON (of the young and female); YeLLOWEYE.}

\section{A scarce but regular winter-visitant to the Solway.}

It must be pointed out that one of the local names of the Tufted Duck (F.cristata) is " Golden-eyed Duck" on account of the golden-yellow colour of its irides, and as that species has been shown to be increasing, it has been difficult to allocate properly the numerous reports of "goldeneyes"

* Kirkcudbright Advertiser, December 11th, 1908. 
with which I have been favoured. All records of the "goldeneye" nesting in the county have been taken to refer to the Tufted Duck.

The Goldeneye arrives here about the middle of October, and though sometimes seen as late as May, usually departs in April. Writing to his friend, P. J. Selby, from Jardine Hall on May 4th, 1850, Sir William Jardine says: "Yesterday I saw a Morillon : very late." The same writer, describing in 1832 the birds of the parish of Applegarth and Sibbaldbie, says : "The golden-eyed duck . . . ascends the river (Annan) during winter in small flocks, most of them in the plumage of the first year ; they swim up the shallow streams and destroy considerable quantities of spawn." * In the Catalogue of the Birds contained in the collection of Sir William Jardine, are recorded four specimens from the River Annan, two being from near Jardine Hall.

In 1854 a Goldeneye is included in a list of "Birds of rare and beautiful plumage" got near Sarkfoot, stuffed by Mr. Andrew Plenderleath of Longtown †; and on January 22nd, 1858, a pair of "golden-eyed garrots" + are reported from Dumfries district. $\$$ Thomas Maxwell, of Allanton Mill, told Dr. Grierson in 1862 that the "Golden-eyed Teal "was frequently met with during the winter months. Mr. R. Service states: "In the winter of 1878 and spring of 1879 the Goldeneyes were abundant on the River Nith. I had the pleasure of seeing a group of six beautiful adult males, on the water a little below Mavisgrove at daylight on the morning of the last day of January." || This is noteworthy, as adult males are but rarely seen, the full plumage not being assumed till the bird is four years old. A stuffed specimen of a very fine male, now at Drumlanrig, was shot on the Nith near

* New Stat. Acct. Scot., Vol. IV., p. 181.

† Dumfries Courier, March 28th, 1854.

† The word "Garrot," a French name for the Goldeneye, was probably applied to this species on account of its rapid flight, one meaning of the word being a crossbow-bolt. (Dict. Birds, 1893-1896, pp. 309, 310.)

§ Naturalist, 1858, Vol. VIII., p. 117.

II Trans. D. and G. Nat. Hist. Soc., November 7th, 1879. 
there on October 29th, 1878. Mr. John Corrie says in 1888 that a single specimen shot within recent years on the Cairn is now at Crawfordton,* but Captain Walker writes me that it is not there now and he has no recollection of the specimen. In 1893 a Goldeneye was shot on Eliock Estate (Sanquhar) by Mr. Monteath, as I am informed by Mr. R. McMillan; and Mr. P. Coleman tells me that one was shot by Colonel J. Ewing on the River Cairn in November, 1899 or 1900, but Colonel Ewing writes me that he does not remember shooting it. In 1901 Dr. J. W. Martin, in a list of Glencairn birds, says of this species : "A few are usually to be found on the Cairn every winter ; an old drake is seldom seen." $\dagger$ On November 14th, 1908, I shot an immature female at Capenoch (Keir) ; and five days later the keeper, C. Hyslop, obtained a similar specimen; both were single birds, and were the first I had seen in the locality.

Mr. J. W. Payne writes me from Annan that the Goldeneye is occasionally shot there in winter ; and a female shot on a loch near Denbie (Dalton) on January 22nd, 1910, was sent to me by Major H. Hall.

Doubtless this species will be found in such localities as Lochmaben, for it is in open weather essentially a bird of inland lakes, and frequents the rivers and tidal estuaries when driven from its favourite haunts by frost and ice; but, till a more discriminate use is made of the name "goldeneye" it is impossible to be more precise with regard to its distribution.

The Goldeneye has never yet been proved to have nested in Great Britain, but breeds in parts of northern Europe and Asia, where it nests in holes in trees, sometimes at a considerable height from the ground, the disused nest of a Black Woodpecker being a favourite choice. In winter it is found throughout Europe in suitable localities as far south as the Mediterranean, while eastwards its migrations extend to upper India, Japan and China.

* Trans. D. and G. Nat. Hist. Soc., November 10th, 1888.
† Op. cit., December 13th, 1901 . 


\section{THE LONG-TAILED DUCK.}

Harelda glacialis (Linnæus).

\section{Local name-CALLOo.}

\section{An occasional winter-visitor to our shores.}

William Hastings in recording a Long-tailed Duck shot at the mouth of the Lochar and sent to him during the winter of 1879-1880 for preservation, states " that it is an extremely rare species on that part of the coast, only one having previously come into my hands."* Mr. J. Harkness writes me that he shot a female in 1885 on the Blackshaw Bank. During the autumn and early winter of 1887 there was quite a "visitation" of this species to the English shores; and a small flock which came far up the Solway Firth mostly perished in the cause of science. Thus, W. Duckworth writes from Carlisle to Mr. R. Service that three Long-tailed Ducks had been obtained in Dumfriesshire waters about October 17th. Later he sent to Mr. Service two Long-tailed Ducks shot near Gretna, which he bought in Carlisle market on November 15th. They were the first he had seen since his previous communication. These birds, a male and female, were shot off Dornock, and Mr. Service writes me that "one of them had eighty-six speckled goby (Gobius minutus) in its gullet and a large, partially-digested, mass of the same fish in its stomach." H. A. Macpherson notes that the birds shot on the Solway in 1887 proved, on dissection, to have dieted almost exclusively upon shrimps. $\dagger$ Two out of three seen off Borron Point in November, 1896, were shot and preserved by Mr. McCall of Carsethorn, $\ddagger$ and these specimens are here recorded, though they may

* Proc. Nat. Hist. Soc. Glasg., 1880, Vol. IV., pp. 323, 324.

$\dagger$ Fauna of Lakeland, 1892,-p. 300.

† Dumfries Courier and Herald, November 24th, 1896. 
more properly be regarded as Kirkcudbrightshire birds. Mr. R. Service writes: "On the 5th November, 1897, I had the pleasure of handling a fine old drake of the Longtailed Duck in the finest feather. It had been shot the same morning near Kingholm on the Nith. Of late years this duck has shown a tendency to put in a more frequent appearance on the Solway Firth, but here, as elsewhere, it is extremely unusual to find one on inland waters. This specimen was found some four or five miles from the sea."* H. A. Macpherson records another specimen obtained in the same season, as follows: "A small but adult female of Harelda glacialis was sent me as an unknown bird from Priestside, near Annan, on 14th December, 1897. The specimen is chiefly remarkable for having a pure white neck, more resembling that of a male Harelda than the neck of the average female." $\dagger \mathrm{Mr}$. Service records a female which came into his possession in the winter of 1899-1900 $\uparrow$; and an immature female shot by T. Peal on October 31st, 1903, it is believed in Dumfriesshire waters, is in Tullie House Museum, Carlisle, as is also an adult male killed near Gretna by a fisherman on November $2 n d, 1909$. This latter is in almost full winter-dress, a remarkably early date for this stage of plumage and in which this bird is very rarely seen in the Solway. Writing of the status of this species in the Solway area, Mr. Service says in 1905: "Within the last ten or twelve years little parties have been finding their way round the Mull of Galloway into our waters, and a few have even got inside Southerness." I

From the foregoing it will be seen that the Long-tailed Duck, once a very rare visitor to our shores, has, of comparatively recent years, become far less intermittent in
its visits.

* Ann. Scot. Nat. Hist., 1898, p. 52.

$\dagger$ Loc. cit.

$\ddagger$ Op. cit., 1900, pp. 49, 50.

$\S$ Tullie House Museum Registers.

\| Trans. D. and G. Nat. Hist. Soc., April 20th, 1905. 
Few onomatopœic names are so expressive as the name "Coal an can'le licht" by which in some localities the Longtailed Duck is known. In the Outer Hebrides where I became familiar with the species, I was instantly struck by the resemblance of its gabbling cry to these words; though it must be remembered, as Robert Gray says, that "it speaks with a good Scotch accent."*

Its breeding-range may be roughly said to be circumpolar, but it has nested in the Shetland Isles, while in winter it migrates as far south as about lat. $40^{\circ}$ north, both in the eastern and western hemispheres.

\section{THE COMMON EIDER. Somateria mollissima (Linnæus).}

An irregular and uncommon visitor to our coast.

In his Vertebrate Fauna of Lakeland (1892) the late H. A. Macpherson stated that the Eider Duck was entirely unknown in the upper portions of the English Solway, $\dagger$ and the same might at that date have been said of our coast.

A specimen obtained by Mr. McCall on the Solway off Carsethorn in 1896, and now in his possession, $\$$ can hardly be claimed as taken within our limits; but the Common Eider, of recent years, has been observed occasionally off our shores. The report of an Eider said to have been shot by one Tom Gunzean in November or December, 1882, on the Nith near Kingholm, sounds improbable, though Dr. J. W. Martin writes me : "The man who shot it says he knew it was an Eider, because he was in the fowl trade and recognised the bird." The species is exclusively maritime, and Kingholm is some four or five miles from the sea.

The Common Eider seldom leaves its breeding-places unless driven by stress of weather. It nests in the

* Birds of West Scotland, 1871, p. 393.

$\dagger$ Fauna of Lakeland, 1892, p. 301.

$\ddagger$ Dumfries Courier and Herald, November 24th, 1896. 
northern countries of Europe ; and in Great Britain, from Northumberland to the Orkney and Shetland Isles. It is said to be increasing as a breeding-species in the western isles of Scotland, and it bred, so Mr. R. Service informs me, for the first time within the Solway area, in Colvend parish (Kirkcudbright) in 1908.

\section{THE COMMON SCOTER. EEdemia nigra (Linnæus).}

Local names-Black Scoter; Black Duck.

\section{A common winter-visitant to the Solway Firth.}

"Mabie Moss" writes: "Since 1876 I have known that each season a larger or smaller flock of Black Scoter remained on the Solway the whole season through, but it is not long since I became aware that the fact was most unusual. They are mostly to be found somewhere between a point two or three miles seawards of Heston and another point abreast of Southerness, and . . - are never very far out ; seldom out of sight with a pair of binoculars. This comparatively small flock appears to be immature birds which never fly inland. Some winters, indeed most winters, there are thousands of Scoters in the Solway, but when these depart in spring for more northern waters a small remnant is left. I believe that no Scoters remain anywhere else in Britain in summer except at some spots in the Inner Hebrides-Tiree,for instance."* Howard Saunders, however, states that " a comparatively small number of immature Common or Black Scoters may be observed on our coasts [i.e. of Great Britain] during the entire summer, but the autumn and winter months are those in which this species is really abundant. . . . On the Solway ... thousands are sometimes seen." $\dagger$

\footnotetext{
* Dumfries Courier and Herald, September 7th, 1896.

† Man. Brit. Birds, 1899, p. 465.
} 
This species is more abundant with us in some seasons than in others, and its movements are at all times affected by the tides. Scoters come all along the foreshore to Annan Water-foot, and in 1881,1882 , and 1883 they were observed in thousands. "Mabie Moss" described a Common Scoter in such full moult on September 7th, 1889, that it could not fly, ${ }^{*}$ and the same observer records a most unusual congregation of the species off Southerness in June, 1891. They were estimated at from ten to twenty thousand, $\uparrow$ and at so late a date such a quantity is all the more extraordinary. A flock of Scoters and Scaup-Ducks of about two thousand in number was seen off our shores on April 19th, 1906. $\ddagger$ The above observations, it will be seen, hail mostly from the neighbouring county of Kirkcudbright; but, as has been explained, the species is so dependent on the tides for its food, that it is ever and again shifting its quarters, and may therefore be in and out of whatever may be considered our county limits at sea, within the twenty-four hours.

A Common Scoter was obtained at the Carse Loch $\S$ (Dunscore) twelve miles from the sea, in October, 1862, an unusually inland locality for the occurrence of this species.

It is remarkable that Sir William Jardine, writing in 1843 of the Common or Black Scoter, states: "This species we consider in Scotland at least as more uncommon than the last " $\|$ (i.e., the Velvet-Scoter). T. C. Heysham wrote of the Common Scoter three years previously as " a species of common occurrence in most parts of the country." 9 and I am at a loss to know why Sir William was not better acquainted with a bird which, judging from the writings of contemporary observers, must have been of common occurrence in Scotland, and presumably also on the Solway.

* Dumfries Courier and Herald, September 17th, 1889.

† Op. cit., June 30th, 1891.

* Tullie House Museum Registers.

$\S$ Grierson's MS. Notes, October 17th, 1862.

|| Nat. Lib., 1843, Vol. XIV., p. 166.

I Fauna of Lakeland, 1892, pp. 301, 302. 
The Common Scoter nests in northern Europe and Siberia as far as the Taimyr district and sparsely in the north of Scotland, and in one locality in Ireland.. In winter it is common on the sea-board of most parts of western Europe and is found less abundantly in parts of the Mediterranean and Caspian Seas.

\section{THE VELVET-SCOTER. EEdemia fusca (Linnæus).}

\section{An uncommon winter-visitor to the Solway Firth.}

This species is observed among flocks of Common Scoter on the Solway, in about the proportion of one to three hundred, and when seen thus in company it may be readily distinguished by the white bar on its wing, which makes the adult males somewhat resemble an old Blackcock. In those seasons, as in 1881, 1882, and 1883, when the Common Scoter is plentiful, this species also occurs more numerously. It is essentially a maritime bird and the following record by Richard Bell of Castle O'er, from a locality some eighteen miles inland, is therefore remarkable. He states: "I saw one of these birds on the River Esk in front of Billholm House either in 1870 or 1871, I think. It was easily distinguished from the Black Scoter by the white bar on the wing and the white round the eye. It was not at all shy and may have been an escape."* Mr. R. Service records that on October 29th, 1902, he received a fine Velvet-Scoter " that had been shot the same morning by the side of the Nith below Dumfries, and some five or six miles from the open firth. That it had not long left the sea was shown by the fact that its stomach was crammed with shells of Tellina. . . this is the first local occurrence inland of the Velvet-Scoter that I have met with." $\dagger$

* My Strange Pets, p. 152.

† Ann. Scot. Nat. Hist., 1903, p. 50. 
Mr. W. Nichol writes me that he saw six Velvet-Scoters off the Dumfriesshire coast on June 10th, 1908.

This species breeds in northern Europe and parts of western Siberia, and it has possibly bred in the northern Highlands of Scotland; in winter it visits the Baltic, North Sea and the waters of western Europe, and is more rarely found on the Adriatic, Black and Caspian Seas.

\section{THE GOOSANDER. Mergus merganser, Linnæus.}

Local names-SAW-NEB; SAW-NeBbed DUCK; SAwBIll; Stockannet ; Stockgander; Dun Diver (of female and immature male).

\section{A winter-visitor of less marine habitat than most of the diving ducke.}

Sir William Jardine, writing of the birds of the parish of Applegarth and Sibbaldbie in 1832, says of the Goosander: "Male and female ascend the Annan during winter in small flocks. Those of immature plumage and females are most abundant."* This observation still holds good, and the full-plumaged adult males, are but rarely seen compared with the more sober-coloured females and immature males. For the first year the plumage of the sexes is nearly similar and such birds were long considered distinct species, and were known as the Dun Diver, Mergus castor. Thus we read in 1838 of the Goosander and Dun Diver as among the rarer wildfowl to be found in the Lochar Mosst; and in a letter to P. J. Selby, written from Jardine Hall on May 4th, 1850, Sir William Jardine says: "Yesterday I saw a Dun Diver: very late." In the Catalogue of the Birds contained in the collection of Sir William Jardine are mentioned three Goosanders from the River Annan, and one shot at Jardine Hall by the gamekeeper.t A bird of this species is included

* New Stat. Acct. Scot., Vol. IV., pp. 181, 182.

† Dumfries Courier, February 28th, 1838.

$\ddagger$ Cat. Birds in coll. Sir W. J., p. 179 (7282), a, a, a, b. 
in a list of "Birds of rare and beautiful plumage" obtained at Sarkfoot in 1854 and stuffed by Mr. Andrew Plenderleath of Longtown,* Cumberland ; and a "Buff Breasted Merganser" is recorded from Dumfries district on January 2nd, 1858, $\uparrow$ while a fine male was sent to William Hastings for preservation from Stranfasket (Glencairn) in December, 1886. In $1888 \mathrm{Mr}$. John Corrie records a single specimen killed on the Cairn in recent years, now in the gun-room at Crawfordton. $\ddagger$ This bird, shot by the late Sir George Walker, may still be seen there, a sadly-faded relic of what was once a fine male. Mr. T. Ranken writes me from Dalswinton (Kirkmahoe) that the Goosander is seen on the River Nith occasionally, and that his keeper shot two in 1899. Mr. Hugh Mackay mentions in his MS. notes that a specimen sent him for preservation in January, 1895, when shot, vomited three eels varying from twelve to fifteen inches in length. Dr. J. W. Martin states in 1901 that an occasional bird is seen during the early months of the year on the Cairn but that he only once saw a male, $\S$ and on December 27th, 1902, I shot a right and left at Goosanders on Scaur Water below Penpont. I noticed that the delicate rosy "blush" on the breast of the male faded appreciably within ten minutes of the bird being shot. None of these birds were seen on the Scaur subsequently until December 30th, 1909, when I saw two males and five females. Richard Bell of Castle O'er writes in 1905 that this species frequents the River Esk nearly every winter " and at that season are in splendid plumage and colour." $\|$ He also informed me that in 1906 a few Goosanders were to be seen on the river there as late as March 28th. Miss Wallace records a male and two females shot by a poulterer at Lochmaben on January 24th, 1906 ; and in 1907 a Goosander was killed by flying against

* Dumfries Courier, March 28th, 1854.

$\uparrow$ Naturalist, 1858, Vol. VIII., p. 117.

† Trans. D. and G. Nat. Hist. Soc., November 10th, 1888.

$\S$ Op. cit., December 13th, 1901.

|| My Strange Pets, p. 135. 
the telephone-wires near Ruthwell. Mr. Laidlaw writes me (1908) that one was shot on the Esk some years ago, and on February 14th, 1910, I shot an adult male at the Far Loch, Capenoch.

This species may be said to be almost an annual visitant to our larger lakes and rivers, but somewhat more irregular in its visits to their tributaries and upper reaches. It frequents shallow or smooth-running waters and consumes an immense number of small trout and salmon-parr.

In view of the fact that its breeding-range in Scotland is believed to be extending, it is interesting to note that in the Dumfries and Galloway Standard for May 29th, 1895, Mr. Hugh Mackay records that on June 27th, 1894, "6 a Goosander was obtained on the Nith a few miles from Dumfries, .. [and] . . several of the same species were afterwards observed." This seemed to him to be conclusive evidence that these birds had nested in the locality, especially as a pair of Goosanders were observed in May the next year near the same place. He goes on to say: "Mr. Coupland, to whom I am indebted for many interesting observations on this species, informs me that two years ago [i.e., 1893] he found a nest containing eggs in the locality where these birds now are, and so accurately described the size and colouring of the eggs, the construction and situation of the nest, as to prove almost beyond doubt that it was the nest of the Goosander. I fully expect to confirm the statement relating to the nesting of the Goosander in Dumfriesshire at some future period."

I wrote to Mr. Coupland, who replied as follows: "I once found a Goosander's nest up on Craigshields (Kirkmichael), but unfortunately it was destroyed and they never came back, at least not to nest. I found the nest as near as I can mind in about the end of April or beginning of May, 1888. It was in a thick heather bush on a ledge of rock. There were nine eggs in it of a darker blue than the common wild duck and a bit bigger. I saw the two birds often in a pool near the place and just by chance going 
through the heather I put her off the nest. I did not know what kind of a duck it was at that time, but have shot many a one since. The Sheld-Duck is much like the Goosander, but different in head and beak, it nests in burrows on the moss here." I wrote to Mr. Hugh Mackay that the dates in the two accounts did not agree, and also pointed out that this description of the eggs as "of a darker blue than the common wild duck," threw considerable doubt on the alleged occurrence. In his reply Mr. Mackay states that to the best of his recollection, Mr. Coupland told him that the eggs were buff, that the construction and situation of the nest were satisfactorily described, and that the date was as he had previously stated; but that all his notes on the subject had been unfortunately lost.

The allegation of the Goosander having nested in Dumfriesshire, therefore remains unsubstantiated; and it is well to remember that the name "Stockannet," or "Stockgander " is often locally applied to this species as well as to the Sheld-Duck.

The Goosander nests in parts of northern and central Europe and Asia, as also in the Scottish Highlands. "A hole in the trunk of a tree (frequently an alder), a recess beneath gnarled roots, a hole in a peat bog, or sometimes a sheltered ledge of rock, are the localities selected "* for the nest, in which from eight to thirteen creamy or buff-white eggs are laid. In winter the bird occurs in Europe as far south as Spain and is seen with us usually from November till April, or occasionally even later.

\section{THE RED-BREASTED MERGANSER.}

Mergus serrator, Linnæus.

\section{A winter-visitant to the Solway.}

Sir William Jardine in 1843 writes of this species: "In the south of Scotland it does not ascend rivers regularly

* Man. Brit. Birds, 1899, p. 472. 
like the last, nor is it nearly so common in winter, and the specimens which we have procured have been generally from the sea or its vicinity."

An adult male Red-breasted Merganser obtained on the Sccttish Solway in January, 1866, may be seen in the Tullie House Museum, Carlisle. Mr. R. Service records that "several Mergansers were procured in November, 1881, both on the sea, and on inland waters. Although common in some parts of the country they are very scarce here " $\uparrow$; another was obtained at the beginning of November, 1883. Mr. Hugh Mackay states: "On 3rd February, 1894, Mr. Davidson, fisherman, sent me a beautiful adult male specimen of the Red-breasted Merganser. Immature specimens are frequently met with in the Solway, but it is on very rare occasions that adult male birds are found.'\$

This species, owing to its worthlessness for food, is not much sought after, so that the records of its occurrence are but few ; in most winters, however, it is observed on our coasts, though in annually varying numbers. It arrives late in autumn, and stays till May or even June; and in good weather it may be seen on most days within a quarter of a mile of the shore. H. A. Macpherson states that: "In July, 1890, Mr. Nicol saw a half-grown brood of Mergansers swimming in the Waver [Cumberland] with their parents, but the party had probably crossed over to us from the Scottish Solway." I It has not been known to nest in the county; though the alleged instance of the Goosander's nesting in Dumfriesshire (see pp. 298, 299) might have been referred with more probability to this species.

The Red-breasted Merganser breeds in many counties in Ireland and north-west Scotland, and in the rest of Europe throughout the northern area. The nest is usually

* Nat. Lib., 1843, Vol. XIV., p. 181.

† Trans. D. and G. Nat. Hist. Soc., February 3rd, 1882.

$\ddagger$ Op. cit., December 7th, 1883.

§ Op. cit., April 20th, 1894.

|| Fauna of Lakeland, 1892, p. 310. 
in thick cover, seldom at any great distance from fresh water, and contains from eight to eleven greenish-drab eggs. At this season of the year the birds subsist chiefly on trout and salmon-parr. In winter they become more marine in their habitat.

\section{THE SMEW. Mergus albellus, Linnæus.}

\section{A rare irregular winter-visitor.}

Sir William Jardine, writing in 1843, would seem to indicate that he knew of at least one local specimen of the Smew ; for he says : "In Scotland it can only stand as an occasional straggler; a single specimen of the male has only occurred to ourselves recently killed, though we know of a few other instances that can be depended on."* In 1864 Dr. Grierson exhibited "a Smew or White Nun . . . which was obtained in the vicinity of Thornhill [eighteen miles from the sea], and which so far as known to Dr. Grierson, was the only one ever seen in that district." $\dagger$ This specimen, a male in a very dilapidated condition, may still (1909) be seen in Grierson's Museum, Thornhill. To this record of Dr. Grierson's, Sir William Jardine adds the footnote : "A specimen was shot on the River Annan near Dormont, and is now in the collection of British birds there formed by the late W. T. Carruthers, Esq." $\$$; Dormont is about six miles from the sea. This bird, which it is believed was got about 1861, cannot now be traced. An undated specimen labelled "Dumfriesshire," passed from the Edinburgh Museum in 1876, and is now in the Royal Scottish Museum. Mr. W. Eagle Clarke writes me in 1908 that it is apparently a very
ancient specimen, from sixty to seventy years old. The

* Nat. Lib., 1843, Vol. XIV., pp. 175, 176.

$\dagger$ Trans. D. and G. Nat. Hist. Soc., April 5th, 1864.

¥ Loc. cit. 
above, if not all, may be some of the specimens referred to by Robert Gray when he writes in 1871 that this species has occurred in Dumfriesshire.*

William Hastings received a Smew which was shot at Lochmaben in the winter of 1878-1879, $\uparrow$ and another in 1879-1880. The lacustrine district of Lochmaben, though some eight to ten miles from the sea, often attracts stormdriven rarities. In the Birds of Cumberland, published in 1886, it is stated that an immature bird was shot on the Scottish side of the Solway, "about five years since,"§ and Mr. J. Harkness writes me that he has a Smew shot in 1886 by William Murray, of Priestside (Cummertrees). During the severe weather of January and February, 1891, Smews were more plentiful than usual on the Solway, and among them were several adult males. An immature female was obtained at Riggfoot (Gretna) on January 11th, 1907, |l and Mr. T. Ranken writes me from Dalswinton (Kirkmahoe) that he shot a female Smew there on January 6th, 1908. It was one of two which rose from a ditch near the Nith. Dalswinton is some ten miles from the sea, and there was hard frost and snow at the time. This specimen (which is not a male, as I have previously recorded it $/$ ) is still in the possession of Mr. T. Ranken.

The Smew nests in Finnish Lapland, parts of north Russia and up to the limit of forest-growth across Siberia, and in winter it visits parts of central and western Europe, while it is generally distributed in the Mediterranean ; it also visits China, Japan and north India. Specimens which occur on the coast of Great Britain are for the most part in immature or female dress, the full plumage of the male not being assumed until the second year. These full-plumaged

* Birds of West Scotland, 1871, p. 397.

$\dagger$ Trans. D. and G. Nat. Hist. Soc., November 7th, 1879.

‡ Proc. Nat. Hist. Soc. Glasg., 1880, Vol. IV., p. 323.

$\S$ Birds of Cumberland, 1886, p. 119.

|| Tullie House Museum Registers.

I Ann. Scot. Nat. Hist., 1908, p. 119. 
birds seem to keep further out at sea than their fellows, and are only met with nearer the shore in exceptionally severe weather.

\section{THE RING-DOVE. Columba palumbus, Linnæus.}

Local names-Wood-Pigeon ; Cushat ; Cushie ; CushaDoo.

"The cushat, startled from her ivied tree,

Comes clapping out above him, down right o'er

The river takes, and, folding her smooth wings,

Shoots like an arrow up the woody face

Of yon high steep, and o'er it bears away,-

Thomas AIRD.-" Frank Sylvan."

A common resident in the arable district, its numbers being increased in
autumn and winter by immigrants.

The place-name, Cushathill (Middlebie) owes its origin to the Ring-Dove or Wood-Pigeon, which, it would appear, has always been a common breeding-bird in this county; an opinion shared as regards Lakeland by $\mathbf{H}$. A. Macpherson.* Robert Gray states in his Birds of the West of Scotland in 1871: "Though at the present day it exists in very great numbers in cultivated districts, its first appearance is an event actually within the recollection of old people now living in the county in which the species is most abundant. In East Lothian it is not more than 80 years since it was quite unknown." $\dagger$ At the beginning of the nineteenth century, this species was certainly not so superabundant as it is now. We read of it as "cooing in the enchanted groves at Langholm " in 1794, $\ddagger$ and Sir William Jardine, writing of it in 1842, describes it as abundant in the south of Scotland, and adds : "It is even blamed, and with some reason, for its depredation of the crops of the farmers,

* Fauna of Lakeland, 1892, p. 313.

$\dagger$ Birds of West Scotland, 1871, p. 213.

† Stat. Acct. Scot., Vol. XIII., p. 597. 
particularly turnips, to which the appearance of snow or frost invariably drives them. ... Nevertheless, they are a favourite bird, and are not frequently molested or wantonly destroyed."* How different is our attitude towards the WoodPigeon to-day, when it is regarded as one of the most noxious of agricultural pests; and though every opportunity is taken to reduce its numbers, the species still thrives.

Three broods are occasionally reared in one year; the first often in April, and Mr. E. A. Johnson-Ferguson informs me that in 1904 he found a nest with eggs at Springkell (Kirkpatrick-Fleming) on October 11th.

The Wood-Pigeon is popularly supposed at harvest time to eat three times its own weight of corn in the day; and it is recorded that one shot at Hoddom Castle contained "6 37 acorns, 6 beech nut kernels, 2 wild cherry stones, and two of the crops or sockets of the acorn." $\dagger$

In autumn flocks of migratory birds visit the county, varying in numbers as it happens to be a good or bad season for acorns; and in hard winters, as in 1846-1847, 1878-1879, and 1894-1895, they suffer severely.

Variability in the plumage of the Wood-Pigeon is not common. A white variety got at Rigg Farm (Gretna) may be seen in the Tullie House Museum, Carlisle. This bird was obtained on January 16th, 1895, by T. Peal, from whom it was purchased for twenty-five shillings. When I saw the specimen in 1908 it was wrongly labelled as obtained February 23rd, 1905. "Mabie Moss" describes one shot at Carnsalloch (Kirkmahoe) in January, 1898, as regularly spotted with white feathers on every part except the tail and flight-feathers which were of the normal colour.ई A cream-coloured Wood-Pigeon was seen more than once for two successive seasons about 1902 in the Keeper's wood, Capenoch, but seemed to bear a charmed life.

* Nat. Lib., 1842, Vol. XII., pp. 60, 61.

$\dagger$ Dumfries Courier, December 8th, 1818.

$\ddagger$ Op. cit., December 21 st, 1846.

§ Kirkeudbright Advertiser, January 17th, 1898. 
This species in some seasons is almost decimated by a diphtheritic infection. In the winter of 1907-1908 several dead birds were picked up in various parts of this county ; but perhaps nowhere were there more deaths than at Henleyon-Thames, Berkshire, where thousands of Wood-Pigeons were found dead below the trees. Recent investigations go to prove that this epidemic of diphtheria occurs when many Pigeons have congregated together where beech-mast and acorns are plentiful; and infection may be carried by regurgitated portions of infected food being devoured by previously healthy individuals.

The peculiar feather-disease which is frequently noticed, is always associated with moult, and Mr. C. B. Ticehurst informs me that " the cause is unknown and that the disease has nothing to do with diphtheria." It is interesting to read of such an outbreak locally in February, 1852, concerning which Mr. Richard Rimmer wrote from Kirkmichael House : "I have shot a great many [Wood-Pigeons] and I think I am not wrong in saying that one-third have been in a most deplorable condition, mattering under the wings and thighs, feathers loose, and altogether presenting a diseased appearance."**

\section{THE STOCK-DOVE. Columba anas, Linnæus.}

Local name-Rock-Dove. "Thou stockdove whose echo resounds thro' the glen,
Ye wild whistling blackbirds in yon thorny den,
Thou green-crested lapwing, thy screaming forbear-
I charge you, disturb not my slumbering fair !"

Robert Burns.- "Sweet Afton." A resident, annually increasing in numbers throughout the county, though
many of our locally-bred birds migrate south in autumn.

The above quotation is from Messrs. W. E. Henley and Thomas F. Henderson's edition of The Poetry of Burns, 1901.

* Naturalist, 1852, Vol. II., p. 206. 
In their notes on this poem they write : "There has been no little discussion as to the date, the heroine, and the scene... We are able to put a term to this "pleasing state of uncertainty.' Flow Gently, Sweet Afton was sent to Mrs. Dunlop 5th February 1789 (Lochryan MSS.), and in the enclosing letter Burns explicitly declares that it was written for Johnson's Musical Museum, as a 'compliment' to the 'small river Afton that flows into Nith, near New Cumnock, which has some charming wild romantic scenery on its banks." "* Robert Burns has thus sung, with poetic licence, of a bird not known in Scotland in his day, and I regret to say that so good a naturalist as our poet Thomas Aird has followed his precedent. Even if I thought the identification of the species satisfactory, I could not claim this record of the Stock-Dove in 1789, for Afton Water rises on the west of the Black Lorg in Ayrshire, some five hundred yards beyond our county boundary.

Sir William Jardine, writing in 1842, says of the StockDove: "so far as we can ascertain [it] has not yet been met with in Scotland or Ireland ; it is, in fact, confined to a few of the southern counties in England." $\dagger$ In a letter to Mr. R. Service in 1887, H. A. Macpherson remarks on the absence of this species from the collection of Sir William Jardine's birds sold on June 17th, 1886, and adds: "But most of his British specimens are mounted at Edinburgh." There is, however, no record of any Stock-Dove, local or otherwise, having passed from Sir William Jardine to the Edinburgh Museum. The first local record I have come across is of " one shot on Duncan [i.e., Donkins] lime-kiln, near Ecclefechan, in November, $1858 " ¥ ;$ as reported by Thomas Armstrong, a Post Office clerk at Carlisle, and a keen collector of birds. Mr. J. A. Harvie-Brown, in his paper on "The Increase and Dispersal of the Stock-Dove in Scotland,"§

* Poetry of Burns, 1901, Vol. III., pp. 395, 396.

† Nat. Lib., 1842, Vol. XII., p. 64.

‡Zoologist, 1859, p. 6378.

§ Proc. Roy. Phys. Soc. Edin., 1883, Vol. VII., pp. 241-254. 
does not mention this record; and it is impossible at this late date to verify the statement. H. A. Macpherson writes in 1892: “The Stock-Dove appears to have been always a winter visitant, if not an actual resident in Lakeland, but there can be no doubt that it is only within a comparatively recent period that it has bred pretty generally in this region"; and he goes on to describe a nest found six miles to the west of Carlisle on April 28th, 1861.* If the Stock-Dove in 1861, as above stated, nested in Cumberland within ten miles of our boundary, it is possible that from lack of observation this species may have passed unnoticed in Dumfriesshire. At any rate, in view of the "opinion of H. A. Macpherson that the Stock-Dove was "always a winter visitant, if not an actual resident in Lakeland," coupled with the discovery of the nest near Carlisle within three years of the alleged occurrence of the species at Ecclefechan, the truth of this allegation would seem not impossible, but probable.

A. G. More, in his paper published in 1865 on the "Distribution of Birds in Great Britain during the Nesting Season," $\dagger$ does not mention Dumfriesshire as a vernal habitat of the Stock-Dove; but a "Wood-Pigeon's nest ... built upon the ground in a hill side," $\ddagger$ is chronicled by Mr. Kirkpatrick in 1871 ; and this makes one wonder if by an error in identification Dumfriesshire has been deprived of the first record of the Stock-Dove nesting in Scotland; although it is true that the Wood-Pigeon has been known to nest occasionally on the ground. Robert Gray only mentions the Stock-Dove in his Birds of the West of Scotland in 1871, as a very rare species in Caithness, and as having occurred once in Orkney in 1861, $\S$ but must this be taken as negative evidence of its previous occurrence in our county? Mr. J. A. Harvie-Brown in 1883 states that in Dumfriesshire

* Fauna of Lakeland, 1892, p. 314.

$\dagger$ Ibis, 1865, p. 141.

$\ddagger$ Minutes of D. and G. Nat. Hist. Soc., February 7th, 1871.

$\S$ Birds of West Scotland, 1871, pp. 219, 220. 
" the Stock-Dove appears to have been a breeding species for several years at all events, if not for a much longer period,"* a statement with which I entirely concur, though I know of no authenticated record prior to 1883 or 1884 .

Mr. J. Harkness writes me in 1908: "It is twenty-two years since I saw first the Stock-Dove at Kinmount, and the keeper told me that they had nested three or four years before that. They nested in the cow-park south of the mansion in the thick growth of the lime trees. Whether these trees still stand I do not know, as there has been such an alteration, and I have not been there for eighteen years or more." Mr. Tom Brown in 1888 records a nest found in Tynron "some years ago under an overhanging bank." $\dagger$ I am informed by Mr. J. H. Milne-Home in 1908 that this species breeds annually near Langholm, and in one place since about 1889 ; a similar report concerning Raehills (Johnstone) reaches me from Mr. W. Renwick. Mr. E. A. Johnson-Ferguson tells me (1908) that the Stock-Dove is quite common at Springkell (KirkpatrickFleming); he has observed them ever since he first began to take an interest in birds (i.e., about 1888), and they nest in rabbit-holes. Mr. S. Bell informs me that this species was noticed at Crichope Linn (Closeburn) in 1892, and that it breeds there annually in rabbit-burrows or under rocks. Mr. John Dalzell writes me in 1908 from Middlebie, that the Stock-Dove has nested there since about 1893, and I have reports of its having bred more recently in the parishes of Kirkconnel, Sanquhar, Penpont, Keir, Glencairn, Dunscore, Holywood, Kirkmahoe, Hoddom, Tinwald, Kirkpatrick-Juxta, Moffat and Canonbie. Doubtless this species also breeds in many of the remaining parishes where it has not yet been detected from lack of observation.

In this county the nest is, as a rule, in a rabbit-burrow, a cliff-recess, or hidden among a mass of ivy ; but Mr. Norman Maclachlan tells me that he found a nest in May, 1908, some

* Proc. Roy. Phys. Soc. Edin., February 21st, 1883, Vol. VII., p. 253.

† Trans. D. and G. Nat. Hist. Soc., December 4th, 1885. 


\section{BIRDS OF DUMFRIESSHIRE}

sixteen feet from the ground, built in the open cleft of a tall lime tree which stands in the policies of Nithsdale School, Carnsalloch. Mr. J. Harkness from Ruthwell and Mr. E. A. Johnson-Ferguson from Ecclefechan also inform me of similar situations.

During autumn and winter this species is often found in company with flocks of Wood-Pigeons; but occasionally it is seen in separate flocks of from thirty to forty individuals. In 1889 it appears to have been unusually numerous.* It is believed, however, that the great number of our locallybred birds migrate south in October, returning to their nesting-haunts in March and April.

From having been a rare bird five and twenty years ago, the Stock-Dove has now (1910) become almost a common species, and is annually increasing. Though this addition to our avifauna is welcome, it must not be supposed that a superabundance of these birds would be anything but detrimental to agricultural interests. If our birds of prey were only allowed to increase, there is no doubt that they would keep in check both this and the preceding species.

[THE ROCK-DOVE. Columba livia, J. F. Gmelin. Local names-Blue Rock; The Doo.

"It's no the doo-cot that makes the doo."

HENRY SCOTT-RIDDELL.

So long ago as 1837 William Macgillivray questioned whether the Rock-Doves nesting on the west coast of Scotland were quite pure, $\dagger$ and nowadays there are but few spots on the British coasts where this species may be found uncontaminated by tame Pigeons, unless, perhaps, on the rocky cliffs of Ireland. Being essentially a bird of the sea-cliffs, instances of its nesting inland are tainted with the suspicion

* Dumfries Courier and Herald, September 17th, 1889.

† Macgillivray, Hist. Brit. Birds, 1837, Vol. I., p. 268. 
that such individuals may have escaped from domestication; and it is well to remember that the Stock-Dove is often called the Rock-Dove locally. Dumfriesshire having no maritime cliffs, it is unlikely that this species was ever a resident in a wild state. There is no modern record of its occurrence, and its present claims to inclusion in our list only entitle it to be regarded as a domesticated or semi-domesticated species; consequently it is placed in square brackets.

The pigeons of the old Baronial dovecotes were, I believe it is always admitted, "Blue Rocks." Dr. Singer, in his agricultural survey of Dumfriesshire in 1812, says : "Most of the gentlemen of landed property were at one period in the practice of erecting dovecotes and of keeping large flocks of Pigeons ; but at present there are very few of them to be seen. By the Scottish Act, 1503, ch. 74, landholders were enjoined to make parks for deer, and to have rabbit warrens and dovecotes. But it was found that pigeons were so destructive to corn, that by a posterior Act, 1617, ch. 19, landholders were not allowed to build houses for them, unless they were each in possession of ten chalders ( $160 \mathrm{bolls}$, or near to 360 Winchester bushels) of annual victual rents, from lands within two miles of the pigeon house. At present there is little value put on pigeons, and not many proprietors of land having legal rights are disposed to keep them, a few persons, however, pretend to keep them who have no right."* From Moffat it was reported in 1834: "There are common pigeons which have bred in remote parts or old towers, and have become wild."†]

\section{THE TURTLE-DOVE. Turtur communis, Selby.}

\section{A rare and irregular summer-visitor, but is not known to nest.}

Sir William Jardine in 1842 writes thus: "The Turtle Dove may be considered as a species entirely southern;

* Gen. View of Agriculture in Dumfries, p. 386.

$\dagger$ New Stat. Acct. Scot., Vol. IV., p. 108. 
the instances of its capture in the northern counties of England, or in one or two instances in Scotland or Ireland, being only those of stray birds, which, from some cause or other, have exceeded the limit of their migration. . . . In the instance, which we communicated to Mr. Yarrell, of shooting a specimen in the garden at Jardine Hall, the bird had frequented a break of peas, nearly ripe, for several days, and at last attracted the attention of the gardener, as one not previously known to him. When it was afterwards sought for, it was discovered in the same place, rose with considerable noise, and alighted on a neighbouring tree, whence it was shot. The plumage was that of an immature bird."* This specimen was shot in " 1814 or 1815," $\dagger$ presumably in July. Another specimen "shot at Lochrutton Gate, Dumfriesshire, in June, 1870," $\ddagger$ is in reality a Kirkcudbrightshire record. Dr. Anstruther Davidson writes in 1891: “About thirty years ago a Turtle-Dove was shot near Crawick (Sanquhar), the only instance of its occurrence in the district." § In answer to my inquiries, Dr. Anstruther Davidson wrote me in 1908 that the specimen was in the possession of Lindsey, a gamekeeper, when he saw it, and that this was all its history as far as he could remember. This may be the same specimen as that referred to in 1886 by William Hastings as having been shot in the neighbourhood of Sanquhar and sent to him "some years ago."

A fine specimen of a male Turtle-Dove was shot early in June, 1886, in Tinwald parish ; and the species was then described as "very irregular in making its appearance in this country, many years passing without one being seen or heard of here."T This specimen was shot by

* Nat. Lib., 1842, Vol. XII., pp. 70, 71.

$\dagger$ Trans. D. and G. Nat. Hist. Soc., May 5th, 1868.

$\ddagger$ Loc. cit.

$\S$ Hist. Sanquhar, p. 28.

\| Trans. D. and G. Nat. Hist. Soc., November 5th, 1886.

II Loc. cit. 
Mr. Farish, on his farm of West Mains as it was feeding in a turnip-field.*

Mr. W. J. Laidlaw writes me that a pair of Turtle-Doves were seen at Eliock (Sanquhar) in June, 1900, but that they did not nest; subsequent inquiries leave no doubt as to their identity. Mr.P.A.Pasley-Dirom, of Mount Annan, tells me that he thinks he may have shot one of these birds in September or October, 1901 ; and on October 12th, 1901, a Turtle-Dove was killed near Gretna, and passed into the possession of the Royal Scottish Museum, Edinburgh, $\uparrow$ where it may now (1909) be seen.

Mr. R. Service tells me that the late H. A. Macpherson firmly believed that the Turtle-Dove nested in Eskdale; but I have not been able to substantiate this belief; though the occurrence of the species elsewhere in the county in the breeding-season, renders it not improbable.

The Turtle Dove is only a summer-visitant to the British Isles, being abundant in the southern, eastern and midland counties of England, and becoming rarer further north. It is generally distributed in summer throughout central and southern Europe, migrating in winter to the countries south of the Mediterranean as far as Abyssinia.

\section{PALLAS'S SAND-GROUSE.}

Syrrhaptes paradoxus (Pallas).

\section{A very rare accidental visitor.}

This species, a native of the steppes of central Asia, visited Great Britain in considerable numbers in $1859,1863,1872$, 1876,1888 , and 1908 , by far the most extensive immigration

* R. Service, MS. Diary, August 26th, 1886.

† Ann. Scot. Nat. Hist., 1902, p. 134. 
being that of 1888. The literature on the subject is exhaustive, and of these visitations only those of 1863 and 1888 were observed in Dumfriesshire.

William Hastings, speaking of the appearance of Pallas's Sand-Grouse in 1888, says: "About some twenty-five or betwixt that and thirty years ago [i.e., 1859-1864] I had two specimens of the same kind of bird sent me for preservation. If I mistake not, they came from the Moffat district, but they were too far gone, and did not make good specimens."* These possibly may have been two of the birds of which Mr. R. Service wrote to H. A. Macpherson: "Hastings the taxidermist had three Sand-Grouse in 1863. One was from somewhere in the neighbourhood of Lockerbie, the other two from Kirkbean, Kirkcudbrightshire."

During the incursion of 1888, "seven nice specimens" obtained locally were received by William Hastings for preservation. $\dagger$ Richard Bell of Castle O'er wrote me that a small flock of Sand-Grouse was seen in Eskdalemuir in 1888, in May-an exceptionally early date for the species to have occurred in Scotland, though in Cumberland (near Longtown) two flights of about a dozen birds were observed by Robert Moscrop on May 21 st. $\ddagger$ On June 9th of the same year four Sand-Grouse were seen at Ruthwell, and others were observed at Cummertrees and Lochar Moss, $\S$ and in this latter locality they were often seen during the next two months by William Jardine of Tinwald Downs. On June 13th a party of ten crossed over to the Scottish side of the Solway from Wolstey farm, Cumberland, and on June 25th a single bird was seen coming to the Cumberland shore from Scotland.\| On July 17th a large flock was seen in Cummertrees, and three days later a flock of eight or

* Trans. D. and G. Nat. Hist. Soc., February 1st, 1889.

$\dagger$ Loc. cit.

¥ Fauna of Lakeland, 1892, p. 319.

\$ Visit of Sandgrouse to Scotland in 1888, p. 16. $59-75$. 
nine was observed flying to the Cumberland from the Dumfriesshire coast.* Mr. J. Harkness writes me that he saw five go over Priestside Moss during "the year they visited Britain." Mr. McLean tells me that one day towards the end of August or beginning of September, 1888, he was shooting near Ruthwell on the Merse, when he saw a bird he did not know. He kept putting it up, and at last made up his mind to shoot it so as to have it identified. On returning home, he was reading his paper, when he noticed a paragraph describing the Sand-Grouse, and referring to their protection by law; he promptly realised what was the bird he had shot, and, to avoid any possible trouble, sent the specimen off to a bird-collector in Bolton. It is unfortunate that the exact date of this specimen cannot be ascertained, as the majority of these birds appear to have left the locality by August 17th. $\dagger$

Such are the facts relating to the occurrence of these birds in 1888 in Dumfriesshire, where, owing to the lack of suitable haunts, they were not nearly so numerous nor so constantly observed as in the neighbouring counties of Kirkcudbright and Cumberland.

H. A. Macpherson wrote on May 4th, 1888, to Mr. R. Service of some Sand-Grouse recently shot in Cumberland, as follows: "The females would breed almost at once. One of the ovaries contained an egg as large as that of a Blackbird, and another as large as that of a Great Tit, both yolked, of course. Very sad, is it not, for the birds had begun to pair off to breed." There are no local records of the Sand-Grouse having nested, but two clutches of eggs were taken near Beverley in Yorkshire, and a young bird was found on the Culbin Sands, Moray, by Major Chadwick's gamekeeper. In August, 1889, Major Chadwick sent a nestling which had been found in the same locality to Professor Alfred Newton, and the contents of this specimen were sent to Mr. Service to determine. He found forty-

* Trans. Cumb. and Westmorland Assoc., 1887-1888, No. XIII., pp. 59-75.

† Op. cit., 1887-1888, No. XIII., p. 114. 
five seeds, "Three of which were those of rye grass (Lolium perenne), one of tufted hair grass (Aira coespitosa) and one of broom (Cytisus scoparius)."* $\mathrm{He}$ also identified some seedling plants, raised in pots from seeds, which William Hastings had taken from a Sand-Grouse he had skinned in 1888. The majority were wild mustard and fescue grass, while the rest were Vicia cracca, Ranunculus sp., and a few clover.

The late Frederick McConnell confidently informed Mr. R. Service that he saw four or five Sand-Grouse in a garden at Blackyett, Ecclefechan, in mid-January, 1898; but this date is not contemporaneous with any other recorded occurrence of this species in Great Britain. In 1908 SandGrouse appeared in the west of Europe and were reported from various parts of England $\dagger$; but I should not care to vouch for the authenticity of what I firmly believe to have been a flock of twenty to twenty-five of these birds, seen by myself on June 18th, near Tynron, about three hundred feet up, flying very swiftly WNW.

\section{THE CAPERCAILLIE. Tetrao urogallus, Linnæus.}

\section{A rare straggler to the county from an introduced stock.}

At the end of the eighteenth century the Capercaillie, once a denizen of the Scottish Highlands, had become extinct. As to whether in still earlier days it had once inhabited this county there is no evidence, though such evidence may possibly yet be forthcoming if, as is suggested by the late H. A. Macpherson, "it is by no means unlikely that bones of this species may yet be discovered among the animal remains which lie hidden in the fissures of the limestone rocks of Westmorland." $\$$ “In 1837," Howard Saunders

* Ibis, 1890, p. 213.

$\dagger$ British Birds (Mag.), Vol. II., pp. 98, 134, 167, 208, 245, 309.

$\ddagger$ Fauna of Lakeland, 1892, p. xci. 
writes, "its re-introduction from Sweden was successfully accomplished in Perthshire, and from that county, Forfarshire, and some other centres of distribution it has now [1899] spread on to the central districts as far as Loch Lomond, East Stirlingshire and Fife, while its further extension seems chiefly a question of time."* An introduction of this species to Dumfriesshire was attempted about 1865 near Sanquhar; and in the Dumfries and Galloway Courier of December 7th, 1869, we read of two females being recently shot, one at Auchencairn (Kirkcudbrightshire), the other near Newton-Stewart (Wigtownshire) both of which were stuffed by William Hastings. The supposition having been expressed that these birds came from Perthshire, a correspondent of the same journal writes from Sanquhar as follows: "This may be the case, but I now beg to inform you that I have brought both eggs and birds, on different occasions from Arran. The eggs were hatched by greyhens, and we have now a few in the plantations here. Should any sportsman fall in with a stray bird, I hope he will spare it." $\dagger$ It is stated by Dr. Anstruther Davidson, that the late Duke of Buccleuch " reared Capercaillie with difficulty; that they haunted the surrounding woods for a brief space, and then one by one disappeared to fall before the marauder's gun in other districts." $\$$ In answer to my inquiries Dr. Anstruther Davidson writes in 1908: "I can add nothing about the Capercaillie, except that as the story goes the last seen of those liberated was near Scaur ; but ask Mr. Wilson." The latter gentleman very kindly replied to my inquiry as follows: "The late Mr. Lindsey, keeper, got some eggs from the Duke of Hamilton's keeper in Arran, and brought out five, which were set free in the Bank plantation; this was in 1865. One was shot in Galloway, and another in the Scaur direction. All were scattered and lost. A second trial

\footnotetext{
* Man. Brit. Birds, 1899, p. 491.

$\uparrow$ Dumfries Courier, December 14th, 1869.

‡ Hist. Sanquhar, p. 32.
} 
was made by placing eggs from the same source in a Pheasant's nest at Kirkland (Kirkconnel) but the eggs were destroyed by Crows." I have been unable to obtain any further information as regards the specimen alleged to have been shot in the Scaur valley; at any rate, the introduction of the species thus failed, and there have been, as far as I know, no further experiments to introduce the species locally.

Mr. Frederick Villiers writes me: "One day coming home from shooting, and passing by Crichope Linn (Closeburn) we saw what I believe was a Capercaillie cock. I fancy it was in November, 1882 or '83, but I really do not remember." Mr. R. Greaves, who is acquainted with Capercaillie in Perthshire, told me he saw a male and two females on Appin (Tynron) in November, 1905. He tried to stalk them, but they rose when just out of shot, and flew off in a northerly direction.

This species has flourished since its re-introduction to the Highlands in 1837, and is extending its range so consistently that its occurrence in the county is not unexpected. Whether it would be altogether welcome as a resident is questionable. It is stated to be "injurious in nurseries and cultivations of conifers in winter and spring by biting off buds and young shoots; it also damages birch buds and cones, the cock being more injurious than the hen. But it also does good by destroying insects, and its value for sport and food must discount any damage it does."* Capercaillie and Blackgame are not believed to live together in peace and harmony, and the claims of the Capercaillie as a sporting and edible bird are perhaps over-rated in the above quotation, while its powers of destruction to plantations are not. To the bird-lover its addition to our avi-fauna may seem desirable, but in a county so much given to afforestation as Dumfriesshire, I fancy any one who established the Capercaillie in our midst would be regarded in much the same spirit as the man who introduced the rabbit into Australia.

* Science Progress, 1907, Vol. II., p. 281. 


\section{THE BLACK GROUSE. Tetrao tetrix, Linnæus.}

Local names-HeathCocK; BLACKCock (of the male); Heathren ; Greyhen (of the female); Blackgame; Blackfowl; Heathfowl ; Heathpoult; Black.

"And if up a bonnie Blackcock should spring, To whustle him down wi' a slug in his wing, And strap him on to my lunsie* string, Right seldom would I fail."

\section{Old Dumfriesshire Ballad.}

\section{A common resident throughout the upper portions of the county.}

At the end of the eighteenth century this species, probably from lack of protection, seems to have been decreasing. The following is reported in 1793 from Sanquhar: "Black game are more rarely to be met with than formerly, owing in part, perhaps, to the woods being cut, but chiefly to the devastation of poachers, who favoured by a wide range of uninhabited country, load themselves with booty, and frequently escape with impunity." $\dagger$ From Closeburn in 1794 comes the following: "The moors in this parish used to abound with black-fowl, ... but have become scarce." $\ddagger$ About the same date they are stated to be " in great plenty in different quarters of the parish of Langholm "§ and the woods upon Tarras are said to be the haunt of the Blackcock.\| In 1792 it was stated that this species had sometimes been seen in the west of Johnstone parish, and, the account goes on to say, "we are likely to

* Wallet.

$\dagger$ Stat. Acct. Scot., Vol. VI., p. 459.

$\ddagger$ Op. cit., Vol. XIII., p. 243.

§ Op. cit., Vol. XIII., p. 597.

|| Op. cit., Vol. XIV., p. 413. 


\section{BIRDS OF DUMFRIESSHIRE}

have more of these some years hence; for, according to naturalists, corn and young plantations always attract them,"* and from Moffat it is reported: "There are both red and black game in the parish: not much, indeed, of the latter; but they are increasing, and as the plantations get forward, it is expected, that they will become more numerous." $\dagger$

In the Statistical Account of Scotland (1791-1799), from which the above extracts are quoted, the species is also reported as known in the parishes of Mouswald, Kirkmichael, Hutton and Corrie, and Westerkirk. In 1812 Dr. Singer wrote that Blackgame seemed to be "rather on the increase on some lands" $\ddagger$; but in 1820 , in referring to a Blackcock which entered a house in Chapel Street, Dumfries, it is remarked that the bird " is now so rare in Scotland that some sportsmen go a whole season without finding one."§ "Five years later, however, we find the following statement: "Most sportsmen agree in thinking that the community of Blackcocks has increased in numbers of late years, while muir-fowl are getting rather thin," $\|$ and in the following year Blackgame are reported as fetching from "four shillings to six shillings the brace with difficulty." T

Writing of the birds of Applegarth and Sibbaldbie in 1832, Sir William Jardine says that Blackgame " abound in the higher parts of the parish, and within these few years have extended to the lower districts."** Similar reports seem to show that the species was at this time increasing, and in 1842 Sir William writes of it as found sparingly in England and traces its distribution from the south "until we reach the "Border," where it becomes abundant in the wild districts

* Stat Acct. Scot., Vol. IV., p. 226.

$\dagger$ op. cit., Vol. XI., p. 290.

$\ddagger$ Gen. View of Agriculture in Dumfries, p. 451.

§ Dumfries Courier, March 21st, 1820.

\| Op. cit., August 9th, 1825.

If Op. cit., September 26th, 1826.

** New Stat. Acct. Scot., Vol. IV., p. 180. 
which conduct us to its still more frequent haunts in Scotland. There it is abundant, and may be found in most of the districts which are suited for it, extending north to Sutherland, and to the islands of Mull and Skye."* He writes in 1851 : "It is a pretty general opinion, though an erroneous one, that they drive away the Red Grouse; the two species require very different kinds of cover, and will never interfere." $\dagger$

On October 4th, 1869, the largest bag of Blackgame ever shot in a single day was obtained at Glenwharrie (Kirkconnel). The eleven guns on this memorable occasion were H.R.H. Prince Christian, Count Hompesch, Duke of Buccleuch, Viscount Marsham, Lord William Thynne, Lord George Hamilton, Lt.-Col. Grordon, Lt.-Col. A. Thynne, Hon. William Home, Lord Walter Scott, and Edward Balfour. The actual bag was five grouse, two hundred and forty-seven Blackgame, twenty-one Partridges, one Pheasant, forty hares, two rabbits. The Glenwharrie total has never been surpassed, and the following extracts from the Drumlanrig game-books show how plentiful this species was in Upper Nithsdale about that period:-

$\begin{array}{cccccccc}\text { 1870.-October 14th } & \ldots & \text { Glenwharrie (Kirkconnel } & \ldots & 144 & \text { Blackgame. } \\ \text { Do. } & \text { Do. 21st } & \ldots & \text { Eliock (Sanquhar) } & \ldots & 148 & \text { Do. } \\ \text { 1871.-October 18th } & \ldots & \text { Glenwharrie (Kirkconnel) } & \ldots & 147 & \text { Do. } \\ \text { Do. Oon } & \text { Do. 19th } & \ldots & \text { Barr Muir (Kirkconnel) } & \ldots & 134 & \text { Do. } \\ \text { Do. } & \text { Do. 20th } & \ldots & \text { Todholes and Tower } & \ldots & 136 & \text { Do. } \\ \text { (Kirkconnel) } & & & & \end{array}$

Richard Bell of Castle O'er states that the late John Wilson, shooting in Eskdalemuir, once killed eighteen Blackgame at a shot. He stalked one sitting on the top of a stone dyke, which was joined by a large flock, and he fired just as they were settling 'heids and thraws,' that is, with their heads looking in different directions, with the result mentioned.t

Since about 1870, a steady decrease must be recorded, for which it is not altogether easy to account. The bird was formerly in considerable numbers on the Lochar

* Nat. Lib., 1842, Vol. XII., p. 85.

$\dagger$ Nat. Hist. Selborne, 1851, p. 27.

$\ddagger$ My Strange Pets, p. 182. 
Moss, but is now rarely, if ever, seen there ; and the noticeable falling-off for years past in the number of Blackgame throughout the county* is likely to continue unless farther steps be taken to preserve and encourage them. The diminution of cropping in our uplands, and the general drainage of "sprittie," or rush-covered stretches of hill-land, may have something to do with their decrease; but the increase of the Pheasant and its consequent extension of range, thereby making two hungry mouths to fill where the food-supply has already been diminished to a point below the proper requirements of one, is to my mind a still more probable cause. A beat carefully 'nursed' and with the Pheasants well kept down, yielded to four guns, on November 1st, 1906, seventy-one Blackgame : forty-four being old cocks, fourteen young cocks, ten old hens, and three young hens. Much has been written for and against the desirability of sparing all hens, and unhesitatingly I vote against such a proceeding. If in the early autumn the old hens can be killed, an immense amount of good is done, which will be felt in the following season. The Greyhen is not supposed to be fertile for more than two or three years, $\dagger$ and for some unaccountable reason the old barren hens seem to be the most attractive to the Blackcock when making up his harem in the spring. The early opening date of the shooting season (August 20th) is to be regretted, unless discrimination is used and only old birds are killed; and it is a most excellent rule never to shoot a cock on which one can see any brown feathers. The maintenance of a young and healthy stock is the first ideal to be aimed at by those who wish to encourage this species rather than the Pheasant, which latter in some districts bids fair to become almost ubiquitous.

In spring Blackcocks assemble at early morning on some annually-frequented mound or hillock, where they dance and spar, and show off their outspread tails as an attraction to the Greyhens sitting near their "playground." This

\footnotetext{
* Trans. Edin. Field Nat. Soc., 1904-1905, Vol. V., Part 3, p. 184.

$\dagger$ Game Birds, 1894, p. 58.
} 
performance, so admirably described by Mr. J. G. Millais,* takes place at an hour when most people are in their beds; which may perhaps account for the impossible yet deeprooted local ideas as to the mating of this species. Richard Bell records an instance of a Blackcock which showed extraordinary devotion to a dead Greyhen. For two months he "strutted round the remains, . . . until a circle six feet in diameter was 'paidled' quite bare round the place where they lay." + At this season of the year the Blackcock is in all his glory, and with lyre-shaped tail, glossy blue-black plumage and flaming cheeks, presents a very different picture to the tailless object kicked out of the bracken in the latter days of August. By October he is in better fettle again, and is sometimes deceived by a bright gleam or two of sunshine, to indulge in his spring antics. He struts about, uttering his " burrling" (as it is called locally) cry, in full enjoyment of amatory recrudescence, or "pseudo-erotism " $\div$; and this unseasonable performance is occasionally seen even in November and December. This " burrling" note, which at a distance, sounds like a curling-stone travelling on keen ice, I have often heard uttered within a few feet of me, and may be syllabled " terrar-terrar-terrar-terrar-techekikeka-terarto."

The Greyben's nest with its seven to twelve eggs, is but slight and is badly concealed on some grassy hillside ; and many eggs are destroyed by Rooks and Crows, which systematically quarter likely localities. My photograph of a Greyhen on her nest (here produced) was taken at Capenoch (Keir). Major W. McCall tells me of a Greyhen's nest in a tree near Glencairn. "The nest," he writes, "was thought to be an old one of an owl. It was on a spruce fir tree, about twenty feet from the ground. The bird laid nine eggs, seven of which came out. The nest was watched, and the day after the eggs were chipped it was found that two young birds had fallen

* Game Birds, 1894, pp. 69-79.

† My Strange Pets, p. 188.

† Bird-Life of the Borders, 1907, p. 208. 


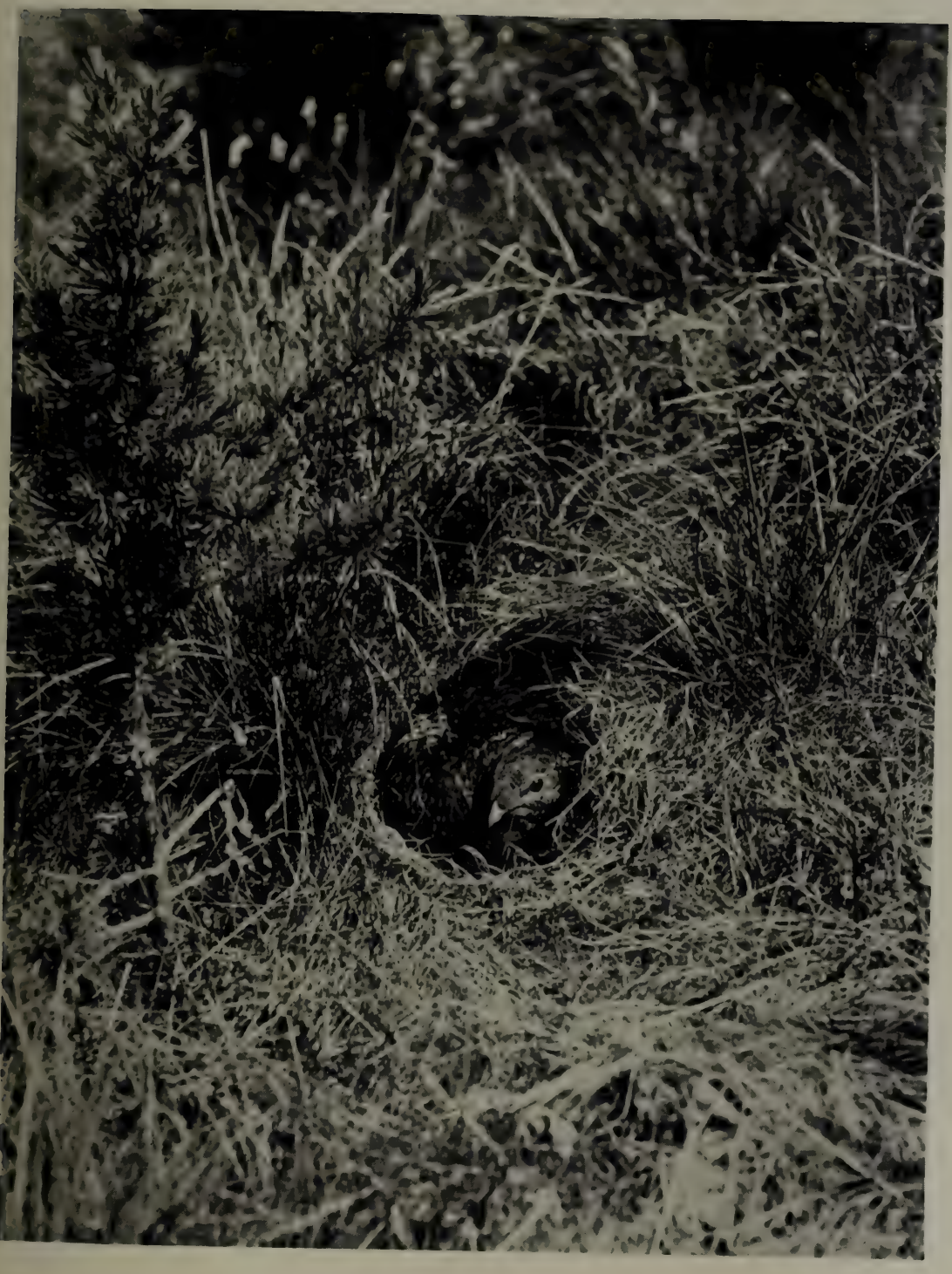

GREYHEN (Tetrao tetrix) ON THE NEST. 

out and been killed, so the nest was taken down and placed at the foot of the tree with the remaining five young birds in it, and it is believed the Greyhen took them away." Twenty-four days are required for incubation, and the chicks receive but little attention from their mother, a notoriously bad parent. At this period of their existence severe thunderstorms are most harmful, numbers of young Blackgame being drowned in the ditches and drains, which in but a few minutes become raging torrents.

On August 20th the young birds in many cases are not fit to shoot, and they remain with the Greyhen till the end of September. By October it becomes difficult to pick out a young cock of the year on the wing, though a Blackcock shot on November 7th, 1906, at Clonrae, resembled in plumage an average bird of September 1st. There are some brown feathers on the neck and head, however, until the second autumn-moult, and it is only with advancing years that the bluish-black plumage of the Blackcock attains its full metallic lustre. About September the two sexes separate, going about in flocks of from ten to fifty, or even more, where the species is sufficiently plentiful. Blackgame are essentially the birds of the "fringe of the moor," and may be found either in heather, in birch plantations, among
thorn bushes, or coming down to the farmer's 'stooks' of
corn, varying their habitat as the of diet. They do great damage to young conifers, especially Scots fir, nipping off the leading shoots with their strong bills; and I know of a larch plantation on Capenoch estate, which has been completely ruined in this way. In severe winters these birds may be found in unaccustomed haunts and nearer the habitations of man, driven down from the approach of spring they resort once more but on The following

The following note of an unusual habitat, from
Mr. P. A. Pasley-Dirom, is interesting. " think 1904, there was a is interesting: "One year, I 
on the Mount Annan part of Woodcockair, which is a thing I have never heard of at any other time."

In Northumberland the name 'Black' is still commonly used instead of Blackgame; and in a letter to P. J. Selby, Sir William Jardine writes in 1831: "I think we can now get some black when the snow drives them in."*

Variations in plumage are not common. Dr. Archbald includes in his "Account of the curiosities at Drumfriess" (circa 1684) "Black-cock, whereof Sir Rot. Dalyell hath one hanging in his Hall, which is white almost all over his body." $\dagger$ Sir Robert Dalyell lived at Glenæ (Tinwald). Sir William Jardine records a curious variety of a Greyhen in his collection which was shot in August (1828) by Sir Sydney Beckwith on the moors above Beattock Bridge, in Annandale. "The ground colour of the whole bird was a dusky yellowish white, paler on the underparts, with the dark markings of the feathers brown. When shot she had a brood of several young with her." $\ddagger$

Mr. Harting points out : "Most writers agree in describing the Blackcock as having white under tail-coverts, but they omit to state that these coverts are tipped with black markings which vary in size and intensity of colour with age, the older birds having darker tips and more of them."§ Mr. J. G. Millais considers that there are light and dark forms of plumage and writes: "In these very dark birds the tendency to melanism generally shows itself by the white feathers covering the vent being ribbed more or less broadly with black. One killed by John Sutherland, Lord Cawdor's keeper, had thick black bars across every feather under the tail." II The late Professor Alfred Newton wrote me in 1898: "It has long been known that the lower tail-coverts in Blackcocks are sometimes pure white, and sometimes spotted . . . but I am not aware that any one has found

* Sir W. Jardine, in litt. to P. J. Selby, November 4th, 1831.

$\uparrow$ Sibbald's MS. Collections, p. 228.

† Mag. Nat. Hist., 1829, Vol. II., p. 90.

§ Handbook Brit. Birds, 1901, p. 135.

II Game Birds, 1894, p. 104. 
anything to account for the variations. . . . I should be prepared to find that it was, in some instances at least, the effect of age ; only in that case I should expect from analogy that the black spots become smaller at each successive moult, and finally disappear. Analogy, however, is often very deceitful ... . such varieties in birds generally are far more common than most people suppose, because few look closely enough to perceive them." I have shot Blackcocks of all ages with spotted under tail-coverts, and the best specimen I ever saw, similar to that described above by Mr. Millais, was shot by Mr. D. Legard on September 27th, 1899, at Chanloch (Penpont) the bird apparently not being a very old one.

This species has been known to hybridise with other game-birds. I have been unable to trace a hybrid between a Pheasant and a Black Grouse said to have been shot at Craigdarroch (Glencairn) about 1888-1893. Two hybrids between a Red and a Black Grouse, labelled "Dumfriesshire, 1896," to be seen in the Tullie House Museum, Carlisle, were actually shot in Kirkcudbrightshire just over our boundary; but a hybrid between a Red Grouse hen and a Blackcock was shot, so Mr. J. Laurie informs me, in Kirkconnel parish in October, 1902, by Mr. John Martin of West Regent Street, Glasgow ; it is a very fine specimen and is still in the possession of that gentleman.

Greyhens assuming the plumage of the male are occasionally met with. John Shaw in 1842 wrote to Sir William Jardine of such a bird, and says he only once before saw another. A remarkably fine specimen of this abnormality from Arkleton (Ewes) is to be seen in the Royal Scottish Museum, Edinburgh, to which institution it was presented by Mr. W. Scott-Elliot in November, 1856 ; and Dr. J. W. Martin in 1901 records shooting three Greyhens in male plumage in one day in Glencairn.* One was shot at Auchanbrac (Tynron) by Mr. E. F. Penn on September 17th, 1902; and on October 21st of the same year I killed another at High Scaur (Penpont) which is now

* Trans. D. and G. Nat. Hist. Soc., December 13th, 1901. 
in my collection. A very beautiful dark bird with lyrate tail was shot near Langholm on November 15th, 1909 ; and, curiously enough, another specimen of a Greyhen assuming the plumage of the Blackcock was picked up on the same moor a few days later.*

Hand-rearing Blackgame, so far as my experience goes, is not satisfactory, and the experiment has been tried for many years, both at Drumlanrig and Capenoch, with indifferent success. In 1899 the few birds of both sexes reared at Capenoch were kept in an aviary, and the following spring one of the females laid eggs which were fertile. One chick hatched but died within a week, and some calamity overtook the old birds, all of which died that year at the autumn moult. This, I believe, is the first record of the species breeding in captivity, and conclusively proves that they can breed in their first year.

A curious instance of a brace of Blackgame having been knocked down by an engine on the railway near Thornhill, is recorded by the late $\mathrm{H}$. A. Macpherson. $\dagger$

THE RED GROUSE. Lagopus scoticus (Latham).

Local names-Grouse; Gorcock; Moorfowl; MoorCOCK ; Moorhen; MUIrcock; MuIrhen ; Red Game.

"Blyth August is come, and the sportsmen at morn Are waked by the watch-dog, the cock, and the horn; Switht off to the moors where the heathcock is whirring, The blackcock, the grey grouse, and plovers are stirring. The day is propitious, the scene is inviting,

The pastime is pleasant, the sport is delighting." JAMES KenNEDY.- "Epistle to Mr. Thompson."

A common resident on our moors and uplands.

In neither of the Statistical Accounts of Scotland is there any reference, as regards Dumfriesshire, to the

* Field, December 4th, 1909.

$\dagger$ Zoologist, 1883, p. 259.

$\ddagger$ Quickly. 


\section{BIRDS OF DUMFRIESSHIRE}

decrease of the Red Grouse, except in Closeburn, where, as was stated in 1794, "The moors in this parish used to abound with grouse."* In 1826 Grouse and Blackgame apparently commanded the same price, namely, four shillings to six shillings the brace.t

Sir William Jardine, writing in 1842, says: "The Red Grouse is still plentiful in Scotland and England, but is now more sparingly spread over the southern districts of the former; upon the moors it is well known that not a tenth of the former number of birds at present exist, and it is only in the more remote districts, where access and accommodation for sportsmen are still in some degree wanting, that they are to be seen in anything like their former numbers."

Those of us who shoot have probably pleasant recollections of short but sweet Grouse-drives off stubble-fields, particularly on wet or damp afternoons, when the 'stooks' seem to possess a more than usual attraction for the Grouse. It is, therefore, interesting to note that this habit of eating grain has been acquired in comparatively recent years: for in 1837 "W. L." states: "It was formerly believed that the Muirhen, as the female of the Redgrouse was called .... kept her young aloof from the haunts of men, and from all human cultivation; so neither would she approach his dwelling nor eat grain herself. That of old times this had been the case I make no doubt, because I well recollect when such a thing was unknown in this district, and this belief was corroborated by a proverb in ancient rhyme :"

"The Muirhen has sworn by her rough shin She salई never taste o' the carle's|| win. ๆ"

and the writer goes on to say that it is supposed that the

\footnotetext{
* Stat. Acct. Scot., Vol. XIII., p. 243.

$\dagger$ Dumfries Courier, September 26th, 1826.

\$ Nat. Lib., 1842, Vol. XII., p. 90.

$\S$ Shall.

|| Countryman's.

ๆ Harvest.
} 
Grouse learned this habit from the Blackgame about the year 1810* In the Dumtries and Galloway Courier of January 10th, 1837, we read of Grouse having attacked 'stooks,' and this is described as "somewhat unusual." Sir William Jardine wrote in 1842 : "The habits of the bird have considerably changed. By the approaches of cultivation to the higher districts, and by insulated patches of grain even in the middle of the wildest, the Grouse have learned to depend on the labours of the husbandman for his winter's food, and instead of seeking a more precarious subsistence, during the snow, of tender heath-tops or other mountain plants, they migrate to the lower grounds and enclosures, and before the grain is removed, find a plentiful harvest." $\dagger$ This practice of upland cropping has long since died out, and in the lowlands the harvest is usually too soon garnered to allow the Grouse to do much damage to it; the migration, therefore, of which Sir William writes can now only be considered an autumnal visitation.

In winter Grouse may frequently be seen perched insecurely in the thorn-bushes, seeking for any haws that may yet remain; and in very severe weather they pack together and are then occasionally found in strange localities, as in 1894-1895, when they visited and fed in the cottage-gardens at Wanlockhead in enormous packs.

An old rhyme referring to the great extent of moorlandproperty in the county owned by the Duke of Buccleuch, ran :

"If heather birns; were corn o' the best,

Buccleuch wad\$ ha'e a bonnie grist." II

and to-day there are few better beats than those in Eskdale belonging to him. Lord Henry Scott writes me: "We have frequently killed over three hundred brace of Grouse in the day on the Langholm moors in Dumfriesshire."

* William Laidlaw, Mag. Nat. Hist., 1837, Vol. I., p. 120.

† Nat. Lib., 1842, Vol. XII., pp. 90, 91.

$\ddagger$ Stems of burnt heather.

§ Would.

II The grain to be ground at the mill. 
It is to be regretted that on so many moors in the county the heather receives such little attention. In many cases the right of " burning" is relegated to the tenantfarmer, and the result, if beneficial to the sheep-stock, is disastrous to the heather-crop. The wonderful increase in the bracken (Pteris aquilina) of late years, is a matter which calls for the consideration of both sheep-farmers and gamepreservers, and more co-operation in its destruction would be to their mutual advantage.

The dark-red bird is the characteristic type of the county, but in plumage this species is subject to much variation according to sex, age, and season, varying from buffcoloured birds to plum-coloured individuals.

A peculiar pale grey Grouse was killed in 1887 at Dalswinton, so Robert Maxwell told Mr. R. Service; and at Dardarroch there is a pied Grouse which is believed to have been shot on one of the Glencairn Moors. A Grouse with white outer primaries was found dead on Strathmilligan (Tynron) in 1905; but such variations are repeatedly reported. Hybrids between this and the preceding species have occurred and have been already referred to (see p. 325). It was reported in the Field that a Red Grouse, shot in Dumfriesshire on August 20th, 1879, had the claws of all the toes considerably elongated, "but those of one foot were much more so than those of the other, the claw on the central toe measuring more than an inch and a half in length."*

The tests to differentiate between old and young birds, such as the ability or disability of the lower mandible when held by it to support the weight of the bird's body without breaking, or the absence or presence of blood in the quill of the third primary, or the blunt or pointed character of the first primary, are by no means infallible. Mr. W. R. Ogilvie-Grant writes me that he does " not believe that a young bird in the end of September or October can be distinguished from an old by plumage."

* Field, 1879, Vol. LIV., p. 287. 
The causes of the disease to which this species is from time to time subjected are still much discussed; and the Commission to inquire into the question has as yet only issued an interim report. The germs of disease, we are told, are always present in all birds, and the outbreak is believed to occur when their condition has become lowered, as by lack of food. Grouse feed all day, and their food-supply is a vital question. Since they do not eat what is known as "frosted" heather, their food-supply becomes diminished when it gets into this state, and they therefore fall off in condition. It may here be noted that this "frosted" appearance of the heather is due not to frost but to the attacks of the larvoe of a small beetle (Lochmoea suturalis).* February and March are the least well provided months, and should a moor be overstocked it cannot then produce a sufficiency of food for the abnormal numbers of birds, whose health suffers in consequence. Under these conditions disease may break out; the infected birds become more sluggish, their plumage appears duller, and they frequently leave the moors for the grass-fields. The cocks succumb in spring; the hens after incubation in late summer; each, it will be observed, " at the time when it would be expected that their vitality and power of resistance would be at its lowest, and when any shortage of food would be most felt." $\dagger$ Dumfriesshire does not appear to have suffered as extensively from disease as many other counties (though a bad outbreak in May, 1852, is recorded), and this may be attributable to the fact that our moors are seldom allowed to get overstocked. There is a local idea that the ups and downs of good and bad seasons are contained in a cycle of seven years. Late frosts and early summer "thunderplumps" do much to deprive us of these good seasons, and the protection of the nests and eggs themselves demands a constant war against the Crows, and nowadays the Rooks as well.

* Ann. Scot. Nat. Hist., 1898, p. 27.

$\dagger$ Grouse Disease Inquiry. Interim Report, August, 1908. 
"Mabie Moss" in 1899 thus describes a very curious clutch of Grouse eggs : "They were five in number, and all were so small as to be barely recognisable as Grouse eggs at all. One of them was quite white in colour, the others were normal in colouration, although two of them are rather darker than usual in the shade of deep umber brown. The largest was only $1 \frac{18}{16}$ in. in length by $\frac{5}{8}$ in. in breadth, while the smallest only measured $\frac{13}{16}$ in. long by $\frac{5}{8} \mathrm{in}$. in breadth, the others being intermediate in size. The two of which I give the measurements are comparable in dimensions to a Blackbird's and a Hedge-Sparrow's egg respectively. I have seen at times single eggs of the Grouse similarly diminutive, but a whole clutch of such is something quite unexpected. Ovarian exhaustion or disease may be set down as a reason for this interesting aberration."* An egg, now in my collection, taken at Kilmark (Tynron) on May 8th, 1906, from a normal clutch, measures 1.50 by $1 \cdot 12$ inches, and it was observed that for the remainder of the clutch twenty-four days were required for incubation. Seebohm states that the eggs of the Grouse "are not subject to much variation; they are usually 1.75 inch in length and 1.32 inch in breadth, and of an almost uniform oval shape, the smaller end being scarcely more pointed than the larger one." $\dagger$

THE PTARMIGAN. Lagopus mutus (Montin).

\section{A former resident.}

The Ptarmigan was formerly a resident in the highest and most mountainous parts of the county, but it is difficult to ascertain whether it was ever numerous.

* Kirkcudbright Advertiser, August 22nd, 1899.

† Col. Figs., Eggs Brit. Birds, 1896, p. 272. 
Possibly it is the Ptarmigan which is referred to in a description of Tweeddale, ${ }^{*}$ printed in the text of Blaeu's Atlas, and of which I give a translation. The author is unnamed, but is presumably Sir John Scott of Scotstarvet, who seems to have written his contributions to the Atlas about 1645 :-

"In this district are many mountains, of which very few or none are rocky; the following are bigger and higher than the rest, 'the Hill of Stags,' commonly called Hartfiell $\uparrow$; ' the Broad Hill of the Stag's Stone,' commonly called Braidalb, $t$ of Hertstone, which is remarkable, among other things, for the great quantity of wild birds upon it, especially . atagenarum $\S$. spotted with white, and of most delicious flavour."

Such an observation is rendered highly probable, since in 1684 we read that in Galloway " there are plenty of Moor fowls, Partridges, Tarmakens, etc.|l" ; about the same period it is recorded of Minnigaff parish (Kirkcudbrightshire): "In the remote parts of this great mountain [? Lamachan Hill, 2,349 feet] . . . and about the top thereof, that fine bird, called the Mountain Partridge, or, by the commonalty, the Tarmachan, about the size of a Redcock, and its flesh much of the same nature ; feeds, as that bird doth, on the seeds of the bullrush, and makes its protection in the chinks and hollow places of thick stones

* “Multi sunt in hac provincia montes, quorum pauci admodum aut nulli saxosi ; magnitudine autem et altitudine præ ceteris eminent, Cervorum Mons, vulgo Hartfiell; Latodunum Cervini Lapidis, vulgo Braidalb of Hertstone : hunc inter alia commendat magna copia ferarum avium, præsertim atagenarum albis maculis interstinctarum, saporis delicatissimi." Theatrum Orbis Terrarum, 1662, p. 34.

$\dagger$ Now called Hartfell, 2,651 feet, in the parish of Moffat.

+ Now call Broadlaw, 2,754 feet; in the parish of Tweedsmuir, Peeblesshire. The Gaelic alb or alp (like the Anglo-Saxon law) means a mountain or hill. Hertstone is the modern (1910) Hearthstane, a farm extending up on to Broadlaw.

$\S$ The impossibility of assigning any precise meaning to the word atagen (or attagen) is made clear by Lord Lilford in the Ibis, 1862, pp. 352-356.

If A Large Desc. of Galloway, p. 79. 
from the insults of the eagles which are in plenty."* In 1793 it is reported from Sanquhar that " a covey, or rather part of a covey of Ptarmigans, among common grouse, a few years ago, was discovered upon the hills, which was considered a curiosity." $\dagger$

In 1823 it is stated: "An individual in Sanquhar obtained last season no fewer than ten brace of Ptarmigans, which were eagerly purchased by stuffers and persons curious in ornithology." $\ddagger$ At a later date from the same source we learn that during the tremendous snow-storm of 1822 " three or four brace of Ptarmigans were killed somewhere above Sanquhar, although the opinion had become prevalent that not one of these birds existed among the highest hills of Dumfriesshire. Some of the Ptarmigans were sent to our townsman Mr. Shanks to be stuffed."§ The two records above, probably refer to the same incident, and the discrepancy between the numbers is remarkable. $\mathrm{Mr}$. R. Service, who has dealt exhaustively with all that is known of this species in the Solway area, writes in 1887: "I have failed to discover any trace of the person who captured the birds above Sanquhar; but the gamekeeper at Wanlockhead, who has been fifty years a keeper in the district, says he had heard that some Ptarmigans in the Dumfries Museum were killed near Wanlockhead. The museum was established in 1835 , but the catalogue of the contents, printed in 1843 , does not mention any Ptarmigan. There were two old specimens in the museum, however, that had been there for over forty years. It is a painful reflection to me to know that these were thrown on the rubbish-heap by myself three or four years ago, being then so much moth-eaten and moulded, owing to a long course of neglect, that they were hardly recognisable as Ptarmigans.

* A Large Desc. of Galloway, p. 134.

$\dagger$ Stat. Acct. Scot., Vol. VI., pp. 459, 460.

† Dumfries Courier, August 26th, 1823.

\& Op. cit., February 21 st, 1826. 
I am convinced from inquiries made into their history, that they were really two of the birds captured near Sanquhar in 1822."* That these birds should have been obtained in the tremendous snow-storm of 1822 does not necessarily prove that at this time they were residents ; these individuals may have been forced down from more northern habitats by the unusually severe weather.

H. A. Macpherson writes: "The remarks of Mr. Service regarding local specimens of Lagopus mutus in the Museum at Dumfries reminds me that one or more specimens exist in the Carlisle Museum. I therefore wrote to Mr. W. Duckworth suggesting that the Carlisle birds were probably from Dumfriesshire, and asking him to refer to the Old Museum Catalogue, with a view, if possible, to trace their history. This he has kindly done, and finds that three specimens of $L$. mutus (two in summer and one in winter dress) were included in a series of birds presented many years ago by Mr. J. D. Murray of Murraythwaite, Dumfriesshire. In all probability these were local birds; at least the presumption is favoured by the facts which Mr. Service has recently set forth in connection with his own district." $\dagger$ As regards these latter birds, Mr. W. Murray of Murraythwaite writes me in 1908 that his grand-father frequently shot in the north of Scotland, and it cannot be regarded as proof that these were locally-obtained specimens, simply because they were presented to the Carlisle Museum by a local gentleman.

A hybrid between a Red Grouse and a Ptarmigan, stated to have been shot on August 18th, 1823, by Mr. Murray of Broughton, + is said to have been obtained in Kirkcudbrightshire between Cally and Cairnsmore; and therefore cannot, whether authentic or not, be claimed as a local specimen.

John Lewars (the Exciseman, one of Burns' friends, and

* Zoologist, 1887, pp. 81-89.

$\dagger$ Op. cit., 1887, p. 194.

¥Dumfries Courier, August 26th, 1823. 
whose daughter Jessie was one of the poet's heroines), is reported, in 1826, to have had "a brace of young Ptarmigans alive and so tame that they run about the doors like domestic fowls. These birds were brought, we understand, from the English side, and were probably hatched on the top of Skiddaw."* H. A. Macpherson in his Vertebrate Fauna of Lakeland refuses to recognise these birds, remarking that this story is " not only of uncertain authorship, but is too wildly improbable to stand in need of serious refutation." $\dagger$ But he subsequently told Mr. R. Service that after all there might "perhaps be something in it." In 1834 it is reported from Moffat that "Ptarmigan are very rarely seen," $\ddagger$ and in 1842 Sir William Jardine thus sums up the distribution of this species in Great Britain : "Its only habitation now, seems to be in the high mountain ranges in the middle of Scotland, increasing in abundance as the same kind of wild country reaches to the north; and it also extends to the Hebrides. According to Pennant, and some contemporary writers, these birds were once found on the hills of Westmoreland and Cumberland; and, we believe, recollections even exist of a few having been seen upon the high ranges which appear on the opposite border of Scotland. These have been for some time extirpated, and unless a few solitary pairs remain on Skiddaw, or some of its precipitous neighbours, the range of the Grampians will be its most southern British station."§ "The high ranges " here referred to "on the opposite border of Scotland" are presumably the Moffat Hills.

An attempt about 1847, by the late Duke of Buccleuch to re-introduce Ptarmigan on his moors near Sanquhar failed, it is believed, because of a sequence of mild winters, and

* Dumfries Courier, January 1st, 1826.

$\dagger$ Fauna of Lakeland, 1892, p. 334.

$\ddagger$ New Stat. Acct. Scot., Vol. IV., p. 108.

$\S$ Nat. Lib., Vol. XII., 1842, pp. 94, 95. 
Dr. Anstruther Davidson states that they hatched out successfully, "found their wings and departed."* It is to be hoped that the introduction of the species to Cairnsmore in the neighbouring county, by the Duchess of Bedford, will meet with more success. Mr. Richard Roy informed Mr. R. Service in 1887 that Mr. James Marchbank saw some Ptarmigan at the head of Fruid Water near Moffat in 1846 or 1847. Is it possible that these were some of the introduced birds from Sanquhar?

The Ptarmigan is only found in the higher mountains from the vicinity of Ben Lomond northwards. Outside the British Isles the species inhabits the 'fjelds' of Scandinavia and Finland above the limit of tree-growth, the Kola Peninsula and the Urals; it is also found in the Alps, Tyrol, Styria, Carinthia and the Pyrenees; across Siberia, in the higher mountains to Kamchatka and down to the Altai. $\dagger$

THE PHEASANT. Phasianus colchicus (Linnæus).

Local name-FAISAN.

" Lo ! from yon brake on whirring wings, Roused by the finely scented hound, The painted pheasant proudly springs, But feels, alas ! the flying wound :He wheels around in many a mazy flight, Till, spent, he drops from his aerial height."

Nithsdale Minstred-" To the fall of the Leaf."

A common resident in the woodland and arable districts.

This species seems to have been introduced to this county towards the end of the eighteenth century, for it is reported

* Hist. Sanquhar, pp. 31, 32.

$\dagger$ Man. Brit. Birds, 1899, p. 498. 
from Langholm in 1794 that some Pheasants "sent by the Duke of Buccleuch from Dalkeith some years ago, are increasing in the woods. Some of them have been shot twenty miles distant from their first settlement;"* and in $\mathbf{1 7 9 5}$ it is stated that " they frequently make their appearance in Canonbie." $\dagger$ Dr. Singer in 1812 says: "The common Pheasant now appears in the Duke of Buccleuch's estate in Eskdale, and if it escapes from foxes and other beasts of prey it may increase." $\ddagger$ Apparently it did escape from the " beasts of prey," for it is recorded circa 1835 as found in great numbers in Westerkirk, $\S$ and very abundant, in Ewes.|| Sir William Jardine, writing of the birds of the parish of Applegarth and Sibbaldbie in 1832, says that the Pheasant was "introduced here about ten years ago, and is now tolerably abundant." From Ruthwell the report comes in 1834: "Various kinds of pheasants have within a very few years been introduced to these [Comlongon] woods, where they were increasing rapidly so long as they were protected, but during the last year their numbers have been greatly
diminished by poachers." $* *$

Of the present status of the species there is no need to write at length. On many estates the hand-reared birds may be said to exist in a state of semi-domestication; and the Pheasant, being a hardy bird, as well as prolific and a great wanderer, may be justly suspected of seriously competing for existence with the Blackgame on the outer edge of our arable districts. Pheasants turn up in the most unexpected places nowadays, and are often shot in a Grousedrive at long distances from any covert.

Abnormalities in plumage are of common occurrence,

* Stat. Acct. Scot., Vol. XIII., p. 579.

† Op. cit., Vol. XIV., p. 413.

† Gen. View of Agriculture in Dumfries, p. 451.

§ New Stat. Acct. Scot., Vol. IV., p. 431.

\| Op. cit., Vol. IV., p. 438.

Tा Op. cit., Vol. IV., p. 180.

** Op. cit., Vol. IV., p. 220. 
ranging from pure white and speckled specimens, to innumerable minor varieties, the latter being doubtless attributable to constant importation of nearly-allied species such as the Mongolian ( $P$. mongolicus) and Japanese ( $P$. versicolor). "Black-necked" individuals (the true $P$. colchicus) may be regarded as extinct since the introduction of the Chinese Ring-necked Pheasant ( $P$. torquatus), and the so-called "Bohemian Pheasant" is but a pale lavender variety. Females assuming the plumage of the male are of fairly common occurrence, and often pass unnoticed. So long ago as 1842 John Shaw wrote to Sir William Jardine from Drumlanrig: "We have abundance of hen Pheasants at this moment in our woods exhibiting the plumage of the cock."

A cross between this species and a Black Grouse has already been noticed (see p. 325), and a fine hybrid cock between a Pheasant and a farm-yard fowl was obtained at Raehills early in 1888. Silver-Pheasants (Euplocamus nycthemerus) were kept at Capenoch in 1901, and bred readily with the common species; but the produce were not fertile, and the same may be said of the Pheasant and Golden Pheasant (Chrysolophus pictus) hybrid.

Pheasants' eggs vary in coloration from olive-brown to pale blue, and " in size from 1.9 to 1.75 by 1.45 to 1.35 inch" but I possess eggs 2.2 by 1.5 , and 1.0 by 0.8 inch. The following extract from the Ibis may be worth quoting here : "During the spring of 1903, when picking up Pheasants' eggs which had been laid in precarious places, such as the sides of roadways or near human habitations, I happened to weigh some of them, and was at once struck by the variation in their weight. Thinking that this variation might be caused by the length of time the eggs had been incubated, I had ten newly laid eggs from ten different hens marked, and weighed them every fourth day, with the following results.

"I reckoned 27 grs. $=1 \mathrm{dr}$.

* Col. Figs., Eggs of Brit. Birds, 1896, p. 275. 


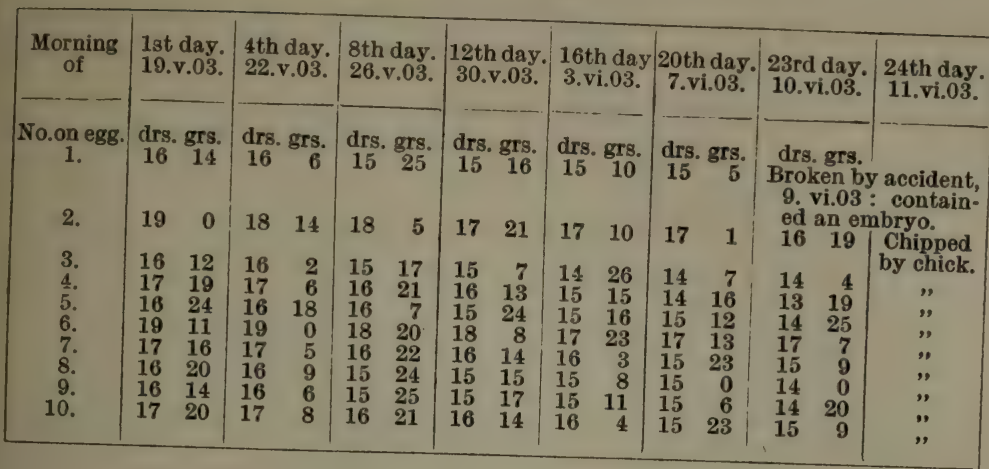

"This proves that a general decrease in the weight of eggs took place whilst incubation was proceeding, the following table shewing the average decrease every fourth day:- "*

\begin{tabular}{|c|c|c|c|}
\hline $\begin{array}{l}\text { Variation in weight } \\
\text { from first day. }\end{array}$ & & & A verage Weight. \\
\hline $\begin{array}{l}\text { grs. } \\
-10 \\
-21 \\
-21 \\
-30 \\
-40 \\
-49 \\
-66\end{array}$ & $\begin{array}{ll}\text { First day. } & \\
\text { Fourth day } & \because \\
\text { Eighth day } & \because \\
\text { Twwelfth day } & \because \\
\text { Sixteenth day } & \because \\
\text { Twentieth day } \\
\text { Twenty-third day }\end{array}$ & $\begin{array}{ll}\because & \because \\
\because & \because \\
\because & \because \\
\because & \because\end{array}$ & 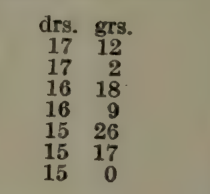 \\
\hline
\end{tabular}

As an erratic nester the Pheasant has no equal, which cannot be wondered at, if we remember how domesticated this species has become. Eggs have been found in the nests of the Partridge, Greyhen, Mallard and Woodcock, while a squirrel's disused drey, and the old nest of a Wood-Pigeon, both several feet from the ground, may be recorded as proof of the versatility of the hen Pheasant in its choice of a nestingsite. In 1902 a nest was discovered at Capenoch by the side of a rabbit-proof wire-netting fence : visiting the nest next day it was found that the bird had moved all her ten

* Hugh S. Gladstone, Tbis, 1904, p. 376. 
eggs through the netting (they could only just pass through the mesh), and was sitting on them in a new nest on the opposite side of the fence.

As regards the utility of the Pheasant, Mr. Fred. V. Theobald states: "Some farmers complain of Pheasants and Partridges. Certainly the former scratch up some seed-corn and cause minor inconveniences, but the complainers must not forget that they do an enormous amount of good by destroying various grubs, and those who preserve the same are doing more good than harm to the farmers, as well as providing themselves with sport. Game birds may well be protected, not only from the sportsman's point of view."*

The subject of "record bags" is not here considered, as it is obviously only a question of how many hand-reared birds are turned out; but it is improbable that finer coverts for "showing" Pheasants can exist than are to be found round Drumlanrig.

When shooting the Capenoch coverts on October 26th, 1904, a hen Pheasant was shot as it came over some spruce trees about forty feet high. It fell dead on to a hare breaking covert, between two of the guns. The hare appeared seriously hurt, staggering as it ran, and having run about fifty yards, fell over dead. The swimming powers of the Pheasant have often been noted, usually in the case of wounded birds, but when shooting on November 12th, 1909, I was astonished to see a hen Pheasant alight at the edge of Scaur Water, walk into the river and then swim leisurely across.

In Dumfriesshire it has always been the variety of the bag that has rendered sport so enjoyable, and it is to be hoped that some of the attention and expenditure now lavished on Pheasant rearing may be diverted before too late towards more fitting species, such as the Black Grouse and Partridge.

* Science Progress, 1907, Vol. II., pp. 281, 282. 


\section{BIRDS OF DUMFRIESSHIRE}

\section{THE PARTRIDGE. Perdix cinerea, Latham.}

\section{Local names-Paitritch ; Paitrick.}

"The Partridge, too, and her light-footed brood, As yet half fledged, now haunt the corn field skirts, Or on new-weeded turnip fields are spied, Running in lengthened file between the drills." James Grahame. "British Georgics" (August).

A common resident in the arable district.

In both the Statistical Accounts of Scotland we find references to the abundance of the Partridge in many parishes; and in 1812 Dr. Singer writes: "Partridges are numerous in most parts of this county."* In 1826 they fetched twelve to fifteen pence a pair, as compared with the four to six shillings demanded for a brace of Grouse or Blackgame. $\dagger$

Nowhere in the county is this species now more plentiful than in lower Eskdale, and Lord Henry Scott writes me in 1908: "We have frequently got over 100 brace of Partridges at Langholm in a day; over 150 brace one day in 1887." Elsewhere in the lowland districts it is questionable if they are as plentiful as they were, and in the upper districts the diminution of cropping has caused an exodus, or at any rate a disappearance, of what was once a familiar bird half a century ago.

Mr. Abel Chapman writes: “The true fell-partridge (by which is meant those that have seldom or never seen corn for generations) differ in plumage from their relatives of the stubble in having the chestnut-red colours on head, scapulars, and flank-feathers distinctly paler and less vivid. The whole colour-plan has, moreover, a pale ashen-grey cast

\footnotetext{
* Gen. View of Agriculture in Dumfries, p. 451.
}

$\dagger$ Dumfries Courier, September 26th, 1826. 
that recalls the partridges exposed for sale in game-shops in spring, and said to come 'from Russia.' These hill-partridge weigh-cocks, 13 to 15 ozs.; hens, 12 to $13 \frac{1}{4}$ ozs."* I well remember some fifteen to twenty years ago finding such birds frequenting the little cultivated patches near the shepherds' houses, at the heads of our valleys. Recently I have seen none in these localities, and writing of central Nithsdale, the part of the county with which I am most intimate, I am sure $I$ am right in saying that of late years our stock of Partridges has diminished. Hungarian importations have been tried, but without benefit; indeed, one of my neighbours considers that they brought with them some novel disease, and dates the decrease of the species from their introduction! A succession of unfavourable springs has been unfortunate, and there is a growing tendency to lay out less and less land in crop, so that the natural food-supply of the Partridge has decreased. Pheasants being more and more encouraged, the ground is unable to carry both species and our Partridges are in danger of being starved out.

H. A. Macpherson states that on the continent the Partridge " is probably a more decided migrant, or semi-migrant, than in our ccuntry, since it is exposed to greater extremes of heat and cold, whilst its movements are hampered only by such imperfect barriers as mountain ranges or great rivers present. Even in Britain the partridge is a quasi-migrant, since coveys frequently perform short journeys-as, for example, across the Solway Firth. In this case the birds are apparently shifting from the slopes of the Dumfriesshire hills to the well-cultivated lands of the Cumbrian plain. ..." $†$ The two sexes in maturity are readily distinguished by the feathers forming the wing-coverts and scapulars. In the female these are barred horizontally with buff, whereas in the male these feathers are not barred, the buff coloration extending only longitudinally in a narrow stripe on either side of the shaft. During their first season the young may

* Bird-Life of the Borders, 1907, p. 194.

† The Partridge, 1893, p. 8. 
be distinguished from the old birds by the pointed character of the first primary; and in the earlier part of the season the legs and feet of immature specimens are yellowish-brown, as compared with bluish-grey in the adults.

Albinism in this species is not common, but a pure white Partridge is recorded as obtained locally in 1884.*

In defence of their young the parents are most anxious, fluttering along the ground with assumed broken wing, and doing all in their power to attract the attention of the disturber from their precious offspring; a pair have been seen to keép a Kestrel at bay, while their young made good their escape.

The eggs are usually laid in May or even June, and incubation lasts twenty-four days; but in 1822, the weather being extraordinarily mild, a covey of young Partridges was seen on the estate of Murraythwaite in April. $\dagger$ In August, 1812, a fowl and a Partridge are reported as sharing a nest together near Waterbeck (Middlebie). $\ddagger$ A female Partridge hand-reared at Capenoch in 1906, consorted with the keeper's fowls, with which it regularly roosted, perching like them on the branches of some young spruces.

A terrible monstrosity is thus recorded in 1812: "A few weeks ago in the Parish of Kirkconnel near Sanquhar there was found in a Partridge's nest, a young Partridge with two distinct bills, three eyes, one of which was in the centre of the head, four wings, and four legs. The young bird was alive when found, but is since dead. It is now in the possession of Mr. Thomson, surgeon in Sanquhar, who has preserved it as a curiosity." $\$$

Hybrids of this species, I believe, are unknown; and the story from Langholm Lodge in 1822 that " one of a brood of young Partridges brought up under a barndoor hen,

\footnotetext{
* Trans. D. and G. Nat. Hist. Soc., November 7th, 1884.

$\dagger$ Dumfries Courier, June 11th, 1822.

\$ p. cit., August 11th, 1812.

$\S O p$. cit., July 14th, 1812.
} 
mated with a common cock and brought up thirteen young ones in the result*, is highly improbable."

[Eggs of the Red-legged Partridge(Caccabis rufa (Linnæus)) sent to Capenoch from Norfolk in 1906 took twenty-four days to hatch under a fowl, and a covey of twelve birds was reared. These were most unfortunately all shot except one, which, however, stayed on the beat all the winter and the following spring, before disappearing. The species is only here included, to record the fact that the attempted introduction of 1906 thus failed.]

[An adult male of the Chukar Partridge (C. chukar (Gray)) shot by me at Bierholm (Keir) on January 20th, 1894, must undoubtedly have been an "escape."]

\section{THE QUAIL. Coturnix communis, Bonnaterre.}

Local name-WEET-MA-FEET.

A very irregular summer-visitor, formerly more regular if not annual in its visits.

The only local reference to this species in the Statistical Account of Scotland, is from Kirkmichael, 1791, where it is included in a list of birds of that parish. $\dagger$ From the way in which the species is mentioned by William Bennet in his Traits of Scottish Life and Pictures of Scenes and Character, the Quail would appear to have been a common bird in Glencairn $\ddagger$ about 1830. Sir William Jardine, writing of the birds of the parish of Applegarth and Sibbaldbie in 1832, says that the Quail " is occasionally met with in September and October at the time of migration. In 1819 they bred

* Dumfries Courier, July 23rd, 1822.

$\dagger$ Stat. Acct. Scot., Vol. I., p. 60.

† Traits of Scottish Life, 1830, Vol. III., p. 183. 
here and produced large bevies."* In his Natural History of Game Birds (1834) Sir William writes: "Thirty years since they were tolerably common and regular in their returns ; and even in the south of Scotland a few broods were occasionally to be found. ... In these same districts they are now very uncertain; we have known of broods only twice, and occasionally have shot a straggler apparently on its way to the south. They are extremely difficult to flush after the first time. The nest is made by the female, but, like the partridges, the eggs are deposited almost on the bare ground; these, also, unlike the uniform tint which we find prevailing in those of the true partridges, are deeply blotched with oil-green, and, except in form, are somewhat similar to those of the snipe." $\dagger$ In 1835 it was reported that Quail had been seen at Lochmaben + ; and Sir Emilius Laurie of Maxwelton tells me he shot a Quail on Braco Farm (Glencairn), about 1838.

Writing in 1842 Sir William Jardinedescribes the plumage of this species in his Naturalist's Library from a specimen shot at Jardine Hall in autumn, $\S$ and in the Catalogue of the Birds contained in the collection of Sir William Jardine are recorded two specimens of " $C$.dactylisonans," one from Murraythwaite and the other from Jardine Hall. On September 29th, 1847, "there was found on the estate of Trailflat, in the Parish of Tinwald, a brood of Quails, a very unusual circumstance indeed, in this part of the country. Our informant, who killed three, says that he has shot there for twenty years, and during that period never saw more than one at a time." John Wilson, of Billholm, shot a Quail on the Castle O'er property in Eskdalemuir in 1847. 1 On April 25th, 1848, four of these birds, "now very rare in this quarter," were

* New Stat. Acct. Scot., Vol. IV., pp. 180, 181.

$\dagger$ Nat. Lib., 1834, Vol. IV., pp. 106, 107.

‡ New Stat. Acct. Scot., Vol. IV., p. 382.

\$ Nat. Lib., 1842, Vol. XII., p. 108.

II Dumfries Courier, October 5th, 1847.

I Op. cit., October 18th, 1853. 
flushed in a nursery in the vicinity of Dumfries.* In February, 1849, it was reported that Mr. Wilson, of Hunter House Lodge (Tinwald) had captured a Quail " about three months ago " and had kept it in a cage ever since. $\dagger$ One was shot on October 15th, 1853, on Graham Bell's property of Castle O'er (Eskdale) by John Wilson of Billholm, who had only previously seen one other in the district. W. S. T[horburn] wrote in 1857: "I have lately been informed by a gentleman who is the proprietor of a portion of Lochar Moss that fifteen years ago (say 1842) not an individual of this species was to be seen on the Moss. Since that time two or three pairs arrived yearly, until recently he has observed that the number of immigrants has increased. From 1853 to 1856 the piping of the Quail was regularly heard, and several individuals were seen, and in the summer of 1854, in cutting a field of grass, a mower came upon a nest containing about a dozen eggs, with the bird crouching close to the ground," and the account goes on to say that she " eventually hatched her brood, a numerous family." $\$$ The same writer later states: "I have again the pleasure of informing your readers that this year (1857) another brood has been seen. . . . If undisturbed they are sure to return, and I trust we may be able to class them among our common species.'"I A Dumfries correspondent of the Naturalist in January, 1854, writes of the Quail as "seen lately as a winter visitor; very rare." I

Mr. R. Armstrong informs me that he has in his possession an egg given him by Dr. Grierson, which is marked on the shell "Blackwood, 1864," and which in all probability was taken in Keir parish. Mr. John Dalzell writes me in 1908 that the first Quail he saw was one shot by his father

* Dumfries Courier, May 2nd, 1848.

+ Op. cit., February 6th, 1849.

$\ddagger$ Op. cit., October 18th, 1853.

$\S$ Notes for Naturalists, p. 70.

II Op. cit., p. 107.

II Naturalist, 1854, Vol. IV., p. 51 
in the parish of Middlebie, about forty years since. It is stated in 1885 that "fifteen years ago a pair frequented the fields near Barkerlands "* (Dumfries), while in 1873 a Quail was seen in the parish of Mouswald. $\dagger$ In 1877 about fifteen Quail were imported from abroad and turned down near Sanquhar, but they soon disappeared, and a similar experiment at the same time to introduce the species at Drumlanrig also failed. Mr. J. Harkness informs me that he only once saw one in the flesh, and that it was shot near the Lochar (Torthorwald) by one of Colonel Salkeld's keepers about 1881. I am informed by Mr. John Dalzell that in 1883 he saw four, apparently two old and two young, on the Hoddom Estate.

In the fine season of 1893 this species put in an appearance in unusual numbers. "They suddenly descended on all the fields of rye grass between Cumnock and Annan, and no one could understand what their peculiar calls were, until the mowers discovered their nests." + A pair were identified in a field near Amisfield Station (Tinwald), and shortly afterwards one was picked up on the railway line there that had apparently been killed by flying against the telegraph-wires. In some parts of Lochar Moss birds of this species were noticed, and others on a farm in Dunscore. $\S$ Mr. R. Armstrong informs me that he heard them that year in the hayfields at Kirkbog (Closeburn), and Mr. John Corrie states that Glencairn was visited by a pair of these birds during the month of June. When first heard they were quartered in a rather bare pasture-field, but they subsequently settled down in a field of corn quite close to the village of Moniaive, and he adds: "Here they remained until the beginning of September. That they remained to nest is almost certain, but harvest is late in Glencairn, and by the time a search for the nest was possible

* Trans. D. and G. Nat. Hist. Soc., December 4th, 1885.

† Field, 1893, Vol. LXXXII., p. 597.

$\ddagger$ Trans. D. and G. Nat. Hist. Soc., April 20th, 1905.

$\S$ Dumfries Courier and Hercild, August 10th, 1893. 
the young had flown ... For half a century they have been unknown."* On October 3rd of the same year, a solitary Quail was shot on Mr. Paterson's estate of Brocklehirst (Mouswald), as recorded in the Field, and the correspondent adds: "It was in good condition, and the keeper, who has lived in the district all his life, said it was just twenty years since he had last seen one." $\dagger$

Mr. R. Service records : "Early in August, 1896, a nest of eight eggs of the quail was uncovered while mowing down the corn at Rockhall (Mouswald), and two of these eggs were shown me by Mr. Irving. I also understand that, judging from the calls, there must be several pairs of these birds in that vicinity, and in the adjoining parts of Lochar." $\ddagger$ Mr. N. Menzies tells me he saw a Quail at Craigenputtock (Dunscore) at the end of August, 1899. Mr. J. E. Steel believes he heard these birds calling in Glencairn in 1905 , and a bird of this species is said to have been seen on the Hoddom Estate in 1906. Major Critchley writes me that he remembered years ago seeing a brood of Quail near Springfield (Gretna) and the Rev. W. McDowall informs me that he has been told of their occurrence in Kirkmahoe parish, but that he has not seen them personally.

Such are the records that $I$ have been able to obtain of the appearance of the Quail in this county ; many of the dates have been supplied by my correspondents from memory, and may therefore be unintentionally inaccurate; could they be adjusted it would probably be shown that marked visitations occurred at intervals of several years.

The Quail in summer is found in Europe as far north as lat. $65^{\circ}$, and it ranges widely through temperate Asia, while some remain in North Africa; it is at this season that it visits parts of Great Britain. In winter a considerable number sojourn in the countries bordering the Mediterranean,

* Trans. D. and G. Nat. Hist. Soc., February 16th, 1894.

† Field, 1893, Vol. LXXXII., p. 597.

† Dumfries Courier and Herald, September 7th, 1896. 
though the majority pass on and are found in Africa as far south as Cape Colony.

[The VIrgInIaN QuaIL (Ortyx virginianus, Linnæus) was introduced to this county at Drumlanrig in 1858 by John Shaw, head-gamekeeper to the Duke of Buccleuch. They were liberated on the " big holm," west of Nith Bridge, but soon disappeared; one was killed in Kirkcudbrightshire, and the species never became established. It is generally distributed throughout North America, and, being purely an introduced species to this county, is only mentioned as such.]

THE LAND-RAIL. Crex pratensis, Bechstein.

Local name-CoRN-Crake.

"... now at ove is heard

The corn craik's harsh, yet not unpleasing call,

Oft pausing, still renewed from place to place.

Vain all attempts to trace her by her note;

For, when the spot whence last it came is reached,

Again 'tis heard hoarse-harping far behind-

Till silenced by the mower's rasping stone."

JAMES GRAHAME. - "British Georgics"” (May)

A summer-visitant, in some seasons more numerous than in others.

Sir William Jardine writes of the Land-Rail : "In the vale of the Annan, in the south of Scotland, ten years since, the bird was extremely common, its note being heard in almost every alternate field; at the present time, it may almost be accounted rare; during the last summer (1841) only one or two pairs being heard within a stretch of several miles."*

In some years this species appears in far greater numbers than in others: thus in 1891 it was very numerous in Upper

* Nat. Lib., 1842, Vol. XII., pp. 331, 332. 
Nithsdale ; in 1902 the scarcity of Land-Rails was remarked*; in 1907 they were abundant in our vicinity, but there were comparatively very few in the following year.

In the date of its annual immigration it seldom deviates more than a couple of days on either side of April 29th, though its appearance in our uplands is a few days later than on the coast. Mr. William Wright informs me that in 1908 , he was sent the wings of one that had been killed by the telegraph-wires on the Carlisle and Annan Road, at the beginning of April. Such an early date, however, suggests some error in identification, and as this species seldom arrives even in the southern counties of England before the last ten days of April, Mr. Wright's statement cannot be admitted without comment. By the middle of September most of our Land-Rails have left for their African winter-quarters, though individuals occasionally pass the winter in Ireland, the south-west of England, and the Outer Hebrides. Mr. R. Service records in his diary in 1883, that he received from Mr. McMeekan, Dockhead, a "finely-conditioned" LandRail that had been shot near Annan on November 4th.

Mr. R. Armstrong tells me he once saw a very lightcoloured variety; and late in August, 1908, Mr. R. Service obtained a specimen with white-edged primaries which had been killed by flying against the telegraph-wires near Annan. Telegraph-wires seem to be very deadly to this species, especially at the migration seasons. It is wonderful to think that so involuntary a flyer as we know the Land-Rail here to be, should be able and willing to undertake such an extended migration; with us it only uses its wings as a last resort, and prefers to sneak and run among the grass or other cover, till absolutely cornered. It has also been known to feign death when caught. Its ventriloquistic powers are well known, and it is seldom seen except by the patient observer. Its feathers are used for dressing a trout-fly which bears its name locally.

The Corn-Crake was regarded by the family of * Ann. Scot. Nat. Hist., 1902, p. 252. 
Glenhowan (i.e., the Smith family of Glenjaan, Glencairn) as ominous of the most fatal disasters, and was feared and persecuted accordingly. "This superstition arose from its voice having once been heard immediately contiguous to the house, a few hours previous to the demise of " a former laird.*

In winter this species visits Arabia, and in Africa is found as far south as Natal and sometimes Cape Colony.

\section{THE SPOTTED CRAKE. \\ Porzana maruetta (Leach).}

\section{An uncommon summer-visitant.}

Sir William Jardine, writing of the birds of the parish of Applegarth and Sibbaldbie in 1832, says :- "The Spotted Gallinule, or water-crake (Crex porzana), is found around Perch-Hall Loch " $\uparrow$; and in 1842 he writes: "In a marsh in our own vicinity it may be always met with, if carefully looked for; but we have often run it for twenty minutes before a dog, previous to its taking wing; and it will often creep into some hole or matted parcel of grass, rather than rise a second time." Sir William goes on to describe the plumage of the species from a "specimen shot at Jardine Hall in the month of July," $\$$ which is probably the same as that recorded in the Catalogue of the Birds contained in the collection of Sir William Jardine. The Spotted Crake arrives here in April, and departs in autumn, at which season specimens are occasionally picked up below telegraphwires against which the birds have flown. It is of extremely secretive and skulking habits and is therefore generally supposed to be much rarer than it is.

* Traits of Scottish Life, 1830, Vol. II., p. 149.

† New Stat. Acct. Scot., Vol. IV., p. 181.

। Nat. Lib., 1842, Vol. XII., pp. 334, 335. 
Mr. J. E. Harting states that the late Captain A. ClarkKennedy had seen this bird on two occasions on the Nith in Dumfriesshire,* probably between the years 1874-1876. A Spotted Crake was obtained in the county in 1878-1879, as recorded by William Hastings, $\uparrow$ and this bird has been ascertained to have come from Annandale ; another was got at Lockerbie House in September, 1881. Speaking of a specimen obtained locally in 1888 William Hastings describes the species as "equally rare as the Water-Rail."§ Mr. John Corrie informed Mr. R. Service that a Spotted Crake was shot on September 14th, 1889, near Loch Urr (Glencairn); and on May 9th, 1891, Mr. R. Armstrong wading in Kirkbog Marsh (Closeburn) flushed what he believed to be a bird of this species.\| Mr. Adam Fyfe states that on October 9th, 1892, he shot a Spotted Crake in a marsh near Moffat, 9 and Mr. J. T. Johnstone informs me that Mr. Fyfe has shot more than one in that district, but he can give no actual dates. Mr. R. Service, writing of a bird reported as captured near Moffat at the beginning of November, 1892, may refer to Mr. Fyfe's specimen, and he remarks: "Its nest has been found occasionally in Annandale, and the bird has been met with in that dale far oftener than in the other Dumfriesshire dales."** A bird of this species killed itself against the telegraph-wires at Cummertrees on October 18th, 1895, †† and was set up by Mr. J. Harkness of Newfieldburn, Ruthwell. "Mabie Moss " writes in 1896: "Mr. Tom Day, the taxidermist, has shown me a fine specimen of the Spotted Crake shot near Lockerbie. The species has occurred with some frequency of late years." I† In 1897 one in full plumage

* Handbook of Brit. Birds, 1901, p. 223.

† Proc. Nat. Hist. Soc. Glasg., 1897, Vol. IV., p. 177.

+ Trans. D. and G. Nat. Hist. Soc., February 3rd, 1882.

§ Op. cit., February 1st, 1889.

II Dumfries Courier and Herald, June 30th, 1891.

II Ann. Scot. Nat. Hist., 1893, p. 45.

** Zoologist, 1893, p. 24.

†† Ann. Scot. Nat. Hist., 1896, p. 123.

† Dumfries Courier and Herald, September 7th, 1895. 


\section{BIRDS OF DUMFRIESSHIRE}

was picked up under the telegraph-wires on the Annan and Carlisle Road, and brought to Mr. William Wright of Annan, as he kindly informs me. In the same year "Mabie Moss" stated that this species occurred almost every autumn, and " a fine male was shot at Carnsalloch on October 5th, 1897."* He adds: "Although its nest has not been got for many years, there can be only small doubt that a pair or two still breed with us." A specimen, presented to the Royal Scottish Museum, Edinburgh, by Mr. R. Service, was picked up beneath the telegraph-wires at Noblehill (Dumfries) on September 3rd, 1903. $\dagger$

The Spotted Crake in the breeding-season is generally distributed throughout Europe in suitable localities. To the southern and eastern counties of England it is a summervisitant, but some individuals stay throughout the winter in the southern and south-western counties.

\section{BAILLON'S CRAKE. Porzana bailloni (Vieillot).}

\section{Has occurred once.}

Sir William Jardine writes in 1842 that a specimen of Baillon's Crake "is now before us, shot in summer, a few years since, in an extensive moss in this vicinity." $\$$ There is no mention of this specimen either in the Catalogue of the Birds contained in the collection of Sir William Jardine, nor in the actual sale-catalogue of June 17th, 1886 ; nor did it pass with his collection of British birds to the Edinburgh Museum in 1876. Mr. R. Service authoritatively gives the date and place of this occurrence as "1835, near Lochmaben."'§

* Kirlecudbright Advertiser, November 15th, 1897.

† Ann. Scot. Nat. Hist., 1904, p. 69.

† Nat. Lib., 1842, Vol. XII., p. 336.

§ Trans. D. and G. Nat. Hist. Soc., April 20th, 1905. 
This species has not occurred half a dozen times in Scotland; and is much more irregular in its summer-visits to England than the preceding, but it is believed to have nested on more than one occasion in East Anglia. Its distribution in the breeding-season in central and southern Europe is somewhat scattered, while in Africa it nests as far south as Natal, and in Asia as far east as the Persian Gulf.

THE WATER-RAIL. Rallus aquaticus, Linnæus.

A local resident, but probably often overlooked.

Owing to its shy and retiring nature, it is difficult to write with certainty as to the status of the Water-Rail. Many observers regard it solely as a winter-visitor, but it is possible that at this season when the tangled undergrowth has died down in the swampy marshes which the Water-Rail inhabits, it becomes more noticeable, and thus is more easily seen than at other seasons of the year. It is, however, satisfactory to be able to record it now as an increasing species; though at the beginning of the nineteenth century, when many suitable localities remained undrained, it was probably far more numerous than at the present day.

In the parish of Kirkmichael in 1791 there was "great plenty of the rarer species of birds, the land and the waterrails,"* and Sir William Jardine writes in 1842: "During winter, in our own vicinity, we generally see or procure a few specimens in wet ditches which do not soon freeze, and to which the bird at this time resorts, being driven from its better covered haunts by the severity of the storm; in such places, after being pursued, it will creep into some hole or under cover, and allow itself to be taken by the hand. In summer we have shot it once or twice, but have always been unable to discover the nest." $\dagger$ That the Water-Rail

* Stat. Acct. Scot., Vol. I., p. 60.

† Nat. Lib., 1842, Vol. XII., p. 328. 
may nest undetected in many localities is highly probable ; and I have reports of its having done so from Moffat, Ruthwell and Cummertrees. Mr. Copland tells me that it nested on the farms of Briery-hill and Broomhill, in the parish of Applegarth, during his residence there from 18941900, and Mr. R. Martin believes that it nests on the Cairn,
near Dardarroch.

In the winter months the Water-Rail has been reported from so many places in the county, that I believe its presence in suitable localities elsewhere often goes unnoticed; and the examination of the mud at the sides of our rivers and swamps frequently reveals the footprints of this species. Referring to a Water-Rail obtained locally in 1888, William Hastings describes the species as equally rare as the Spotted Crake*; a statement not to be taken too seriously. It is interesting to note that in $1908 \mathrm{Mr}$. Underwood writes from Lochmaben that "numbers are seen by the slow running streams," while in 1835 the Water-Rail is described as "very abundant about the outlets from the lakes" $\dagger$ in that parish. Mr. Hugh Mackay reports finding one frozen to death in the Cairn in January, 1895 ; and Dr. Scott tells me of two killed in May, 1908, by flying against the telephone-wires at Ruthwell, adding that the Water-Rail is fairly frequently seen in the Lochar Moss. Richard Bell wrote me that the only specimen he had ever seen in Upper Eskdale, was taken near Billholm (Westerkirk) far out on the hill-ground by one of his shepherds, but Mr. William Laidlaw from Lower Eskdale infers that the Water-Rail is fairly plentiful. One that I shot from an open ditch on Clonrae Farm (Tynron) on November 4th, 1906, was the first I had ever seen in that district; and Mr. W. J. Laidlaw tells me that one shot near Eliock (Sanquhar) in January, 1909, is the only one that has come under his notice, but Mr. R. McMillan informs me that he knew of a nest in Sanquhar parish in 1908. Mr. R. Service writes me that he has fairly frequently seen

* Trans. D. and G. Nat. Hist. Soc., February 1st, 1889.

† New Stat. Acet. Scot., Vol. IV., p. 382. 
eggs taken near Dumfries, contiguous to the Lochar Moss; and that on January 1st, 1909, a bird of this species was shot at Powfoot (Ruthwell).

From elsewhere the Water-Rail is reported as occasionally seen in winter, in Kirkconnel, Morton, Closeburn, Holywood, Glencairn, Johnstone, Tinwald and Kirkpatrick-Juxta; but I should be sorry to give the impression that the omission of any other parish signifies that the bird is unknown there. As has already been stated, this species is believed to be a resident which owing to its shy and retiring habits has gained the epithet uncommon; and it is probably to be found in suitable localities throughout the county far more generally than is at present supposed.

Sir William Jardine states that "white varieties sometimes occur,"* but there is nothing in the context to show that this statement refers to local individuals; and I am not aware of any such varieties obtained in the county.

THE MOOR-HEN. Gallinula chloropus (Linnæus).

Local names-Water-hen; STANK-Hen ; StANKIE.

A common resident on our lochs and rivers.

The trivial name of this species had its origin at the time when " moor" was equivalent to "mire" and " marsh" $\dagger$; and the more common local name of "stankie" is derived from the Latin stagnum, a still pond or pool.

The Moor-hen has of late years considerably increased, and has become a nuisance in its augmented numbers because of the amount of 'Pheasant's food 'it takes in the winter months. When Wild Duck are artificially reared, the mischief it does in this respect is more manifest, and in their earliest

* Nat. Lib., 1842, Vol. XII., p. 329.

+ Man. Brit. Birds, 1899, p. 517. 
stages young ducklings are much bullied and even eaten by this species. Poisoned eggs put out for Crows have frequently been found sucked by Moor-hens, but Mr. J. J. Armistead writes from the Solway Fisheries that it "is often seen about the fish-ponds, and I cannot find it does any harm."*

The nest is usually built at the edge of some pond or loch, but occasionally in a tree growing over water; and the species is, I believe, becoming more arboreal in its habits. Mr. R. Armstrong tells me that he once found a nest in a hawthorn bush fifteen feet from the ground, built on an old nest of a Wood-Pigeon; and "Mabie Moss" records one situated on the top of a yew-hedge in a garden. $\uparrow$ Two or even three broods are reared in the year, and it has been noticed that the young of the first brood assist in the feeding of the second.

In the colder months the Moor-hen commonly approaches the dwellings of man, frequenting the stackyards and farmbuildings in search of food. Richard Bell of Castle O'er mentions one which was so tame that it roosted every night in the kitchen of a shepherd's cottage.t In hard winters this species suffers greatly, as in the severe weather from November, 1878, to March, 1879.§

W. G. Gibson writes in 1858 :- "A variety of the Moorhen was shot in Dumfries district answering in every description to one shot at Branford, near Ipswich, Suffolk, on December 16th, 1847." || This English specimen is described in Morris' History of British Birds as showing "all the plumage of the body with the webs disunited, having the appearance of hair." "बा

On October 23rd, 1907, when shooting near Capenoch, one

* Zoologist, 1888, p. 269.

† Dumfries Courier and Herald, June 18th, 1889.

‡ Trans. D. and G. Nat. Hist. Soc., April 17th, 1901.

$\$$ Op. cit., November 7th, 1879.

|| Naturalist, 1858, Vol. VIII., p. 117.

I Morris' Hist. Brit. Birds, 1870, Vol. V., p. 68. 
of the beaters found a Moor-hen sitting at the side of a small stream. He tried to catch it with the crook of his stick but failed, and it slid into the water. It then swam down the stream under water for about fifty yards, using its wings as a man uses his arms in swimming. We headed it off, and it then swam up-stream in a similar manner, when it came to the surface and was taken by a retriever. It was a performance I had not seen before, and all present were astonished at the ease and at the length of time the bird swam under water.

The Moor-hen is not regarded as a migrant in our county, though in continued severe weather it changes its habitat. H. A. Macpherson says that the species is migratory to a considerable extent, and adds that he has "found the remains of Moor-hens washed up on the Solway Firth after heavy gales, as though the birds had been blown out from land and perished at sea."* I should be inclined to think that these were birds which had succumbed inland to the severity of the season, and had been washed down by the rivers to the Solway shores.

THE COOT. Fulica atra, Linnæus.

Local name-BALd Соот.

"The coot came forth at times to show the speck Of white upon his wings, then swept away Behind the twisted roots. The silent heron, Amid the tiny pillars of the reed,

Kept eager watch, nor stirr'd upon his post,

But stood a feather'd patience waiting prey." Alexander Anderson.-_ Agnes Died."

A resident, but very subject to partial migration.

To many of our lochs and lochans Coots are only known as spring-visitants, and they are believed to be decreasing

* Fauna of Lakeland, 1892, p. 345. 
in numbers locally. Their nesting-haunts are often annually resorted to, the birds arriving at them about mid-April; departing again in August or September. In winter they congregate on our larger lakes, and only in severe weather are they to be found on our estuaries. They are subject to great variation in numbers, probably caused by emigrations and immigrations to and from other districts. Some waters in late autumn may hold them for a week in large parties, and then again none will be seen for some months. Sir William Jardine writing in 1832 says this species "breeds on Perch-Hall Loch, but leaves on the approach of winter."* In 1835 Coots were recorded as "abundant in the Castle and Hightae lochs," $\uparrow$ (Lochmaben) and it is interesting to know that nowadays, so Miss Wallace informs me, they are seen there numerously in winter. Coots being very pugnacious in spring, it is probable that this combativeness causes the break-up of the preceding winterparties, and so the larger lakes remain tenanted by but a few pairs of birds where scores were seen the previous autumn, the majority having been driven off to find nesting-places on smaller sheets of water. In courting-time pairs go for long walks over the grass and ploughed fields.

Mr. R. Armstrong informs me that he has personally seen Coots destroying the eggs of the Little Grebe.

In severe winters, such as 1878-1879, this species, like other waterfowl, is known to suffer severely.

\section{[THE CRANE. Grus communis, Bechstein.}

H. A. Macpherson, in a letter to Mr. R. Service, writes: "I can find no evidence of Cranes having ever bred in Scotland; but that the bird was well known in Scotland and much sought after in the sixteenth century is indisputable... 1503. Item,

* New Stat. Acct. Scot., Vol. IV., p. 181.

$\dagger$ Op. cit., Vol. IV., p. 382. 
the $\mathrm{XXj}$. day of December, to ane man brocht quik cranes and quik pertrikis to the King fra William Cunynghame of Drumfries,...V Vs. Extracted from 'Accounts of the Lord High Treasurer of Scotland,' 8vo, Edinburgh (Government Publication) 1900, Vol. II., p. 411." The Heron was frequently termed "the Crane," and the validity of this record is therefore questionable, though none the less interesting.

The Crane is believed to have bred in East Anglia until about 1590, and till a later date was a regular wintervisitant; but its visits to the British Isles from the Continent are nowadays irregular and rare.]

THE DOTTEREL. Eudromias morinellus (Linnæus).

Local name-Dotterel-Plover.

A very rare spring-visitor.

Formerly an annual visitant to this county, the Dotterel has long since ceased to be anything but a very rare spring visitor, and at no time is it believed to have been numerous.

In 1795 we read in a list of "migratory birds" compiled by the Rev. John Russel, Minister of Canonbie: "The curlew appears in the higher situations, bordering upon Castleton and Ewes; and also the plover, dotterel, and fieldfare."* Sir William Jardine, writing of the birds of the parish of Applegarth and Sibbaldbie, says: "The common Dotterel was met with last spring " (i.e., 1831) " in a flock of about twenty birds" $\dagger$; and some ten years later he writes of this species in his Naturalist's Library: "In our own district, there is a locality on some subalpine moorland, partially cultivated, which is visited during their passage in spring, but we have not been able to trace them on their return migration." Sir William goes on to describe

* Stat. Acct. Scot., Vol. XIV., p. 413.

$\dagger$ New Stat. Acct. Scot., Vol. IV., p. 181. 
the plumage of the species from "a specimen killed in Dumfriesshire, in the end of March."* The Catalogue of the Birds contained in the collection of Sir William Jardine includes only one local specimen, obtained at Gillesbie in the parish of Hutton and Corrie. After the auction of Sir William's collection on June 17th, 1886, H. A. Macpherson wrote to Mr. R. Service that a Dotterel shot in March on the Scottish side of the Solway had been included in the sale; this bird he gave to Mr. Duckworth. Collectively these references give the history of this bird. March is a remarkably early date for the occurrence of this species; flocks, or as they are more properly termed "trips," of Dotterel having seldom been noticed before May, usually in the latter half of that month.

In an article on this species T. C. Heysham wrote in 1838 : "I have examined all the upland moors . . . always without success in the south-western part of Scotland, where indeed it is of very rare occurrence, even during its periodical flight, the line of the migration of the passing bodies that visit us in the spring being along the eastern coast of Great Britain." $\uparrow$

In 1871 Robert Gray writes: "Sir William Jardine has lately written to me as follows: 'The Common Dotterel (Ch. morinellus) used to appear regularly in spring and the fall in some moors near this [Jardine Hall, Dumfriesshire], and I have reason to suppose that one or two pairs bred here. I did not discover the locality until too late, and they have left now, but I have specimens shot during the spring visit. The locality is about five miles from this." $\ddagger$ Robert Gray continues: "It is not to be expected that the few breeding localities from the heights of Dumfries to Inverness-shire will be otherwise than scantily occupied. I am doubtful, indeed, if more than a dozen pairs are to be found nesting together in any part of Scotland." $\$$ This was written in

* Nat. Lib., 1842, Vol. XII., pp. 297, 298.

† Mag. Nat. Hist., 1838, Vol. II., pp. 295-304.

$\ddagger$ Birds of West Scotland, 1871, p. 256.

$\S$ Op. cit., p. 257. 
1871, in which year, so Mr. James Anderson tells me, he saw one of these birds in May, on Queensberry (Closeburn) when draining for the tenant of Locherben Farm. The bird was sitting apparently on its nest, but "looked sae bonnie that I did na' fash wi' it."

In 1876, Dumfriesshire is mentioned as a possible breedingplace of this species, ${ }^{*}$ and on July 18th, 1887, Mr. R. Service wrote to the late Professor Newton: "Re the Dotterel nesting: The particular locality ... is just at the head of the Scaur Water, a tributary of the Nith and close to the western boundary of Dumfriesshire. ... . It was discovered last year by my friend Dr. Anstruther Davidson of Sanquhar, who was searching at the time for Golden Plovers' nests which along with the Ring Ouzel abound there. He mentioned the matter to me and we agreed not to say anything about it for another year. This season the Doctor has been several times trying to find the nest, with the assistance of the herds, but has failed. I saw him on Saturday, and he says he has no doubt from the behaviour of the birds when he was among them a few days ago, that they have now young concealed among the moss hags .... They are on the top of Corriedow, a hill of about 1,600 feet ... Sir W. Jardine speaks of a locality five miles from Jardine Hall (B. of W. of Scotland, p. 256) which so far as I know is the only recorded mention of the species breeding in the S.W. of Scotland. It is very probable that the species breeds extremely sparingly all along the range of mountains from Moffat to Minnigaff" (Kircudbrightshire). In very kindly sending me the draft of this letter, Mr. R. Service wrote in 1908: "Up to the present day I have never learned of any more precise location than the foregoing, as Dr. Davidson became reticent on the subject." I wrote to Dr. Anstruther Davidson, who replied that he had no more information to give as regards this species, beyond what he had stated in 1891, viz. : "Mr. John Laurie, of Dalgonar, mentions having seen and shot the

* Proc. Roy. Phys. Soc. Edin., 1876, Vol. IV., p. 115. 
Dotterel Plover on the Scaur hills some years ago. Whether this was the genuine Dotterel or only the Dunlin, it is impossible to state, as the birds have not been observed for the last few years, though I have searched the hills far and wide."*

In 1886 William Hastings, the taxidermist, told Mr. R. Service that he had only once received a Dotterel for preservation, and that the specimen came from Holywood. In an interview with the Sanquhar gamekeepers in 1908, I gathered that the Dotterel had unquestionably occurred in the locality, within the last three years on three different occasions. On each of these, single birds only were seen, at altitudes of from five hundred to one thousand five hundred feet; and in the interest of the birds themselves I refrain from giving full particulars. In his paper on "The Waders of Solway," Mr. R. Service recorded in 1905: "At one time there were a few pairs on the Moffat range, but whether they are still there in the breeding season I am without any recent information." $\dagger \mathrm{Mr}$. J. Bartholomew, to whom I am indebted for so much information from that locality, writes me in 1908 that this species is "not known apparently in Moffat." In his paper, above quoted, Mr. Service states that the eggs of the Dotterel have been taken in Kirkcudbrightshire on the mountains above Loch Dungeon, and goes on to say: "On their northward migration in spring, flocks were often seen on the ploughed fields some thirty to forty years ago. These are not observed now-a-days, and for the last ten years at least I have neither heard of nor seen any on the southward journey." $\ddagger$

Trips of Dotterel may yet again be seen, and may possibly revisit their former nesting-haunts in the county, if, as is believed to be the case, the species farther north is extending its breeding-range, and it is to be hoped that they may receive the benefit of strict protection at all hands.

This bird, formerly persecuted on account of the value

* Hist. Sanquhar, p. 31.

$\dagger$ Trans. Nat. Hist. Soc. Glasg., 1905, Vol. VIII., p. 47.

† Loc. cit. 
of its feathers for dressing artificial flies, and more lately robbed of its eggs on account of their rarity, has been exterminated at many of its breeding-haunts throughout Great Britain. It is undesirable, on account of the greed of the egg-collector, to specify any exact locality, but the Dotterel still nests at altitudes of from two thousand five hundred to three thousand feet in Scotland and more rarely in the north of England. It breeds on the mountains and tundras of northern Europe and parts of Siberia, more rarely on certain highlands of central Europe. Its winter-quarters are in northern Africa, Palestine, Persia and Turkestan.

The nest, a mere depression in the ground, is usually near the summit of the mountain, and contains but three eggs of a yellowish-olive colour, thickly blotched and spotted with blackish-brown.

THE RINGED PLOVER. Agialitis hiaticola (Linnæus).

Local names-Ring-Dotterel; Five-toed Plover; RINGIE; SAND-TRIPPER.

A very common resident species along the shores of the Solway, and in spring a few birds ascend our larger rivers to nest.

In a letter dated April 17th, 1826, from Jardine Hall, Sir William Jardine writes to P. J. Selby: "The Ring Dotterels have come to the River Annan preparing for their breeding quarters. Three or four pairs breed annually near me." Writing in 1842, Sir William says of this species:" in our own vicinity they perform a short migration, breeding and retiring afterwards. On the banks of the Annan, fifteen or sixteen miles from the coast, one or two pairs annually take up their station, seldom varying far from it. They arrive about the same time with the Common Sandpiper, and are sometimes later in retiring."*

The Ringed Plover nests commonly along the shores of the

* Nat. Lib., 1842, Vol. XII., p. 300. 
Solway from the Viaduct to the River Sark, but it is believed that the habit of breeding inland on the gravelbeds of our larger rivers is becoming more common. Eggs have been taken near Thornhill, on the Nith, and at many places on its lower reaches, as well as on the Annan. Mr. R. Armstrong writes me that in 1890 he found a small colony of about six pairs nesting on the gravel-beds lying between the junction of the Cample and the Scaur with the Nith; thither they returned every year for twelve years, but then suddenly deserted their nesting-ground. However, a few pairs have nested in the district since 1905.

Ringed Plover are usually very conservative in returning to their breeding-haunts, where they may be looked for from April 17th to 23rd. Later in autumn, our locally bred birds probably migrate south, their places being taken by immigrants from farther north; and at this season of the year the species is most numerous on our coast. During a severe winter they are occasionally seen in large flocks, but on the return of milder weather they disperse.

Owing to its tame and confiding nature the Ringed Plover is but seldom shot by the local shore-shooter, to some of whom it is known by the name of the "Five-toed Plover." How this nickname has been derived it is difficult to surmise.

\section{THE GOLDEN PLOVER. Charadrius pluvialis, Linnæus.}

Local names-Pliver ; Grey Plover; Green Plover.

"As far upon the moorland grey

The plover seeks its summer home,

And sunshine fills the scene of day,

As far as foot or eye can roam."

HeNRY SCOTT-RIDDELL. - " Lines written on a Hawk."

A summer-visitant to our uplands, frequenting the lowland and littoral
districts in autumn and winter.

In both the Statistical Accounts of Scotland the Golden Plover is mentioned as a local bird, being in those days 
as now, miscalled the Grey, or Green Plover in many districts. In some seasons this species is not so numerous as in others ; thus it was very scarce in Dumfriesshire in November and December, 1879, and was almost totally absent as a breeding-species in the following spring.* It is rarely seen on the coast in such large flocks, or as they are called "stands," as thirty or forty years ago ; but I consider, that within the last ten or fifteen years, it is more frequently met with in autumn along the banks of the Nith in midNithsdale. It was reported as unusually numerous during the autumn of 1908 at Glencaple. $\dagger$

Early in spring the Golden Plover resorts to its nestinggrounds, which are seldom at an altitude of less than eight hundred feet. Richard Bell wrote me in 1908 that the Golden Plover arrived at Castle O'er on February 17th, and in 1907 on February 27th. Mr. J. Bartholomew writes me that in 1908 he found a nest with four eggs as early as April 16th; but as a general rule incubation does not commence till the end of that month. Mr. Myles Quinn writes me in May, 1908: "For the first time in my life I saw a brood of young Golden Plover on Merkland Moss (Caerlaverock) last summer. This year I have twice seen a pair of old birds just on our boundary in the Colony Moss. That they are there for the purpose of breeding I am certain, but the female had not started to sit when I last saw them on May 15th." A glance at the map will show this locality to be a remarkably low-lying nesting-place. During the period of incubation this species becomes considerably tamer, and is at this time one of the most characteristic birds of our upland grassy hills.

In July and August the Golden Plover begin to pack together into "stands" of from thirty, to two or three hundred, frequenting the 'holms' on the banks of our larger rivers. Mr. R. Service writes: "Some seasons they

* Zoologist, 1880, p. 66.

$\dagger$ Dumfries Courier and Herald, October 21st, 1908. 
will remain in their breeding-places till far on in the autumn, and $I$ have noted flocks on Queensberry in mid-November in mild weather. One of the pleasantest sounds of returning spring is the plaintive whistle of the Golden Plover falling down from the heavens when a migration rush is coming on. Long after our own Golden Plover are engaged in nesting duties, I have recognised the notes of the same species going northwards at night in company with Knots and others so far on as the end of April and till mid-May. Where these birds were going to is one of the puzzles presented to the student of migration."* As winter approaches Golden Plover repair to the coast and are seen inland less frequently, only returning again in numbers during any mild spell of weather. At this season of the year, it is probable that the birds seen on our shore are immigrants from farther north, which have taken the place of our locally-bred birds, which have in turn migrated southwards. On the coast Golden Plover feed on mollusca, and when inland, worms, slugs, insects and their larva form their food, but at certain periods of the day sand-beds are resorted to for the necessary supply of digestive grit.

When on the wing they fly at a headlong pace, and they have a habit of dropping to the shot when fired at. I remember once shooting at a flock coming to me, when I was standing behind a wire-fence. At my first barrel they dropped below the level of the fence, and, dashing through it, six birds were killed by the wires, one of them having its leg torn off from its body.

The Golden Plover nests throughout northern Europe, and in western Siberia; in autumn migrating south from its more northern breeding-haunts. Its chief winter-quarters are in the basin of the Mediterranean, and along the coasts of Africa as far south as Cape Colony. It breeds in many suitable localities in Great Britain and Ireland, and is abundantly met with along many coastal districts in winter.

* Trans. Nat. Hist. Soc. Glasg., 1905, Vol. VIII., p. 48. 
The photograph of a nest and eggs reproduced in the accompanying plate was taken in 1903 by Mr. D. Legard at the head of Scaur Water.

THE GREY PLOVER. Squatarola helvetica (Linnæus).

\section{Local name-SILVER-Plover.}

\section{A somewhat scarce winter-visitant to the Solway.}

Sir William Jardine wrote in 1842 of the Grey Plover: "We have met with them frequently on the Solway, and once shot a pair on the banks of one of the lochs at Lochmaben."* These specimens are recorded in the Catalogue of the Birds contained in the collection of Sir William Jardine as obtained by him at the "Castle Loch, Lochmaben," and Mr. R. Service states that they were shot so early as August. $\dagger$ A Grey Plover, recorded by William Hastings as one of only two received by him in many years, + has been ascertained to have been obtained at Caerlaverock on November 1st, 1884.

The Grey Plover does not congregate in flocks, and is found in small parties, but very locally on our coast during frosty weather, often consorting with Bar-tailed Godwits. On the muddy flats at the mouth of the Lochar on the east of the Blackshaw Bank, this species may usually be met with every winter, but in its numbers it is very irregular. It must also be remembered that the Golden Plover is often miscalled the "Grey Plover."

The species breeds in arctic Europe from Kolguev eastwards and across Siberia to Kamchatka, as well as in parts of arctic America. In winter it is found on the coast-line of Europe, on both sides of Africa, the greater part of Asia, and in Australia, while in America it reaches Guatemala.

* Nat. Lib., 1842, Vol. XII., p. 288.

† Trans. Nat. Hist. Soc. Glasg., 1905, Vol. VIII., p. 48.

‡ Trans. D. and G. Nat. Hist. Soc., November 7th, 1884. 


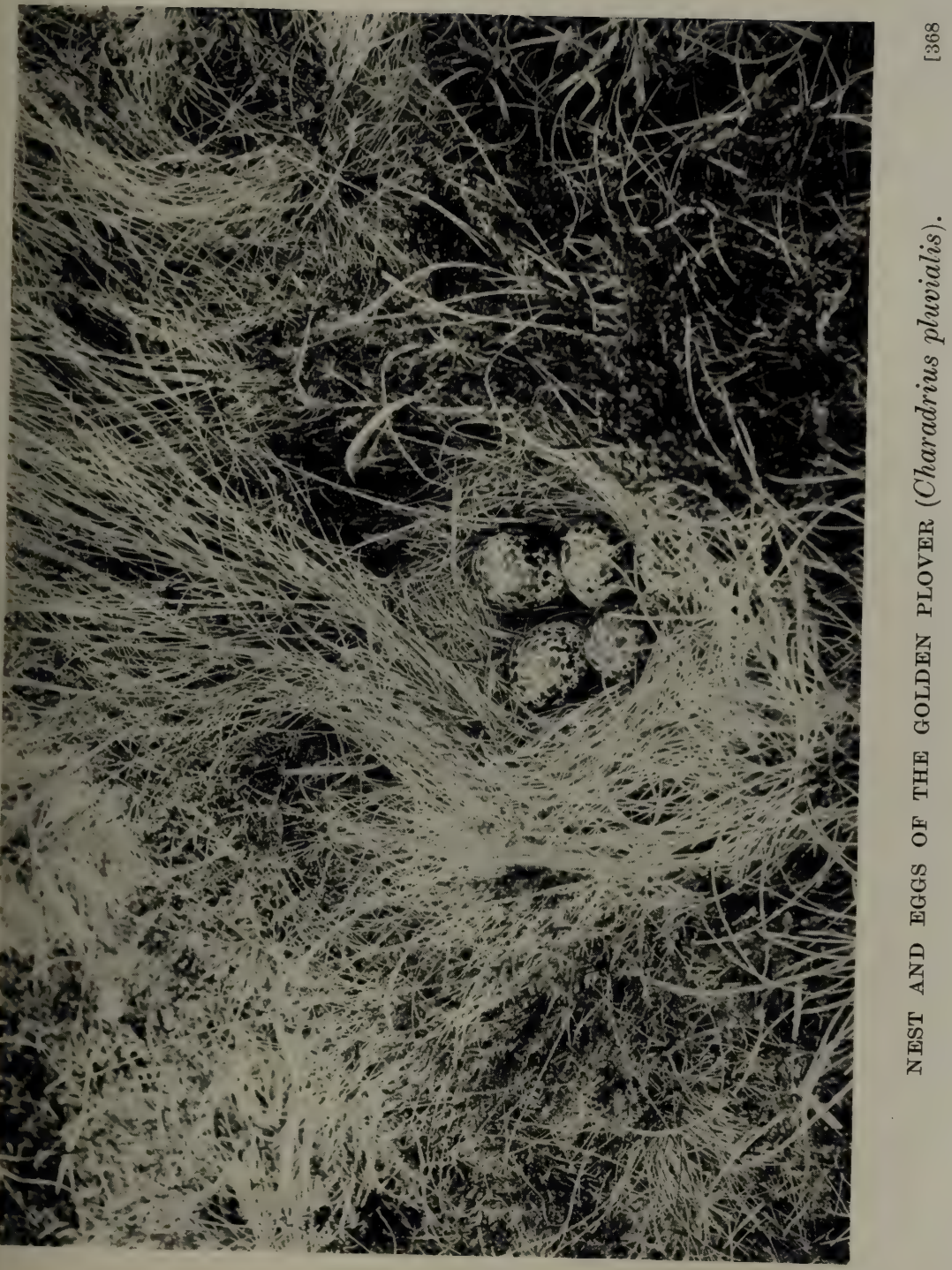





\section{THE LAPWING. Vanellus vulgaris, Bechstein.}

\section{Local names-Green Plover; Pewit ; Peesweep ;} Tee-wheet ; De'll's Plover; Crested Lapwing.

" 'Tween herds and you there's deadly feud;

He breaks your eggs and skails* your brood,

And-waurt than grudging ye a rood

He'd pook§ ye bare, frae tail to hood, To the last feather.

He minds what Scotland greets\| for yet,

When helpless Hill Folk, hard beset,

Could naewhere but in muirlands get

A night's safe quarters -

Ye brocht the troopers on them het, And made them martyrs."

"To the Peesweep."

A very common resident, subject to seasonal movements.

The above lines quoted, as Robert Gray says, from the " 'Poet's Corner' of a country newspaper," show how in a county rich in traditions of the Covenanters, the Lapwing came to be called the "De'il's Plover." The poor wretch trying to hide from Claverhouse's bloodthirsty troopers, and crawling from moss-hag to moss-hag on the heather-clad hills, may at times have been betrayed by the Lapwings circling over him ; but as surely, must many a secret conventicle have been apprised of the approach of the dreaded troopers by the actions of this bird, and so had time to disperse undiscovered. But superstition dies hard, and in some out-of-the-way districts the Lapwing is still disliked. It is nowadays but rarely called the "De'il's Plover," and is most commonly known as the Peesweep, with which

* Scatters.

$\dagger$ Worse.

$\ddagger$ Ill-thriven.

$\S$ Pluck.

II Weeps.

I Birds of West Scotland, 1871, p. 264. 
onomatopœic name may be compared the French nickname of "Dix-huit" for this bird.

Dr. Archbald notices this species in his "Curiosities at Drumfriess," written about 1684 : "Green plovers returning every spring in abundance and staying all summer"*; and there are many local references to the Lapwing in the Statistical Account of Scotland. It was recorded from Hutton and Corrie in 1794 that it was "very numerous forty years since. They are now, it is reckoned, not one for a hundred." $\dagger$ The New Statistical Account of Scotland, published some fifty years later, testifies to the abundance of the species in our county. Sir William Jardine wrote in 1842: "We have, at this moment, a wide range of land, once favourite haunts of the Pewit and Curlew, where few are now to be found; and on one farm, not exceeding a hundred acres in extent, forty or fifty pairs of Pewits might have been seen breeding yearly, whereas, at present, a single pair could not be shot upon it. This, in a sense, may give some satisfaction in the improvement which has taken place, and the additional rental it may bring in ; yet there was a charm in these wild pastures, animated by their peculiar inhabitants, that cannot be replaced by any change produced artificially upon them." $\$$ The alterations in the methods of agriculture may have influenced the habits of the Lapwing; for they now nest as commonly on the cultivated land as on the uncultivated moor. In recent years this evolution, if so it may be called, has been considerably retarded again, by the far greater amount of pasturage now rendered necessary by economic changes in the conditions of agriculture. It is sufficient to note that changes in conditions of the land's surface will not much affect the nesting of this species. It is something to be proud of, that Dumfriesshire, by its Wild Birds Protection Act of June 1st, 1896, was one of the first four Scottish counties

* Sibbald's MS. Collections, p. 228.

† Stat. Acct. Scot., Vol. XIII., p. 579.

† Nat. Lib., 1842, Vol. XII., pp. 281, 282. 
(Kirkcudbrightshire, Wigtownshire and Aberdeenshire being the others) to prohibit the taking of Lapwing's eggs after April 15th,* and though it is doubtful if the species is as plentiful as it was fifty or sixty years ago, it is still numerous.

In February, or even January, great numbers of Lapwings leave the county; and these are believed to be going to more northerly breeding-places, since our nesting-birds seldom arrive in their upland summer-haunts before the latter days of February. Mr. R. Service records that on the morning of February 11th, 1909, fifteen to eighteen hundred Lapwings, which had been near his residence at Maxwelltown for three weeks, suddenly showed signs of restlessness; "in a few minutes the whole flock were on the wing, and going through a lot of movements that they had not previously shown. By-and-by in a very compact body, they headed NNW., and were out of sight in less than another minute, going high and swiftly." $\dagger$ In 1837, Sir William Jardine, writing from Jardine Hall on February 22nd, tells his friend P. J. Selby, "Peesweeps are come." Towards the end of July, Lapwings begin to gather into flocks, and with Golden Plover, they frequent the "holms" bordering our larger rivers, where they may also be seen in winter should the weather be mild for any length of time. In October and November they "crowd down " to the littoral parishes in extraordinary numbers, and many leave at this season for more southerly parts. The numbers of birds in these great autumnal migrationflocks, ebb and flow as the birds daily decrease or increase with departures or arrivals as time goes on; till, by December there is left a nucleus, a considerable one, that remains till the general immigration in February. During the winter of 1896-1897 there was a larger emigration than usual. For two consecutive days in October, 1900, small flocks of Lapwings kept pouring down Nithsdale, and later it was estimated that on a seven-acre field near

* Dumfries Courier and Herald, May 29th, 1896.

$\dagger$ Ann. Scot. Nat. Hist., 1909, pp. 210, 211. 
Maxwelltown there were congregated " at least 50,000 birds whose murmurings were audible three hundred yards away."* Lapwings escaped the severe winter of 1878-1879, for they left Dumfriesshire at the end of November, and did not return till the beginning of March; a phenomenon Mr. R. Service had never previously met with. $\dagger$

Eggs may be found in the last week of March, and are eagerly sought for, often by undesirables. In some seasons the period of laying is much retarded, as in 1892, when these birds were recorded as laying in June owing to unfavourable dry cold weather at the proper season. $t$ In 1866 eggs fetched a penny a piece in Dumfries, and were despatched to the large towns, chiefly to the Metropolis.§ This trade still continues, and the amount of eggs sold in 1888 can be judged from an entry in Mr. R. Service's diary, which notes: "John Kennedy tells me a friend of his this season picked up on the Blackshaw to his own hand in one day, forty-eight dozen Lapwing eggs." H. Seebohm gives the measurements of the eggs as from " 2.0 to 1.75 by 1.4 to 1.28 inch," $\|$ but they are liable to much variation and a specimen in my possession taken at Low Lann (Tynron) on May 14th, 1903, measures 2.12 by 1.25 inch. After April 15th, as above stated, it becomes illegal to take the eggs; but the harrowing and rolling of the fields, which takes place at this time, destroys many nests. The birds have also other enemies than man, and Rooks and Crows are perhaps the worst. Though a pair of Lapwings can keep off one or even two Rooks, they cannot keep off three ; for while they are engaged in pursuing two of the thieves, a third is profiting by the absence of the owners of the nest. A dog, a Pheasant, or a Partridge coming too near, is swooped at and buffeted with their wings, and at

* Ann. Scot. Nat. Hist., 1903, p. 198.

† Proc. Nat. Hist. Soc. Glasg., 1879, Vol. IV., p. 169.

$\ddagger$ Zoologist, September, 1892, pp. 333, 334.

\$ Dumfries Courier, May 8th, 1866.

|| Eggs of British Birds, 1895, p. 127. 
times they come daringly near one's own head. I once saw an inoffensive Black-headed Gull "knocked out of time " and in danger of losing its life, till I picked it up and released it on a neighbouring loch. The late W. G. Hunter states that he has found five eggs in one nest occasionally, but that four are the usual "clutch " at the first laying, and should these be destroyed, only three are laid.* When disturbed during incubation the female creeps secretly off her nest, and it is the male which executes all manner of aërial evolutions to attract one's attention. He may always be recognised from his mate by his longer crest and the rounder appearance of his wings ; the third primary being the longest, the second and fourth equal, and the first as long as the seventh. In the female the second and third primaries are the longest, and the first and fourth are equal in length to the seventh. $f$ Twenty-six days are required for incubation, and it is when the young are newly hatched or "run" that the parent Lapwings become most bold. An observation made by Mr. R. Service, though not actually within the confines of the county, may perhaps be here quoted; he states: "One day at the end of May, 1892, while passing along a road near Southwick, a Lapwing flew over my head holding betwixt its legs, pressed up against its abdomen, with its tail at the same time much depressed, what I have every confidence in saying was a young one. The bird alighted in the adjoining field, and I marked the spot, and, on running up, found a young one, perhaps four days old, or less. Many years before I had seen a similar incident, and the belief is very general amongst country folks that Lapwings will, when any danger threatens, remove their young to safe spots by carrying them."

As regards its utility to agriculture, there is no bird more beneficial than this species. "Its food consists entirely of wireworms, leather-jackets, surface larvæ, snails, slugs,

- Dumfries Courier and Herald, April 15th, 1908.

$\dagger$ Ibis, 1904, pp. 446-451.

‡ Trans. Nat. Hist. Soc. Glasg., 1905, Vol. VIII., pp. 48, 49. 
and many other injurious animals. The good done by the Lapwing cannot be overestimated," thus writes Mr. Fred V. Theobald,* and to this list of food may be added, cockchafers and also the larvo of the antler-moth (Charceas graminis), so injurious to upland hill-pastures.

In 1905 I found a Lapwing which proved to be " the subject of advanced tuberculosis." I had seen the bird in the same spot for several days, and on July 23rd ran it down and caught it. Wishing to know from what it was suffering, I sent it to Dr. C. G. Seligman, who subsequently figured the intestines of the bird in the Proceedings of the Royal Society of Medicine, and wrote: "So rare is the disease amongst wild birds that we venture to append a figure showing advanced tuberculosis in a Lapwing which was captured in a moribund condition in Scotland." $\dagger$ I have on several occasions found birds of this species in early autumn, whose feet and legs had become so entangled in little fleeces of sheeps' wool as to render these members swollen and distorted; such birds were always emaciated and thin, and must sooner or later have died a miserable death.

In autumn and winter, if Lapwings are seen diving and tumbling in the air they are said locally to predict rain, a similar prediction being foretold if Rooks behave in the same manner at sunset.

\section{THE TURNSTONE. Strepsilas interpres (Linnæus).}

A scarce winter-visitant to the Solway; more abundant in autumn.

The shores of our coast are not suitable for this species, which is, however, occasionally seen at the mouths of the Annan, and Esk.

Sir William Jardine writes in 1842 : "We have frequently shot the young and adult states of the bird on the shores of

* Science Progress, 1907, Vol. II., pp. 271, 272.

† Proc. Roy. Soc. Med., November 19th, 1907, Vol. I., Pathological section, p. 22, Fig. 3. 
the Solway."* A specimen (No. 180) from his collection may be seen in the Royal Scottish Museum, labelled as obtained on the Solway, but whether this bird was from the Dumfriesshire coast is not known. The species is rare on our shores, except for a few weeks in September or early October, when a good many immature birds may be seen. The majority of these pass on, and only a very few stay throughout the winter. In 1909, they were unusually

numerous at Powfoot and were observed so early as August.
The Turnstone is a circumpolar bird, breeding in the high north of both hemispheres. In the cold season it ranges over Asia, the African region, Oceania and South America, while on migration it is found on the entire coast-line of Europe and many inland waters. To Great Britain it is principally a spring and autumn-migrant on its way to and from its northern breeding-quarters, though a few remain throughout the winter on the milder south and west coasts. The return northwards takes place in May, and in July or August the southern movement begins. Hitherto it has not been detected breeding in Great Britain, but it may yet be discovered to do so in the Hebrides or on the west coast of Ireland.

\section{THE OYSTER-CATCHER.}

Hormatopus ostralegus, Linnæus.

\section{Local names-Sea-PIE ; SEA-PYET.}

An abundant resident along our shore, the numbers being augmented in
autumn by immigrants; in spring a few pairs ascend the larger rivers to nest.

Of this species Mr. R. Service writes: “ The Oyster-catcher, or, as I prefer to call it, the Sea-Pie, is far and away the most conspicuous bird of the flats of the Solway Firth. Flocks extending along shore for nearly a mile in length may be seen now and again in autumn, and the enormous numbers to be seen in the course of an October day in the

* Nat. Lib., 1842, Vol. XII., p. 260. 
vicinity of Southerness [Kirkcudbrightshire] must be seen to be believed. . . . It breeds in small numbers all round our shores, doing so on the shell beds well within highest water mark, . . . or [on] . . . the merse banks. . . . On the Annan and the Nith ... occasional pairs nest far inland on gravel beds and low meadows. In September and October single birds or pairs, or sometimes small parties, are frequently seen on the inland pasture fields far from the sea. I have a strong impression that we see the Sea-Pyets at inland localities far more frequently than was formerly the case."* This is certainly so, and the reports of the appearance of the Oystercatcher far inland are now of common occurrence. On June 7th, 1880, Dr. Grierson wrote to Mr. R. Service from Thornhill : "The other day an Oyster-catcher (Homatopus ostralegus) was brought to me. It was shot here. I never knew of the bird having been taken in this district, and I would like to know from you ... if you have known of it being seen inland."

This species now nests annually near Thornhill, on the gravel-beds of the River Nith, and in May, 1908, a pair was seen above Auchansell (Durisdeer) twenty-four miles inland; so that what was a novelty to Dr. Grierson in 1880, was but a forerunner of what are now summer-visitants. Mr. R. Armstrong informs me that a pair have nested for many years at the junction of the Scaur with the River Nith. He first saw them there in 1890 , and there are never more than one pair, but he has occasionally seen, and more often heard, small parties passing up the Nith. On the Cairn these birds have been seen above Crossford Bridge, some eighteen miles from the sea, in 1904 and 1905, and three are believed to have been seen some years ago on the Annan below Moffat, twentyfive miles inland. In the spring of 1907 and again in 1908 a pair were seen for about a week on the Esk three miles below Langholm, but apparently did not nest; and Mr. James Malcolm writes me in 1908, that his son captured an Oystercatcher some years ago in the neighbourhood of that burgh,

* Trans. Nat. Hist. Soc. Glasg., 1905, Vol. VIII., pp. 49, 50. 
which is some thirteen miles from the sea. I have purposely only mentioned records of this species from the farthest inland localities on our large rivers; to suitable nesting-places on their lower reaches and on some of their tributaries the Oyster-catcher is an annual spring-visitant, arriving in March or April to nest, and departing in August for the coast.

In autumn the numbers of Oyster-catchers to be seen on our shore are prodigious, having been augmented at this season of the year by immigrants from the northward and eastward. The species has probably always been numerous on our coast, but of late years has been increasing most markedly, and this increase may account for the growing tendency to resort to inland localities to breed.

An extraordinary accident which befel a flock of these birds near Ruthwell, is thus told by Mr. George Smith in a letter to Mr. R. Service : " On September 5th, 1886, a very severe thunderstorm visited this district. The preceding twenty-four hours had been terribly oppressive. Between 3 and 4 p.m. just after the storm burst, a whirlwind (said to have been accompanied by a waterspout) swept across the Nith estuary going in a north-westerly direction taking with it a flock of Sea-pies. They were dashed against a wire-fence on the Thwaite Farm, and literally cut to pieces, some of them being severed as if they had been cut with a razor. The wind was so strong that it blew them away, as it were, and as they are a very low-flying bird, they came in contact with the fence, and upwards of seventy were killed."

\section{THE BLACK-WINGED STILT.}

Himantopus candidus, Bonnaterre.

Has occurred twice, possibly three times.

The first occurrence of the Black-winged Stilt in Great Britain was recorded by Sir Robert Sibbald in 1684,* and I am

* Scotia Illustrata, Part II., Book III., p. 18, Plates Nos. XI. (Fig. 1) and XIII. (Fig. 2). 
indebted to my cousin Mr. Robert Gladstone, jun., for the following translation :-

"The Himantopus of Pliny . . . . This bird (of which two drawings, one large and the other small, made from the bird itself, are included among our illustrations) was sent to me by William Dalmahoy, an officer of the Royal Guards, and an excellent ornithologist. It had been shot with a gun at a lake near the town of Dumfries, where also a second specimen was subsequently shot, but, through some carelessness on the part of my military friend, was lost." *

"I presume," adds Mr. Gladstone, "that both birds (i.e., the one which Dalmahoy sent to Sibbald and the one which was lost) were shot by Dalmahoy,-though the text does not actually say so much. I find in Douglas's Baronage of Scotland (Vol. I., p. 550) that William Dalmahoy of Ravelridge was ' an officer in the Scots Horse-Guards.' He was the second son of Sir Alexander Dalmahoy of that ilk."

The illustration here given is a reproduction of the larger and better of the two illustrations (i.e. No. XI., Fig.1) referred to by Sir Robert Sibbald in his text, and I desire to thank Mr. G. B. Wright for the pains he has taken in photographing it. Professor Newton, commenting on this illustration, writes: "Sibbald was unfortunate in his draughtsman, who gave " the bird a hind toe" $\dagger$; but it will be seen that it has been so far correctly drawn as to show but three toes, one of which on each foot, however, is pointing backwards. The "lake near the town of Dumfries," where these first Black-winged Stilts were shot, cannot now be identified. The Darduff, Black and Sand Lochs were within two miles of the north of the town and would have answered the description, but they have long since been reclaimed and

* Latin text.-“ Himantopus Plinii. . . . Avis hæc (cujus binæ icones de ipsa ave desumptæ in tabulis nostris habentur, una major, altera minor) mihi transmissa fuit a Gulielmo Dalmahoy uno ex præfectis cohortis regiæ, historiæ avium peritissimo, apud lacum prope Drumfrisium oppidum sclopeto transfixa, ubi et altera quoque postea confossa fuit, quæ militis incuria perdita."

† Dict. Birds, 1893-1896, p. 914. 


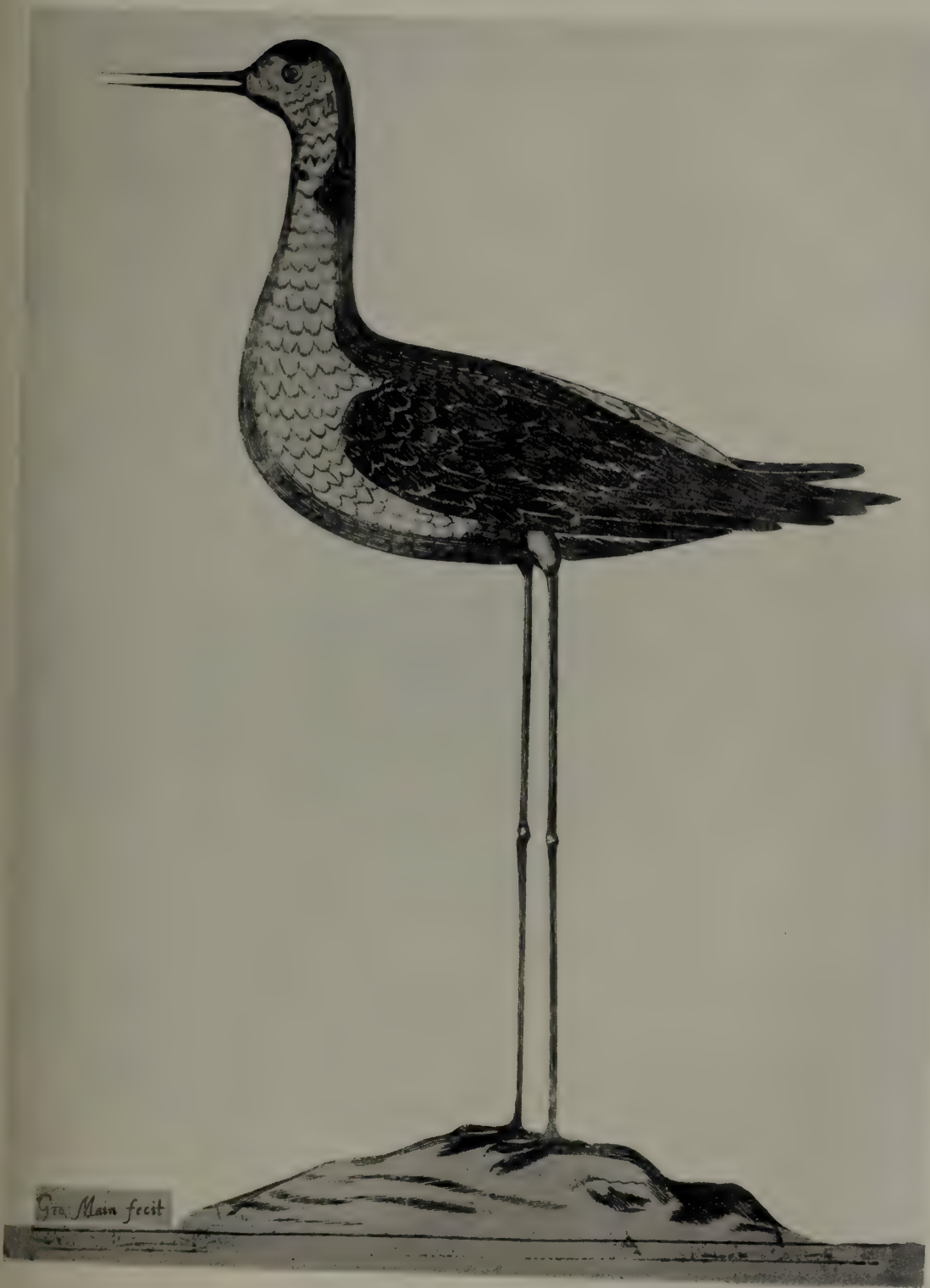

THE BLACK-WINGED STILT (Himantopus candidus). From Sibbald, Scotia Illustrata (1684), Tab. XI., Fig. 1.
Drawn from the actual specimen "shot . . a at a lake near the town of Dumfries." 

ploughed over, though in a map of Dumfriesshire, published in 1853 by Messrs. William Blackwood and Sons, the Black and Sand Lochs are both shown. Darduff Loch is marked in the map accompanying Dr. Singer's General View of the Agriculture in the County of Dumfries, published in 1812 ; or perhaps Maxwelltown Loch (Kirkcudbrightshire), formerly known as Babington's Loch, may have been the actual spot where they were obtained.

Writing on December 25th, 1867, Sir William Jardine informs Robert Gray that his gamekeeper gave him the description of a " bird he saw about six weeks ago, that I could make out to be nothing but a Black-winged Stilt, and $I$ heard of it being killed about eight miles off, but it had to be thrown out, and not a feather was to be got."* It is noteworthy that in the same year, birds of this species were said to have been seen near Don Mouth, Aberdeen, on September 15th; and at Possil Marsh, near Glasgow, for three or four days in Octobert; so that the bird recorded by Sir William Jardine as killed early in November, may have been one of a small flock that visited Scotland in 1867.

The Black-winged Stilt is an irregular and very rare visitor to Great Britain or even to central Europe. It breeds in suitable localities in Spain, Sicily and Hungary, on the low shores of the Black, Caspian and Aral Seas, and in the warm and temperate regions of Asia and in parts of North Africa. In winter it is found on both sides of Africa and in Madagascar.

THE GREY PHALAROPE.

Phalaropus fulicarius (Linnæus).

An uncommon and irregular visitor on the autumn-migration.

The first local specimen of the Grey Phalarope that we find recorded, is one shot on the shores of the Solway Firth in the

* Birds of West Scotland, 1871, p. 304.

$\dagger$ Op. cit., pp. 303, 304. 
winter of 1828-1829. This bird passed into the possession of Mr. John D. Murray, of Murraythwaite, and " had nearly attained its perfect winter plumage, retaining only a few black and reddish markings."*

Sir William Jardine, writing in 1842, says of this species: "a few have come under our notice freshly killed both from the Firth of Forth and from the Solway, all during winter, or when they had attained their complete, or nearly complete grey plumage." $\dagger$ A specimen "from the Solway Firth," recorded thus in the Catalogue of the Birds contained in the collection of Sir William Jardine, subsequently passed into the Royal Scottish Museum. Mr. W. G. Gibson, writing from Dumfries, on December 17th, 1856, records: "A very fine male specimen of this bird was shot this week in a neighbouring parish, about sixteen miles from the Solway." †

In 1866 three Grey Phalaropes are recorded as having been obtained at the mouth of the Nith $\S$; but Sir William Jardine states in a MS. note in his personal copy of the Naturalist's Library :-_"Mr. Hastings, Dumfries, has received several specimens killed, Brow on Solway-six or sevenin the grey state but having the back marked as in the summer plumage-all procured month of October, 1866." In the winters of $1873-1874$ and $1874-1875$ many specimens are stated to have been killed on the banks of the Nith near Dumfries.|| A pair was shot by Mr. Jonah Murray at Priestside (Cummertrees) on October 23rd, 1887; one of these birds was given to Mr. J. Harkness, of Newfieldburn, Ruthwell, the other to Mr. John Kennedy, who gave it to Mr. R. Service. Mr. J. Harkness informs me that an example was picked up on the railway-line near Ruthwell Station in October, 1890. Another was shot at Portrack (Holywood)

* Mag. Nat. Hist., 1829, Vol. II., p. 282.

† Nat. Lib., 1842, Vol. XII., p. 266.

† Naturalist, 1857, Vol. VII., p. 32.

$\S$ Trans. D. and G. Nat. Hist. Soc., December 4th, 1866.

\| Hist. Berwick. Nat. Club., Vol. VII., p. 259. 
on October 2nd, 1891, by Mr. Webster, and is now in Mr. Service's collection. After a severe storm on November 17th, 1893, three birds of this species were obtained in Holywood parish, and one of these was sent from Gribton to Mr. Hugh Mackay* to be stuffed. A rather small male was shot on the Nith near Kelton (Caerlaverock) on September 19th, 1896 ; it appeared after some days of stormy $\mathrm{NNW}$. wind, and being very tame, "it was easily procured as it swam near to the river edge." $\dagger$

Writing of its status as a "Wader of Solway," Mr. R. Service states: "The Grey Phalarope is a species of pretty frequent occurrence in some autumns, though by no means always present at that season. November is its usual time of appearance. I have often thought that they are sure to occur after any unusually wild gales from west or north-west in early November, as the times of their appearance here have always been preceded by such a storm. Possibly they may about that time be passing down outside our western Scottish coasts to their winter quarters, which are understood to be somewhere off the Canaries on the open ocean, though this seems to be only vaguely known. When seen in Solway, the Grey Phalarope is always extremely tame, as is the case elsewhere in Great Britain." $\ddagger$

This circumpolar breeding-species is found on its wintermigration as far south as Chili, New Zealand, and China; in Europe it occurs on many inland waters and on the coasts down to the Mediterranean; but its winter-quarters and migration-routes are imperfectly known. It is but an irregular visitor to the British Isles, appearing in some winters in far greater numbers (as in 1866 and 1891) than in others, the majority of such visitors being young birds.

* Naturalists' Journal, 1894, Vol. III., p. 62.

$\dagger$ Dumfries Courier and Herald, November 24th, 1896.

‡ Trans. Nat. Hist. Soc. Glasg., 1905, Vol. VIII., p. 50. 


\section{THE RED-NECKED PHALAROPE.}

Phalaropus hyperboreus (Linnæus).

Has occurred twice.

A female Red-necked Phalarope was shot on September 6th, 1907, while swimming close to the shore at Powfoot (Cummertrees). This bird is now in the collection of Mr. R. Service, who writes: "This is the first local specimen I have handled. It seems strange that while the Red-necked Phalarope (Phalaropus hyperboreus) breeds at points to north and west of Solway in Scotland, we should practically never see it here, while the Grey Phalarope breeding a thousand miles farther away should occur here with comparative frequency."* William Hastings, the taxidermist of Dumfries, told Mr. Service that about 1865 he was sent a Red-necked Phalarope, which had been obtained on the Caerlaverock shore, and that this was the only specimen he had ever received.

This species, like the preceding, is a circumpolar bird, but its breeding-range extends further to the south. Formerly it nested in considerable numbers in the Shetlands, Orkneys and Outer Hebrides, as well as on the north-west mainland of Scotland. The Red-necked Phalarope, however, has been banished from many of its nesting-haunts; but in the north-west of Ireland, and in those places where it has been protected, it still breeds. At these few favoured localities it arrives late in May, and departs again in early August.

In winter, it visits the Black Sea district and some waters of central Europe, occurring irregularly on both sides of the Mediterranean, though rarely in south-western Europe. Its migration in the Old World may be said to extend to the Indo-Malayan region, China and Japan; while in the

* Ann. Scot. Nat. Hist., 1908, p. 120. 
New World it is found at this season as far south as the Bermudas and Guatemala.

\section{THE WOODCOCK. Scolopax rusticula, Linnæus.}

"Oft at this season, near an oozy spring,

O'erhung by alder boughs, the woodcock haunts ;

Sure harbinger, when thus so early come,

Of early winter tedious and severe."

James Grahame, "British Georgics" (November).

A winter-visitant, but annually increasing as a breeding-species.

As long ago as 1678 Francis Willughby wrote of the Woodcock : "Some straglers by some accident left behind when their fellows depart remain also in England all summer, and breed here."* and though possibly some stragglers have always bred with us undetected, it is only of late years that the Woodcock has become so plentiful as a breedingspecies in Dumfriesshire. This decision is arrived at, not only from my own observations, but from the numerous reports which I have received from all parts of the county.

The earliest record of the actual discovery of a nest locally, of which I am aware, is in 1848, when on April 8th one was found about a mile from Langholm Lodge, by Walter Bell and others, while cutting wood. $\dagger$ But in this connection the place-name, Woodcockair (Annan) is especially interesting. In a charter dated March 3rd, 1334, appointing John de la Forest, bailiff of the Park of "Wodecok Heyr," the name is thus spelt. The Rev. James B. Johnstone (author of "Place-names of Scotland," 1903), who has kindly written to me on the subject, is of the opinion that the termination "Heyr" is equivalent to the word "aire," the older form

* The Ornithology of F. Willughby, 1678, p. 290.

† Dumfries Courier, April 25th, 1848. 
of "aerie" = bird's nest; so that we have here a very early reference to a Woodcock's nest.*

There are numerous local references to this species in both the Statistical Accounts of Scotland, but always as a " migratory bird," or "in its season by no means uncommon." Doubtless insufficient observation in the past, has caused many instances of their having bred to have been overlooked; and whether the present numbers of nestingbirds is due to a change in habits, or whether our plantations are now more numerous and more suitable as breeding-places, it is difficult to determine. Mr. R. Service has blamed the "late springs and cold weather of the late 'seventies," for retarding the vernal migration of Woodcock from Scotland $†$; and I am inclined to think that it is from about some such date as this, that they have bred increasingly in the county. Undoubtedly about 1900, their numbers as nesting-birds became markedly augmented; and some of my correspondents put this date four years earlier, and others four years later.

The Woodcock has its first brood very early, and Mr. C. Hyslop found a nest with two eggs at Crawfordton

* Rotuli Scotix, 8 Edw. III., Membr., 26. (Printed edition, Vol. I., p. 264).

\section{Latin text.}

Balliva parcariæ de Wodecok Heyr in Anandirdale committitur Johanni de la Forest.

The office of Bailiff of the Park of Woodcockair in Annandale is con : ferred on John de la Forest.
Rex omnibus ad quos \&c. Sciatis quod commisimus Johanni de la Forest ballivam parcariæ de Wodecok Heyr in le Val de Anand in Scotia, habendam quamdiu nobis placuerit, percipiendo in balliva illa tantum quantum alii qui ballivam illam hactenus habuerunt in eadem percipere consueverunt. In cujus \&c. Teste Rege apud Eboracum tertio die Martii.

Per breve de privato sigillo.

\section{Translation.}

The King to all to whom these present letters shall come, greeting. Know ye that we have conferred on John de la Forest the office of Bailiff of the Park of Woodcockair in the Vale of Annan in Scotland, to hold as long as it pleases us, taking in that office so much as others who have hitherto held that office have been accustomed to take in it. In Witness Whereof, \&c. Witness, the King, At York, the third day of March.

By Writ of Privy Seal.

† Kirkcudbright Advertiser, June 28th, 1880. 
(Glencairn) at the end of February, 1900 or 1901, when snow was lying on the ground. This date is exceptional, but nests with their full complement of four eggs are commonly found before the middle of March. The shooting of these birds, therefore, up till March 1st, as allowed under the old regulations, was to be regretted, and is now very properly not allowed. For, by the latest "Order" of the Dumfries County Council, (see Introduction) it has become illegal to kill Woodcock between February 1st and October 1st, both dates exclusive. As has already been indicated, the Woodcock has two broods in the year (some authorities say three), and nests with eggs have been found so late as July 17th. Twenty-three days being required for incubation, it is obvious that the young birds of such late broods were not fit to be shot on August 1st, as allowed under the old regulations. But there are some who object to its now being illegal to shoot them in September, urging as a contention that our locallybred birds all leave us late in that month or early in October.

The usual number of eggs laid is four, but Mr. S. Copland writes me from Canonbie that in 1908 he knew of a nest containing five. Woodcock often carry their young to and from their feeding-grounds, the young bird being held between the feet and pressed close up against the abdomen, but Mr. John Bell assures me that he once surprised a Woodcock near Drumlanrig which took its nestling by the neck and carried it off in its beak.

In August and September, when the coverts and plantations are at their densest, these birds resort to the moorlands, being frequently flushed from stretches of bracken. At this season of the year the old birds are moulting. Howard Saunders writes:- "Early in autumn the homebred birds disappear from their haunts, few, if any, being seen until the October influx, and they are popularly supposed to have left the country; but their disappearance is partially attributable to self-effacement during the moult, for many birds which had been captured and marked with metal rings in the spring in Northumberland, have been shot in the same county 
in autumn "*: but it should be noted that nearly as many were shot very far afield from their birth-places, and that the majority of the birds thus marked could never be traced. The question how far our home-bred birds are migratory, is the basis of dispute whether our County Council "Order," above referred to, has been advisable or otherwise. Even if our home-bred birds do emigrate in September or October, it is presumable that those birds which have been protected under the new provisions of our "Order," will, if they escape destruction further south, return in correspondingly greater numbers in the following spring, and so increase our stock of nesting Woodcock. Could the "Order" be more generally adopted, instead of being in force only in Wigtownshire, Kirkcudbrightshire, Dumfriesshire, and a few Irish counties, I fancy it would receive less comment. At present there exists a disagreeable feeling that we in Dumfriesshire are rearing Woodcock for other people to shoot, and however righteous this may be, it is not pleasant. In Scandinavia and Russia the Woodcock breeds abundantly and it is probably from parts of these countries that our immigrants, in some seasons more numerous than in others, visit us from October onwards. A return emigration takes place late in February or March, but as the species is nowadays seen with us in every month of the year, it is impossible to record early or late arrivals or departures. In the severe winter of 1878-1879, numbers of Woodcock were "crowded down" to Dumfriesshire, and many were then seen on the sea-shore, a habitat seldom frequented in this county except during seasons of intense frost. Large bags of Woodcock are not often made locally, though there are many places where from fifteen to twenty may be obtained in a day; the best bag I have heard of is fifty-two, made during a day's covert-shooting at Langholm on December 15th, 1908. $\dagger$

The sex of Woodcock cannot be determined by the plumage,

* Man. Brit. Birds, 1899, p. 569.

† Lord Henry Scott, in litt., December 26th, 1908. 
though the males weigh lighter as a rule and are smaller than the females.

Howard Saunders writes that "partial albinisms are not uncommon"*; and as long ago as 1824 it was recorded that the gamekeeper to C. G. S. Menteath, of Closeburn Hall, killed two Woodcock, each of which had six white feathers in each wing. $\dagger$ A pale, or as it was reported to me, " a pigeon-grey coloured Woodcock," was seen at Capenoch in the last week of October, 1908, but most unfortunately was not obtained.

In olden days this species was frequently snared, if not in our own, in neighbouring counties. $\div$ On July 27th, 1905, a Woodcock was found at Capenoch caught in a snare set for rabbits, and it is difficult to conjecture how the bird could have been caught in this manner. Another curious instance of the capture of a Woodcock came under my notice on November 21st, 1907 ; the bird had run forward at the end of a beat, poked its head through the mesh of some rabbit-netting, and was caught by a beater.

To kill two Woodcock at one shot is the rarest of rare events, and I therefore cannot resist quoting the following, though the incident recorded occurred in Kirkcudbrightshire: "On Tuesday last" (November 18th, 1851) "Mr. Garlies C. Maitland, Kells Manse, when shooting on the Kenmuir estate flushed a brace of Woodcock which he brought down with one shot. An unfortunate Blackbird which had flown within range at the time also fell a victim to the same discharge." $\$$

\section{THE GREAT SNIPE. Gallinago major (J. F. Gmelin).} Only one authentic record.

Mr. W. J. Laidlaw writes me: "I shot a large snipe near the lake at Eliock which I took to the late Mr. Veitch as

* Man. Brit. Birds, 1899, p. 570.

$\dagger$ Dumfries Courier, February 24th, 1824.

¥ Fauna of Lakeland, 1892, p. 371.

$\S$ Dumfries Courier, November 25th, 1851. 
I thought it an extra large one. He told me it was called the large snipe; and it had sixteen tail-feathers, and a shorter bill than the Common Snipe. The bird was plucked, cooked and eaten." I subsequently learned that this specimen was shot below Craigdarroch Farm (Sanquhar) on November 6th, 1901. This is the only record of the occurrence of the Great Snipe in Dumfriesshire, which is at all satisfactory; doubtless from its similarity to the Common Snipe the bird may have sometimes passed unnoticed, but our three species of snipe can be readily distinguished by the number of their tail-feathers, which in the Great are sixteen, in the Common fourteen, and in the Jack Snipe twelve.

A snipe, which may have been a Great Snipe, frequented a marsh near Bierholm (Keir) for some days in the winter of 1889-1890. It appeared to be larger, more heavy in its flight and certainly more solitary in its habits, than a Common Snipe. A specimen is reported to have been got in Glencairn parish in $1889,{ }^{*}$ but Mr. John Corrie, writing on the subject to Mr. R. Service in 1890, says :- "I have so far been unable to procure the specimen, and can therefore only say in a general way that my information as to its occurrence may be considered trustworthy." Mr. P. A. Pasley-Dirom writes me from Mount Annan: "In January, 1895, when curling, a snipe, which may have belonged to this species, alighted on the pond in a very exhausted condition and was captured by one of the players." I am informed by Dr. J. W. Martin that a snipe "the size of a Partridge and solitary in its habits" was seen in some marshes near Irongray Station in September, 1907. Mr. J. Bartholomew writes me that a gamekeeper named Campbell told him he had once shot a very large snipe in winter near Moffat, but he could not say whether it was a Great Snipe.

It is impossible to say whether any of the above records refer to the present species or not, and it only remains to

* Trans. D. and G. Nat. Hist. Soc., February 6th, 1890. 
point out that a specimen of the Great Snipe shot by Mr. C. Hinton on September 28th, 1904, and previously recorded as from Dumfriesshire* was obtained near The Brae, Lochrutton, Kirkcudbrightshire. This specimen, which is believed to be a male, is now (thanks to the generosity of Mr. Hinton) in my collection. Another example, obtained near Crocketford, Kirkcudbrightshire, on October 2nd, 1896, has also been recorded as a Dumfriesshire specimen, but it is only fair to add that neither of these localities is more than six miles from our boundary.

This species breeds in northern, north-eastern, and parts of central Europe and north-western Asia; on passage it is regularly found in southern Europe from the Rhone Valley eastwards; and in Africa from Morocco to Egypt, whence it passes south to Natal; it has also been found in Turkestan, Persia and Kashmir. To England it is an annual autumn-visitant, but in small numbers, and it more rarely visits Scotland and Ireland.

\section{THE COMMON SNIPE. Gallinago coelestis (Frenzel).}

Local names-Mire-Snipe ; Heather-bleat ; Heatherbleater ; Heather-blite; Heather-blitter.

"The cuckoo and the gowk, The laverock and the lark, The Heather-bleat, the mire-snipe, How many birds is that ?"

Old Dumfriesshire Riddle.

A common resident in suitable localities, but subject to migration.

That the long bill of this species gained for it the name of Snipe is traceable through the old-time name of "snite" for snout. Dr. Archbald, about 1684, in his account of

* Field, 1904, Vol. CIV., p. 654. 
the "Curiosities at Drumfriess," writes thus of the species : "Myre-snipes (which is like a Feldefare) called Heatherbleet. In pleasant summer evenings they soar high in the air with a quivering voice, and are excellent meat."* In both the Statistical Accounts of Scotland there are many local references as to its abundance, and there is no doubt that in those old days of undrained bogs and mosses, Snipe were more common with us than now. The names "Heatherbleat," or "bleater," are earned by this species in spring, when it may be seen high overhead circling around its nesting-haunt, now rising, now falling with outspread tail, through which the rushing air causes the weird sound so like the distant bleating of a goat. This "drumming," as it is also called, is produced by both sexes, and the subject has been recently dealt with in an exhaustive manner by Dr. P. H. Bahr, who conclusively confirms previous statements that the sound is produced by the two outer tailfeathers. $\dagger$ I have heard the "Heather-bleat" locally, so early as February 4th and so late as August 1st. Richard Bell of Castle O'er writes in 1905: "There is a bird which scares many a country man and woman, though they do not know what the terrible thing really is," and he adds that he remembers as a boy (1840) being told by a servant-maid "among other terrors" of "the Heatherbleat, the most fearsome of all, believing as she did, that it was a ghost pure and simple." +

Eggs, rarely found as early as the end of March, have been found so late as June 23rd in 1905, on which date my photograph, reproduced in the accompanying plate, was obtained. In some seasons, as in 1904, Snipe appear at their breeding-haunts in far greater numbers than in others.

A great and most noticeable augmentation of their numbers occurs in October, at which season our home-bred birds leave the vicinity of their breeding-places and gather into

* Sibbald's MS. Collections, p. 228.

$\dagger$ Zoologist, 1907, pp. 12-35.

‡ My Strange Pets, p. 86 . 


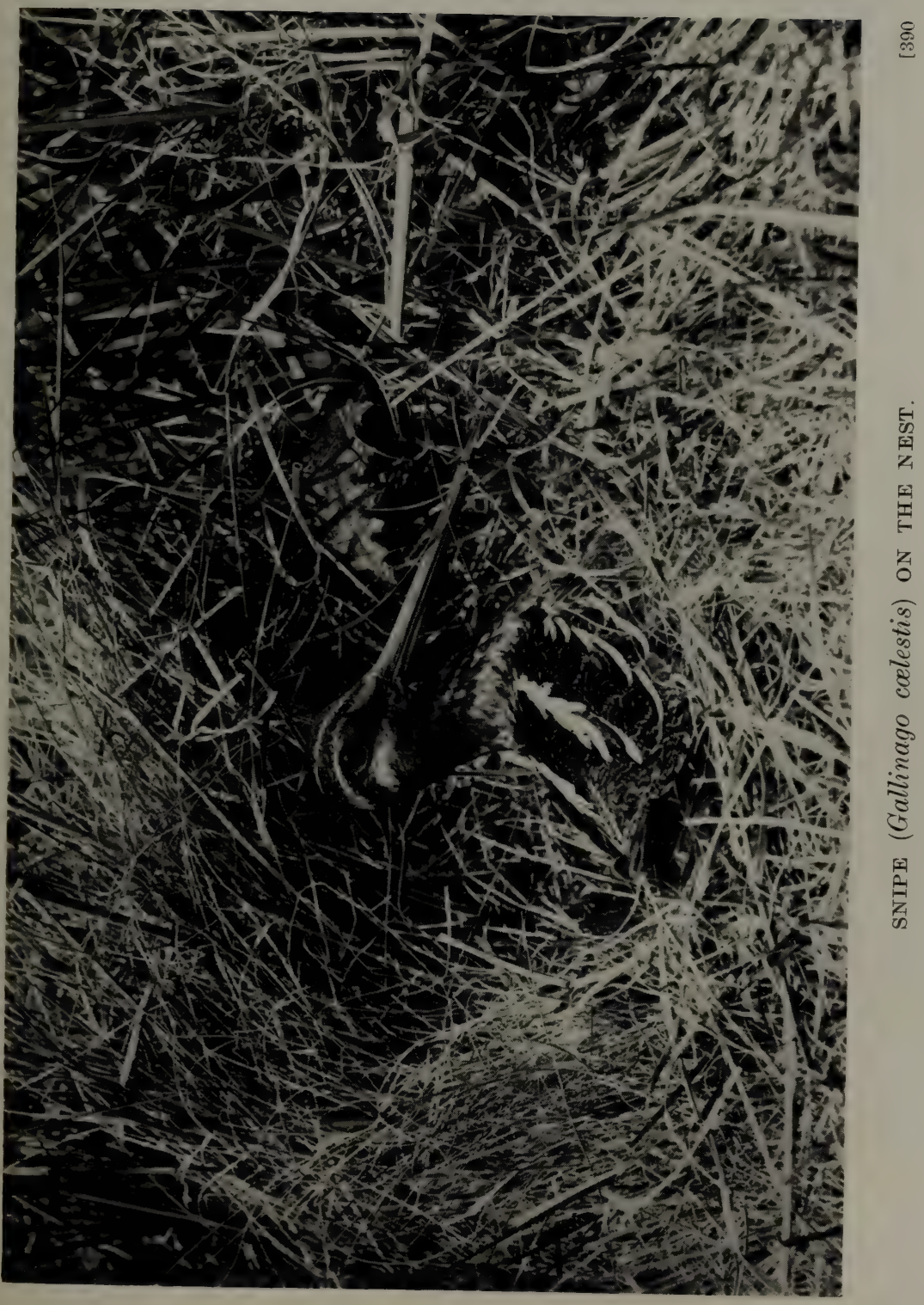



their winter-quarters, their numbers being swelled by immigrants from the Continent, whose return movement takes place in February or March. During protracted frost this species becomes considerably tamed as its feeding-places are frozen over, and it may at such times be flushed on the saltings near the coast. I have no information of any big bags of Snipe having been obtained locally in one day; from eight to ten couple would be considered a good day's sport. A Snipe shot at Capenoch on August 10th, 1905 , had only one leg, having lost the other probably in a trap. Though the trapping and snaring of this species was in general practice a century and a half ago, I was somewhat surprised, when in western Ireland in 1903, to see "Snipe-traps" exposed as such for sale in an ironmonger's shop at Ballina. They were like the common "figure of four" rabbit-trap, but on a smaller scale.

The sexes of this species cannot be differentiated by their plumage. A specimen with white secondaries and scapulars, and a sprinkling of white feathers on the body was shot at a loch near Clonrae (Tynron) on November 7th, 1906. The so-called "Sabine's Snipe" is now generally admitted to be merely a dark variety, and a very dark bird was shot at the above-mentioned loch on September 20th, 1902. Howard Saunders writes: "The numerous variations in the plumage of the Snipe have led to the creation of several bad species."* In this category must be included the specimen of Gallinago brehmi as recorded in the Catalogue of the Birds contained in the collection of Sir William Jardine. Of this bird Sir William writes: "Two specimens of Gallinago brehmi have been shot at Jardine Hall on 9th and 10th October [1849] being the first time that this species has been noticed as visiting our Islands ... on comparing the tail with that of the common Snipe it will be seen that the outline of the latter is rounded, while in G. brehmi the outer feathers exceed the length of the second." $\dagger$ Elsewhere, Sir William writes concerning

* Man. Brit. Birds, 1899, p. 574.

$\dagger$ Annals and Mag. of Nat. Hist., 1849, Vol. IV., p. 282. 
this specimen: "On 7th and 8th October the wind had been east and north east, and a gale of considerable force. On 9th and 10th the frost was hard and a good deal of ice on the springs, and on these days there were a large number of Snipes on all the higher grounds. They lay very close, were evidently fatigued, and were, no doubt, portions of a flight on their passage. Eight were put up from a few rush bushes, growing in a space of twenty yards square from which the specimen alluded to was shot. Next day scarcely a Snipe was to be seen."*

A Snipe marked N. 1908, shot in Gretna parish on September 3rd, 1908, came from Netherby† (Cumberland) : where it had been "ringed" in July of the same year.

\section{THE JACK SNIPE. Gallinago gallinula (Linnæus).}

An autumn and winter-visitant; but in varying numbers.

In the closing days of September or in early October, the Jack Snipe may be met with, and is often flushed from unexpected spots. As the season advances, the influx continues, but a considerable movement goes on, as this species is said to be "peculiarly sensitive to meteorological changes" $\ddagger$; and it seldom stays with us as late as March. Mr. John Corrie of Glencairn, states: "I am disposed to think it remains to nestle, but cannot speak positively as to this. It has been seen about the commencement of August, and if not a nesting species, August seems a late month to leave, and an early one to return." § Individuals, which for some cause or another, have not been able to accompany their fellows in their emigration, have been observed elsewhere in Great Britain on similar early dates, but this fact proves nothing. My attention having been drawn to a paragraph in the

* Contributions to Ornithology, 1849, p. 135.

$\uparrow$ Field, 1908, Vol. CXII., p. 540.

† Trans. Nat. Hist. Soc. Glasg., 1905, Vol. VIII., p. 52.

$\S$ Trans. D. and G. Nat. Hist. Soc., November 10th, 1888. 
Field, where Mr. Reginald Haines states that a Jack Snipe's nest and eggs had been taken in Dumfriesshire,* I made inquiries. In due course Dr. W. Bell kindly wrote me from New Brighton as follows: "It is now many years since I obtained the eggs of the Jack Snipe (to which you refer). It has, I know, always been a disputed question about its breeding in this country, although Yarrell speaks of it as breeding in Yorkshire. The egg I have was taken by a gamekeeper near Moffat, in Dumfriesshire, nearly fifty years ago, and I am told that the bird was flushed from its nest and was an undoubted Jack Snipe. I cannot give you any further information. I wish I could." In view of the fact that similar allegations from other parts of Great Britain, have on investigation, proved only to have been instances of the nesting of the Common Snipe, or of the Dunlin, I quote Dr. W. Bell's letter with all reserve.

The Jack Snipe breeds in Scandinavia, north-west Russia and on the tundras of Siberia up to lat. $70^{\circ}$ north; over the rest of Europe it is a bird of passage and wintervisitant, at which season it also visits North Africa, Egypt and Abyssinia, while further east it is found in Japan, the Indian region, Persia and Turkestan.

\section{THE DUNLIN. Tringa alpina, Linnæus.}

Local names-Sea-Lark; Sea-Mouse; PURre.

A common resident species on the Solway shore; but many individuals
nest far inland in spring.

"Mabie Moss" records that Dunlin were seen on the gravelbeds of the Nith near Thornhill on May 14th; and at least half-a-dozen pairs, which were probably nesting, were seen at Townfoot Loch (Closeburn) on June 6th, 1891.† Mr. R.

* Field, 1906, Vol. CVIII., p. 540.

† Dumfries Courier and Herald, June 30th, 1891. 
Armstrong writes me in 1908 that a few breed in Closeburn parish regularly. Richard Bell of Castle O'er states that a pair of these birds nested near Dumfedling (Eskdalemuir) in 1900 , but that the eggs proved unfertile; another pair were also seen in the vicinity.* In the nesting-seasons of 1908 and $1910 \mathrm{I}$ heard the wild trilling note of these birds at Loch Urr, at the head of Glencairn parish. The above mentioned localities are some twenty miles from the sea; and the species may nest unnoticed in many other inland situations. It is remarkable that at these inland breedinghaunts eggs are seldom to be found before the first week in June; but those birds that nest near the shore breed a month earlier, and it has been observed that a week often elapses between the laying of two eggs. Mr. S. Chrystie in 1881 notes the Dunlin as a breeding-species on Lochar Moss, $\uparrow$ and it also nests in suitable localities, from Caerlaverock eastwards along our coast.

Howard Saunders writes: "The Dunlin varies considerably in size, length of bill, and colour of plumage ; and even in the Palæarctic region there appear to be two races: a large and northern one of duller tints, and a smaller brighter bird to which Brehm applied the name T. schinzi." $\ddagger$ Both these forms are met with in this county, and it is believed by some, that the large race nests in far inland localities, while the smaller bird breeds nearer the coast. However this may be, in autumn and winter when these birds congregate on the Solway coast, both forms are frequently shot out of the same flock. The variation of the species, both in measurement and in seasonal and age-changes of plumage, is extensive, and formerly the "Purre" was considered a different bird; it is now recognised that this name was given to the Dunlin in its winter-dress.

In early autumn the inland nesting-haunts are deserted, and small "trips" of some three to six Dunlin may be seen

* Trans. D. and G. Nat. Hist. Soc., April 17th, 1901.

† Op. cit., December 4th, 1881.

† Man. Brit. Birds, 1899, pp. 583, 584. 
on the stretches of sand, mud and shingle of our coast; but later they gather into large flocks moving up and down the Solway Firth with the ebb and flow of the tide, and vie numerically with the Knots and Oyster-catchers. At this season of the year their numbers are temporarily reinforced by immigrants from further north. "Altogether," writes Mr. R. Service, "the Dunlin is an interesting study, whether we see it at its breeding stations on the merseland pools or around the moorland tarns in the wilder and lonelier lands ... or see it rush along the shore on stormy winter days, now showing their dark upper wings to the observer or turning up their silvery white under-parts as they glide past, or hear it on dark spring nights piping plaintively as parties of them migrate on their northward flight."*

\section{THE LITTLE STINT. Tringa minuta, Leisler.}

A rare and irregular visitor to our shores on the autumn-migration.

Sir William Jardine, in 1842, writing of this species as the "Minute Sandpiper," says, "Mr. Yarrell states, on the authority of Mr. Heysham, that they have been several times taken on the shores of the Solway. We have never been so fortunate as to meet with them there, nor do we hear of any instances of their capture in Scotland being recorded." $\dagger$

The Little Stint is recorded in 1887 as very seldom met with on our shores, $\$$ and in 1886 William Hastings told Mr. R. Service that he had never received any specimens of this species for preservation. In $1894 \mathrm{H}$. A. Macpherson wrote : "It is a curious fact that the Solway Firth is visited almost every year by certain species which are exceedingly rare on the West Coast of Scotland. . . The Little Stint (Tringa minuta) is a species in point. A few Little Stints visit us every year, and we meet with them both on the

* Trans. Nat. Hist. Soc. Glasg., 1905, Vol. VIII., p. 52.

$\dagger$ Nat. Lib., 1842, Vol. XII., p. 244.

‡ Trans. D. and G. Nat. Hist. Soc., November 4th, 1887. 
Scottish and English sides of the Solway Firth."* In 1901 the same authority states that every autumn a few odd birds are to be found along the shores from Annan to Gretna, any time between August and January, but chiefly in September. $\dagger$ In September, 1903, a pair were seen on the Blackshaw at the mouth of the Lochar. $\ddagger$ In 1905 a remarkable visitation took place in September, and Little Stints were seen by many observers between Cummertrees and Gretna. Probably the species passes undetected in many seasons, its stay on the shore being of but a few days' duration, and its habits and plumage unobtrusive. It will be seen that the appearance of the Little Stint has usually been in September, but Mr. W. Murray informs me that his keeper, J. Murray, asserts that he saw a pair of these birds on the River Annan in March, 1906, and that a specimen was shot also in that month on the coast near Cummertrees about 1898, and sent to Carlisle.

The Little Stint, on its autumnal migration, visits the greater part of Europe, and with the exception of western France, is as widely distributed on its return passage in spring. Its chief winter-quarters are in the extreme south of Africa, Arabia and India; though many sojourn during the cold months on the southern shore of the Mediterranean. Its breeding-quarters are on the tundras of northern Europe and western Siberia from the Porsanger Fjord to the Yenesei.

\section{TEMMINCK'S STINT. Tringa temmincki, Leisler.}

\section{A very rare visitor to the Solway shore.}

Sir William Jardine in 1842 writes of Temminck's Stint:

"We have not met with Scotch specimens."

* Zoologist, 1894, p. 115.

† Ann. Scot. Nat. Hist., 1901, p. 49.

‡ Trans. Nat. Hist. Soc. Glasg., 1905, Vol. VIII., p. 53.

§ Nat. Lib., 1842, Vol. XII., p. 245. 
Mr. R. Service, in his paper on "The Waders of Solway," says : "There is one certain occurrence in a bird I saw at Hastings' (the bird-stuffer) shop about thirty years ago [i.e., circa 1875] and Hastings told me he had had another long previously."* Mr. R. Service assures me that both these birds were obtained in Dumfriesshire.

Mr. Abel Chapman, comparing the status of Temminck's Stint on the north-east, with the west coast of England; states: "On the west they appear slightly less irregular, their passage on the Solway taking place during the first week of September." $\dagger$ Writing in 1892, H. A. Macpherson says : "considering that this Stint nests on the Norwegian fells, fide Collett, it is a little surprising that not a single specimen has strayed to the marshes of the English Solway during the last half-century." $\ddagger$ Mr. L. E. Hope writes me from Carlisle in 1909, that during the last fifteen years he has handled some twenty-five specimens of the Little Stint, but never one of this species. In view of the above, and the fact that no specimen of this species is known to have been obtained in the Solway area since about 1875, it is difficult to accept Mr. Abel Chapman's statement.

Temminck's Stint is a more irregular visitor to Great Britain on its autumn and spring-migrations than the preceding, having occurred most frequently on the southern and south-eastern coasts of England. It breeds commonly in Scandinavia as far south as Trondhjem and eastwards across European and Asiatic Russia beyond the limit of tree-growth. Its migrations extend to the Indo-Malayan region, China, and both sides of Africa as far south as lat. $10^{\circ}$ north; some, however, winter in the Mediterranean basin; while on passage it visits in Europe many of the shores and inland waters.

\footnotetext{
* Trans. Nat. Hist. Soc. Glasg., 1905, Vol. VIII., p. 53.

$\dagger$ Bird-Life of the Borders, 1907, p. 403.

† Fauna of Lakeland, 1892, p. 384 .
} 


\section{THE CURLEW-SANDPIPER.}

Tringa subarquata (Güldenstädt).

\section{A scarce visitor to the Solway shore on the autumn-migration.}

Writing to his friend P. J. Selby in 1826, Sir William Jardine says: "I had the pick of Murray's collection last week. He had a very nice specimen of the pigmy-curlew which he shot at the same time that I got my specimen." In 1842 Sir William Jardine writes of this species: "It has been in the autumn, after their return from breeding, that we have met with it on our shores, and have killed it on both sides of the Solway, either in small parties, or mixed with the Purre, or feeding by some muddy streams, in a salt marsh which they seemed fond of frequenting, and, when come upon unawares, would utter a shrill lengthened whistle, very different from that of the Purre under similarcircumstances." "*

The above quotations do not mention any locality actually in the county as a place where this species was obtained; and the "salt-marsh" referred to may perhaps have been at Southerness (Kirkcudbrightshire), a well-known haunt of shore-birds, which Sir William Jardine was in the habit of visiting with his friend J. D. Murray of Murraythwaite. Whether in former days the Curlew-Sandpiper was more often met with on our shores is difficult to say, but its appearances on the autumn-migration are nowadays but casual.

"The breeding grounds" of this species "are in Aretic Siberia east of the Yenesei, and it winters in the tropical regions of the old world." $\dagger$ To certain parts of the east and south coasts of England the Curlew-Sandpiper is an annual migrant in varying numbers, arriving in August and September, and sometimes staying till October: on the return passage to its northern breeding-haunts it is seen from April till June.

* Nat. Lib., 1842, Vol. XII., p. 241.

+ Birds of Britain, 1907, p. 328. 


\section{THE PURPLE SANDPIPER.}

Tringa maritima, J. F. Gmelin.

\section{An uncommon autumn and winter-visitor to our coast.}

The Purple Sandpiper arrives on the shores of the Solway in September and seldom stays so late as May. Mr. R. Service writes : "It is to be found the whole winter through in small parties of half a dozen or less, wherever seaweedcovered rocks fringe the shore. They delight in remaining just where the surf splashes about, requiring them to jump up out of its reach as each wave dashes in."* The above short description of the habits of this species, is quoted from Mr. Service's paper on the Waders of the Solway Area, and it must be remembered that the shores of Dumfriesshire offer few attractions to this rock-loving species. Sir William Jardine in 1842 wrote of the "Purple or Rock Sandpiper" as a not very numerous winter-visitant to the coasts of the south of Scotland. $\dagger$ A bird of this species was shot at Glenæ (Tinwald), about eleven miles from the sea, early in November, 1886. Mr. R. Service informs me that it was in immature plumage, with the feathers rather broadly edged with white, and was sent to William Hastings for preservation, whence it passed into the collection of the late Mr. Marsland. On November 10th, 1887, a Purple Sandpiper was shot at Kirkmichael $\ddagger$ some fourteen miles from the sea, and is now in the possession of Mr. T. Farish. Mr. J. Harkness writes me that he shot one of these birds on Blackshaw bank on January 1st, 1888, and Mr. Hugh Mackay informs me that in the winter of 1894-1895, the Purple Sandpiper was more plentiful than in former years, while Dr. Scott has sent me word that these birds have been seen on the Ruthwell coast.

\footnotetext{
* Trans. Nat. Hist. Soc. Glasg., 1905, Vol. VIII., p. 53.

† Nat. Lib., 1842, Vol. XII., p. 237.

† Trans. Nat. Hist. Soc. Glasg., 1905, Vol. VIII., p. 54.
} 
The Purple Sandpiper nests in northern and circumpolar Europe, from Nova Zembla westwards, its nearest authenticated nesting-place to us being in the Færöes. In winter it is an abundant, but local, visitant to the shores of Great Britain, and of the countries of western Europe. It also breeds in north-east America, and winters in the Great Lakes and middle States.

\section{THE KNOT. Tringa canutus, Linnæus.}

\section{A very common autumn and winter-visitant to the Solway shore.}

The Knot may be seen any time between September and May, frequenting the sandy banks of the Solway, and often huge flocks are observed coming and going to Southerness (Kirkcudbrightshire), which is a favourite locality especially in late autumn, and at this season it is only exceeded in numbers by the Dunlin and the Oyster-catcher. Mr. R. Service writes me : "There is every reason to believe from the observation of older gunners that the Knot was at one time far less abundant than nowadays on our shores. It has always been very numerous in my own experience, with the exception that occasionally in some autumns few are to be seen, and that now and again it will be strangely absent for weeks. It may be that on such occasions it is over on the English side, induced to go or stray there by some peculiar state of the wind or weather, or some vagary in the tidal flow, which so far as the Solway is concerned is ever varying or changing. In spring on a late April evening it is often of great interest to make an observation of the Knots with a pair of glasses. They will then allow a closer approach, and the smaller flocks which are the least timid will be seen to have a large proportion in more or less full breeding-dress." Specimens in this plumage have been obtained locally in May. 
Arctic America and Greenland are believed to afford the principal nesting-grounds for the Knot; but the first authentic eggs were found (June 23rd, 1901) in the Taimyr district of Siberia. In winter it occurs on the coasts of western Europe and in West Africa as far south as Damaraland ; in America it is well known on the Atlantic shore, and it is found in Australia and New Zealand. On the shores of Great Britain it is abundant in autumn and winter in suitable localities, except on the coast of Scotland north of the Solway.

\section{THE SANDERLING. Calidris arenaria (Linnæus).}

A visitant to the Solway shore on the spring and autumn-migrations.

The late H. A. Macpherson wrote in 1892 as regards the status of this species on the Cumberland shores: "When I wrote of the Sanderling in the Birds of Cumberland,* our local experience of this bird was limited to the spring and autumn-indeed we only knew of one individual obtained in winter dress, and that at a distance from the sea. Since then I have frequently met with a few Sanderlings near Beckfoot in winter, while in December, 1886, Mr. J. N. Robinson shot a bird out of a large flock on Burgh Marsh. But our reference to the Sanderling as 'not remaining to winter' is still true in the main, the bird being of course chiefly a spring visitant." $\dagger$ With us this species: puts in an appearance in August, and again in April, though small flocks have been seen so late as the first week in June, and it is now observed in winter far more commonly than in former years. William Hastings told Mr. R. Service: that in the course of his business career (1860-1885). he had occasionally received birds of this species for preservation. Mr. Service, in his paper on "The Waders.

* Birds of Cumberland, 1886, p. 153.

† Fauna of Lakeland, 1892, pp. 391, 392. 
of Solway," says of the Sanderling: "Though never very abundant this species is of general distribution in small parties. ... The whiteness of their plumage makes them very easily seen and identified. ... Whether they always remained with us in winter may be a matter of doubt, so far at least as any considerable number is concerned."* The great majority of birds which visit our shores on the autumnal migration, pass on to more southern climes; but the comparatively few which remain with us through the winter, may be found in small parties frequenting suitable spots, where there is a mixture of shingle and ooze.

The species breeds in Greenland and arctic America, and possibly in north-east Siberia as far west as Taimyr. On passage it is common on parts of the coast of Europe, except the Baltic, while in winter it is so widely scattered in its distribution that it may be said to be almost cosmopolitan.

\section{THE RUFF. Machetes pugnax (Linnæus).}

An irregular visitor on the autumn-migration, occurring at fairly long intervals.

The Ruff (male) and Reeve (female) must have been regular autumn-visitants to our shores in former years for, Sir William Jardine, writing of the status of the species in Great Britain, says: "When the breeding season has terminated, and the young have attained their first plumage, the males having lost their sexual adornments, a dispersion from the fens takes place. It is after this period, about the end of August or the beginning of September and for the next two months, that they are most frequently met with in Scotland, either as straggling birds passing along the moors, or on the sea-shore, where they continue, often intermixed with plovers, and are to be met with in small parties. .... We have often shot them ... on the banks of the Solway,

* Trans. Nat. Hist. Soc. Glasg., 1905, Vol. VIII., p. 54. 
where, at the seasons alluded to, they may almost always be met with."* This was prior to 1842 , and in subsequent years the visits of the species have become less frequent.

In 1885 William Hastings records a Ruff in winterplumage shot near Caerlaverock. $\dagger$ This specimen, in reality a Reeve, and a bird of the year, was shot on October 21st, 1885 , so I am informed by Mr. R. Service, in whose collection it now is; and he tells me that more than one specimen of the Reeve had been sent to Hastings from Caerlaverock in previous years. An immature Ruff was shot by the late Lord Herries on Blackshaw bank on September 18th, 1885, and is now (1910) at Kinharvie. A Ruff was shot near the shore not far from Caerlaverock, on October 30th, 1905, by Myles Quinn, head-keeper on Lord Herries' estate. It was the first he had ever seen in the district, but he thought that in the past some three or four had been got at various timest: this specimen is now in the collection of Mr. R. Service. From the end of May till September, 1907, a party of four, and sometimes five, Ruffs and Reeves, was seen on and about the merse-lands from Glencaple up to Netherwood, and as often on the opposite shore of the Nith estuary on the Kirkconnell estate. No nest was discovered, but the Ruffs were in their characteristic breeding-plumage, and often indulged in those ostentatious sham-fights which have gained for this species the cognomen of pugnax. Their prolonged visit at this season was possibly attributable to the exceptionally wet and cold weather then experienced. Mr. J. M. Haining shot a Reeve at Eastpark (Caerlaverock) on September 15th, 1908, and it is now in his possession.

It will be observed that all the specimens recorded, hail from Caerlaverock, and a Ruff in my collection believed to have been obtained near Capenoch (Keir) about 1880, is of doubtful origin. A Rough-legged Buzzard, which had been trapped that year, was stuffed standing over a Ruff; the

* Nat. Lib., 1842, Vol. XII., pp. 225, 226.

$\dagger$ Trans. D. and G. Nat. Hist. Soc., December 4th, 1885.

$\ddagger$ R. Service, op. cit., November 3rd, 1905. 
details of the capture of the "Buzzard-hawk" are evergreen in the memory of the keeper who trapped it, but he can recollect nothing as regards the smaller bird, which may or may not have been a local specimen.

This species has never been known to nest in the county, and $H$. A. Macpherson wrote in 1892 : "The Ruff has never been obtained in Lakeland during the breeding season. $\mathrm{Mr}$. C. M. Adamson assured me that he once received from James Cooper a clutch of the eggs of this species, which had been taken in the neighbourhood of the English Solway. Mr. Adamson subsequently presented these eggs to $\mathrm{Mr}$. Hancock." *

On its autumn and spring-migrations the Ruff is found throughout Europe and Asia except in the extreme north. Its winter-quarters extend from the southern shores of the Mediterranean to Cape Colony, and to India, Burmah, China and Japan, in Asia. It breeds in Scandinavia, and parts of Russia, Siberia and central Europe, and a few pairs, stringently protected, still sometimes nest in East Anglia. There, in days when drainage had not destroyed so many favourite haunts, and before the avidity of the egg-collector had been aroused by the growing rarity of the species, the Ruff and Reeve were among the characteristic birds of the fens and broads.

\section{THE COMMON SANDPIPER.}

Totanus hypoleucus (Linnæus).

Local names-SUMmer-SNIPE ; SAND-WhaUP ; CURWILLET ; KITTIE-NEEDIE ; SAND-TRIPPER.

A common summer-visitant to all suitable lakes and rivers throughout the county.

The Common Sandpiper arrives at its nesting-haunts about the third week of April, its appearance varying by a few

* Fauna of Lakeland, 1892, p. 390. 


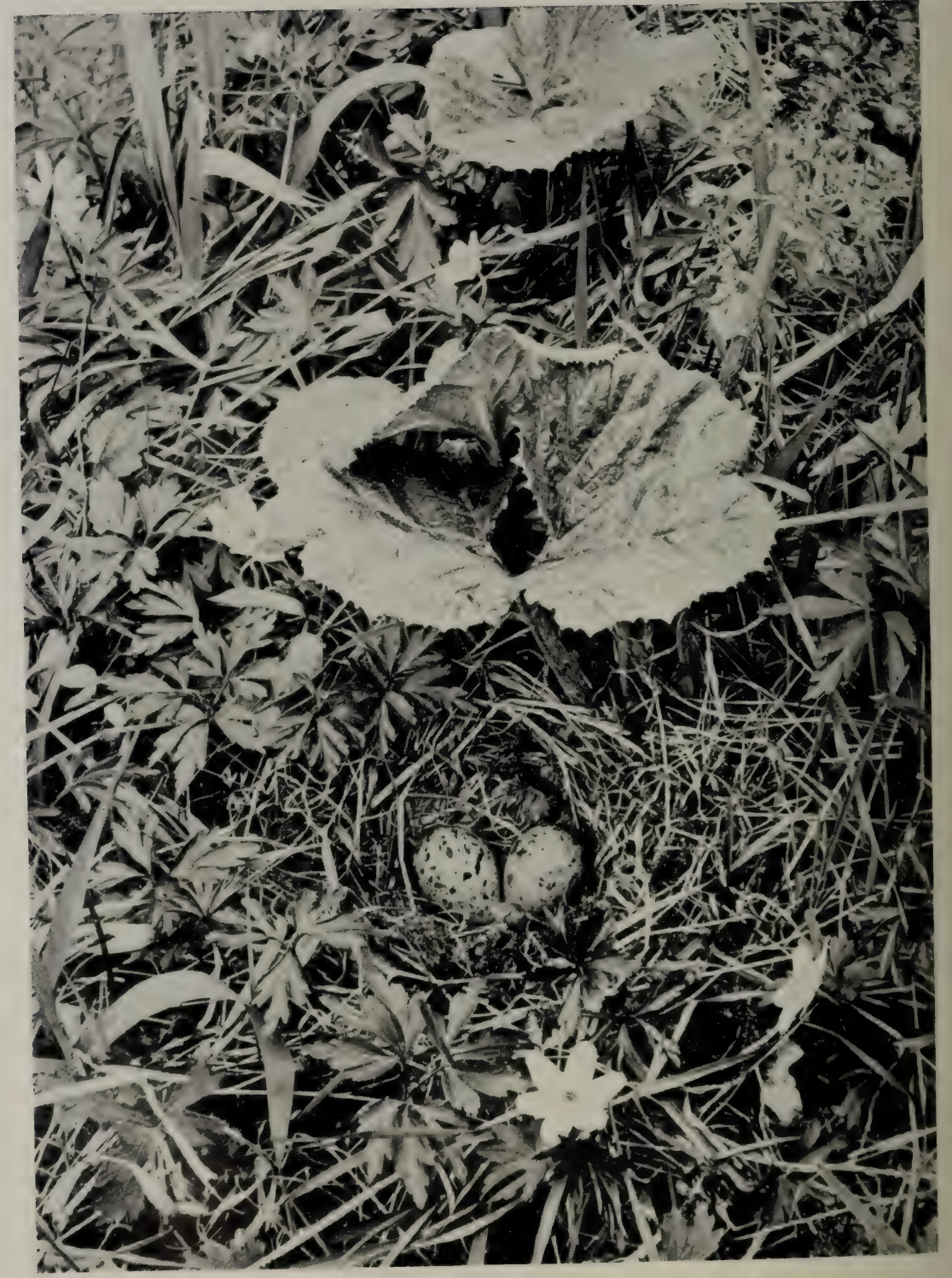

NEST AND EGGS OF THE COMMON SANDPIPER (Totanus hypoleucus). 405] 
days, according to the climatic conditions at the time. Sir William Jardine in a MS. note in his personal copy of the Naturalist's Library, records its arrival at Jardine Hall in 1836, so early as April 3rd. It frequents the sandy or gravelly shores of most of our lochs and rivers, and is met with along their tributaries, even in upland districts. On more than one occasion a nest has been found in the Capenoch gardens which extend along the banks of Scaur Water; and I am informed by Miss Winifred Young that in 1908 and 1909 a pair nested in a herbaceous border in the garden of Blacket House, Eaglesfield, close to which the Kirtle flows. The nest, which is usually well concealed, contains four eggs, and incubation lasts twenty-three days. Mr. R. Armstrong informs me that in 1907 he found a clutch of five eggs by the Nith near Thornhill (Morton). Late in July or early in August our birds leave their nesting-haunts, and, after a brief sojourn of a week or two on the coast, depart to their more southerly winter-quarters.

In winter, this species is found in the Mediterranean basin, throughout Africa, India and Australia, as far south as Tasmania.

The accompanying photograph of the nest and eggs of the Common Sandpiper was obtained by Mr. D. Legard on the banks of Shinnel Water above Tynron Village.

\section{[THE WOOD-SANDPIPER.}

Totanus glareola (J. F. Gmelin).

Writing of this species Howard Saunders says that along the west side of England "the bird is very rare, even in such congenial situations as the flat shores of the Solway."*

H. A. Macpherson in his Vertebrate Fauna of Lakeland records two specimens obtained near Edenhall, Cumberland, in August, 1867, and another believed to have been seen by

* Man. Brit. Birds, 1899, p. 607. 
W. Duckworth in the breeding-season.* One was got near Skinburness, Cumberland, in 1893, and another at the same locality on August 20th, 1898. $\dagger$

I am not aware of the occurrence of the Wood-Sandpiper in Dumfriesshire. The specimen mentioned in "Some Bird Notes from Eskdale " $\div$ by Richard Bell of Castle O'er was shot by him on August 14th, 1857, a little to the west of the village of Heriot, among the Muirfoot Hills, in Midlothian.]

\section{THE GREEN SANDPIPER.}

\section{Totanus ochropus (Linnæus).}

\section{A very irregular autumn-visitor.}

In a letter dated from Jardine Hall on August 25th, 1827, Sir William Jardine informs his friend P. J. Selby, that he saw two Green Sandpipers on August 12th, but he could not get near them. "They were," he writes, "on a small burn in the muir and flew an immense distance whenever raised." Sir William writes in 1842 : "The specimens alluded to by Mr. Yarrell, as shot in Dumfriesshire, were killed in spring, at the mouth of a small tributary of the Annan, where they remained some days-notice having been sent to Mr. Murray of their being there, as a bird not known; they had also been seen near the same spot in previous years." $§$ These Green Sandpipers, a male and female, were shot in May, 1829, at the foot of Skein Water by Mr. J. D. Murray of Murraythwaite, and were recorded as the first authenticated specimens of the species obtained in the district.\| They passed into his collection, 9 but their

* Fauna of Lakeland, 1892, p. 395.

† Trans. Carlisle Nat. Hist. Soc., 1909, p. 57.

† Trans. D. and G. Nat. Hist. Soc., April 17th, 1901.

§ Nat. Lib., 1842, Vol. XII., pp. 210, 211.

|| Mag. Nat. Hist., 1829, Vol. II., p. 282.

II Illust. Brit. Ornith., 1833, Vol. II., p. 76. 
subsequent history cannot be traced. In a list of the birds of the parish of Applegarth and Sibbaldbie in 1832, this species is described as " occasionally seen on its migratory passage."* Sir William Jardine further states: "Once or twice the green Totanus has been seen near Jardine Hall in winter, stationary for some weeks, frequenting the banks of the Annan, where it was soft, or some large ditches. One was shot in January 1836, which had remained for some time, and was frequently seen in some ditches, sheltered all around with wood. When disturbed, it would not continue flitting along the ditch, but would at once rise over the trees, and leave for the time; its return being often intimated by its shrill whistle, when passing in, before alighting." $\dagger$ In the Catalogue of the Birds contained in the collection of Sir William Jardine, two specimens are recorded as obtained at Jardine Hall, $\ddagger$ and Robert Gray, writing in 1871, says: "Sir William Jardine informs me that he has frequently procured it in (Dumfriesshire) since 1836." $\S$

On January 5th, 1885, a Green Sandpiper was shot by Mr. Farish at Kirkland (Kirkmichael), and preserved by William Hastings; while Mr. Hugh Mackay records two of these birds shot on Conheath Merse (Caerlaverock) a day or two prior to December 27th, 1892. One of these he stuffed, the other being too badly shot for preservation; and he adds they were "the first specimens recorded in this locality after an interval of four years." $\|$ A female was shot by Mr. Paterson, jun., of Broomlands, at Locharbriggs (Dumfries) on December 29th, 1906, $\uparrow$ and Mr. R. Service informs me that Mr. Tom Little secured a specimen on January 20th, 1909, at Carse of $A$ (Kirkmichael).

During the first half of the last century the species was

* New Stat. Acct. Scot., Vol. IV., p. 181.

† Nat. Lib., 1842, Vol. XII., p. 211.

‡ Cat. Birds in coll. Sir W. J., p. 202 (8241), d.d.

$\S$ Birds of West Scotland, 1871, p. 293.

II Trans. D. and G. Nat. Hist. Soc., May 12th, 1893.

II Ann. Scot. Nat. Hist., 1907, p. 113. 
evidently not very scarce, but after that there came a long period in which it was rarely recorded, though in later years several specimens were obtained. The species may be described as formerly tolerably regular, but now only an intermittent visitor to our coast from September till February.

Throughout Great Britain with the exception of the north and west of Scotland the Green Sandpiper is widely distributed during its autumnal migration. It is sometimes met with throughout the winter, and may occasionally stay to breed, but of this there is no positive proof. The nestinghabits of this species are remarkable, in that the old nest of some other bird, such as a Thrush, Blackbird, or RingDove, is frequently utilised. It breeds from the Arctic circle southwards in Europe to central Russia, Poland and Germany, and in Asia to the great mountain ranges, being found on its subsequent migration throughout these continents, and in winter it extends its range south as far as Cape Colony, southern India, and the Malay Archipelago.

\section{THE REDSHANK. Totanus calidris (Linnæus).}

Local name-REDLEGS.

A resident and increasing species on the coast, widely distributed inland in spring.

Sir William Jardine writes of the Redshank in 1842: "This species is one of the most common of the larger British Totani, and although breeding in marshes, is perhaps more decidedly a maritime species than the others. . . In a few localities, on the Scottish coasts, it is stationary during the whole year; these are where some suitable marsh is near for a breeding place.... We have several times procured them in the breeding season, and with the young, 
in a marsh such as we have noticed, on the banks of the Solway at Southerness, where a few pairs annually breed."*

From the above it is gathered that about seventy years ago the Redshank did not nest far from the coast. Now it does so throughout the county, and Mr. R. Service, dating this extension in their breeding-range from about 1880, adds : " Long after my boyhood, when nesting rambles occupied in their season every hour of spare time, there were no Redshanks to be found breeding away from strictly shore localities. As I have said, they are everywhere now-a-days in spring." $\dagger$ This extension is believed to be due, not so much to a change in the habits of the Redshank, as to an increase in their numbers, and it will be interesting here to note the distribution of this species in some of the more inland parishes in spring.

Richard Bell of Castle O'er states that prior to 1887 or 1888 the Redshank was unknown in Eskdale, but that in 1901 two or three pairs were observed, and that they were believed to breed on the farm of Dumfedling. $\ddagger$ He wrote me in 1908: "There were none a few years ago; now several nest at head of Eskdalemuir parish." Mr. J. Milne-Home writes me from Langholm that the Redshank is heard passing over in April, but that it does not nest in that locality. Mr. J. Little from Moffat informs me that this species was first noticed in a marsh below the town about 1904. In Nithsdale, Mr. Thomas Ballantyne writes that the Redshank was first seen in Sanquhar parish in 1883, and that it has greatly increased since then; and Mr. A. Park informs me that it was known in the vicinity of Kirkconnel prior to 1900. In Glencairn, the Redshank in 1888 is recorded as nesting annually at Loch Urr §; but Dr. J. W. Martin in 1901 states that five years ago this species was a rare visitor to Glencairn, though " now a pair

* Nat. Lib., 1842, Vol. XII., pp. 201, 202.

$\dagger$ Trans. Nat. Hist. Soc. Glasg., 1905, Vol. VIII., p. 56.

¥ Trans. D. and G. Nat. Hist. Soc., April 17th, 1901.

$\S$ Op. cit., November 10th, 1888. 
may be heard, if not seen, about any marshy land in the nesting season."* On the coast, and elsewhere throughout the county in all suitable localities, the Redshank is reported as present and increasing as a nesting-species.

At its inland breeding-haunts it arrives in March or early April ; the nest is usually well concealed in a tuft of rushes or long grass, and both birds take part in incubation, which lasts twenty-two days. The cares of domestic life ended, they and their progeny depart in July or August for the shore. Here, later, they become a positive nuisance to the wild-fowler, as they act as most vigilant sentries for the geese and other valuable fowl, flying off uttering their shrill note on the approach of danger. At this season they occasionally congregate into flocks, and Sir William Jardine states that he once at the end of August obtained thirteen at one shot out of a large flock on the Solway Firth. $\uparrow$ On the shore they frequent the margins of salt and brackish water, where they find a plentiful supply of Crustacea and Mollusca. Though no diminution in the numbers of our Redshanks takes place, even in winter, it is possible that our locallybred birds emigrate south, their places being filled by immigrants from farther north, which in turn, at the approach of spring, make way for those birds returning from more southerly winter-quarters.

\section{THE SPOTTED REDSHANK. \\ Totanus fuscus (Linnæus).}

Has occurred once.

I only know of one record of the occurrence of the Spotted or Dusky Redshank in the county. This was a specimen shot by Captain W. J. Maxwell-Scott on Lantonside Farm

* Trans. D. and G. Nat. Hist. Soc., December 13th, 1901.

† Nat. Lib., 1842, Vol. XII., p. 204. 
(Caerlaverock) on October 5th, 1907, as it was flying inland from the shore. He informed me that it was sent to Kinharvie to be stuffed, but being mislaid was not found until its condition was such that it had to be thrown away. The species is but an irregular migrant on the spring and autumn-migrations to the east coast of England, being even more rarely observed elsewhere in the British Isles.

H. A. Macpherson writes: "It is a curious fact that the Solway Firth is visited always every year by certain species which are excessively rare on the west coast of Scotland. The Spotted Redshank (Totanus fuscus) is a species in point. ... Since we have searched for the Spotted Redshank, it has been met with in immature plumage nearly every autumn almost always on the same part of the [English ?] Solway."*

The record from Caerlaverock above mentioned; a specimen shot by Mr. Robert McCall near Carsethorn (Kirkcudbrightshire) on February 13th, 1899†; and another seen near there in October, 1903t; are the only three instances I know of the occurrence of the Spotted Redshank on the Scottish side of the Solway. But its presence may often pass undetected, for the duration of its stay is probably short, and its identification from the preceding species is not easy, except at close-quarters. The supposition that it may occur unnoticed is somewhat strengthened by the confident reports of local gunners, well acquainted with the calls of the various sea-birds, who state they at times can distinguish its peculiar cry: moreover, the species is regarded as an irregular autumn-migrant on the English side of the Solway. $\S$

The Spotted Redshank nests in northern Europe and Asia, its winter-quarters extending to Cape Colony, northern India, China, Japan, and Burmah.

* Zoologist, 1894, p. 115.

† Ann. Scot. Nat. Hist., 1899, p. 112.

† Op. cit., 1904, p. 216.

§ Trans. Carlisle Nat. Hist. Soc., 1909, p. 58. 


\section{THE GREENSHANK.}

Totanus canescens (J. F. Gmelin).

A fairly regular visitant to certain localities on the autumn-migration.

A pair of Greenshanks, as recorded by W. J.[ardine] on May 21st, 1829, were shot on the Annan, about two miles below Jardine Hall ; "they frequented also the adjoining lochs of Lochmaben; and when disturbed, immediately passed over, always nearly by the same route, to the quieter haunts, flying very high, and incessantly uttering their shrill piping whistle. They are now in the collection of Sir W. Jardine, Bart."* The same authority writes of the Greenshank in 1832 as "seen sometimes on the Annan," in the parish of Applegarth and Sibbaldbie, $\dagger$ and some ten years later he states: "In the south of Scotland (in our own vicinity) they are frequently, in autumn, observed in the evening, flying or passing over at a considerable elevation, as if on some passage or migration, and are betrayed by their noisy notes. During winter one or two individuals are seen, and occasionally procured, by the riverside, or near some wide ditches." $\ddagger$

A few specimens were obtained on the shores of the Solway during the severe winter of 1878-1879. A Greenshank, "shot upon the Annan Water, as far up as Dalfibble" (Kirkmichael), in July or August, 1887, is thus recorded by William Hastings, who adds : "I have not had above two or three specimens of the same bird for more than thirty years." § Mr. R. Service informs me that a fine adult male was shot near Caerlaverock on August 15th, 1887, and a

* Mag. Nat. Hist., 1829, Vol. II., p. 283.

† New Stat. Acct. Scot., Vol. IV., p. 181.

† Nat. Lib., 1842, Vol. XII., p. 206.

§ Trans. D. and G. Nat. Hist. Soc., November 4th, 1887. 
young bird in the following month, by Dr. Williamson of Carzield (Kirkmahoe). Two were shot at the mouth of the Nith near Glencaple in September, 1889, by a gunner named West; and Mr. Norman Maclachlan writes me that one was shot at Halleaths (Lochmaben) towards the end of September, 1890. Mr. Hugh Mackay records a specimen obtained near Dalscone (Dumfries) in the second week of January, 1895, and remarks, "it is most unusual for this species to appear so early in the year in this district."* Miss Dorothea Bate informs me that one was shot on Wyseby Moss (Kirkpatrick-Fleming) on August 20th, 1903.

From the above records it will be seen that the Greenshank has occurred from August to January, and Mr. R. Service states that " there is a suspicion that the Greenshank breeds somewhere in the recesses of the Galloway or Dumfriesshire hills, as young birds have been shot in a very early stage of plumage" $\dagger$; but this has yet to be proved. In 1907 two eggs, thought to belong to this species and taken in Closeburn parish by Mr. Samuel Bell, were brought for verification to Mr. Service, who could, however, give no definite decision with regard to them.

Towards the end of August, and for some six weeks later, this species is often seen at certain favoured spots on our shore, as at the mouth of the Nith, and they ascend the tidal portion of our rivers to a considerable distance in search of food on the gravel-beds.

The Greenshank nests in the Hebrides and in the north of Scotland, where its breeding-range is believed to be extending, but in northern Europe and Asia it breeds far more numerously. It is observed on many of the coasts and inland waters of Europe on passage, and though many Greenshanks do not go farther south in winter than the Mediterranean basin, the species is found at this season over the greater part of the eastern hemisphere down to the Australian region.

* Dumfries Standard, May 29th, 1895.

$\dagger$ Trans. Nat. Hist. Soc. Glasg., 1905, Vol. VIII., p. 56. 


\section{THE BAR-TAILED GODWIT.}

Limosa lapponica (Linnæus).

A regular and common autumn-visitant to the shores of the Solway; occasionally remaining throughout the winter.

Bar-tailed Godwits appear on our coast late in August or early in September, their numbers being reinforced till the end of October, when they begin to diminish, though this species is seldom entirely absent until its northward passage in April. They frequent the soft muddy banks adjoining the green merse-lands, away from the firm sand or shingle, the estuary of the Nith being a favourite resort. In some autumns, as in 1882, they are far more abundant than in others. From one hundred and fifty to five hundred birds may sometimes be seen in one flock, but from thirty to forty is the more usual number. In some seasons many large or small parties continue on our coast throughout the winter, and this would seem to happen after a more than usually great autumn immigration. Regarding the status of this species on the Solway, Mr. R. Service writes in 1907 as follows: "The whole of the winters of the 'eighties were marked by a continuance of the Bar-tailed Godwits. The decade following was just as strongly marked by sharply defined autumn and spring visits only. In more recent seasons only few have put in an appearance in autumn, and very seldom have $I$ seen them at all during winter proper. This current season has been, up to the present time, remarkable for the large numbers on the Solway.... But the most extraordinary thing in connection with the Bar-tailed Godwit, as a Solway species, I have now to record. During the whole summer season (so-called) of 1907, a flock of the species, estimated to consist of about 200 birds, has remained near to Carsethorn [Kirkcudbrightshire] far down the estuary of the Nith. ... Most of the birds 
assumed full breeding plumage, but it was not noticed that any separations for nesting ever took place. So far as I can find out, not one was shot, nobody apparently having thought of breaking the close time."*

This species nests in northern Europe and Asia from Lapland to the Yenesei, and in the colder months is found in northern India, on the shores of the Mediterranean countries, and in Africa as far south as Somaliland on the east and Gambia on the west.

\section{THE BLACK-TAILED GODWIT.}

\section{Limosa belgica (J. F. Gmelin).}

\section{A rare and irregular visitor to the Solway shores on migration.}

In 1842 Sir William Jardine wrote of the Black-tailed Godwit: "This handsome species breeds annually in the fenny districts of England, and, during winter, is partially distributed along the oozy shores of the English coast, and those of the south of Scotland; but, although a frequent, it is by no means an abundant species." $\dagger$ Tempora mutantur, and it is now upwards of sixty years since the last eggs of this species were taken in Norfolk, and it has long since ceased to be a frequent visitor to the shores of the Solway.

I must thank Mr. R. Service for pointing out to me that the records of this species as given in the Transactions of the Dumfriesshire and Galloway Natural History and Antiquarian Society, on November 3rd, 1882, and December 7th, 1883, respectively, are erroneous. A specimen of the Blacktailed Godwit was shot in November, 1881, near Kingholm by a gunner named West, and passed into the hands of William Hastings, who remarked that it was the first of its kind he had ever had to preserve. In November, 1883, another specimen, a female, was obtained at the same place

* Ann. Scot. Nat. Hist., 1908, pp. 85-87.

$\dagger$ Nat. Lib., 1842, Vol. XII., p. 192. 
by the same man, and was also acquired by William Hastings. Others were seen at the time and another was shot and lost. The late H. A. Macpherson wrote to Mr. R. Service that an adult in red plumage was shot on July 24th, 1890, at the mouth of the Esk; and this record is here included, although outside the confines of our boundary, to draw attention to the remarkably late date of the occurrence of this individual in the Solway area.

The Black-tailed Godwit visits chiefly the southern and south-eastern coasts of England on its autumnal passage, and from April to May on its return, but at no time is it numerous : it is rarely met with further north, and still more rarely on the west of Great Britain, though fairly frequent in Ireland. As has been stated, it bred formerly in the fens of East Anglia. Its present nesting-haunts are in north-west and northern Europe as far as lat. $65^{\circ}$ north, and in parts of central Europe and western Siberia. Over the rest of Europe it is found on passage, in winter in north-east Africa, the countries of the Mediterranean, and north-west India.

\section{THE COMMON CURLEW.}

Numenius arquata (Linnæus).

\section{Local name-WHAUP.}

"For what's in the lilt o' the laverock* to touch ocht mair than the ear! The merle's lown craik $\uparrow$ in the tangled brake can start nae memories dear, And even the sang o' the Mavisł but waukens a love-dream tame

To the whaup's wild cry on the breeze blawn by, like a wanderer's word frae hame."

RoBert REID.- "The Whaup."

A resident; common on the shore in autumn and winter, nesting abundantly inland.

The poet is right; wherever I am, and whatever time of the year I hear it, the "whaup's wild cry" brings back to

* Skylark.

† Blackbird's low chatter.

‡ Song-Thrush. 
me memories of my home among the hills, where the arrival of the Curlew is welcomed as one of the first signs of the approach of spring. Living in a country rich in the traditions of the Covenanters, I have heard the Curlew praised for the part it played in giving warning to the secret conventicle of the approach of the troopers, but as often blamed for betraying the whereabouts of some poor fugitives to their relentless persecutors.

Its shrill cry, so like its trivial name, is well known to most of us; but the curious rippling crescendo note of the Curlew in spring is reserved for those who know the bird at its breeding-haunt. On all the moors, mosses and grassy hillsides of our uplands this species is abundant at this season, and Mr. John Edmond, writing to me from Wanlockhead, says it is plentiful there, and that nests are found up to the very top of the Lowthers. Richard Bell of Castle O'er wrote me in 1909 that a good many years ago, on striking an average for thirteen years he found that the date of arrival of the Curlew in Eskdalemuir worked out at February 27th. He also sent me the following table for the eleven years, 1899-1909:-

$\begin{array}{llllll}1899 & \text {.. February 27th. } & 1905 & \text {. F February 10th. } \\ 1900 & \text {. F February 25th. } & 1906 & \text {. F February 29th. } \\ 1901 & \text {. F February 27th. } & 1907 & \text {. F February 25th. } \\ 1902 & \text {. F February 23rd. } & 1908 & \text {. F February 17th. } \\ 1903 & \text {.. February 8th. } & 1909 & \text {. F February 6th. } \\ 1904 & \text {.. January 28th. } & & \end{array}$

But these observations probably refer to the first arrival of individuals, for though the vernal migration of the Curlew begins in February, the big general movement from the Solway shores takes place as a rule during the first week in March. In 1893 this departure was observed so early as February 5 th, and in 1881 it was delayed till the unusually late date of March 14th. But long after this date Curlews are annually observed migrating farther north, usually at night. A few birds, presumably barren, remain on the 
shore throughout the spring. In their nesting-places they feed chiefly on beetles (geodephaga), and are believed to destroy the "hill-grub" or larvoe of the antler-moth (Charoeas graminis) so injurious to upland hill-pastures. The nest almost invariably contains four eggs (personally I have never seen five and very rarely but three), and these take twenty-eight days to incubate. Within thirty hours of being hatched the young ones leave the nest, though they do not go far from its vicinity. The eggs vary much in colour, and measure as a rule " 2.8 to $2 \cdot 45$ inches by 1.95 to $1 \cdot 75$ inch $" *$; but one found at Bennan (Tynron) measures $3 \cdot 1$ by $2 \cdot 25$ inches. They are much coarser in flavour than those of the Lapwing, and there is no market for them nowadays; but it was recorded in 1867 that Curlews' eggs fetched sixpence a dozen as compared with a shilling a dozen for Plovers' eggs. $\dagger$

Although I have seen an individual bird up in the hills so late as November 15th, and have often observed laggards there in August and even September, the Curlews bred on our uplands come down as a rule to the lower ground about July, where they frequent the meadows or cultivated land. Here they may stay for a week or two in August (at which time they are by no means bad eating), before resorting to the flats of sand and mud on the Solway. These home-bred birds are joined by those of more northern and eastern origin, "and the watcher will note how the flocks he has been observing will disappear some dark October evening, and how for the next few days only a few odd birds will be seen. Then flocks muster up, from he knows not where, and again go off, leaving comparatively few to pass the winter months and enliven the wide solitude of the sand-banks with their movements and long-drawn eerie cries." + There can be no doubt that the Curlews to be seen on our shore at this season are

* Col. Figs., Eggs Brit. Birds, 1896, p. 133.

$\dagger$ Dumfries Courier, April 30th, 1867.

‡ Trans. Nat. Hist. Soc. Glasg., 1905, Vol. VIII., p. 57. 
but visitants taking the place of our locally-bred birds, which in turn have migrated to winter-quarters farther south. "The species is well known on passage throughout central and southern Europe, ranging as far west as the Canaries and Azores; while it winters in Africa from the Mediterranean to Damara-land and Natal, and visits Madagascar."* In severe winters, as in 1878-1879, these birds become emaciated and thin, and are occasionally picked up on our coast; and in August, 1904, so many Curlews were found dead in their spring-quarters as to lead to the supposition that some unknown disease had been rife among them.

During its life on the shore the chief food of the Curlew consists of crustaceans and sand-worms, and its flesh at this time cannot be recommended to a cultivated palate.

An old proverb says that "to kill seven Curlews is the work of a lifetime," the species being one of the most wary of our shore-birds. As an alert sentry it often gives warning to the geese and other wild fowl of the approach of the gunner, though considerably tamer and quite easily "called" to the gun before leaving its inland breeding-places.

A white Curlew was observed at the head of Shinnel Water in the spring of 1904, and although shot at more than once, it has annually visited the same spot. When I saw the bird on June 6th, 1910, and watched it for a long time at close range through my field-glasses, it appeared to be pure white, with flesh-coloured legs and bill. The shepherds on the beat tell me it comes and goes at about the same time as the other Curlews, and it always returns to within half a mile of the same place. They also say that at first it was party-coloured, but has annually become more white ; certainly when I saw it, it was apparently spotless.

Both the Statistical Accounts of Scotland have many references to the local abundance of this species, whose habits do not seem to have altered, though possibly its numbers may be said to have increased.

\footnotetext{
* Man. Brit. Birds, 1899, p. 628.
} 


\section{THE WHIMBREL. Numenius phcoopus (Linnæus).}

\section{A scarce and local visitant to the shores of the Solway on the autumn migration; seen more numerously on the spring-passage, usually passing high overhead.}

Sir William Jardine, writing in 1842 of the Whimbrel, says that on the shores of the north of England and south of Scotland "they are commonly to be met with in autumn or winter, in small parties, and are at once betrayed, among a flock of curlews, by their peculiar note."* Of more recent years they have never been observed in winter, nor can they be considered as commonly to be met with nowadays. "In May," writes Mr. R. Service, " it is an interesting occupation to watch the small parties of Whimbrel passing on their migration from some such favourable place of observation as Southerness Point [Kirkcudbrightshire]. These are, as a rule, at great heights, but their tittering calls will attract the eyes upwards to the compact little flocks rapidly passing out of sight. From the 10th to the 15th May, during the mid-day hours, the Whimbrels will regularly be seen at this time if the weather be warm and genial, with a gentle breeze or none at all, and light, fleecy white clouds speckling the skies. Only a few of these passing migrants alight, and they never stay more than a day or so, although a succession is kept up during the most of the month. ... The Whimbrels stay long with us in autumn, but are then scarce and local." $\dagger$

A pair of Whimbrels were shot near Caerlaverock at the end of August, 1888, and were sent to William Hastings for preservation. Mr. Hugh Mackay writes from Dumfries: "On August 29th, 1894, I received a specimen of the Whimbrel sent me from Lockerbie. So far as I can learn this species is not at all common in this locality." $\ddagger \mathrm{Mr}$.

* Nat. Lib., 1842, Vol. XII., p. 277.

† Trans. Nat. Hist. Soc. Glasg., 1905, Vol. VIII., p. 59.

‡Dumfries Standard, May 29th, 1895. 
J. E. Steele writes me that he saw a Whimbrel on the Powfoot Golf Course (Cummertrees) in the last week of August, 1906, and at the end of September, 1908, this species was more than usually numerous near Glencaple.*

Mr. R. Service records : "On a moor in Closeburn a nest, supposed to be that of a Whimbrel, was shown to me on June 15th, 1895. Two eggs had been taken from it, one of which I examined. It looked like that of a Whimbrel, and certainly no one could have distinguished it from an authenticated egg, but, of course, full proof was wanting." $\dagger$ He further informs me that he personally saw the bird, and " could almost be sure that it was a Whimbrel," however, it was not shot, so the record remains unsubstantiated.

This species, called the "May-bird" in the southern and eastern counties of England on account of its regular appearance there in that month, nests sparingly in the Orkneys, Shetlands, and Outer Hebrides. In northern Europe it nests on the "fjelds" and beyond the limits of forestgrowth. In winter it is found in parts of India, Mauritius, Madagascar, and in Africa as far as the Cape, while on passage it occurs on most of the shores of Europe.

THE BLACK TERN. Hydrochelidon nigra (Linnæus).

A very rare visitor to our coast.

This species is said to have nested in $1855+$ on Solway Flow, which, although not within the boundaries of the county, is sufficiently near to have warranted its inclusion in the once "Debateable Land." That it has occurred in the county more often than the records show, is probable from its visits to the shores of the English side of the Solway, as well as off the neighbouring county of Kirkcudbright. Sir William Jardine writes in 1843 : "In Scotland we are

* Dumfries Courier and Herald, October 7th, 1908.

† Trans. Nat. Hist. Soc. Glasg., 1905, Vol. VIII., p. 59.

† Naturalist, Vol. VII., p. 251. 
not aware of specimens being obtained, and no breeding station exists."* Robert Gray, writing in 1871, states: "In Haddington, Berwick, Aberdeen, Fife, and Dumfries shires many specimens have from time to time been shot and preserved." $\uparrow$ A Black Tern is recorded as shot on Conheath Merse on the Nith (Caerlaverock) in 1866, $\ddagger$ and I have ascertained that it was obtained on or about April 15th and passed into the hands of William Hastings. As Sir William Jardine frequently made purchases from the local taxidermist, this may have been one of the two specimens labelled "Nos. 353 and 354, from the River Nith," in his collection, bought in 1876 by the Edinburgh Museum.

The Black Tern nests in suitable localities throughout Europe south of the Baltic, north Africa and in Asia west of Turkestan. The last British-taken eggs were found in Norfolk in 1858. The winter-quarters of the bird are in Africa as far south as Loango on the west and Abyssinia on the east. On migration in April and May, and again from August to November, it is a regular visitant to the south and east coasts of England, and is often seen on inland waters. To the north and west of the British Isles it is of irregular occurrence, and though individuals are reported almost annually in September from the Cumberland coast, it cannot be considered as anything but a very rare visitor to our shore.

\section{THE WHISKERED TERN.}

Hydrochelidon hybrida (Pallas).

Has occurred once.

The first Whiskered Tern obtained in Scotland was shot by Mr. John Kirkpatrick, gamekeeper, near the Carse

* Nat. Lib., 1843, Vol. XIV., p. 285.

$\dagger$ Birds of West Scotland, 1871, p. 472.

† Trans. D. and G. Nat. Hist. Soc., December 4th, 1866. 


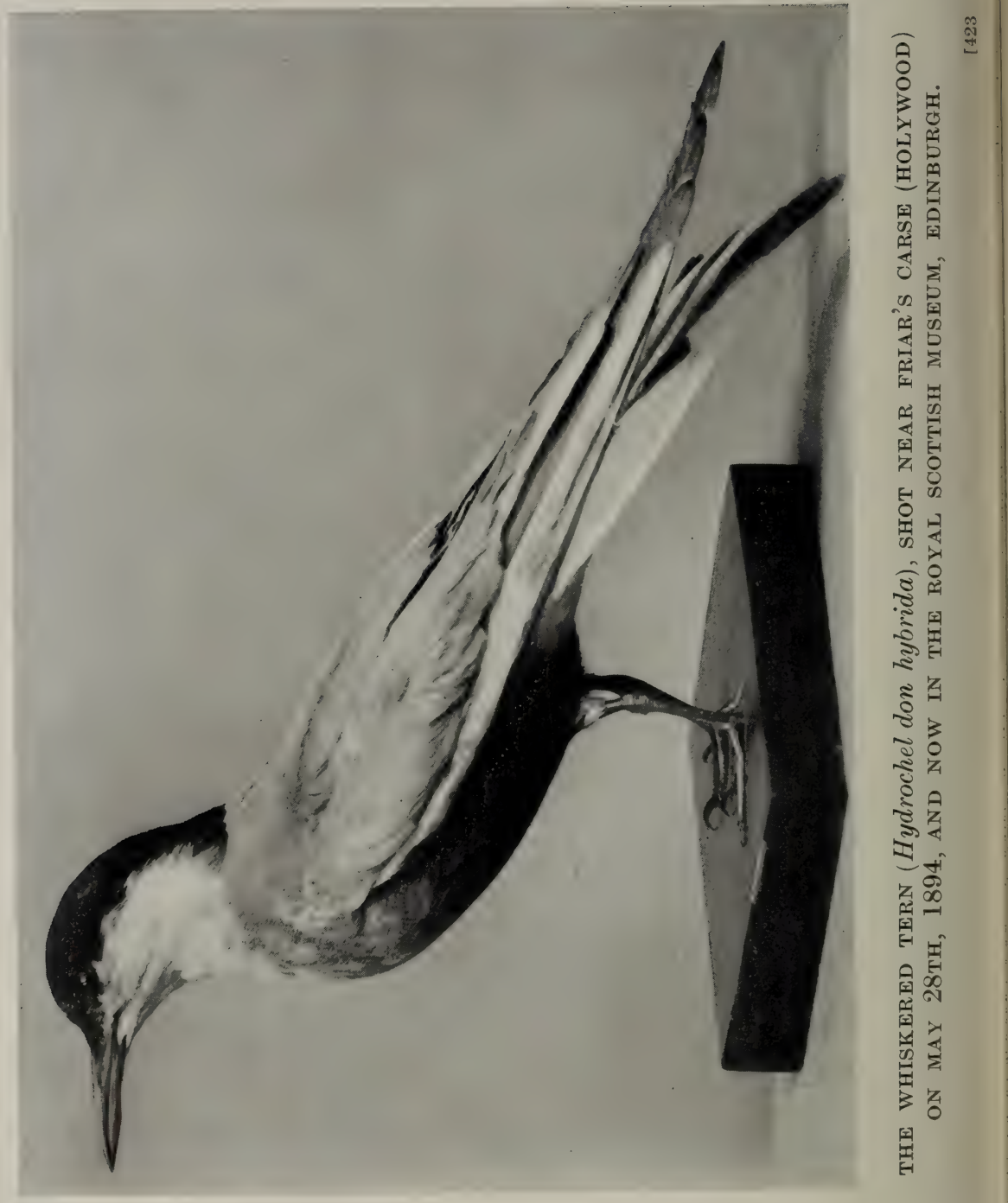
Loch of Friar's Carse (Holywood), some six miles NNW. of Dumfries, on May 28th, 1894. It was found on dissection to contain semi-digested portions of the fresh-water shrimp (Gammarus pulex). This specimen, an adult male, was stuffed by Mr. Hugh Mackay, and may now be seen in the Royal Scottish Museum, Edinburgh, having been presented by Mr. R. Service, who duly recorded its capture.* For the photograph of the actual specimen (here reproduced) I am indebted to the courtesy of the authorities of the abovementioned museum.

The Whiskered Tern nests in northern India and in Africa. In Europe important colonies exist in south-west Spain, the delta of the Rhone, Greece, Turkey, the Danubian swamps, the south of Russia, and in Poland. Its winterquarters are further south, and it is only a very rare straggler to the British Islands; or, in fact, north of its nesting-colonies.

THE SANDWICH TERN. Sterna cantiaca, J. F. Gmelin.

An occasional summer-visitant off our coast.

Sir William Jardine writes of the Sandwich Tern in 1843 : "We have seen it on the Solway also, but do not know of any breeding station there." $\dagger$ The occasional individuals which are seen fishing off our coast probably come from a small but increasing nesting-colony in the neighbouring county of Kirkcudbright. From the Farne Islands on the east around the coast of Scotland to as far south as Walney Island, off Lancashire, on the west, there are several breedingstations of this species. In Ireland, there are colonies on Lough Erne and near Ballina; and in $1903 \mathrm{I}$ found two or three nests of this species on an island in Loch Conn. When persecuted, the Sandwich Tern has been known to abandon

* Ann. Scot. Nat. Hist., 1894, p. 179.

† Nat. Lib., 1843, Vol. XIV., p. 273. 
its nesting-places, and a more concise statement of its distribution is, therefore, undesirable.

The Sandwich Terns which breed in Great Britain arrive about April, departing again in early autumn. The winterquarters of this species extend to Cape Colony and Natal.

\section{[THE ROSEATE TERN. Sterna dougalli, Montagu.}

The rumours of the occurrence of the Roseate Tern off our shore are only rendered admissible on account of its reported presence by good observers in a neighbouring county.* In certain lights the more common terns often appear rosycoloured, and local reports of this species require further verification before it can be admitted to this list without square brackets.

To Great Britain the species comes late in April or early in May, departing directly the young can fly. From many of its former breeding-places it has been banished, and it might be prejudicial to enumerate the present summerquarters of the Roseate Tern in Great Britain.

It nests in small colonies on the west coast of France and north-west Africa, its chief breeding-places being along the Atlantic seaboard of America from New England toVenezuela. It also nests in north Australia, Ceylon, Andaman Isles and south China. In winter its distribution is very imperfectly known.]

\section{THE COMMON TERN. Sterna fluviatilis, Naumann.}

Local names-Sea-Swallow; Pirr.

\section{A summer-visitant off our coast.}

The Common Tern may not infrequently be seen fishing off our coast, and, as it is not known to nest in the county, * Trans. D. and G. Nat. Hist. Soc., April 20th, 1905. 
these visitors probably come from the fairly large "ternery," situated on Rockliffe marsh, Cumberland, or possibly from the settlement in Kirkcudbrightshire. Sir William Jardine, writing in 1843, says: "Many years since we have shot this tern on the River Annan, fifteen miles from the sea ; and in spring, one or two pairs appeared regularly following the course of the stream and fishing, but apparently returning seaward the same day. Their appearance for a month or six weeks was quite regular, darting into the stream, as in the sea, after minnows, etc., and approaching clamorously any one walking on the banks. It has not now been seen for many years."* In the Catalogue of the Birds contained in the collection of Sir William Jardine a specimen of the Sterna hirundo (presumably this species) is recorded as shot at Jardine Hall, by Sir William Jardine.

William Hastings in 1878 described the species as "not common with us" $\dagger$; but given the right time and locality, this description nowadays would hardly be correct. A dead specimen was picked up at Marwhirn, three miles north of Moniaive (i.e., twenty-three miles from the sea) on October 2nd, 1893, as recorded by Mr. John Corrie. $\ddagger$

The Common Tern arrives in May and nests in colonies in suitable parts of the British coast, and on some inland waters. In England it is the commonest Tern, but in the north of Scotland and Ireland the Arctic Tern predominates, and both species may often be found nesting in contiguity. Mr. R. Service writes me as regards the Terns nesting in Kirkcudbrightshire: "The Arctic is mixed up with the Common Tern locally, in the proportion perhaps of, let me say, two per cent., or may be a higher percentage, but they are comparatively very few in number."

The Common Tern is widely distributed during the nestingseason throughout nearly the whole of Europe, temperate Asia, northern Africa, and the eastern seaboard of the

* Nat. Lib., 1843, Vol. XIV., p. 278.

† Trans. D. and G. Nat. Hist. Soc., October 4th, 1878.

$\ddagger$ Op. cit., February 16th, 1894. 
United States of America, from Labrador to Texas. In winter it can be traced down the west side of Africa to Cape Colony, and in Asia to India, Ceylon and the Malay Peninsula, while it has also been obtained in Bahia and Brazil.

\section{THE ARCTIC TERN. Sterna macrura, Naumann.}

Local names-Sea-Swallow; Pirr.

An occasional visitor off our coast.

The Arctic Terns that are occasionally seen off our coast from May to September, probably come from the colony, which, in the neighbouring county of Kirkcudbright, shifts about from year to year between Southerness and Heston. An Arctic Tern shot at Brow Well (Ruthwell) in 1866 is recorded by William Hastings.*

The species in England is known chiefly on migration, though there are isolated colonies in the north and west; and in the northern half of Scotland it is the commonest of the terns. In Ireland it nests in many places, especially on the wind-swept islets of the west and north. Elsewhere it breeds in circumpolar regions, and has been met with in winter in antarctic seas, $\uparrow$ so that it has a latitudinal range of from $82^{\circ}$ north to $74^{\circ}$ south, probably the most extensive range recorded for any one species. $\ddagger$

THE LITTLE TERN. Sterna minuta, Linnæus.

A summer-visitant off our coast.

A list of birds of the parish of Kirkmichael in 1792 includes the "Lesser and greater Terns." $\$$ Mr. R. Service, com-

* Minutes of D. and G. Nat. Hist. Soc., May 1st, 1866.

$\dagger$ W. Eagle Clarke, Ibis, 1907, pp. 345-347.

¥ Birds of Britain, 1907, p. 356.

$\S$ Stat. Acct. Scot., Vol. I., p. 61. 
menting on this record in a letter to Mr. J. A. Harvie-Brown, says: "Kirkmichael is an inland parish fifteen or sixteen miles from the sea; the birds are only likely to have been stragglers, but there is a loch there." What species was meant by the "Greater Tern" one cannot tell ; and the "Lesser" seems in early days to have been very little known, at least locally. Mr. John McDiarmid, an ornithologist of high standing in his day, states that on October 30th, 1826, a bird "never before seen in this country was shot in Kirkblain meadow [Caerlaverock]. It is the lesser Tern or Sea Swallow, Sterna minuta of Linnæus. The bird is about eight inches long and nineteen inches broad from tip to tip of the expanded wings. It answers to Bewick's description and figure exactly with this exception, that the feathers of the tail are not white as he describes, but of a pale lead colour, like that of the beak [!] and wings."* The use of the word "country" in the above quotation probably means " in this locality," and can hardly be expected to indicate Scotland; though John Fleming, in his History of British Animals, published in 1828, states that this species " inhabits England along with the common Tern," $\dagger$ and omits, expressly or otherwise, any mention of Scotland. H. A. Macpherson remarks that Dr. Heysham [b. November 22nd, 1753 ; d. March 23rd, 1834] " catalogues the Lesser Tern as breeding in Cumberland, though without a hint as to any locality. T. C. Heysham [his son] informed a friend in 1829, that the Lesser Tern was a scarce visitant to the Solway Firth ; " $\ddagger$ but Sir William Jardine, writing in 1843, mentions a colony upon the Solway at Skinburness,§ Cumberland. Mr. R. Service tells me that he can remember Little Terns being brought to him as rarities by local gunners so recently as 1875 .

It is believed that this species in the first half of the

* Dumfries Courier, November 21st, 1826.

$\dagger$ Hist. Brit. Animals, 1828, p. 144.

‡ Fauna of Lakeland, 1892, p. 419.

§ Nat. Lib., 1843, Vol. XIV., p. 283. 
last century was quite an uncommon visitor to our shore. Its appearance nowadays in summer is fairly frequent, and such birds as are seen are believed to come from colonies in Cumberland and Kirkcudbrightshire.

It is quite possible that the Little Tern may nest in the county undetected, but it should here be stated that Mr. J. Harkness, in 1908, informed me that no Terns are known to nest on the Dumfriesshire coast-a statement which refers to the whole sub-family Sternince as far as the county is concerned.

The Little Tern arrives at its nesting-places in Great Britain in May, and departs again in September or October. Colonies are found around the coasts of the British Isles, more commonly in the south than in the north. It also nests in suitable localities throughout Europe south of the Baltic, as also in north Africa and the Asian plateau as far as north India; while in winter it is found as far south as Cape Colony.

\section{THE LITTLE GULL. Larus minutus, Pallas.}

\section{A rare and irregular visitor off our coast.}

A Little Gull killed by Mr. Irving Murray on January 13th, 1894, and now in the Tullie House Museum, Carlisle, is thus recorded by the late H. A. Macpherson: "Although the Little Gull (Larus minutus) wanders to the Solway Firth at not infrequent intervals, I have never met with it on the Scottish side of our estuary until the present winter. On January 13th last an immature bird of this species was shot on the Solway between Annan and Dumfries."* An immature male, shot on September 16th, 1896, $\uparrow$ as it was hovering over the mouth of the Esk in the immediate

* Zoologist, 1894, p. 115.

† op. cit., 1896, p. 385 . 
vicinity of the Solway, cannot be claimed as a Dumfriesshire occurrence; but Mr. W. Nichol writes me that he saw a Little Gull off our shore on September 3rd, 1907. It is noteworthy that the species is regarded as a casual migrant in winter and spring on the English side of the Solway Firth: and it is therefore possible that it may have occurred on other occasions off our coast, but without having being recorded.

A Little Gull shot in the autumn of 1824 on the shore of the Solway Firth was presented by Mr. Neill to the Edinburgh Museum, and was said to be the first Scottish specimen.* It cannot now be traced, and there is no evidence to show that it was obtained in Dumfriesshire, it being presumably the same bird as that described in the Memoirs of the Wernerian Natural History Society as shot in Galloway by Lieutenant McCulloch, Barholm House.†

This species breeds in colonies from Denmark eastwards, in Finland and Russia to the Urals and across temperate Asia, and is found on passage and in winter on the waters of Europe as far south as the Mediterranean, north Africa and the Black Sea. It is an irregular visitor to the southern and eastern shores of England, being more rarely recorded from the west and north.

\section{THE BLACK-HEADED GULL.}

Larus ridibundus, Linnæus.

Local name-PeEWIT-GULL.

A common resident, breeding inland in certain localities.

The trivial name of this species is certainly a misnomer, for however black its head may appear at a distance, it is in

* Hist. Berwick. Nat. Club, Vol. VI., p. 84.

$\dagger$ Mem. Wern. Nat. Hist. Soc., 1826, Vol. V., p. 578. 
reality of a chocolate-brown colour. It is well, too, to remember that this characteristic coloration is only present in the spring, and that in the winter-plumage the head, with the exception of some grey feathers in front of the eye, on the crown, and behind the ear-coverts, becomes white.

The undoubted increase in the numbers of the Blackheaded Gull makes one wonder whether these birds will continue to find a sufficiency of their natural food, or whether they will in the near future adopt bad habits. At present they receive the benefit locally of the Wild Birds Protection Act, and the question if this protection is wise or otherwise has been dealt with in a Report on the food of the Black-headed Gull drawn up for the Cumberland County Council in 1907 by Messrs. D. Losh Thorpe and L. E. Hope. It is to be regretted that this Report should have concluded by the recommendation to the authorities to relax, for a term of years, the protection given to the species. It would seem that in arriving at this conclusion much evidence was adduced which can only be regarded as problematical; the recommendation would therefore appear to be, at least, premature.*

The question has also been dealt with by Mr. T. G. Laidlaw, who sums up his opinion in the following words: "I consider it on the whole to be an extremely useful as well as an extremely beautiful bird." $\dagger$

The Black-headed Gull devours large numbers of grubs, worms and caterpillars, and also takes cockchafers and moths on the wing. Mr. R. Service writes that this habit was first noticed in 1868, and that the insects are taken as food for the young.t Richard Bell of Castle O'er states that he has known the Black-headed Gull to take salmon-smolts and rats. $\S$ It is recorded that in February, 1900, a pair of

* Brit. Birds (Mag.), Vol. I., pp. 191, 231, 259, 293.

$\dagger$ Ann. Scot. Nat. Hist., 1908, p. 141.

‡Zoologist, 1902, p. 216.

§ My Strange Pets, pp. 202-204. 



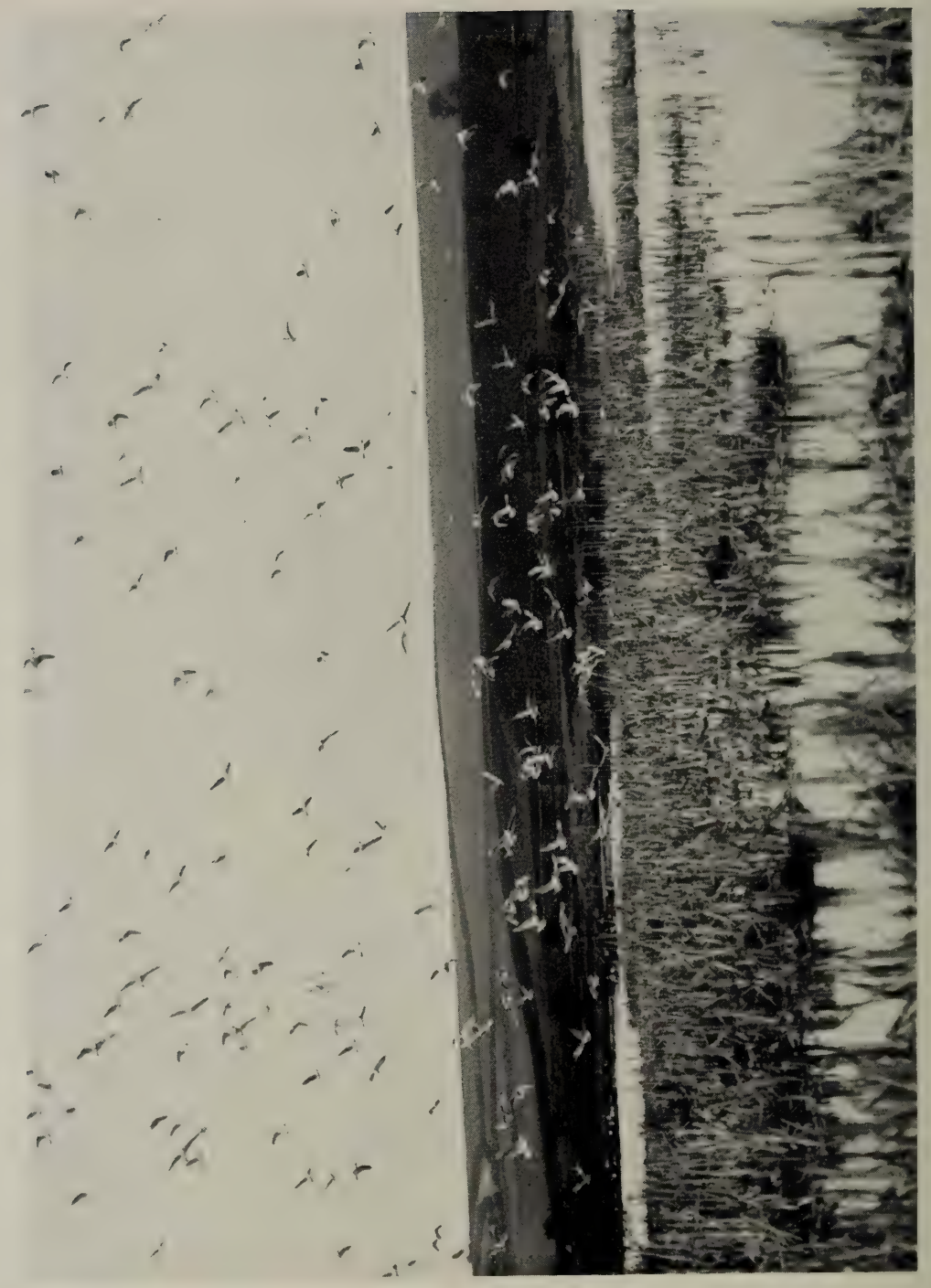

$\stackrel{5}{Ð}$

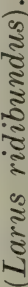

옹

贫

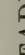

I

궁

岁

E

5

2
$z$
0
0
0
0
1
0
2
5
0
0
$z$ 
Pied Wagtails were tripping about on the frozen river at Dumfries amongst some Black-headed Gulls, when suddenly a bird of the year made a dart at one of the Wagtails, seized it in its bill, and proceeded to batter it to death. The other gulls tried to share the morsel unsuccessfully. This attack may have been caused by excessive hunger.*

I have heard the species recently accused of taking the eggs of other birds, and there is no doubt that it is almost omnivorous; but at present the balance of good that it does to the farmer by its destruction of injurious insects, far outweighs any harm it may do to the sportsman or fisherman. Black-headed Gulls are certainly more attached to the land than in former years, and they spend nowadays a far longer time on the pasture-land than on the shore.

They often alight on trees and bushes, and Mr. R. Service tells me that it was not till the abnormally severe winter of 1878-1879 that they were seen perching on the houses in Dumfries, as they commonly do now.

The Black-headed Gull breeds in colonies; the nests, made of sedges, rushes, etc., usually contain three, sometimes two, and still more rarely four eggs. These take twenty days to hatch. In some seasons an unknown epidemic almost decimates the young; and in 1900, owing it is believed to lack of food from drought, fully 60 per cent. of the young birds died of starvation at Loch Urr $\dagger$ (Glencairn).

A nestling marked No. 3649 on July 12th, 1909, at the Dhu Loch (Penpont) was recovered on November 27th of the same year at Carluke, Lanarkshire, $\ddagger$ that is, thirty-five miles north of the spot where it was bred.

For the excellent photograph, here reproduced, of a colony of this species, I am indebted to Mr. D. Legard; and for the following list of local " Gulleries," I must thank many willing correspondents.

* Ann. Scot. Nat. Hist., 1900, p. 120.

$\dagger$ Trans. D. and G. Nat. Hist. Soc., December 13th, 1901.

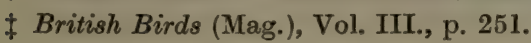




\section{Nesting-Places of the Black-headed Gull in occupation IN 1908.}

\begin{tabular}{|c|c|c|c|}
\hline \multicolumn{2}{|l|}{ Parish. } & $\begin{array}{l}\text { Situation and Approximate Number of Nests. } \\
\text { How long in existence, etc. }\end{array}$ & Source of Information. \\
\hline \multicolumn{2}{|c|}{ CAERLAVEROCK .. } & $\begin{array}{l}\text { Eastbank Foreshore. About four hundred nests. } \\
\text { The gulls came here from Lochar Moss in 1907. }\end{array}$ & P. Smith, 19.vi.1909. \\
\hline \multicolumn{2}{|l|}{ CLOSEBURN } & $\begin{array}{l}\text { Townfoot Loch. About } 1875 \text {, a very large colony, } \\
\text { but owing to the subsidence of the peaty island on } \\
\text { which the gulls nest, it was almost entirely } \\
\text { deserted. Recently there seems a tendency to } \\
\text { increase. } \\
\text { Three hundred to four hundred nests in } 1909\end{array}$ & R. Armstrong, 5.ix. 1908 \\
\hline DUMFRIES & . & $\begin{array}{l}\text { One mile west of Racks Rly. Station. Nests decreas- } \\
\text { ing owing to keepers destroying eggs. About } \\
\text { eight hundred nests. }\end{array}$ & $\begin{array}{l}\text { John Anderson, } \\
\text { 11.vi.1908. }\end{array}$ \\
\hline \multirow{2}{*}{\multicolumn{2}{|c|}{ DURISDEER }} & $\begin{array}{l}\text { Cleughhead. In } 1878 \text { about two hundred and fifty } \\
\text { nests. } \\
\text { This used to be a favourite colony, but many eggs } \\
\text { were taken, and they left for a time, returning in } \\
1899 \text {. } \\
\text { On islets and sides of loch in fir-wood. About } \\
\text { one hundred and sixty to one hundred and eighty } \\
\text { nests. }\end{array}$ & $\begin{array}{l}\text { R. Service, 30.v.1908. } \\
\text { J. Riddell, 1.vi.1908. } \\
\text { H. S. G., 1.vi.1908. }\end{array}$ \\
\hline & & $\begin{array}{l}\text { Muiryhill Loch. On floating islands of bog-myrtle. } \\
\text { Forty to sixty nests. }\end{array}$ & H. S. G., 1.vi.1908. \\
\hline \multirow{3}{*}{\multicolumn{2}{|c|}{ ESKDALEMUIR }} & $\begin{array}{l}\text { Langshawburn Loch. At sides of loch, have known } \\
\text { a small colony for some sixty years. } \\
\text { A bout two hundred nests. Annually increasing .. }\end{array}$ & $\begin{array}{l}\text { Rev. R. Bell, 25.v.1908. } \\
\text { A. McDonald, 2.vi.1908. }\end{array}$ \\
\hline & & $\begin{array}{l}\text { Tanlawhill. On islands, sides of loch and on moss- } \\
\text { hags. About two hundred nests ; increasing. }\end{array}$ & $\overline{A . ~ M c D o n a l d, ~ 2 . v i .1908 . ~}$ \\
\hline & & $\begin{array}{l}\text { Foulbog. On two little ponds at boundary of Dum- } \\
\text { friesshire with Selkirkshire and Roxburghshire. } \\
\text { Not increasing; came about } 1898 \text {; twenty nests. }\end{array}$ & A. McDonald, 2.vi.1908. \\
\hline \multirow{4}{*}{\multicolumn{2}{|c|}{ GLENCAIRN }} & $\begin{array}{l}\text { Loch Urr. } 1792 \text { " A A vast number of water-fowls } \\
\text { [query } L \text {. ridibundus-H. S. G.] bring forth their } \\
\text { young on the island, where there are bushes." } \\
\text { Sixty per cent. died from starvation caused by } \\
\text { drought in spring of } 1900 \text {. }\end{array}$ & $\begin{array}{l}\text { Stat. Acct. Scot., Vol. II., } \\
\text { p. } 34 \% . \\
\text { Trans. D. and G. Nat. } \\
\text { Hist. Soc., December } \\
\text { 13th, 1901. }\end{array}$ \\
\hline & & $\begin{array}{l}\text { Immense destruction by rats in } 1902 \text { or } 1903 \\
\text { About five hundred and fifty nests on island, one } \\
\text { hundred and forty on islet, and two hundred on } \\
\text { mainland }=890 \text { in } 1908 \text {. }\end{array}$ & $\begin{array}{l}\text { J. Corrie, 2.iv.1909. } \\
\text { H. S. G., 11.v.1908. }\end{array}$ \\
\hline & & $\begin{array}{l}\text { A bout nine hundred on island, three hundred on } \\
\text { islet, and one hundred on mainland }=1,300 \text { in } \\
1910 \text {. }\end{array}$ & H. S. G. 17.v.1910. \\
\hline & & $\begin{array}{l}\text { Stranshalloch Loch. In existence many years, } \\
\text { believed to be increasing. } \\
\text { Twenty five to forty nests in } 1909 \quad \ldots\end{array}$ & \multirow{2}{*}{$\begin{array}{l}\text { J. Corrie, 13.vii.1908. } \\
\text { H. S. G., 9.vi.1909. } \\
\text { P. Coleman, 3.vi.1909. }\end{array}$} \\
\hline KIRKMAHOE & ${ }^{\circ}$ & $\begin{array}{l}\text { Black Loch, near Gledenholm. On and at sides of } \\
\text { loch, on low boggy moor. In existence over fifty } \\
\text { years; upwards of fve hundred nests in } 1908 . \\
\text { Great decrease in } 1909 \text {. } \\
\end{array}$ & \\
\hline $\begin{array}{l}\text { KIRKPATRICK- } \\
\text { FLEMING. }\end{array}$ & & $\begin{array}{l}\text { Raeburn Moss. In tufty grass ; could hardly walk } \\
\text { without stepping on nests. Eggs are taken and } \\
\text { sold as "Plovers' eggs." Nests in hundreds. } \\
\text { Probably an offshoot from large colony between } \\
\text { Gretna and Longtown on Solway Moss. }\end{array}$ & $\begin{array}{l}\text { W. F. Graham, 2.vi.1908. } \\
\text { Miss D. M. Bate, } \\
\text { 30.v.1908. }\end{array}$ \\
\hline
\end{tabular}


Nesting-places of the Black-headed GUll in occupation IN 1908-continued.

\begin{tabular}{|c|c|c|c|}
\hline \multicolumn{2}{|l|}{ Parish. } & $\begin{array}{c}\text { Situation and Approximate Number of Nests. } \\
\text { How long in existence, etc. }\end{array}$ & Source of Information. \\
\hline PENPONT. & . & $\begin{array}{l}\text { Dhu Loch.* On an island, or floating bog, in } \\
\text { centre; and round sides of loch. About six } \\
\text { hundred and fifty nests on island and one hundred } \\
\text { and fifty round sides, in 1908. } \\
\text { Came from Cleughhead, Durisdeer, about } 1883\end{array}$ & H. S. G., 1.vi.1908. \\
\hline RUTHWELL & . & $\begin{array}{l}\text { Longbridgemuir. An offshoot from the Racks Moss } \\
\text { Colony. }\end{array}$ & J. Harkness, 1.vi.1908. \\
\hline SANQUHAR & . & $\begin{array}{l}\text { Black Loch. In Town Moor, on island and sides of } \\
\text { loch. Twenty-four nests in 1883; now about two } \\
\text { hundred. } \\
\text { In } 1884 \text { a few ; in season following numbers so } \\
\text { increased that island was covered with nests, and } \\
\text { the gulls built at the sides of the lake. }\end{array}$ & $\begin{array}{l}\text { Thos. Ballantyne, } \\
\text { 1.vi.1908. } \\
\text { Trans. D. and G. Nat. } \\
\text { Hist. Soc., November } \\
\text { 10th, 1888. }\end{array}$ \\
\hline TORTHORWALD & & $\begin{array}{l}\text { Racks Moss. On Brocklehirst property. Upwards } \\
\text { of two hundred nests. }\end{array}$ & J. McRoberts, 4.vi.1908. \\
\hline
\end{tabular}

The Black-headed Gulls that nest on, or in the vicinity of Lochar Moss, are subject to much persecution, and consequently shift from one part of the Moss to another, almost annually. This persecution is not so culpable as might seem at first thought, for a certain number of Lesser Blackbacked Gulls nest with the smaller species, and in their desire to do their work thoroughly some gamekeepers have been known to become indiscriminate.

Concerning a former nesting-place, Sir William Jardine writes in 1843: "We possess a reedy loch which was for many years a haunt of these birds, but the edges were planted, and they left it; ten years afterwards, and when the plantation had grown up, a few pairs returned, and in time increased to a large colony, when an artificial piece of water was made by damming up a narrow pass in an extensive muir nearly two miles distant; thither the gulls resorted the following spring, leaving their ancient ground, and they have been increasing in numbers for some years past." $\dagger$ No locality is given, but I take it the loch

* Till about 1736 the Dhu or Dow loch was supposed by a superstitious peasantry to possess the healing qualities of the Pool of Bethesda.

$\dagger$ Nat. Lib., 1843, Vol. XIV., p. 295. 
was in Applegarth parish, though there are no reports at hand of the existence of any such colony in that neighbourhood at the present time.

\section{THE COMMON GULL. Larus canus, Linnæus.}

Local names-Mewgull ; Mew ; Sea-Maw ; Mar ; BlueHEAD ; WiNTER-GULL.

"Bird of silver wing outspread, How thou mock'st me overhead, As thou floatest far up there On the buoyant evening air Giving forth thy sounds that seem Now a laugh and now a scream." DAvid DunBaR.- "The Sea Gull (Larus canus)."

\section{A common visitant from autumn to spring.}

If the poet had not expressly dedicated these lines to Larus canus I should have said that the gull which indulged in "now a laugh and now a scream" was the Black-headed Gull. The name, Common Gull, is most misleading, for though frequently seen in autumn and winter, it is certainly not the " common" gull of the county. In the Statistical Account of Scotland, there are several local references as to the appearance of the "sea-mew" inland, foretelling excessive rains or high winds ; and in the list of birds of the parish of Kirkmichael in 1792, the gull and the mew are catalogued distinctively.* Sir William Jardine, in a list of the birds of the parish of Applegarth and Sibbaldbie, wrote in 1832: "The common gull ( $L$. Canus) in autumn and winter frequent the pasture and plowed fields in considerable flocks ; the greater part, in the plumage which gives them the name of winter-gull." $\dagger$ In some years it appears more numerously than others, as

* Stat. Acct. Scot., Vol. I., p. 61.

† New Stat. Acct. Scot., Vol. IV., p. 182. 
in October and November, 1879 ;* but it may usually be seen on the Solway throughout the greater part of the year.

The food of this species consists of crustacea, mollusca, and small fish, but when driven inland by the approach of rough weather it may often be seen in company with Rooks, feeding with them. Mr. R. Service records in his diary that he dissected two Common Gulls in November, 1888, which had their crops distended as large as his fist with earthworms.

I am told that two or three pairs of this species nest at Powfoot (Cummertrees), but of this I have no confirmation, though it has been known to nest in the Solway area since $1871 . \dagger$

The Common Gull breeds in Scandinavia, north and central Russia, and occurs in winter on the waters of Europe down to the Mediterranean basin and the Persian Gulf. As regards Great Britain, it nests around the coasts of Scotland, and on some inland lochs ; less commonly in Ireland, and not at all in England, but is well known all along the British coast from autumn to spring.

THE HERRING-GULL. Larus argentatus, J. F. Gmelin.

\section{Local name-CAT-GULL.}

A common visitant from autumn to spring.

The Herring-Gull is a well-known bird on our coast from autumn to spring, but is comparatively seldom seen in full plumage; the species is principally a shore-feeder, but is occasionally seen far inland, being attracted by any offal it may find. In the nesting-season it is very destructive to the eggs of other species, and it occasionally attacks weakly or new-born lambs. Baited traps set for vermin

* Proc. Nat. Hist. Soc. Glas., 1880, Vol. IV., p. 325.

Fauna of Lakeland, 1892, p. 428. 
often cut short its career. The individuals met with inland are usually immature. I shot a Herring-Gull at Grennan (Penpont) in December, 1905, whose mandibles had become tied together in some inexplicable way by the intestines of a rabbit on which it had been feeding. Mr. J. Harkness writes me that immature Herring-Gulls cross inland in autumn, and Mr. Bruce Campbell, in a list of birds seen at Moffat from October, 1896, to February, 1897, describes the species as plentiful.*

Howard Saunders says : "This species is the most widely distributed member of its family on the coasts of the British Isles, breeding wherever precipitous rocks or isolated 'stacks' afford a suitable refuge. ... Occasionally it resorts to low marshy ground, and colonies may be found on islets in lochs in some parts of Scotland." $\dagger$

Although nesting on the cliffs in the neighbouring county of Kirkcudbright, this species is not definitely known to nest in Dumfriesshire. Mr. W. F. Graham assures me that among the Lesser Black-backed Gulls breeding at Raeburn Moss (Kirkpatrick-Fleming) there are always some Herring-Gulls, and that in 1908 there were four nests of this species; but I cannot personally corroborate this statement.

An albino Herring-Gull shot in the autumn of 1898 may have given rise to the reported presence of the Ivory Gull (see p. 442) in the Solway.

\section{THE LESSER BLACK-BACKED GULL.}

Larus fuscus, Linnæus.

A common resident from February to November, breeding in some littoral parishes, rarely seen in December and January.

Sir William Jardine, writing in 1843 of the Lesser Blackbacked Gull, says : "During winter, spring, and autumn

* Zoologist, 1898, p. 508.

$\dagger$ Man. Brit. Birds, 1899, p. 673. 
a few pairs may be constantly seen upon the Annan, fifteen miles from its mouth, passing and re-passing daily from the sea; at this time it is not very shy, and before being disturbed, will sail along the river within shot, only in passing gives utterance to its alarm note."*

The Lesser Black-backed Gull is more frequently seen inland than the preceding species, though it is better known on or near the coast throughout the year excepting in midwinter. At this season, our locally-bred birds probably migrate south, since the absence of the species from the county is then often very conspicuous. It is a very unwelcome visitor inland in spring, for, besides being very destructive to the eggs and young of both moorland-game and wild-fowl, it often attacks lambs. Happening to call on Mr. R. Service on April 10th, 1908, he told me that that very morning a farmer from Eskdale had complained to him of its destructive habits in that district. I saw three specimens of this species, in various phases of plumage, in Mr. Martin's collection at Dardarroch; and he told me that the offal from the butcher's shop at Dunscore attracted many, and that they were great robbers. They are also often seen on the Nith, certainly as far from the sea as Thornhill.

Mr. W. Wright informs me that although he has never noticed the Black-headed Gull taking fish, he considers it has been a mistake to give so much protection to other gulls, as in his opinion they do immense damage to salmon-smolts while they are descending the river to the sea. Mr. Wright adds that in August, 1906, he saw " one large gull take five herling (apparently $\frac{1}{4} \mathrm{lb}$. each) and devour them in the space of twenty minutes, and watch for more." The gull here referred to may well have been $L$. fuscus, which is known to be very inimical to fishing interests. Neither this species nor the Great Black-backed Gull is protected under the Wilds Birds Protection Act in Dumfriesshire ; and in spite of persecution, a colony of Lesser Black-backed Gulls, which is said to be increasing, and to number some two to three

* Nat. Lib., 1843, Vol. XIV., p. 303. 
hundred nests, still continues to breed in Lochar Moss. Mr. W. F. Graham writes me in 1908 that a good many birds breed on Raeburn Moss, and about ten pairs on Nutberry Moss (Kirkpatrick-Fleming). In 1908 a pair are believed to have nested at Townfoot Loch (Closeburn).

\section{THE GREAT BLACK-BACKED GULL. \\ Larus marinus, Linnæus.}

\section{A not uncommon visitant to the shores of the Solway.}

As far as I know the Great Black-backed Gull does not nest in the county, though on the peat-mosses bordering the Cumberland side of the Solway it is known as a breeding species. In some winters it appears off our coast in greater numbers than in others, as in 1883, when it was recorded as very common.* Mr. R. Service writes me in 1909 that this species can be seen "every day quartering the long tidal banks that stretch for so many miles along the coast from the Nith to the Esk. These are for the most part immature birds, but when something good gets stranded, such as the carcase of a cow, or still more rarely a defunct cetacean, then the fine old birds will appear and become the hosts at the feast. Many Great Black-backed Gulls frequent the banks even during the spring and summer; but these are non-breeding birds as a rule, although a good many pairs nest at only a few miles distance on the "Bowness and Wedholme flows,' and on the cliffs of the Stewartry coast." Nothing in the way of animal-food comes amiss to this gull, and it is known not only to attack lambs, but the ewes themselves. Many of the reports I have received of the occurrence of this species far inland, refer I think, with all due deference to the reporters, to the preceding species.

A curious capture of a Great Black-backed Gull is recorded in 1837; Mr. John Riddick, of Carzield, set a line in the

* Trans. D. and G. Nat. Hist. Soc., December 7th, 1883. 
Nith ; a fish took the hook, and a gull "five feet across the wings" took the fish, and was thus caught.* The local fishermen shoot this species whenever an opportunity occurs, not that it does them any harm, but out of a sort of superstitious revengefulness, for human bodies drifted ashore are very often disfigured by gulls.

On the north and west of Scotland and Ireland, the Great Black-backed Gull breeds abundantly, becoming more local in its breeding-range in England and Wales.

THE GLAUCOUS GULL. Larus glaucus, O. Fabricius.

A rare and irregular winter-visitor.

Sir William Jardine, writing of this species, says, in 1843 : "For the last two winters a gull with white wings has occasionally travelled up and down the river Annan for fifteen miles, but has been so shy as to baffle all endeavours to procure it." $\dagger$ A specimen of the Glaucous Gull labelled as obtained on the Solway passed from the Jardine collection in 1876 to the Edinburgh Museum. This specimen was sent to Sir William Jardine from Dumfries on February 4th, 1829.t

"A fine Glaucous Gull, apparently in the plumage of the second year," is recorded as having been shot at Shieldhill (Tinwald), in the last week of December, 1880, and was sent to William Hastings for preservation. In a letter to Mr. J. A. Harvie-Brown, Mr. R. Service mentions seeing a gull of this species in 1888. On February 6th, 1892, a Glaucous Gull in third winter's plumage was shot on Netherwood Merse (Caerlaverock), near the mouth of the Nith.\|

* Dumfries Courier, August 15th, 1837.

+ Nat. Lib., 1843, Vol. XIV., p. 307.

$\ddagger$ Jardine, MS. Diary, February 4th, 1829.

$\S$ Proc. Nat. Hist. Soc. Glasg., 1881, Vol. V., p. 63.

II Ann. Scot. Nat. Hist., 1892, p. 141. 
The Glaucous Gull is a circumpolar breeding-species, and is a visitor to the northern parts of the British Isles during the colder months, being more frequently met with in severe weather, but always more rarely in the south. Its migrations in winter extend to the shores of the Mediterranean, Black and Caspian Seas in Europe, Japan and California in the Pacific, to the Great Lakes, Mississippi, Florida and Texas in America.

\section{THE ICELAND GULL. Larus leucopterus, Faber.}

\section{Has occurred twice.}

On February 8th, 1835, an immature specimen of the Iceland Gull was killed on the coast near Browhouses* (Gretna). H. A. Macpherson, writing of this occurrence, says: "Mr. T. C. Heysham recorded, as new to Cumberland, an immature Iceland Gull killed on the Solway at Browhouses; but Mr. Heysham evidently mistook the exact locality of Browhouses, which is on the Scotch, not on the English, side." $\dagger$ Six years later, however, in his Vertebrate Fauna of Lakeland, the same author refers thus to the specimen: "The late Mr. T. C. Heysham was the first naturalist to record the occurrence of this Gull in Lakeland. The specimen which he obtained had been killed on the Solway Firth on the 8th of February, 1835." + Browhouses, as has been stated, is in Scotland, in the parish of Gretna, and this occurrence of the Iceland Gull is therefore confidently claimed for Dumfriesshire.

Sir William Jardine writes in 1843 : "We have occasionally seen what we considered to be this bird, on the shores of the Solway" $§ ;$ and in a MS. note in his personal copy of the

* Mag. Nat. Hist., Vol. IX., 1836, p. 187.

$\uparrow$ Birds of Cumberland, 1886, p. 169.

‡ Fauna of Lakeland, 1892, p. 436.

§ Nat. Lib., 1843, Vol. XIV., p. 308. 
Naturalist's Library he records: " Specimen shot near Elshieshiels [Lochmaben] by gamekeeper there, winter of 1862 . Saw the specimen in William Hastings' shop before being skinned." I am not aware of any other authenticated records in recent years, though Mr. R. Service writes me that he believes he has seen the Iceland Gull off our coast " afar off, but without satisfactory identification."

This species breeds in Jan Mayen and Greenland; in the colder months visits Iceland, the Færöes, and the shores of north-west Europe as far as the Gulf of Gascony in severe winters; and in America it occurs at this season as far south as Lake Michigan. In some winters it is fairly numerous off the coasts of Scotland, but is always more rarely met with elsewhere round the British Isles.

\section{THE KITTIWAKE GULL. Rissa tridactyla (Linnæus).}

\section{An occasional visitor to the Solway.}

The Kittiwake is more pelagic in its habits than the rest of the gulls, and is only seen locally when unusual weather has driven it in from the open sea, or the more distant Galloway coast. Dumfriesshire lies rather too far inland for this species, yet when a driving snow-squall occurs, the Solway fishermen are sometimes astonished at the sudden appearance of numbers of Kittiwakes. The bird does not breed nearer than the Ross in Kirkcudbrightshire.

A Kittiwake is recorded* as got at Jardine Hall, and the occurrence of the species twelve miles inland is remarkable. A specimen shot near Gretna on January 13th, 1906, is recorded in the Tullie House Museum Registers at Carlisle ; and to the fact that this species seldom comes in-shore is attributable my lack of records of its occurrence in the county.

* Cat. Birds in coll. Sir W. J., p. 204 (8340), b. 
The Kittiwake Gull nests in huge colonies on many precipitous cliffs round the British Isles, and in myriads in the arctic and sub-arctic regions of the old and new worlds. In winter it wanders as far south as the Mediterranean, Caspian and Black Seas in Europe, and in America to the coasts of California, Virginia and Bermuda.

[Mr. J. J. Armistead states that he saw an Ivory-GuLL (Pagophila eburnea (Phipps)), on August 3rd, 1898, "when riding at anchor in the Solway Firth," and the next day he again saw it feeding on the ooze about one hundred and fifty yards from him.* This individual was seen on the Barnhourie Bank outside of Southerness, Kirkcudbrightshire, and Mr. R. Service writes "as an albino of the Herring Gull was got shortly after, there seems little doubt the record must be rejected." $\dagger$

The Ivory-Gull is circumpolar in its distribution, and is but a rare visitor to northern Europe, some forty specimens having been obtained from time to time in Great Britain.]

THE GREAT SKUA. Megalestris catarrhactes (Linnæus).

\section{A very rare visitor.}

Writing of the "Common Skua, Lestris Skua," in 1843, Sir William Jardine says : "we have seen them occasionally on the Solway Firth." + It is probable that in those days the species generally was more numerous than it is now, and it may therefore have been met with "occasionally on the Solway Firth " at the time at which Sir William wrote.

Mr. W. Nichol writes me that on August 4th, 1907, he observed a Great Skua off the Dumfriesshire coast.

* Zoologist, 1898, p. 414.

$\dagger$ Trans. D. and G. Nat. Hist. Soc., April 20th, 1905.

‡ Nat. Lib., 1843, Vol. XIV., p. 264. 
Although the species is regarded as a " casual migrant in spring and autumn "* on the English side of the Solway, I suspect that the majority of the allegations of its local occurrence refer to Richardson's Skua, which in itsautumnal journey southwards is from time to time mistaken for its larger congener. Mr. Nichol's record is however trustworthy, for he " has exceptional opportunities for observing such birds, since his entire time is spent, summer and winter, in fishing and shooting in the waters of the Solway Firth. . . [He] ... is well acquainted with the other species of Skuas, and has himself shot both the Arctic and Buffon's Skua." $\dagger$

The Great Skua is rarely seen in winter off the coasts of Britain, where its breeding-places are confined to certain islands in the Shetlands group. Here it is rigidly protected. In the Færöes, Iceland, and possibly on some islands north of Hudson Strait it also nests, migrating southwards in winter.

\section{THE POMATORHINE SKUA.}

Stercorarius pomatorhinus (Temminck).

\section{A rare autumnal and winter-visitor.}

On January 6th, 1863, William Hastings exhibited a " Pomarine Skua," shot near Glencaple Quay (Caerlaverock), at a meeting of the Dumfriesshire and Galloway Natural History and Antiquarian Society. This bird is now in Kirkcudbright Museum (No. 288). Hastings remarked at the time " that the only specimens killed in Dumfriesshire or Galloway which had come under his notice as a preserver of birds for the last thirty years, was that now exhibited, and another which was killed about the same time by a lad, who

* Trans. Carlisle, Nat. Hist. Soc., 1909, p. 90.

† Fauna of Lakeland, p. 439. 
struck it with a stick while fighting with a common gull in a field in the parish of Kirkmahoe."* Robert Gray, writing in 1871, says : "It has occurred in the Firth of Clyde and on the Ayrshire coast ; in Wigtownshire, Kirkcudbright and Dumfries-shires, but only, so far as I am aware, in the winter season." $\dagger$ Two Pomatorhine Skuas were obtained in Gretna parish in 1892, $\ddagger$ and two immature examples were shot on October 26th and November 1st, 1898, between Annan and Gretna.§ Mr. R. Service states that on the morning of October 29th, 1902, a fine immature bird of this species was shot as it passed Glencaple Quay, going up the Nith on the flood-tide. "It was sitting," he adds, "on the carcase of a Herring-Gull, which it was busy devouring. I found its stomach gorged with gull's flesh and feathers." In the autumn of 1907 a good many Pomatorhine Skuas were observed off the English coast of the Solway; and Mr. W. Nichol writes me that on September 4th, 1907, he saw one in Dumfriesshire waters.

It is only after persistent gales from the east or north that this species, driven out of its course, is found locally. It is a tolerably regular autumnal visitant to the eastern coasts of Great Britain, in some seasons being more numerous than in others. More than a year is required for the assumption of full adult plumage, and immature specimens are usually obtained.

The Pomatorhine Skua nests " in Eastern Siberia, and thence eastwards across arctic America to Greenland," "I and in winter it has been recorded from north Australia, Burmah, Japan, northern South America, and the waters of Europe down to the Mediterranean shores, and parts of the West African coast.

* Trans. D. and G. Nat. Hist. Soc., January 6th, 1863.

$\uparrow$ Birds of West Scotland, 1871, p. 495.

$\ddagger$ Dumfries Courier and Herald, December 11th, 1908.

$\S$ Ann. Scot. Nat. Hist., 1899, p. 52.

|| Op. cit., 1903, p. 51.

I Birds of Britain, 1907, p. 372. 


\section{THE ARCTIC OR RICHARDSON'S SKUA.} Stercorarius crepidatus (J. F. Gmelin).

Local names-Boatswain-GULL; BLACK-Toed GULL.

\section{An occasional visitor to the Solway.}

A specimen of the "Boatswain or Black-toed Gull" is recorded as having been caught alive on September 12th, 1839, " on the shore at Conheath, near Glencaple Quay, a spot very distant from its native habitat; to which it had been driven by the late storm. Mr. Pennant gives a description of the bird in question, which Bewick adopts, accompanied by a drawing of one shot on the coast of Durham in October, 1800 , and the resemblance, we must say, between these memoranda and the specimen before us is complete in all its points."*

A Richardson's Skua was obtained at Priestside (Cummertrees) on August 13th, 1895. Mr. J. Harkness writes me from Ruthwell in 1908 that he had not heard of any for some years, but that they used in some winters to be common. After severe gales individuals are occasionally found inland, and a specimen shot at Holehouse Linn near Moffat in the winter of 1896 is now (1908), so Mr. J. A. Johnstone tells me, in the possession of Mr. A. Fyfe of that town. Mr. W. Nichol informs me that he saw a bird of this species off the Dumfriesshire coast on October 5th, 1907, and on September 10th, 1908, a Richardson's Skua was found lying dead in the Nith opposite Kingholm Mill. It is now in Mr. R. Service's collection, who writes that it was perfect in plumage, but extremely emaciated. On skinning it he found several lead pellets embedded in its flesh, so that the cause of its death was obvious. $\dagger$ One was shot at Powfoot (Cummertrees) by Mr. J. Dalrymple on November 13th, 1909,

* Dumfries Courier, October 2nd, 1839.

† Kirkcudbright Advertiser, November 27th, 1908. 
and Mr. J. Reid tells me he has seen this species many years ago near Kelton, and once on the Nith within a hundred yards of Castledykes Cottage, which was at one time the residence of Sir John Richardson, the eminent Arctic explorer and naturalist, from whom this bird derives its trivial name.*

The method used by Richardson's Skua of gaining a livelihood, consists in chasing the terns and smaller gulls and forcing them to relinquish any fish they may have taken ; it also preys upon disabled birds.

There exist light and dark forms of this species, which, however, mate indiscriminately where they meet. The light-breasted form in its breeding-grounds may be said to predominate in the far north, the dark form being in the ascendancy in the south. As a breeding-species this Skua may be described as circumpolar, but it nests on the north of the Scottish mainland, locally in the Hebrides, and more plentifully in the Orkneys and Shetlands. In the autumn it migrates south; and in winter it frequents the coasts of Europe down to the Mediterranean, West Africa as far as the Cape, the Persian Gulf, and the American coast as far south as California and Barbados; while it has occurred in Tasmania and New Zealand. Along the Scottish seaboard and the eastern coasts of England this species is the commonest of the Skuas, and is a regular migrant in autumn.

\section{THE LONG-TAILED OR BUFFON'S SKUA.}

Stercorarius parasiticus (Linnæus).

A scarce and irregular visitor.

Buffon's Skua is, perhaps, the most irregular of the genus Stercorarius in its visits to this county; but when these birds do come there is usually a party of them, or, when single birds have been observed, more usually follow. Richard Bell

* Sir John Richardson was the son of Gabriel Richardson, a Provost of Dumfries, and was born in that town on November 5th, 1787. 
of Castle O'er, in recording one of a pair which was shot at the head of Kirtle Water (i.e., some twelve miles inland) in the autumn of 1867, says that he sent it on loan to " the late Dr. John Alexander Smith, Edinburgh, for exhibition at a meeting of the Royal Physical Society, held on 22nd January, 1868. . . . In acknowledging receipt Dr. Smith wrote me :- ' it is the Lestris buffonii Buffon's Skua of Yarrell's British Birds." "**

Mr. R. Service records a fine adult male of this species shot in Torthorwald parish, at a place some six or seven miles from the sea on June 12th, 1881, and adds: "I had an opportunity of seeing the bird shortly afterwards, while it was in Mr. Hastings' possession for preservation. Its plumage was perfect, and the throat, neck and underparts were suffused with crocus-yellow." + June is a remarkable month for the occurrence of this species in Great Britain, and regarding this bird Mr. R. Service writes me in 1908 : "It was in full nuptial plumage, and by far the finest specimen, without any exception, I ever saw in any collection, public or private."

During the early part of October, 1891, a prevalence of gales, more or less from the westward, accounted for an unusual number of these birds on our shore. Some two dozen adults and birds " in change" were reckoned to have been killed between Walney Island and the Solway Firth, + and "Mabie Moss" writes: "More Buffon's Skuas have been seen or shot in October, 1891, on both sides of the Solway than have been known to visit us during all the years put together of half a century past." $§$ During this visitation two males "in change" (one of them retaining the long central rectrices) were obtained in the neighbourhood of Dumfries on October 17th, $\|$ and sent to

* Trans. D. and G. Nat. Hist. Soc., April 17th, 1901.

$\dagger$ Zoologist, 1881, p. 469.

†. Ibis, 1892, p. 184.

$\S$ Dumfries Courier and Herald, November 10th, 1891.

II Ann. Scot. Nat. Hist., 1892, pp. 73, 74. 
Mr. James Barnes of Carlisle. On the 21st, one (now in the collection of Mr. R. Service) was shot by Mr. Irving Murray at Priestside (Cummertrees)*; and a specimen obtained on the same date at Glen $\mathbb{E}$ (Tinwald), some twelve miles inland, was sent to William Hastings for preservation. $\dagger$ These birds were mostly in an emaciated and exhausted condition. Mr. W. Nichol writes me that on June 10th, 1908, he saw an adult male Buffon's Skua off the Dumfriesshire coast. As already pointed out, the month of June is an unusual date for the occurrence of this species in Great Britain.

Buffon's Skua is a circumpolar breeding bird, migrating as far south in winter as the Mediterranean; and in America reaching to the coast of Mexico on the west, and the mouth of the Delaware River on the east. It is less regular than the Arctic Skua in its visits to the British Isles, but in some autumns it is comparatively common and occasionally even abundant on the north-east coast of England; while southward it is rarer, and on the west coast is seldom met with.

THE RAZORBILL. Alca torda, Linnæus.

\section{A common visitant to the Solway.}

Breeding as it does no farther off the Dumfriesshire coast than Balcarry and the Ross (Kirkcudbrightshire), the Razorbill is an every-day visitant to the estuaries of the Esk, Annan, and Nith in the spring, summer and early autumn months. At these seasons it may be said to be never out of sight, more especially so after the young take to the sea. It leaves the immediate vicinity of the Dumfriesshire shore usually in September and thereafter may be found far down the channel, or on the open sea, where it remains throughout the winter and early spring. Razorbills are sometimes found washed up on our shores

* Dumfries Courier and Herald, November 10th, 1891.

$\uparrow$ Loc. cit. 
after severe winter-storms, as for example, in 1881-1882, when they could have been picked up " in cart loads,"* and again in 1893-1894. Mr. R. Service records many birds found dead in 1869 and in 1906, when quantities were brought to him from the end of July to mid-September. $\dagger$

The Razorbill nests in great numbers on suitable precipitous sea-cliffs around the United Kingdom. On the northwest coast of Europe it breeds from Brittany as far north as lat. $71^{\circ}$ in Scandinavia, and on the north-east coast of America and Greenland from $45^{\circ}$ north lat. to $73^{\circ}$ north lat. During late autumn and winter it is a pelagie species, seldom frequenting the shallower water unless under stress of weather.

\section{THE COMMON GUILLEMOT. Uria troile (Linnæus).}

\section{Local name-Aitsa Craig Cock.}

\section{A common visitant to the Solway.}

The Common Guillemot is certainly a more numerous species than the Razorbill locally. Breeding as it does in Kirkcudbrightshire, it may be said to be a common every-day visitant off our shores, except in late autumn and winter, when it becomes more pelagic in its habits.

A specimen of the Guillemot is included, in 1854, in a list of "Birds of rare and beautiful plumage" sent to Mr. Andrew Plenderleath of Longtown for preservation, from Sarkfoot. $\$$ In the autumn and winter of 1881-1882 "cartloads of them were washed ashore," particularly on October 14th $\S$; as also in 1859 and 1869. Similarly in March, 1894, Mr. Hugh Mackay records that numbers of Guillemots and Razorbills were washed up near Glencaple. Most of the Guillemots

* Trans. D. and G. Nat. Hist. Soc., February 3rd, 1882.

† Ann. Scot. Nat. Hist., 1907, p. 53.

$\ddagger$ Dumfries Courier, March 28th, 1854.

$\S$ Trans. D. and G. Nat. Hist. Soc., February 3rd, 1882. 
were young, but the Razorbills, old birds ; and he counted over fifty lying dead on the shore in a ten minutes' walk.*

Mr. R. Service writes in 1906: "Since the end of July there has been one of the mysterious epidemics (?) running its course amongst the Solway Guillemots, and, to a lesser extent amongst the Razorbills too. Old and young have been equally affected, and many of the latter were mere chicks. All along the tide mark from about Auchencairn eastwards defunct individuals have been strewn in very large numbers, and up till mid-September this fatality seems to have been continuous. Since then it hardly appears to have been so bad. Such epidemics amongst these rockbirds have occurred occasionally, one of the most fatal having taken place in 1869. Some authorities attribute this widespread destruction of the birds to destitution following upon tempestuous weather; others to starvation owing to absence of their food over the banks where they dive for it; while most seem to favour the disease theory. It seems strange that no precise observations upon the cause of the mortality seem to have been made. All the birds that I handled in August and September, cast ashore as described, were extremely emaciated, but in fine condition as to plumage. Their stomachs were always empty. Some few I caught ashore in a helpless condition. Many were noticed close inshore, within a stone's throw of the edge, and this was a most unusual place for these birds, in such shallow water as our firth." $\dagger$ Mr. Service writes me that after mature consideration he is of the opinion that the lack of some staple food, rather than an outbreak of an epidemic disease, is the cause of the periodical decimation of this and kindred species.

On some occasions the Guillemot is found driven inland many miles from the sea. Thomas Maxwell told Dr. Grierson in 1862 that this species had once been seen at Friar's Carse Loch, $\div$ some twelve miles from the sea; and Richard Bell

* Naturatists' Journal, 1894, Vol. III., pp. 62, 63.

† Ann. Scot. Nat. Hist., 1907, p. 53.

$\ddagger$ Grierson's MS. Notes, October 17th, 1862. 
of Castle O'er records an involuntary visitor found on the public road near Eskdalemuir.* On January 21st, 1890, a pair of Guillemots actually entered the mill-race below the Town Mills in Dumfries. One was killed by boys, and was found on dissection to contain eight parr, two of these over seven inches in length : the other bird escaped. $\dagger$

In 1908 this species was recorded from three unexpected localities : Mr. A. Robertson tells me a Guillemot was picked up alive at Crichope Linn (Closeburn) on September 21st, but died after three days; while on October 23rd another, so Major McCall informs me, was found on Moniaive Golf Course (Glencairn), and on November 30th a third was found in a moribund condition in the River Shinnel at Auchenbrac (Tynron). All these places it will be seen are some fifteen to twenty miles from the sea, and the appearance of this species so far inland is, of course, exceptional, and due to stormy weather.

The "Ringed" or "Bridled" Guillemot, which Howard Saunders says is " now generally admitted to be a variety, with an unusual development of white round the eye and along the crease or furrow behind it," + has been noticed amongst the carcases washed up on our shore from time to time.

The Common Guillemot nests in immense numbers on suitable sea-cliffs around the British Isles. On the northwest coast of Europe it breeds along the west coast of France to as far north as Bear Island; and on the northeast coast of America from New England to lat. $64^{\circ}$ north.

THE BLACK GUILLEMOT. Uria grylle (Linnæus).

\section{A very rare visitor to our coast.}

The Black Guillemot is of very rare occurrence in the Solway Firth. A single bird in full breeding-dress was

* Trans. D. and G. Nat. Hist. Soc., April 17th, 1901.

$\dagger$ Dumfries Courier and Herald, February 14th, 1890.

† Man. Brit. Birds, 1899, p. 700. 
observed by Mr. Linnæus Hope near Heston Island, Kirkcudbrightshire, on May 23rd, 1907* : but I do not know of its nesting in that locality. A specimen was picked up dead at Brow Well (Ruthwell) in August, 1884, by Mr. R. Service, who tells me that during the epidemic, so rife among the Guillemots and Razorbills from July to September in 1906, more than one Black Guillemot was found dead on the Solway shores.

This species is at all seasons uncommon off the coasts of England, but breeds in suitable precipitous cliffs around Scotland and Ireland. It also nests on parts of the coasts of Denmark, Scandinavia, the Færöes and the White Sea, also in north-east America and south Greenland; and is normally as pelagic in its habits as the rest of the family.

\section{THE LITTLE AUK. Mergulus alle (Linnæus).}

\section{A rare winter-visitor under stress of weather.}

Sir William Jardine writing of the Little Auk in 1843 says : "We have never had the satisfaction to meet with this species in a recent state... On the southern Scottish coasts, specimens have been very seldom procured." $\dagger$ Thomas Maxwell told Dr. Grierson that a "Rotche," found about 1860 at Lagganburn (Dunscore) was the only one he had ever heard of as obtained locally. $\neq$ This place is some thirteen miles inland.

Mr. J. Harkness found a Little Auk on the shore near Brow Well (Ruthwell) in the winter of 1886-1887; which passed into the possession of Mr. Wilkin of Tinwald Downs. After the great gale of November 17th, 1893, numbers of this species were driven on to the shores of Great Britain, and this unusual visitation has been christened by Mr. W. Eagle Clarke "The Wreck of the Little Auk."

* Trans. Carlisle Nat. Hist. Soc., 1909, pp. 86, 87.

† Nat. Lib., 1843, Vol. XIV., pp. 224, 225.

‡ Grierson's MS. Notes, October 17th, 1862. 
About a dozen specimens were picked up in the "Solway area." On this occasion, one which was found about November 21 st in the streets of Sanquhar, some thirty miles inland, had apparently flown against an overhead telephone-wire : before it was recognised as an uncommon bird a dog had spoilt it.* A few weeks later another, found about eighteen miles inland, was sent from Lockerbie to Mr. Hugh Mackay for preservation. $\dagger$

The Little Auk is an inhabitant of Arctic seas, breeding in north Iceland, Nova Zembla, more numerously " in Greenland, Spitzbergen, and Franz Josef-land, but it does not occur in Arctic America nor to the east of the Kara Sea. In winter it migrates southwards, and a few are found on the northern shores [of the British Isles] every year, but in severe winters it often occurs in considerable numbers, and many storm-driven birds are found in adying condition far inland." $\ddagger$

\section{THE PUFFIN. Fratercula arctica (Linnæus).}

\section{An occasional visitant to the Solway.}

Thomas Maxwell in 1862 told Dr. Grierson that the only specimen of the Puffin that he had ever heard of as obtained in the county, was found at the mouth of the Nith about twenty years previously§; but living as he did in an inland locality, his knowledge of the status of the species may not have been extensive. The Puffin is certainly less numerous on our coast than the Razorbill and Guillemot, and it is not definitely known whether, like them, it breeds at Balcary and the Ross in the neighbouring county of Kirkcudbright.

Many were washed ashore early in October, 1859, $\|$ and a few during the stormy weather of the winter of 1881-1882. 1 In

* Dumfries Courier and Herald, April 19th, 1894.

$\dagger$ Loc. cit.

†irds of Britain, 1907, p. 380.

$\S$ Grierson's MS. Notes, October 17th, 1862.

II Dumfries Courier, October 4th, 1859.

ๆ Trans. D. and G. Nat. Hist. Soc., February 3rd, 1882. 
February and March, 1903, several Puffins were caught on the Caerlaverock bird nets, * and Mr. R. Service informs me that he has several specimens captured in this way in late winter and early spring. In the 1906 " epidemic," already referred to (see p. 450), this species appeared also to be a sufferer.

The Puffin breeds in large colonies in Scotland and Ireland. In England it nests on the west coast; but on the east it is only known as a breeding-species at the Farne Islands and Flamborough Head. On the west coast of Europe it breeds in suitable localities from the north of Scandinavia to Portugal, and in North America as far south as Newfoundland. By the end of August these birds leave their breeding-stations, but their exact distribution during the ensuing months before they return again in April, is still to be determined. During this period, however, the species may be met with round our coasts, down the Atlantic seaboard, and as far east as Sicily in the Mediterranean.

\section{THE GREAT NORTHERN DIVER. Colymbus glacialis, Linnæus.}

Local names-Immer-Goose ; Ember-Goose.

\section{A winter-visitant, occasionally seen off our shores.}

In 1854 the Great Northern Diver is recorded from Dumfries as " seen lately as a winter visitor." $\dagger$ In January and February, this species is occasionally observed in the Solway when the weather is foggy and calm. It may be seen fishing along the channels that run off the Dumfriesshire sand-banks, coming and going with the tide at the first of the flow and the last of the ebb; but it is at all times shy and wild, and shuns observation.

Its occurrence up our rivers is most unusual ; but in 1862 Dr. Grierson was informed by Thomas Maxwell of Allanton

* Ann. Scot. Nat. Hist., 1904, p. 69.

† Naturalist, 1854, Vol. IV., p. 51. 
Mill (Dunscore) that a specimen had been obtained in that district "many years ago."* Mr. W. J. Maxwell informs me that " a fine specimen in full plumage, caught in the nets on the Kirkconnel side of the Nith near Glencaple in 1874, was given by the late Mr. Witham to Captain Maxwell of Terregles, but was destroyed by fire in 1904." The mention of this specimen here is, perhaps, hardly warrantable, except for the purpose of giving the full data of an occurrence of this species, hitherto vaguely reported as obtained " at the mouth of the Nith in 1875." A Great Northern Diver, shot on the Cairn on February 2nd, 1877, was exhibited at a meeting of the Dumfriesshire and Galloway Natural History and Antiquarian Society by Mr. Rutherford, the same day. $\dagger$ On November 17th, 1881, a bird of this species (a young female) was shot by Mr. Irving Edgar in Castledykes Pool (Dumfries). $\$$ Mr. William Laidlaw informs me that one killed on January 18th, 1909, in a storm near Bailie Hill, about nine miles above Langholm, was sent for preservation to Mr. Law of Hawick.

The Great Northern Diver is a western species breeding in North America, Greenland, and Iceland. In winter it is seen in Europe, on the Atlantic seaboard, in the Mediterranean and Black Seas, and on certain inland waters. Around the British shores, immature specimens are most frequently met with, except on the west, where adults are occasionally abundant.

\section{THE BLACK-THROATED DIVER. \\ Colymbus arcticus, Linnæus.}

\section{An uncommon winter-visitor to the Solway.}

The Black-throated Diver is an irregular visitor to our shores in the later months of winter and on the

* Grierson's MS. Notes, October 17th, 1862.

$\uparrow$ Trans. D. and G. Nat. Hist. Soc., February 2nd, 1877.

$\ddagger$ Op. cit., February 3rd, 1882. 
approach of spring; and very few are procured or seen in full plumage. Mr. J. Harkness writes me that he received a Black-throated Diver in winter-plumage shot at Powfoot (Cummertrees) in 1886, and a specimen was obtained locally towards the end of November, 1890* Mr. Hugh Mackay writes that a fine "two-yearold" specimen of the Black-throated Diver was brought to him from Lochmaben on March 4th, 1893, and adds that he had been informed that "considerable numbers frequented Lochmaben and vicinity during the past winter." $\dagger$ Mr. John Borland informs me that a bird of this species was found on the banks of the Nith at Shawsholm (Closeburn) in the early spring of 1908.

During the breeding-season this species is found on the lakes of Scandinavia, Finland, north Russia, and across Siberia to the Pacific, migrating south in winter to the Mediterranean and the inland waters of Europe; and in the east, to Japan. It also breeds in the north of Scotland, the Outer Hebrides, the Orkneys, and possibly the Shetland Isles, but it is the most uncommon visitor of its family to the British coasts.

THE RED-THROATED DIVER.

Colymbus septentrionalis, Linnæus.

Local names-Speckled Diver ; Loon ; Small Northern Diver.

\section{A common visitant to the Solway from autumn to spring.}

The Red-throated Diver appears off our coast about the end of September or in October, and departs in April or May to its more northerly breeding-places.

* Dumfries Courier and Herald, January 22nd, 1891.

$\uparrow$ Trans. D. and G. Nat. Hist. Soc., May 12th, 1893. 
I have been unable to find any record of the species having nested in the county, but "Mabie Moss," writing in 1896, asks: "Does this fine bird ever breed in any of our lonely lochs amongst the hills?" He adds that he has never seen it there, nor heard of it, although it is " frequently captured by fishermen in their nets in June, and is plentiful in the shallow waters of the Solway in winter."* I used to see the Red-throated Diver frequently on Loch Howie (Kirkcudbrightshire) in August some twenty years ago, and in 1899 I put one off Loch Ettrick (Closeburn) on April 11th; but, as above stated, I know of no record of its having bred in Dumfriesshire.

Formerly it was more commonly met with inland than nowadays, judging from the recollections of the older gamekeepers with whom I have discussed the subject; but on the shore it is still frequently observed, and Mr. R. Service tells me that he has often obtained specimens which have been caught in the salmon-nets of the local fishermen.

In 1791, in a list of birds of the parish of Kirkmichael, "the Diver" is included, but there is no information as to the species intended. $\dagger$ In 1832 Sir William Jardine states that the Red-throated Diver had been once met with in the parish of Applegarth and Sibbaldbie " in immature plumage, or as the speckled diver of Bewick." $\ddagger$ In 1843, he writes : "Along all the Scottish coasts it is [during winter] common, sometimes coming inland to such lochs as are not frozen, and occasionally ascending rivers; we have shot specimens in the Annan fifteen miles from the sea," and he goes on to say that he had only once or twice met with birds apparently breeding, though he was never able to discover the nest\$; the context, however, gives one no idea as to whether Sir William refers to the vicinity of Jardine Hall, or to Scotland in general. Thomas Maxwell told Dr. Grierson

* Dumfries Courier and Herald, June 25th, 1896.

$\dagger$ Stat. Acct. Scot., Vol. I., p. 61.

‡ New Stat. Acct. Scot., Vol. IV., p. 182.

$\S$ Nat. Lib., 1843, Vol. XIV., pp. 188, 189. 
in 1862 that a "Small Northern Diver" was obtained that season at Cowhill, and he refers to this as "the same bird as the one I got from Mr. Broadfoot at Glencairn, and which was got in a loch near Maxwelton."* About 1885 a Red-throated Diver was shot at the Far Loch, Capenoch (Keir), and is now in my possession. "In July, 1886, a small but full-dressed male ... was found dead by a platelayer near Gretna, having struck the wires full upon the lower neck." $\uparrow$ A Red-throated Diver was seen on May 30th, 1901, at Loch Skene, + which is fully thirty miles inland; and Miss Wallace informs me that a bird, presumably of this species, was seen on one of the Lochmaben Lochs on February 13th, 1906. Another example was found dead on the hills near Castle O'er (Langholm) by a shepherd in November, 1908.

The above records refer to the occurrence of the species inland; but on the coast, as has already been stated, it is far more common. Mr. W. Nichol writes me that this species was remarkably numerous on the Solway in April and May, 1905, and that one day he counted twenty-one between the Solway Lightship and Southerness; while in 1906 birds were seen on the Scottish side of the Solway on April 11th and 30th.

This species nests in Scotland in variable numbers from Arran northwards, and in the Hebrides, Orkneys and Shetland Isles. In Ireland a few pairs may still escape the persecution of the egg-collector, and outside the British Isles the Red-throated Diver has a circumpolar distribution during the nesting-season. In winter, it is a common visitant around the coasts of Great Britain, immature examples preponderating, and at this season the species has a more extended range than the Black-throated Diver.

* Grierson's MS. Notes, October 17th, 1862.

† Fauna of Lakeland, 1892, p. 450.

$\ddagger$ Ann. Scot. Nat. Hist., 1901, p. 201.

$\S$ Tullie House Museum Registers. 


\section{THE GREAT CRESTED GREBE.} Podicipes cristatus (Linnæus).

Local name-Large Grebe.

A very local resident, and an irregular visitor from Autumn to spring.

In 1843 Sir William Jardine writing of the Great Crested Grebe says: "Although Mr. Heysham has recorded the occurrence of this bird in Cumberland, we have never been so fortunate as to meet with it on the border during summer. It may be considered, indeed there, and in Scotland, rather as a winter visitant, and that in no great abundance."* Dr. Grierson was told by Thomas Maxwell of Allanton Mill that a "Large Grebe" was obtained on the Nith about 1856. $\dagger$

William Hastings exhibited a specimen of the Great Crested Grebe from Lochmaben, to the Dumfriesshire and Galloway Natural History and Antiquarian Society on February 14th, 1871, and stated that:- "it is very rarely seen in this part of the country." During the severe winter of 1878-1879 a bird of this species, shot locally, was sent to him for preservation, $\$$ and in January, 1891, another was shot near Gretna $\S$; while a specimen was obtained in January, 1892, in the estuary of the Nith.\|

The earliest record of the breeding of the Great Crested Grebe in Dumfriesshire, of which I am aware, is in the summer of 1891, when Mr. George Johnstone saw a young bird with its parent on the Castle Loch (Lochmaben). I

* Nat. Lib., 1843, Vol. XIV., p. 202.

$\uparrow$ Grierson's MS. Notes, October 17th, 1862.

+ Trans. D. and G. Nat. Hist. Soc., December 5th, 1879.

$\S$ Scot. Nat., 1891, p. 95.

|| Dumfries Courier and Herald, April 26th, 1892.

If R. Service's MS. Diary, August 16th, 1891. 
Mr. William Henderson of Lochmaben, as I am informed by Mr. W. J. Halliday, states that it was not till 1903 or 1904 that he personally noticed the Great Crested Grebes together with their young on the Castle Loch. In the spring of 1905 a brood is recorded in Miss Wallace's MS. diary as having been successfully reared on the Mill Loch; while the same observer noted that one bird was seen at Lochmaben Loch on March 23rd and four on May 21st, 1906. In 1907 two fine specimens, now to be seen stuffed at the King's Arms Hotel (Lochmaben), were shot on Hightae Loch. I am further indebted to Mr. Halliday for the information that in August, 1908, Mr. William Henderson counted fifteen Great Crested Grebes on the Castle Loch, and saw three birds with respectively one, three, and five young ones; while a pair also frequented the Mill Loch. Mr. Halliday adds that the species has increased summer by summer since 1903 or 1904, and is now (1910) comparatively numerous.

The Rev. Hugh Parry tells me that he is almost certain he saw a Great Crested Grebe swimming in Dalswinton Loch (Kirkmahoe) in September, 1909. In confirmation of this, a bird of the grebe kind, unknown to Mr. T. Ranken who knows the Little Grebe well, was seen by him early in October, 1909, in the same loch.

On May 17th, 1910, Mr. H. F. Witherby and I identified three Great Crested Grebes on Loch Urr (Glencairn). They swam together in the centre of the lake, seldom diving, and showing no signs of being anything more than migrants resting. Our opinion was confirmed when I visited the locality ten days later, and could see no trace of the birds. This record of the species from the extreme north-west of Dumfriesshire is interesting, as being the first that I know of from that part of the county.

It will be noticed that all records of the breeding of the Great Crested Grebe hail from the vicinity of Lochmaben.

The species nests in suitable localities throughout England and Ireland, in Scotland as far north as Aberdeenshire, and 
is increasing in numbers. It is found "over the greater part of the Old World, breeding in most countries of Europe and the Mediterranean Basin, as far north as the Baltic provinces, Denmark and Southern Sweden, across Siberia to Japan and China, and south to Australia and New Zealand. It has not been recorded from any part of America."*

\section{THE RED-NECKED GREBE.}

Podicipes griseigena (Boddaert).

\section{A very rare and irregular visitor.}

Sir William Jardine in 1843 writes of the Red-necked Grebe: "This bird has never come under our own observation living." $\dagger$ but in the Catalogue of the Birds contained in the collection of Sir William Jardine (printed, it is believed, some four years later), there is recorded a specimen shot " on the Frith by J. Hotches," which may or may not have been obtained on the Solway Firth.

In "A running Catalogue of the Contents of my Museum," Dr. Grierson of Thornhill records a "Redthroated Grebe from Maxwelton Loch (Glencairn)"; no date is given, but this would be approximately about 1867 . Another, recorded as "No. 216 from near Drumlanrig," without further data, must have been obtained at a later date, but prior to 1871. I must here state that in my opinion, these two records of Dr. Grierson's may refer to the Red-throated Diver; and this opinion is arrived at from the similarity of the first of the records here given, to that of the "Small Northern Diver" (see p. 458).

In January, 1891, a Red-necked Grebe was killed on the Solway Firth near Gretna, $\ddagger$ but details of its subsequent history are not forthcoming. Mr. R. Service states that a fine male was shot on the Nith on October 6th, 1903, by

* Lloyd's Nat. Hist., 1897, Vol. IV., p. 196.

† Nat. Lib., 1843, Vol. XIV., p. 204.

$\ddagger$ Fauna of Lakeland, p. 452 . 
a gunner named West and was brought to him the same evening; "This," adds Mr. Service, "is a rare species in Solway."*

The "species breeds throughout Russia from Archangel to the Caspian and Black Seas, as far east as Turkestan, and westwards in the Baltic and Northern Germany to the South of Norway." $\dagger$ To the east coast of Great Britain it is a tolerably common winter-visitant, being much more rarely met with on the west coast, while the species has only been obtained eleven or twelve times in Ireland.

\section{THE SLAVONIAN OR HORNED GREBE. Podicipes auritus (Linnæus).}

\section{A rare and occasional visitor.}

Sir William Jardine stated in his list of birds of the parish of Applegarth and Sibbaldbie in 1832: "The Dusky Grebe (C. cornutus) has been found with us once or twice" + ; and in 1843 he wrote: "We have frequently shot it in the river Annan during winter; it never attempted to fly, but was not nearly so watchful as the Little Grebe, diving but coming up again in sight, and allowing itself to be approached within shot."§

In the Dumfries and Galloway Courier of February 20th, 1872, we find the following record: "A specimen of the Red-eyed or Dusky Grebe, a very rare bird in this locality, was shot the other day by Mr. C. Waugh in the Kirk Loch (Lochmaben). It may be seen in the shop of William Hastings, taxidermist, Dumfries ; who in the whole of his lengthened experience can recollect of only one other speci-

* Ann. Scot. Nat. Hist., 1904, p. 69.

† Lloyd's Nat. Hist., 1897, Vol. IV., p. 199.

$\ddagger$ New Stat. Acct. Scot., Vol. IV., p. 182.

§ Nat. Lib., 1843, Vol. XIV., p. 207. 
men of this bird being found in the south of Scotland." In December, 1878, a Slavonian Grebe was killed, also at Lochmaben*; and in 1889 William Hastings, recording a local specimen obtained recently, says that the species is "by no means common." $\dagger$ "Mabie Moss" in 1891 wrote : "A bird unusually common this winter [i.e., 1890-1891] in fresh waters, and also on the Solway Firth, is the Dusky or Slavonian Grebe. Several were washed ashore dead."

The Slavonian Grebe breeds throughout parts of northern Europe, Siberia, and North America. In winter, its emigrations extend to the waters of Europe down to the Mediterranean; and in the Western Hemisphere, to the northern States, and occasionally as far south as the Bermudas. To the north coast of Scotland it is a regular winter-visitant, as also in a less degree to the east coast of England; to the west and to Ireland its visits are more irregular. It has been found lately nesting in Argyllshire, $\S$ the first authentic record for the British Isles.

\section{THE BLACK-NECKED OR EARED GREBE.}

Podicipes nigricollis (C. L. Brehm).

\section{Has occurred once.}

The only local record of the occurrence of the Black-necked, or, as it is sometimes called, the Eared Grebe, is of a pair shot in 1863 at Castledykes Pool, $\|$ on the Nith; they were seen and handled by Sir William Jardine. $\uparrow$

This species is of a more southerly habitat than the preceding. It breeds in central and southern Europe,

* Trans. D. and G. Nat. Hist. Soc., December 5th, 1879.

+ Op. cit., February 1st, 1889.

†umfries Courier and Herald, February 26th, 1891.

$\S$ Bulletin of Brit. Ornith. Club., Vol. XXV., pp. 75, 76.

|| Trans. D. and G. Nat. Hist. Soc., April 20th, 1905.

If R. Service's MS. Diary, December 3rd, 1887. 
in northern Africa and in the temperate regions of Asia. To Scotland and Ireland it is a very rare straggler ; and is but an irregular visitor in spring and summer to the east coast of England, where there is evidence that it may have nested more than once, as well as elsewhere in Great Britain.*

\section{THE LITTLE GREBE. Podicipes fuviatilis (Tunstall).}

\section{Local names-Dabchick; Wee Diver; Wee Douker.}

A common resident, frequenting many of our lakes in spring, and the larger rivers and lakes in winter.

The first record we have of the Little Grebe is in 1832, when Sir William Jardine included it in his list as one of the birds of the parish of Applegarth and Sibbaldbie, and refers to it as common in the River Annan "during winter in pairs, or in small parties of five or six." $\dagger$ In 1843 he writes: "In our own vicinity there are many suitable places, but we are not aware that it incubates, though very common in winter. ... We never saw it attempt to save itself by flight, except once, when we suddenly came upon a party of four or five, towards evening, in very shallow water." $\ddagger$ Two specimens, labelled as shot "on the River Annan," are recorded in the catalogue of his collection.§

Speaking in 1900 of the past century's changes in the vertebrates of Solway, Mr. R. Service says of the Little Grebe: "This is another addition to our breeding residents. It was first noted nesting at Falbae Loch, in Parton [Kirkcudbrightshire] in 1876, and since then it has been noticed in several other localities." $\|$ Mr. R. Service further informs

* Brit. Birds (Mag.), Vol. II., p. 368.

$\dagger$ New Stat. Acct. Scot., Vol. IV., p. 182.

† Nat. Lib., 1843, Vol. XIV., pp. 209, 210.

§ Cat. Birds in coll. Sir W. J., p. 209 (8523), a, a.

II Trans. D. and G. Nat. Hist. Soc., November 20th, 1900. 
me that he did not know of their breeding in the Solway area till he was told by the late Sir Edward Newton that he and his two daughters had seen a brood on Carlinwark Loch (Kirkcudbrightshire) in 1886. Under these circumstances the following extract from a letter from Mrs. Pollock is most interesting: "Spring 1866, Water Grebe. Nest built of rushes in some red willows in Dalswinton Loch. The bird made a loose lid or roof, and on going off she always pushed it over the nest so as to resemble a large loose sod floating among the red willows, so you might step on it and never know it was a nest. I have taken the lid off, and removed an egg and replaced the roof. James Robson found the nest." After a perusal of this letter Mr. Service writes me: "This is in all likelihood the oldest record of the species nesting hereaway, unless indeed it formerly (say before 1870) nested, and then for twenty years or more disappeared in nesting time; or the Dalswinton case may have been sporadic."

The shy and unobtrusive habits of the Little Grebe may account for the lack of early records of its breeding in the county; certainly its nest might easily be overlooked. In a letter dated April 13th, 1881, Mr. Tom Brown informed Mr. R. Service of three small divers, reddish-brown about the neck, observed in a loch near Drumcuil (Durisdeer). Writing in 1888 of the birds of Glencairn, Mr. John Corrie describes the species as "seen on the Cairn in the winter of 1885. Subsequently found breeding on a very small loch."* In a letter to me in 1908 he kindly supplements this observation by stating that it was in 1887 that he first found the nest, and that the species now breeds on several lochs in the parish. Nowadays reports from many localities in Nithsdale and Annandale show that the Little Grebe nests regularly, and is as a breeding-species increasing; but I have no reports of it as such from Eskdale.

The Little Grebe arrives at its nesting-haunts late in March or early in April, and its presence is often detected by its "curious trilling chatter." The nest, which is a raft

* Trans. D. and G. Nat. Hist. Soc., November 10th, 1888. 
of aquatic vegetation moored to the reeds or rushes at the side of the loch, is often indistinguishable from a tangled mass of water-weeds, and the similarity is strengthened by the fact that the bird on leaving the nest is careful to cover up the eggs with weeds. Four to six creamy-white eggs (with a green lining-membrane) are laid, which soon become stained from their constant contact with the decayed vegetation; and eighteen days are required for incubation.

During autumn and winter and until early spring, Little Grebes are met with on the larger lochs and the smoothflowing reaches of our main rivers. Miss Wallace records the species in her diary as seen at the Upper Loch (Lochmaben) on January 27th and 29th, February 12th and 13th, and March 10th, 1906. In severe weather these birds are driven to the estuaries; and in some winters are observed more numerously than in others, as in 1870, 1874, and 1878-1879, when several were brought alive, but moribund, to William Hastings*; having doubtless been frozen out of haunts where previously they were concealed and inconspicuous.

The Little Grebe is found throughout Great Britain in suitable localities and is an inhabitant of temperate Europe and Asia, as well as North Africa. In most parts of its range it is a resident, and closely allied forms render the species almost cosmopolitan in its distribution.

THE STORM-PETREL. Procellaria pelagica, Linnæus.

A rare and irregular visitor.

Writing in 1843 of the Storm-Petrel Sir William Jardine says: "To our own observation, this is a much more uncommon bird than that which we shall notice next [Fork-tailed Petrel]; we have scarcely ever met with it living." $†$ H. A. Macpherson wrote in 1892 in his

* Trans. D. and G. Nat. Hist. Soc., December 5th, 1879.

† Nat. Lib., 1843, Vol. XIV., p. 258. 
Vertebrate Fauna of Lakeland: "In bygone years we used to regard this Petrel as the most frequent representative on our coasts of the family to which it belongs, and there can be no doubt that such it used to be. Moreover, it occurred inland on more numerous occasions than the Fork-tailed Petrel. Whatever the reason may be, there can be no doubt that this species has become rarer on our coast than it was at one time, while the larger species has visited us in larger numbers than was formerly the case."* It is difficult to reconcile the statements of these two authorities; but there is no doubt that Sir William Jardine's "observation" of 1843 is applicable to the two species nowadays.

Some of the old records of the occurrence of the StormPetrel in Dumfriesshire probably refer to the next species; and it is impossible now to check their authenticity, but with this preamble I give them for what they are worth. In February, 1857, W. G. Gibson records a specimen which was caught some time previously in a small burn, "in the parish of Kirkmahoe, upwards of thirty miles from the Solway Firth; it appeared to be much fatigued, but after two days rest, in a cage, on being taken out, it made right for the sea." $\dagger$ A "Stormy Petrel " was recorded in December, 1866, as recently caught in the neighbourhood of Annan.t In the Annan Observer of November 19th, 1872, it was stated that Mr. Peter Muir, taxidermist, Ecclefechan, had just had through his hands " a rare bird, got on the Solway coast; it is the small black Stormy Petrel"; and this may be the same specimen as that recorded as "killed recently at the mouth of the Annan," and exhibited to the Dumfriesshire and Galloway Natural History and Antiquarian Society on December 3rd, 1872. Mr. Hugh Mackay states in the Dumfries and Galloway Standard of May 29th, 1895, that he had a specimen of the Storm-Petrel from Newbie (Annan) about the end of January, 1895, and he adds that

* Fauna of Lakeland, 1892, p. 456.

$\dagger$ Notes for Naturalists, p. 48.

Trans. D. and G. Nat. Hist. Soc., December 4th, 1866. 
this species is the "least often met with in this district, the Fork-tailed or Leach's Petrel being obtained more frequently." On October 1st, 1900, an individual was shot on Hightae Moor near Lochmaben; Mr. R. Service, who records this occurrence, adds that it was the first local specimen he had ever handled, all the others having been Fork-tailed Petrels.* Richard Bell of Castle O'er states that on December 10th, 1901, a shepherd going his rounds in Eskdalemuir, found a Storm-Petrel buried in the snowt; and Mr. C. Sanderson assures me that a bird of this species was shot during the covert-shooting at Castlemilk (St. Mungo) in December, 1907.

In its range outside the British Isles the Storm-Petrel breeds in the Færöes, north-west France, and on both sides of the Mediterranean as far as the Ionian Sea. It visits the Madeiras, Canaries, Azores, and the west coast of Africa to Cape Colony in winter; and though it has been found in north-east America it is not known to breed there. It is found in autumn on all the seas around Great Britain, and breeds on the islands off the coasts of Scotland and Ireland, and more sparsely on those off the west of England.

\section{LEACH'S FORK-TAILED PETREL. \\ Oceanodroma leucorrhoa (Vieillot).}

An irregular autumn and winter-visitor.

Leach's Fork-tailed Petrel is an irregular visitor in October and November to the Solway Firth, being at times driven inland during tempestuous weather; as in September, 1891, when an unusual number were noticed around the Irish and Scottish coasts. In fact, after any severe NNW. gales, individuals of this species, "flung across the country," may be expected locally.

Sir William Jardine in a letter dated from Jardine Hall, December 23rd, 1831, to his friend P. J. Selby, says: "I

* Ann. Scot. Nat. Hist., 1901, p. 80.

$\dagger$ My Strange Pets, pp. 149, 150. 
have got another Procellaria bullochii, found also on a road. The only bird worth noting this winter." Writing in 1843 Sir William records* a specimen sent him from Lower Annandale by Sir Patrick Maxwell, and this I have ascertained was procured on December 2nd, 1838, near Springkell (Kirkpatrick-Fleming). In the Catalogue of the Birds contained in the collection of Sir William Jardine there is included a Leach's Fork-tailed Petrel, $\uparrow$ picked up on the Glasgow and Carlisle road by Mr. John Jardine; it was " still alive, but exhausted, dying within ten minutes of being found." $\ddagger$ William Hastings told Mr. R. Service that about 1865 one of these birds was sent to him, which had been found alive in a ditch near Parkgate (Lochmaben); and a bird of this species was observed near Newbie (Annan) on October 3rd, 1885. On November 21st, 1888 Mr. Service records in his MS. Diary that he received one from Mr. John Kennedy, Priestside, which "had been blown in by the continued gale of the past week."

In the autumn of 1891 a visitation of Leach's Fork-tailed Petrels in unusual numbers occurred in Scotland and Ireland, as also on the Cumberland coast§; and the following specimens were obtained locally. On September 27th, one killed by telephone-wires in High Street, Annan, was found by Mr. W. Wright. The following day Mr. Wardrop shot one from a flock of six or eight near Solway Viaduct, and shortly after saw four or five at Annan Water-foot, and later, a single bird at Milnfield Railway Bridge. On the same day two were caught at Newbie (Annan), and Mr. Farish of Kirkland (Kirkmichael) found one at Gamerigg plantation fifteen miles from the sea; while another was picked up in the High Street of Moffat, some twenty-five miles inland. On November 2nd a specimen was picked up near Monybuie (Kirkcudbrightshire), just outside the limits of Dumfriesshire.

\footnotetext{
* Nat. Lib., 1843, Vol. XIV., p. 262.

$\dagger$ Cat. Birds in coll. Sir W. J., p. 208 (8468), a.

¥ Nat. Lib., 1843, Vol. XIV., p. 262.

§ Fauna of Lakeland, 1892, pp. 455, 456.
} 
This unprecedented and widespread immigration was attributable to the severe gales then experienced, and doubtless many more individuals must have been seen and procured.*

On December 15th, 1893, a Leach's Fork-tailed Petrel was secured in one of the bird-nets on Caerlaverock shore, $\dagger$ and this is possibly the same specimen as that recorded by Mr. Hugh Mackay as caught in the nets at Caerlaverock in the beginning of January, 1894, and sent him by Mr. Turner to set up. $\%$

The winter of 1906-1907 produced several records. On November 18th one was captured near Dunscore; on the same day two specimens were picked up in the vicinity of Lochar Moss, and two days later a fourth was obtained at Castlemilk near Lockerbie.§ Mr. J. Harkness informs me that he found the remains of a Leach's Fork-tailed Petrel in Newfield Wood (Ruthwell) in December, 1906 ; and Mr. J. McCarfrae writes me that he shot a "Stormy Petrel [but which I suspect to have been an example of Oceanodroma leucorrhoa] in the winter of 1906 during a terrific gale, some thirty miles inland, on Crawick Water." Another was picked up dead near Annan on January 1st, 1907.\| This last local visitation was probably due to the severe NNW. gales which raged in the latter half of November; and, as may be judged from the foregoing, the appearance of this species, though irregular, is nothing like so rare as that of the preceding.

This species occurs irregularly on all the coasts of Great Britain in winter, generally after gales, and breeds on St. Kilda, the Outer Hebrides, and in Mayo and Kerry on the west coast of Ireland. It is found on the Atlantic and Pacific Oceans, and may be termed an inhabitant of "the temperate waters of the Northern Hemisphere."

* Dumfries Courier and Herald, October 6th, 1891.

$\dagger$ Op. cit., April 19th, 1894.

† Trans. D. and G. Nat. Hist. Soc., April 20th, 1894.

§ Ann. Scot. Nat. Hist., 1907, p. 113.

i| Trans. Carlisle Nat. Hist. Soc., 1909, p. 89 


\section{THE MANX SHEARWATER.}

$$
\text { Puffinus anglorum (Temminck). }
$$

An uncommon visitor to our coast.

In 1843 Sir William Jardine wrote: "We are not aware of this Shearwater having been seen in the Solway, or about its entrance, for many years."* During the severe winter of 1878-1879 several Manx Shearwaters were sent to William Hastings, who remarked at the time that this species seemed to be more frequently met with of late years. $\dagger$ Mr. W. Nichol writes me in 1909: "The Manx Shearwater is a bird that I have only twice seen in the upper reaches of the Solway; once on the Scotch side and once on the English side."

This species nests in many places along the west coast of Great Britain and also around the Irish coast, but owing to its usually nocturnal habits, it may breed undetected in many localities. It is more generally distributed in winter, but is rarely seen as far up the Solway as Annan Waterfoot.

"The Manx Shearwater breeds in the North Atlantic Ocean, in Iceland and the Faeroes, extending to the coast of Norway and south to Madeira and the Canaries; $" \$$ and in American waters it has been but rarely met with.

\section{[THE FULMAR. Fulmarus glacialis (Linnæus).}

Although I am not aware of any record of the Fulmar having been actually obtained within the limits of the county, I am informed by Mr. R. Service that this bird has at times

* Nat. Lib., 1843, Vol. XIV., p. 255.

$\dagger$ Trans. D. and G. Nat. Hist. Soc., December 5th, 1879.

$\ddagger$ Lloyd's Nat. Hist., 1897, Vol. IV., p. 164. 
been observed at sea from Annan Water-foot westwards after tempestuous weather. A female was obtained on Rockeliffe Marsh, Cumberland, on February 9th, 1892,* and this fact is here quoted as strengthening Mr. Service's statement. But in view of the fact that the Fulmar Petrel is thoroughly oceanic in its habits and is seldom seen near shore except at its breeding-stations, unless driven in by severe storms, I feel compelled to employ square brackets for this species. It nests on St. Kilda, the Shetland Isles, the Færöes, Iceland, Spitzbergen, Franz-Joseph Land, Greenland and north-east America; and it may be briefly summarised as an inhabitant of "the Arctic and subarctic regions of the North Atlantic."†]

[In the Annan Observer of November 19th, 1872, we find the following statement: "Mr. Muir, taxidermist, of Ecclefechan, preserved and stuffed last winter the Wandering Albatross, a very rare bird, which was shot on the Solway Coast." The Wandering Albatross (Diomedea exulans) is found throughout the Southern Ocean, seldom occurring northward of $30^{\circ}$ south, $\ddagger$ and has never been recorded in Great Britain. The Black-browed Albatross (D. melanophrys) has, however, been obtained in Cambridgeshire (July 9th, 1897), and is believed to have been seen by Mr. J. A. HarvieBrown off the Orkneys on June 18th, 1894.ई In any case, this local record of a supposed Albatross is too vague to enable one to say to what species the bird may have belonged that Mr. Muir stuffed. Sailors often bring back from their voyages in the Southern Ocean the feet of these birds as tobacco pouches and their beaks as curios; and it is possible that one more thorough in his ways brought back a whole skin, around which a very improbable story has been woven.]

* Fauna of Lakeland, 1892, p. 454.

$\dagger$ List of British Birds, B.O.U., 1883, p. 199.

‡ Dict. Birds, 1893-1896, p. 8.

$\S$ Man. Brit. Birds, 1899, pp. 753, 754. 


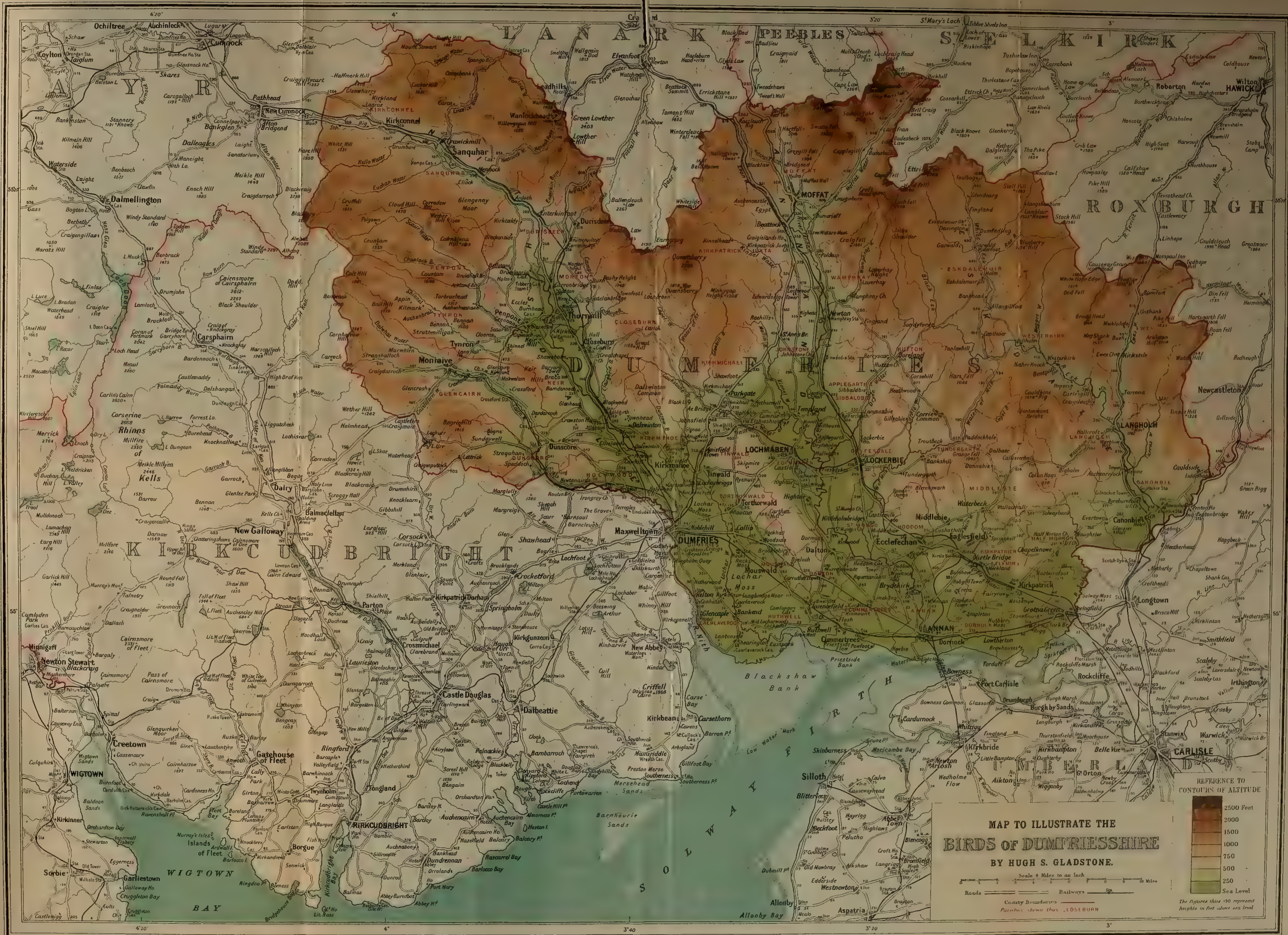





\section{INDEX.}

NoTE.-Each name is indexed one way only ; the specific name being viscivorus, Turdus : Tatin, and the generic in the Vernacular names [e.g., have been indexed as they aphear in-]. In the case of Local names, these being placed after them in the proper name

accipitrinus, Asio, 176.

acuta, Dafila, 272.

cegyptiaca, Chenalopex, 254.

ceruginosus, Circus, 184 .

asalon, Falco, 215.

Ailsa Craig Cock (Common Guillemot), 449.

alba, Ardea, 230.

Motacilla alba, 46.

Albatross, Wandering, 472.

albellus, Mergus, 301 .

albicilla, Falco, 199.

Haliaëtus, 198.

albifrons, Anser, 242.

alle, Mergulus, 452.

alpina, Tringa, 393.

aluco, Syrnium, 181.

anglicus, Dendrocopus major, 157.

anglorum, Puffinus, 471.

Regulus cristatus, 23.

apivorus, Pernis, 211.

apus, Cypselus, 151.

aquaticus, Rallus, 354.

arborea, Alauda, 148.

arctica, Fratercula, 453.

arcticus, Colymbus, 455 .

arenaria, Calidris, 401.

argentatus, Larus, 435.

arquata, Numenius, 416.

arvensis, Alauda, 146.

atra, Fulica, 358.

atratus, Cygnus, 261.

atricapilla, Muscicapa, 59.

Sylvia, 21.

Auk, Little, 452.

auritus, Podicipes, 462.

bailloni, Porzana, 353.

Bald Coot (Coot), 358.

Bank-Swallow (Sand-Martin), 67.

Barn-Swallow (Swallow), 61.
Basket-Hinger (British Goldencrested Wren), 23.

bassana, Sula, 224.

belgica, Limosa, 415 .

Bellringer (British Long-tailed Titmouse), 37.

bewicki, Cygnus, 258.

bifasciata, Loxia, 98.

Bittern, 233. American, 237. Little, 232 .

Bittour (Bittern), 233.

Black (Black Grouse), 318.

Flycatcher) 59 . Flycatcher (Pied

Blackbird, 5 .

Blackeap, 21.

- (British Coal-Titmouse), 39.

Blackcock (Black Grouse), 318.

Black Douker (Cormorant), 221. Duck (Common Scoter), 293.

- fowl (Black Grouse), 318.

Blackgame (Black Grouse), 318.

Black-headed Bunting (Reed-Bunt-

ing), 102.

- Scoter (Common Scoter), 293.

Swift (Swift), 151.

-toed Gull (Aretic or Richardson's Skua), 445.

Blackie (Blackbird), 5.

Blue-bill (Scaup-Duck), 285.

- Bonnet (British Blue Tit-

mouse), 42.

Hawk (Peregrine Falcon), 212.

-head (Common Gull), 434.

- Rock (Rock-Dove), 309.

Boatswain-Gull (Arctic or Richard. son's Skua), 445.

Bog-drum (Bittern), 233.

boscas, Anas, 265.

brachyotus, Asio, 176.

brachyrhynchus, Anser, 246. 
Brambling, 80.

brehmi, Gallinago, 391.

brenta, Bernicla, 253.

britannica, Certhia familiaris, 44.

britannicus, Carduelis elegans, 72.

Cinclus cinclus, 34.

Parus ater, 39.

Brown Linnet (Linnet), 81.

Martin (Sand-Martin), 67.

Owl (Tawny Owl), 181.

buffonii, Lestris, 447.

Bullfinch, British, 86.

bullochii, Procellaria, 469.

Bully (British Bullfinch), 86.

Bunting, Corn-, 100.

Reed-, 102.

Snow-, 103.

Yellow, 101.

Burnbecker (British Dipper), 34.

Buttour (Bittern), 233.

Buzzard, Common, 188.

- -Gled (Common Buzzard), 188. 188. -Hawk (Common Buzzard),

Honey-, 211.
Rough-legged, 192.

calidris, Totanus, 408.

Calloo (Long-tailed Duck), 290.

canadensis, Bernicla, 254.

candidus, Himantopus, 377.

canescens, Totanus, 412.

cannabina, Linota, 81.

canorus, Cuculus, 168.

cantiaca, Sterna, 423.

canus, Larus, 434.

canutus, Tringa, 400.

Capercaillie, 315.

carbo, Phalacrocorax, 221.

casarca, Tadorna, 264.

castor, Mergus, 296.

catarrhactes, Megalestris, 442.

Cat-Gull (Herring-Gull), 435.

caudata, Acredula caudata, 38.

Chaffinch, 79.

Chiffchaff, 26.

Chimney-Swallow (Swallow), 61.

chloris, Ligurinus, 69.

chloropus, Gallinula, 356.

Chough, 110.

chrysaëtus, Aquila, 194.

chukar, Caccabis, 344.

cineraceus, Circus, 186. cinerea, Ardea, 225.

Perdix, 341 .

Sylvia, 19.

cinereus, Anser, 239.

circia, Querquedula, 279.

citrinella, Emberiza, 101.

clarkei, Turdus musicus, 2.

clypeata, Spatula, 269.

Cock o' the North (Brambling), 80.

coelebs, Fringilla, 79.

coelestis, Gallinago, 389.

colchicus, Phasianus, 336.

collurio, Lanius, 56.

Colvend Elder (Cormorant), 221.

comminutus, Dendrocopus minor, 161.

Common Harrier (Hen-Harrier), 185.

communis, Coturnix, 344.

- Grus, 359.

- Turtur, 310.

Coot, 358.

corax, Corvus, 117.

Corbie (Carrion-Crow), 120. (Raven), 117.

-Craw (Carrion-Crow), 120.

Cormorant, 221.

Corn-Crake (Land-Rail), 349.

Corncrow (Rook), 124.

cornix, Corvus, 122.

cornuta, Tadorna, 262.

cornutus, Colymbus, 462.

corone, Corvus, 120.

Craigie (Common Heron), 225.

Crake, Baillon's, 353.

—_ Spotted, 351.

Crane, 359.

- (Common Heron), 225.

crecca, Nettion, 274.

crepidatus, Stercorarius, 445.

Crested Lapwing (Lapwing), 369.

- Tit (British Golden-crested Wren), 23.

Wren), Wren (British Golden-crested

Wren), 23.

cristata, Fuligula, 282.

cristatus, Podicipes, 459.

Crossbill, Common, 91.

Parrot-, 98.

Scottish, 97.

Two-barred, 98.

Crow (Rook), 124.

Carrion-, 120.

Hooded, 122.

Cuckoo, 168. 
Curlew, Common, 416.

curruca, Sylvia, 20.

curvirostra, Loxia curvirostra, 91.

Curwillet (Common Sandpiper), 404.

Cusha-doo (Ring-Dove), 303.

Cushat (Ring-Dove), 303.

Cushie (Ring-Dove), 303.

Cut-throat (Whitethroat), 19.

Cutty (Wren), 43.

- Wren (Wren), 43.

cyaneus, Circus, 185.

Dabchick (Little Grebe), 464.

dactylisonans, Coturnix, 345.

Daw (Jackdaw), 116.

De'il's Plover (Lapwing), 369.

Dipper, British, 34.

discors, Anas, 276.

Querquedula, 276.

Diver, Black-throated, 455.

- Great Northern, 454 .

Red-throated, 456.

domesticus, Passer, 76.

Doo (Rock-Dove), 309.

Dotterel, 360.

- -Plover (Dotterel), 360.

dougalli, Sterna, 424.

Dove, Ring-, 303.

- Rock-, 309.

Stock-, 305.

- Turtle-, 310.

dresseri, Parus palustris, 40.

Duck, Common Sheld-, 262.

Long-tailed, 290.

Muscovy, 262.

North American Summer, 275.

- Ruddy Sheld-, 264.

- Scaup-, 285.

Tufted, 282.

Dun Diver (Goosander), 296.

Dunlin, 393.

Dunnock (British Hedge-Sparrow), 33.

Dyker (Wheatear), 8.

Dykie (Wheatear), 8.

Eagle, Golden, 194.

White-tailed, 198.

eburnea, Pagophila, 442.

Egret, Little, 230.

Eider, Common, 292.
Ember-Goose (Great Northern

Diver), 454.

enucleator, Corythus, 89.

Pyrrhula, 89.

epops, Upupa, 166.

Erne (White-tailed Eagle), 198.

erythropus, Anser, 243.

europoeus, Caprimulgus, 152.

excubitor, Lanius, 55.

exulans, Diomedea, 472.

fabalis, Anser, 244.

Faisan (Pheasant), 336.

Falcon (Peregrine Falcon), 212.

- Peregrine, 212.

Feather-Poke (British Long-tailed

Titmouse), 37.

Feltiflier (Fieldfare), 4.

- (Mistle-Thrush), 1.

Felty (Fieldfare), 4.

- (Mistle-Thrush), 1.

ferina, Fuligula, 281.

ferus, Anser, 244.

Cygnus, 256.

Fieldfare, 4.

Fieldlark (Meadow-Pipit), 52.

Firetail (Redstart), 12.

Fish-Eagle (Osprey), 219.

Fishing Hawk (Osprey, 219.

Five-toed Plover (Ringed Plover), 364.

flammea, Strix, 173.

Flapper (Mallard), 265.

flava, Motacilla flava, 49.

flavirostris, Linota, 85.

fluviatilis, Podicipes, 464. Sterna, 424.

Flycatcher, Pied, 59.

Spotted, 58.

frugilegus, Corvus, 124.

fulicarius, Phalaropus, 379.

Fulmar, 471.

fusca, Édemia, 295.

fuscus, Larus, 436.

Totanus, 410.

Gadwall, 268.

galbula, Oriolus, 54.

gallinula, Gallinago, 392.

Game-Hawk (Peregrine Falcon), 212. 
Gannet, 224.

Garganey, 279.

garrulus, Ampelis, 57.

Coracias, 165.

garzetta, Ardetta, 230.

glacialis, Colymbus, 454.

- Fulmarus, 471.

- Harelda, 290.

glareola, Totanus, 405.

glaucion, Clangula, 287.

glaucogaster, Bernicla, 254.

glaucus, Larus, 439.

Glead (Common Buzzard), 188.

Gled (Common Buzzard), 188.

Goatsucker (Nightjar), 152.

Godwit, Bar-tailed, 414.

Black-tailed, 415 .

Gold-Crest (British Golden-crested Wren), 23.

Golden Cuttie (British Goldencrested Wren), 23.

Goldeneye, 287.

Golden-eyed Duck (Goldeneye), 287.

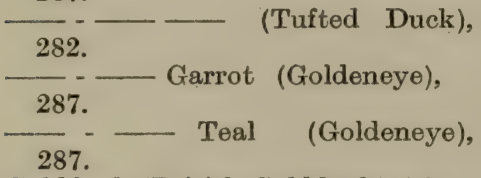

Goldfinch (British Goldfinch), 72.

- British, 72.

Goldie (British Goldfinch), 72.

Gooldie (British Goldfinch), 72.

Goosander, 296.

Goose, Barnacle-, 250.

- Bean-, 244, 247.

- Brent, 253.

Canada, 254.

- Egyptian, 254.

- Grey Lag-, 239, 247.

L__ Lesser White-fronted, 243.

- Pink-footed, 246, 247.

- Red-breasted, 249.

- Snow-, 247.

-W White-fronted, 242, 247.

- Gorcock (Red Grouse), 326.

Goshawk, 204.

(Peregrine Falcon), 212.

Gouldspink (British Goldfinch), 72. Gowdspink (British Goldfinch), 72.

Gowk (Cuckoo), 168.

graculus, Carbo, 223.

- Phalacrocorax, 223.

Pyrrhocorax, 110.
Greater Blackcap (British Great Titmouse), 38.

Grebe, Black-necked or Eared, 463.

- Great Crested, 459.

Little, 464.

Red-necked, 461.

- Slavonian or Horned, 462.

Green Cormorant (Shag), 223. 223.

Greenfinch, 69.

Green Linnet (Greenfinch), 69.

_L Lintie (Greenfinch), 69.

Plover (Golden Plover), 365. (Lapwing), 369.

Greenshank, 412

Grey-backed Crow (Hooded Crow), 122.

- Crow (Hooded Crow), 122.

- Duck (Mallard), 265.

- - -headed Buzzard (Marsh-Harrier), 184.

Greyhen (Black Grouse), 318.

Grey Owl (Tawny Owl), 181.

_ Plover (Golden Plover), 365.

Wagtail (Pied Wagtail), 45.

griseigena, Podicipes, 461.

griseus, Nycticorax, 231.

grisola, Muscicapa, 58.

Grosbeak, Pine-, 89.

Grouse (Red Grouse), 326.

- Black, 318.

Pallas's Sand-, 312.

Red, 326.

grylle, Uria, 451.

Guillemot, Black, 451.

Common, 449.

Gull, Black-headed, 429.

Common, 434.

Glaucous, 439.

_- Great Black-backed, 438.

Herring-, 435.

- Iceland, 440.

Ivory-, 442.

Kittiwake, 441.

Lesser Black-backed, 436.

Little, 428.

haliaëtus, Pandion, 219.

Harrier, Hen-, 185.

Marsh-, 184.

Montagu's, 186.

Harvest-Teal (Shoveler), 269. 
Hawfinch, 70.

Hawk, Sparrow-, 206.

Heathcock (Black Grouse), 318.

Heather-bleat (Common Snipe), 389. -bleater (Common Snipe), 389. -blite (Common Snipe), 389. -blitter (Common Snipe), 389. -Lintio (Twite), 85.

Heathfowl (Black Grouse), 318. Heathhen (Black Grouse), 318.

Heathpoult (Black Grouse), 318. helvetica, Squatarola, 368.

Hempie (British Hedge-Sparrow), 33.

Heron, Common, 225. Great White, 230. Night-, 231.

Heronsheugh (Common Heron), 225. hiaticola, AEgialitis, 364. hibernans, Pratincola torquata, 11. hirundo, Sterna, 425.

Hobby, 214.

Hoodie (Carrion-Crow), 120. (Hooded Crow), 122. Craw (Carrion-Crow), 120.

- (Hooded Crow), 122.

Hoolet (Tawny Owl), 181.

Hoopoe, 166.

Horned Owl (Long-eared Owl), 174. hortensis, Sylvia, 22.

House-Swallow (Swallow), 61.

Hunting Hawk (Peregrine Falcon), 212.

hybrida, Hydrochelidon, 422.

hyperboreus, Chen, 247.

Phalaropus, 382.

hypoleucus, Totanus, 404.

ictinus, Milvus, 209.

ignicapillus, Regulus, 24.

iliacus, Turdus, 3.

Immer-Goose (Great Northern

Diver), 454.

interpres, Strepsilos, 374.

isabellina, Saxicola, 9.

ispida, Alcedo, 162.

Jackdaw, 116.

Jay, British, 111.

-Pie (British Jay), 111.

-Piet (British Jay), 111.
Jay-Teal (Teal), 274.

Jenny Cut-throat (Whitethroat), 19. Hern (Common Heron), 225. Hoolet (Tawny Owl), 181. -Wren (Wren), 43.

Keea (Jackdaw), 116.

Keeaw (Jackdaw), 116.

Keelie (Kestrel), 217.

Kestrel, 217.

Kingfisher, 162.

- (British Dipper), 34.

King's Fisher (Kingfisher), 162.

Kite, 209.

Kittie-needie (Common Sandpiper), 404.

Kitty (Wren), 43.

- Raan (Wren), 43.

-Wren (Wren), 43.

kleinschmidti, Parus atricapillus, 41.

Knot, 400.

Laggie (Grey Lag-Goose), 239.

lagopus, Buteo, 192.

lapponica, Limosa, 414.

Lapwing, 369.

Large Grebe (Great Crested Grebe), 459.

Lark (Skylark), 146.

- Wood-, 148.

Laverock (Skylark), 146.

lentiginosus, Botaurus, 237.

leucopsis, Bernicla, 250.

leucoptera, Loxia, 99.

leucopterus, Larus, 440.

leucorodia, Platalea, 239.

leucorrhoa, Oceanodroma, 468.

- Saxicola onanthe, 9.

linaria, Linota, 82.

Linnet, 81.

Lintio (Linnet), 81.

livia, Columba, 309.

Long-necky (Common Heron), 225. 225.

-tailed Wren (British Longtailed Titmouse), 37.

Loon (Red-throated Diver), 456.

Luggie (Long-eared Owl), 174.

lugubris, Motacilla alba, 45.

luscinia, Daulias, 18. 
macrura, Sterna, 426.

Maggie Cut-throat (Whitethroat), 19.

Magpie, 114.

major, Dendrocopus, 157.

major, 161.

Gallinago, 387.

Lanius, 56.

Mallard, 265.

Mar (Common Gull), 434.

marila, Fuligula, 285.

marinus, Larus, 438.

maritima, Tringa, 399.

Martin, House-, 65.

Sand-, 67.

maruetta, Porzana, 351.

Mavey (British Song-Thrush), 2.

Mavis (British Song-Thrush), 2.

Meadow-Lark (Meadow-Pipit), 52.

melanocephala, Emberiza, 102.

melanope, Motacilla, 48.

melanophrys, Diomedea, 472.

melophilus, Erithacus rubecula, 16.

merganser, Mergus, 296.

Merganser, Red-breasted, 299.

Merle (Blackbird), 5 .

Merlin, 215.

merula, Turdus, 5.

Mew (Common Guil), 434.

Mewgull (Common Gull), 434.

miliaria, Emberiza, 100.

minuta, Ardetta, 232.

- Sterna, 426.

Tringa, 395.

minutus, Larus, 428.

Miredrum (Bittern), 233.

Mire-duck (Mallard), 265.

-Snipe (Common Snipe), 389.

Mochrum Elder (Cormorant), 221.

mollissima, Somateria, 292.

monedula, Corvus, 116.

mongolicus, Phasianus, 338.

montanus, Passer, 78.

montifringilla, Fringilla, 80.

Moor-Buzzard (Marsh-Harrier), 184. -hen, 356.

Moorcock (Red Grouse), 326.

Moorfowl (Red Grouse), 326.

Moorhen (Red Grouse), 326.

Morillon (Goldeneye), 287.

morinellus, Eudromias, 360.

moschata, Cairina, 262.

Moss-Cheeper (Meadow-Pipit), 52. -duck (Mallard), 265.

Mountain-Blackbird (Ring-Ouzel), 7
Mountain-Blackie (Ring-Ouzel), 7.

- -Finch (Brambling), 80.

-Linnet ('Twite), 85.

Muircock (Red Grouse), 326.

Muirhen (Red Grouse), 326.

musicus, Cygnus, 255.

Mussel-Teal (Scaup-Duck), 285.

mutus, Lagopus, 331.

noevia, Locustella, 31.

Nettle-Creeper (Whitethroat), 19.

newtoni, Parus major, 38.

Nighthawk (Nightjar), 152.

Nightingale, 18.

Nightjar, 152.

nigra, Hydrochelidon, 421. CEdemia, 293.

nigricollis, Cygnus, 261.

- Podicipes, 463.

nisus, Accipiter, 206.

nivalis, Plectrophenax, 103.

nycthemerus, Euplocamus, 338.

obscurus, Anthus, 53.

Parus corruleus, 42.

occidentalis, Accentor modularis, 33.

ochropus, Totanus, 406.

onanthe, Saxicola, 8.

cenas, Columba, 305.

olor, Cygnus, 260.

Oriole, Golden, 54.

Osprey, 219.

ossifragus, Falco, 199.

ostralegus, Hamatopus, 375.

otus, Asio, 174.

Ouzel, Ring-, 7.

Owl, Barn-, 173.

Long-eared, 174.

Short-eared, 176.

Snowy, 183.

Tawny, 181.

Oxee (British Great Titmouse), 38.

Oxeye (British Great Titmouse), 38.

Oyster-catcher, 375.

Paitrick (Partridge), 341.

Paitritch (Partridge), 341.

palumbarius, Astur, 204.

palumbus, Columba, 303. 
paradoxus, Syrrhaptes, 312.

parasiticus, Stercorarius, 446.

Partridge, 341.

Chukar, 344.

Red-legged, 344.

parvulus, Troglodytes, 43.

Peesweep (Lapwing), 369.

Peewit-Gull (Black-headed Gull), 429.

Pegpie (Magpie), 114.

pelagica, Procellaria, 466.

penelope, Mareca, 279.

peregrinus, Falco, 212.

Petrel, Leach's Fork-tailed, 468. Storm-, 466.

Pewit (Lapwing), 369.

phocopus, Numenius, 420.

Phalarope, Grey, 379.

- Red-necked, 382.

Pheasant, 336.

Bohemian, 338.

Chinese Ring-necked, 338.

Golden, 338.

Japanese, 338.

Mongolian, 338.

Silver-, 338.

phoeniceus, Ageloeus, 105.

phoenicurus, Ruticilla, 12.

phragmitis, Acrocephalus, 30.

pictus, Chrysolophus, 338.

Pie (Magpie), 114.

Piet (Magpie), 114.

pilaris, Turdus, 4.

pileata, Pyrrhula pyrrhula, 86.

Pink (Redstart), 12.

Pintail, 272.

Pipit, Meadow-, 52.

Richard's, 53.

Rock-, 53.

Tree-, 51.

Pirr (Arctic Tern), 426.

(Common Tern), 424.

Pliver (Golden Plover), 365.

Plover, Golden, 365.

Grey, 368.

- Ringed, 364.

pluvialis, Charadrius, 365.

Pochard, 281.

pomatorhinus, Stercorarius, 443.

porzana, Crex, 351.

pratensis, Anthus, 52.

Crex, 349.

Ptarmigan, 331.

Puffin, 453.

pugnax, Machetes, 402.
Purre (Dunlin), 393.

Puttock (Common Buzzard), 188.

pytyopsittacus, Loxia, 98.

Quail, 344.

—_Virginian, 349.

raii, Motacilla, 50.

Rail, Land-, 349.

Water-, 354.

Raven, 117.

Razorbill, 448.

Redbreast, British, 16.

Red Game (Red Grouse), 326.

Hawk (Kestrel), 217.

Redlegs (Redshank), 408.

Red Linnet (Linnet), 81.

Redpoll (Linnet), 81.

— Lesser, 83.

Mealy, 82.

Redshank, 408.

- Spotted, 410.

Redstart, 12.

Black, 13.

Redtail (Redstart), 12.

Redwing, 3.

Reed-Sparrow (Reed-Bunting), 102.

Reeve, 402.

richardi, Anthus, 53.

ridibundus, Larus, 429.

Ring-Bunting (Reed-Bunting), 102.

- - Dotterel (Ringed Plover), 364.

Ringie (Ringed Plover), 364.

Ringtail (Hen-Harrier), 185.

Ringtailed Hawk (Hen-Harrier), 185.

riparia, Cotile, 67.

River-Swallow (Sand-Martin), 67.

Robin (British Redbreast), 16. 16.

-Redbreast(British Redbreast),

Rock-Dove (Stock-Dove), 305.

_-Lark (Rock-Pipit), 53.

Roller, 165.

Rook, 124.

rosea, Acredula caudata, 37.

Rose-Linnet (Linnet), 81.

-Lintie (Linnet), 81.

rubetra, Pratincola, 10.

rufa, Caccabis, 344.

rufescens, Linota, 83. 
Ruff, 402.

ruficollis, Bernicla, 249.

rufitergum, Garrulus glandarius, 111.

rufus, Phylloscopus, 26.

rustica, Hirundo, 61.

- Pica, 114.

rusticula, Scolopax, 383.

Sanderling, 401.

Sandpiper, Common, 404.

-_ Curlew-, 398.

- Green, 406.

Purple, 399.

- Wood-, 405.

Sand-tripper (Common Sandpiper), 404.

—_- (Ringed Plover), 364. 404.

Sawbill (Goosander), 296.

Saw-neb (Goosander), 296.

_-nebbed Duck (Goosander), 296.

Scaleduck (Common Sheld-Duck), 262.

scandiaca, Nyctea, 183.

Scart (Cormorant), 221.

Scaup-Pochard (Scaup-Duck), 285.

schoniclus, Emberiza, 102.

Scoter, Common, 293.

- Velvet-, 295.

scotica, Alauda arvensis, 148.

- Loxia curvirostra, 97.

scoticus, Lagopus, 326.

- Parus cristatus, 42.

Screech-Owl (Barn-Owl), 173.

Sea-Crow (Hooded Crow), 122.

- -Eagle (White-tailed Eagle), 198.

-Lark (Dunlin), 393.

-Maw (Common Gull), 434.

-Mouse (Dunlin), 393.

-pie (Oyster-catcher), 375.

-Pyet (Oyster-catcher), 375.

- -Swallow (Arctic Tern), 426. (Common Tern), 424.

septentrionalis, Colymbus, 456.

serrator, Mergus, 299.

Shag, 223.

Shearwater, Manx, 471.

Sheildrake (Common Sheld-duck), 262.

Shelfie (Chaffinch), 79.

Shilfa (Chaffinch), 79 .
Shoveler, 269.

Shrike, Great Grey, 55.

- Red-backed, 56.

sibilatrix, Phylloscopus, 29.

Silver-Plover (Grey Plover), 368.

-Wren (Willow-Wren), 28.

Siskin, 74.

Skua, Arctic or Richardson's, 445. Great, 442.

__ Long-tailed or Buffon's, 446. Pomatorhine, 443.

Skylark, 146.

Small Northern Diver (Red-throated

Diver), 456.

Smew, 301.

Snabby (Chaffinch), 79.

Snipe, Common, 389.

- Great, 387.

- Jack, 392.

Snowbird (Fieldfare), 4.

Snow-Finch (Snow-Bunting), 103.

- Flake (Snow-Bunting), 103. -Fleck (Snow-Bunting), 103.

Solan Goose (Gannet), 224.

Sparrow, British Hedge-, 33.

- House-, 76.

— Tree-, 78.

Sparry (House-Sparrow), 76.

Speckled Diver (Red-throated

Diver), 456.

Speug (House-Sparrow), 76.

spinus, Chrysomitris, 74.

sponsa, Aix, 275.

Spoonbill, 239.

Sprug (House-Sparrow), 76.

Spyng (House-Sparrow), 76.

Stanechacker (Wheatear), 8.

Stank-hen (Moor-hen), 356.

Stankie (Moor-hen), 356.

Starling, 105.

- American Red-winged, 105.

Stegg (Grey Lag-Goose), 239.

stellaris, Botaurus, 233.

Stilt, Black-winged, 377.

Stint, Little, 395.

- Temminck's, 396.

Stockannet (Common Sheld-Duck), 262.

- (Goosander), 296.

Stockgander (Common Sheld-Duck), 262.

(Goosander), 296.

Stonechat, British, 11.

Stormbird (Mistle-Thrush), 1.

Stormeock (Mistle-Thrush), 1. 


\section{INDEX}

strepera, Anas, 268.

streperus, Acrocephalus, 30.

Sturlin (Starling), 105.

subarquata, Tringa, 398.

subbuteo, Falco, 214.

Summer-Snipe (Common Sandpiper), 404.

supercitiosus, Phylloscopus, 25.

Swallow, 61.

Swan, Bewick's, 258.

Black, 261.

Mute, 260.

Whooper, 255.

Swift, 151.

Tame Swan (Mute Swan), 260.

Teal, 274.

- American Blue-winged, 276.

Tee-wheet (Lapwing), 369.

temmincki, Tringa, 396.

Tern, Aretic, 426.

Black, 421.

Common, 424.

Little, 426.

Roseate, 424.

Sandwich, 423.

Whiskered, 422.

tetrix, Tetrao, 318.

Thrush, British Song-, 2.

Mistle-, 1.

Tiercel (Peregrine Falcon), 214.

tinnunculus, Falco, 217.

Titlark (Meadow-Pipit), 52.

Titmouse, British Blue, 42.

- Coal-, 39.

- Great, 38.

__ Long-tailed, 37.

Marsh-, 40.

Crested, 42.

titys, Ruticilla, 13.

torda, Alca, 448.

torquatus, Phasianus, 338. Turdus, 7.

torquilla, Iynx, 154.

Tree-creeper, British, 44.

—-Lark (Tree-Pipit), 51.

44.

-speler (British Tree-creeper),

tridactyla, Rissa, 441.

trivialis, Anthus, 51.

trochilus, Phylloscopus, 28.

troile, Uria, 449.
Tufted Pochard (Tufted Duck), 282.

Turnstone, 374 .

Twite, 85.

urbica, Chelidon, 65.

urogallus, Tetrao, 315.

versicolor, Phasianus, 338.

virginianus, Ortyx, 349.

viridis, Gecinus, 156.

viscivorus, Turdus, 1.

vulgaris, Buteo, 188.

Coccothraustes, 70. Sturnus, 105.

Vanellus, 369.

Wagtail, Blue-headed, 49.

Grey, 48.

Pied, 45.

White, 46.

Y Yellow, 50.

Warbler, Garden-, 22.

Grasshopper-, 31.

Reed-, 30.

Sedge-, 30.

Yellow-browed, 25.

Water-Craw (British Dipper), 34. -Crow (British Dipper), 34. (Cormorant), 221. -hen (Moor-hen), 356. -Ouzel (British Dipper), 34. -Peggie (British Dipper), 34. -Pyet (British Dipper), 34.

-Raven (Cormorant), 221.

-Swallow (Sand-Martin), 67.

-Wagtail (Pied Wagtail), 45.

Waxwing, 57.

Wee Blue Hawk (Merlin), 215. Cut-throat (Willow-Wren), 28.

Diver (Little Grebe), 464.

Douker (Little Grebe), 464.

Hawk (Merlin), 215.

174.

Horned Owl (Long-eared Owl),

Weet-ma-feet (Quail), 344.

Whaup (Common Curlew), 416.

Wheatear, 8.

Isabelline, 9.

Whimbrel, 420. 
Whinchat, 10.

Whin-Lintio (Linnet), 81.

White Owl (Barn-Owl), 173.

Whitethroat, 19. Lesser, 20.

Wigeon, 279.

Wild Duck (Mallard), 265.

Window-Martin (House-Martin), 65.

-Swallow (House-Martin), 65.

Winter-Gull (Common Gull), 434.

Woodcock, 383.

Wood-Lark (Tree-Pipit), 51. -Owl (Tawny Owl), 181.

Woodpecker (British Tree-creeper), 44.

British Great Spotted, 157. Lesser Spotted, 161. Green, 156.

Wood-Pigeon (Ring-Dove), 303. -Thrush (Mistle-Thrush), 1.
Wren, 43.

British Golden-crested, 23.

Fire-crested, 24.

Willow-, 28.

Wood-, 29.

Wryneck, 154.

Wullie Wagtail (Pied Wagtail), 45.

Yeldrock (Yellow Bunting), 101.

Yelloweye (Goldeneye), 287.

Yellow Hammer (Yellow Bunting), 101.

Wagtail (Grey Wagtail), 48.

Wren (Wood-Wren), 29.

Yite (Yellow Bunting), 101.

Yeorlin (Yellow Bunting), 101.

Yirn (White-tailed Eagle), 198.

Yoit (Yellow Bunting), 101. 


\title{
THE BIRDS
}

OF

\section{DUMFRIESSHIRE}

BY

\section{HUGH S. GLADSTONE,}

\author{
M.A., F.Z.S., F.R.S.F., M.B.O.U.
}

(President of the Dumfriesshire and Galloway Nat. Hist. \& Antiquarian Society.)

With Twenty-four Full-page Plates from Photographs of typical Haunts and notable Birds.

A Specially Prepared Map showing contours of altitude in colours.

FULL Bibliography.

Biographical Notices.

INDEx. Lists OF CORRespondents and SUBSCRIB ERS.

Square Demy 8vo. $\left(9 \times 6 \frac{1}{4}\right)$

Cloth (extra). Gilt Top.
A Handsome Volume of about 600 pages.

Price to Subscribers, £1 1s. nett.

The Edition will be strictly limited to 350 Copies, of which only 325 Copies will be offered for Subscription. Each Copy will be numbered.

The Price will be raised on publication to $25 \mathrm{~s}$. nett should any copies remain unsubscribed for.

WITHERBY \& CO., 326, High Holborn, London, W.C. 


\section{PROSPECTUS.}

UMFRIESSHIRE is fortunate in the possession of a 1 varied bird-life within a comparatively small compass, consequent upon its diversity of physical features. The shores of the Solway Firth-" that great ornithological junction "- the rugged mountains rising to over 2,500 feet, the fertile dales, the moors, the woods, the rivers and the lakes all have their attractions for different birds.

Mr. Hugh S. Gladstone has spared no labour to make this account of the birds of his county complete. In accomplishing this he has been fortunate in two notable ways. For the history of the past he has had access not only to the published writings, but to the private notes of SIR WILLIAM JARDINE, whose home-Jardine Hall-was in Dumfriesshire, and whose fame as a naturalist was world-wide. Happily connecting Sir William Jardine's work of the first half of the last century with the present, is the life-long experience of Mr. Robert Service, the well-known ornithologist of Dumfries. Mr. Service's aid has been whole-hearted and unstinted, and he has placed the whole of his notes at the author's disposal, besides being in constant communication with him. The author has carefully searched all available published sources for information, and has besides had the assistance of a large number of CoRRESPONDENTS both in and out of the county. In the sifting, arranging, and authentication of the material thus collected no pains have been spared, and the book will prove a valuable addition to the list of county avifaunas.

Among the Important Features of the work to which attention may be specially directed are the following :-

The thorough details of the distribution of each species in the county, and of the movements of migrants. 
The careful historical accounts of the rare birds.

The interesting comparisons in the cases of species which have become scarcer or more plentiful.

The detailed tables of Heronries, Rookeries and Gulleries, past and present.

The Biographies of Dumfriesshire Ornithologists.

The full Bibliography.

The Illustrations from photographs (mostly by the author and Mr. D. LEGARD) of (1) Historical Birds; (2) Typical Birds and Nests; (3) Typical Haunts.

The specially engraved Map showing contours of altitudes in colours.

The Volume will be a bulky one of some 600 pages, and will be produced in extra good style throughout, with a strong and serviceable cloth binding.

(For specimen page see over.)

\section{NOTICES TO SUBSCRIBERS.}

A list of Subscribers will be printed in the volume.

The price to Subscribers only is 218 .

The Edition is strictly limited to 350 copies, only 325 of which will be available for subscription. Each copy will be numbered.

On publication the price will be raised to $25 \mathrm{~s}$. nett. 
in confinement till May, 1887, when seven couple were liberated. They were seen for a few weeks in the vicinity, but then disappeared, and subsequently " one or two were reported as having been seen and shot in different parts of Scotland."*

The occurrence of this species being due to importation, it cannot be regarded as a genuine visitor to the county. It is an inhabitant of the United States, migrating southwards to Central America.]

\section{THE STARLING. Sturnus vulgaris, Linnæus.}

\section{Local name-STURLING.}

“ The Starling flew to his mother's window stane, It whistled and it sang;

And aye the ower-word $\dagger$ ' the tune

Was-'Johnie tarries lang!" "

"Johnie of Breadislee," Ancient Nithsdale Ballad.

A very common resident throughout the county, but subject to partial as well as general migrations.

At the end of the eighteenth century there is reason to believe that the Starling was quite common.

Sir William Jardine writing in 1832 , says :-It " is found in flocks during autumn and spring, but few in number; having diminished much of late years. In 1819 and 1820, flocks of many hundreds frequented the holms on the Annan, but of late not more than from ten to twenty have been seen together." $\$$ About the time that Sir William wrote, Sir Charles Granville Stuart Menteath sent a pair of young Starlings to Closeburn Hall to be brought up and liberated. They were entrusted to William Hastings, then an under-gardener on the estate (subsequently the taxidermist of Dumfries), "who did as he was instructed; and in the following year, one was shot and no one knew

* Fauna of Argyll, 1892, pp. 80, 81.

+ Refrain.

$\ddagger$ New Stat. Acct. Scot., Vol. IV., p. 180. 





\section{Date Due}

MAR 1970 


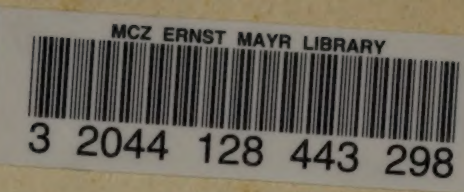

Gladstone's 'The Birds of Dumfriesshire.' 1- The avifauna of Dumfriesshire numbers 218 indigenous species, of which 56 are given as "very rare or accidental visitors," while 29 others are entered as of doubtful occurrence; 10 others are included as introduced species. The author has followed the classification and nomenclature of Howard Saunders, except in the case of geographical races, where trinomials and the nomenclature of Dr. E. Hartert are employed.

It is a very comprehensive work in all that relates to the manner of occurrence of the species of birds in Dumfriesshire. The general character of the presence of each is summarized in a line or two of small heavy-faced type as a sort of heading to the detailed account which immediately follows, with references in footnotes to the authorities on which the various statements in the text rest, when not based on the personal knowledge of the author.

The introduction includes short biographies of the ornithologists of Dumfriesshire (pp. xxv-xlii), a list of correspondents who have assisted the author in the work, an extended bibliography (pp. xlix-lxiii), a sketch of the physical features and climate of Dumfriesshire (pp. lxv-lxxvii), a few pages on bird migration as observed in the county, two pages on 'flight-nets' as used by fishermen in capturing wild-fowl, six pages on bird protection (including "The Wild Birds Protection Order" of 1908 for the County of Dumfries), a few pages of "local misnomers and names," and three pages on the number of species recorded for Dumfriesshire, and the method of their treatment in the "Birds of Dumfriesshire," which occupy the rest of the volume (pp. 1-472). The illustrations include, besides a large folding map of the county (printed in colors to show contours of altitude), twenty-four finely executed half-tone plates, representing scenic features of the county, nests and eggs, and birds fro $n$ life or from historic specimens. The volume is beautifully printed on heavy unglazed paper, and forms an attractive and important addition to the series of works relating to local faunas in the British Isles.- J. A. A.

${ }^{1}$ The Birds | of | Dumfriesshire | a contribution to the Fauna of the Solway Area | By | Hugh S. Galdstone | M. A., F. Z. S., F. R. S. E., M. B. O. U. | President of the Dumfriesshire and Galloway Natural History / and Antiquarian Society. | With illustrations from photographs | by | Messrs. D. Legard, F. Barber-Starkey, the Author | and others, and a map. | Witherby \& Co. | 326 High Holborn London $1910-8$ vo, pp. xcix $+482,24$ half-tone plates, and a folded map. Edition, 350 numbered species. 25s. net. 
